\title{
Arqueologia e Turismo: \\ sustentabilidade e inclusão social
}

\author{
Louise Prado Alfonso
}

Orientador:

Pedro Paulo Abreu Funari

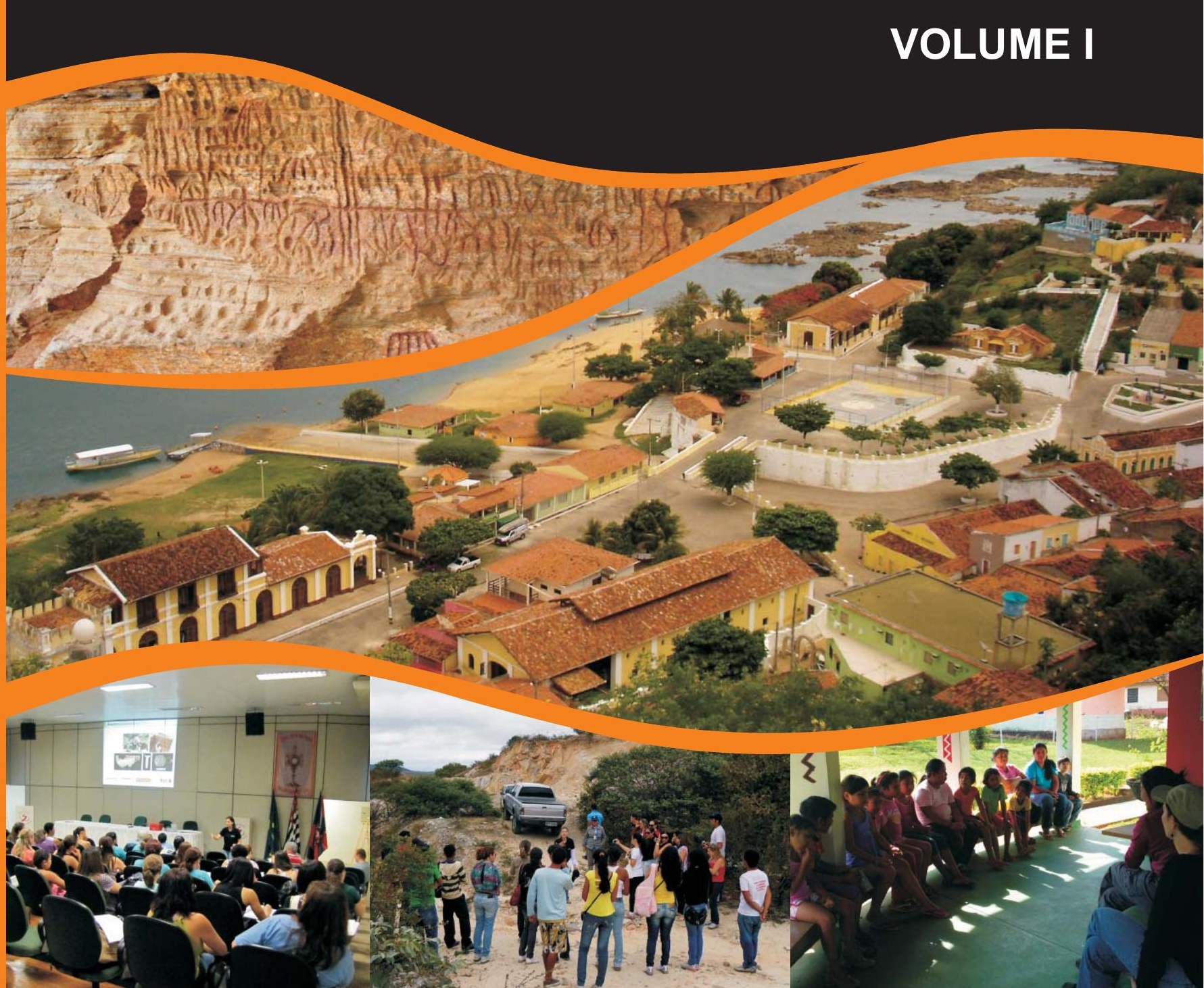




\author{
Universidade de São Paulo \\ Museu de Arqueologia e Etnologia \\ Programa de Pós-Graduação em Arqueologia
}

ARQUEOLOGIA E TURISMO: sustentabilidade e inclusão social.

Aluna: Louise Prado Alfonso

Tese de Doutorado, apresentada ao Programa de Pós-Graduação em Arqueologia, do Museu de Arqueologia e Etnologia da Universidade de São Paulo para obtenção do título de doutor em Arqueologia.

Orientador: Pedro Paulo Abreu Funari

Linha de Pesquisa: Gestão do Patrimônio Arqueológico

São Paulo

2012 
Dedico esta tese aos meus pais e irmãos e a todas as comunidades com quem trabalhei nos últimos seis anos, que certamente, são co-autores deste trabalho. 
BANCA EXAMINADORA 


\section{Agradecimentos}

Meu primeiro agradecimento é para meu orientador, professor Pedro Paulo Funari, pelo incentivo e pela confiança que depositou em mim. Sem seu apoio esta tese não seria possível. Obrigada.

Aos professores e ao Programa de Pós-Graduação do Museu de Arqueologia e Etnologia da Universidade de São Paulo. Aos funcionários da Pós-Graduação, que me auxiliaram sempre, em especial à Vanusa e à Regina por seu apoio com as questões burocráticas e amizade, e ao Paulo e à Dária por sua ajuda e parceria.

À Coordenadoria de Aperfeiçoamento de Pessoal de Nível Superior (CAPES), pelo apoio financeiro concedido, que tornou possível a realização deste trabalho.

À Pró-Reitoria de Pós-Graduação da USP pelo apoio concedido que possibilitou a realização de estágios no exterior e a participação em congressos internacionais.

Aos professores Dr. Paulo Eduardo Zanettini e Dr. Camilo de Mello Vasconcellos por suas valiosíssimas contribuições durante o exame de qualificação.

À professora Maria Cristina Oliveira Bruno pelos ensinamentos e por tornar possível meu ingresso no Programa de Pós Graduação.

Ao Instituto Nacional de Antropología e Historia (INAH) do México pelas informações concedidas e ao professor Dr. Pedro Jiménez pelos contatos apresentados.

Ao Instituto Nacional de Cultura - Dirección Regional de Cultura La Libertad Trujillo - Peru por todo apoio dado a esta pesquisa desde o ano de 2007, em especial pelo estágio a mim concedido durante o mês de janeiro de 2009. Com certeza a experiência adquirida em temas como a supervisão de complexos arqueológicos, educação, extroversão, museus, programas de revitalização de centros históricos e turismo, todos aplicados em 
diferentes sítios arqueológicos da costa norte peruana, contribuíram para meu atual olhar para a Arqueologia. Aos arqueólogos do INC pelas conversas, reflexões e visitas técnicas.

Ao professor Santiago Uceda Castillo pelas informações concedidas e por seu apoio durante minhas estadas em Trujillo. Sem duvida a experiência por mim adquirida em visita técnica e discussões sobre os projetos de las Huacas del Sol y La Luna foram de extrema importância para minha formação. Ao arqueólogo Régulo Franco Jordán por me permitir compartilhar das experiências de finalização do Museu de El Brujo.

À Família Muro que tantas vezes me hospedou no Peru. Em especial à Susy por sua dedicação, companheirismo e amizade durante todos estes anos.

Também sou grata à professora Dra. Niède Guidon e à Rosa Trakalo, da Fundação Museu do Homem Americano pelas informações que muito auxiliaram nas reflexões desta tese e receptividade durante minha estada no Piauí. À Carolina e à Luana pelo companheirismo e pelas discussões sobre arte rupestre durante nossas visitas técnicas aos sítios arqueológicos do Parque Nacional Serra da Capivara.

À Zanettini Arqueologia, em especial ao Paulo, pelo convite para participar de projetos tão importantes para minha formação como arqueóloga e para minha vida acadêmica, por seu apoio e sua confiança, desde sempre. E à Camila, pelo companheirismo, pelas reflexões, contribuições, pelos ensinamentos, pela confiança, risadas e amizade. À Gabriela por sua amizade e pelo designe detantos projetos. Ao Rafa, Flávio, Louis, Luana, Junior, Ariane e demais funcionários e companheiros de campo, cada um contribuiu de alguma maneira para esta tese.

À $17^{a}$ regional do Instituto do Patrimônio Histórico e Artístico Nacional - IPHAN Alagoas por seu apoio na realização e divulgação do estudo de caso do sertão alagoano. Em especial ao Yuri Batalha de Magalhães, naquele momento funcionário da citada regional.

Às comunidades de Olho D’Água do Casado e Delmiro Gouveia pelos ensinamentos e trocas de experiências, em especial à comunidade da Cruz e às Agrovilas do Assentamento Nova Esperança II. À Janaina de Melo, então diretora de turismo de Olho D’Água do Casado por seu apoio e amizade. À Telma por toda sua ajuda. 
À Renova Energia por todo seu apoio durante a realização do projeto desenvolvido no sudoeste baiano. Às comunidades de Guanambi, Igaporã e Caetité pela participação, pelas discussões e ensinamentos. À Jozê, ao Adail, ao Marcondes, à Fernanda, à Adriana, à Lira, à Emanoela, ao Dácio, à Juliana, entre tantas outras pessoas que tornaram possível o desenvolvimento do projeto.

À Prefeitura Municipal de Lins e à Secretaria de Desenvolvimento Sustentado pela confiança e por todo o apoio concedido para a realização da Exposição Arqueológica Kiju Sakai e para implantação do Museu Histórico e Arqueológico de Lins, apresentado como estudo de caso. Aos diversos segmentos da comunidade linense por sua participação e parceria durante anos de trabalho. Aos meus companheiros de projeto Robson Rodrigues e Márcia Lika Hattori pela parceria, pelas reflexões e discussões. E à Camila por sua dedicação e seu comprometimento. Aos professores da Escola indígena Índia Maria Rosa por seu apoio e pelas reflexões e ensinamentos.

À minha mãe Eula pelo exemplo, apoio, suporte e carinho. Ao meu pai Israel pela confiança e companheirismo sempre. Aos meus irmãos Lívia e Daniel, ao David e à Beatriz pelo carinho, pela parceria, risadas e pelo apoio. À Livia também devo a formatação das referências, imagens e a leitura atenta desta tese. Vocês todos são os grandes responsáveis por este trabalho. E também a toda minha família, em especial pela torcida e pela compreensão, pois nem sempre pude estar com vocês em momentos muito importantes.

Aos meus amigos: Rafael, pela parceria, pelas peripécias que passamos juntos, pelas discussões, ensinamentos, pela amizade e pelo apoio nos momentos de desespero. Carol, por tudo, tudo mesmo, até pelos churrascos de cogumelo, crepes, fondues de queijo, pela neve, restaurantes coreanos pela América Latina... e em especial pelo sedex. Flávia, minha companheira de viagens, por todas nossas aventuras e risadas. Patrícia pelo companheirismo, amizade e dedicação. Marcinha, pelas discussões, risadas e parcerias, em tantos, tantos projetos. Fabio, por nossas conversas e aventuras mundo afora e pela possibilidade de escavar um sítio com instrumentos tão fantásticos e passar pela experiência única de tirar sedimento para datação de um canavial, e sem a minha trena! Verônica pelo companheirismo, amizade e ensinamentos. À Roberta, Joana, Selma, Juliana, Flávia, Camila, Andréia, Nashieli, Bertrand 
e tantos outros com os quais tive o prazer de conviver durante estes anos, seria impossível citar tanta gente. Obrigada pela amizade de todos vocês.

Ao Renato, por suas palavras escritas e considerações.

A todas as pessoas que de alguma forma contribuíram para realização deste trabalho, que acreditaram em mim ou que estiveram presentes na minha vida nestes anos, pois a cada uma delas devo um pouco do que sou. 
Quanto mais me capacito como profissional, quanto mais sistematizo minhas experiências, quanto mais me utilizo do patrimônio cultural, que é patrimônio de todos e ao qual todos devem servir, mais aumenta minha responsabilidade com os Homens (Freire 2001: 20). 


\section{RESUMO}

O presente trabalho busca refletir sobre a importância de uma abordagem interdisciplinar na Arqueologia, em especial acerca do papel do Turismo como disciplina útil e interessante para fomentar uma reflexão sobre projetos que visem a uma Arqueologia descolonizante e cumpridora de seu papel social. Neste estudo, outras duas disciplinas se mostram importantes, a saber, a Antropologia e a Museologia. A partir de exemplos internacionais que propiciam elementos para incrementar o debate sobre como o Turismo Arqueológico vem sendo pensado em outras realidades, realiza-se aqui uma breve análise acerca de atrativos arqueológicos nacionais desenvolvidos para o Turismo Convencional brasileiro. Essas discussões permeiam três estudos de caso em que o Turismo inserido em projetos de Arqueologia foi propulsor de reflexões sobre os bens patrimoniais, dando ensejo a possibilidades de sustentabilidade e inclusão social para as comunidades envolvidas.

Palavras-chave: Arqueologia; Turismo Arqueológico; Gestão do Patrimônio; Inclusão Social; Educação Patrimonial. 


\begin{abstract}
The present work aims to ponder on the importance of an interdisciplinary approach in Archaeology, in particular on the role of Tourism as an useful e interesting discipline to stimulate reflections about projects with the aim of a decolonizing Archaeology which is aware of its social role. In the study carried out in this thesis other two disciplines are important, namely Anthropology e Museology. From international examples that provide elements to instigate a debate over how Archaeological Tourism has been understood in other realities, here is presented a brief analysis of archaeological attractions developed for the national archaeological Conventional Tourism in Brazil. These discussions permeate three case studies in which Tourism, inserted in archaeological projects spurred reflections about patrimonial property, creating opportunities of sustainability e social inclusion for the communities involved.
\end{abstract}

Keywords: Archaeology; Archaeological Tourism; Archaeological Heritage Management; Social Inclusion; Archaeological Heritage Education. 


\section{SUMÁRIO}

VOLUME I

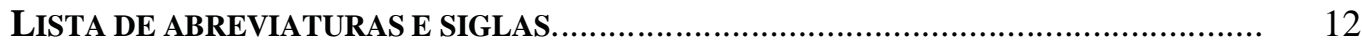

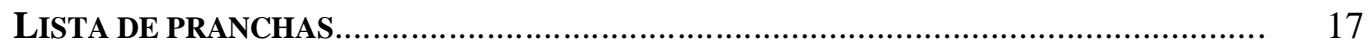

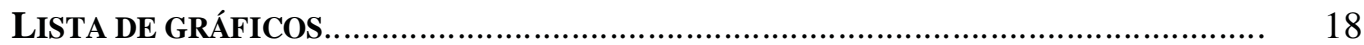

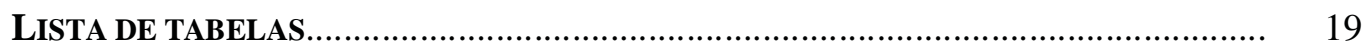

APRESENTAÇÃo DE UMA TRAJETÓRIA................................................................ 20

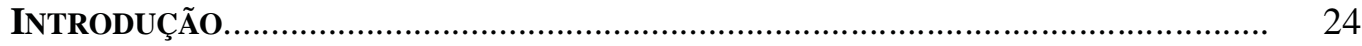

CONSIDERAÇÕES SOBRE SUSTENTABILIDADE QUE DIALOGAM COM ESTA TESE......... 26

INCLUSÃO SOCIAL E DIÁLOGOS COM A VALORIZAÇÃO DA DIVERSIDADE

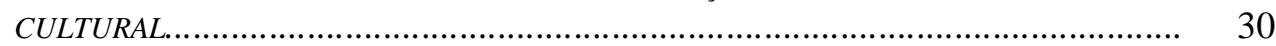

OBJETIVOS. TESTANDO UMA HIPÓTESE......................................................... 32

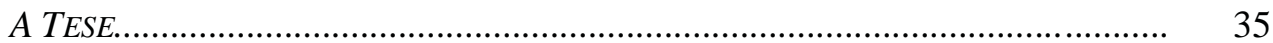

CAPÍTULO 1 - DIÁLOGOS INTERDISCIPLINARES....................................................... 38

1.2 TURISMO, PATRIMÔNIO E PLANEJAMENTO PARTICIPATIVO................................. 52

1.3 O OLHAR ANTROPOLÓGICO DA ALTERIDADE SOBRE A DIVERSIDADE................. 62

1.4 A MUSEOLOGIA E OS BENS PATRIMONIAIS COMO HERANÇA............................... 75

1.5 BENS ARQUEOLÓGICOS E NOVAS PRÁTICAS SOCIAIS: APROXIMAÇÕES INTERDISCIPLINARES

Capítulo 2 - O CONTEXto internacional: Turismo Arqueológico em DUAS REALIDADES DA AMÉRICA LATINA............................................................... 91

2.1 MÉXICO: NAÇÃO, NEOLIBERALISMO E MOBILIZAÇÕES SOCIAIS.......................... 92

POLÍTICAS PÚBLICAS E PROJETOS CULTURAIS NA HISTÓRIA DO PATRIMÔNIO ARQUEOLÓGICO MEXICANO.

MOVIMENTOS SOCIAIS E USOS CRÍTICOS DO PATRIMÔNIO ARQUEOLÓGICO NO ÂMBITO DO NEOLIBERALISMO. 
TURISMO E APROPRIAÇÃO SIMBÓLICA DE REFERENCIAIS INDÍGENAS PARA A INDÚSTRIA CULTURAL

MOCHE, INCA E CHIMÚ: CONFLITOS SOCIAIS E DESIGUALDADE NAS POLÍTICAS DE USO DO PATRIMÔNIO ARQUEOLÓGICO PERUANO.

TURISMO CULTURAL E NOVOS DISCURSOS SOBRE A “CULTURA INDÍGENA” E O PASSADO PRÉ-HISPÂNICO.

Capítulo 3 - Arqueologia e Turismo Convencional no conteXto BRASILEIRO.

POLÍTICAS PÚBLICAS NA HISTÓRIA DO TURISMO DO BRASIL......

O TURISMO ARQUEOLÓGICO NA SERRA DA CAPIVARA. 150

SÃO MIGUEL DAS MISSÕES - ONDE ESTÃO OS INDÍGENAS?

\section{VOLUME I I}

Capítulo 4 - Estudo de Caso 1: O Turismo E A relação entre COMUNIDADE E PATRIMÔNIO NO SERTÃO ALAGOANO.

ALGUMAS REFLEXÕES SOBRE OS PROGRAMAS REALIZADOS NO SERTÃO ALAGOANO.

CAPítulo 5 - Estudo de Caso 2: o TuRismo em Programas de EduCAÇão Patrimonial na Arqueologia Preventiva - um eXemplo no sudoeste BAIANO.

ETAPA 1 - DIAGNÓSTICO PRELIMINAR DO TERRITÓRIO PATRIMONIAL. 205

ETAPA 2 - CONCEPÇÃO DO PROGRAMA DE EDUCAÇÃO PATRIMONIAL. 205

ETAPA 3 - PRIMEIRA ETAPA DE INTERVENÇÃO. 206

EtaPAS 4 e 5 - RETROALIMENTAÇÃo Do Diagnóstico e do PROGRAMA E ESTRUTURAÇÃO DO MATERIAL DE APOIO.

ETAPA 6 - SEGUNDA ETAPA DE INTERVENÇÃO....... 212

AVALIAÇÃO DAS ATIVIDADES REALIZADAS.

ETAPA 7 - ACOMPANHAMENTO DA MULTIPLICAÇÃO DO CONHECIMENTO E DO INVENTÁRIO TURÍSTICO. 
RESULTADOS DO PROCESSO DE INVENTARIADO 243

ETAPA 8 - FECHAMENTO DO PROGRAMA DE EDUCAÇÃO PATRIMONIAL. 246

AÇÕES DE CONTINUIDADE 246

ALGUMAS REFLEXÕES SOBRE AS AÇÕES REALIZADAS NO SUDOESTE BAIANO. 250

Capítulo 6 - Estudo de Caso 3: O Museu Histórico e Arqueológico de LINS.

AVALIAÇÃO DA EXPOSIÇÃO ARQUEOLÓGICA KIJU SAKAI. 268

UM MUSEU EM PROCESSO. 275

A CONCRETIZAÇÃO DOS SONHOS DE TANTOS GRUPOS. 288

ALGUMAS REFLEXÕES SOBRE O PROCESSO DE FORMAÇÃO DO MHA DE LINS.......... 297

Algumas CONTRIBUIÇÕES AO TURISMO ARQUEOLÓGICO 306

REFERÊNCIAS BIBLIOGRÁFICAS. 312

ANEXO 1 - GLOSSÁRIO (MINISTÉRIO DO TURISMO 2007) 339

ANEXo 2 - MAPA do CiRCUITO TURÍSTICO dO SERTÃo ALAGOANO. 342

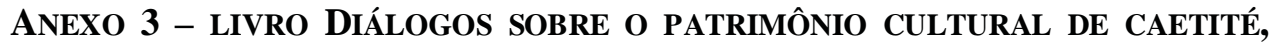
GUANAMBI E IGAPORÃ E FOLDER. 343 


\section{LISTA DE ABREVIATURAS E SIGLAS}

ABCEL - Associação Beneficente Cultural e Esportiva de Lins

AECID - Agência Espanhola de Cooperação Internacional para o Desenvolvimento

APAE - Associação de Pais e Amigos dos Excepcionais

APRA - Aliança Popular Revolucionária Americana

Areté - Centro de Estudos Helênicos do estado de São Paulo

BNDES - Banco Nacional de Desenvolvimento Econômico e Social

CAPES - Coordenadoria de Aperfeiçoamento de Pessoal de Nível Superior

CDHU - Companhia de Desenvolvimento Habitacional e Urbano do Estado de São Paulo

CEIMAM - Centro de Estudos Indígenas Miguél Angel Menedez

CETEP - Centro Territorial de Educação Profissional do Sertão Produtivo

CHCM - Centro Histórico da Cidade do México

CICATUR - Centro Interamericano de Capacitação Turística

CICLA - Conselho de Integração Cultural Latinoamericana

CONACULTA - Conselho Nacional para a Cultura e as Artes

CONAMA - Conselho Nacional do Meio Ambiente

CONCYTEC - Conselho Nacional de Ciência e Tecnologia

CNTur - Conselho Nacional do Turismo

CTI - Centro de Trabalho Indigenista

ECA-USP - Escola de Comunicações e Artes da Universidade de São Paulo

EJA - Educação para Jovens e Adultos

EMBRATUR - Instituto Brasileiro de Turismo

ETEC - Escola Técnica Estadual

FAPESP - Fundação de Amparo à Pesquisa de São Paulo

FATEC - Faculdades de Tecnologia de São Paulo

FNA - Fondo Nacional Arqueológico

FUMDHAM - Fundação Museu do Homem Americano

FUNAI - Fundação Nacional do Índio

GESTA - Grupo de Estudos em Temáticas Ambientais

GLO - Resultados Genéricos de Aprendizado

GT - Grupo de Trabalho

IBAMA - Instituto Brasileiro do Meio Ambiente e dos Recursos Naturais Renováveis 
IBGE - Instituto Brasileiro de Geografia e Estatística

ICMBio - Instituto Chico Mendes de Conservação da Biodiversidade

ICOFOM - International Committe For Museology

ICOM - International Council of Museums

IDH - Índice de Desenvolvimento Humano

IHGB - Instituto Histórico e Geográfico Brasileiro

INAH - Instituto Nacional de Antropología e Historia

INC - Instituto Nacional de Cultura

INCRA - Instituto Nacional de Colonização e Reforma Agrária

IPHAN - Instituto do Patrimônio Histórico e Artístico Nacional

LEEH - Laboratório de Estudos Evolutivos Humanos

LFMZAAH - Lei Federal de Monumentos y Zonas Arqueológicos, Artísticos e Históricos

MAE-USP - Museu de Arqueologia e Etnologia da Universidade de São Paulo

MASB - Museu do Alto Sertão da Bahia

MAX - Museu de Arqueologia de Xingó

MHA - Museu Histórico e Arqueológico

MHOL - Movimento Homossexual de Lima

MINOM - Movimento Internacional da Nova Museologia

MITINCI - Ministério de Indústrias, Turismo, Integração e Negociações Comerciais

Internacionais

MST - Movimento Sem Terra

MTM - Museu do Templo Mayor

MTUR - Ministério do Turismo

OMT - Organização Mundial do Turismo

ONGs - Organizações não governamentais

ONU - Organização das Nações Unidas

PAC - Plano de Aceleração do Crescimento

PCNs - Parâmetros Curriculares Nacionais

PEA - Proyectos Especiales de Arqueología

PIB - Produto Interno Bruto

PIT - Posto de Atendimento ao Turista

PNE - Programa Nacional de Ecoturismo

PNMT - Programa Nacional de Municipalização do Turismo

PNSC - Parque Nacional Serra da Capivara 
PNT - Plano Nacional de Turismo

PRODETUR - Programa de Apoio ao Desenvolvimento Regional do Turismo

PROECOTUR - Programa de Desenvolvimento do Ecoturismo na AmazôniaLegal

PROMPERÚ - Comisión de Promoción del Perú para la Exportación y el Turismo

SAA - Society for American Archaeology

SAB - Sociedade de Arqueologia Brasileira

SEBRAE - Serviço Brasileiro de Apoio às Micro e Pequenas Empresas

SECTUR - Secretaria de Turismo

SEDESU - Secretaria de Desenvolvimento Sustentado

SENAI - Serviço Nacional de Aprendizagem Industrial

SEPLAN - Secretaria de Estado do Planejamento e do Orçamento

SISEM - Sistema Estadual de Museus

SPI - Sistema de Proteção ao Índio

T.I. - Terra Indígena

TRC - Turismo Rural Comunitário

UFBA - Universidade federal da Bahia

UNCED - Comissão Mundial sobre o Meio Ambiente e o Desenvolvimento

UNEB - Universidade do Estado da Bahia

UNESCO - Organização das Nações Unidas para a Educação, a Ciência e a Cultura.

UNESP - Universidade Estadual Paulista

UNICAMP - Universidade Estadual de Campinas

UNIMEP - Universidade Metodista de Piracicaba

UNISALESIANO - Centro Universitário Católico Salesiano Auxilium

UNSAAC - Universidade Nacional San Antonio Abaddel Cusco

USP - Universidade de São Paulo

WAC - World Archaeological Congress

WMF - Word Monument Fund

WTTC - Conselho Mundial de Viagens e Turismo 


\section{LISTA DE PRANCHAS}

Prancha 01. Imagem dos povos indígenas nos materiais de divulgação Elaborados pela EMBRATUR.

Prancha 02. Ações educativas realizadas em 2007, no Sertão Alagoano. 175

Prancha 03. Proposta de Roteiro Arqueológico 176

Prancha 04. Projeto Circuito Arqueológico do Sertão Alagoano. 178

Prancha 05. Oficinas realizadasno Sertão Alagoano. 181

Prancha 06. Oficina realizada na Comunidade da Cruz - Delmiro Gouveia......

Prancha 07. Oficinas do Programa de Educação Patrimonial desenvolvido no sudoeste baiano

Prancha 08. Visitas Técnicas aos Sítios Arqueológicos.

Prancha 09. Palestras do Programa de Educação Patrimonial desenvolvido no sudoeste baiano

Prancha 10. Trabalhos referentes às palestras, avaliados a partir da metodologia proposta pelo GLO.

Prancha 11. Trabalhos referentes às ações de multiplicação, avaliados a partir da metodologia proposta pelo GLO..

Prancha 12. Exposição Arqueológica Kiju Sakai. 266

Prancha 13. Trabalhos referentes à Exposição Kiju Sakai, avaliados a partir da metodologia proposta pelo GLO...

Prancha 14. Ações realizadas durante o processo de formação do Museu Histórico e Arqueológico de Lins.

Prancha 15. Alguns painéis da Exposição Externa do Museu Histórico e Arqueológico de Lins..

Prancha 16. Alguns Painéis da Exposição de Longa Duração do Museu Histórico e Arqueológico de Lins.

Prancha 17. Alguns painéis da Exposição de Curta Duração do Museu Histórico e Arqueológico de Lins.. 


\section{LISTA DE GRÁFICOS}

Gráfico 01. Temáticas que aparecem nas composições das Palestras........................ 236

Gráfico 02. Formas das composições das Palestras............................................... 237

Gráfico 03. Temáticas que aparecem nas composições das ações de multiplicação................................................................................................... 240

Gráfico 04. Formas das composições das ações de multiplicação............................ 241

Gráfico 05. Distribuição das fichas do Inventário da Oferta Turística de Caetité.... 243

Gráfico 06. Distribuição das fichas do Inventário da Oferta Turística de

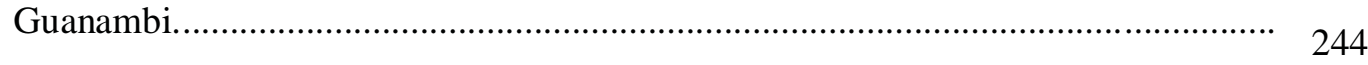

Gráfico 07. Distribuição das fichas do Inventário da Oferta Turística de Igaporã.... 245

Gráfico 08. Temáticas que aparecem nas composições sobre a exposição................ 272

Gráfico 09. Formas das composições sobre a exposição............................................ 272 


\section{LISTA DE TABELAS}

Tabela 01. Esquema das Ações Realizadas no Âmbito dos Projetos Desenvolvidos em Alagoas...................................................................................

Tabela 02. Esquema das Ações Realizadas no Âmbito do Programa de Educação Patrimonial.

Tabela 03. Esquema do Planejamento Estratégico do Turismo no Programa de Educação Patrimonial.

Tabela 04. Processo de Formação do Museu Histórico e Arqueológico de Lins. 296 


\section{APRESENTAÇÃO DE UMA TRAJETÓRIA}

As discussões realizadas no decorrer deste texto partem de um olhar interdisciplinar, em larga medida pautado por minha trajetória acadêmica e profissional. Deste modo, para que o leitor possa compreender melhor as escolhas teóricas e metodológicas que norteiam este trabalho considero crucial discorrer sobre o caminho que percorri entre o Turismo, a Antropologia, minha passagem pela Museologia e a atuação hoje na Arqueologia.

Desde o segundo ano de minha graduação em Turismo pela Pontifícia Universidade Católica de Campinas (PUCC), passei a ter interesse pela inserção do patrimônio cultural como atrativo turístico e sua aproximação com a sociedade. Concluí a graduação em 1999, com a apresentação de uma monografia sobre a Casa de Cultura de Lins, em que discuti a implantação e estruturação da entidade, as possibilidades de visitação turística e a importância de sua relação com a comunidade na qual estava inserida.

Com o término da graduação desenvolvi uma série de atividades na área do Turismo que me propiciaram uma percepção mais aguçada sobre os elementos responsáveis pela eleição e construção de símbolos e destinos turísticos que passaram a representar cidades, estados e o próprio Brasil como lugares receptivos de turistas. Após travar contato com o antropólogo peruano Mario Salas, compreendi que uma aproximação com a Antropologia auxiliaria o Turismo a entender de que maneira o patrimônio cultural se inseriu - e se insere — na construção de "imaginários” como produtos, bem como as vantagens e os problemas gerados a partir da apropriação turística do patrimônio.

Assim, ingressei como mestranda em Antropologia Cultural no Instituto de Filosofia e Ciências Humanas (IFCH) da Universidade Estadual de Campinas (Unicamp) sob a orientação do Professor Dr. Omar Ribeiro Thomaz. Minha dissertação, intitulada "EMBRATUR: formadora de imagens da nação brasileira”, teve como objetivo investigar e analisar a atuação da EMBRATUR, órgão governamental então responsável pela regulamentação do setor turístico nacional, enquanto entidade fornecedora e divulgadora de determinadas imagens da nação e da cultura brasileira. O estudo abrangeu 40 anos de história do instituto, enfatizando tanto as representações de "Brasil" que ao longo do tempo a EMBRATUR produziu, fixou, reproduziu e legitimou como aquelas que foram objeto de transformação, contextualizando-as vis-à-vis as políticas turísticas oficiais. Meu intuito, pois, era compreender de que maneira os diversos bens patrimoniais foram incluídos na construção da imagem turística nacional. 
Em janeiro de 2006 fui convidada pelo Rotary Internacional e pelo governo peruano para realizar um trabalho de análise e construção da imagem turística de algumas cidades da costa norte do Peru, no âmbito dos preceitos da sustentabilidade e da humanização do Turismo. Vale ressaltar que os resultados desse projeto foram publicados em um livro de minha autoria, A Humanização do Turismo: uma experiência de voluntariado (Alfonso 2006). O objetivo dos municípios envolvidos no projeto era sua inserção na Ruta Moche, circuito turístico alternativo às rotas incas que atualmente são as maiores receptoras de Turismo no Peru.

No decorrer do mencionado projeto tive a oportunidade de trabalhar diretamente com o patrimônio arqueológico daquela região peruana, na tentativa de compreender de que modo o Turismo se apropriou de tal conjunto de bens naturais e culturais e quais as relações da comunidade com o patrimônio arqueológico regional e nacional e com a atividade turística propriamente dita. Entrei em contato com diferentes populações, cidades e, principalmente, com os diferentes conflitos envolvendo as comunidades, os arqueólogos, os turistas e os empresários que investiam na atividade turística. De volta ao Brasil comecei a refletir acerca de duas questões, a saber, qual é ponto de inserção do patrimônio arqueológico na construção do imaginário brasileiro; e por que razão o Turismo não faz - ou pouco faz -- uso desse patrimônio como forma de atrativo ou de representação do país ou ainda como possibilidade de geração de melhorias de ordem socioeconômica para as comunidades. Destarte, passei a me interessar pela Arqueologia "no" e "do" Brasil e sua relação com a sociedade.

Meu primeiro contato com o Museu de Arqueologia e Etnologia da Universidade de São Paulo (MAE - USP) ocorreu no ano de 2006, e desde então passei a desenvolver uma série de atividades voltadas à Arqueologia com o objetivo de ampliar meus conhecimentos na área. Em 2007 prestei o processo seletivo do Programa de Pós-Graduação do MAE - USP para ingressar no doutorado em Arqueologia. A partir daí desenvolvi uma série de trabalhos de campo, alguns no âmbito de projetos acadêmicos e da Arqueologia preventiva. Além disso, cursei várias disciplinas e realizei trabalhos de laboratório.

Minha matrícula foi efetivada em 2008 com um projeto de tese intitulado “Arqueologia e Turismo: uma proposta de modelo de roteiro de Turismo Arqueológico para o interior do estado de São Paulo”, sob a orientação da Professora Maria Cristina Oliveira Bruno. O projeto previa a elaboração de modelos de roteiros turísticos direcionados à incorporação do patrimônio arqueológico do estado de São Paulo e buscando a aproximação entre o Turismo e a Arqueologia por meio da musealização. Assim se fortaleceu meu interesse pela Museologia. 
Minha participação em uma série de atividades curriculares e extracurriculares, bem como a realização de estágios no Brasil e no exterior — com mais de uma dezena de trabalhos apresentados em congressos e eventos nacionais e internacionais - trouxeram à baila novos elementos que incrementaram minha perspectiva e permitiram que eu pudesse pensar de maneira diferente a interação entre Arqueologia, Turismo e sociedade.

O interesse geral da pesquisa extrapolou o citado projeto; após levar a cabo um extenso levantamento bibliográfico, cumprir estágios e analisar alguns estudos de caso, pude constatar que a tese permitiria discussões mais amplas, que, sim, envolvem os museus e a Museologia, porém incluem também outra gama de aspectos que não poderiam ser desconsiderados ou tidos como de menor importância.

Essa mudança de viés fez com que a tese se aproximasse de outros vetores da extroversão do conhecimento arqueológico e interação com a sociedade. Foi nesse contexto que elaborei um novo projeto de tese denominado "Arqueologia e Turismo: sustentabilidade e inclusão social", inserido na linha de pesquisa "História da Arqueologia e perspectivas teóricas contemporâneas”, sob a orientação do professor Pedro Paulo A. Funari.

A perspectiva de Funari - segundo a qual o Turismo Arqueológico faz parte das concepções mais atuais que giram em torno das interações entre Arqueologia e comunidade visando a uma ciência mais inclusiva - vai ao encontro do que minha própria trajetória intelectual vinha indicando. Para o autor, o Turismo e a Arqueologia intersectam-se em nível epistemológico, pois “o discurso e a narrativa arqueológicos sobre o passado são uma preocupação presente", sendo o Turismo "a busca por uma experiência com a diferença, no tempo e espaço” (Funari 2009). Com o final do século XX e no decorrer do século XXI, cada vez mais a Arqueologia é desafiada por questões relacionadas à mercantilização do patrimônio e dos sítios arqueológicos, bem como pela necessidade de interação da disciplina com atores e áreas diversos, o que torna as discussões sobre essas temáticas relevantes, pertinentes, atuais e extremamente necessárias. Assim, a interação entre a Arqueologia e o Turismo é parte integrante das perspectivas teóricas contemporâneas da disciplina, e é no âmbito desse novo enfoque que se apresenta o texto da presente tese, para cuja elaboração realizei um levantamento bibliográfico sistemático, debruçando-me sobre um sem-número de dissertações, teses, livros e periódicos de relevância nacional referentes a aspectos relevantes das temáticas aqui esmiuçadas.

Conforme já mencionado anteriormente, com o intuito de fomentar o debate com pesquisadores nacionais e internacionais interessados no desenvolvimento do Turismo Arqueológico realizei estágios no exterior, bem como publiquei e apresentei artigos em 
congressos e periódicos no Brasil e no exterior, o que foi de inestimável valia para uma reflexão mais amadurecida acerca do eixo temático aqui discutido. 


\section{INTRODUÇÃO}

Ao tratar dos estudos da realidade material das sociedades, por muito tempo a Arqueologia esteve atrelada a nichos específicos e assuntos dialógicos ao contexto em que se inseria, sendo muitas vezes utilizada como instrumento de legitimação e justificativa de projetos políticos. Segundo Shepherd (2002: 194), a relação entre a Arqueologia e o colonialismo, por exemplo, foi marcada por uma interdependência de conhecimento e de poder, pois se por um lado os processos políticos e econômicos do colonialismo serviram para a abertura de novos territórios, por outro a Arqueologia se converteu em poderosa forma de validação de projetos coloniais. Se muitas vezes as Arqueologias colonialistas subestimaram as conquistas das sociedades nativas, as Arqueologias nacionalistas tenderam a fazer o oposto. A preocupação generalizada com o passado desempenhou papel importante na retórica nacionalista e anticolonial (Shepherd 2002: 196).

Assim como o Turismo, desde seus primórdios a Arqueologia se desenvolveu a partir de posturas de cunho elitista, "associada às classes altas, ao imperialismo e à aristocracia” (Funari 2009). Inicialmente o “estudo das coisas antigas” foi pensado a partir dos museus, que eram espaços de guarda, fruição e poder. Apenas muito recentemente passou a ganhar importância o caráter social da disciplina, enfatizando-se a relevância de temas como o estudo das relações de poder, o engajamento dos arqueólogos com as comunidades nativas e a relação da Arqueologia com a sociedade em geral (Funari 2009). A disciplina também passou a voltar sua atenção para questões políticas e éticas relacionadas ao saber e ao trabalho arqueológicos.

No caso do Brasil, nos últimos anos houve um aumento considerável das pesquisas arqueológicas, uma vez que leis federais, estaduais e municipais concernentes ao patrimônio propiciaram a inserção da Arqueologia em projetos de desenvolvimento em todo o país, em sua maioria. Em sua maioria esses projetos partem da iniciativa privada, no âmbito do que denominamos Arqueologia de Contrato, Arqueologia Preventiva, Arqueologia de Resgate ou de Salvamento. O atual debate e os trabalhos realizados pelas empresas de Arqueologia de Contrato permitem definir ferramentas e estratégias voltadas à sustentabilidade socioambiental em um contexto capitalista. “Arqueólogos podem contribuir significativamente para este processo auxiliando na coesão da comunidade, ao construir elos entre o presente e o passado, ao preservar história e tradição, valorizando o patrimônio cultural” (Funari e Robrahn-González 2005). A principal questão ética, também inserida nessa 
discussão, está relacionada à inclusão da comunidade no discurso e na prática arqueológica a comunidade entendida não apenas como o conjunto dos habitantes locais, mas também grupos étnicos, alunos e o público em geral (Funari e Robrahn-González 2005).

A legislação brasileira que regulamenta a Arqueologia Preventiva estabelece em caráter obrigatório a Educação Patrimonial como meio de aproximar a Arqueologia da sociedade. Contudo, o conceito vem sendo compreendido de maneira problemática. A expressão “Educação Patrimonial” remete a uma metodologia que no Brasil é confundida com múltiplos trabalhos de extroversão e divulgação de projetos e escavações que, na maioria das vezes, apresentam alcance limitado, tanto em número de pessoas quanto em informação, além de serem pontuais e momentâneos. No país são poucas as iniciativas que preveem projetos interessados na democratização do conhecimento arqueológico e na real troca com a sociedade em geral.

Nesse intento de aproximação com a sociedade o Turismo surge como importante aliado da Arqueologia. A atividade turística promove a divulgação do patrimônio, sua identificação pela população local, sua valorização e reconhecimento, o que gera a consciência da necessidade de sua preservação, além de seu potencial de propiciar melhorias socioeconômicas para a comunidade (Alfonso 2009). O Turismo vem desafiando os arqueólogos e pesquisadores ao se apropriar cada vez mais do patrimônio arqueológico e objetificá-lo, seja por meio dos museus, artefatos, sítios ou narrativas. O Turismo pode ser utilizado como opção criativa com vistas à promoção de uma maior interação dos arqueólogos com a comunidade, dando ensejo a "uma mais profunda compreensão não apenas do passado, mas dos usos presentes do passado” (Funari et al. 2009), o que acarreta melhorias para o futuro.

Por muito tempo o Turismo foi alvo de críticas por se disseminar pelo mundo de forma não planejada e irresponsável, causando destruição nos lugares em que foi sendo implantado. Nas últimas décadas a atividade turística passou a levar em conta seu papel social, e a tendência atual é a de criação de propostas de desenvolvimento sustentável - que, de acordo com a Assembleia das Nações Unidas de 1983, apresenta três eixos principais: o crescimento econômico, a igualdade social e o equilíbrio ecológico e cultural.

A sustentabilidade prevê o distanciamento do Turismo de Massa, também conhecido como Turismo Convencional, e o incentivo a outro tipo de Turismo, denominado nãoconvencional. As principais diferenças entre ambos são a forma de planejamento e implantação da atividade, a motivação de viagem do turista e o respeito às comunidades receptoras, ao meio ambiente e às diferenças culturais e sociais. 
Para a Organização Mundial do Turismo (2002) o desenvolvimento turístico sustentável é um processo contínuo, que exige ações de manejo que possam prever e minimizar impactos negativos e maximizar os benefícios, introduzindo medidas preventivas ou, quando necessário, ações de correção e alteração (Alfonso 2009). A estruturação da atividade turística de forma sustentável requer um planejamento estratégico direcionado, realizado de forma integrada e participativa em todas as suas etapas e oferecendo os meios adequados para sua implantação e administração. O planejamento participativo não pode ser visto como uma consulta ou meramente como a sensibilização ou conscientização turística da comunidade, mas deve atender às exigências e solicitações das partes envolvidas; em outros termos, deve propiciar uma troca. Levando em conta os conflitos, a ausência de metodologias disponíveis e principalmente as peculiaridades locais, Cardozo (2008) afirma ainda que não se trata de um processo simples. Vale ressaltar que aqui o termo "sociedade" é entendido não como um único público, mas sim uma gama de públicos muito diversos, tanto culturalmente quanto socialmente. É no cerne dessas questões explicitadas que esta tese se insere.

\section{CONSIDERAÇÕES SOBRE SUSTENTABILIDADE QUE DIALOGAM COM ESTA TESE}

Nas últimas décadas o discurso da sustentabilidade tem se fortalecido, em especial com os debates que envolvem questões relacionadas ao meio ambiente e ao desenvolvimento social em sentido amplo. Segundo Lima (2002: 1), "sustentabilidade” "tornou-se uma palavra mágica, pronunciada indistintamente por diferentes sujeitos, nos mais diversos contextos sociais e assumindo múltiplos sentidos”. Faz-se importante destacar que sustentabilidade e desenvolvimento sustentável não são sinônimos. O debate sobre sustentabilidade, que se iniciou na Ecologia e extravasou para a Economia, favoreceu a evidenciação da necessidade de um novo paradigma social econômico ou novo estilo de desenvolvimento - uma vez que o atual se mostrou insustentável --, constituído de diversas perspectivas, uma delas a da conscientização da finitude dos recursos (Baroni 1992: 24).

As bases do discurso da sustentabilidade remontam a meados da década de 1970, em especial aos movimentos sociais em defesa da ecologia, "nas conferências internacionais promovidas pela Organização das Nações Unidas (ONU) para debater os temas do meio ambiente e do desenvolvimento; nos relatórios do Clube de Roma e, mais ou menos diretamente, nos trabalhos de autores pioneiros, de diversos campos, que refletiram sobre as mesmas questões” (Lima 2002: 3). Em 1973, Ignacy Sachs formulou os princípios básicos da noção de Ecodesenvolvimento, estratégia alternativa de desenvolvimento pautada pela 
articulação da preservação ambiental, participação social e promoção econômica. "Perseguia, com especial atenção, meios de superar a marginalização e a dependência política, cultural e tecnológica das populações envolvidas nos processos de mudança social” (Lima 2002: 3).

A sustentabilidade se firmou como estratégia de desenvolvimento no Relatório Brundtland, resultado do trabalho da Comissão Mundial (da ONU) sobre o Meio Ambiente e o Desenvolvimento (UNCED). Tal comissão partiu de uma concepção multidimensional para definir desenvolvimento sustentável de forma a não apenas atender às demandas do presente, mas também não comprometer a capacidade das gerações futuras de atender a suas próprias demandas (Lima 2002: 4). O texto ressalta a ligação entre economia, tecnologia, sociedade e política e enfatiza a necessidade de uma nova postura ética que tenha por objetivo a responsabilidade, tanto entre as gerações quanto entre os membros contemporâneos da sociedade. Mesmo calcada em muitas ideias do Ecodesenvolvimento, a Comissão Brundtland apresentou resultados bem diferentes, que ressaltaram uma ênfase econômica e tecnológica, despolitizando a proposta de Sachs (in Lima 2002: 3).

A Agenda 21 foi um dos documentos resultantes da Conferência sobre Meio Ambiente e Desenvolvimento, realizada no Rio de Janeiro em 1992, que reforçou o uso do termo “desenvolvimento sustentável”. Tal agenda caracterizou um documento ético em que os países signatários assumiram um compromisso com o meio ambiente, discutido a partir dos debates iniciados na Conferência de Estocolmo, em 1972. A agenda objetivou a promoção de "uma mudança de atitude pelos países ricos em relação ao seu modelo de crescimento econômico no sentido de torná-los mais responsáveis com as questões relativas à degradação ambiental” (Pereira 2009: 42). O conceito de desenvolvimento sustentável passou a ter conotação extremamente positiva, e entidades como a Organização das Nações Unidas para a Educação, a Ciência e a Cultura (UNESCO) passaram a adotá-lo para representar uma nova filosofia de desenvolvimento que combina eficiência econômica, justiça social e prudência ecológica.

O discurso da sustentabilidade surgiu como substituto possível do discurso do desenvolvimento econômico, difundido pelos países capitalistas no contexto da Guerra Fria e que entrou em crise na década de 1970. O desenvolvimento sustentável consistia de uma estratégia voltada para remediar contradições descortinadas pelos modelos de desenvolvimento anteriores. Para seus defensores, o crescimento da economia não reduz "as irracionalidades do sistema capitalista”, vindo o desenvolvimento sustentável a ser considerado um novo modelo de produção, que abrange questões esquecidas ou negligenciadas pelos modelos anteriores - caso das questões sociais, políticas, culturais e 
ecológicas (Pereira 2009: 41). Assim, o conceito de desenvolvimento econômico sustentado passou a expressar uma preocupação não apenas econômica, mas também socioambiental. Foi então a questão ambiental que forneceu o ingrediente que "ampliava a crítica social na direção de uma revisão mais abrangente do modelo de civilização ocidental e da necessidade de incorporar ao debate os múltiplos aspectos que constituem as relações entre a sociedade e seu ambiente" (Lima 2002: 3).

Assim, conforme foi se tornando mais complexo e se difundindo socialmente, o debate sobre a sustentabilidade acabou sendo apropriado por diferentes segmentos sociais, que passaram a revesti-lo de significação de acordo com seus próprios valores e interesses. Lima (2002: 7) apresenta duas matrizes teóricas que polarizam diferentes tendências do debate: a primeira favorece as dimensões econômicas e tecnológicas do desenvolvimento sustentável, considerando que o mercado pode se desenvolver de forma sustentável por meio de mudanças como o aumento do uso de tecnologias limpas, a contenção do crescimento da população e o incentivo às ações ecologicamente orientadas. Vale ressaltar que essa primeira matriz foi pautada pelas discussões da Comissão Brundtland e tema de debates nas grandes conferências internacionais e nos programas governamentais.

A segunda matriz vem contradizer a primeira. Dialoga com os princípios da democracia participativa, priorizando conceitos da equidade ambiental. Considera que a sociedade civil deve não apenas ser partícipe, mas também ter papel predominante nas discussões sobre sustentabilidade social em suas respectivas localidades. Essa matriz se divide em duas tendências com relação ao papel do Estado: uma vertente defende o papel do Estado como subordinado à sociedade civil, outra vê o Estado como agente indispensável na transição para a sustentabilidade. Esta última tendência defende que a "sociedade civil isolada não é capaz de se contrapor às forças do mercado e na suposição de que o ambiente, como patrimônio público, não pode ser preservado sem a ação normativa e política do Estado” (Lima 2002: 7-8). Seus defensores argumentam que não é possível haver sustentabilidade sem a "incorporação das desigualdades sociais e políticas e de valores éticos de respeito à vida e às diferenças culturais” (2002: 8). É com esse conceito de sustentabilidade que a presente tese dialoga.

Lima discute ainda alguns pontos positivos e algumas dificuldades e problemas do discurso de sustentabilidade. Como ponto positivo está a estratégia multidimensional que incorpora uma visão de futuro, considera a dimensão política e social dos problemas ambientais e incentiva a multidisciplinaridade no estudo da relação sociedade-ambiente. Contudo, camufla os conflitos existentes entre diferentes segmentos - capitalistas, 
socialistas, conservacionistas, ecologistas, empresários, ambientalistas, ONGs, movimentos sociais, agências governamentais, entre outros (Lima 2002: 5). Para o autor, as críticas ao discurso de sustentabilidade dizem respeito às dificuldades de concretização de metas em uma sociedade que é orientada pelo mercado, favorece a concentração e as desigualdades sociais e parece contrária à distribuição de riquezas e oportunidades. "A experiência tem demonstrado, por numerosas evidências, que o mercado é um perverso gestor das disparidades sociais” (Lima 2002: 6).

Outro fator que o autor considera como obstáculo é a dificuldade de conciliar a participação social e o crescimento econômico em projetos de sustentabilidade direcionados pelo mercado. Lima aponta a dificuldade de se estabelecer, em sociedades divididas pela desigualdade, relações mais horizontais que permitam uma democracia participativa capaz de garantir que as comunidades participem de forma consciente do processo decisório sobre seus rumos sociais.

Por outro lado, os pesquisadores do Grupo de Estudos em Temáticas Ambientais (GESTA) defendem, por exemplo, o licenciamento ambiental como um dos poucos instrumentos de participação efetiva das comunidades nos processos decisórios, uma vez que possibilita, pelo menos em teoria, a participação social por meio das audiências públicas. Essa premissa é interessante para uma reflexão sobre o licenciamento como uma instância possibilitadora do envolvimento da Arqueologia nas discussões de desenvolvimento sustentável, e em especial com o envolvimento do Turismo, a partir de metodologias participativas e de ferramentas antropológicas para a compreensão e o diálogo com as comunidades.

Atualmente os processos de sustentabilidade devem ser entendidos como processos voltados "para a promoção social, econômica e cultural do ser humano, na forma de gerenciamento para utilização dos recursos naturais e/ou culturais de um local ou região, mediante o envolvimento da população e participação de diversos parceiros institucionais" (Pereira 2009: 43). Os três fatores essenciais que devem ser articulados para que a sustentabilidade local aconteça são: os recursos, as comunidades e as organizações governamentais e não governamentais. Para Pereira, as metodologias que almejam a sustentabilidade devem levar em conta uma política participativa, ou seja, a participação da comunidade na identificação das necessidades e na priorização de ações que tragam melhorias na qualidade de vida em suas localidades (Pereira 2009: 43). É justamente com o debate sobre essas metodologias participativas que esta tese procura dialogar. 
INCLUSÃO SOCIAL E DIÁLOGOS COM A VALORIZAÇÃO DA DIVERSIDADE CULTURAL

Outros conceitos caros a esta tese são os termos "exclusão" e "inclusão” social. Vale ressaltar que são termos abstratos, caso não acompanhados de um adjetivo que os qualifique, como discutiu Ribeiro (2006: 157). O conceito de “exclusão social” foi entendido, a princípio, como noção relacionada ao capitalismo, modo de produção estruturalmente excludente. Assim, a exclusão social era compreendida como o resultado de um processo de acumulação. Segundo Sposati, foi este processo que possibilitou a naturalização do termo "exclusão" no senso comum, “como apregoava Adam Smith sobre a naturalidade da diferença e do processo seletivo da natureza” (Sposati 1999: 1-2). Diferentemente de Smith, Marx entendeu a exclusão social como uma lógica do processo de produção, e não como uma condição individual.

Os debates sobre exclusão social ganham força no final do século $\mathrm{XX}$, não mais apenas relacionados à economia, como anteriormente, porém agora envolvendo outros aspectos. A excludente lógica capitalista "ganha novos contornos e se torna uma questão social, cultural e ética” (Sposati 2006: 1). Territórios, etnias, migração, cidadania são alguns dos conceitos inseridos nos debates sobre exclusão e inclusão social, em especial no que se refere às políticas públicas. Contudo, para Sposati ainda há uma banalização dos conceitos exclusão e inclusão social, diretamente relacionada a seu uso como sinônimo e substituto de conceitos como: “opressão, dominação, exploração, subordinação, entre outros tantos, que derivam do exame crítico da luta de classes da sociedade salarial” (Sposati 2006: 1).

Outra crítica da autora é sobre a relação exclusão/inclusão. Como ela, vários autores criticam as análises que definem inclusão a partir do conceito de exclusão, colocando "seres humanos posicionados como sujeitos que excluem, de um lado, ou como objetos que são excluídos, de outro” (Ribeiro 2006: 157). Outros criticam as definições embasadas no dualismo do universo, "como se alguém pudesse ser considerado incluído ou excluído totalmente, isto é, de todos os setores e espaços da sociedade” (Passerrino e Momtardo 2007: 3). Ninguém é totalmente excluído ou incluído. Sposati enfatiza que confrontar a exclusão com a inclusão coloca "a análise no patamar ético-político, como questão de justiça social, possibilitando a descoberta de novas identidades e dinâmicas sociais (Sposati 2006: 1). Para a autora a análise dos conceitos envolve também o significado que estes têm para o sujeito, ou para os sujeitos, que os vivenciam” (Sposati 2006: 1).

Ladeira e Amaral (in Passerrino e Momtardo 2007: 4) deslocam o foco do debate inclusão versus exclusão e definem esses termos a partir da ideia de processo, considerando 
diferentes situações no decorrer da vida. Passerrino e Momtardo também consideram a inclusão social como processo "que busca satisfazer necessidades relacionadas com qualidade de vida, desenvolvimento humano, autonomia de renda e equidade de oportunidades e direitos para os indivíduos e grupos sociais que em alguma etapa da sua vida encontram-se em situação de desvantagem com relação a outros membros da sociedade” (2007: 4).

A luta pelo direito à diferença também marcou intensamente o debate sobre inclusão social no final do século XX. "A noção de igualdade neste contexto passou a estar diretamente ligada à noção de equidade” (Sposati 1999: 2). Para Aranha, o conceito de inclusão social se fundamenta em uma filosofia que reconhece e aceita a diversidade, garantindo o acesso "de todos a todas as oportunidades, independentemente das peculiaridades de cada indivíduo e/ou grupo social” (2000: 2).

De acordo com Dupas (2000: 65), a inclusão social conta com dimensões como educação, saúde, lazer, religião, cultura, etnia, política, economia, entre outras. Em um sentido mais amplo, para Moreira a inclusão envolve propiciar condições para que todos os cidadãos sejam cidadãos plenos, dotados de meios e mecanismos de participação política (2006: 11). Em uma compreensão de Inclusão Social cara a esta tese, para Sposati (in Passerrino e Momtardo 2007: 4), a inclusão social está direcionada à busca pelo acesso a quatro utopias básicas: autonomia de renda (o suprir das necessidades básicas, sociais e culturais), desenvolvimento humano (o desenvolver das capacidades intelectuais e biológicas), equidade (o garantir da igualdade de direitos e oportunidades e o respeito à diversidade humana) e qualidade de vida (democratizar acessos à preservação do homem, da natureza e do meio).

A inclusão social, pensada a partir de instituições e ações culturais, somente será alcançada com o reconhecimento de que o cultural está inextricavelmente ligado ao social (Dodd e Sandell in Aidar 2002: 15). Para Aidar (2002: 54), a exclusão social opera em três níveis: a exclusão de sistemas políticos, que resulta na perda de direitos; a exclusão de redes de assistência social e mercado de trabalho, que gera a perda de recursos; e a exclusão de elos familiares e comunitários, que resulta na deterioração de relações pessoais - em todos o patrimônio e as instituições culturais podem servir como instrumentos de inclusão. Para Bobbio a consolidação da democracia não se dá "apenas pelo aprimoramento da democracia representativa, mas especialmente pela democratização das relações sociais” (in Tojal 2007: 44). As ações culturais devem valorizar a diversidade, buscando a inclusão de diferentes grupos sociais e favorecendo uma reflexão crítica sobre um mundo onde (con)vivem diferentes vozes. Devem, assim, reconhecer a "diversidade cultural e social trabalhando a 
favor não somente da comunicação de seus objetos culturais, sob o ponto de vista multicultural” (Tojal 2007: 29), mas também protagonizar um processo de transformação social, contribuindo para "a democratização social e cultural por meio dos processos de inclusão social” (2007: 45). A relação da Arqueologia com as comunidades é diretamente afetada por noções de inclusão social, uma vez que é papel da Arqueologia mais democrática, ética, participativa e não-elitista romper com essas fronteiras e colaborar para direitos mais uniformes a recursos não-renováveis, um deles o próprio patrimônio arqueológico. Essas reflexões pautaram diferentes discussões da presente tese.

\section{OBJETIVOS. TESTANDO UMA HIPÓTESE}

O presente trabalho busca refletir sobre o papel do Turismo como disciplina interessante para a discussão acerca de projetos que visem a uma Arqueologia descolonizante e que cumpra seu papel ético e social. A partir do pressuposto de que no contexto brasileiro pouco se discute a relação entre Turismo e Arqueologia, esta tese foi desenvolvida com o objetivo principal de demonstrar que o Turismo participativo pode fornecer elementos e metodologias que auxiliem a Arqueologia na democratização do patrimônio arqueológico e no repensar da forma como as pesquisas arqueológicas vêm sendo desenvolvidas no Brasil.

Para isso, o ponto de partida foi a realização de uma pesquisa bibliográfica sistemática em publicações de relevância nacional, a fim de demonstrar os diálogos e debates envolvendo tentativas de relacionar o Turismo e a Arqueologia levados a cabo ao longo do tempo no Brasil. O mote era relacionar o Turismo Sustentável Participativo à Antropologia Aplicada, à SocioMuseologia e à Arqueologia Pós-Processual, com o objetivo de traçar caminhos para uma atuação mais ética e democrática do arqueólogo. A fim de explicitar os pontos positivos e negativos resultantes das tentativas de aproximar o Turismo da Arqueologia, aqui serão apresentados e analisados exemplos concretos de contextos nacionais e internacionais de países próximos da realidade brasileira.

No âmbito desses exemplos, nesta tese consta um levantamento oficial divulgado pelo Ministério do Turismo sobre os atrativos arqueológicos desenvolvidos dentro dos preceitos do Turismo Convencional, e são apresentados estudos de caso que abordam a inserção do Turismo participativo em projetos de Arqueologia pensados dentro dos preceitos do Turismo Não-Convencional no Brasil. Com essa discussão pretende-se, por fim, apresentar diretrizes que favoreçam a relação entre Turismo e Arqueologia, buscando contribuir com a prática 
arqueológica em sua necessidade de interação com a comunidade e de preservação do patrimônio arqueológico.

Como um teste da hipótese de pesquisa que norteia esta tese — referente à escassez de estudos sobre a relação entre a Arqueologia e o Turismo no Brasil - , a metódica pesquisa bibliográfica realizada teve o intuito de investigar os diálogos e debates entre as duas áreas no decorrer do desenvolvimento das disciplinas no país. A premissa básica é a de que os principais periódicos nacionais, publicados por instituições historicamente ligadas à Arqueologia, poderiam oferecer uma interessante amostra de dados sobre a real participação do Turismo nas principais discussões acerca da Arqueologia nacional no decorrer do espaço de tempo de abrangência dos periódicos. Vale ressaltar que se trata de uma amostra, definida a partir da percepção de que existem outros periódicos nacionais sobre Arqueologia também relevantes, bem como poucos livros publicados sobre a temática -- alguns destes últimos inclusive citados ao longo da tese.

Para a pesquisa foram selecionados, então, periódicos publicados por duas das principais instituições ligadas à Arqueologia no Brasil, a saber: publicações do Museu de Arqueologia e Etnologia da Universidade de São Paulo (MAE - USP) e do Museu Paraense Emilio Goeldi - além do periódico da Sociedade de Arqueologia Brasileira (SAB).

Era importante que a pesquisa bibliográfica abrangesse também o principal periódico de Turismo nacional, a revista Turismo em Análise, editada pelo Departamento de Relações Públicas, Propaganda e Turismo da Escola de Comunicações e Artes da Universidade de São Paulo (ECA - USP). Vale ressaltar que a instituição possui o segundo mais antigo curso universitário de Turismo do Brasil. A inclusão do citado periódico se deu uma vez que se julgou necessária uma análise sobre os debates realizados pelo Turismo visando uma aproximação com a Arqueologia e uma compreensão mais ampla dando conta das tentativas de diálogo entre as duas áreas.

De modo a se obter um entendimento histórico da relação entre as duas disciplinas optou-se por analisar os periódicos desde seus primórdios, pois já no século XVIII o termo “Turismo" possuía seu sentido atual, relacionado a viagens ou deslocamentos (Beni 2006: 35). Foram consideradas as separações e fusões de diferentes publicações das citadas instituições no decorrer dos anos. Decidiu-se que para delimitar o universo da pesquisa seriam analisadas as publicações realizadas até o ano de 2007. Das quase 350 publicações analisadas, totalizando 2.405 textos - entre artigos, resenhas, teses e notas - , apenas 0,16\% discutem a relação entre o Turismo e a Arqueologia. A pesquisa evidenciou que as publicações das mais conceituadas instituições vinculadas à Arqueologia do Brasil - e que discorrem sobre temas 
de importância para a teoria e a prática arqueológicas desde o século XIX — apresentam um número ínfimo de textos relacionando as duas áreas do saber.

Dos mais de 300 textos concernentes ao Turismo publicados na revista Turismo em Análise, em forma de artigos, resenhas ou relatórios de eventos, apenas 0,66\% relacionaram o Turismo e a Arqueologia. Também sob a perspectiva do Turismo a pesquisa evidenciouassim como no caso das publicações das mais conceituadas instituições vinculadas à Arqueologia do Brasil -- que são poucas as reflexões sobre o diálogo entre o Turismo e a Arqueologia.

Para complementar os dados coletados pela pesquisa bibliográfica julgou-se interessante fazer um levantamento sobre os temas e discussões das reuniões científicas da Sociedade de Arqueologia Brasileira (SAB). Por tratar-se do principal evento nacional de Arqueologia, os debates realizados durante as reuniões são importantes para a compreensão da trajetória dos diferentes temas relacionados à atividade arqueológica. Para este estudo foram levantadas as apresentações que buscavam uma aproximação com o Turismo, no decorrer dos anos, até 2007. Uma vez que a área do Turismo não possui um congresso ou reunião nacional regular, não foi possível a realização de pesquisa semelhante com material da atividade turística.

Foi a partir da Reunião Científica da SAB de 1994 que o Turismo começou a aparecer, ainda que timidamente, como tema de discussão. Porém, foi em 2005 que o tema passa a ganhar relevância: o XIII Congresso da SAB teve como temática o trinômio "Arqueologia, Patrimônio e Turismo". Durante todo o evento, 14 comunicações e três simpósios apresentaram textos destacando o patrimônio arqueológico como atrativo turístico. Em 2007, concomitantemente ao XIV Congresso da SAB - "Arqueologia, Etnicidade e Território" ocorreram o I Congresso Internacional da SAB - "Arqueologia Transatlântica" - e o III Encontro do IPHAN e Arqueólogos, na cidade de Florianópolis. Durante os citados eventos foram apresentados 14 trabalhos envolvendo temas relacionados ao Turismo (SAB 2007).

O exame de todos os temas relacionados ao Turismo apresentados e debatidos durante os encontros nacionais de Arqueologia permite uma constatação interessante acerca da maneira como a comunidade foi envolvida nas discussões, na maioria das vezes apenas como beneficiária de melhorias socioeconômicas e mera participante passiva em trabalhos de Educação Patrimonial; pouco se falou no envolvimento ativo e efetivo da comunidade no processo de planejamento da atividade e como gestora do patrimônio arqueológico. A maioria dos trabalhos limitou-se apenas a apresentar os estudos de caso, sem refletir sobre o diálogo 
teórico entre as áreas ou debater sobre as metodologias de trabalho utilizadas em seus contextos de ação.

A pesquisa bibliográfica possibilitou ainda a percepção de que as discussões e debates que relacionam a atividade turística à prática arqueológica são bastante incipientes no país. Ao longo da história das duas disciplinas no Brasil pouco se discutiu ou se pensou em termos de ações conjuntas e interdisciplinares vinculando Arqueologia e Turismo. Vale ressaltar, porém, que mesmo com a deficiência de estudos e exemplos de planejamento sustentável envolvendo o patrimônio arqueológico nacional, por todo o Brasil notam-se iniciativas de implantação e desenvolvimento do Turismo Arqueológico, na maioria das vezes de maneira desordenada, com grandes possibilidades de prejuízo ao patrimônio.

Embora sejam importantes as iniciativas isoladas de turismólogos e arqueólogos no sentido de compreender e desenvolver produtos que apresentem o patrimônio arqueológico como atrativo, a presente tese procura demonstrar a necessidade de um conhecimento aprofundado em ambas as áreas, para que sejam compreendidos a fundo os possíveis benefícios, dificuldades e possibilidades da relação entre Turismo e Arqueologia. Assim, o que anima esta tese é o pressuposto essencial de que uma abordagem interdisciplinar que promova a intersecção entre as duas áreas possibilitará significativos avanços no debate sobre o Turismo Arqueológico no Brasil.

\section{A TESE}

Esta tese está organizada em seis capítulos, relacionando as abordagens teóricometodológicas adotadas a modelos práticos desenrolados a partir da práxis da socialização da Arqueologia. São apresentados projetos associados a diferentes conjunturas, públicas ou particulares, relacionados ao licenciamento ambiental ou a projetos governamentais, em diferentes contextos brasileiros e em contraponto a experiências internacionais.

O Capítulo 1 lança sobre a Arqueologia um olhar interdisciplinar, possibilitando uma aproximação entre correntes teóricas da Arqueologia, do Turismo, da Antropologia e da Museologia, levando em conta que as quatro disciplinas propiciam reflexões quanto ao patrimônio cultural, quanto aos usos presentes destes bens, às possibilidades de melhorias socioeconômicas das comunidades e sua inclusão social.

A fim de levantar dados comparativos e compreender melhor os diferentes contextos relacionados ao papel das políticas voltadas ao patrimônio cultural no que concerne à atuação do Turismo na gestão do patrimônio arqueológico, foram realizados estágios e visitas técnicas 
em dois países, México e Peru, cujos resultados serão apresentados como estudo de caso no Capítulo 2 desta tese. Ainda como parte da pesquisa in loco foram entrevistados arqueólogos e gestores de importantes sítios arqueológicos daqueles países abertos à visitação turística. Também foram igualmente analisados periódicos importantes dos citados países, com o intuito de averiguar os diálogos e debates envolvendo as relações entre o Turismo e a Arqueologia no contexto mexicano e peruano.

Efetuou-se um levantamento dos atrativos turísticos nacionais oficiais que envolvem Arqueologia, de modo a demonstrar as alterações na divulgação desses atrativos no decorrer dos últimos cinco anos, bem como as permanências e os abandonos de atrativos divulgados durante o período. O intuito é compreender os preceitos do desenvolvimento turístico convencional para o arqueoturismo no país. Esses dados estão descritos no Capítulo 3.

O primeiro estudo de caso é apresentado no Capítulo 4 e se refere à análise do “Projeto Circuito Arqueológico do Sertão Alagoano. Municípios de Piranhas, Olho D’Água do Casado e Delmiro Gouveia”, realizado pela Zanettini Arqueologia em 2008 e financiado pelo Instituto do Patrimônio Histórico e Artístico Nacional (IPHAN) de Alagoas (Zanettini Arqueologia 2007, Zanettini Arqueologia 2008). Tal estudo apresenta as ações desenvolvidas no sertão alagoano com o propósito de planejar um fluxo turístico já existente em sítios arqueológicos locais. Trata-se de um projeto relevante para se pensar o uso de metodologias participativas de Turismo em ações de Educação Patrimonial, possibilitando o envolvimento da comunidade em processos de inventariado e gestão de bens patrimoniais. As ações possibilitaram uma aproximação do patrimônio arqueológico de outros bens patrimoniais, sua inserção na identidade regional, bem como a percepção de diferentes compreensões do patrimônio arqueológico que interferiram diretamente em sua preservação.

O Capítulo 5 descreve as ações desenvolvidas no sudoeste baiano, nos municípios de Caetité, Guanambi e Igaporã, no âmbito do Programa de Educação Patrimonial do Programa de Prospecções e Resgate Arqueológico dos Parques Eólicos da Renova Energia (Zanettini Arqueologia 2011). O trabalho realizado no âmbito de um projeto de Arqueologia Preventiva também previu o uso de metodologias de planejamento turístico participativo como uma de suas frentes de ação. O capítulo descreve atividades realizadas com o objetivo de envolver diversos segmentos das comunidades nas reflexões sobre os bens patrimoniais no presente, valorizando uma abordagem pluralista destes bens. Também apresenta discussões sobre as possibilidades de projetos em Arqueologia preventiva que sejam adaptáveis a diferentes contextos. Outra discussão proposta neste capítulo diz respeito ao olhar do profissional de campo sobre as realidades locais, buscando discutir a pertinência do tema "Turismo" em 
projetos de Educação Patrimonial. Neste caso a temática aproximou os atores locais e incrementou os resultados do programa, que teve o Turismo enquanto mote disparador de reflexões. Os debates resultaram na criação de um grupo de atores locais, que hoje compõem um GT para a definição do Plano Museológico do Museu do Alto Sertão da Bahia, instituição em período de implantação.

No Capítulo 6 é apresentado um estudo de caso que discorre sobre a implantação do Museu Histórico e Arqueológico de Lins. A vontade de se desenvolver turisticamente fez com que o poder público investisse em ações educativas e na construção de um museu que possibilite a salvaguarda e a comunicação do patrimônio arqueológico. Todas as atividades educativas, as exposições e o Plano Museológico da instituição foram pensados pela própria comunidade por meio de ações participativas. O mesmo capítulo apresenta a realização de ações interdisciplinares voltadas para uma proposta pluralista e democrática, que envolve a inserção de novas narrativas à identidade regional, e busca apresentar as dificuldades e possibilidades do diálogo entre os diferentes atores sociais interessados pelos bens patrimoniais. O estudo ainda possibilita um repensar do fazer arqueológico. 


\section{CAPÍTULO 1 - DiÁLOGOS INTERDISCIPLINARES}

Este trabalho se pretende interdisciplinar.

Uma das principais características do método científico cartesiano é a fragmentação da realidade a ser estudada. Os principais elementos da forma de produção de saberes denominada cartesiana foram propostos pelo filósofo, físico e matemático francês René Descartes (1596 - 1650), que ressaltava que "o conhecimento racional implica a decomposição da coisa a ser conhecida por meio de uma série de operações que a reduziam às suas partes mais simples” (Almeida Filho 1997: 3). Conhecer implicava uma etapa inicial de fragmentação. A disciplinaridade restrita, também denominada monodisciplinaridade, é compreendida como uma estratégia de organização "histórico-institucional da ciência baseada na fragmentação do objeto e na especialização do sujeito científico, o pesquisador, cujo sucesso se realiza através de teorias e experimentos validados pela comunidade de pares científicos” (Porto e Almeida 2002: 337). Segundo Porto e Almeida, essa estratégia fez com que pesquisadores mantivessem seus estudos voltados a áreas específicas de atuação, forjando a divisão entre diversas áreas do conhecimento e disciplinas e gerando métodos específicos para a solução de problemas (2002: 336).

No final do século $\mathrm{XX}$, pesquisadores passam a tomar consciência da necessidade de “abrir a ciência a questionamentos em um nível mais global fundamental, sob pena de terem suas disciplinas transformadas em um mero repertório de técnicas e conhecimentos desde já superados" (Almeida Filho 1997: 6). Kuhn enfatiza que "as disciplinas científicas são conformadas historicamente por um dado paradigma, que compreende o conjunto de regras, princípios e instrumentos que permitem entender e classificar determinados fenômenos dentro de uma certa visão de mundo” (in Porto e Almeida 2002: 337). Ainda para o autor, os paradigmas evoluem "por meio de revoluções científicas, em consonância com novas demandas históricas e novos referenciais teóricos, onde os fenômenos são redefinidos através de novos paradigmas, que substituem os anteriores” (2002: 337). Em sua "investigação arqueológica” sobre a produção do conhecimento da medicina, Foucault (1977) demonstra como o olhar criado pela ciência possibilitou uma visão de mundo específico, um paradigma, ou "regime de verdade". Em suas pesquisas em sociologia do conhecimento, autores como Collins e Latour apontam para a subjetividade científica, demonstrando que os objetos científicos existem somente em relação “e que a ciência é a materialização de projetos sociais e políticos, sendo, portanto, uma construção humana, histórica e em permanente 
transformação” (Almeida in Porto e Almeida 2002: 337). Maturana, Varela e Sarnaja afirmam que cada vez mais a ciência se configura como uma "prática de construção de modelos, de formulação e solução de problemas num mundo em constante mutação" (in Almeida Filho 1997: 3).

Contribuições mais recentes sugerem uma ciência alternativa à estrutura hegemônica da ciência normal. Tal ciência teria caráter "reflexivo e integrador entre diferentes dimensões e saberes”. Para esses autores a separação entre sujeito e objeto constitui um profundo obstáculo para a construção de uma prática científica ética e democrática (Porto e Almeida 2002: 337). Eles propõem, assim, uma crítica aos limites da disciplinaridade restrita e da ciência normal, às suas características e suas consequências para a sociedade e o meio ambiente.

Dentre os principais elementos dessas críticas estão: o viés humanista, que busca um diálogo ecumênico e reflexivo entre as várias áreas do conhecimento, centrando a transformação em uma mudança de espírito dos próprios pesquisadores e do sistema de ensino; a crítica da complexidade, avaliação epistemológica à ciência contemporânea e que ressalta a temática da complexidade e da perspectiva sistêmica de forma a contribuir para o “aprofundamento teórico metodológico em torno das diferentes estratégias de integração disciplinar” (Porto e Almeida 2002: 337); e a crítica social, pautada pela noção de que a produção de conhecimento é analisada dialeticamente como instrumento de poder. Esta última serve tanto à "lógica de estruturação, dominação e reprodução social, por meio de um discurso "neutro" e despolitizador que demarca os territórios de especialistas técnicocientíficos”, quanto de instrumento de transformação na produção de uma nova ordem, em que "o que é marginal, subterrâneo e reprimido possa aparecer com força e se afirmar" (Coimbra in Porto e Almeida 2002: 337). Essa tendência tem como eixo as relações entre o sujeitos/pesquisadores e os objetos de estudo/sujeitos históricos e uma "sinergia entre produção de conhecimento e transformação social” (Porto e Almeida 2002: 337).

Para Almeida Filho (1997: 14), o processo de produção do conhecimento cientifico deve ser social, político-institucional, matricial e amplificado, sendo que a produção científica deverá viabilizar abordagens totalizantes, apesar de parciais e provisórias, capazes de "atravessar as fronteiras disciplinares" (1997: 9). Ainda para o autor, a organização convencional da ciência em disciplinas autônomas e por vezes estanques precisa ser "superada por novas modalidades da práxis científica, instaurando formas alternativas da disciplinaridade" (1997: 10). Para esta tese, consideramos a interdisciplinaridade, que pode ser entendida como a reunião de diferentes disciplinas articuladas em torno de uma mesma 
temática com diferentes níveis de integração, “uma cooperação de complementaridade sem articulações axiomáticas ou preponderância de uma disciplina sobre as demais” (Porto e Almeida 2002: 340).

Para Tambellini (in Porto e Almeida 2002: 340), a prática interdisciplinar, como reconstrução do saber constituído, poderia se desenvolver a partir de duas possibilidades: por um processo coletivo em equipes multiprofissionais ou "por trajetórias individualizadas por um sujeito de origem disciplinar que vai se apropriando de outros olhares, ampliando seu olhar original” (2002: 340). Garcia (in Porto e Almeida 2002: 340) considera que a interdisciplinaridade solitária, realizada por um "sujeito interdisciplinar" pode ser limitada, pois "o entendimento de sistemas complexos também dependeria de uma multiplicidade de enfoques e estudos especializados”. Almeida Filho, por sua vez, defende a formação de “operadores transdisciplinares da ciência” que tenham “o 'perfil anfíbio’ de transpassarem as fronteiras e facilitarem o diálogo entre as distintas disciplinas científicas na construção de campos teóricos e operacionais” (1997: 14).

Para Jupiassu (1976) e Morin (2001) fazem parte do trajeto de estudos interdisciplinares, o buscar de novos olhares, o transitar por diferentes áreas de conhecimento e a procura da contextualização e integração dos saberes, de forma a se obter uma maior compreensão do objeto de estudo. Para esses autores os estudos interdisciplinares devem propiciar um diálogo entre as diferentes áreas de conhecimento e reflexões sobre as tensões teóricas e metodológicas que porventura surgirem no transcorrer do processo da pesquisa interdisciplinar. Para Morin (2001: 63), as pesquisas interdisciplinares favorecem a contextualização e a integração dos saberes, possibilitando uma problematização mais ampla e um diálogo entre os diferentes conhecimentos de cada disciplina. Segundo o autor, na contemporaneidade os problemas são polidisciplinares, transversais, multidimensionais e globais, por isso estudos puramente disciplinares podem impedir a plena compreensão da essência dos problemas, pois a realidade é tecida em seu conjunto. Para Jupiassu (1976: 86) a interdisciplinaridade deve possibilitar a formação de um espaço de integração e convergência de disciplinas, pois implica trocas reais e intensas, conceituais e metodológicas. Trata-se de um processo conflituoso, pautado por incertezas, porém a aproximação de diferentes disciplinas favorece a ampliação de perspectivas de compreensão e análise da interação com um objeto de estudo, uma vez que as fronteiras disciplinares deixam de ser uma limitação, o que possibilita novos desafios e novas possibilidades para a solução de problemas contemporâneos. 
Destarte, esta tese se propõe a abranger conceitos e metodologias de quatro áreas científicas que se intersectam epistemologicamente, a saber, a Arqueologia, o Turismo, a Antropologia e a Museologia ${ }^{1}$. Na atualidade as quatro disciplinas demonstram preocupação sobre seu papel social - visando o bem-estar e melhorias da qualidade de vida das populações - e refletem sobre possibilidades de inclusão social por meio de elementos patrimoniais - objetos ou narrativas, materiais ou imateriais. Em suas discussões contemporâneas essas quatro disciplinas pensam as comunidades como capazes de gerir de forma sustentável o patrimônio, almejando não somente melhores condições socioeconômicas, mas novas práticas sociais. Assim, as questões teóricas que norteiam este trabalho são apresentadas a partir de uma análise essencialmente interdisciplinar.

\subsection{Por uma ArQueologia Engajada}

As mudanças ocorridas na Arqueologia na última década foram importantes para a autocrítica das práticas ainda coloniais que estavam ligadas à própria criação da disciplina. A Arqueologia vem buscando abandonar sua herança imperialista e de práticas colonialistas, que muitas vezes serviram a ditaduras e regimes fascistas, e passou a valorizar os aspectos sociais e públicos inerentes à disciplina (Funari et al. 2009: 120). Nesse sentido, cada vez mais os arqueólogos têm buscado questionar sua prática, repensando formas que possibilitem que a Arqueologia se torne uma ferramenta importante para a reinvenção de sociedades entendidas como “pós-ditatoriais, pós-soviéticas ou pós-socialistas, ou pós-colonialistas” (Little 2009: $128)^{2}$. Segundo Little, diante dessa realidade, recuperar a credibilidade é essencial para que a Arqueologia possa progredir, já que por muito tempo a disciplina foi tida "como uma prática que não é totalmente confiável, um julgamento devido mais aos poderes a que serve do que à ambiguidade de suas interpretações”3(Little 2009: 128).

Para Mortensen, as fronteiras da disciplina nunca estiveram tão fluidas como no presente:

“questões sobre projeto de pesquisa, a construção de narrativas sobre o passado e a comercialização do passado, todas ultrapassam fronteiras que explodem o que outrora eram

\footnotetext{
1 Vale ressaltar que a proposta pioneira de aproximação entre as Arqueologias pós-processuais e a SocioMuseologia é de Wichers (2010). Sua proposta pautou reflexões que serão apresentadas nesta tese.

2 "post-dictatorship, post-soviet or post-socialist, or post-colonialist” (Little 2009: 128).

3 "as a practice that is not altogether trustworthy, a judgment due more to the powers it serves than to the ambiguity of its interpretations” (Little 2009: 128).
} 
círculos hermenêuticos que tradicionalmente controlavam a produção do conhecimento

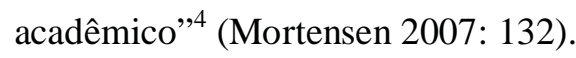

Nas últimas décadas, após a criação do World Archaeological Congress, em 1986, a Arqueologia "tem fomentado cada vez mais a diversidade e servido para estimular a responsabilidade social” ${ }^{\prime 5}$ (Funari et al. 2009: 120). A preocupação com o papel social do arqueólogo ganhou força com as discussões da Arqueologia Pós-Processual, inserida nos debates sobre o Pós-Modernismo, conceito difundido nas ciências humanas na década de 1980 e pautado pela noção de que as ciências seriam construções discursivas, incluídas em contextos sociais (Funari 2003: 50). Segundo Hodder, a Arqueologia Pós-Processual buscou analisar a inserção social da Arqueologia e dos arqueólogos, e seus interesses, tanto no passado, como no presente. Também foi chamada de Arqueologia contextual, pois se preocupa com o contexto social e histórico da produção do conhecimento, além de pensar o comprometimento do arqueólogo com grupos sociais (Carneiro 2009: 87).

Vale ressaltar que não é recente a constatação de que a Arqueologia tem um viés social, que vai além de sua contribuição para o conhecimento científico (Little 2009: 115). Segundo Morse (1994: 169), “tal discurso ético foi inflado por um interesse geral em conservação na década de 1960 e gerou o que agora é conhecido ou como gestão do patrimônio ou gestão de recursos culturais" ${ }^{6}$. Ainda para o mesmo autor, assim que os arqueólogos preocupados com a conservação do material arqueológico passaram a se dedicar à preservação do bem patrimonial, iniciou-se uma segunda discussão ética, agora sobre a relação entre arqueólogos e outros interessados nos vestígios do passado (Morse 1994: 169). Para Morse, foram estes dois grandes debates relacionados à ética da Arqueologia que resultaram em uma série de publicações visando "criar um padrão ético para a disciplina”" (Morse 1994: 169).

Segundo Joyce (2005: 254), foi a partir dos mais variados casos legais e políticos relacionados à repatriação de objetos arqueológicos que se intensificaram debates que provocaram uma reflexão mais substancial sobre diferentes questões éticas da disciplina junto à comunidade arqueológica. Entre os debates inserem-se discussões sobre "inclusão dos

\footnotetext{
4 "questions of research design, the construction of narratives about the past, e the marketability of the past, all straddle borders that explode the once hermeneutic circles that have traditionally controlled the production of scholarly knowledge” (Mortensen 2007: 132).

5 "has increasingly sponsored diversity e served to foster social responsibility" (Funari et al 2009: 120).

6 "such ethical discourse was ignited by a general interest in conservation in the 1960s e gave birth to what is now variously known as heritage management e cultural resource management” (Morse 1994: 169).

7 "to create an ethical standard for the discipline" (Morse 1994: 169).
} 
povos nativos, acadêmicos periféricos” ${ }^{8}$ (Funari 2009), bem como sobre o potencial e os reais benefícios que a Arqueologia pode gerar ao lidar com temas como justiça social, paz, fortalecimento de comunidades e preservação do meio ambiente (Little 2009: 115).

Apesar do crescente interesse das novas gerações de arqueólogos no que concerne às questões relacionadas às responsabilidades éticas da disciplina, entre os que se dedicam à Arqueologia ainda não existe um consenso acerca de "como balancear da melhor maneira as responsabilidades arqueológicas”9 (Morse 1994: 169). Para Rodriguez e Alfaro a pesquisa e a conservação do patrimônio arqueológico devem ter consequências sociais, econômicas e políticas concretas; o por que estudar e o para que conservar são temas eivados de possibilidades, e torna-se inevitável a criação de programas com tais fins, a serem implementados e utilizados como exemplos positivos (2003: 303).

A ideia de que a Arqueologia deve se destinar à preservação de restos materiais, conservando-os como recurso para pesquisas futuras sobre o passado humano, foi crucial para o desenvolvimento dos códigos de ética da Society for American Archaeology (SAA) (Joyce 2005: 260). A rapidez com que se dá a destruição de sítios arqueológicos no mundo contemporâneo fez com que os debates sobre preservação ganhassem maior urgência. Grande parte da pressão por uma ética relacionada à preservação esteve embasada no pressuposto de que novas metodologias possibilitarão aos futuros pesquisadores extrair outras informações dos vestígios arqueológicos.

Porém, segundo Joyce, se os primeiros códigos de ética assumiam que os interesses dos arqueólogos pautariam as ações e a disposição dos vestígios materiais do passado, para a SAA o entendimento contemporâneo de ética assume posicionamento diferente, evidenciando que os arqueólogos não ocupam uma posição privilegiada que lhes garanta serem os únicos responsáveis pela tomada de decisão sobre esses vestígios. "Essa remodelação da posição do arqueólogo como uma administração conjunta deve estimular arqueólogos a trabalhar com outras partes interessadas de modo a fomentar a tomada de decisões compartilhadas com relação aos materiais dos quais depende a prática arqueológica”10 (Joyce 2005: 260).

Seguindo essa ideia, Meskell (2007: 443) afirma que os arqueólogos estão cada vez mais conscientes de que são primordiais a inclusão e os debates com outros grupos interessados pelo patrimônio. Muitos arqueólogos perceberam que suas preocupações com a

\footnotetext{
8 "inclusion of indigenous people, peripheral scholars" (Funari 2009).

9 "how archaeological responsibilities are best balanced" (Morse 1994: 169).

10 "This reframing of archaeologist's position as one of joint stewardship should encourage archaeologists to work with other stakeholders to develop shared decision making concerning the materials on which archaeological practice depends” (Joyce 2005: 260).
} 
gestão e preservação do patrimônio arqueológico não devem desconsiderar as necessidades e preocupações de outros grupos. No âmbito dessa compreensão, o World Archaeological Congress (WAC) de 2008, realizado em Dublin, Irlanda, teve como um de seus temas as "Engaging Archaeologies” (“Arqueologias Engajadas”), baseadas na ênfase à participação da comunidade na gestão do patrimônio arqueológico e de outros patrimônios culturais. Vale citar como exemplo a série de estudos realizados no Arqueologia Grassroots, debate internacional crescente em nome de uma Arqueologia pensada de acordo com os preceitos da Organização das Nações Unidas para a Educação, Ciência e Cultura. A UNESCO, em seu programa cultural, definiu a criação de um movimento grassroots (termo inglês que pode ser traduzido como "movimento popular”, “local”, “de base” ou "da sociedade civil”), visando a conservação de culturas tradicionais, suas práticas, manifestações artísticas e ambiente, dentro dos preceitos de sustentabilidade. A proposta da UNESCO tem como um dos objetivos principais o incentivo à participação de indivíduos, comunidades, iniciativa privada e organizações de serviço em todos os projetos grassroots. Porém, a definição do termo “comunidade” ainda não está muito clara, nem mesmo a maneira de se alcançar essa participação (Pikirayi 2009: 125). Mais uma razão pela qual se tornam extremamente importantes os estudos voltados a essa temática.

Assim, as "Engaged archaeologies” propõem a adoção de uma abordagem pluralista para o estudo do passado (Pikirayi 2009: 125). Segundo Little, os interesses da ciência (Arqueologia) devem levar em conta os interesses da sociedade (humanidades); os arqueólogos devem ultrapassar esse limite, inserindo a disciplina no âmbito das necessidades e expectativas de cada comunidade (Little in Pikirayi 2009: 125). As comunidades devem participar das definições de parâmetros relevantes para a Arqueologia, e suas vozes devem ser ouvidas (Pikirayi 2009: 125), pois "parte do trabalho que a Arqueologia pode fazer é demonstrar a inclusão, incluindo todos no passado”"11 (Little 2009: 117).

As realidades políticas também interferem no quanto será exclusiva ou inclusiva a prática arqueológica e o discurso sobre os vestígios arqueológicos (Kohl 2004: 299). O reconhecimento dos múltiplos interessados pelo patrimônio, devido às "implicações políticas, culturais, sociais e econômicas do passado", pode gerar estratégias para garantir maior valorização e proteção do patrimônio para o futuro (Rodriguez e Alfaro 2003: 296). Essa noção legitima uma estratégia metodológica específica na Arqueologia, em que a reconstrução das sociedades passadas vem cumprir um papel especial sobre a cultura material

11 "part of the work that archaeology can do is demonstrate inclusion by including everyone in the past" (Little 2009: 117). 
das sociedades atuais. A conjuntura em que se desenvolve a prática arqueológica nos leva a indagar sobre o patrimônio cultural e sua relação com a população local. Tal compreensão é relevante para a disciplina, pois existe uma relação de pertencimento expressa por meio de sua valorização coletiva e que, consequentemente, envolve a preservação, a conservação e a proteção dos sítios arqueológicos como herança cultural (Poblete 2003: 332).

O envolvimento de diferentes atores faz-se importante e útil não apenas para os arqueólogos, mas também para a comunidade, em termos de educação e informação sobre patrimônio cultural e possibilidades de inclusão social por meio de elementos patrimoniais. Vale ressaltar que ela não deve apenas ser levada a cabo considerando arqueólogos e comunidades indígenas, mas sim arqueólogos e qualquer comunidade que conviva com tal patrimônio. Dessa forma almeja-se que a disciplina tenha uma conotação social mais aberta e mais próxima das pessoas, visando refletir sobre o "valor cultural" - e não meramente monetário - do patrimônio, o que resulta na proteção do conjunto de bens culturais (Carrasco et al. 2003: 325), bem como em transformações sociais.

Como bem expressou Lerner, a preservação do passado se faz não apenas salvando-se e cuidando-se dos vestígios materiais de culturas pretéritas, mas também por meio da reflexão sobre o passado (Lerner in Caldarelli, 2007: 167), o presente e o futuro a partir do patrimônio cultural. Levar o conhecimento arqueológico para a comunidade não serve apenas para angariar apoio aos arqueólogos, nem para que as pessoas tomem consciência de que o mundo é formado por pessoas e culturas diferentes, mas também para a compreensão de um processo profundamente imerso em ambiguidades, complexidades e incertezas, e para que se amplie a percepção de que essas características aplicam-se à vida em geral e não apenas à Arqueologia (Joyce 2005: 254). Segundo Little, os arqueólogos devem se comprometer com as comunidades para que possam usar o processo e os resultados da Arqueologia "para dar sentido às histórias comunitárias e criar comunidades mais fortes”12 (Little 2009: 116).

É papel do arqueólogo criar uma relação mais profunda entre as sociedades contemporâneas e o passado por meio da cultura material, pois muitas das "coisas do presente têm raízes no passado e podem ser claramente compreendidas à luz da História. O conhecimento das origens de um processo, evento, objeto, pessoa etc. estimula nossa curiosidade e gera múltiplas indagações”13 (Musteata 2009: 122). A Arqueologia pode suscitar um profundo histórico de questões contemporâneas, tais como imigração, tratamento

\footnotetext{
12 "to make sense of their community histories e to make stronger communities" (Little 2009: 116).

13 "present things have roots in the past e can be clearly understood in the light of history. Knowledge of the origins of a process, event, object, people etc. stimulates our curiosity e generates multiple questions" (Musteata 2009: 122).
} 
de estrangeiros, pobreza, fome e subsistência, escravidão e poder militar. Baseando-se nessas descobertas e abordagens, os arqueólogos podem buscar novas narrativas, capazes de contribuir para a melhoria -- presente e futura - tanto das condições ambientais como sociais das populações (Little 2009: 118).

Em muitos lugares no mundo as convenções acadêmicas foram incorporadas e internalizadas no léxico social das áreas por elas descritas, muitas vezes com efeitos muito reais para as pessoas do presente. Os modelos culturais propagados ao longo do tempo por arqueólogos, historiadores, linguistas, antropólogos culturais, geógrafos, entre outros, não permanecem como meras construções acadêmicas. Em vez disso, circulam no discurso público e recebem peso adicional na implantação de projetos nacionalistas e campanhas de Turismo. (Mortensen 2007: 132)

Assim, a Arqueologia deve deixar de ser exercida de forma a alienar o passado "como uma representação objetiva, um registro, entendendo que os sítios arqueológicos não estão mortos", que o passado e o presente se constroem mutuamente, dia a dia. "Pois o tempo não é linear nem progressivo, mas cíclico e imanente. Desse modo, os sítios arqueológicos não estão nem mortos nem são inertes” ${ }^{14}$ (Rodriguez e Alfaro 2003: 299).O papel do arqueólogo como cientista social está pautado pela busca da informação que lhe permita compreender coerentemente o comportamento social e a história que nos precedeu, superando a ideia de um passado morto e inerte.

O conhecimento do passado tem uma clara função social, que faz parte das ideologias que configuram nosso mundo e nossa identidade. Os arqueólogos devem se desprender da ingenuidade de uma neutralidade imposta pela ciência ocidental e pelo capitalismo e assumir que o seu trabalho tem efeitos sociais importantes, e que eles obviamente não têm motivo algum para cair em um paternalismo igualmente ingênuo, tampouco para deixar de fazer Arqueologia. Pelo contrário, trata-se de seguir fazendo ciência, porém com “consciência”, aceitando o diálogo e a participação dos outros, assim como mantendo uma postura crítica (Rodriguez e Alfaro 2003: 303). Somente dessa maneira a pesquisa arqueológica fornecerá uma peça fundamental capaz de auxiliar na compreensão da dinâmica do presente (2003: 302). A Arqueologia deve ter como meta a criação de mecanismos que the possibilitem cumprir sua função social, sem cumprir meramente o papel de "espectadora ascética dos fenômenos naturais e humanos” (2003: 301).

14 "Por lo que el tiempo no es lineal ni progresivo, sino cíclico e inmanente. De este modo, los sitios arqueológicos no están ni muertos ni son inertes” (Rodriguez e Alfaro 2003: 299). 
É no âmbito desse debate que a Arqueologia mundial cada vez mais se desloca em direção a um maior interesse no que tange ao desenvolvimento de projetos arqueológicos que busquem dar respostas ou contribuir para as discussões atuais, seja sobre o reconhecimento da disciplina, os interesses da comunidade, a gestão do patrimônio, a revitalização da identidade, o desenvolvimento econômico (Mortensen 2007: 133), o papel do indivíduo como ato social, a critica às desigualdades, os significados simbólicos dos vestígios arqueológicos que variam de contexto para contexto, bem como sobre questões políticas e éticas relacionadas ao saber e ao trabalho arqueológico (Funari, 2009). Os arqueólogos podem se beneficiar explorando "as histórias das transgressões de fronteiras que moldam seus conflitos atuais”15 (Mortensen 2007: 133). São essas as discussões das "Engaged archaeologies” ou “Arqueologias pósprocessuais”, no plural, como denominou Wichers (2010: 334).

No Brasil a disciplina seguiu trajetória semelhante; pois segundo Bastos (2007a: 299), a Arqueologia como disciplina "é filha mais nova da ciência pragmática, cartesiana, positivista, elitista e excludente”. Essa realidade começou a ser alterada quando, no final do século XX, o potencial social e político da Arqueologia começou a ganhar relevância e a ser antevisto no país (Lima, 1988). Ganhou força nas últimas décadas a denominada Arqueologia Pública, que "engloba um conjunto de ações e reflexões que objetiva saber a quem interessa o conhecimento produzido pela Arqueologia; de que forma nossas pesquisas afetam a sociedade; como estão sendo apresentadas ao público, ou seja, mais do que uma linha de pesquisa da disciplina, a Arqueologia Pública é inerente ao exercício da profissão” (Bezerra de Almeida 2002; Funari 2001). O termo Arqueologia Pública ganhou destaque com a publicação da obra Public Archaeology, de Charles McGimsey III, em 1972 (Carneiro 2009: 88). Segundo Silveira e Almeida, seu desenvolvimento no Brasil ainda é incipiente. A Arqueologia Pública propõe uma alteração na postura do profissional, o que gera muitas reações, em especial de arqueólogos mais conservadores que ainda não refletiram sobre "o impacto que causam na sociedade e sobre o fato de que assumir a perspectiva de uma 'Arqueologia baseada na comunidade, ${ }^{16}$ é apostar na sobrevivência da própria disciplina" (Silveira e Bezerra 2007: 85). No Brasil, esta se aproxima cada vez mais da Arqueologia de Salvamento, gerando debates e reflexões interessantes. Cabe ressaltar que a presente tese dialoga com esta perspectiva da Arqueologia e procura contribuir para as mencionadas reflexões.

\footnotetext{
15 "the histories of border crossings that shape their present day encounters" (Mortensen 2007: 133).

16 "based-community archaeology” (Silveira e Bezerra 2007: 85).
} 
O crescimento da Arqueologia de Contrato ou de Salvamento no Brasil propiciou uma série de debates sobre o fazer arqueológico e sobre o papel social e ético da Arqueologia. Para se compreender a importância desse ramo da disciplina no Brasil é interessante salientar que mais de $90 \%$ das pesquisas arqueológicas hoje desenvolvidas no país são de caráter preventivo ou de salvamento. Segundo Zanettini, a Arqueologia de Salvamento obteve um crescimento expressivo, em muito relacionado ao Plano de Aceleração do Crescimento (PAC) do Governo Federal, que previa até 2010 a implantação de mais de 1.800 empreendimentos de porte diverso, tais como "hidrelétricas, termoelétricas, rodovias, ferrovias, portos, linhas de transmissão, obras de saneamento básico e outras iniciativas de relevância econômica e social” (Zanettini 2005: 75).

A inserção da pesquisa arqueológica em projetos de salvamento, executada por empresas privadas, foi propiciada por leis federais, estaduais e municipais concernentes ao patrimônio.

O patrimônio cultural, que inclui o arqueológico, foi favorecido primeiramente por sua vinculação ao Licenciamento Ambiental. A resolução número 01 do CONAMA, em seu artigo $6^{\circ}$, inciso I, referente ao diagnóstico ambiental, dispõe sobre a Política Nacional de Meio Ambiente e considera o meio socioeconômico como:

“o uso e ocupação do solo, os usos da água e a socioeconomia, destacando os sítios e monumentos arqueológicos, históricos e culturais da comunidade, as relações de dependência entre a sociedade local, os recursos ambientais e a potencial utilização futura desses recursos”.

A resolução "estabelece os fundamentos dos estudos de impacto ambiental em qualquer forma de empreendimento e inclui o patrimônio cultural”.

A Constituição Federal do Brasil, em seu artigo 225, discorre sobre a proteção do meio ambiente e favorece definitivamente a preservação do Patrimônio Cultural e Arqueológico brasileiro, ao garantir que:

"todos têm direito ao meio ambiente ecologicamente equilibrado, bem de uso comum do povo e essencial à sadia qualidade de vida, impondo-se ao Poder Público e à coletividade o dever de defendê-lo e preservá-lo para as presentes e futuras gerações”. 
A Constituição favorece a preservação do patrimônio cultural a partir do reconhecimento da interferência humana na natureza, ao vincular o ser humano diretamente ao meio ambiente. A Carta Magna apresenta ainda uma tentativa de definir cultura ao reconhecer que nem toda forma de expressão merece ter o mesmo tratamento de salvaguarda e proteção.

Segundo Caldarelli, a legislação ambiental hoje vigente no Brasil surgiu para assegurar que "no processo de planejamento econômico e territorial do país, não sejam considerados apenas os interesses e necessidades do empreendedor, mas também outras variáveis, importantes no que concerne o bem-estar público”, dentre elas um ambiente mais “equilibrado e saudável e o respeito ao patrimônio cultural da sociedade brasileira” (2007: 156).

A proteção do patrimônio arqueológico brasileiro foi favorecida ainda com a Portaria 230 do Instituto do Patrimônio Histórico e Artístico Nacional (IPHAN), de 2002, documento que disciplinou os procedimentos arqueológicos a serem executados por qualquer requerente que deseje realizar empreendimentos potencialmente causadores de danos ao Patrimônio Cultural Arqueológico (Alfonso 2010). O suporte legal estabelece que para a obtenção da licença oficial de alteração no uso atual do solo no Brasil as empresas precisam "subsidiar levantamentos arqueológicos, de modo a identificar o impacto de seus projetos sobre os bens culturais que testemunham o passado da nação” (Caldarelli 2007: 157).

Segundo Zanettini “nunca se escavou tanto (bem ou mal), nunca se publicou tanto (com ou sem substância), inúmeros são os campos de investigação que encontraram solo fértil para lançarem suas raízes. Fala-se sobre Arqueologia Pública, da Arqueologia Forense, da Arqueologia Subaquática, do Turismo Arqueológico, socialização do conhecimento, dentre outros”. O mesmo autor julga que se ampliou o debate em torno de temas capitais para a disciplina, como a preservação e destinação de acervos e a educação, "constituindo estas algumas das linhas de ação/reflexão surgidas e/ou ampliadas no contexto de expansão do mercado" (Zanettini 2005: 75). Os projetos e ações realizados nos últimos anos dentro da Arqueologia de Salvamento propiciaram assim uma série de debates sobre diferentes temas relacionados ao saber e ao fazer arqueológico: questões que envolvem políticas de acervos, a relação entre a pesquisa acadêmica e as empresas de Arqueologia, as limitações de tempo e dinheiro dos projetos de salvamento, a formação e capacitação de mão de obra, entre outros. Esses debates visam ainda definir ferramentas e estratégias voltadas à sustentabilidade socioambiental num contexto capitalista. 
Dentre várias outras questões éticas inseridas nestas discussões destacam-se ainda as possibilidades de inclusão social por meio da Arqueologia. Para Bastos “a inclusão social poderá se valer da preservação e assumir compromissos ao lado da classe arqueológica com o patrimônio arqueológico” (2007a, 298). Outra forma de inclusão que também merece destaque é a incorporação da comunidade no discurso e na prática arqueológica.

Como meio de aproximar a Arqueologia da sociedade, a legislação que regulamenta a Arqueologia de Salvamento estipula o caráter obrigatório da Educação Patrimonial. A proposta chegou ao Brasil por meio de um seminário organizado por Horta em 1983, mas desde então vem sendo compreendida de maneira problemática no país. A Educação Patrimonial é uma metodologia organizada de maneira "a sistematizar as ações educacionais desenvolvidas, principalmente, no âmbito das instituições museológicas brasileiras (Carneiro 2009: 122), e que também vem se estruturando como um campo de conhecimento que “congrega diferentes reflexões e estratégias, desde que atreladas ao universo de produção e divulgação do conhecimento a partir do patrimônio cultural” (Carneiro 2009: 122). Contudo, no Brasil essa metodologia vem sendo confundida, principalmente em projetos de salvamento, com propostas e ações de divulgação e extroversão de escavações e de trabalhos realizados pelas empresas.

O campo da Educação Patrimonial tem sido conflituoso, um "território em litígio, aberto para trânsitos, negociações e disputas de sentidos. Orientações, tendências e metodologias diversas estão em jogo nesse território” (Carneiro 2009: 126). “Os programas de Educação Patrimonial ainda são considerados apenas como uma obrigatoriedade Legal e não como uma ação imprescindível, parte inexorável da pesquisa arqueológica. Esta mudança de mentalidade é algo que vem se transformando lentamente" (Carneiro 2009: 130). Na maioria das vezes a Educação Patrimonial vem sendo realizada por meio de propostas de alcance limitado, tanto em número de pessoas quanto em informação, além de serem meramente pontuais ou tópicas. Sabe-se de casos em que se considerou "ação educativa” a distribuição de doces para alunos do ensino público, por exemplo. Nos relatórios entregues ao IPHAN é possível verificar que, no país, são poucas as iniciativas que preveem projetos realmente preocupados não apenas com a democratização do conhecimento e da prática arqueológica, mas que favoreçam debates e reflexões relevantes junto à sociedade (Hattori 2011).

A democratização do conhecimento arqueológico vem sendo discutida por vários autores no Brasil. Pardi e Bastos, entre outros, enfatizam que o conhecimento produzido pelos arqueólogos brasileiros permanece restrito à divulgação entre seus pares, realizada, usualmente, por meio de apresentações e discussões em seminários ou congressos científicos 
ou por meio de textos acadêmicos ou relatórios obrigatórios entregues ao IPHAN - e que em seguida ficam guardados nas estantes de bibliotecas especializadas ou arquivos, sem que a sociedade entre em contato com os resultados dos trabalhos ou discussões propostas. Para Bastos (2007), no Brasil a Arqueologia não tem se preocupado com a gestão "totalizante do patrimônio arqueológico", não contempla a democratização do conhecimento adquirido e geralmente apenas "produz para pares, e pares específicos, notadamente sem nenhuma transversalidade”.

É importante compreender que democratizar o conhecimento arqueológico não é apenas levar à sociedade informações sobre o trabalho do arqueólogo ou possibilitar que membros da comunidade local participem das atividades de escavação de sítios arqueológicos. Tampouco realizar ações pontuais e ineficientes julgando-as exemplos de Educação Patrimonial sem que haja um processo planejado de continuidade dos trabalhos, de atualização das informações e avaliação dos resultados.

Segundo Carneiro, a Educação Patrimonial "não é por si só emancipadora ou repressora, fértil ou estéril, transformadora ou conservadora” por si (Carneiro 2009: 126). Ela deve favorecer que o contato com o patrimônio possibilite leituras, sua desconstrução e a revelação de possibilidades interpretativas. "Neste processo a Educação Patrimonial mais que uma possibilidade de capacitação quanto às leituras específicas (conhecimento científico, histórico e artístico), proporcionando as ferramentas e os códigos específicos desses campos do conhecimento" (Carneiro 2009: 128), deve estabelecer uma "possibilidade de diálogo, de conflito, onde possam vir à tona diferentes leituras e diferentes possibilidades de caminhos, tanto para quem é considerado público, quanto para o profissional que está conduzindo a ação” (Carneiro 2009: 128).

A Educação Patrimonial pode ser uma forma importante de ação, em que enfoques participativos e pluralistas favoreçam a inclusão social; mas, para tanto, novas formas e propostas de ações que propiciem a extroversão do conhecimento arqueológico fazem-se importantes e necessárias. São, assim, cruciais estudos de caso e pesquisas bem documentadas que possam servir de exemplo ou trazer informações que possibilitem debates que ajudem a Arqueologia brasileira a avançar em metodologias aplicáveis a projetos voltados à relação da Arqueologia com as comunidades. "O patrimônio encontra sentido em sua democratização e não em sua exclusão”17 (Ballar in Yrais 2009/2010: 257); em outras palavras, “a preservação de valores do patrimônio depende de sua deselitização, de sua apropriação social, de sua

17 “Lo patrimonial encuentra sentido en su democratización y no en su exclusión” (Ballar in Yrais 2009/2010: 257). 
promoção como interesse geral, da construção de um projeto coletivo e do fortalecimento do sentido de cidadania”18 (Ballar in Yrais 2009/2010: 257).

Os arqueólogos possuem várias versões de respostas sobre por que a Arqueologia é relevante hoje, com motivos que variam desde a conservação do meio ambiente e da diversificação das culturas ao incentivo a "perspectivas de longo prazo na tomada de decisões públicas, ao Turismo, à promoção da herança e identidade, ao combate ao racismo”19 (Little 2009: 115). Em sociedades altamente estratificadas, como em países da América Latina, “com o impacto aparentemente irreversível dos processos de globalização, subscritos a novas formas de imperialismo, dominação, racismo, exclusão”20 (Yrais 2009/2010: 256), o patrimônio cultural deve ser assumido como "o eixo do motor que dinamiza a ruptura de modelos econômicos de consumo e de mercado, e que a gestão do mesmo responda ao desenvolvimento sustentável endógeno das necessidades socioculturais das comunidades”21 (Yrais 2009/2010: 256). Por fim, quando se trabalha com patrimônio e seu significado no passado e no presente não se pode desconsiderar a importância da reflexão acerca de uma ação conjunta entre a Arqueologia e outras áreas ou atividades (Little 2009: 118).

\subsection{TURISMO, PATRIMÔNIO E PLANEJAMENTO PARTICIPATIVO}

Primeiramente, este trabalho julga de extrema importância explicitar que o Turismo não é sinônimo de visitação. Essa conceituação é primordial, uma vez que o equívoco consta de muitos trabalhos e relatórios acadêmicos escritos por pesquisadores de outras áreas, que tentam uma aproximação com o Turismo e que afirmam estar desenvolvendo projetos “turísticos” em diferentes partes do país. Considera-se Turismo não apenas o ato praticado pelos turistas, mas também o planejamento da atividade, o sistema comercial montado para atender aos visitantes, os serviços prestados dentro deste sistema e a série de relações econômicas, políticas e sociais que acontecem a partir do planejamento e do ato em si,

\footnotetext{
18 "la preservación de valores del patrimonio depende de su deselitización, de su apropiación social, de su promoción como interés general, de la construcción de un proyecto colectivo y del fortalecimiento del sentido de ciudadanía” (Ballar in Yrais 2009/2010: 257).

19“"long-term perspectives on public decision making, to tourism, to promoting heritage e identity, to battling racism” (Little 2009: 115).

20“con el impacto aparentemente irreversible de los procesos de globalización, suscritos a nuevas formas de imperialismo, dominación, racismo excusión” (Yrais 2009/2010: 256).

${ }^{21}$ “el eje del motor que dinamice la ruptura de modelos económicos de consumo y de mercado, y que la gestión del mismo responda al desarrollo sustentable endógeno de las necesidades socio-culturales de las comunidades” (Yrais 2009/2010: 256).
} 
praticado pelo turista. Segundo Barretto, o Turismo é um fenômeno social complexo e diversificado (1995: 17).

Sendo assim, as bases para o Turismo moderno, da forma como a área se configura hoje, foram estabelecidas no século XVI, com as chamadas Grand Tours, viagens organizadas como jornadas de estudos com duração de dois a três anos e empreendidas principalmente por jovens da nobreza e da burguesia inglesas. O Turismo, assim como a Arqueologia, teve início elitista. Entre os grupos mais abastados, além das viagens de estudos também ganharam relevância as jornadas voltadas a tratamentos de saúde, principalmente relacionadas às águas termais (1995: 43).

O Turismo só passa a ser consumido por um maior número de pessoas a partir da década de 1840, quando se iniciaram os pacotes organizados, com fretamentos de meios de transporte que possibilitaram a formação de grupos compostos por um grande número de passageiros, a elaboração e publicação de guias turísticos e roteiros e o aparecimento de profissionais dedicados exclusivamente à organização das viagens. Assim, a despeito da origem elitista o Turismo passa a chegar até a população em geral, sendo consumido também pelas massas (Barretto, 1995).

Porém, a atividade turística há muito vem sendo criticada pela maneira como tem se desenvolvido nas mais diferentes partes do mundo. Por se expandir de forma irresponsável, não planejada e exclusivista, tem causado sérios impactos nos locais em que é implantada, acarretando graves prejuízos aos bens patrimoniais culturais e naturais, bem como às comunidades envolvidas no processo. A relação entre Turismo e patrimônio tem geralmente sido analisada sob um ponto de vista essencialista e reducionista, em que a atividade turística é alvo de críticas como um fenômeno negativo que, por meio do processo de mercantilização, destrói ou modifica a autenticidade de culturas ou lugares (Meethan in Carman e Keitumetse 2005: 38).

A mercantilização cultural é entendida por muitos pesquisadores como "um processo em que se designa às formas e práticas culturais um valor monetário e se vendem como mercadorias no mercado turístico"22 (Wyllie in Salazar 2006: 105). A ideia da mercantilização da cultura se funda na crença de que o Turismo gera uma perda de autenticidade e significação cultural. Vale ressaltar que atualmente alguns pesquisadores consideram que essa forma de pensar o Turismo é semelhante à postura de alguns antropólogos paternalistas, que

\footnotetext{
22،un proceso en el que se asigna a las formas y prácticas culturales un valor monetario y se venden como mercancías en el mercado turístico” (Wyllie in Salazar 2006: 105).
} 
tentam proteger a "sua ${ }^{23}$ gente do presente" ${ }^{24}$ e os congelam em uma espécie de passado etnográfico (Salazar 2006: 105). O mesmo autor considera interessante constatar que muitos antropólogos mostram-se extremamente irritados ao ter de dividir o acesso à cultura com turistas “ignorantes ${ }^{25}$ ” (2006: 105). Tal postura é constante em diálogos entre antropólogos culturalistas e pesquisadores de Turismo e patrimônio.

A discussão foi levantada recentemente durante o Ecos del $53^{\circ}$ Congreso Internacional de Americanistas, evento realizado em julho de 2009 na Cidade do México. O simpósio envolveu um número considerável de pesquisadores da América Latina, estudiosos do patrimônio tangível e intangível. Durante a apresentação de trabalhos relacionados ao Turismo e à democratização do patrimônio cultural, alguns antropólogos posicionaram-se contrariamente, inclusive citando exemplos de seus respectivos estudos de caso em que os visitantes propiciaram alterações ao modo de vida das comunidades envolvidas. $\mathrm{O}$ fato demonstra que é bastante atual o questionamento dessa visão sobre autenticidade cultural e Turismo. Apenas recentemente ganham força trabalhos em que diferentes estudiosos passam a defender a ideia de que a autenticidade "se constrói socialmente ou pode ser negociada" (Salazar 2006: 105).

Nos últimos anos os estudos sobre o patrimônio passaram a ser vistos como um fenômeno em si próprio, tornando-se uma área distinta dentro das ciências humanas; porém, muitos deles ainda estão pautados no pressuposto de que cultura é pura, tendo como foco de investigação os agentes contaminadores dessa fórmula pura. Tal enfoque ignora o fato de que, em virtude de seu dinamismo, é impossível que a cultura seja pura. Porém, em um contexto de dinâmica global, forças econômicas, políticas, ideológicas e sociais do final do século XX e início do século XXI têm permitido aos pesquisadores uma consciência mais aguçada de que a cultura e a construção de identidades é fluida (Silverman 2002: 881).

O pressuposto da pureza obscureceu por muito tempo a busca pelo impacto que a cultura exerce sobre o Turismo como um fenômeno em constante desenvolvimento e/ou como as comunidades manipulam a atividade turística para alcançar alguns privilégios culturais anteriormente indisponíveis (Carman e Keitumetse 2005: 38). Em anos recentes o reconhecimento de que o patrimônio, em suas mais diversas formas, constitui uma forte influência na sociedade, e de que as sociedades do presente estão sempre reavaliando o passado como parte de seu processo contínuo de autotransformação, vem influenciando os

\footnotetext{
${ }^{23}$ Grifo do autor.

24“"su gente del presente” (Salazar 2006: 105).

${ }^{25}$ Grifo do autor.
} 
estudos sobre o Turismo. Diferentes trabalhos mostram que o Turismo internacional pode chegar a ser um veículo capaz de autorrepresentação, que as pessoas podem deliberadamente optar por sua própria reinvenção ao longo do tempo, mudando a maneira como são vistas e percebidas pelo “outro”. (Salazar 2006: 107). Em vez de aceitar sua “difícil situação” de dominada, a população local pode ser proativa e/ou impor resistência, enquanto negocia constantemente e questiona a direção do desenvolvimento turístico (Joseph e Kavoori in Salazar 2006: 117).

Para Salazar, o Turismo não se impõe inevitavelmente a pessoas passivas e impotentes. A incorporação do ativismo local nos estudos sobre Turismo tem possibilitado uma nova dimensão à imagem binária de uma população local dominada por empresas turísticas e turistas. Com tal mudança de perspectiva, considera-se que o poder opera em ambas as direções, e rejeita-se o pressuposto da opressão das populações locais (2006: 117).

Assim, o aspecto relevante não é simplesmente o impacto do Turismo nos locais, mas a forma como as culturas locais se desenvolvem durante os processos dinâmicos de uso do Turismo para redefinir suas próprias identidades (2006: 117). Nesse sentido, ganham cada vez mais importância os estudos de viés fortemente interdisciplinar (Carman e Keitumetse 2005: 38). Apesar do aumento do número de pesquisas interdisciplinares em Turismo, poucas têm levado em conta as relações de poder que governam o comportamento dos turistas e populações envolvidas nos sistemas turísticos (Salazar 2006: 117).

É relevante ressaltar que o Turismo é apenas um entre os vários fluxos globais com influência para afetar, de maneira significativa, as atitudes e valores das pessoas em diferentes sociedades (Salazar 2006: 118). Outros fluxos incluem os meios de comunicação, a educação e urbanização. O Turismo não é apenas uma atividade econômica, mas pode ser agente de transformações sociais e culturais geradas como resultado direto do desenvolvimento econômico, dos diferentes usos do poder e da maneira como as pessoas decidem se representar (2006: 118). Trata-se de um dos catalisadores da mudança cultural, em que o que importa é a natureza da experiência e não como processos culturais devem ser salvos do impacto negativo do Turismo. "A cultura tem a ver com diferenças... [ao passo que] o Turismo trata das experiências das diferenças culturais, seja isso desejado ou não"26 (Robinson e Boniface in Carman e Keitumetse 2005: 40). Para Yamashita, o Turismo pode ser considerado como um marco ideológico da História, da natureza e da tradição, marco que tem

\footnotetext{
26 "Culture is about differences... [while] tourism is about the experience of cultural difference whether it is desired or not” (Robinson e Boniface in Carman e Keitumetse 2005: 40).
} 
o poder de dar nova forma à cultura e à natureza segundo as necessidades das comunidades envolvidas (Yamashita in Salazar 2006: 118).

Desde o início da década de 1970 passou a ser reivindicada uma forma de Turismo diferente do Turismo de Massa, que buscasse minimizar os aspectos negativos da atividade, com responsabilidade social e ecológica, refletindo sobre o conceito de autenticidade e o papel das comunidades locais no desenvolvimento turístico. Vários trabalhos foram publicados apresentando diferentes estudos e modelos tendo em vista esse tipo de Turismo mais responsável. Dentre eles destaca-se o trabalho de Krippendorf (1985), que buscou, em seu modelo teórico sobre a humanização do Turismo, evidenciar a importância do ser humano e do meio ambiente no desenvolvimento turístico, colocando-os em posição de igualdade frente aos interesses econômicos. Para o autor, o desenvolvimento harmonioso do Turismo prevê que a comunidade tenha controle sobre a atividade, de modo que suas ansiedades e seus interesses sejam atendidos. Em sua proposta teórica, Krippendorf incentiva ainda a qualificação da mão de obra local para o Turismo e a preservação e valorização da cultura e patrimônios locais. Prevê também a necessidade de uma alteração do comportamento do próprio turista para um Turismo mais responsável. Vale ressaltar que segundo a Organização Mundial do Turismo tem sido crescente uma demanda turística formada por consumidores mais informados e conscientes, que possuem maior preocupação ecológica e com a conservação de traços culturais das comunidades tradicionais (OMT in Zamignan e Sampaio 2010: 4).

O assim chamado Turismo Sustentável foi pensado de forma a se inserir nas discussões sobre o desenvolvimento sustentável, e se converteu em clichê no final da década de 1980. Mas foi a partir da Rio-92 que ganhou força o debate de sustentabilidade no Turismo, quando a atividade turística passou a ser valorizada "como instrumento de conservação da natureza, atrelado aos paradigmas de promoção da diversidade, de integração entre povos e sustentabilidade” (Rabinovici 2010: 7).

Em 1996, a Organização Mundial do Turismo (OMT), o Conselho Mundial de Viagens e Turismo (WTTC) e o Conselho da Terra divulgaram a Agenda 21 para a Indústria de Viagens e Turismo. Esse programa de ação enfatiza e recomenda que o Turismo passe a objetivar a estruturação da atividade de modo a gerar benefícios econômicos e melhorias na qualidade de vida das comunidades envolvidas, preservando a paisagem, a natureza e traços culturais característicos das regiões visitadas, envolvendo a comunidade em seu processo de planejamento e implantação. 
No Brasil, desde meados dos anos de 1990 há investimentos dos órgãos públicos no sentido de incentivar o Turismo Sustentável ou "Ecoturismo", outro termo que entrou em voga após a Rio-92. O Governo Federal estabeleceu metas, diretrizes e ações em diferentes documentos, tais como: Diretrizes para uma Política Nacional de Ecoturismo (1994), Diretrizes para a Política Estadual de Ecoturismo- SP (1997), Programa de Desenvolvimento do EcoTurismo na Amazônia Legal (PROECOTUR) (1999) e os Pólos de EcoTurismo do Brasil (1998). Para Irving, a sustentabilidade no Turismo prevê uma "concepção estratégica e duradoura de desenvolvimento amparada por um novo olhar sobre as questões sociais, culturais, ambientais dos destinos” (in Rabinovici 2010: 4). Contudo, no país as próprias iniciativas governamentais costumam ser descontínuas e "muitas vezes se resumem a colocar no papel diretrizes e projetos visando à sustentabilidade” (Rabinovici 2010: 8), sem sua implantação, incentivo ou fiscalização.

A base para a estruturação do Turismo no âmbito da ideia de sustentabilidade é o planejamento sustentável, que se entende por aquele que "envolve e considera o meio ambiente, profissionais, a sociedade local, a economia, e política no sentido de abranger a máquina estatal” (Cardozo 2008). É o sucesso em todos esses aspectos que garantirá a desejada sustentabilidade, que só será assegurada nas localidades turísticas "se todos esses eixos trabalham em sincronia” (Cardozo 2008).

Para diferentes autores (Getz 1991, Barreto 2000, Beni 2006, Cooper et al. 2001, Goeldner et al. 2002, Mason 2003 e Ruschmann 1997) o planejamento turístico estratégico deve levar em considerar a preservação ambiental e sociocultural, tendo como fim a valorização dos bens patrimoniais, a realização do planejamento de forma participativa, a inclusão da comunidade no desenvolvimento do Turismo, a maximização dos impactos positivos e a diminuição dos impactos negativos da atividade turística. Segundo o Ministério do Turismo do Brasil (2005), o planejamento sustentável deve ser pensado de modo a oferecer os meios adequados para a implantação e administração da atividade turística, de forma integrada e participativa em todas as suas etapas, visando a descentralização desde a formulação até a implementação do projeto. Como afirma Molina (2003), a “descentralização facilita um enfoque integral, mais apto a detectar, recolher, processar e concretizar ideias e conceitos que desemboquem em inovações estruturais, funcionais e de produtos turísticos”.

Diferentes autores concordam com a afirmativa de que é crucial o papel da comunidade em todo o planejamento e implantação da atividade. O envolvimento da comunidade local, assim, deve visar ao: 
“engajamento em educação, hospitalidade e na compreensão da atividade turística; a promoção da integração e participação social das comunidades locais no planejamento turístico regional; na conscientização para preservação dos patrimônios históricos, culturais, arqueológicos e ambientais; e a capacitação e utilização da mão de obra local” (Alfonso 2009).

Porém, o planejamento participativo é assunto delicado. Segundo Cardozo (2008), existem modelos de planejamento ultrapassados, ou exclusivos, que não valorizam a comunidade como um todo, favorecendo a obtenção de resultados tendenciosos, e a comunidade local acaba sendo a mais prejudicada pelos impactos desse planejamento irresponsável. Rabinovici afirma que ao invés de criar oportunidades o mau uso dos processos participativos pode acirrar conflitos já existentes, "criar novas demandas que levam ao aprendizado social e a retrocessos no diálogo entre os interessados. Pode gerar novas desigualdades, enclaves, conflitos, novos graus de participação e empoderamento dos envolvidos" (2010: 1).

Assim, não basta apenas ouvir a população, mas "sim considerar suas colocações, necessidades e intuitos. Essa é a essência do planejamento participativo”. O planejamento participativo não se reduz a consultar ou sensibilizar a comunidade sobre os rumos do patrimônio ou da atividade turística, mas propiciar uma reflexão e criar condições para que a comunidade seja partícipe dos diferentes processos de tomada de decisões e gestão. A população deve ser agente ativa, determinando como quer a atividade, o que quer mostrar, o que deve preservar, ou até, por exemplo, inventando deliberadamente tradições ou artesanatos típicos para os turistas. Para Picard e Wood, a cultura é objeto de manipulação consciente dentro de um contexto social, econômico e político mais amplo (in Salazar 2006: 108). Desse modo, o planejamento sustentável e participativo, que leva em conta todos estes debates e questões, não é um processo simples, considerando os conflitos e a ausência de metodologias disponíveis para tal, principalmente devido às peculiaridades de cada contexto. Não podemos considerar que as diferentes comunidades sejam homogêneas em termos culturais e sociais (Cardozo 2008), o que faz do processo participativo um desafio.

Cada vez mais os pesquisadores do Turismo refletem sobre seu papel social, por exigência de turistas e profissionais mais conscientes, e a tendência da atividade turística é a criação de propostas inclusivas. No âmbito da ideia de sustentabilidade foram pensados vários ramos ou segmentos turísticos, que, embora diferentes, têm objetivos semelhantes. Ao longo 
do tempo alguns desses segmentos passaram a ter propostas diferentes, ampliando ou alterando sua abrangência de acordo com os debates de cada época.

O conceito de Turismo Social é um exemplo interessante. Foi em 1979 que se tentou instalar pela primeira vez no Brasil uma política mais relevante de Turismo Social, que, contudo, era então compreendido pelo governo como uma forma de Turismo que pretendia executar medidas que possibilitassem a democratização da atividade turística como forma de lazer (Alfonso 2006a: 57). Dentro dessa mesma compreensão de Turismo Social, em 1986 foram criados programas que visavam, entre outras coisas, a inclusão da população em propostas de lazer, com medidas como o incentivo a albergues da juventude e a Clubes da Terceira Idade e a adaptação de estabelecimentos para atender aos turistas com necessidades especiais - sintomas da tentativa de movimentar o Turismo interno do país. O esforço de fortalecimento do Turismo Social refletia, naquele momento, “a preocupação mundial e brasileira quanto à questão da liberdade e dos direitos humanos, inquietação expressa na Constituição de 1988, que garantia o direito a aposentadoria e a férias remuneradas, benefícios que influenciavam diretamente o setor do Turismo" (Alfonso 2006a: 65). Hoje o Turismo Social é compreendido como modalidade que almeja formas de estruturar, implantar e desenvolver a atividade turística de modo a garantir a solidariedade, a cidadania e a igualdade de oportunidades, dentro da perspectiva da inclusão social. Procura-se planejar o Turismo de forma participativa e inclusiva, "privilegiando cada um dos atores envolvidos na atividade” (Ministério do Turismo 2006: 5).

Outro segmento interessante também propõe o envolvimento da comunidade; trata-se do Turismo Grassroots, que vem ganhando importância a cada ano e que busca inovar, desenvolver e descobrir produtos que envolvam o patrimônio e traços culturais em comunidades rurais, incentivando a pesquisa voltada a comunidades tradicionais tendo em mira sua sustentabilidade e a preservação dos patrimônios naturais e culturais por meio da atividade turística de caráter interativo, e auxiliando na criação de empregos voltados à comunidade, dentre outros objetivos.

O Turismo de Base Comunitária valoriza “os valores, signos e símbolos que favorecem as relações interpessoais e de hospitalidade entre turistas e visitados (Zamignan e Sampaio 2010: 7)” e tem como fim a preservação do patrimônio comunitário, formado por "um conjunto de valores e crenças, conhecimentos e práticas, técnicas e habilidades, instrumentos e artefatos, lugares e representações, terras e territórios, assim como todos os tipos de manifestações tangíveis e intangíveis existentes em um povo. Através disso, se 
expressam seu modo de vida e organização social, sua identidade cultural e suas relações com a natureza” (Maldonado in Zamignan e Sampaio 2010: 6).

Outro campo de crescente valorização na área turística é o Turismo Patrimonial, definido como uma viagem que possibilita uma experiência autêntica e que divulga a vida, eventos e realizações dos povos do passado. Ou seja, isso inclui viajar para sítios históricos e arqueológicos, parques, museus ou outros lugares tradicionais ou étnicos, bem como rumar para outros países a fim de vivenciar diferentes culturas e explorar suas raízes históricas e préhistóricas. O Turismo Patrimonial é também chamado de Turismo Cultural; ${ }^{27}$ independentemente da nomenclatura, é uma atividade de proporções significantes (Pinter 2005: 9). Trata-se de segmento que discute de forma mais intensa a preservação e que exige a necessidade contínua de pesquisas dedicadas à compreensão das características culturais do patrimônio, seus usos e sua importância para as sociedades contemporâneas (Shackel 2005: 33).

Muitos desses diferentes conceitos de segmentos turísticos voltados à inclusão, à sustentabilidade e à preservação propõem um distanciamento entre o Turismo de Massa, também conhecido como Turismo Convencional, e o desenvolvimento de um tipo de Turismo Não-Convencional. Segundo Salazar (2006: 109), a principal diferença entre os dois referidos tipos de Turismo seria a forma de condução e estruturação da atividade, bem como objetivos dos turistas ao viajar. Para o autor, enquanto o Turismo Convencional lota aviões, elege destinos específicos e realiza certa padronização de viagens e serviços oferecidos aos visitantes, o Turismo Não-Convencional busca privilegiar grupos menores, com atendimento individualizado e especializado; valoriza a sensibilização quanto ao meio ambiente, às diferenças culturais e sociais durante toda a experiência turística.

Outros autores compreendem como "formas alternativas" as configurações turísticas que tentam se distanciar do Turismo Convencional ou Turismo de Massa, valorizando a interação pessoal entre os turistas e as pessoas que vivem nos destinos turísticos. Definidas em termos amplos, essas formas alternativas referem-se às formas de Turismo consistentes com os valores naturais, sociais e comunitários e que permitem a anfitriões e a visitantes gozarem de uma interação positiva e compartilhar experiências (Smith e Eadington in Salazar 2006: 104).

Embora o Turismo de Massa ou Convencional tenha suscitado duras críticas como experiência degradante, as formas ditas alternativas ou não-convencionais de Turismo têm

\footnotetext{
${ }^{27}$ Para este texto optei por chamar o Turismo Patrimonial de Turismo Cultural — de resto sinônimos —, pois preferi seguir a nomenclatura oficial do governo brasileiro.
} 
sido alvo de poucas críticas e muitos estudos favoráveis. Vale ressaltar que o Turismo Sustentável inicialmente se configurou no Brasil como um "Turismo Convencional, porém esverdeado e cheio de contradições e incoerências, bastante questionável eticamente” (Rabinovici 2010: 7). Apenas recentemente pesquisadores têm se esforçado para compreender as várias facetas da sustentabilidade no âmbito dessas formas alternativas e de diversos segmentos da atividade, levando em conta sua importância e pensando em metodologias que propiciem sua implantação, com a divulgação de estudos de caso que sirvam como exemplo para outras iniciativas.

Para Jafari (1994: 16), é a partir de estudos interdisciplinares - que criam condições para que diferentes áreas do saber partilhem conhecimentos tendo em vista a análise de um problema - que se faz possível uma maior compreensão do Turismo em toda a sua complexidade. Segundo o autor, são necessários estudos que atendam ao que ele chamou de "plataforma do conhecimento" e "plataforma pública”, a saber, estudos que tenham como desígnio uma análise mais aprofundada do Turismo e uma reflexão sobre a relação entre o Turismo e a sociedade no presente.

Enfim, não importa a denominação dada aos diferentes segmentos do Turismo: EcoTurismo, Turismo de Base Comunitária, Turismo Social, Turismo Grassroots, Turismo Patrimonial, Turismo Educativo, Turismo Étnico, Turismo Folclórico, Turismo Pedagógico, entre tantos outros. São apenas nomenclaturas dadas pelo mercado turístico como forma de especializar produtos, públicos e demandas. O importante de fato são os debates teóricos que embasaram esses segmentos, debates sobre a "nova” compreensão da atividade turística, mais responsável, sustentável, inclusiva, participativa e preservacionista. É pensar o Turismo como atividade que visa à preservação das paisagens, patrimônios e de lugares como forma a garantir sua continuidade, no âmbito da percepção de que a cultura é dinâmica, cabendo aos atores locais a decisão sobre mudança e continuidade. Possibilitar o diálogo multicultural, que auxilia no aprendizado de práticas participativas de planejamento e condução das atividades pelo contato entre alteridades, pode ensejar a repartição dos benefícios de modo equitativo entre todos os envolvidos. Esse tipo de Turismo incentiva a capacitação, organização e empoderamento dos atores locais, favorecendo o diálogo (Rabinovici 2010: 5). É nessa esfera de pensamento e de discussões teóricas que este trabalho pretende se inserir. 


\subsection{O OLHAR ANTROPOLÓGICO DA ALTERIDADE SOBRE A DIVERSIDADE}

Outra disciplina primordial para este trabalho é a Antropologia. Trata-se de uma área de conhecimento cuja formação teve início em um período em que ocorreu uma grande afinidade entre a teoria científica e seu uso político, e que se estabeleceu quando da transformação do antigo sistema colonial, baseado no capitalismo mercantil e no pacto colonial e quando religiosos buscavam levar aos então denominados "povos primitivos" a fé redentora. O novo sistema colonial, implantado pela expansão imperial no século XIX e movimentado pelo capitalismo industrial, baseava-se em novas relações de trabalho e em posturas que privilegiavam a ideia de nação. Com a expansão imperialista sobre novos territórios e o contato com diferentes povos, os colonizadores passaram a se deparar com o fato da diversidade cultural; essa multiplicidade dizia respeito não apenas aos povos distantes, mas também ao reconhecimento da diversidade cultural em suas próprias fronteiras. Isso acarretou uma série de reflexões que giraram em torno do conceito de cultura, utilizado nesse momento como ferramenta voltada para a criação de argumentos que justificassem a hegemonia necessária para a afirmação das nações soberanas que subjugavam outros povos, “congelados” em diferentes etapas de evolução cultural.

Um dos aspectos fundantes da Antropologia girou em torno da ideia de alteridade. A alteridade pressupõe que as relações entre os homens se dão a partir de um eu e um outro, sendo o outro, em geral, definido a partir daquilo que o eu não é , o outro como a antítese do eu, o anti-eu, como pontuou Hartog (1999: 239). Segundo Peirano, por muito tempo a Antropologia foi definida pelo exotismo do seu objeto de estudo e pela distância cultural que separava o pesquisador de seu grupo de pesquisa (1999: 225). Para Lévi-Strauss o caráter específico da Antropologia não estava em seu objeto empírico concreto, mas sim na dimensão de diferença que sempre havia estado presente no estudo dos povos então denominados “primitivos” (Peirano 1999: 231).

Para Das (1997: 3), o conhecimento antropológico veio a ser um mapa da diferença, da alteridade, pois os antropólogos procuraram produzir conhecimento por meio de um único objeto intelectual - o outro exótico. Esse outro exótico não foi encontrado acidentalmente, uma vez que se tratava do oposto do "eu” (Das 1997: 3). A construção do eu (self) depende de uma série de identificações por empatia; o "eu” é construído na base de uma série de "nós" (Cabral e Lourenço 1993: 44). Assim, a questão da relação que se estabeleceu com indivíduos considerados diferentes, pertencentes a outras culturas (ou não), sempre permeou as 
discussões da Antropologia Social ocidental. O outro, que foi considerado primitivo, enfrentou políticas de segregação, de conversão e subjugação. Nesse contexto, ganharam peso categorias como raça ou racismo, etnia etc. Para Clifford, toda versão de um "outro" é também a construção de um "eu" e "a elaboração de textos etnográficos sempre envolveu processos de "automodelação". Poiesis cultural - e política - é a constante reconstituição do "eu” e "outros" através de exclusões específicas, convenções, e práticas discursivas”28 (Clifford 1986: 24).

A pesquisa antropológica voltada para o estudo deste "outro" teve a princípio trabalhos pautados em curtas pesquisas de campo junto às comunidades estudadas; a dificuldade de se falar a língua nativa influenciou a qualidade desses primeiros trabalhos. Vale ressaltar que muitos pesquisadores contavam com diferentes relatos de viajantes, missionários, entre outros informantes, como fontes principais de suas análises. Com o tempo esses estudos se tornaram cada vez mais profundos e sistemáticos. Somente entre as décadas de 1920 e 1950 a autoridade teórico-metodológica do pesquisador de campo acadêmico se estabelece, com a publicação dos trabalhos etnográficos, verdadeiros manuais de campo, de Radcliffe-Brown e Malinowski - este, o primeiro pesquisador a realizar sua investigação na língua nativa e a viver a vida da sociedade local.

Para Malinowski a Etnografia como ciência requer um relato honesto de todos os dados observados em uma comunidade. Segundo o autor o trabalho etnográfico deve cobrir a totalidade dos aspectos sociais, culturais e psicológicos de uma sociedade, "pois estes aspectos são de tal forma interdependentes que um não pode ser estudado e entendido a não ser levando-se em consideração todos os demais” (1984: 16-17). Malinowski afirma ainda que o valor científico do trabalho etnográfico está diretamente ligado à distinção clara entre os resultados da observação direta e das declarações e interpretações da comunidade e as inferências do pesquisador, "baseadas em seu próprio bom-senso e intuição psicológica" (1984: 22). Sendo assim, o relato final feito pelo pesquisador pode ser completamente diferente "das asserções dos nativos" (1984: 22-23).

Após a Segunda Guerra Mundial, em um contexto pós-colonial, antropólogos tentaram identificar as transformações ocorridas nas sociedades, privilegiando a observação de processo, contradição, conflito de normas e manipulação de regras, almejando assim a possibilidade de análise das sociedades “complexas”. Durante a década de 1970 a

\footnotetext{
28 "and the making of ethnographic texts, has always involved process of "self-fashioning. Cultural poiesis - e politics - is the constant reconstitution of selves e other through specific exclusions, conventions, e discursive practices” (Clifford 1986: 24).
} 
preocupação com o contato "avançou sobre o tema das fronteiras de expansão, tornando tópicos antropológicos legítimos aqueles relacionados ao colonialismo interno, camponeses e desenvolvimento do capitalismo" (Velho in Peirano 1999: 240). O trabalho etnográfico se voltou para a identificação das desigualdades e relações de poder, tendo função complexa “quase sempre ambivalente, potencialmente contra-hegemônica”29 (Clifford 1986: 9).

Na década de 1980, Geertz consolidou a ideia de que "agora somos todos nativos”, e a Etnografia deixou de ter como enfoque as distâncias culturais e geográficas e passou a considerar também as comunidades próximas do pesquisador; segundo Peirano, a "Etnografia foi trazida para casa” (1997: 72). Para Geertz, somente por meio da compreensão do que é a prática etnográfica "é que se pode começar a entender o que representa a análise antropológica como forma de conhecimento" (1973: 15). Para o autor, o que define um bom trabalho etnográfico "é o tipo de esforço intelectual que ele representa" (1973: 15). Geertz julga que o trabalho efetivo do antropólogo é tentar fazer com que "as diversas sociedades (que são cada vez mais complexas e envolvem cada vez mais pessoas) sejam capazes de atingir algum entendimento entre si” (Geertz 2001:4).

Geertz afirma que o antropólogo não deve tornar-se nativo, como víamos antes e ainda vemos hoje em tantas tentativas, mas deve buscar conversar, o que a seu ver é muito mais difícil. Muitas vezes o etnógrafo está tão preocupado em "entrevistar informantes, observar rituais, deduzir os termos de parentesco, traçar as linhas de propriedade, fazer o censo doméstico e escrever seu diário" (1973: 20) que não atenta a "uma multiplicidade de estruturas conceptuais complexas, muitas delas sobrepostas ou amarradas umas às outras, que são simultaneamente estranhas, irregulares e inexplícitas” (1973: 20). Cabe ao etnógrafo apreender essas estruturas para depois apresentá-las em formato de texto.

Ainda para o autor, o trabalho final do antropólogo — seu texto — é uma "construção das construções de outras pessoas” (1973: 19), pois se trata de uma interpretação, algo que foi modelado, “não que seja falsa, não-fatual ou apenas experimento de pensamento” (1973: 2526). Para Clifford, "verdades etnográficas são, portanto, inerentemente parciais comprometidas e incompletas”30 (1986: 7).

O etnógrafo “inscreve” o discurso social: “ele o anota” (Geertz 1973: 29), e, quando o faz, transforma o discurso de um acontecimento pretérito "que existe apenas em seu próprio momento de ocorrência, em um relato, que existe em sua inscrição e que pode ser consultado novamente” (1973: 29). Assim, a descrição etnográfica é interpretativa, explicitando o fluxo

\footnotetext{
29،“often ambivalent, potentially counter-hegemonic (Clifford 1986: 9).

30،"ethnographic truths are thus inherently partial - committed e incomplete (1986: 7).
} 
do discurso social, em uma tentativa de salvar o que foi dito da possibilidade de seu desaparecimento, transformando-o em algo que possa ser reacessado. Geertz enfatiza que o problema metodológico "que a natureza microscópica da Etnografia apresenta” é real, mas pode ser resolvido quando compreendido que as ações sociais são "comentários a respeito de mais do que elas mesmas; de que, de onde vem uma interpretação não determina para onde ela poderá ser impelida a ir. Fatos pequenos podem relacionar-se a grandes temas” (1973: 34).

Ainda para Geertz, o objetivo principal da Antropologia é o alargamento do universo do discurso humano. Ele usa o conceito de cultura semiótica para definir cultura como “sistemas entrelaçados de signos interpretáveis, a cultura não é um poder, algo ao qual podem ser atribuídos casualmente os acontecimentos sociais, os comportamentos instituições ou os processos” (1973: 24). A cultura é um contexto, “algo dentro do qual os sistemas podem ser descritos de forma inteligível - isto é, descritos com densidade” (1973: 24). Segundo Geertz, é necessário que os antropólogos compreendam que a linha entre o modo de representação e o conteúdo substantivo é intraçável na análise cultural (1973: 26). E é por meio do fluxo do comportamento das pessoas e comunidades, de artefatos e de estados de consciência que as formas culturais encontram articulação (1973: 27).

“O ponto global da abordagem semiótica da cultura é auxiliar-nos a ganhar acesso ao mundo conceptual no qual vivem os nossos sujeitos, de forma a podermos, num sentido um tanto mais amplo, conversar com eles” (1973: 35). Para Geertz o antropólogo tem a dupla tarefa de descobrir as estruturas conceptuais que informam os atos dos sujeitos de suas pesquisas, o que foi “dito" no discurso social, e elaborar um sistema de análise em que o que é genérico a essas estruturas se destaca contra outras determinantes do comportamento humano. (1973: 38). Ele completa dizendo que em uma Etnografia a teoria tem o dever de disponibilizar um vocabulário que possibilite a expressão do que o ato simbólico tem a dizer sobre si mesmo, ou seja, “sobre o papel da cultura na vida humana” (1973: 38). A Etnografia deve ter por objetivo "tirar grandes conclusões a partir de fatos pequenos, mas densamente entrelaçados; apoiar amplas afirmativas sobre o papel da cultura na construção da vida coletiva empenhando-as exatamente em especificações complexas” (1973: 38).

Produzir uma análise a partir de um conceito semiótico de cultura e de uma abordagem interpretativa é se comprometer com a visão de uma "afirmativa etnográfica como essencialmente contestável, tomando emprestada a famosa expressão de Gallie” (in Geertz 1973: 39). A Antropologia interpretativa é uma "ciência cujo progresso é marcado menos por uma feição de consenso do que por um refinamento do debate” (1973: 39), é uma ciência que tem por vocação não responder às questões mais profundas do pesquisador, porém colocar à 
sua disposição "as respostas que outros deram — e assim incluí-las no registro de consultas sobre o que o homem falou” (1973: 41).

Da Matta concorda com Geertz no que tange ao fato de que a "prova" das etnografias estaria no que ele denominou de "marrada dialética”, que revela "duas mentalidades: a do nativo e aquela que todo etnógrafo traz dentro de si” (Da Matta 1987: 23). Para Leite, as características emocionais e intelectuais do antropólogo interferem nas condições da percepção, bem como os compromissos específicos dos indivíduos observados também determinam o resultado final da percepção. A percepção sempre traz predisposições intelectuais e emocionais determinadas por suas expectativas e experiências anteriores, sendo muitas vezes responsável por certas acentuações, assim como pela eliminação de outros dados perceptuais. Para Geertz não "há nada de errado nisso, é inevitável, o erro ocorre quando as pessoas não se conscientizam disso e simplesmente assumem que qualquer sensação que têm não precisa ser confrontada com a realidade” (Geertz 2001:7).

Para Rabinow, tanto o antropólogo quanto o seu sujeito pretendem uma interpretação dos sentidos do cotidiano. Segundo o autor os problemas de representação "são centrais para ambos e são locus da imaginação cultural” (1999: 99). Ele complementa afirmando que as representações servem como meio para dar sentido aos mundos da vida, em que a construção difere em suas funções. Para ele "as metas do antropólogo e do nativo são distintas" (1999: 99).

Para Da Matta, "uma hermenêutica não deve falar somente de regras capazes de produzirem tradução e entendimento. Ela deve estar também referida à descoberta de que tentando falar do lugar do outro, nós produzimos testemunhos e revelações de nós mesmos” (1987: 23). O falar "objetivado" do outro nos permite enxergar o nosso próprio sistema de classificação “como um espaço localizado e claramente arbitrário. Dentro dele, há um 'nativo' universalizador e cosmopolita que nada mais é do que outro sujeito, também cultural e historicamente construído" (1987: 23). "Parodiando F. Boas, que dizia que todo olho que vê é órgão da tradição" (Schwarcz 1995: 62).

Para Pina Cabral, cada pessoa tem uma história e um contexto referencial diferentes, e todas possuem referenciais semânticos distintos. Sendo assim, é impossível saber exatamente o que outra pessoa tem em mente "quando recorre a uma expressão, quando pretende transmitir uma crença” (2003: 9). Pina Cabral usa uma expressão de Quine para afirmar que a mente humana é uma rede de crenças. Uma crença só possui conteúdo e identidade por fazer referência a muitas outras crenças. Cada pessoa forma suas crenças baseando-se em crenças anteriores, isto é, "as crenças não são unidades autossuficientes de significado, elas são 
necessariamente integradas em redes que 'fazem sentido'” (Davidson in Pina Cabral 2003: 23).

As pessoas experimentam novas crenças ou novas relações entre crenças posicionando-as e reposicionando-as até que acabem por "fazer sentido" (2003: 24). Tanto a rejeição como o desinteresse ou a dúvida são resultados certos desse processo de "fazer sentido”. Os seres humanos não compartilham apenas pedaços de informação, mas também uma arquitetura da crença, ou seja, "as classificações e protótipos que formam uma visão do mundo e estes, finalmente, são condições indispensáveis para a participação social” (2003: 25). Para executar as atividades cotidianas as pessoas "encontram utilidade em aderir a grandes padrões de crenças que são geralmente partilhados pelos seus interlocutores sociais cotidianos" (2003: 24$)$.

Ainda para Pina Cabral, as identidades são um tipo de crença, “a identidade social não é algo que se posicione como uma representação perante a mente de um sujeito, mas é sim uma actividade, uma disposição cognitiva do sujeito" (2003: 6). Ela é “objectivada” em nomes, em narrativas, em formas de linguagem, em normas e em leis. Também em objetos, formas de consumo, entre outros. Essas objetivações, depois de criadas, são menos “evanescentes do que o sentido de identidade que as criou”, tornam-se partes da vida cotidiana e agentes ativos nos processos de constituição identitária (2003: 11). Cada pessoa se identifica com muitas identidades, sendo o self o resultado de um processo dinâmico de negociação destas identidades. Assim, não existe "uma” identidade pessoal, todas as pessoas são “muitas coisas ao mesmo tempo, em tempos distintos e em locais distintos” (2003: 29).

Todas as identidades são produtos da relação de instâncias particulares de identificação e diferenciação. Assim como todas as “crenças”, as identidades são construídas na relação entre o self, o mundo e o outro. Para Jaramillo a construção da identidade está diretamente ligada ao conceito de diferença; é no olhar para o outro que me construo, como um reflexo do outro (2009/2010: 180). Para Pina Cabral, a relação entre self e outro é assimétrica, pois enquanto o self é mais ou menos unitário, o outro é sempre plural, indefinido identitariamente (2003: 10). O autor argumenta ainda que o processo de atribuição e reconhecimento de semelhanças e diferenças é mais fluido que o de constituição de crenças identitárias (2003: 28). Citando Victor Turner, Pina Cabral afirma que "o conflito não é uma coisa que exista unicamente entre pessoas e entre grupos, o conflito entre interesses diferentes e entre identificações diferentes é algo que existe no interior da própria pessoa humana” (in Jaramillo 2003: 30). Segundo Jaramillo, não existe um ser humano que não seja confrontado com a gestão complexa de suas identificações com identidades distintas, pois é impossível a 
"vivência social sem complexidade identitária e, portanto, sem qualquer forma de conflitualidade anterior" (2003: 31).

O conceito de identidade deve sempre ser relacionado ao conceito de interesse, por sua vez caracterizado por constantes alterações e limitações (2003: 42). A noção de interesse torna possível a compreensão da "ação social” como uma constante negociação do futuro e do passado.

"O engajamento dos agentes sociais com o mundo e com os outros agentes sociais afeta dialeticamente os próprios processos de produção e reprodução dos agentes sociais - a identidade que lhes atribui reflexividade na ação. $\mathrm{O}$ fato de que toda a ação envolve motivações e que estas são construídas através de processos de intersubjectividade e, mais ainda, que estes processos de intersubjectividade envolvem dinâmicas de dominação” (Pina Cabral 2003: 41).

Assim, os agentes sociais se alteram de acordo com as condições em que se encontram, em um processo de mudança que não é unidirecional, já que as identificações e autodefinições “são passíveis de reversão, desvio, bifurcação ou redução” (2003: 42). Os agentes sociais podem mudar no decorrer do tempo e alterar seus interesses. A identidade então é construída e se constitui em contextos de ação. Pina Cabral parte do conceito de habitus de Bourdieu para negar a relevância da oposição entre interesses conscientes e inconscientes, sendo o interesse algo complexo, multifacetado e em constante evolução, um engajamento das pessoas no mundo e nos agentes sociais que as rodeia. Pina Cabral afirma que os limites do interesse determinam contextos de inserção social, o que a seu ver é o reconhecimento de que diversos contextos de ação se cruzam sem se cancelarem mutuamente. Os contextos de inserção "permitem a formação, fixação ou revisão das identidades”. Para o autor, toda identidade social e toda a agencialidade são resultados de processos de construção social, a formação identitária é uma transformação identitária, portanto toda a formação de identidades é uma inserção social de identidades (2003: 43). Por outro lado, pode haver agentes sociais que são excluídos da socialidade e toda exclusão é sempre relativa a um contexto definicional. “O tecido social está perpassado por interesses, isto é, por relações de apropriação e, portanto, de poder” (2003: 43).

Aqui o conceito de inserção social se faz importante por se referir não apenas a agentes sociais, mas também a diferentes práticas, modos de vida e campos de ação, sendo a vida social "uma tessitura complexa de relações e objetos que constantemente produz novas 
relações e objetos, que são constantemente inseridos no seu interior por virtude das relações que os amarram ao todo da vida social” (2003: 43-44). Para Strathern a vida social está em constante movimento de um estado ao outro, de um tipo de socialidade para outro, de uma unidade à divisão ou à comunhão com o outro, e essas alternâncias são replicadas em inúmeras formas culturais (1988: 14).

Guillermo Wilde (2011) afirma que os processos de mudança social são determinantes das configurações identitárias; para tanto, considera necessária a recuperação da História como forma de restabelecer o presente para, assim, compreender a identidade como um processo vivo, dinâmico e atual. Segundo Jaramillo, nos estudos contemporâneos tanto a identidade como a memória têm sido compreendidas como um processo dinâmico, múltiplo, em constante movimento e construção. Ambas, pois, não se esgotam no passado (2009/2010: 180). O patrimônio cultural, segundo a autora, está intimamente ligado ao passado como herança, sendo por meio da memória reatualizado no presente e convertido em referência para o futuro, tornando-se parte importante da identidade (Jaramillo 2009/2010: 178). Os debates e reflexões sobre o patrimônio cultural devem o relacionar com o que a autora considera os três conceitos básicos que o confrontam: herança, identidade e memória (2009/2010: 179).

Jaramillo cita Bergson para refletir sobre o fenômeno da memória em relação ao patrimônio. Para Bergson a memória é um ente vivo e atual, na medida em que a lembrança possibilita a percepção do presente, sendo os bens patrimoniais pertencentes ao presente por meio da apropriação da memória - mesmo tendo sido criados no passado. Para o filósofo, a memória não está radicada no passado, pois o passado é reatualizado no presente. Essa atualização se dá tanto a partir de elementos do presente como via utilização de outras reconstruções feitas em épocas anteriores (in Jaramillo 2009/2010: 181). Halbwachs entende a memória coletiva como um processo social de reconstrução do passado vivido e experimentado por um determinado grupo ou uma comunidade. Halbwachs afirma que todo processo de construção de memória social envolve negociações e disputas entre diversos integrantes dos grupos sociais ou entre diferentes grupos de poder. O autor afirma que as memórias coletivas e a memória nacional não são opostas e vê a nação como a "forma mais acabada de um grupo e a memória nacional a forma mais completa e uma memória coletiva” (Halbwachs in Cassiano 2000: 99). Para Jaramillo, é por meio da memória coletiva que se reatualiza o passado no presente, sendo o patrimônio cultural material e imaterial a referência de tudo que uma comunidade já criou.

Assim, de acordo com Jaramillo o patrimônio cultural também é um processo dinâmico e em constante construção, que gera nos seres humanos um sentimento de diferença 
e pertencimento, sentimento este que faz parte dos elementos diferenciadores e identitários dos povos (2009/2010: 181). A autora ainda afirma que identidade, cultura, memória e patrimônio são alguns dos termos que hoje apontam como importantes nos discursos de diferentes países da América Latina, sendo o termo patrimônio "um dos conceitos mais complexos, e por si, difusos no âmbito cultural”31 (2009/2010: 179).

Segundo o Coloquio de Quito de 1977, existe uma pluralidade de valores do patrimônio, bem como uma diversidade de interesses, porque toda sociedade "sempre é a união da comunidade e da rivalidade, da aliança e da competição, interesses sociocêntricos e egocêntricos, fitting (ajuste mútuo) e matching (rivalidade, concorrência)”32 (Morin in Urtizberea 2009/2010: 285). Para Urtizberea, toda sociedade é multissocial, pois contém diversas "associações e grupos baseados em distinções de classe, gênero, orientação sexual, religião, crenças morais e ideologia política”33 (2009/2010: 285). Portanto, cada sociedade possui não apenas uma identidade cultural, mas várias identidades culturais e vários patrimônios culturais ou, inclusive, diferentes compreensões de um mesmo bem patrimonial (2009/2010: 285).

Urtizberea usa a categoria de "campo" definida por Bourdieu como um jogo de relações de força entre diferentes agentes envolvidos que objetivam "obter com o monopólio da definição e dos usos legítimos, no nosso caso, do patrimônio cultural que permite uma abordagem válida ao estudo da participação, mas também para a sua concepção na ação»34 (2009/2010: 285). E complementa afirmando que valorizações do patrimônio, diversos interesses e relações de poder assimétricas favorecem conflitos pelo controle do campo, cada jogador — cada agente - usando de seus diferentes capitais (culturais, simbólicos, sociais e econômicos) (2009/2010: 286). É justamente com essas discussões sobre memória, patrimônio, herança, identidade, ação e inserção social que esta tese dialoga.

Desde seus primórdios enquanto disciplina de pesquisa a Antropologia tem um aspecto pragmático, em que o pesquisador é treinado para resolver problemas na prática a partir de seus conhecimentos antropológicos. Historicamente esse aspecto da Antropologia vem sendo denominado Antropologia Aplicada, conceito que remonta a 1906, quando foi

\footnotetext{
31 "uno de los conceptos más complejos en el, ya por sí, difuso ámbito de lo cultural” (2009/2010: 179).

32 "siempre es la unión de la comunidad y la rivalidad, la coalición y la competición, intereses sociocéntricos e intereses egocéntricos, fitting (ajuste mutuo) y matching (rivalidad, concurrencia)” (Morin in Urtizberea 2009/2010: 285).

33 "asociaciones y grupos basados en distinciones de clase, genero, orientación sexual, religión, creencias morales e ideología política” (2009/2010: 285).

34،"hacerse con el monopolio de la definición y de los usos legítimos, en nuestro caso, del patrimonial cultural que permite un aproximación válida al estudio de la participación, pero también para su concepción en la acción” (2009/2010: 285).
} 
usado para estabelecer um programa na Oxford University. Já o termo “Antropologia Prática” foi cunhado no início da década de 1860 por James Hunt, fundador da Anthropological Society of London (Eddy e Partridge 1987: 4). De acordo com um Dicionário de Ciências Sociais de 1964, Radcliffe-Brown foi o primeiro pesquisador a usar o termo "Antropologia Aplicada” no artigo (publicado em 1930) “Anthropology as Public Service e Malinowski's Contribution to It" (Willigen 1993: X).

Willigen cita Eliot Chapple, que define Antropologia Aplicada como o aspecto da ciência antropológica que lida com a mudança nas relações humanas e o isolamento dos princípios que as controla (Willigen 1993: X). Definições mais contemporâneas giram em torno da noção da resolução de problemas humanos da atualidade, a partir de um corpo de conhecimentos da Antropologia. Os autores dos primeiros textos sobre a Antropologia Aplicada oferecem diferentes concepções acerca do tema. Chambers discorre sobre como os pesquisadores da Antropologia Aplicada usam os conhecimentos, habilidades e perspectivas da disciplina para ajudar na resolução de problemas humanos e facilitar mudanças (in Willigen 1993: X). A ideia de Malinowski de que a prática antropológica implica trabalho realizado fora da Academia é utilizada por muitos autores (Chambers 1985; Eddy e Partridge 1987) como sinônimo de Antropologia Aplicada (Willigen 1993: X).

Para Forte, o trabalho antropológico é público em sua natureza: “A Antropologia não pode ser sobre o mundo e, de repente, dar um jeito de se separar desse mundo”35 (2011: 3). Para ele o alicerce da atuação do antropólogo é estar envolvido com o mundo, por meio da “chamada 'Antropologia de gabinete' do final dos anos 1800, que exigia a manutenção de ao menos uma relação de trabalho com membros públicos (tais como missionários, viajantes e

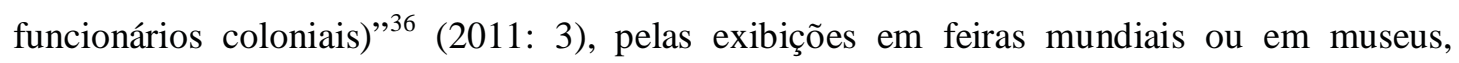
gastando meses e anos como hóspede em alguma pequena comunidade longínqua fazendo um trabalho etnográfico ou dedicando-se ao ensino. Forte (2011: 3-4) acredita que todas essas atividades são públicas. A prática antropológica é definida por Baba e Hill como uma profissão cujo compromisso é crucial para a aplicação do conhecimento para resolver os problemas do homem moderno (1997: 2). Para as autoras, os pesquisadores da Antropologia Aplicada são mediadores, coordenadores, administradores, avaliadores, ativistas e motivadores culturais e políticos (1997: 2).

\footnotetext{
35 "anthropology cannot be about the world e then suddenly manage to remain separate from that world" (2011: 3).

36 "so-called armchair anthropology of the late 1800s, which required that one at least entertain working relationships with members of the public (such as missionaries, travelers, e colonial officials)” (2011: 3).
} 
Para Willigen, a Antropologia Aplicada é a Antropologia colocada em uso. O autor afirma que existem dois tipos de prática antropológica, a saber, “Antropologia Intervencionista e Política de Investigação”37. A “Antropologia Intervencionista” combina as duas abordagens abrangendo os aspectos da:

“Antropologia da ação (estratégia de valor explícito com objetivos de autodeterminação da comunidade e verdade científica), pesquisa e Antropologia do desenvolvimento (intervenção participativa baseada em pesquisa), desenvolvimento comunitário (ação coletiva de autoajuda através da participação da comunidade e cooperação voluntária), Antropologia de defesa da comunidade (facilitando a ação baseada na comunidade fornecendo dados e assistência técnica), mediação cultural (lógica de intervenção relacionando pessoas de sistemas socioculturais similares através de indivíduos), e marketing social (estratégias baseadas em pesquisas combinando marketing comercial com ciências sociais aplicadas para auxiliar as pessoas a mudar para comportamentos benéficos). Políticas de pesquisa combinam os métodos avaliação de impacto social (coletando dados socioculturais comunitários para uso dos planejadores de desenvolvimento), pesquisa de avaliação (determinando o sucesso de um projeto), pesquisa de desenvolvimento tecnológico (agindo como um elo de comunicação entre produtores e usuários de novas tecnologias), e avaliação dos recursos culturais (identificando o impacto do desenvolvimento federal nos sítios arqueológicos e prédios históricos)”38(Willigen 1993: 7).

Para Willigen, o aumento do número de termos para as atividades práticas da Antropologia cresceu concomitantemente ao número de antropólogos que aplicam seu conhecimento e habilidades em atividades outras que não o ensino ou a pesquisa básica. O

\footnotetext{
37 "intervention anthropology e policy research".

38 "action anthropology (value-explicit strategy with the goals of community self determination e scientific truth), research e development anthropology (research-based participant intervention), community development (self-help group action through community participation e voluntary cooperation), advocacy anthropology (facilitating community-based action through providing data e technical assistance), cultural brokerage (intervention approach linking people of co-equal sociocultural systems through an individual), e social marketing (research-based strategy combining commercial marketing with applied social science to assist people to change to beneficial behaviors). Policy research combines the methods of social impact assessment (collecting sociocultural community data for use by development planners), evaluation research (determining the success of a project), technology development research (acting as a communication link between producers e users of new technology), e cultural resource assessment (identifying the impact of federal development on archaeological sites e historic buildings)” (Willigen 1993: 7).
} 
autor acredita que termos como Antropologia Pública, Antropologia Prática, Antropologia da Ação, entre outros acima citados, têm significado para circunstâncias específicas. Embora acredite que os termos ou "nomes" tenham importância, e apesar das críticas de outros autores, Willigen prefere utilizar “Antropologia Aplicada” como "um rótulo geral para todo o conjunto de situações e enfoques para colocar a Antropologia em uso"39(1993: xiii). Afirma ainda que a Antropologia Aplicada fornece ao antropólogo diferentes estratégias de ação efetivas, que podem ser usadas para auxiliar comunidades a atingir seus objetivos dentro de um contexto de autodeterminação. Vale ressaltar que o conceito de autodeterminação está diretamente relacionado ao direito de uma comunidade fazer suas próprias escolhas sem intervenção externa.

Os antropólogos podem recorrer a experiências do passado e do presente como exemplos para ações de intervenção e pesquisa, e para a resolução de problemas. As técnicas de pesquisa utilizadas por eles são baseadas na ideia da identificação sistemática dos anseios, das necessidades e do olhar dos membros da comunidade, em especial quando relacionados a ações de desenvolvimento ou de implantação de programas e projetos (Willigen 1993: xiii). É a perspectiva da democracia que guia a Antropologia Aplicada, tanto para a intervenção como para a pesquisa, tendo como essência o compromisso de descobrir e comunicar a perspectiva da comunidade. Segundo o autor, uma função da orientação democrática é a preocupação com os interesses da comunidade local, sendo que, a depender do contexto, a prática antropológica pode favorecer o empoderamento de comunidades (Willigen 1993: xiii). Willigen afirma ainda que não se trata de fazer com que as pessoas mudem contra sua própria vontade, mas de ajudá-las a expressar seus anseios e vontades. Nenhuma das abordagens mencionadas envolve imposição unilateral "das metas de desenvolvimento a partir de fora da comunidade»40 (1993: xiii). Para ele, todo antropólogo deve ter bom conhecimento da teoria, porque é ela que guia a pesquisa e que amplia as possibilidades de aplicação das informações levantadas. A Antropologia Aplicada, ainda, implica questões éticas, em especial ao considerar os conflitos entre diferentes grupos formadores de uma comunidade (Willigen 1993: xiii). Para Rylko-Bauer et al., a Antropologia Aplicada é um componente vital para a disciplina e deve servir como suporte para a construção de uma Antropologia mais engajada (2006: 178).

Forte (2011: 11-12) acredita que a capacidade de conhecimento da Antropologia deve ser ampliada e compreendida como uma ampla arena de investigação humana e engajamento,

\footnotetext{
39 “a general label for the entire array of situations e approaches for putting anthropology to use” (1993: xiii).

40 "of development goals from outside the community" (1993: xiii).
} 
estando imersa nas lutas sociais, colaborando para a construção de novas formas de engajamento e abordando questões como a violência, o poder e a desigualdade. Para Forte, esse tipo de engajamento — que está entre as melhores formas de se fazer Antropologia — é baseado na participação em debates públicos, em lutas contra o poder, "o poder de controlar recursos, o poder melhorar certas vidas ao custo da diminuição de outras, e o poder de moldar e perpetuar representações que nos mantêm presos num molde imperialista”41 (2011: 15). Se a Antropologia não fizesse referência à busca da possibilidade de coexistência pacifica entre povos diversos, no favorecimento do diálogo através das fronteiras da diferença cultural, à tentativa de fazer do mundo grande o suficiente para permitir a autodeterminação das sociedades múltiplas e divergentes, respeitar a autonomia e a autodeterminação dos outros, discutir questões sobre a condição humana contemporânea em um contexto específico de guerra e do capitalismo, e à construção conjunta de uma compreensão desses problemas, então o que seria a Antropologia? (2011:15). Se o papel do antropólogo é falar sobre o que significa ser Humano, ele deve falar sobre o que é ser humano em um sistema global, pautado por desigualdades, injustiças sociais, guerras, conflitos e domínio imperial. Bem como de colonização cultural aliado a um sistema de consumo de massa insustentável, e antidemocrático que favorece a dominação. "A Antropologia, mesmo quando se julga inovadora, deve tratar mais do que apenas um mundo 'em rápida mudança', deve ser sobre mudar o mundo"42 (Forte 2011: 18).

Para o autor, os debates que definem a prática antropológica ainda defendem que se trata de uma prática guiada pela autoconsciência, que envolve o ativismo social ou algo mais inerte em termos políticos, como levar o conhecimento para públicos de fora da Academia. Porém, a seu ver tais debates parecem dar como finalizado o pensar antropológico, sendo a missão atual da Antropologia apenas a divulgação dos resultados. Forte afirma que, na prática, a Antropologia não vem sendo pensada e aplicada de forma a construir, por meio do enfrentamento, do encontro, do ensinar e aprender recíprocos e no repensar as ideias e as práticas a partir do encontro. Segundo Forte, mesmo com viés prático a Antropologia continua estática, conservadora, hierárquica, afastada da população (2011: 5), e os pesquisadores que tentam agir com uma nova perspectiva encontram um sem-número de problemas.

Em seu trabalho com comunidades indígenas, Sillitoe (2007: 147) apresenta algumas dificuldades da prática da Antropologia Aplicada, a saber: a definição ou escolha da temática

\footnotetext{
41، the power to command resources, the power to enhance certain lives at the cost of diminishing others, e the power to shape e perpetuate representations that keep us locked in an imperialist framework” (2011: 15).

42 "Anthropology, even when deeming itself innovative, should be more than just about a "rapidly changing" world, but about changing the world” (Forte 2011: 18).
} 
a ser trabalhada, as implicações da multidisciplinaridade para as ciências humanas, o problema do "expert status" ou das relações desiguais entre pesquisadores e comunidade, a aplicabilidade dos métodos etnográficos e o envolvimento com as demandas desafiadoras da pesquisa participativa. Vale ressaltar que, numa tentativa de diálogo com essas questões, ao longo desta tese os estudos de caso fornecerão exemplos práticos das tentativas de aplicabilidade dos referenciais teóricos interdisciplinares apresentados neste capítulo. Sillitoe (2007: 147) discorre sobre algumas ações que podem favorecer a Antropologia Aplicada, dentre as quais se destacam: facilitar a exposição dos conhecimentos de diferentes segmentos da comunidade ou grupo pesquisado, usar o conhecimento e compreensões locais para o desenvolvimento e implantação de ações, o compartilhamento e a troca de conhecimentos e práticas entre diferentes grupos e atores no processo, buscar maneiras auxiliar uso responsável do conhecimento pelo mercado.

Assim, o olhar da Antropologia, em especial da Antropologia Aplicada, para a Arqueologia possibilita uma maior compreensão e percepção do "outro” nas relações entre diferentes atores que de alguma forma participam dos processos de negociação acarretados pela relação entre arqueólogos, comunidades e patrimônio cultural. E favorece também a percepção das formas como o uso do passado e dos bens patrimoniais podem auxiliar o fortalecimento das comunidades envolvidas neste processo.

\subsection{A MUSEOLOGIA E OS BENS PATRIMONIAIS COMO HERANÇA}

A Museologia é outra disciplina de interesse desta tese. As discussões apresentadas no decorrer do trabalho estão pautadas por referências e debates ora apresentados.

Foi no século III, em Alexandria, que apareceu pela primeira vez o Museion. Desde então "o museu tem sua história ligada à evolução do pensamento humano, relacionando-se aos diversos processos de mudanças econômicas, sociais e culturais” (Tamanini 1998: 195). Os museus modernos surgem a partir da herança das galerias e gabinetes de curiosidades, que eram espaços de poder. Nos séculos XVIII e XIX os museus foram usados como suporte da ideia de nação, fortalecida com o poder da colonização. Ainda no século XIX os museus se apoiaram na ideia de abandono, dando novas significações a coisas negligenciadas ou descartadas. Já no século XX, em relação direta com sua função social, os museus passaram a tratar dos traumas das sociedades e da humanidade. Assim, no século XX os museus viram o rompimento de sua perspectiva elitista e passaram a dar mais atenção às comunidades, grupos 
marginalizados, diferentes grupos sociais, lidando diretamente com sua potencialidade para a inclusão social e sua inserção na reciprocidade entre a globalização e a ação comunitária.

Foi na década de 1960, na França, que surgiram os primeiros expoentes da tentativa de criar esses museus mais democráticos. Os "Ecomuseus", conceito cunhado por Hugues de Varine-Bohan, tiveram seus fundamentos e conteúdos desenvolvidos por Georges Henri Rivière, que levou em conta problemas da identidade cultural, em especial de grupos minoritários (Carmona 2011: 118). Os Ecomuseus eram vistos como "instrumentos da população, em relação profunda com a identidade e ligados ao auge do Turismo que se via à época” (Wichers 2010: 157), um instrumento que "um poder público e uma população concebem, fabricam e exploram conjuntamente” (Rivière in Wichers 2010: 157). Um local onde a população se observa, se reconhece, tenta explicar seu território, onde ela se autoconstrói para o “outro” visitante (2010: 157).

A partir da década de 1970 alguns estudiosos também passaram a questionar o paradigma existente; foram os pioneiros de um movimento denominado "Nova Museologia", que ocorria "de forma isolada em diversos países, sob diferentes denominações: EcoMuseologia, Museologia Comunitária, Museologia Social” (Wichers 2010: 158) e discutia o objetivo da disciplina, não apenas como o estudo dos museus, mas sim voltado ao desenvolvimento comunitário, como promotor de postos de trabalho por meio da revitalização artesanal, agrícola e industrial (Moutinho 2008: 2).

Na década de 1980 prosseguiram em diferentes reuniões do Comitê Internacional para a Museologia (ICOFOM) as discussões relacionadas à ciência museológica, sua aproximação com outras disciplinas, sua metodologia de trabalho, capacitação profissional e seus rumos e possibilidades futuras. Discussões fortalecidas com a organização do Movimento Internacional da Nova Museologia (MINOM). Em 1984, ao buscar uma revisão de conceitos e sistematizar as novas práticas museológicas, o Ateliê Internacional Ecomuseus - Nova Museologia evidenciou a existência de uma nova postura, "renovadora, criativa e militante mais ampla que a 'ecomuseologia'” (Moutinho in Wichers 2010: 157).

Já no final do século XX inicia-se o que Chagas denominou de "efervescência no campo da prática e da teoria museal”, que acarretou diferentes tentativas de reconceituação da Museologia (1994: 15). De acordo com o autor, por algum tempo a disciplina esteve estabelecida, seus estudiosos e praticantes aceitavam o que seria o objeto de estudo e o campo de atuação da ciência museológica. Chagas usa a expressão de Kuhn, “ciência normal”, aplicável quando determinado paradigma vence seus contrapositores (in Chagas 1994: 15). 
Diante dos diferentes caminhos percorridos pela Museologia, há várias conceituações e compreensões sobre objeto de estudo da ciência museológica, as quais foram sintetizadas por Mensch:

“a. A Museologia como estudo da finalidade e organização dos museus; b. A Museologia como o estudo da implementação e integração de um certo conjunto de atividades, visando à preservação e o uso da herança cultural e natural: 1 . dentro do contexto da instituição museu 2.independente de qualquer instituição; c. A Museologia como o estudo: 1.dos objetos museológicos 2. da musealidade como uma qualidade distintiva dos objetos do museu; d. a Museologia como o estudo de uma relação específica entre homem e realidade” (Mensch 1994: 3).

Cara a esta tese é a quarta definição, que tem como um de seus expoentes a brasileira Waldisa Rússio, que em sua definição de fato museológico é responsável por uma das maiores contribuições ao avanço da discussão da relação entre homem e realidade. Rússio articulou de maneira inédita a organização epistemológica da Museologia aos movimentos sociais, sob duas orientações: a cognitiva, do Leste Europeu, e a pragmática, dos franceses e canadenses (Wichers 2010: 36). Rússio dialoga mais especificamente com Stranky e Gregorová. Stranky define a Museologia dentro dessa última abordagem - que estuda a relação do homem e realidade -, afirmando que o homem seleciona objetos de sua realidade, alterando a realidade desses objetos de forma a preservá-los (2010: 34). Gregorová critica as outras tendências e situa a Museologia como "uma disciplina científica distinta e independente, que se inclui nas ciências sociais" (in Wichers 2010: 34).

Rússio considerou a Museologia como uma "ciência em formação", a "ciência do fato museológico" (Rússio 1990: 7), uma "disciplina que tem por objeto de estudo a relação profunda entre o homem/sujeito e os objetos/bens culturais", “Tudo isso fazendo parte de uma mesma realidade historicamente determinada” (Chagas 1994: 22). Para Rússio o homem tem o poder de agir nesta realidade, "de exercer a sua ação modificadora” (in Wichers 2010: 35). No cenário institucionalizado, que para a autora seria o museu, o museólogo se preocuparia com a relação Homem/Realidade ou Homem/Objeto, dentro de parâmetros de fidelidade, documentalidade e testemunhalidade (Rússio 1990: 9). Para Chagas, os pesquisadores da Museologia que seguem esse pressuposto teórico podem, ao objetivar o estudo da relação sujeito / objeto, analisar também a instituição museu, a preservação e a dinamização do patrimônio cultural e natural e a atribuição de significado aos bens musealizados e 
testemunhos ausentes, pois todas essas temáticas estão diretamente relacionadas ao campo delimitado por Rússio (Chagas 1994: 23).

Ao analisar os componentes do fato museológico, Wichers afirma que nesse contexto o homem é compreendido como "indivíduo, grupo, comunidade, sociedade e população. Nessa relação com a realidade, o homem cria a cultura como resultado de seu trabalho”, dá significado e valores às suas criações, fazendo com que "coisas” e histórias se transformem em patrimônio (Wichers 2010: 35). O objeto seria "tudo que existe fora do homem [paisagem física, os artefatos imóveis, os bens móveis e a criação imaterial]”, sendo a hierarquia de valores o elemento que faz com que os objetos se tornem patrimônio. Enfatizando que a patrimonialização dos objetos se dá a partir de uma seleção (Wichers 2010: 35), a autora ressalta ainda a reelaboração do fato museológico preconizada por Bruno (2000), consistindo na relação entre homem e objeto em um cenário, um "edifício/instituição, espaço aberto, múltiplos espaços, território de intervenção” (Bruno in Wichers 2010: 38). Para Primo, os cenários são compreendidos como "locais onde o relato é levado à cena podendo o espaço museal ser entendido como um desses cenários. Entender o museu como cenário nos leva a percebê-lo como espaço de reestruturação, encenação e reencarnação, no qual os processos de hibridação das representações do social e do cultural são elaborados como sentidos simbólicos” (Primo in Wichers 2010: 38).

Bruno entende a Museologia como uma disciplina aplicada, que possui três campos de ação museológica: campo essencial, campo de interlocução e campo de projeção. O campo de interlocução lida com a identificação e compreensão da relação do homem com seu patrimônio, ao longo do tempo. Já o campo de projeção lida com os processos de transformação do patrimônio em herança. Toda ação museológica deve estar diretamente ligada à perspectiva de preservação e pesquisa, por sua vez os fundamentos do campo essencial. Tal campo se consolida a partir da dinâmica da cadeia operatória de procedimentos museológicos de salvaguarda e comunicação, estes sempre amparados pelo planejamento e avaliação. A avaliação, análise dos resultados e constantes tentativas de melhorias, realimenta a cadeia operatória. A cadeia operatória museológica engloba os procedimentos de apropriação, proteção, intervenção e devolução de semióforos. A salvaguarda e a comunicação são campos de ação diretamente relacionados, interdependentes, e devem se adaptar às variáveis: homem, objeto e cenário.

Para Cury, o campo museológico estuda o mencionado ternário em seu conjunto, ou a partir de um de seus aspectos, porém considerando o todo. Segundo a autora, esse é um dos pontos que diferencia a produção em Museologia “da produção de outras áreas que se 
aproximam do ternário ou de um de seus pontos constitutivos, mas com outras problemáticas” (Cury 2009: 29). Ela enfatiza que a multidiciplinaridade no estudo do ternário é essencial para a Museologia, pois a aproximação e a reciprocidade com outras áreas se mostram cruciais para "a construção da transversalidade, da estrutura epistemológica transdisciplinar e do quadro teórico-conceitual” da área (Cury 2009: 29). A autora afirma ainda que as diferentes disciplinas contribuem ao aproximar "outros elementos, argumentos, teorias e conceitos”, ampliando os limites da Museologia e trazendo análises e reflexões que podem ser apropriadas por ela, transformando a própria disciplina museológica. Por ser a Museologia um campo em construção, Chagas (1994: 23) considera que os estudos sobre as trocas possíveis com outras disciplinas são de grande importância. Para Rússio a Museologia é constituída por diferentes domínios de conhecimento e seus objetos de estudo, portanto a interlocução com outras áreas do conhecimento poderia articular e orientar as práticas museológicas visando ao desenvolvimento das sociedades (in Bruno et al. 2008: 34). A “interdisciplinaridade deve ser o método de pesquisa e de ação da Museologia e, portanto, o método de trabalho nos museus e cursos de formação de museólogos e funcionários de museu” (Rússio in Bruno et al. 2008: 36).

Assim, a reflexão sobre novos métodos de trabalho sempre esteve presente no pensamento de Rússio. Segundo Bruno (et al. 2008: 33), a autora antecipou discussões — que ganharam força apenas no final da década de 1990 - sobre novas possibilidades dos museus para o enfrentamento de questões como a inclusão cultural e social. Para Varine-Bohan, na citada década houve uma proliferação de museus locais, que adotaram nomenclaturas tais como "ecomuseus, etnomuseus, museus locais, museus de bairro e de vizinhança, museus comunitários, museus de sociedade e museus de território” (Chagas 2007: 219), bem como expressões mais consagradas, caso de "museus históricos, museus artísticos, museus científicos e museus ecléticos” (2007: 219).

Para Varine, os museus em geral deveriam se preparar para “desempenhar seu papel libertador das forças criativas da sociedade, para a qual o patrimônio não é apenas um objeto de deleite, mas, antes de tudo, uma fonte maior de desenvolvimento" (1995: 19). Wichers ressalta que as afirmações de Varine-Bohan continuam atuais, pois a "noção de museu como instrumento de desenvolvimento integrado tem, cada vez mais, um peso maior nos processos museológicos em curso e já se faz notar também nos ‘museus tradicionais'” (2010: 156). A autora afirma que embora as discussões da Nova Museologia tenham avançado em direção a uma nova prática museológica, "em muitos países ainda temos a exclusão de imensas 
camadas da sociedade dos museus, para as quais esses continuam sendo, no senso comum, o 'lugar das coisas velhas e sem vida'” (Wichers 2010: 156).

Segundo Wichers (2010: 158) essas experiências tomaram uma multiplicidade de formas, desde um Ecomuseu Tradicional polinucleado a um Ecomuseu de Desenvolvimento, preocupado com a articulação entre População, Patrimônio e Comunidade e que tinha como meta o desenvolvimento integrado, a sustentabilidade, a "valorização das identidades locais e a consolidação do exercício da cidadania” (2010: 158). Vale ressaltar ainda a relação que esses museus estabeleceram com questões do desenvolvimento sustentável que atendessem "às necessidades do mundo contemporâneo, aspectos inerentes à função social dos museus” (Wichers 2010: 158). Nesse período consolidou-se o conceito de "Museu integral”, como uma instituição “a serviço inseparável da sociedade que lhe dá vida” (Moutinho in Tamanini 1998: 212/13), que estimula a vontade de ação da comunidade, aprofundando "a consciência critica de cada um de seus membros buscando os fundamentos da ação nas condições históricas de desenvolvimento de cada comunidade” (Moutinho in Tamanini 1998: 212/13). Os preceitos da Nova Museologia influenciaram diretamente esta tese.

Segundo Moutinho, a Sociomuseologia traduziria parte do esforço “de adequação das estruturas museológicas aos condicionalismos da sociedade contemporânea” (Moutinho 2007: 1). Para o autor, esta constitui uma "área disciplinar de ensino, investigação e actuação que privilegia a articulação da Museologia em particular com as áreas do conhecimento das ciências humanas, dos estudos do Desenvolvimento, da Ciência de Serviços e do Planejamento do Território” (2007: 1). Moutinho enfatiza a abordagem interdisciplinar da área como meio para consolidar o reconhecimento da Museologia como "recurso para o desenvolvimento sustentável da humanidade, assente na igualdade de oportunidades e na inclusão social e econômica” (2007: 1), a partir da "intervenção social no patrimônio cultural e natural, tangível e intangível da humanidade” (2007: 1). Esses conceitos aproximam esta tese da abordagem da SocioMuseologia.

Destarte, seriam as principais preocupações da área: a valorização e proteção dos bens patrimoniais culturais e naturais; a valorização de questões relacionadas ao desenvolvimento e à cultura como elementos de "uma responsabilidade Social onde assenta a intervenção museal”; a mudança, pois as sociedades estão em permanente transformação e os museus devem se inserir neste processo; os museus como entidades prestadoras de serviços, que devem se atualizar e envolver em suas reflexões os conhecimentos de outras áreas; novas maneiras de formação e qualificação profissional que ultrapassem as formações técnicas (2007: 1-3). 
Essa nova percepção faz sobressair uma gama de preocupações, métodos e objetivos que, cada vez mais, dão sentido a "uma Museologia cujos limites não cessam de crescer, a visão restritiva da Museologia como técnica de trabalho orientada para as coleções, tem dado lugar a um novo entender e práticas museológicas orientadas para o desenvolvimento da humanidade” (2007: 3). Vale ressaltar que é com essa percepção de Museologia e de museu que esta tese pretende dialogar.

Para Chagas, a nova maneira de pensar os museus fez com que essas entidades ultrapassassem diferentes fronteiras e limites, e assim "quebraram regras e disciplinas, esgarçaram o tecido endurecido do patrimônio histórico e artístico nacional e estilhaçaram-se na sociedade. As suas práticas de mediação atualizaram a potência de uma imaginação que deixou de ser prerrogativa de alguns grupos sociais. Não se tratava mais, tão-somente, de abrir os museus para todos, mas de admitir a hipótese e de desenvolver práticas em que o próprio museu, concebido como um instrumento ou um objeto poderia ser utilizado inventado e reinventado com liberdade, pelos mais diferentes atores sociais. Por essa estrada, o próprio museu passou a ser patrimônio cultural, e o patrimônio cultural uma das partes constitutivas da nova configuração museal” (Chagas 2007: 219/220).

Ainda para o autor, na contemporaneidade o museu teve seu conceito de "objeto" ampliado, “tudo passou a ser museável” (2007: 220): o "objeto de museu passa a ser visto como um meio de dizer ou significar algo, um elemento da linguagem, resultando daí o foco do museu como canal de comunicação” (Wichers 2010: 37). A musealização, como prática social específica, "saiu” dos museus institucionalizados: "casas, fazendas, escolas, fábricas, estradas de ferro, músicas, minas de carvão, cemitérios, gestos, campos de concentração, sítios arqueológicos, notícias, planetários, jardins botânicos, festas populares, reservas biológicas, tudo isso poderia receber o impacto de um olhar museológico (Chagas 2007: 220)". São agentes e atores patrimoniais e culturais do "microdesenvolvimento dos territórios”, que em cada localidade se faz original, único, pois se adapta “à interação complexa dos fatores e de múltiplos parceiros, segundo as configurações cada vez mais diferentes, e mesmo evolutivas, para se adaptar às mudanças endógenas e exógenas” (VarineBohan 2008: 15). Os museus são fortes referências para as comunidades, são pluridisciplinares, ligados ao desenvolvimento global e sustentável. Todavia, "esses ecomuseus, museus comunitários são ainda uma minoria, mesmo que nos últimos trinta anos têm-se multiplicado em quase todos os países do mundo” (2008: 15).

Segundo alguns autores (Tamanini 1998, Vasconcellos 2008), a grande identidade entre todos os tipos de museus, "tanto nos países hegemônicos como nos periféricos, é o 
serviço educativo” (Tamanini 1998: 198). Para Tamanini, todo museu aberto ao público transmite uma mensagem, “educa através do objeto qualquer pessoa que nele entrar, seja qual for a sua classe social, sexo idade, raça ou escolaridade” (1998: 196). Há séculos os museus se preocupam com a educação de seu público, utilizando o objeto como instrumento possibilitador de aprendizado. A base do modelo institucional dos museus foi formada pelo despertar, a partir da cultura material, de interesses científicos além do contato entre diferentes povos e culturas ocasionado pela colonização. No século XIX já era evidente a importância da cultura material e dos museus para a produção de conhecimento, bem como sua vocação educacional e seu papel na preservação patrimonial.

Um dos aspectos que possibilitou aos museus servirem de instrumento político foi sua compreensão como um espaço de educação, que por meio de seu exercício de trabalho educacional consegue atribuir aos patrimônios novos usos e novas significações e que contribuem para uma reflexão do indivíduo em relação ao patrimônio do qual é herdeiro. Os museus educam a partir do patrimônio, e essa educação pode se dar em diferentes aspectos: pela convivência, conhecimento e reconhecimento do patrimônio pela comunidade; pelos objetos como indicadores da memória, colaborando para construção da memória individual e coletiva; para a inclusão, o trazer as memórias ou culturas marginalizadas para um debate sobre sua inserção em um discurso oficial.

Desde o século XIX os museus foram utilizados para "forjar uma identidade europeia abastada que opunha o europeu/civilizado/abastado e sua cultura à ignorância e atraso de indígenas, negros e gente pobre em geral” (Funari in Tamanini 1998: 199). Para Bruno, boa parte dos museus latino-americanos desenvolve atividades educativas voltadas para as crianças, ocupando o lugar que a escola não assume, por ser deficitária em muitos países do continente americano (in Tamanini 1998: 198). A autora cita Furter, que ressalta que na América Latina a situação atual é "resultante de uma colonização que criou sociedades fragmentadas, onde coexistem elites - tradicionalmente identificadas com a cultura das metrópoles - e populações esparsas e isoladas que lhes pareciam tão estranhas e longínquas como os povos estrangeiros” (in Tamanini 1998: 198). Porém, a partir da década de 1970 “o projeto burguês de utilizar os museus para educar o povo nos gostos definidos pela classe dominante começou a dar mostras de exaustão à medida que o conceito de educação passou por revisão” (Barreto in Tamanini 1998: 196).

A partir de uma nova concepção de educação, que não se restringe ao espaço escolar formal, mas como uma atividade de criação e aprofundamento pessoal, social, cultural e permanente "inseparável da vida política”, a educação do fim do século XX tornou- se 
permanente e social (Gadotti in Tamanini 1998: 197). O Programa Nacional de Museus passou a adotar os pressupostos da Educação Permanente para as ações educativas, seguindo as considerações da UNESCO. Os conceitos da Escola Nova de John Dewey foram trazidos para o Brasil pelo educador Anísio Teixeira (Vasconcellos 2008: 60). Pierre Furter considerava que o conceito de Educação Permanente deveria ser compreendido no contexto da modernização da sociedade, cabendo a ela substituir o ensino regular, por ser mais flexível e eficiente (2008: 61). Para Vasconcellos (2008: 60), nesse contexto o importante era “aprender a aprender”.

Como crítica a essa tendência pedagógica surge uma nova vertente, com caráter mais progressista: a pedagogia progressista libertadora de Paulo Freire, que almejava a construção do conhecimento por meio do diálogo entre educadores e educandos, mediada pela realidade concreta em que vivem. Os conteúdos deveriam ser extraídos e apreendidos dessa realidade e, depois de estudados, deveriam retornar à mesma realidade, transformando-a. No contexto brasileiro, a pedagogia progressista foi responsável pelo movimento social denominado "Educação popular”, voltado para as camadas sociais menos favorecidas economicamente, visando engajá-las na luta política.

Para Freire, a relação entre o público e o patrimônio estaria intrinsecamente ligada à identidade; em outros termos, para que uma pessoa construa e assuma sua identidade "é preciso que dê significação à realidade ao seu redor. É essencial a formação de um olhar crítico sobre as coisas. Isso permite que o indivíduo abandone a sua condição e subserviência, de passividade e torne-se cidadão, capaz de transformar sua realidade” (Freire in Almeida 2003: 285). Apesar de ter influenciado autores e teorias por todo o mundo, inclusive aquelas relacionadas à Nova Museologia, a metodologia de educação popular desenvolvida por Paulo Freire nunca foi adotada de forma sistemática pelos museus brasileiros (Vasconcellos 2008: 61). Este tese pretende dialogar com a pedagogia libertadora de Freire.

Os museus foram reduzidos a um complemento da escola, seguindo conceitos da corrente pedagógica escolanovista, segundo a qual o aprendizado deve acontecer em ambientes "motivadores, com diversidade de materiais didáticos, que estimulem as aptidões e o interesse pessoais” (1998: 201). De acordo com Lopes, a perspectiva escolanovista significou um avanço para "o rompimento da inércia em que sobrevivem os museus brasileiros, inserindo nos esforços por modernizações (modelos internacionais)” (in Tamanini 1998: 202). Para Lopes, “Ambas — a educação popular e a educação permanente —, apesar de suas diferenças significativas, propuseram-se a enfrentar a mesma necessidade de 
propostas globalizantes para a questão educacional brasileira, que superassem os programas paliativos de alfabetização, que se sucediam no país” (in Tamanini 1998: 202).

Concomitantemente foram introduzidas no Brasil as discussões da Educação Patrimonial, já explicitadas anteriormente. Para Candau (in Tamanini 1998: 205), "tanto a Educação Permanente como a Educação Patrimonial são convergentes”. O autor ressalta que a primeira objetiva "o aprofundamento tanto da experiência pessoal quanto da vida social global, que se traduz pela participação afetiva, ativa e responsável de cada sujeito”, sendo então a Educação Patrimonial “uma das áreas de intervenção da Educação Permanente, capaz de permitir através da interpretação do objeto, a leitura dos contextos nacional e universal da cultura, o que viabiliza a extrapolação da cultura” (1998: 205). Vários museus brasileiros passaram a adotar esta metodologia. Porém, em sua grande maioria, as ações não foram contínuas (1998: 4).

Segundo Vasconcellos, a partir do inicio da década de 1990 a prática educacional em alguns museus brasileiros passou a questionar o modelo escolar e tiveram início reflexões sobre o papel do profissional e sobre a importância da busca por uma prática pedagógica comprometida com os interesses do público e com a transformação social. Tais reflexões ocasionaram a ampliação das experiências educativas não-formais voltadas para diferentes públicos, que normalmente não tinham acesso aos espaços museológicos — idosos, indígenas, portadores de necessidades especiais, entre outros (2008: 61). Algumas instituições têm buscado reverter um processo que já dura séculos, tentando alterar os olhares elitistas e refletir sobre acervos criados a partir de saques e favorecendo debates provenientes das contradições e ambiguidades dos processos museológicos. Amplos segmentos da população economicamente desfavorecida permanecem, até hoje, distantes dos museus, não só sem acesso físico como também em sua representação nesses espaços. Nas últimas décadas os museus vêm "derrubando as paredes” de seus espaços tradicionais, buscando, cada vez mais, novos públicos, criando exposições que incorporam diferentes linguagens, tanto relativas ao conteúdo como na forma e espaço. Exposições que buscam agregar memórias exiladas (Bruno 2005: 238), que foram marginalizadas ou excluídas na partilha dos sentidos e significados que constituíram a nação e seu discurso oficial. Buscando diminuir as diferenças, lidando não somente com a diversidade cultural, mas também com os diferentes discursos éticos e políticas culturais. Desvinculando-se das amarras tradicionais, que "somente preservam o gosto da minoria e a grande maioria da população não se encontra interessada em sua 
existência”43 (Carmona 2011: 119). Assim, os museus devem participar ativamente dos debates contemporâneos sobre ética, respeito e "reconhecimento da diversidade cultural e social, trabalhando a favor não somente da comunicação de seus objetos culturais, sob um ponto de vista multicultural, como também contribuindo para a democratização cultural por meio dos processos de inclusão social”. (Tojal 2007: 81) “O museu não existe isoladamente, mas dinamicamente, na sociedade” (Rússio in Bruno et al. 2008: 25).

Outra questão crucial que vai além do papel dos museus na busca e na afirmação de identidades da sociedade é a criação de condições para que a comunidade participe ativamente da salvaguarda de seu patrimônio cultural (Carmona 2011: 115). Um museu responsável socialmente investe em ações interdisciplinares em toda sua cadeia museológica, desde o "gerenciamento de coleções, pesquisa e documentação, que dentro dessa concepção poderiam estar mais abertas à participação de diferentes grupos sociais dispostos também a dar a sua contribuição nos processos de aquisição, seleção e complementação de pesquisas sobre os objetos” (Tojal 2007: 82).

As práticas de mediação museal possuem papel fundamental nesse processo. Seu redimensionamento deve envolver os interesses dos grupos representados, favorecendo dinâmicas e processos inovadores (Chagas 2007: 177), não apenas alterando as práticas que alimentam preconceitos e estereótipos, mas "na apropriação das tecnologias de mediação museal e das ferramentas de combate ao racismo e ao preconceito por diferentes grupos culturais" (Chagas 2007: 192). Um processo comunicativo eficaz deve situar "as pessoas no seu próprio 'habitat', dinamizando novas relações nos mais diferentes espaços em que vivem essas mesmas pessoas, com, e não apesar de, sua diversidade” (Tojal 2007: 45-46).

\subsection{BENS ARQUEOLÓGICOS E NOVAS PRÁTICAS SOCIAIS: APROXIMAÇõES INTERDISCIPLINARES}

As quatro disciplinas apresentadas - Arqueologia, Turismo, Antropologia e Museologia - se aproximam por considerarem que os bens arqueológicos podem possibilitar novas práticas sociais. Vale ressaltar que se entende por patrimônio arqueológico o conjunto de coleções, artefatos, sítios e narrativas. Porém, estamos considerando para esta análise teorias específicas de cada disciplina, conforme demonstrado nos textos apresentados anteriormente. Assim, são os debates da Arqueologia Pós-Processual, do Turismo

43 “sólo preservan el gusto de la minoría y la gran mayoría de la población no se encuentra interesada en su existencia” (Carmona 2011: 119). 
Sustentável, da Antropologia Aplicada e da Sociomuseologia que possibilitam tal aproximação, por meio dos bens patrimoniais como geradores dessas novas práticas.

A Arqueologia Pós-Processual, formada por segmentos como a Arqueologia Colaborativa, a Arqueologia Comunitária, a Arqueologia Simétrica e a Arqueologia Pública, enfatiza o envolvimento das comunidades na investigação e análise do contexto arqueológico. O Turismo Sustentável, assim como a Arqueologia, defende o envolvimento das comunidades locais em todo seu processo de planejamento e implantação, inclusive tendo voz acerca da forma como seu passado é apresentado ao mundo exterior (Shackel 2005: 33) e sobre como o Turismo deve ser desenvolvido: "Essa forma de inclusão necessita de um diálogo contínuo entre as várias partes interessadas, uma vez que as diferentes ideias sobre o passado podem tornar o processo controverso",44 (Shackel 2005: 33). Para o Turismo Sustentável as comunidades devem ser agentes culturais (Carman e Keitumetse 2005: 40). A Museologia, conforme demonstrado anteriormente, vem buscando a democratização não apenas do acesso da comunidade aos museus, mas também à seleção e produção do patrimônio cultural. A Antropologia Aplicada (Pyburn e Wilk 2006, Shackel e Chambers, 2004) defende a percepção de diferentes sujeitos e o "reconhecimento do uso do passado como um caminho para o fortalecimento de comunidades” (Silveira e Bezerra 2007: 86), bem como o empoderamento de atores, com vistas a transformações sociais.

Para Ballart, a participação direta dos cidadãos em programas de que envolvem o patrimônio cultural constitui uma das melhores práticas para as políticas patrimoniais (in Yrais 2009/2010: 262). A participação de diferentes grupos sociais vinculados aos bens patrimoniais por meio de práticas sociais e simbólicas cotidianas deve ser levada em consideração de modo a gerar reflexões sobre o valor que sua cultura, do passado ou do presente, apresenta para contextos culturais mais amplos (Silveira e Bezerra 2007: 88). A participação eficaz da comunidade favorece o conhecimento mais amplo do patrimônio cultural, dos interesses e valores que os diferentes coletivos sociais e instituições vinculadas dão a estes bens. Por isso são importantes reflexões sobre instrumentos teóricos, metodológicos e participativos das diferentes áreas interessadas nos bens patrimoniais arqueológicos (Urtizberea 2009/2010: 265). Para as quatro disciplinas o importante é debater, refletir, compartilhar definições, objetivos, metodologias, estratégias e instrumentos de ativação do patrimônio cultural entre todos os agentes sociais. Sem deixar de lado a responsabilidade de cada agente, pois assim o patrimônio cultural deixará de ser um

\footnotetext{
44، This form of inclusiveness needs a continuous dialogue between the various stakeholders, as different ideas about the past can make the process contentious” (Shackel 2005: 33).
} 
“aparelho" para passar a ser um "campo", no âmbito da compreensão de Bouedieu (Urtizberea 2009/2010: 283).

Segundo Wichers (2010: 45), os arqueólogos pós-processualistas compreendem o indivíduo como ator social, sendo o contexto o que dá significado ao registro arqueológico. Para a autora essa teoria arqueológica favorece a identificação e valorização de diferentes interpretações do passado, o que daria uma abertura para a aproximação de outras áreas como a Sociomuseologia e a Antropologia - , pois tal abertura possibilita novas leituras e ressignificações do contexto arqueológico. Ainda para Wichers, a subjetividade do trabalho arqueológico construído no presente evidencia que os significados simbólicos dos vestígios arqueológicos variam de contexto para contexto (2010: 45). Por isso a autora enfatiza a importância da compreensão de que o contexto é construído socialmente por sujeitos sociais imersos em um universo econômico, político, cultural e simbólico.

Para Silveira e Bezerra, antes de se interpretar as paisagens e os objetos como bens patrimoniais deve-se considerar que "tais elementos estão imersos numa complexa teia de significações que encerra nexos singulares, de modo que as coisas fazem sentido de acordo com o ethos e o eidos específicos ao contexto sócio-histórico em que aparecem” (2007: 90). Os autores afirmam que há uma hermenêutica das paisagens, ou dos contextos, que está intimamente relacionada "às interpretações do que comumente denominamos patrimônio, pelas sociedades que vivem e experienciam o seu lugar” (2007: 90). As disciplinas buscam a compreensão e valorização dos diferentes contextos, visando possibilidades de transformálos.

As disciplinas entrecruzam-se em nível epistemológico, pois consideram que a narrativa ou o discurso arqueológico sobre o passado é uma preocupação do presente, uma vez que "é no presente que são estabelecidas as relações entre os indivíduos e o patrimônio; é no presente que os interesses de grupos sociais distintos elegem o seu patrimônio" (Almeida in Carneiro 2009: 106). Para Salamon, o trabalho da memória não é cultivar a recordação, mas situar o passado aqui, na responsabilidade presente e do presente. Essa presentificação é pensar a memória e a tradição como tarefas por fazer, por inventar (2006: 143). Há, portanto, um conjunto de saberes e de fazeres relacionados aos bens patrimoniais e que apresenta o desafio de se lidar com "esta herança de caráter local como um patrimônio situado”, que provoca reflexões sobre quem o produz ou produziu no passado e aqueles que o recebem como herança (Silveira e Bezerra 2007: 92).

A partir de reflexões das mencionadas disciplinas é possível que coleções, bens e narrativas impulsionem debates e reflexões “críticas acerca dos processos sociais 
contemporâneos, introduzindo qualidade na vivência das comunidades envolvidas” (Wichers 2010: 337). O desenvolvimento dentro das perspectivas teóricas elencadas para esta tese é compreendido como integral, que vai além do consumo, um processo global que promove melhorias na qualidade de vida das comunidades partícipes dos programas e projetos propostos (Rússio in Wichers 2010: 336). O desenvolvimento humano sustentável tem como seu componente mais importante a gestão participativa dos bens patrimoniais, e deve ser implantado de modo a gerar melhorias para as populações que se encontram em estado de pobreza ou exclusão (Yrais 2009/2010: 258).

Silveira e Bezerra afirmam que a Educação Patrimonial é um instrumento possível de mediação entre pesquisadores e comunidade (2007: 86), aproximando as diferentes disciplinas. Para os autores, a intersecção entre educação e Arqueologia é tensa; eles ressaltam a resistência de alguns arqueólogos, para quem os profissionais que trabalham com a temática da educação na Arqueologia são estudiosos de uma área menor - muitas vezes sequer os consideram arqueólogos (Silveira e Bezerra 2007: 84-85). Os autores afirmam ainda que no Brasil tanto a Antropologia como a Arqueologia têm dado pouco valor às "experiências de ensino-aprendizado que buscam a valorização dos bens patrionializáveis pelas comunidades nas quais os mesmos desempenham algum papel em sua dinâmica cultural, mais especificamente aquelas tentativas de envolver as pessoas que convivem diariamente com os bens a serem conservados em projetos de desenvolvimento a fim de que considerem os seus saberes e fazeres acumulados ao longo do tempo e suas relações com os patrimônios como relevantes para o próprio âmbito da conservação” (Silveira e Bezerra 2007: 86-87).

Pode-se acrescentar que o Turismo no país também não tem dado muita atenção a seu papel educativo. Conforme mencionado anteriormente, apenas a Museologia tem em seu histórico uma preocupação com questões educativas; porém, apenas recentemente reflete sobre a questão de forma mais democrática.

As ações educativas devem, então, ser pensadas por essas disciplinas de forma a se distanciar da ideia de conscientização do outro, "tão propalada por educadores e técnicos do campo do patrimônio, revela uma violência simbólica ante as comunidades" (Bourdieu in Silveira e Bezerra 2007: 87). Tal ideia de conscientização não é aceita antropologicamente, pois não compreende o Outro "como um sujeito capaz de realizar a sua própria hermenêutica do mundo no qual está inserido” (2007: 87). A Educação Patrimonial deve ser pensada no contexto de uma perspectiva ética, denominada por Silveira e Bezerra de ética da reciprocidade, que valoriza o diálogo e as trocas culturais entre os diferentes atores, 
empoderados durante o processo. Para os autores, a questão ética é crucial para as ciências humanas (2007: 84), mais especificamente para as disciplinas de interesse desta tese.

As ações educativas no âmbito das perspectivas teóricas mencionadas devem ser pensadas de forma interdisciplinar, levando-se em conta diferentes áreas do conhecimento devotadas ao estudo do domínio patrimonial. As reflexões interdisciplinares sobre a comunicação do patrimônio arqueológico e do conhecimento científico junto à sociedade devem ampliar os horizontes de atuação da Arqueologia, colocando os profissionais como agentes na construção de um saber novo e, por isso mesmo, complexo e instável (Silveira e Bezerra 2007: 88). Assim, a perspectiva interdisciplinar deve ser considerada central "para as pesquisas e intervenções sobre a temática do patrimônio, especialmente quando se trata de pensarmos sobre o papel dos profissionais e dos técnicos do campo do patrimônio junto às comunidades em que tais elementos aparecem” (2007: 88). Eles ressaltam também “os dilemas e complexidades existentes na aproximação de saberes, metodologias e perspectivas teórico-conceituais que precisam ser negociadas no ato mesmo de se lançar à interdisciplinaridade" (2007: 88).

Segundo Wichers a interface entre a Museologia e a Arqueologia é marcada por relações dialéticas, pois ambas se influenciam a todo o momento, "ambas produzem narrativas, rompendo com uma possível dicotomia entre produção e socialização do conhecimento" (Wichers 2010: 336). Acerca dessa consideração é importante para a presente tese que o Turismo e a Antropologia sejam compreendidos como áreas que também produzem narrativas que envolvem o patrimônio arqueológico.

A aproximação das diferentes disciplinas enfatiza o fato de que as quatro áreas têm em comum o caráter subjetivo do conhecimento. Outro elemento de aproximação é a compreensão de que diferentes interesses interferem na seleção de referências patrimoniais e sua inserção nas memórias individuais e coletivas das comunidades, procurando analisar este processo. Todas tentam analisar as desigualdades, tanto as sociais e econômicas, bem como na representação de diferentes identidades e segmentos patrimoniais nas identidades mais amplas, locais e regionais. Todas estão voltadas para o estudo da Multifocalidade do patrimônio, gerando práticas arqueológicas mais democráticas, possibilitando ainda um diálogo entre o patrimônio arqueológico e os demais bens patrimoniais.

Outro questionamento comum entre as áreas diz respeito ao papel social da disciplina e suas responsabilidades éticas, bem como o papel dos bens patrimoniais no presente, na contemporaneidade. As quatro áreas buscam compreender de que maneira esses bens podem favorecer o desenvolvimento socioeconômico de populações, visando melhorias na 
qualidade de vida das comunidades, garantindo, por outro lado, a preservação do patrimônio. E também propiciando o empoderamento de diversos atores sociais, criando condições para que se tornem cidadãos responsáveis pela gestão participativa de seus bens patrimoniais e pelas possibilidades de transformação do contexto em que estão inseridos.

Em suma, é com essa gama de reflexões que esta tese procura dialogar. 


\section{CAPÍTULO 2 - O CONTEXTO INTERNACIONAL: TURISMO ARQUEOLÓGICO EM DUAS REALIDADES DA AMÉRICA LATINA}

Este capítulo pretende demonstrar como se dá a interação entre Arqueologia, Turismo e sociedade a partir do exemplo concreto de alguns contextos latino-americanos. Foram selecionados como estudos de caso o México e o Peru, nações que de diferentes maneiras construíram uma importante relação entre as disciplinas relevantes para este trabalho. Ademais, os dois países são os maiores receptores de Turismo Arqueológico das Américas.

Cabe aqui uma conceituação: o segmento turístico que lida com a incorporação do patrimônio arqueológico na atividade turística é denominado Turismo Arqueológico ou Arqueoturismo, segmento este que é parte do Turismo Cultural, já apresentado no Capítulo 1. Doravante será adotada essa nomenclatura por sua importância como um delimitador do objeto de análise.

O Turismo Arqueológico vem crescendo consideravelmente em diferentes partes do globo. No México e no Peru o Arqueoturismo movimenta significativamente a economia. Ambos os países possuem como seus principais atrativos turísticos o patrimônio arqueológico: a atividade turística influencia diretamente o cotidiano dos moradores e o seu contato com os bens arqueológicos. Tanto no México como no Peru o conhecimento arqueológico está presente no processo de construção do imaginário nacional, gerando mecanismos de poder. Nos dois países a comunidade está em contato direto e constante com os bens arqueológicos, suas imagens e símbolos. Guardadas suas peculiaridades nacionais, os casos mexicano e peruano possuem muitas semelhanças, já que ambos elevaram o patrimônio arqueológico ao status de símbolo nacional, o que faz extrema diferença para o desenvolvimento do Turismo, em especial o Turismo Convencional.

Vale ressaltar que os imaginários nacionais estão diretamente ligados à construção da imagem turística de cada nação, influenciando incisivamente a valorização de cada bem patrimonial como atrativo turístico. Para a atividade turística a "função, a forma e o significado dos produtos são definidos pelo contexto cultural do consumo, determinando o motivo pelo qual as pessoas compram o produto, suas expectativas e os símbolos associados a este” (Guardani et al. 1996: 24). A cultura é absorvida pela socialização, em que o indivíduo desenvolve seus valores, motivações e atividades habituais. Para tanto, é importante compreender alguns fatores relacionados à demanda turística e de que maneira esta influencia a seleção e o planejamento de atrativos para a atividade. Dentre os fatores que influenciam a escolha do turista está a cultura, compreendida como complexo de valores, ideias, artefatos e 
símbolos que auxiliam o "indivíduo a comunicar-se, interpretar e avaliar-se como membro da sociedade” (Guardani et al. 1996: 24).

Porém, segundo Villalobos, pesquisador da Durham University, o desenvolvimento do Turismo Arqueológico nesses países traz a reboque questões mais profundas que devem ser pensadas e debatidas. Em uma análise mais cuidadosa, pode-se perceber que ambos os países tanto o nacionalismo como também o Turismo estão ancorados a alguns poucos sítios. Para o pesquisador, as duas nações geraram uma exploração ideológica de alguns poucos símbolos, cuja repetição exaustiva acabou por distorcer outras situações mais complexas relacionadas aos sítios arqueológicos. Vale citar como exemplo o caso mexicano de Teotihuacan, sítio sobre o qual foi construído o bem-sucedido imaginário de Turismo Arqueológico mexicano. Trata-se realmente de um sítio excepcional, que, porém, passa por um processo muito contraditório e complexo. Por um lado os sítios que representam essas nações são assumidos como locais que divulgam e representam a identidade nacional; por outro, se desnacionalizam a partir de sua inclusão na lista de Patrimônios da Humanidade da UNESCO. Tanto no México como no Peru é preciso levar em conta que grande parte dos atrativos do Turismo Arqueológico - pelo menos os sítios mais visitados e naqueles mais divulgados pelos governos - é tida como Patrimônio da Humanidade.

Vale ressaltar também o intenso trabalho de criação de novos produtos arqueológicos no Peru, com altos investimentos em infraestrutura e divulgação, devido à possibilidade de proibição das visitações a Machu Picchu, carro-chefe do Turismo nacional. Nesse contexto, mostra-se complexa a relação que se constrói dentro do Turismo Arqueológico entre os sítios tidos como altamente turísticos, os demais sítios arqueológicos, pouco visitados, e as comunidades locais. Um paradoxo entre o Turismo Convencional e a possibilidade do Turismo Não-Convencional, dentro dos preceitos da sustentabilidade.

\subsection{MÉXICO: NAÇÃO, NEOLIBERALISMO E MOBILIZAÇÕES SOCIAIS}

O primeiro país a ser analisado é o México. Várias das informações apresentadas neste item da tese são resultantes de um intenso diálogo com diferentes pesquisadores mexicanos, firmado a partir do $53^{\circ}$ Congresso Internacional de Americanistas e do evento Ecos del $53^{\circ}$ Congresso Internacional de Americanistas, ambos ocorridos na Cidade do México. Tais eventos possibilitaram uma importante discussão sobre os problemas e os benefícios que o Turismo Arqueológico acarreta para as comunidades envolvidas na atividade turística e para 
os bens patrimoniais, em especial na realidade mexicana (Mirada Antropológica 2009-2010; Alfonso 2010).

Em 1996, Margarita Barreto (1996: 97) realizou uma pesquisa sobre a bibliografia científica do Turismo no Brasil e comparou os resultados à realidade mexicana. Foram encontrados, até aquele ano, apenas 66 livros de Turismo publicados no Brasil, ao passo que no mesmo ano uma única editora mexicana, a Trillas, chegava a 45 títulos publicados na mesma área. A autora ressalta, ainda, que os primeiros cursos de Turismo no Brasil utilizaram bibliografia mexicana e espanhola por conta da ausência de publicações brasileiras. Em seu artigo sobre a pesquisa em Turismo, Mirian Rejowski (1998: 51) afirma que, diferentemente do México, onde os estudos multidisciplinares já vinham sendo amplamente desenvolvidos, no Brasil foi somente na década de 1990 que novas áreas passaram a estudar o Turismo: a Antropologia, a Sociologia, os sistemas computacionais, as ciências contábeis, entre outras. Essas informações fundamentam a escolha do México como país primordial para a compreensão da aproximação entre as disciplinas em outras realidades que não a brasileira.

O México é um dos dez destinos turísticos mais visitados do mundo; sem dúvida, seu principal atrativo é o patrimônio cultural, que tem sido amplamente reconhecido pela UNESCO - mais de duas dezenas de sítios mexicanos já foram declarados Patrimônio da Humanidade (Mantecón 2005: 236). No país há, desde 1917, leis de proteção do patrimônio. Trata-se de um dos países latino-americanos que mais investiu em conservação de seus bens; contudo, depois da crise econômica da década de 1980 o governo mexicano passou a implementar políticas neoliberais que diminuíram significativamente os recursos do Estado voltados para a educação e a cultura (2005: 237).

Na última década do século XXI foi possível notar importantes avanços na quantificação da contribuição das indústrias culturais ao Produto Interno Bruto (PIB) do país. Tanto o México como o Brasil fazem parte do grupo de países com alta participação de suas indústrias culturais no PIB (Piedras 2006: 35). A produção e a geração de recursos da economia, por meio da cultura, envolvem atividades como teatro, música, dança e o patrimônio cultural ligado ao Turismo (2006: 30). A cultura passou a ser reconhecida como um motor do crescimento econômico e do desenvolvimento do país, e foi alçada à condição de um dos setores mais importantes da economia do México, perdendo apenas para as indústrias maquiladoras, do petróleo e para o Turismo, ultrapassando, por exemplo, as telecomunicações e a agricultura (2006: 31). Vale ressaltar que os três primeiros setores em participação na economia mexicana possuem uma política integral que contempla desde uma estrutura governamental especializada - que no caso do Turismo é representada pela 
Secretaria de Turismo (Sectur) —, tratamento fiscal preferencial e específico, bem como altos recursos financeiros. O patrimônio cultural possui o caráter dual de gerar ao mesmo tempo crescimento e desenvolvimento econômico. Porém, o setor da cultura não apresenta condições semelhantes aos outros mencionados (2006: 34).

Dentro do setor cultural está inserido o patrimônio, o qual tem representado, no decorrer da história mexicana, parte fundamental da cultura no país devido à riqueza de monumentos, zonas arqueológicas, esculturas, pinturas, festas, celebrações e tradições (2006: 37). Já o Turismo Cultural é visto no país como uma atividade que gera, por um lado, homogeneização, e por outro tem o potencial de fazer com que o patrimônio propicie melhorias em muitas regiões do México que possuem como principal capital a cultura (2006: 39-40). É importante destacar que grande parte do patrimônio histórico e arqueológico nacional está localizado em zonas não-metropolitanas, o que favorece que seu aproveitamento turístico possa diminuir diferenças de desenvolvimento entre estados, zonas urbanas e rurais (2006: 40).

O território nacional é dividido em mais de 200 zonas arqueológicas inventariadas até 2005 eram mais de 200 mil sítios. Segundo a Secretaria de Turismo do México, em 2011 cerca de 190 milhões de pessoas visitaram os atrativos turísticos mexicanos. De acordo com informações do Banco de México e do Sistema Integral de Operación Migratoria, o país vem registrando consecutivos crescimentos no número de visitantes estrangeiros. Turismólogos do país afirmam que cinco estados turísticos apostam no Programa Mundo Maya como forma de gerar um aumento considerável do número de visitantes para o ano de 2012, o que demonstra grandes investimentos em alguns poucos sítios e municípios. Os principais sítios arqueológicos em recepção de visitantes no México são: Teotihuacan, Tulum, Chichen-Itza, Palenque e Xochicalco.

\section{POLÍTICAS PÚBLICAS E PROJETOS CULTURAIS NA HISTÓRIA DO PATRIMÔNIO ARQUEOLÓGICO MEXICANO}

Assim como o Peru, o México foi um país pioneiro no tema da proteção ao patrimônio, não pelo interesse em proteger seus bens patrimoniais, mas pela geração de uma política pública voltada para a articulação de um projeto cultural (Alcayaga 2006: 121). O México aparece como paradigma da política estatal de cultura, concebida como um projeto nacional próprio da modernidade. Toda essa diretriz política foi calcada em um programa 
ideológico de nacionalização do passado, unindo ciência e nacionalismo, de tal maneira que possibilitou, por exemplo, que apenas mexicanos realizassem escavações arqueológicas em seu território (2006: 122).

Assim, o interesse pela herança indígena no México se desenvolve desde princípios do século XIX como resultado da independência política e o estabelecimento da nação mexicana. Na construção da nação mexicana, a ideia de nacionalismo eclode junto da noção de patrimônio. Durante a conquista do México, tudo que era relacionado ao mundo pré-hispânico foi severamente atacado; porém, no final do século XVIII, as manifestações independentistas propiciaram as condições para que os olhares se voltassem às populações pré-coloniais, agora convertidas em antecedentes gloriosos e fundamento histórico do novo Estado.

A partir de então a cultura mexicana ocupou um lugar central nas políticas oficiais voltadas para a definição da identidade nacional, apresentada como monumental e grandiosa (Mantecón 2005: 249). Assim, os intelectuais, na busca por embasar uma identidade nacional independente, incorporaram a herança cultural e se utilizaram do patrimônio como instrumento de apropriação de um passado, exilando o passado espanhol (2005: 249). Esse processo de apropriação e exclusão para a construção identitária do povo mexicano pode ser claramente evidenciado, por exemplo, durante as escavações do Templo Mayor, na região central da Cidade do México. O Estado mexicano buscou estabelecer uma filiação direta com os astecas, lançando mão dos benefícios simbólicos da valorização e reprodução de seu poder, excluindo e destruindo bens referentes ao passado colonial (2005: 249).

Florescano (in Reyes 2009/2010: 291) demonstra que cada época processa de maneira distinta seu passado e realiza uma seleção dos bens que possui, em um processo contínuo de identificação do patrimônio e do reconhecimento contemporâneo dos valores do passado. Ademais, realiza também a seleção dos bens patrimoniais de acordo com valores particulares de grupos sociais dominantes, que são restritivos e exclusivos. Para Reyes, apesar de sua condição de elementos simbólicos representativos do passado, os monumentos e objetos - e o valor a eles dispensado - dependem principalmente de interesses ideológicos hegemônicos e políticos, bem como do projeto de nação e dos interesses do governo vigente. O que possibilita mudanças na consideração e uso dos bens patrimoniais, mudanças que podem ser analisadas a partir de pesquisas sobre a história e a memória das instituições culturais (2009/2010: 291).

A apropriação do passado pré-hispânico no século XVIII possibilitou a identificação de tentativas conscientes, por parte dos setores nacionalistas da sociedade e do governo do México, voltadas a evitar a saída de bens patrimoniais para o exterior, evidenciar esses bens 
como patrimônios da nação e valorizar e inventariar diferentes manifestações das culturas nativas. Como exemplo dessas tentativas, Reyes cita o restabelecimento da Junta de Antigüedades, em 1822, e a criação do Conservatório de Antigüedades, em 1825 (2006: 49).

A primeira grande instituição responsável pela recuperação e preservação do passado pré-hispânico, que traria a base para a identidade mexicana, foi o Museu Nacional Mexicano (Cottom in Reyes 2006: 49). Porém, Mantecón destaca que não se pode atribuir apenas ao contato com os museus a responsabilidade da mitificação dos mexicas, pois para o autor a base para a construção de uma "consciência de nação excepcional” corresponde a uma ideia de nacionalidade mexicana homogeneizada também afirmada pela escola e pelos meios de comunicação (2005: 250).

Desde 1821 até os dias atuais a ação primordial no campo cultural no México tem sido papel do Estado, que estabeleceu os elementos normativos e técnicos, as instituições, as metodologias e as ações mais importantes para "recuperar, concentrar, conservar, proteger, vigiar e difundir os sítios e objetos patrimoniais do passado histórico do país” (Reyes 2006: $49)^{45}$. O marco normativo e operativo institucional da ação governamental que se desenvolveu a partir do século XX vincula a cultura à educação (2006: 49). Para Peralta, cultura e educação formam um binômio fundamental para transmitir valores e princípios que alimentam a identidade nacional (2006: 75). Vale lembrar que no final do século XIX as legislações sempre se referiram à noção de uma educação vinculada com o elemento identitário das culturas pré-colombianas. Como exemplo Reyes cita o terceiro artigo da Constituição de 1861, as leis juristas e a Lei Orgânica de Instrução Pública de 1867, assim como a lei de Maximiliano de Habsburgo, de 1865 (Reyes 2006: 50).

No século XX os governos republicanos continuaram nessa mesma direção. Em 1905 foi fundada a Secretaria de Instrucción Pública y Bellas Artes, responsável pelo sistema educacional e pelos principais espaços culturais da nação mexicana (2006: 50).

Em 1939 foi fundado o Instituto Nacional de Antropologia e Historia (INAH), responsável pela maior parte do patrimônio arqueológico e histórico do país. O organismo foi a primeira instituição na qual se materializou e se conjugou o que hoje se compreende como uma política cultural do Estado. Vale destacar que o INAH incorporou o Museo Nacional de Arqueología, Historia y Etnología, a Dirección de Monumentos Pré-Hispânicos e a Dirección de Monumentos Coloniales, instâncias preexistentes que possuíam estrutura, funções e patrimônio próprios.

45 "recuperar, concentrar, conservar, proteger, vigilar y difundir los sitios y objetos patrimoniales del pasado histórico del país” (Reyes 2006: 49). 
Uma das principais preocupações da primeira diretoria do INAH foi "proporcionar uma base jurídica para o trabalho arqueológico" (Robles in Reyes 2009/2010: 294) ${ }^{46}$. A primeira gestão trouxe para o instituto professores das universidades para ocuparem as carreiras de Arqueologia, Etnologia, Antropologia e Linguística, fazendo do INAH um importante espaço educativo (Vid e Lameras in Reyes 2009/2010: 296). Para Reyes, a formação do Instituto foi um processo de reinstitucionalização que potencializou a viabilidade da ação governamental no campo do patrimônio (2006: 52). Foi construído um aparato institucional para a conservação dos bens patrimoniais envolvendo a pesquisa, a conservação e a difusão, assim como a formação de profissionais. Para a conservação do patrimônio cultural mexicano ganharam corpo uma série de princípios, presentes na primeira Lei Orgânica do INAH, uma política cultural e a uma comunidade acadêmica especializada, com interesses e objetivos próprios (Reyes 2009/2010: 296). O INAH nasceu como uma instituição forte, que desde seus primórdios contou com uma importante plataforma acadêmica, política e organizacional, totalmente em consonância com a ideologia nacionalista e popular da Revolução Mexicana e com os objetivos técnicos e políticos do governo que criou a entidade (Reyes 2009/2010: 296-297).

Na década de 1960 teve início uma importante política museológica, que culminou na implantação do Museo Nacional de Antropología, do Museo Nacional del Virreinato, localizado em Tepotzotlán, e do Museo Nacional das Culturas (Reyes 2006: 55). Foram estabelecidos convênios com os governos dos estados para a formação e a reorganização de 17 museus por todo o país (2006: 54). Foi também durante esse período que a Arqueologia se desenvolveu de forma intensa, pois foram realizados importantes trabalhos arqueológicos em Teotihuacán, que culminaram na formação de um museu de sítio.

Em 1970 foi criada a Lei Federal del Patrimonio Cultural de la Nación, o primeiro instrumento a formular no país uma noção mais ampla e integral de patrimônio material, de bens móveis e imóveis (Olivé y Cottom in Reyes 2006: 56). A análise das políticas culturais passou a ganhar força, em especial com os debates incentivados pela UNESCO. Ainda na mesma década foi aprovada a Lei Federal de Monumentos y Zonas Arqueológicos, Artísticos e Históricos (LFMZAAH). Como forma de cumprir o compromisso com o patrimônio, o governo da República apoiou as ações do INAH propiciando recursos e facilidades para a proteção e uso qualificado do patrimônio histórico e arqueológico do país (Reyes 2006: 56). A LFMZAAH teve importantes resultados, pois possibilitou o início da conceptualização do

46 “proporcionar una base jurídica para el trabajo arqueológico” (Robles in Reyes 2009/2010: 294) 
patrimônio, consolidando a participação e responsabilidade do Estado em diferentes aspectos da cultura nacional, e potencializou o papel dos institutos nacionais (Reyes 2006: 57). O INAH teve participação crucial na elaboração da lista de Patrimônios Naturais e Culturais da Humanidade, promulgada pela UNESCO em 1972 (Arizpe 2006: 21).

A partir da década de 1970 foram possíveis diversas experiências de conservação do patrimônio cultural mexicano; por exemplo, a criação de museus locais, comunitários e escolares, cujo propósito era a gestão em parceria com as comunidades. Muitos desses museus poderiam ser considerados importantes exemplos em âmbito internacional, porém pouco se fez quanto à análise e avaliação dessas instituições (Arizpe 2006: 16-17).

Na década de 1980, a reforma da lei Orgânica do INAH consolidou uma concepção integralmente patrimonialista das riquezas culturais mexicanas. Foram estabelecidos os seguintes objetivos gerais do instituto: “investigação científica em Antropologia e História; proteção, conservação, restauração e recuperação do patrimônio cultural arqueológico, histórico - e como um agregado - o paleontológico; assim como a promoção e difusão das matérias e atividades de competência do Instituto” (Reyes 2006: 58). ${ }^{47}$ Nesse período, diversos agentes institucionais, empresariais e acadêmicos do subcontinente começaram a apoiar ações de privatização, comercialização e "turistificação" das riquezas patrimoniais, como alternativas viáveis para o campo cultural. Alguns grupos mais radicais chegaram inclusive a propor modificações legislativas, institucionais e operativas que favorecessem essas ações (2006: 59- 60).

No final da década de 1980 foi realizada uma alteração do modelo institucional do INAH, que extinguiu a Secretaria de Cultura e a substituiu pelo Conselho Nacional para a Cultura e as Artes (CONACULTA). Segundo Reyes, tratou-se de uma das mais problemáticas ações da história da política cultural do país. A mencionada substituição evidenciou uma mudança de enfoque na ação cultural do México: os programas antes voltados para a preservação e conservação dos bens patrimoniais passaram a privilegiar a difusão e o desenvolvimento, “a modernidade” (Reyes 2006: 67). A criação do CONACULTA gerou diversas dificuldades no terreno patrimonial, ligadas principalmente à violação das atribuições concedidas por lei aos institutos nacionais, com a desqualificação e sanção impositiva de projetos, bem como a duplicação de funções e a redução do financiamento institucional (2006: 70). Segundo Reyes, a perspectiva neoliberal foi assumida pelas elites políticas; no

\footnotetext{
47 “investigación científica en Antropología e Historia; protección, conservación, restauración y recuperación del patrimonio cultural arqueológico, histórico - y como un agregado- el paleontológico; así como la promoción y difusión de las materias y actividades competencia del Instituto” (Reyes 2006: 58).
} 
campo cultural as finalidades da vía mexicana almejaram fazer do patrimônio cultural um bom negócio, isto é, desregular um setor tradicionalmente "estatizado", ajustar o compromisso governamental com o setor, estabelecer o livre mercado e os bens artísticos e abrir bens patrimoniais arqueológicos e históricos aos usos comercial ou turístico, para o benefício de empresas privadas e particulares (Reyes 2009/2010: 298).

Embora por um lado o Estado mexicano fizesse alterações consideráveis em sua política cultural, o México influenciou de forma intensa, na década de 1990, os debates internacionais sobre uma nova percepção de patrimônio. A Conferência da UNESCO sobre Políticas Culturais para o Desenvolvimento, realizada em Estocolmo, solicitou aos governos que destinassem recursos humanos e financeiros mais substanciais para o desenvolvimento cultural. O evento também ressaltou o emprego das novas tecnologias da informação e comunicação para a conservação e o desenvolvimento de práticas culturais (Arizpe 2006: 20). Ao longo dessa mesma década a UNESCO passou a valorizar não somente o patrimônio antigo, monumental, eclesiástico e masculino, mas também o moderno, o vernacular, o feminino. Os grupos culturais passaram a ser vistos como complexos e multidimensionais, ressaltando-se sua relação com o ambiente (Munjeri in Arizpe 2006: 22).

Esse processo foi iniciado no país desde a inclusão, em 1963, das culturas indígenas no Museo Nacional de Antropología e Historia. O país revolucionou o conceito de museu ao mostrar que as culturas "etnográficas" e os bens arqueológicos fazem parte de uma mesma “cartografía cultural”. Uma das muitas inovações do museu foi o lançamento de uma “museografia” baseada nessa proposta e não no apego aos objetos, o que somente foi possível, segundo Arizpe, graças a um conceito holístico de Antropologia que abarcava a Arqueologia, a Linguística, a Etno-história, a Etnologia e a Antropologia (2006: 23). A nova museografia do Museu Nacional de Culturas Populares também influenciou museus etnográficos de outros países, caso, por exemplo, do Musée Canadien des Civilisation e do British Museum — o Museu Britânico elaborou uma sala dedicada às culturas contemporâneas em que constava um altar dos mortos do México. (Arizpe 2006: 23).

Embora o México tenha se tornado um exemplo para museus de todo o mundo, Mantecón ressalta que embora os museus sejam parte da imagem que o país apresenta para os visitantes estrangeiros - em especial o Museo Nacional de Antropología, o Templo Mayor, o Palácio de Bellas Artes (2005: 242) e as várias iniciativas de museus comunitários em diversas partes - , a maioria dos museus mexicanos muitas vezes não é acessível à comunidade. Na Cidade do México, por exemplo, o preço da entrada dos museus oscila entre 30 e 35 pesos, o que equivale a um dia de salário mínimo do cidadão mexicano. As restrições 
do mercado para a oferta cultural não estão apenas pautadas pelos preços dos ingressos, mas também nas desigualdades de acesso aos equipamentos, nos hábitos culturais prévios da comunidade e na estruturação do tempo livre da população. Para o autor, a combinação desses obstáculos gera processos de segregação cultural e acarreta o pouco aproveitamento dos serviços culturais existentes (2005: 243).

Já Arizpe aponta para duas áreas em que a política cultural do México apresenta falhas: a primeira seria a desvalorização e a falta de apoio aos grandes mestres das artes populares (2006: 23); a segunda, o comércio de bens com conteúdos culturais. Para a autora, em um mundo caracterizado por um comércio que se move em grande velocidade, as nações e empresas estão utilizando elementos culturais - como desenhos da cultura nacional que se transformam em logomarcas de produtos comerciais - como forma de valorizar sua precedência nacional (Arizpe 2006: 24). O México não possui leis e normas que regulamentem esse tipo de uso.

Segundo a análise de Peralta (2006: 64), no século XXI o México ainda não estabeleceu políticas eficazes que permitam o fortalecimento e a consolidação das múltiplas identidades nacionais como forma de proteger os bens patrimoniais. Para a autora, a tendência mundial que vincula a cultura ao desenvolvimento tem sido negligenciada pelo Estado mexicano, contrariamente às recomendações supranacionais. A atuação do INAH ao longo de 70 anos possibilitou o reconhecimento do México no que tange à preservação do patrimônio material, cultural e também quanto à Museologia, em especial pela formação de um sistema nacional de museus. Porém, o país tem perdido tal reconhecimento, pois nas últimas décadas vem deixando de ser exemplo em gestão cultural. Para Peralta, urge que as instituições estatais respeitem e exerçam o modelo cultural mexicano e a aplicação das leis nacionais de patrimônio (2006: 83). Já para Arizpe são cruciais mudanças de ordem conceitual, uma ampla análise institucional e uma avaliação das condições de operatividade da atual política patrimonial e cultural (2006: 16)

Ainda como crítica à atual política cultural mexicana, Reyes aponta como principais problemas enfrentados pelo INAH os seguintes aspectos: a redução de recursos financeiros para a educação, o que gerou uma gradual incapacidade do cumprimento de sua missão de atender de maneira eficaz às demandas de proteção ao patrimônio cultural; a desigual distribuição das despesas, devido à expansão da proporção do orçamento anual para os salários em detrimento de atividades substantivas de pesquisa, conservação, projetos de restauração, difusão, formação de profissionais, entre outros; os problemas financeiros, organizacionais e institucionais que têm favorecido o aumento do roubo, tráfico e destruição 
do patrimônio arqueológico; a desproporcional concentração de profissionais especialistas em pesquisa, em arquitetura e em restauro na Cidade do México ou nos grandes sítios, ao passo que os centros de pesquisa do interior do país não contam com o número necessário de pesquisadores (Reyes 2006: 63-64). Como alternativa a esses problemas, Reyes propõe endossar o interesse nacional pelo patrimônio artístico e cultural (arqueológico e histórico) do México e defender a prioridade de seu uso social e educacional (Reyes 2006: 70). A experiência mexicana de conservação do patrimônio com o INAH é de suma importância conceitual e operativa, devido à infraestrutura e à qualidade da pesquisa antropológica com que conta o México (Arizpe 2006: 16).

Para Peralta, a controvérsia social na área da cultura decorre da arbitrariedade do capital privado, que em nome do lucro destrói os vestígios culturais do passado e se apropria e explora os bens culturais, por meio de indústrias culturais como a "Televisa, o desenvolvimento do Turismo de sol e praia, entre outros” (Peralta 2006: 76). Vale ressaltar que o "Turismo de sol e praia” é um ícone do Turismo Convencional em países da América Latina, caso do Brasil (Peralta 2006: 76-7).

MOVIMENTOS SOCIAIS E USOS CRÍTICOS DO PATRIMÔNIO ARQUEOLÓGICO NO ÂMBITO DO NEOLIBERALISMO

O investimento maciço em alguns poucos atrativos turísticos voltados para a recepção de turistas estrangeiros ou uma grande quantidade de turistas nacionais tem causado uma série de discussões na realidade mexicana. No final de 2008, Teotihuacán foi palco de importantes debates sobre o patrimônio mexicano, em especial sobre a política cultural de apoio ao Turismo de Massa. O Governo Federal apresentou um agressivo e polêmico projeto denominado Resplandor Teotihuacáno. Tratava-se de um projeto de som e luz voltado para a visitação noturna ao sítio (Reyes 2009/2010: 304), norteado por dois objetivos econômicos fundamentais: o primeiro seria aproveitar a fama da zona arqueológica e de Teotihuacán para incentivar o investimento da iniciativa privada na formação de um circuito turístico que envolvesse, além de Teotihuacán, outros sete municípios; o segundo, oferecer ao público internacional uma rede de hotéis e estabelecimentos de alimentação e serviços de lazer de luxo (Reyes 2009/2010: 304-305). Ou seja, o projeto era movido por poderosos interesses políticos e econômicos. 
Apesar das manifestações desfavoráveis, o projeto foi levado adiante e uma primeira análise superficial da obra, a cargo de empresas privadas, constatou os efeitos nocivos nas pirâmides do Sol e da Lua, o que foi amplamente documentado pelos arqueólogos teothiaqueños e pelas organizações sindicais de arquitetos e administradores, entre outros. Foram realizadas mais de seis mil perfurações, que provocaram infiltrações e afetaram as estruturas bem como o visual dos monumentos arqueológicos (delegaciones sindicales del INAH in Reyes 2009/2010: 305). Segundo Reyes, tanto as empresas contratadas como as autoridades municipais, estaduais e federais - entre elas principalmente as do INAH atuaram sem levar em consideração o caráter histórico e arqueológico das construções, violaram as normas vigentes e causaram danos físicos aos bens patrimoniais (Reyes 2009/2010: 305). Os então diretores do INAH aprovaram o projeto mesmo não cumprindo as exigências necessárias, desconsiderando os laudos e as solicitações dos profissionais do Instituto e as manifestações das Câmaras Legislativas do país (Reyes 2009/2010: 305). Mais que qualquer outra experiência, por suas peculiaridades o projeto Resplandor Teotihuacáno demonstrou a interseção do conjunto das políticas neoliberais para a cultura no México desde o final do século XX (Reyes 2009/2010: 306). Além do citado projeto, as cúpulas diretivas do CONACULTA e do INAH criaram instâncias e projetos novos, como o Fondo Nacional Arqueológico (FNA) e os Proyectos Especiales de Arqueología (PEA), dotados de vultosos recursos financeiros para converter 14 zonas arqueológicas em atrativos destinados ao Turismo internacional (Reyes 2009/2010: 301).

O uso comercial do patrimônio, induzido para a atração turística mundial dentro do Turismo Convencional, não deve sobrepujar o uso educativo, identitário e social da pesquisa e dos bens patrimoniais (Reyes 2009/2010: 307). Vale ressaltar que Teotihuacán é apenas um caso entre vários outros. Além do Resplandor Teotihuacáno, há outros antecedentes, como o evento musical "Las mil columnas de Chichén Itza” e a omissão no episódio em que não houve mobilização ou intervenção que evitasse a demolição de seis monumentos históricos pelo governo da Cidade do México (D II A1 in Reyes 2009/2010: 307). São exemplos que demonstram a necessidade de uma profunda reflexão e busca por soluções inovadoras que favoreçam a conservação do patrimônio cultural dentro dos projetos modernizadores e desenvolvimentistas contemporâneos (Reyes 2009/2010: 307-308).

Atualmente, tem crescido no México o movimento de construção de novos espaços de informação reflexiva e crítica, voltados para a formação de sujeitos proativos a favor dos bens culturais e plenamente conscientes de seus direitos como cidadãos (Peralta 2006: 77). Nas últimas duas décadas ganharam força os movimentos sociais no campo da cidadania cultural 
(Ricoeur in Peralta 2006: 76) e ações da sociedade em matéria de cultura, parte de um debate recente sobre o uso social qualificado do patrimônio cultural (Canclini in Peralta 2006: 77). Como exemplo de ações da cidadania cultural vale destacar as atividades realizadas no centro histórico da cidade de Oaxaca, com o intuito de impedir a construção de uma loja da rede de lanchonetes McDonald's e a modernização do equipamento urbano local. Também importantes foram as ações cidadãs dos habitantes de Coyoacán contra as mudanças do uso do solo e o impedimento da transformação da arquitetura vernácula do centro histórico em comércio. Em Tepoztlán, proibiu-se a construção de um clube de golfe, e em Cuernavaca foram protegidos os vestígios da antiga civilização de Gualupitas (Peralta 2006: 77). Vale ressaltar também as ações em Temzcalzingo e San Antonio Pueblo Nuevo, onde as mulheres mazahuas se organizaram para defender a água como um bem, sua importância para a sobrevivência e seu significado social, o que Martínez Alier (2007) chama de "ecologismo dos pobres”. Para o autor, diferentemente do que se pensa, grande parte dos movimentos socioambientais surge em áreas de comunidades menos abastadas.

Exemplo que vale a pena citar é o da tensão acarretada por um plano de "melhoramento urbano" no Centro Histórico da Cidade do México (CHCM), que suscitou grande contestação de grupos populares, em especial comerciantes ambulantes, intelectuais e políticos, que viam o projeto como uma tentativa empresarial de apropriação do Centro Histórico (Alcayaga 2006: 126). Para se compreender a tensão é importante uma contextualização histórica: a Cidade do México é uma das metrópoles mais importantes das Américas, e lá as autoridades coloniais empenharam-se sobremaneira em retratar o esplendor espanhol. Essa característica fez com que a cidade fosse construída deliberadamente para ser "bela e monumental” (Alcayaga 2006: 126). A maior concentração de monumentos préhispânicos e coloniais - não apenas do México, mas da América Latina - é encontrada no Centro Histórico da Cidade do México: além de vestígios arqueológicos e edificações históricas, vários dos principais museus de arte e história, teatros, cinemas, parques e praças ficam nessa região do município. Trata-se de um território que condensa seis séculos de história urbana e que continua sendo ponto de referência simbólico e político. Sua história tem vínculos com vastas construções relacionadas a habitantes abastados (Mantecón 2005: 245). A partir da década de 1950, com a saída das elites do Centro Histórico, a região passou a ser ocupada por "inquilinos menos afortunados” (2005: 245), que vêm sendo progressivamente expulsos para bairros periféricos devido à expansão das atividades de comércio e serviços. Essa região da Cidade do México foi inscrita na lista de Patrimônios Mundiais. 
As tensões geradas pelo projeto de melhoramento urbano do CHCM estão diretamente ligadas à sua conservação, já que o olhar monumentalista lançado sobre o local provocou a desvalorização das classes populares que habitam e habitaram a área (Alcayaga 2006: 127128). Várias foram as manifestações contra o projeto, repudiando especialmente seu objetivo de "branquear o local”, expressão usada em referência à provável expulsão dos setores populares do centro, como ocorreu na maioria das "modernizações" urbanas na América Latina (Alcayaga 2006: 128). Segundo Mantecón, nas instituições envolvidas não existem regras para a conservação do patrimônio quanto ao número e tipo de monumentos que devem ser conservados. Quando o Centro Histórico foi delimitado por decreto, realizou-se uma listagem de edifícios que foram considerados monumentos históricos, fundamentais por seu valor e relevância arquitetônica. Assim, edificações como habitações populares não foram levadas em conta, o que excluiu a arquitetura popular, que deveria ser englobada como parte do patrimônio do Centro Histórico, já que integra o conjunto arquitetônico e patrimonial. Na busca por legitimação da utilização de determinados espaços o Estado sacralizou funções e hierarquias que tem permitido justificar ou excluir outros usos (Mantecón 2005: 246).

Na hierarquia do patrimônio considerada para o Centro Histórico, além da valorização dos prédios públicos e das elites as produções culturais pré-hispânicas são ainda mais valorizadas que aquelas referentes ao período colonial. Na década de 1970 as escavações do Templo Mayor, localizado na região em apreço, justificaram as ações do governo municipal para a demolição de uma quadra completa de edifícios coloniais. A demolição foi realizada para deixar em evidência as estruturas da pirâmide que fazia parte do recinto sagrado, que ocupava o centro da capital asteca antes de sua destruição pelos espanhóis. Em entrevista realizada por Mantecón junto à comunidade do município, 70\% dos entrevistados se declararam favoráveis à demolição, por considerarem que "a história mais antiga” era "mais mexicana” (2005: 249). Tal resultado demonstra traços do projeto nacionalista mexicano, que valoriza os bens pré-hispânicos em detrimento dos coloniais. Em entrevista realizada em 1990 com turistas no Museu do Templo Mayor (MTM), Mantecón (2005: 249) identificou que mais de $60 \%$ dos entrevistados apresentaram uma imagem idealizada dos mexicas, mesmo sendo um dos objetivos da exposição do museu a desmistificação desse imaginário. A apropriação do patrimônio mexica encontra suas raízes na vida cotidiana da população, em suas necessidades imediatas, pois sobre o mito dos mexicas se projetam expectativas, frustrações e sonhos (2005: 249).

O exemplo demonstra que no México optou-se por uma imagem indígena mitificada de uma única cultura, abalizada pelo discurso oficial dominante. Assim fica patente que a 
concepção de nação excluiu os olhares de diversos setores - indígenas, camponeses, mulheres e outros grupos do campo e da cidade. Os intelectuais do século XIX imaginaram a nação que queriam ter, e agiram politicamente para transformá-la em realidade. O que deixa claro que a nação mexicana é uma criação histórica moderna que, segundo Pérez (2009/10: 3), adquiriu força e continuidade pelo desaparecimento do imaginário coletivo de seu caráter de invenção.

Para Alcayaga, o projeto do Centro Histórico deveria criar condições para que o patrimônio abrisse novas possibilidades, como "patrimônio vivo", "patrimônio como uso social” e "patrimônio popular" (Cancline in Alcayaga 2006: 129), favorecendo diversos olhares, tendo na revitalização habitacional o plano mais apropriado para a região (Alcayaga 2006: 129).

Outros grandes exemplos de ações de cidadania cultural referem-se à luta de diferentes grupos sociais contra intervenções danosas ao patrimônio histórico; por exemplo, o episódio de mobilização contra a construção de um supermercado WalMart em um perímetro da zona arqueológica de Teotihuacán, inaugurado em 2004 com ajuda das instituições federais, mesmo diante das pressões populares; a obra acabou apagando debaixo de seus pisos "a possibilidade de saber a dimensão dos danos patrimoniais causados” (Reyes 2009/2010: 303304). ${ }^{48}$ Em Cuicuilco, manifestações impediram a destruição dos vestígios do assentamento mais antigo da Mesoamérica. O caso de Cuicuilco ilustra:

“a construção da cidadania cultural, assim como um exemplo paradigmático de novas formas de construir cidadania e governabilidade. Ele indica que são possíveis novas formas de relação entre o desenvolvimento globalizador e a cultura. Ilustra também as novas relações entre cidadania e capital derivadas do reconhecimento recíproco” (Peralta 2006: 81$)^{49}$

Em algumas dessas zonas arqueológicas as ações foram acompanhadas pela construção de centros comerciais e outros negócios. Os excessos em Teotihuacán e Cuicuilco deram origem a um movimento social que deteve a construção de duas áreas comerciais e a introdução de um trem turístico no interior de Cuicuilco (Reyes 2009/2010: 301). O confronto

\footnotetext{
48 “posibilidad de saber la dimensión de los daños patrimoniales causados” (Reyes 2009/2010: 303-304).

49 "la construcción de la ciudadanía cultural, así como un ejemplo paradigmático de nuevas formas de construir ciudadanía y gobernabilidad. Ello indica que son posibles nuevas formas de relación entre el desarrollo globalizador y la cultura. Ilustra también las nuevas relaciones entre ciudadanía y capital derivadas del reconocimiento reciproco” (Peralta 2006: 81).
} 
social se tornou tão grave que acarretou em uma crise no INAH, pois pela primeira vez houve um racha, um grande distanciamento entre a Direção Regional, a comunidade acadêmica e os funcionários (Reyes 2009/2010: 301).

Todas essas ações cidadãs expressam demandas da sociedade civil por uma maior participação e justiça social na salvaguarda dos bens coletivos e nos direitos dos bens culturais. Em sentido estrutural, pode-se perceber uma nova junção de forças para o estabelecimento de políticas públicas, em particular com as instâncias que fiscalizam os planos de desenvolvimento (2006: 81). Por sua vez essas instâncias precisam se instrumentalizar de forma a considerar os diferentes segmentos sociais envolvidos na organização e planejamento territorial, como meio garantir que os benefícios sejam abrangentes, coerentes e democráticos (Peralta 2006: 81). Para Peralta, o México moderno não deve apenas se reconhecer no passado para construir o futuro, mas também se reconhecer como nação multicultural no presente, ponto de partida para um projeto de nação do século XXI voltado à construção de uma sociedade aberta, includente e democrática (2006: 83).

Para Peralta, o Estado deve promover um comportamento social ético que privilegie o respeito e o fortalecimento das diversas manifestações culturais dos mexicanos, e deve interferir nos slogans publicitários que tentam, ainda que de forma limitada, promover esses valores, orientando e reorientando os recursos da mídia para fortalecer a noção de "nós e do nosso” (2006: 83). Desde 1996 os interesses dos investidores ligados à exploração mercantil do patrimônio cultural, em suas expressões arqueológicas, artísticas e históricas, têm sido fortalecidos pelo Estado, de modo a eliminar o caráter federal da proteção dos bens e privatizá-los (2006: 83).

Para tanto, Peralta defende que o Estado valorize a experiência acumulada pelas instituições já consagradas como o INAH, levando em consideração a opinião dos especialistas, refletindo e integrando as novas demandas culturais da população ao debate (2006: 84-85). A autora ressalta a importância da realização de um diagnóstico da problemática cultural, com a participação efetiva de segmentos distintos da população. Tal diagnóstico cultural mexicano possibilitaria que os legisladores e a sociedade civil tivessem fundamentos para identificar as necessidades legislativas. Faz-se necessário fortalecer a normatividade em matéria cultural, atualizar os aspectos que resultem em uma proteção adequada ao patrimônio e promover políticas públicas com amplo sentido social (Peralta 2006: 85).

As mobilizações da sociedade civil no sentido de exigir seus direitos culturais ainda são expressões insipientes, mas relevantes para uma nova ordem democrática. Os avanços na 
construção da cidadania cultural não devem significar retrocessos na noção das identidades nacionais e coletivas, implícita na ideia de nação e nacionalismo (Peralta 2006: 85).

A solução não é distanciar os bens das comunidades ou do Turismo, como defendem muitos pesquisadores mexicanos. Para Díaz e Hernández, faz-se necessário encontrar um ponto de equilíbrio entre a preservação e o uso sustentável e qualificado do patrimônio arqueológico, já que os recursos culturais não são renováveis e devem servir para "o desenvolvimento intelectual, cultural, educativo e econômico, tanto individual como coletivo" (2009/2010: 176). ${ }^{50}$ Devido às características dos bens culturais, a recuperação, a conservação, o uso qualificado e a gestão devem atender a critérios de sustentabilidade e planejamento estabelecidos pelo poder público com a participação dos agentes sociais envolvidos, definindo-se critérios de interpretação, intervenção e gestão que garantam tanto a proteção como o uso desses bens (2009/2010: 176).

Díaz e Hernández julgam que o México deve implementar planos de manejo a fim de garantir que no futuro sejam possíveis parcerias capazes de sanar os problemas e que favoreçam a utilização do patrimônio cultural mais como ferramenta de desenvolvimento do que como obstáculo (2009/2010: 176). Esses planos devem ser interdisciplinares, com real participação dos arqueólogos, pois os vestígios arqueológicos não podem ser compreendidos apenas por sua natureza material, mas sim incluindo os valores dados pela comunidade no decorrer da história do país (2009/2010: 176).

\subsection{PERU: ATRATIVOS TURÍSTICOS, CONFLITOS E EXCLUSÃO}

Embora seja um dos países mais pobres da América do Sul, o Peru detém enorme herança cultural e natural. O caso peruano apresenta importantes elementos para a compreensão da presença do passado no presente, pois o passado se encontra expresso nas identidades nacional e local, bem como nos poderes social e político e nos projetos de desenvolvimento econômico. O passado arqueológico do Peru foi convertido em grandes projetos turísticos, extremamente contraditórios, que geraram conflitos e negociações pautados pelas relações entre diferentes atores: ruínas e sítios arqueológicos, pesquisadores, indígenas, comunidades, turistas estrangeiros, o governo peruano e o setor privado (Silverman 2002: 881).

\footnotetext{
50 “el desarrollo intelectual, cultural, educativo y económico, tanto individual como colectivo” (Díaz e Hernández 2009/2010: 176).
} 
O Turismo é tido como uma das mais importantes atividades econômicas do Peru, e responde pela segunda maior fonte de renda externa do país. A política econômica peruana dá alta prioridade aos setores da economia que geram renda externa, caso do Turismo e das exportações de cobre e de pesca. A atividade turística representa aproximadamente 15\% do número de empregos, gerando mais de 45 mil novas vagas por ano (Ugarte e Pacheco 2001: 1). Em 2011, o número de turistas estrangeiros ultrapassou a meta do governo peruano, que previa dois milhões de visitantes. Segundo os órgãos oficiais de Turismo, o aumento do número de visitantes é resultado do intenso trabalho dos setores público e privado, por meio da promoção dos principais destinos turísticos, da implementação de políticas estáveis e promotoras de investimento privado e da diversificação da oferta turística do Peru (Agencia Peruana de Noticias 2011: 1).

A agência governamental responsável pelo Turismo é o Vice-Ministério do Turismo, vinculado ao Ministério de Indústrias, Turismo, Integração e Negociações Comerciais Internacionais (MITINCI). A instância responsável pela divulgação e promoção da atividade turística e por investimentos na área é a PROMPERÚ, ligada ao Ministério da Presidência. O desenvolvimento de infraestrutura turística também é de responsabilidade do Ministério da Presidência, ao passo que o desenvolvimento regional e o planejamento da infraestrutura são responsabilidade dos ministérios do Transporte, da Comunicação e de Obras. A gestão dos sítios arqueológicos e de outros bens culturais fica a cargo do Instituto Nacional de Cultura, subordinado ao Ministério da Educação. Essa divisão de responsabilidades no que tange ao desenvolvimento do Turismo nacional ocasiona uma série de impasses burocráticos que prejudicam a elaboração e implantação de políticas públicas com uma visão mais ampla da atividade.

TURISMO E APROPRIAÇÃO SIMBÓLICA DE REFERENCIAIS INDÍGENAS PARA A INDÚSTRIA CULTURAL

Faz parte da política governamental, em seus mais diversos órgãos e setores, o uso de símbolos arqueológicos e de imagens nativas para o consumo nacional e internacional. O Estado-nação peruano, que existe desde 1821, sempre se apropriou do passado como elemento de reflexão para a elaboração de políticas para o presente e o futuro (Silverman 2002: 884). No Peru, bem como no México e em outros países da América Latina, o conceito de identidade arraigou-se historicamente na nação e teve como suporte construtivo o discurso 
letrado, difundido através da escola pública, das Forças Armadas e de outras instituições (Vich 2007: 194).

Desde a independência do Peru vários grupos têm buscado criar uma identidade para a nação, em uma luta desigual entre classes e grupos étnicos mergulhados em realidades sociais e econômicas pós-coloniais que mesclam pobreza e riqueza e que continuam a dividir o país (Bhabha in Silverman 2002: 883). Além do Estado, que há muito tem utilizado imagens précolombianas para sua autorrepresentação em moedas, selos, álbuns de figurinhas, quadros dos grandes governantes do Peru — sendo os primeiros os governantes incas - etc., são vários os exemplos de apropriação de termos e símbolos das culturas pré-hispânicas em todo o Peru.

Vale mencionar a Aliança Popular Revolucionária Americana (APRA), partido político nacionalista-populista fundado em 1924 por intelectuais interessados na questão indígena e rural, e cujo emblema era uma águia no estilo da cultura Chavin, então considerada a "cultura-mãe da civilização eina” (Tello in Silverman 2002: 882). Ao escolher esse símbolo a APRA recorreu ao passado da civilização peruana como forma de incentivar a criação de uma nova sociedade, livre do imperialismo e dedicada a ajudar a população e promover o indigenismo (Silverman 2002: 882).

Outro exemplo interessante é o da Lundero, revista do La Industria, jornal publicado no município de Chiclayo, no litoral norte do Peru. O slogan da revista é "Resgate o passado para construir o futuro". No final do século XX, quando a moeda peruana passou por grande desvalorização, foi criada uma nova unidade monetária denominada "Inti”, que significa "sol” em quechua, a língua indígena mais falada no Peru. As referências ao passado pré-colombiano também vieram à tona no século XXI. Durante a campanha presidencial de 2001, Alejandro Toledo se utilizou de sua ascendência indígena. Em comícios e aparições públicas, o então candidato usou o poncho tradicional, autodenominou-se Pachacutec, nome de um dos maiores imperadores incas, e se proclamou "filho favorito de Apus", o deus da montanha.

Muitas vezes, símbolos das culturas do passado e dos bens arqueológicos foram apropriados e utilizados sem embasamento em pesquisas arqueológicas, ou fora de contexto, misturando anacronicamente tempo, lugar e cultura. Caso, por exemplo, do nome "Libertador”, um dos melhores hotéis de luxo de Cusco, que faz referência à campanha do venezuelano Simón Bolívar (1783 - 1830) na luta pela independência do Peru; o emblema do hotel é a máscara da boca de um ser místico decorado em um recipiente cerâmico associado a uma cultura que habitou a costa sul peruana um século antes dos incas (Silverman 2002: 887). Outro exemplo interessante é uma pizzaria localizada em Mancora, uma das praias peruanas mais famosas como destino turístico. O estabelecimento se chama "Chan Chan”, cidade de 
adobe localizada no norte do Peru e referente à cultura chimú. O símbolo da pizzaria impresso no cardápio, todavia, é o Coliseu romano (Alfonso 2006b: 31). Esses símbolos referentes aos bens arqueológicos são reproduzidos repetidamente em diferentes locais, e o objetivo da reprodução é somente a imagem e não a exatidão ou os conteúdos e as diversas representações e compreensões que ela expressa tanto para as comunidades, como para os governantes e turistas.

Mesmo que a Arqueologia e os bens arqueológicos sejam controlados por um órgão estatal, por todo o Peru o passado antigo é ativamente construído em nível local, por razões que variam em cada contexto (Silverman 2002: 883). Atualmente a identidade de muitas comunidades vem sendo moldada a partir da invenção de uma imagem que atende às necessidades do mercado turístico e da mídia, e que em certo sentido reinterpreta elementos já constituintes da identidade nacional, porém a partir de outros paradigmas e necessidades. Para Vich (2007: 194), a ideia é vender o passado, e convertê-lo em indústria cultural.

Agentes internacionais, nacionais e locais convertem o passado arqueológico do Peru em um amplo projeto, ao passo que o Turismo e as representações do passado são criados e reforçados por diferentes grupos. Para Silverman (2002: 883), Turismo é uma indústria cultural global, e Turismo Arqueológico é um discurso histórico. De acordo com a autora, as pessoas são envolvidas no projeto por meio dos discursos históricos. O Turismo Arqueológico possibilita que peruanos de diferentes identidades convivam em um mundo em que a história é um veículo de mobilização de recursos, de agência e poder para as comunidades.

Nesse contexto, o Peru se torna um interessante estudo de caso para pesquisadores interessados nos múltiplos aspectos do passado no presente, em especial aqueles que consideram o Turismo como elemento que influencia essa relação. Os monumentais sítios arqueológicos peruanos, de grande visibilidade tanto física como ideológica, favorecem o Turismo Arqueológico, que possibilita uma reconstrução coletiva do passado, com o engajamento de diferentes atores no presente. Em alguns casos o Turismo reforça a ideia, construída pelo Estado, de continuidade cultural entre o passado e o presente, mesmo a partir de novas reconstruções e narrativas. O Turismo Arqueológico pode provocar um processo local de produção cultural examinado em diversos contextos - institucionais, históricos, vividos ou criados (Silverman 2002: 883-4).

São as comunidades e agências locais que, em diversas regiões do Peru, vivenciam o passado em seu cotidiano: os incas em Cusco, os nazca na costa sul, os mochica e os chimú na costa norte. Ao mesmo tempo em que se apropriam desses bens arqueológicos para reforçar o local, as comunidades reforçam também o global, quando o uso dos bens é voltado para a 
atividade turística internacional. No Peru o discurso da modernidade é pautado por termos de desenvolvimento econômico; nesse contexto, o Turismo internacional é ressaltado por diversos setores da sociedade como atividade dotada de grande poder de geração de prosperidade, das pequenas vilas até as grandes cidades (Silverman 2002: 883). Vale ressaltar que até mesmo a escolha dos sítios em que o Estado irá investir grandes quantias em conservação está norteada pelo interesse turístico do sítio.

Três contextos peruanos são interessantes exemplos das dimensões do Turismo Arqueológico no Peru: Cusco, a antiga capital do Império Inca, onde as paredes de pedra são marcantes sinais dessa cultura, pelo menos no centro histórico da cidade; Nazca, onde os sinais do passado pré-colombiano não estão expressos na cidade, mas sim no campo; e Trujillo, onde o Estado tem demonstrado interesse na estruturação de diferentes sítios das culturas moche e chimú para o Turismo. Os habitantes das cidades procuraram ler os sinais no presente, por meio do tempo e das mudanças culturais, convertendo-s em um passado que pode ser "usado" e "vendido" no presente por meio da tradição inventada e da produção cultural (Silverman 2002: 883).

MOCHE, INCA E CHIMÚ: CONFLITOS SOCIAIS E DESIGUALDADE NAS POLÍTICAS DE USO DO PATRIMÔNIO ARQUEOLÓGICO PERUANO

Cusco está localizada na bacia do rio Huatanay, nos ees peruanos, a mais de três mil metros de altitude. Em Cusco se localiza um dos exemplares mais completos da sobreposição da cultura espanhola sobre a cultura pré-colombiana. É uma cidade composta por edificações pré-coloniais, construções que formavam um complexo centro urbano, com áreas administrativas e religiosas, campos de agricultura, artesanato e produção industrial. A “conquista” espanhola no século XVI acarretou a destruição de parte significativa das construções e a manutenção da estrutura básica de algumas edificações, sobre as quais foram erguidos palácios e igrejas barrocas (Murra in Zanirato 2010: 1). Por ser considerada — em função de sua arquitetura - um exemplar único da história da colonização da América Latina, em 1933 Cusco foi eleita, pelo Congresso de Americanistas realizado em La Plata, a “Capital Arqueológica da América”. Em 1978 a cidade foi alçada à condição de "Herança Cultural do Mundo” pela Convenção de Prefeitos das Grandes Cidades Mundiais, ocorrida em Milão. Todo esse legado foi valorizado ainda mais em 1983, quando a cidade ganhou da 
UNESCO o título de Patrimônio da Humanidade. A partir de então Cusco se reforçou como o principal destino turístico do Peru (2010: 1).

Vale ressaltar que muitos dos lugares considerados pela UNESCO como Patrimônio Natural e Cultural da Humanidade se encontram ameaçados ou em risco de desaparecimento, por motivos relacionados a guerras e conflitos políticos; questões étnicas e religiosas tráfico ilícito e negligência, alterações decorrentes de catástrofes naturais, contaminação pelo Turismo massivo e mal organizado, expansão dos centros urbanos e falta de recursos financeiros para protegê-los (Zanirato 2010: 1). ${ }^{51}$

A história de Cusco é marcada por grandes desastres naturais, como os terremotos de 1650 e de 1950, que destruíram parte significativa da cidade. No município acontecem também deslizamentos de terra devido ao aumento nos níveis de infiltração das águas fluviais. Segundo García-Tornel, o histórico de catástrofes da região permite dizer que ali se encontra um "território potencial de risco", ou seja, um espaço que tem a possibilidade de sofrer um evento catastrófico (in Zanirato 2010: 1). O risco não se limita apenas ao elemento construído, mas se estende às pessoas que habitam o lugar. As transformações urbanísticas potencializaram as ameaças existentes na cidade, e os modos de uso de ocupação do solo alteraram o regime hidráulico construído no período anterior à chegada dos europeus, desestabilizaram as ladeiras e acarretaram a acumulação de riscos associados com as atividades sísmicas da cidade (2010: 1).

A iminência de um desastre levou investigadores do Instituto Federal de Tecnologia do Peru, em associação com a UNESCO, a criar meios de identificar e calcular a vulnerabilidade local, traçando um mapa de risco da região e elaborando estratégias de prevenção de modo “a eliminar os riscos claramente intoleráveis” (Renn in Zanirato 2010: 1). O mapa de riscos apontou que os problemas eram resultantes do modo como se organizava o espaço urbano, e que havia a necessidade de modificar esse traçado. A redução das ameaças requeria ações de controle das encostas, drenagem planificada, reconstituição de drenos e canais pré-hispânicos, controle do trânsito de pessoas, de veículos e de animais. As indicações advertiam que para reduzir a vulnerabilidade havia a imperiosa necessidade de diminuir drasticamente a circulação de pessoas na região, ou seja, reduzir o fluxo de turistas, bem como investir na aplicação de técnicas de restauro com o emprego de materiais tradicionais, mais leves e capazes de resistir às catástrofes naturais. Tais medidas eram necessárias tendo

\footnotetext{
${ }^{51}$ É caso, por exemplo, da cidade pernambucana de Olinda, notificada pela UNESCO de que corria o risco de perder o título de Patrimônio da Humanidade por não ter cumprido uma série de exigências voltadas à sua preservação.
} 
em vista que "a destruição desta zona seria uma perda para o Peru e para toda a humanidade" (Carreño in Zanirato 2010: 1). Apesar das considerações levantadas pelo mencionado mapa, as medidas recomendadas não foram aplicadas. O Plano Estratégico Nacional de Turismo, aprovado em 2002, incitou o maior ingresso de turistas em Cusco (2010: 1).

Além dos riscos apontados para Cusco, também foi identificada a fragilidade do meio ambiente ao redor de Machu Picchu, embora as zonas arqueológicas possuam alta capacidade de suporte de visitação. O patrimônio natural de Machu Picchu é parte integral e importante da paisagem local. Grande parte dos visitantes que vai à zona arqueológica percorre a "Trilha Inca” para acessar as ruínas, o que interfere de maneira intensa no ambiente natural. Vale ressaltar que Cusco é a cidade-base em infraestrutura turística para o atendimento da maioria dos visitantes que vai a Machu Picchu. Problemas com desmatamento, desenvolvimento incompatível e poluição são motivo de grande preocupação na área da zona arqueológica. Os estudos identificaram ainda que são necessárias ações para minimizar esses problemas antes que se tornem mais graves e impossibilitem a visitação ao sítio. Os resultados dos estudos acarretaram na implementação, desde outubro de 2007, de um Plano Emergencial "Machupicchu", tendo como objetivo melhorar o manejo de visitantes e prever, controlar e evitar futuros congestionamentos por um eventual incremento do Turismo nos próximos anos (Guerrero 2011: 12).

Investir na salvaguarda dos bens patrimoniais implicaria a redução da visitação turística a ambos os locais e a realização de obras que comprometeriam a entrada de importantes divisas para os cofres públicos e as agências que exploram o Turismo Cultural. Por isso, a decisão governamental foi a de continuar a investir no Turismo em detrimento de ações preservacionistas, tidas como menos prioritárias no contexto em questão. A probabilidade de uma catástrofe parece menos preocupante do que a perda de divisas proporcionada pela redução da atividade turística, ainda que possa ser grande a magnitude dos possíveis impactos dessa catástrofe (Zanirato 2010: 1).

Com as consideráveis ampliações das linhas aéreas internacionais para o Peru e as melhorias na malha aeroviária interna, além das obras realizadas em Cusco após o terremoto de 1950, o Turismo se tornou a maior indústria local (Silverman 2002: 884). A importância do Turismo para a economia de Cusco e da região pode ser medida levando-se em conta que, no período entre 1995 e 2000, 90\% das indústrias locais faliram, sobrevivendo apenas aquelas de propriedade estrangeira. Mesmo com o alto investimento estrangeiro na cidade o dinheiro nem sempre fica no município, pois investidores como as redes de hotéis multinacionais despacham os lucros aos seus países de origem. O retorno para as comunidades e para o 
Estado é muito baixo, o que gera desconfiança nos moradores locais (Castaño 2011: 18). Apesar do baixo retorno, é a indústria do Turismo em Cusco que sustenta a economia local; o preço pago pelo patrimônio cultural, que dá suporte a essa indústria, é bem alto (2002: 887). Segundo Krippendorf (1985), todo local turístico deveria promover uma grande diversificação econômica, incentivando a agricultura, as artes, os ofícios, o artesanato, as pequenas indústrias e serviços não-turísticos. É preciso priorizar todos esses setores, pelo menos em igual escala à importância dada ao Turismo. Nas regiões em que o Turismo cresce rapidamente, outros setores da economia devem ser prioritários. O que não aconteceu em Cusco.

A “Cusco turística”, pautada pela cultura inca, está sendo criada de forma vertical, por aqueles que detêm o poder político e econômico, e vem sendo imposta à comunidade. Os programas de sensibilização para o Turismo desenvolvidos nas escolas reforçam uma identidade inca de Cusco criada pelo Estado, como forma de garantir a preservação do patrimônio e a hospitalidade com o turista. Segundo Siverman (2002: 889), em 1999 mais de uma centena de instituições educacionais participaram de um festival, apresentando danças e encenações sobre a cultura inca.

É a população local que, em seu cotidiano, lida com o passado pré-colombiano. É importante reconhecer que a população local também está ativamente envolvida no processo de criação dessa nova "Cusco Inca”. A comunidade negocia e modifica essa criação de acordo com diferentes interesses, muitas vezes estimuladas pela preservação dos bens patrimoniais. É interessante citar como exemplo um conflito gerado na cidade em 1999, um imbróglio envolvendo arqueólogos, antropólogos, historiadores e o governo municipal, por conta do avanço de obras - voltadas para o Turismo internacional — que se estenderam até uma área próxima a Coricancha, o grande templo inca do sol.

Em 2000 as disputas locais, em especial entre o Instituto Nacional de Cultura e a Direção Regional de Indústria e Turismo, giraram em torno da permissão de passeios a cavalo pelo complexo arqueológico de Sacsayhuaman, e também houve discussões acerca da reabertura do Museu Santa Catalina, que havia sido fechado pelo governo municipal por questões de segurança (Silverman 2002: 888).

Outro desafio para o governo municipal se deu em 2000, quando os oficiais municipais perceberam que a "bandeira inca" - inventada em 1973, oficializada por Resolução Municipal em 1978 e desde então amplamente divulgada pela cidade e nos mais diversos panfletos e materiais voltados a turistas internacionais - era idêntica à bandeira internacional da comunidade gay, formada pelas sete cores do arco-íris. O jornal El Comercio 
publicou uma fala do então prefeito de Cusco queixando-se de que a bandeira inca havia sido “usurpada pela comunidade gay”. Outros representantes do Estado se manifestaram sobre o assunto, defendendo o argumento da que a bandeira precisaria urgentemente ser trocada de forma a evitar o "enfraquecimento moral da sociedade de Cusco", sob a alegação de que os turistas internacionais se recusariam a tirar fotografias em locais em que a bandeira aparecesse, com medo de serem identificados como homossexuais (2002: 888). O Movimento Homossexual de Lima (MHOL) rapidamente publicou seu repúdio às declarações e à possibilidade de mudança da bandeira, afirmando que as cores poderiam ser utilizadas por diferentes grupos e interpretadas de diferentes maneiras. Segundo Silverman (2002: 888), o incidente ilustra bem a fluidez das identidades e as intervenções na ideia de uma nova Cusco Inca.

O mais notório conflito local em Cusco causou repercussões internacionais e teve como mote o projeto de uma empresa privada para a construção de um acesso para automóveis até Machu Picchu, colocando a zona arqueológica e a vegetação local em risco. O conflito envolveu não apenas a UNESCO, mas também o INC e arqueólogos de todo o mundo, entre outros atores que se posicionaram contrariamente aos membros do governo nacional que defendiam o projeto. Alunos de Ciências Sociais e Arquitetura da Universidade Nacional San Antonio Abad del Cusco (UNSAAC) e funcionários públicos locais também manifestaram contra o projeto e a favor do controle local de Machu Picchu. Essa manifestação tem um aspecto interessante, pois a empresa privada que propôs o projeto era um consórcio responsável por grandes hotéis de luxo de Cusco e Águas Calientes, por uma das principais linhas aéreas do país e pela linha férrea que faz o transporte entre Cusco e Machu Picchu (Silverman 2002: 888). Grande parte dos manifestantes defendia que toda a renda gerada pelo Turismo em Cusco e Machu Picchu fosse investida na conservação da zona arqueológica e na criação e abertura de novos atrativos e roteiros turísticos, como forma de distribuição de fluxos de visitantes pelo país (2002: 891). A solicitação de pulverização da atividade turística tinha por objetivo atender à necessidade de diminuição de visitantes do mencionado Mapa de Risco.

Assim, pode-se verificar o intenso engajamento da comunidade do presente com os vestígios do passado. Com o intuito de fomentar a manutenção e o incremento da atividade turística, o governo do país e suas instâncias municipais se utilizam especialmente da cultura inca para a construção do imaginário turístico local.

Diferentemente de Cusco, onde o passado invade o discurso e a vida cotidiana das comunidades (2002: 894), em Nazca a relação entre o passado arqueológico e o Turismo 
apresenta outra configuração (2002: 893). Nazca está localizada na costa sul do Peru e tem como seu principal atrativo as Linhas de Nazca, desenhos feitos no chão e que formam linhas, formas geométricas ou desenhos de animais e figuras humanas, alguns com mais de 200 metros de diâmetro. As linhas de Nazca foram consideradas Patrimônio da Humanidade pela UNESCO em 1994, mais de uma década depois de Cusco. Em Nazca é possível notar o desinteresse dos moradores pelo passado arqueológico, o que contrasta com outros contextos tanto do Peru como de outros países.

O Turismo em Nazca ganhou força a partir da década de 1970, com a publicação da obra do suíço Erich Von Däniken, Eram os deuses astronautas? (Erinnerungen an die Zukunft, no original alemão). ${ }^{52} \mathrm{O}$ Turismo se desenvolveu de forma mais intensa nas proximidades das Linhas, que ficam localizadas fora da área urbana do município. Os habitantes de Nazca não se misturam com os turistas e procuram ter o menor contato possível com os visitantes. A maioria da população local vive sua vida cotidiana longe dos locais turísticos e sem a referência das Linhas de Nazca.

Enquanto em outras áreas do Peru as ruínas divulgadas como atrativos turísticos são monumentais, o passado antigo de Nazca não tem a mesma expressividade, pois em virtude de sua escala, as gravuras formadas pelos geoglifos são melhores vistas de cima, do ar. Ninguém pode tocar as Linhas de Nazca por conta de sua fragilidade, portanto o patrimônio é essencialmente invisível e intangível para grande parcela da população. As Linhas de Nazca estão distantes da área urbana, e não é fácil o acesso da população local - a maioria dos habitantes nunca sequer viu as gravuras, pois os voos turísticos são extremamente caros e existe apenas uma torre que possibilita a visualização de algumas das gravuras, localizada a mais de 20 quilômetros de distância da cidade (Silverman 2002: 894). No entanto, as figuras formadas pelas linhas são utilizadas para decoração da cidade, de hotéis e restaurantes e para a confecção de suvenires. Contudo, para o cotidiano da maior parte dos moradores essas imagens são, segundo Silverman, irrelevantes ideologicamente, sociologicamente, politicamente e economicamente. Para os nazqueños, as populações que fizeram as linhas não são seus antepassados (2002: 895). Há uma separação cultural entre os não-indígenas

\footnotetext{
52 Best-seller em que o autor teoriza a possibilidade de que as antigas civilizações terrestres são resultado de alienígenas.Von Däniken apresenta como provas ligações entre as colossais pirâmides egípcias e incas, as quilométricas Linhas de Nazca, os misteriosos moais da Ilha de Páscoa, entre outros grandes mistérios arquitetônicos.
} 
residentes de Nazca e os indígenas do passado que habitaram a região e construíram os sítios, ao contrário de Cusco, onde a população se reconhece como descendente dos incas.

A situação em Nazca é ainda mais complicada, pois desde a década de 1940 as linhas têm sido divulgadas e interpretadas exclusivamente por estrangeiros. A pesquisadora alemã Maria Reiche, que estudou as linhas e promoveu o Turismo na região, encontrou resistência para se integrar e se comunicar com os habitantes locais, mesmo tendo vivido por aproximadamente 52 anos no município. Os moradores locais se referiam a Reiche como “Gringa louca” ou "Bruxa”, pois não conseguiam entender seu papel de pesquisadora - a alemã passava a maior parte do tempo acampando, e só travava contato com a cidade quando precisava comprar alguma coisa (Silverman 2002: 895). Os guias locais costumam contar que ela passava dias caminhando, olhando para o chão e fazendo contas, e por isso parecia louca. A partir do aniversário de 78 anos (em 1981) de Reiche o poder público passou a fazer ações sistemáticas para integrar a pesquisadora à comunidade - nesse período, uma escola e uma rua receberam seu nome.

Para Silverman (2002: 895), esses fatores são resultado da falta de curiosidade e identificação da população de Nazca com o passado; segundo a autora, há uma inter-relação entre a ausência de interesse, de voz, de orgulho e de identificação com o território. Em 1992, no livro de imagens Broken images [Imagens despedaçadas], o fotógrafo David Parker tentou capturar o dilema entre o patrimônio arqueológico, a comunidade e o território em Nazca.

Em décadas recentes esse contexto foi alterado; Maria Reiche morreu em 1998, e a partir de sua morte a população de Nazca passou a considerar a pesquisadora uma importante figura local. Alguns passaram a dizer que ela era alemã de nascimento, mas nasqueña por opção, apagando da memória seu isolamento e afastamento da comunidade. Estudantes participaram de seu funeral, carregando cartazes com frases de agradecimento à pesquisadora, decorados com as bandeiras do Peru e da Alemanha (2002: 895). Depois de sua morte Reiche passou a ter no cotidiano de Nazca um papel mais importante do que jamais tivera durante toda sua vida. Uma estátua foi erguida em sua homenagem para comemorar os 50 anos de declaração das Linhas de Nazca como Patrimônio Cultural da Humanidade (2002: 895). Também foi construído um museu na casa onde ela viveu e foi sepultada. A morte de Reiche abriu espaço para interpretações locais do passado. A população vem se apropriando da mitologia pré-colombiana, mesmo com os frequentes protestos da Igreja Católica, que vem perdendo espaço físico e ideológico. A lenda de Maria Reiche é uma tradição inventada, segundo o conceito de Hobsbawn, que vem possibilitando uma nova compreensão de identidade e comunidade a partir do passado pré-colombiano, gerando um novo olhar para o 
local e contribuindo para a construção de uma nova localidade e comunidade, pautadas pelas marcas do deserto representadas por Reiche (2002: 896). Assim, as Linhas de Nazca passam a ser um meio para a construção da identidade local, um laço entre políticas públicas e projetos nacionais e regionais, visando melhorias socioeconômicas para a comunidade (2002: 897).

Assim como em Cusco e Nazca, o passado adquire um papel mais intenso no presente das populações da região da costa norte peruana. Pesados investimentos estão sendo feitos pelos governos federais e municipais e pela iniciativa privada tendo em vista o desenvolvimento e a criação de atrativos e infraestrutura turística na região. O amplo investimento realizado está diretamente ligado aos resultados apontados no mapa de riscos da região de Cusco. A possibilidade de diminuição do fluxo de visitantes naquela região fez com que o governo federal peruano passasse a pensar estratégias de pulverização de fluxos turísticos pelo território do Peru.

No âmbito dessa proposta foi evidenciado o potencial de Turismo Arqueológico da costa norte peruana, em especial das culturas moche e chimú. Na última década foi realizado um projeto que culminou na criação e implantação da chamada "La Ruta Moche”, circuito turístico que promove a visitação a monumentos arqueológicos da cultura moche e de outras culturas que ocuparam o mesmo território, e suas aproximações com as diferentes manifestações culturais dos departamentos de Ancash, La Libertad e Lambayeque. Todo o circuito foi criado tendo como os principais atrativos as seguintes zonas arqueológicas: Pañamarca, Pampa de los Incas, Huancaco, las Huacas de Moche, Chan Chan, Galindo, El Brujo, La Mina, Dos Cabezas, Pakatnamú, Farfán, San José de Moro, Pampa Grande, Sipán, Sicán e Túcume, além de alguns importantes museus arqueológicos do país (La Ruta Moche 2012).

Trujillo é um exemplo interessante para a compreensão das mudanças acarretadas com a implantação do circuito turístico. O município está localizado no departamento de La Libertad. Nas últimas décadas sua atividade econômica esteve ligada à agricultura e à produção de sapatos. A cidade já recebia considerável fluxo de visitantes, em especial turistas nacionais. Dentre os principais atrativos turísticos do município estão o Concurso Nacional de Marinera Norteña, uma dança típica do Peru; o centro histórico do município, com casarões coloniais que possuem as janelas trujillanas, típicas da região; a praia de Huanchaco; Chan Chan, capital religiosa e administrativa da cultura chimú; e Las Huacas de Moche compostas pelas Huacas del Sol e La Luna. Apenas recentemente, no escopo da nova proposta de Turismo, o município vem sendo amplamente divulgado pelo Estado para atrair turistas internacionais. 
Chan Chan é um complexo arqueológico situado no vale de Chimor, em Trujillo. Trata-se de uma cidade construída de barro e com mais de 14 quilômetros quadrados, formada por grandes conjuntos arquitetônicos, ruas, pátios, templos piramidais, com altos-relevos que representam a fauna e a pesca da região. O complexo de Chan Chan está dividido em amplos conjuntos de palácios que já foram sedes de diferentes governos, e ganhou o status de Patrimônio da Humanidade em 1986. Vale ressaltar que a estrada que liga Trujillo a Huanchaco, uma das principais praias do Peru, passa dentro do complexo arqueológico. Mais distantes estão as Huacas Arco Iris e Esmeralda, também parte do complexo, mas que devido à grande urbanização da área se encontram separadas do restante dos conjuntos arquitetônicos e cercadas por bairros residenciais. O complexo conta ainda com um museu de sítio.

A relação entre a comunidade de Trujillo e o complexo arqueológico é conflituosa. Em 2006 os moradores das proximidades das Huacas Arco Iris e Esmeralda fizeram grandes manifestações por conta das proibições de construções e uso do espaço onde estão localizadas as Huacas. O descontentamento dos moradores se devia ao fato de que usavam as áreas arqueológicas como passagem para se locomover dentro do bairro. Alegando problemas de preservação dos sítios dado o intenso uso dos moradores, os sítios foram fechados. O que acarretou o aumento de ações de depredação dos sítios por parte da comunidade, inclusive com pichações nos murais de barro. Naquele mesmo ano foi publicada uma reportagem de capa no jornal La Industria mostrando que caminhões de entulho estavam despejando lixo dentro da zona arqueológica. A imprensa municipal cobrava dos responsáveis a efetiva preservação de Chan Chan, já que se tratava de um importante Patrimônio da Humanidade. No mesmo período foi realizada junto à população local uma pesquisa sobre os principais atrativos turísticos de Trujillo; Chan Chan foi considerado o principal atrativo, porém grande parte dos entrevistados alegou nunca ter visitado a zona arqueológica (Alfonso 2006b: 26-27), o que demonstra que a comunidade não conhece nem se reconhece naqueles bens.

Atualmente a questão do lixo despejado pela população na zona arqueológica continua causando manifestações por parte da imprensa. O mesmo jornal La Industria publicou vários artigos nos últimos anos denunciando a continuidade de despejo ilegal de lixo e entulho em Chan Chan. O interessante é notar a alteração do discurso da imprensa no decorrer de praticamente seis anos. Nos primeiros artigos analisados o lixo aparece como um grande problema para um Patrimônio da Humanidade, e ressalta-se a importância desse título. Já os artigos mais recentes mencionam os problemas que o lixo causa para o Turismo, que antes não era mencionado: "a problemática do lixo nos arredores do complexo de Chan Chan tem passado uma imagem ruim da cidade para turistas nacionais e internacionais” ( $L a$ 
Industria.PE 2012). ${ }^{53}$ "Agências de Turismo apresentam propostas para proteger zonas arqueológicas invadidas por resíduos de construção” (La Industria.PE 2012c). ${ }^{54}$ “As festividades da Semana Santa constituem uma oportunidade para Trujillo cativar o Turismo do país. No entanto, essa atividade se vê prejudicada pelo quadro sombrio que fornece um de seus principais atrativos turísticos” (La Industria.PE 2012b). ${ }^{55}$ Nota-se, assim, o fortalecimento da atividade turística na região de Trujillo, a partir do mencionado incentivo do governo federal, e a área turística aparece de forma marcante nos discursos da mídia e da sociedade em geral.

Vale ressaltar ainda que os projetos de desenvolvimento turístico na região, mesmo os vinculados à Ruta Moche, são verticais e pouco envolvem a comunidade local. Ações com a comunidade são pontuais. Um exemplo: o Departamento de Defesa e Segurança Pública do Projeto Especial do Complexo Arqueológico Chan Chan realizou uma palestra com as lideranças de um dos povoados que habitam as proximidades da Zona Arqueológica. Segundo o La Industria, a palestra teve como finalidade fortalecer a identidade cultural dos participantes e sensibilizá-los quanto à problemática do lixo (La Industria.PE 2012). Não existe um Programa contínuo de Educação Patrimonial para as áreas envolvidas no Projeto Turístico.

Outra questão de interesse são as discussões sobre a preservação de Chan Chan. A gestão da zona arqueológica e a responsabilidade por sua preservação ficam a cargo de dois diferentes órgãos, a saber, o INC, responsável pelos bens arqueológicos do país, e a Unidade Executora 110, responsável pelo plano de conservação e preservação de Chan Chan enquanto Patrimônio da Humanidade. Essa gestão compartilhada há décadas gera uma série de conflitos. Em 2009 houve uma grande discussão entre os gestores com relação ao projeto de cobertura dos muros de barro.

Nas últimas décadas os sítios arqueológicos da região vêm sofrendo grande impacto com as chuvas, em especial ocorridas durante os fenômenos El niño e La niña. O Relatório de Avaliação de Risco do Complexo Arqueológico Chan Chan, elaborado pelo Comitê de Defesa Civil do Governo Regional em 2008, informou que o monumento arqueológico apresentava graves riscos frente à possibilidade de terremotos e chuvas (La Industria.PE 2009: 4). Em

\footnotetext{
53 "La problemática del arrojo de basura en los alrededores del complejo Chan Chan ha entregado una mala imagen de la ciudad a turistas nacionales y extranjeros” (La Industria.PE 2012).

54 "Agencias de Turismo plantean propuesta para proteger zonas arqueológicas invadidas por residuos de construcción” (La Industria.PE 2012c).

55 "Las festividades por semana santa constituyen una oportunidad para Trujillo a la hora de cautivar al Turismo del país. Sin embargo, dicha actividad se ve mermada por la penosa imagen que brinda uno de sus principales atractivos turísticos” " (La Industria.PE 2012b).
} 
2009 houve uma intensa discussão entre os órgãos gestores. A Unidade Executora instalou coberturas em algumas áreas do complexo, sem a autorização e o estudo do INC. Durante o período de chuvas as coberturas não se mostraram eficazes, pois os locais para onde a água da chuva escorria receberam fluxo mais intenso de água e foram sensivelmente danificados. A Unidade Executora solicitou que fossem deslocados trabalhadores para auxiliar nos trabalhos de conservação e reconstrução, e exigiu que fosse declarado estado de emergência de modo a receber mais verbas para a realização das ações de conservação. O INC mostrou-se contrário à declaração de estado de emergência, alegando que a Unidade Executora já havia recebido um considerável montante para as ações preventivas, que por negligência não haviam sido realizadas. Além disso, o INC não julgava apropriada a reconstrução dos muros.

No mesmo período o município solicitou ao INC autorização para a realização do “Concurso Miss Libertad” na zona arqueológica, mais especificamente no Pátio Cerimonial principal de Chan Chan. O INC aprovou a solicitação, o que gerou uma intensa discussão com a Unidade Executora e com a mídia local. Assim, a gestão compartilhada de Chan Chan, a cargo de órgãos que apresentam diferentes propostas de conservação, muitas vezes ambíguas e contraditórias, não se revela eficaz. As ações propostas - por um lado, a reconstrução de ruínas; de outro, sugestões mais atuais de uso presente dos bens do passado, como a realização do referido "Concurso Miss Libertad" - têm trazido uma série de problemas para a gestão do patrimônio arqueológico.

Outra aparente mudança que se deu na última década, impulsionada pelo incentivo da atividade turística na região, foi com relação aos museus. No Peru é uma constante a construção de museus de sítio junto às zonas arqueológicas. De certa forma, a Ruta Moche veio fortalecer esses museus, que são voltados para as narrativas e para os bens patrimoniais de cada zona arqueológica. De maneira geral, em quase todas as zonas arqueológicas abrangidas pelo circuito foi incentivada a construção ou a reforma dos museus de sítio, que passaram a ser compreendidos como "museus-show": a expografia é realizada por grandes empresas, há encenações teatrais de importantes cerimônias do passado, e cobra-se dos visitantes um alto valor de entrada.

O primeiro desses grandes museus foi o “Tumbas Reales de Sipán”, construído a partir do descobrimento das Tumbas Reais de Sipán no Complexo Arqueológico Huaca Rajada, na cidade de Chiclayo, região de Lambayeque. O descobrimento arqueológico foi comparado aos realizados em nível mundial, como no Egito, na China e no México (Lebrun Aspillaga 2007: 1). A criação do museu tinha por objetivo abrigar, conservar e expor de forma adequada os bens de Sipán. Realizou-se uma sofisticada curadoria e um esmerado restauro dos vestígios 
arqueológicos coletados, pois os adornos confeccionados em cobre dourado e prata padeciam de sérios problemas de corrosão (2007: 1). O projeto do museu é estritamente temático, expondo a unidade dos contextos funerários cientificamente recuperados, apresentando as joias, ornamentos, emblemas e oferendas como pertences e símbolos dos antigos governantes da região (2007: 1). Segundo a edição de 2004 da revista Artnews, a concepção, construção, implementação museográfica e funcionamento do museu tiveram como meta um museu "a altura deste descobrimento", e atualmente a instituição está catalogada como um dos dez museus mais importantes do mundo (2007: 1). A mesma concepção foi seguida pelo Museu Nacional de Sicán, também em Lambayeque.

O mesmo aconteceu em Trujillo. Em 2006 a cidade contava com três museus que expunham peças arqueológicas e tinham a Arqueologia como temática. O Museu de Arqueologia, Antropologia e História, gerido pela Universidade Nacional de Trujillo, procura abranger as diversas culturas que se desenvolveram na região da costa norte peruana, em diferentes períodos. Localiza-se em um casarão colonial no centro histórico tombado, portanto possui uma série de limitações de infraestrutura. Sua exposição foi planejada na década de 1990. Tratava-se do mais importante museu do município por apresentar o contexto arqueológico regional, e os moradores da cidade eram isentos da taxa de entrada.

O Museu de Arqueologia José Cassinelli foi fundado em 1955. Tratava-se de um museu particular, com acervo formado de forma ilícita e que expunha mais de 1.500 peças de diferentes culturas. As peças ficavam amontoadas em estantes de madeira cobertas por redes de pesca para evitar que fossem tocadas ou retiradas do local. E o Museu de Sítio de Chan Chan, localizado na zona arqueológica, foi implantado para expor objetos encontrados no local, tais como: cerâmicas, material têxtil, metais, esculturas, entre outros. Tanto o Museu de Sítio de Chan Chan como o Museu de Arqueologia José Cassinelli cobravam entrada.

Hoje a realidade dos museus de Trujillo é bem diferente. As exposições do Museu de Arqueologia, Antropologia e História e do Museu de Sítio de Chan Chan foram reestruturadas. Em cumprimento à Política Turística da Prefeitura Distrital de Moche, após um acordo de cooperação e promoção cultural entre o Distrito de Moche e o Museu de Arqueologia José Cassinelli toda a coleção deste último foi transferida para o Museu Arqueológico Municipal de Moche, que hoje conta com uma das mais importantes coleções moche do mundo.

Assim como em Lambayeque, sob a proposta de incentivo do Governo Federal foram construídos em Trujillo dois grandes museus de sítio. O primeiro, denominado Museu Huaca Cao, foi construído no Complexo Arqueológico El Brujo pela Fundação Wiese em 
cooperação com outras instituições. A zona arqueológica ganhou relevância internacional após descoberta, em 2006, de uma múmia de uma jovem tatuada, que recebeu o nome de “senhora de Cao". A jovem foi sepultada acompanhada de joias e outros objetos com os símbolos de poder da cultura moche. A descoberta tornou-se mundialmente conhecida, não apenas por ser a única evidência que aponta para a existência de mulheres governantes no Peru pré-colonial, mas também porque o contexto funerário está intacto e o corpo da jovem extremamente preservado, o que favoreceu que a pesquisa apontasse respostas para perguntas sobre os mochica e sobre as antigas culturas da costa norte peruana. O segundo é do Museu Huacas de Moche, construído a poucos metros da Huaca de La Luna. O museu foi inaugurado em 2010 e seu prédio foi pensado a partir de aspectos construtivos da arquitetura moche. Seus objetivos são melhorar as condições de pesquisa e conservação desenvolvidas pelo Projeto Arqueológico Huacas Del Sol y La Luna, bem como promover e divulgar os conhecimentos adquiridos sobre o sítio de Moche como centro principal da sociedade mochica. O museu foi erguido para impulsionar as estratégias de uso social desses bens patrimoniais, "favorecendo o Turismo e fortalecendo os vínculos com a comunidade local” (Huacas de Moche 2012). Ambos os museus foram pensados por grandes empresas de expografia e cobram entrada dos visitantes.

A realidade dos museus na costa norte peruana é uma exceção, pois no restante do país os museus lidam com muitos problemas, tanto por questões econômicas como por falta de profissionais qualificados; as instituições não conseguem alcançar as metas traçadas a curto, médio e longo prazo. Os museus que pertencem ao INC não são rentáveis e também não criam estratégias adequadas que permitam captar recursos, pois a legislação vigente não permite que os recursos financeiros arrecadados sejam administrados diretamente pelo museu (Lebrun Aspillaga 2007: 1). Sendo assim, o interesse turístico possibilitou uma realidade museológica diferenciada para a região abrangida pela Ruta Moche. Ali os museus foram pensados para a atividade turística e pouco dialogam com as comunidades; são locais luxuosos, que muitas vezes intimidam os visitantes locais.

Tal afastamento da comunidade é um tema importante levando-se em conta que a relação entre museus e comunidade é cada vez mais forte dentro da Nova Museologia. Porém, no Peru essa ainda não é uma prática muito intensa, mesmo que a tendência da Museologia mundial seja reconhecer o museu como instituição integrada aos contextos social e territorial e diretamente relacionada com a comunidade em que está inserida (Carmona 2011: 115). No país podem-se encontrar alguns exemplos de museus comunitários, caso do Museu Comunitário de Pisac, em Cusco, e o de Leymebamba, na Amazônia peruana. Deve-se 
destacar que não são muitos e que a maioria deles foi inaugurada recentemente, embora a referida tendência museológica já venha sendo pensada e desenvolvida em nível internacional desde a década de 1970, com os ecomuseus e museus comunitários participativos (Carmona 2011: 114).

Desse modo, na maior parte dos casos o Turismo no Peru vem sendo imposto de cima para baixo, mesmo quando há participação, mediação e criação da população. Em alguns lugares, como em Cusco, por um lado as populações locais são alienadas e subordinadas; porém, por outro participam ativamente do envolvimento dos turistas por meio da negociação de suas identidades e representações culturais. Em outros casos, como em Nazca, a comunidade imaginada, criada por uma minoria, é produto das mudanças econômicas e tecnológicas, em que o Turismo é um mediador. Como acontece em Trujillo, o interesse turístico causa uma série de investimentos e mudanças, porém as comunidades pouco participam desse processo. (Silverman 2002: 898)

Outra questão a ser ressaltada é que os vestígios arqueológicos podem favorecer relações conflituosas entre as populações, o Estado e os agentes internacionais. Exemplo claro é o incidente ocorrido em 1987 no sítio Sipan — e que ficou conhecido em todo o mundo quando as escavações arqueológicas só puderam ser realizadas após um conflito armado entre a polícia e os habitantes locais, o que resultou na morte de um saqueador (Alva in Silverman 2002: 883). Também digno de nota foi o episódio ocorrido durante a estada desta pesquisadora na costa norte peruana em 2006, quando os governantes de Ferreñafe solicitaram a elaboração de um projeto de Educação Patrimonial como forma de minimizar conflitos nas proximidades da zona arqueológica de Sicán.

Visando propiciar a criação de um roteiro turístico regional, optou-se por construir o Museo Nacional Sicán nas proximidades do Bosque de Pómac, importante atrativo turístico regional, localizado 20 quilômetros ao norte da cidade de Chiclayo. Porém, o local escolhido fica a mais de mil metros de distância do complexo arqueológico de Túcume, onde está localizada a zona arqueológica. A escolha do local suscitou um intenso debate entre as autoridades locais e a comunidade que habita as proximidades da zona arqueológica, para quem era essencial que o museu fosse construído junto aos sítios, como forma de incentivar a visitação turística ao local, gerando possibilidade de renda e criação de empregos para a comunidade. A fim de minimizar o conflito os governantes locais construíram um museu de sítio na zona arqueológica de Sicán, que, contudo, não atraiu o número de visitantes esperado pela comunidade, o que acarretou um ataque às ruínas arqueológicas e ao museu de sítio. Este foi apenas um entre os vários exemplos vivenciados por esta pesquisadora durante a 
realização de uma série de oficinas sobre identidade e patrimônio na costa norte peruana (Alfonso 2006b).

TURISMO CULTURAL E NOVOS DISCURSOS SOBRE A “CULTURA INDÍGENA” E O PASSADO PRÉ-HISPÂNICO

Muitas das questões sobre o Turismo Convencional suscitadas no contexto peruano estão diretamente ligadas à ausência de um planejamento estratégico eficaz para o setor do Turismo e às dificuldades relacionadas às estatísticas da atividade turística, que são incompletas e não levam em conta os inventários turísticos feitos pelas localidades, o que dificulta uma maior compreensão do contexto local. Ugarte e Pacheco apontam para outros elementos, tais como: as dificuldades de diálogo entre as diferentes instituições envolvidas no Turismo, o distanciamento entre os órgãos estatais e o setor privado, a inexistência de regulamentação para os operadores e guias e a falta de eficiência de programas em eamento pouco ou nunca avaliados (Ugarte e Pacheco 2001: 23). Além disso, a deficiência de legislação ou de políticas concretas que visem a uma distribuição igualitária dos benefícios do Turismo entre as partes interessadas, principalmente envolvendo as comunidades locais (Ugarte e Pacheco 2001: 24).

Outro elemento que influenciou de forma decisiva o desenvolvimento do Turismo Cultural no Peru são as políticas culturais. Ao refletir sobre os governos recentes do país, algumas ações se mostram cruciais por marcarem os avanços ou retrocessos das políticas culturais nas últimas décadas. Segundo Conejo, a Carta Fundamental de 1979, a Constituição para a República do Peru, não apresentou um capítulo organizado, coerente e completo sobre cultura, que envolvesse a realidade nacional em toda sua riqueza e complexidade, levando em conta as reflexões internacionais sobre o tema (in Muchotrigo 2006: 43).

O segundo governo de Belaúnde (1982-1985) instituiu a Lei Geral de Amparo ao Patrimônio Cultural, importante instrumento para os bens culturais nacionais. Porém, no mesmo período o governo federal minimizou as atribuições e possibilidades reais de ação do Instituto Nacional de Cultura, o que trouxe a reboque uma série de prejuízos às ações do Instituto voltadas à preservação das zonas arqueológicas abertas para visitação.

O governo de Alan García (1985 - 1990) não apresentou uma política cultural orgânica e explícita. As ações mais importantes para a cultura em seu governo vieram do Conselho de Integração Cultural Latino-Americana (CICLA) e do Conselho Nacional de Ciência e 
Tecnologia (Concytec). Segundo Muchotrigo, no Peru houve pouca consistência no campo do desenvolvimento e da política cultural entre 1985 e 1990 (2006: 43). As diretrizes e programas de Política Cultural do Peru indicaram como objetivo institucional do Instituto Nacional de Cultura o estímulo para que os peruanos se identifiquem entre si e com seu entorno, de modo que seus padrões de pensamento, sentimento e ação atendam às demandas de desenvolvimento a que se propõe o país, eliminando os aspectos negativos que afetam sua valoração e sua visão de futuro (Muchotrigo 2006: 43). O mesmo documento apontou que o Peru vinha gradualmente afastando a universidade desse processo contemporâneo que cria uma imagem de que os valores culturais do país são somente os do passado e que o moderno é apenas uma cópia das realizações de outras culturas (Muchotrigo 2006: 43). Propõe-se ainda a criação de uma instância pública, encarregada de conduzir uma política cultural e científica do Peru, com capacidade para mobilizar os atores e produtores do patrimônio cultural vivo do país e garantir a preservação e promoção desse patrimônio (2006: 44). Porém, essa proposta não foi concretizada; a cultura continua separada da ciência e da tecnologia, e é evidente a desarticulação entre as diferentes culturas que formam o Peru (2006: 45).

Destaca-se ainda a política governamental de divulgação turística do país. A promoção dos mais diversos circuitos turísticos do Peru é escassa ou inexistente, havendo pouco interesse de grande parte das entidades de Turismo, públicas e privadas, na descentralização da promoção do Turismo, atualmente realizada apenas pela Comisión de Promoción del Perú para la Exportación y el Turismo (PROMPERÚ) (Ugarte e Pacheco 2001: 25). A PROMPERÚ surgiu a partir da vontade de um novo posicionamento global, apontado no Plano de Desenvolvimento do Turismo proposto pelo Ministério de Comércio Exterior. Apenas recentemente a propaganda realizada pela Comissão passou a divulgar outros atrativos além de Cusco e Machu Picchu, porém sua ênfase ainda continua sendo a divulgação de lugares que a UNESCO classificou como Patrimônio da Humanidade (Zanirato 2010: 1).

Para Vich (2007: 193), na atualidade o governo peruano usa um discurso exótico e orientalista a fim de vender para o estrangeiro uma imagem "nova” e "limpa” do país. A PROMPERÚ gastou milhares de dólares divulgando uma imagem do Peru em que as grandes mudanças do século XX - como as migrações e a pobreza urbana, entre outras — causaram pouco impacto no chamado mundo tradicional. Seus folhetos e sua participação em distintas exposições internacionais mostram sempre um Peru onde os grupos indígenas são os 
encarregados de representar uma população estetizada, sempre "sorrindo diante de uma câmera que os despoja de sua pobreza e seu presente”56 (Vich 2007: 193).

O Peru é um dos países da América com a maior porcentagem de população rural e nativa. Isso implica diferentes possibilidades de Turismo Cultural que capitalize seu patrimônio pré-hispânico. (Ypeij 2007: 37). Muitas comunidades rurais localizadas em áreas de interesse turístico são caracterizadas por extrema pobreza. Infelizmente os planos de desenvolvimento governamental via de regra não levam em conta o envolvimento em atividades turísticas como opção para aliviar a pobreza (Ugarte e Pacheco 2001: 24). Essas comunidades deveriam ter destaque na diversificação de produtos turísticos do país, dentro dos preceitos do Turismo Não-Convencional ou Alternativo, como modo de favorecer as culturas indígenas.

Como forma de mudança na implantação de projetos turísticos, na década de 1960 algumas iniciativas de Turismo Alternativo ou Não-convencional se iniciaram no Peru, na Ilha de Taquile. Depois de aparecer no guia turístico South American Handbook - conhecido como “a Bíblia para os viajantes à América do Sul” --, a população de Taquile se converteu em ícone do Turismo "new age”, oriundo dos Estados Unidos.

De acordo com as estatísticas de 2010, havia 120 dessas experiências de Turismo Alternativo espalhadas por todo o país, aproximadamente um terço delas concentrada em comunidades indígenas do Departamento de Cusco (Machu Picchu e Parque Nacional de Manu), seguido por Puno (Lago Titicaca) y Ancash (Cordillera Blanca). Segundo Gascón y Cañada (2005), essas iniciativas se apresentam no Peru como um contexto heterogêneo, diferenciando cada caso em origem, formas de gestão e tipo de alianças que as comunidades estabelecem com instituições públicas e privadas para facilitar a gestão e comercialização do produto. Porém, a tendência não se consolidou definitivamente no país (Galán 2011: 47).

$\mathrm{Na}$ atualidade, é frequente que aos turistas que chegam, por exemplo, à cidade de Cusco seja oferecido um circuito "alternativo" em uma comunidade indígena. Esses roteiros de um a três dias de duração têm por objetivo propiciar ao turista a oportunidade de compartilhar experiências culturais com as populações locais. Neles o turista não apenas pagará para ver os indígenas, mas terá a chance de trabalhar junto com eles nas roças, de participar de oferendas rituais à "La Pachamama” (mãe-terra), além de se hospedar e dividir a alimentação nas casas dos nativos, como maneira de contribuir para o sustento dos locais. Esse tipo de Turismo, que vem sendo denominado Turismo Rural Comunitário (TRC), tem

\footnotetext{
56 “soriendo ante una câmera que los despoja de su pobreza y su presente” (Vich 2007: 193).
} 
crescido no Peru nos últimos anos (Galán 2011: 39), porém sua forma de desenvolvimento é alvo de críticas e questionamentos.

Nos ees vivem grupos indígenas que falam quechua e aimara e vivem em situação de pobreza, pois sua atividades agrícola rende apenas o suficiente para atender a suas necessidades básicas (Ypeij 2007: 38). A consolidação de um modelo de crescimento neoliberal embasado na extração de recursos naturais por empresas extrativistas transnacionais - gás, madeira, petróleo e cobre —, aliado ao abandono do Estado quanto às políticas agrárias, levou as comunidades einas à conversão de um modelo de produção rural setorial para outro, mais terceirizado (Galán 2011: 29-30). Nesse contexto, a exploração de novos recursos como o Turismo tem se apresentado para muitas famílias como uma boa possibilidade de geração de renda. Nas últimas décadas, o volume de recursos e de instituições públicas e privadas dedicadas à promoção e à gestão do Turismo se multiplicaram e, com elas, aumentaram as expectativas das famílias indígenas interessadas em se dedicar à atividade (Galán 2011: 29-30).

Como ressalta Yúdice (2002: 13), nesse contexto a cultura passa a ser invocada para resolver uma gama de problemas das comunidades, como as deficiências de participação cidadã, a escassez de emprego e a luta contra a pobreza. Galán (2011: 30) evidenciou as mudanças nas narrativas sobre a cultura indígena nos últimos anos, que, embora reproduzam velhos clichês que remetem ao tradicionalismo da população local e a seu passado préhispânico, são agora mais diversas. A luta contra a pobreza, a inclusão, a interculturalidade e a sustentabilidade ecológica e cultural se sobrepõem no discurso ao velho imaginário e vêm à frente da qualidade da infraestrutura ou da busca do misticismo da experiência individual, como se exemplifica na citação abaixo:

"Em duas comunidades perto de Ollantaytambo em Cusco, os viajantes que começaram a desconfiar dos sonhos de grandeza que a globalização tem prometido, têm a maravilhosa oportunidade de se inscrever em um curso básico para uma vida feliz. E por pouco dinheiro (...). Nas imediações do complexo arqueológico vivem as comunidades rurais que não alteraram significativamente a sua visão de mundo, mesmo com o Turismo de Massa e a urbanização agressiva no vale tendo afetado drasticamente suas vidas, interrompendo suas relações sociais e empobrecendo suas economias historicamente autossuficientes, daí a importância de se encontrar formas inovadoras e alternativas que valorizem o seu 
patrimônio cultural e possibilitem uma Interculturalidade adequada” (PROMPERÚ in Galán 2011: 36). ${ }^{57}$

As campanhas de promoção nacional e internacional da marca turística "Peru" dirigidas a novos clientes fornecem apoio narrativo às atuais produções turísticas sobre a cultura indígena (Galán 2011: 38). As transformações da marca internacional "Peru” fizeram com que a "Perú, país dos incas", que prevaleceu desde a década de 1980, fosse substituída pela "Perú, Viva a Lenda”, slogan da campanha lançada em 2009 pela PROMPERÚ. A campanha objetivou diversificar a oferta turística tradicional do Turismo e transformá-la em um conjunto de experiências marcadas pelo encontro entre a população local e o turista (Galán 2011: 38). Essa nova retórica intercultural inunda campanhas publicitárias, informes e programas:

"Nossa identidade nacional é formada por uma grande diversidade de culturas cuja riqueza se manifesta por meio da arte, da dança, da musica e da tradição oral. São culturas vivas, com línguas e costumes diferentes que oferecem a aquele que procura experiências a possibilidade de participar de atividades comunitárias antigas, cerimônias de magia e religiosas, coloridas festas populares e inúmeras manifestações populares. Estas e outras experiências são a melhor maneira para que o turista se aproxime das raízes e tradições do nosso povo” (PROMPERÚ in Galán 2011: 38). ${ }^{58}$

Foram realizados alguns estudos em planos de desenvolvimento turístico da região eina, elaborados por diferentes organismos: ONGs, governos binacionais, nacionais, regionais e locais. Pode-se observar que normalmente os planos elaborados pelas ONGs enfatizam o

\footnotetext{
57 "En dos comunidades en las proximidades de Ollantaytambo, en el Cusco, los viajeros que han empezado a desconfiar de los sueños de grandeza que la globalización ha prometido, tienen la maravillosa posibilidad de matricularse en un curso fundamental de vida feliz. Y por poco dinero (...) En los alrededores del complejo arqueológico se agrupan comunidades campesinas que no han variado significativamente su visión del mundo; sin embargo, el Turismo masivo y la agresiva urbanización en el valle han venido impactando dramáticamente en sus vidas, trastocando sus relaciones sociales y empobreciendo sus economías históricamente autosuficientes; de allí la importancia de encontrar fórmulas y alternativas novedosas que pongan en valor su patrimonio cultural y posibiliten una adecuada interculturalidad” (PROMPERÚ, in Galán 2011: 36).

58 "Nuestra identidad nacional está conformada por una gran diversidad de culturas cuya riqueza se manifiesta por medio del arte, la danza, la música y la tradición oral. Son culturas vivas con lenguas y costumbres propias, que ofrecen al buscador de experiencias la posibilidad de participar de ancestrales actividades comunitarias, ceremonias mágico-religiosas, coloridas fiestas populares e innumerables manifestaciones populares. Estas y otras experiencias son la mejor forma que tiene el turista para acercarse a las raíces y tradiciones de nuestro pueblo” (PROMPERÚ in Galán 2011: 38).
} 
papel da comunidade rural e indígena no Turismo. Porém, os projetos elaborados por organismos governamentais quase nunca tratam da cultura e dos povos indígenas. Nesses documentos é possível observar que a cultura é compreendida de três maneiras diferentes, a saber: a cultura como algo importante para o Turismo e que pode ser comercializada, a cultura como algo fortemente associada aos povos indígenas, seus antepassados, seu território rural e suas tradições; e a mudança cultural compreendida como ameaça e perda (Ypeij 2007: 54).

O essencialismo da cultura pode, por exemplo, ajudar os grupos indígenas em sua luta política e econômica pela inclusão e na luta por certos direitos do grupo. Para Ypeij é importante compreender que o ator social utiliza esse essencialismo de acordo com suas intenções. Para que o essencialismo funcione como estratégia política e econômica é importante que a própria comunidade exerça controle sobre o processo. Teme-se que as transformações culturais levem a uma perda da identidade cultural; o próprio levantamento de memórias e traços culturais pode fazer parte de sua luta política pela inclusão, reforçando suas identidades e "atribuindo um valor próprio e uma raiz histórica aos seus sentimentos" (2007: 55). As ONGs e agências governamentais podem utilizar este essencialismo cultural para apoiar os grupos na formulação de políticas turísticas que incorporem os povos indígenas como participantes ativos de seu desenvolvimento.

Porém, Ypeij considera ainda que o enfoque essencialista da cultura pode reafirmar e reforçar processos de exclusão social já existentes (2007: 38). Quando o enfoque essencialista vem imposto por atores sociais de fora, há o perigo de se negar aos povos indígenas a iniciativa própria e a capacidade de ação (Ypeij 2007: 55). Considerar como ameaça as mudanças culturais pode fazer com que estes povos, ao invés de atuarem como agentes ativos que constroem sua cultura no cotidiano se transformem em sujeitos que atuam para o olhar do turista (Ypeij 2007: 55). Outro elemento importante é que o governo peruano, ao associar exclusivamente a cultura aos povos indígenas, exclui a outra parcela da população.

A “Nova Lei Geral de Turismo”, promulgada em 2009, eleva o Turismo Sustentável e Inclusivo à categoria de "atividade de interesse nacional”, considerando os princípios de sustentabilidade, descentralização, comércio justo e contra a discriminação (Ley 29408-2009 in Galán 2011: 37). Como forma de promover o Turismo Inclusivo o Estado desenvolveu oficinas de "afirmação cultural”, “cursos de capacitação em identidade cultural” e "estágios” em comunidades nas quais atividades turísticas “alternativas” já estavam em eamento. As equipes técnicas de desenvolvimento, formadas por economistas, empresários do setor turístico e, eventualmente, antropólogos e outros gestores culturais, visam "lembrar” os grupos indígenas participantes da atividade turística de quais são os seus costumes perdidos 
(2011: 39). Essas atividades consistem de processos de reinvenção promovidos por poucos consultores da cidade, na maioria das vezes desconhecedores do mundo rural eino, que circulam de projeto em projeto aplicando suas receitas e sua visão de cultura (2011: 40).

Com a assessoria dos técnicos, o grupo seleciona certos elementos de suas práticas atuais e outras do passado e as estruturam para o Turismo (2011: 40). A padronização dos produtos turísticos se dá devido ao fato de que todas as comunidades recebem os mesmos cursos de capacitação, ministrados pelos mesmos consultores -- bem como o processo de montagem do "pacote cultural" e das visitas técnicas às comunidades selecionadas como ícones do Turismo Alternativo no Peru, caso, por exemplo, da ilha Taquile, no lago Titicaca (2011: 41). O discurso afirmado nessas atividades - ou iniciativas de reinvenção — que define "o eino" em contraposição ao "ocidental” acaba sendo apropriado, em muitos casos, por alguns líderes indígenas participantes, frequentemente convertidos pelas próprias organizações de desenvolvimento em "ícones culturais” que frequentam congressos e eventos em nível nacional e internacional como representantes de suas respectivas comunidades e grupos étnicos (2011: 40).

Assim, a partir da década de 1990, com o discurso global que elogia a participação local e a preservação ambiental, as representações das tradições indígenas para o Turismo se alteram e se institucionalizam em nível local por parte dos povos e comunidades indígenas do Peru e da América Latina em geral. O rápido crescimento da indústria turística no Peru e, em particular, a promoção de novos tipos de Turismo "Sustentável” que enfatizam o valor cultural local, tornam-se fundamentais para o estudo de temas relacionados à exposição e à patrimonialização das culturas indígenas (Brown in Galán 2011: 43). Nos casos apresentados, a maneira como tanto o Turismo Convencional quanto o Não-Convencional vêm se desenvolvendo, influenciados pelos interesses do Estado, tem gerado conflitos e a reprodução de desigualdades, especialmente devido ao uso e à exploração dos recursos com a mediação de agentes externos, por conta da inevitável geração de diferenciações socioeconômicas no interior das comunidades, em que alguns ganham e outros perdem, e também em função da peculiaridade da propriedade do patrimônio cultural, que dá legitimidade à exploração do recurso ao município e às instituições públicas encarregadas da gestão do patrimônio cultural (2011: 44).

Os estudos de caso do México e do Peru exemplificam as relações contraditórias e contestadas envolvidas no Turismo Arqueológico. Relações que vêm sendo negociadas por diferentes atores que se relacionam em um contexto dinâmico construído por eles mesmos, envolvendo paisagens do passado e do presente, locais e internacionais, formais e informais, 
pessoais e históricas, políticas e econômicas. A constante mudança desse caleidoscópio cambiante de paisagens está produzindo novos lugares, localidades, identidades e comunidades.

Cidades turísticas passam a ser importantes fronteiras nas quais múltiplas identidades se cruzam por meio de diferentes indivíduos e cotidianos. Esses lugares podem ser considerados zonas de deslocamento e desterritorialização, onde se fixa o "nós" e se desestabiliza o "outro" (Bhabha in Silverman 2002: 898). O conjunto de lugares turísticos com vestígios arqueológicos torna-se acessível para a exploração ideológica, econômica, política e social. As considerações de Bhabha estão diretamente relacionadas às apropriações dos bens arqueológicos para a construção de identidades contemporâneas, quando as pessoas são ao mesmo tempo objetos históricos de uma pedagogia nacionalista - cujo discurso tem como base a autoridade em uma predeterminada origem histórica no passado - e sujeitos em um processo de significação que deve apagar qualquer presença anterior ou originária do povo ou nação de modo a demonstrar suas conquistas e contemporaneidade (Bhabha 1994: 145). Vale ressaltar que pessoas como "objetos históricos” e "sujeitos contemporâneos” não são fáceis de dicotomizar. Esses dois papéis estão estrategicamente ligados, de acordo com cada situação. Ainda que com o imaginário de passado construído para o Turismo, os locais turísticos ainda são contemporâneos, com preocupações modernas (Silverman 2002: 899).

O Turismo Arqueológico é um recurso para os fluxos culturais globais, pois os visitantes e as comunidades influenciam-se mutuamente, mesmo que não de maneira simétrica. Assim, o passado arqueológico é produzido e consumido como produto turístico que envolve diferentes identidades. Por um lado, o Estado controla seu patrimônio arqueológico pelas leis e agências; por outro, o Turismo Arqueológico está sendo produzido, construído e divulgado por seus próprios atores heterogêneos, por razões que também perpassam os problemas históricos, sociais, pessoais e políticos e as vontades de cada grupo local (Silverman 2002: 899).

No entanto, a interconexão é diferenciada e apresenta níveis diversos. Ao invés de surgimentos-surpresa, são respostas originais, negociações e resistências. O estudo do Turismo Arqueológico, portanto, é um esforço particularmente útil para a compreensão antropológica e teórica das relações entre os domínios global, nacional, regional e local. A ênfase sobre o local é o ponto de partida. É no local que a real interação com o Turismo Arqueológico acontece, porém "local” não necessariamente significa “democrático”. As populações possuem relações múltiplas e contraditórias com os vestígios do passado espalhados pelos territórios nacionais. Outra evidência tem sido o sem-número de constantes 
tensões entre três instâncias: as agências governamentais encarregadas de proteger os sítios arqueológicos, a iniciativa privada e os moradores das proximidades dos sítios, que invariavelmente destroem vestígios arqueológicos visando aumentar seus territórios para a construção de fábricas, supermercados, moradias ou para a produção agrícola.

Segundo Silverman (2002: 899), desde os primeiros saques a tumbas do Egito essas tensões vêm gerando reflexões de pesquisadores sobre a relevância do passado no cotidiano e na vida social e cultural das populações do presente. Para a Arqueologia, foi durante o WAC de 1986 que ganharam força os debates entre arqueólogos sobre o interesse pelo uso do passado no presente a partir de elementos das “Arqueologias alternativas" de Trigger. Atualmente, existe uma vasta literatura que questiona a manipulação do passado em projetos de construção de nações (Bhabha 1994: 142), a criação de atrativos turísticos a partir de sítios arqueológicos (Castaneda 1996) e os museus como locais de representação (Chagas 1994, 2007). Para Silverman (2002: 899), os saques e danos aos bens arqueológicos são indicativos de uma resistência contrária à hegemonia do Estado e às ideologias elitistas, bem como uma solução local de pessoas que vivem na pobreza, mesmo estando sobre riquezas enterradas. 


\section{Capítulo 3 - Arqueologia E TURismo Convencional no ConTEXTo BRASILEIRO}

O Turismo vem crescendo a cada ano no Brasil. As previsões para 2012, mesmo em um contexto de crise internacional, sugerem um crescimento acima de 10\% em comparação a 2011. Segundo D’Andrade (2011a), em 2010 as associadas da Associação Brasileira das Operadoras de Turismo (Braztoa) transportaram aproximadamente 4,7 milhões de passageiros, com faturamento de R\$ 7,5 bilhões. Em 2011 foram mais de 5,5 milhões de turistas e R\$ 9 bilhões de retorno. O autor afirma que o fator que impulsionou a atividade turística em 2011 foi o surgimento de novos consumidores, que inseriram o Turismo em seu orçamento familiar. Para atender a esses novos turistas foram montados pacotes e identificados novos destinos e atrativos, o que exigiu do governo e da iniciativa privada a criação de "uma infraestrutura suficiente para acolher essa expansão" (2011a), em especial com “a construção de aeroportos, reforma de estradas e ampliação da rede hoteleira (2011a).

A meta do Ministério do Turismo é que até o final da década o setor praticamente dobre de tamanho e passe a ser responsável por 6\% do Produto Interno Bruto (PIB) do Brasil (D’Andrade 2011b). A Copa do Mundo de Futebol, a ser realizada no país em 2014, também vem favorecendo investimentos no setor turístico, tanto em infraestrutura para recepção dos visitantes como em qualificação de mão de obra especializada. Contudo, os investimentos estão sendo canalizados em especial para as cidades que serão sedes dos jogos da competição. As estimativas do Departamento de Estudos e Pesquisas do Ministério do Turismo dão conta de que o Brasil vai receber 600 mil turistas estrangeiros e de que aproximadamente 1,1 milhão de brasileiros viajarão pelo país. Atualmente são esses números que guiam as ações governamentais voltadas para o mercado turístico nacional.

\section{POLÍTICAS PÚBLICAS NA HISTÓRIA DO TURISMO DO BRASIL}

Da década de 1960 até princípios do século XXI o Turismo no Brasil foi organizado pelo Instituto Brasileiro de Turismo (EMBRATUR). A entidade foi criada em 1966, por meio de um decreto lei, como parte das instituições tidas como estratégicas pelos militares, pois ajudaria a difundir uma imagem ufanista do país (Alfonso 2006a: 3). "Vale lembrar que o Turismo constituiu uma das esferas privilegiadas por diferentes regimes autoritários, no âmbito de ‘construir' e ‘vender' imagens” (2006a: 3) de uma determinada nação. Por décadas 
a fio a EMBRATUR foi a responsável única não apenas pela divulgação do Turismo para os mercados interno e externo, mas também por sua estruturação e planejamento.

Entende-se por Política Pública de Turismo o conjunto de diretrizes definidas pelos governos federal, estadual, municipal ou regional voltadas para o desenvolvimento da atividade turística, após consulta aos representantes do setor do Turismo e da sociedade. As diretrizes são expressas em um documento denominado Plano Nacional de Turismo (PNT) e nos demais documentos das esferas governamentais (Lohmann e Panosso 2008: 121). A primeira Política Nacional do Turismo data de 1966, quando o Ministério da Indústria e Comércio definiu as linhas básicas e o programa de ação do setor turístico e criou o Conselho Nacional do Turismo (CNTur) e a então chamada Empresa Brasileira de Turismo (EMBRATUR) (Alfonso 2006: 37).

Em 1968 a PNT definiu o "Programa Estratégico do Governo Federal”, que dentre as diretrizes prioritárias mencionadas no documento apontou para o apoio aos investimentos direcionados à região Nordeste do Brasil, em especial a infraestrutura hoteleira no litoral do estado, área que segundo a EMBRATUR tinha “vocação natural” para o Turismo (2006: 37). Vale destacar que as PNTs situam-se no contexto amplo da Política Nacional; assim, naquele momento o Turismo era mais uma ferramenta na tentativa de estabilizar a economia brasileira, meta principal do então governo Castelo Branco (2006: 37). Brusadin (2005) destaca que naquele período não houve investimentos voltados para a sociedade em sentido amplo - por exemplo, com ações destinadas à capacitação de mão de obra das comunidades receptoras - , mas apenas para a infraestrutura.

Entre 1975 e 1978 o presidente da EMBRATUR foi Said Farhat, cuja gestão foi a primeira, em dez anos de funcionamento do Instituto, em que a cultura nacional assume papel importante para as políticas públicas de Turismo. Em 1977 foi aprovado o documento preliminar da Política Nacional do setor, durante a II Reunião do Sistema Nacional de Turismo. A PNT limitava-se a três condicionamentos: o cultural, o social e o econômico, suas inter-relações e interações. Também nesse período foi aprovado um Projeto de Lei que visava ao equilíbrio entre o Turismo e a preservação dos bens naturais e culturais. Farhat defendia a preservação dos bens históricos e artísticos, por considerar que perdê-los seria uma agressão à “consciência cívica dos cidadãos brasileiros”, pois a "nação que não tem um passado a que se ater não terá também futuro para o qual trabalhar. As nacionalidades não suportam cortes em sua continuidade histórica" (Farhat in Alfonso 2006: 60).

Ainda durante a gestão de Farhat foram realizados levantamentos iconográficos de diversas cidades históricas do país, estudos sobre o aproveitamento turístico de destinos como 
a Chapada dos Guimarães e pesquisas em mais de 500 municípios potencialmente turísticos; além disso, implantou-se o ensino de técnicas turísticas no terceiro grau. Também buscou-se o aperfeiçoamento da legislação relativa a investimentos e à formatação de Roteiros Turísticos Nacionais e Guias Turísticos locais (2006: 60). Para Said Farhat os principais bens que davam identidade à nação brasileira eram a extensão territorial do país, a densidade populacional, a diversificação etnográfica, a unidade linguística, a variedade dos climas e de culturas regionais. A identidade nasceria "da capacidade integradora de sua harmoniosa diversidade (2006: 60). Durante décadas a ideia de democracia racial falou alto no discurso do Turismo brasileiro. Ao mesmo tempo em que essa imagem era amplamente divulgada pela publicidade turística, eram feitas campanhas para incentivar o Turismo interno com o objetivo de fomentar o desenvolvimento econômico e social de estados e regiões e incentivar as viagens nacionais. Ambas as ações tinham o objetivo de propiciar que os brasileiros conhecessem seu próprio país e, consequentemente, se identificassem com os bens patrimoniais, o que favoreceria a política governamental de manutenção da unidade nacional (2006: 60). Nesse sentido foi lançado, por exemplo, o Programa "Pró-Brasília", voltado para a "promoção cívico-turística”.

Em 1978 aconteceu o I Encontro de Promoção Turística do Nordeste. A região Nordeste do país era foco de grande atenção do governo militar, que incentivou uma série de investimentos no setor turístico para a região. Segundo a PNT do período a atividade turística era uma ferramenta estratégica nos esforços governamentais para promover o desenvolvimento econômico e social do Nordeste, favorecendo a diminuição dos fluxos migratórios. As principais imagens sobre o Nordeste nos materiais de divulgação da época estavam relacionadas ao litoral, mostrando sol, praias, frutas e artesanato (2006: 62). Em 1979 ganhou forma o Projeto CULTUR-BRASIL, que visava transformar bens patrimoniais como música, literatura, teatro e folclore em atrativos turísticos.

Após uma grave crise, a próxima Política Nacional de Turismo a ser considerada nesta tese refere-se ao período de 1986 a 1989 e esteve voltada à melhoria da qualidade do produto turístico. Para tanto foi elaborado um processo de cadastramento das empresas atuantes no setor. A PNT também discorreu sobre a necessidade de preservação do patrimônio cultural.

A gestão de João Dória Jr., então presidente da EMBRATUR, destacou-se pelas campanhas publicitárias, todas voltadas para a integração da nação e do mercado turístico brasileiro. A principal campanha denominou-se PASSAPORTE BRASIL, que tinha como base a identificação e estruturação de novos atrativos e destinos turísticos (2006: 66). A realização da PASSAPORTE BRASIL possibilitou que 1987 fosse eleito o “Ano Nacional do 
Turismo”, em comemoração aos 20 anos de criação do Instituto. O esforço para a identificação de atrativos e destinos ensejou uma série de pesquisas, inclusive de identificação do público-alvo do Turismo brasileiro, o que favoreceu a segmentação da oferta do Turismo nacional e a criação de programas específicos para atender estes os diversos públicos. O Turismo Cultural, de interesse para este trabalho, era proposto como forma de "ocupar os prédios históricos para preservá-los, transformando-os em hotéis” (2006: 67).

Em 1992 foi criado o Programa Nacional de Municipalização do Turismo (PNMT), instituído oficialmente apenas em 1994 e com ações efetivamente iniciadas em 1995 (Brusadin 2005). O PNMT foi criado pelo governo brasileiro para estimular o desenvolvimento turístico a partir da descentralização das políticas públicas de Turismo e do fortalecimento do planejamento turístico municipal (2005). O programa é relevante por ter sido o primeiro a apontar para a necessidade de um planejamento turístico participativo. Suas ações envolveram a capacitação de monitores municipais, a geração de empregos, renda e melhorias sociais e a preservação dos bens patrimoniais como forma de tornar o produto brasileiro competitivo diante do mercado internacional (Alfonso 2006: 67).

Nesse período manteve-se a proposta de segmentação do mercado turístico, com projetos de desenvolvimento do Turismo Rural, do Turismo Étnico e do Ecoturismo. Vale ressaltar que o Turismo Étnico era compreendido pelo governo brasileiro como uma forma de integrar diferentes etnias formadoras do Brasil, mas na realidade o programa previa entre suas propostas incentivar que comunidades negras estrangeiras visitassem Salvador (2006: 67). Dos programas voltados ao incentivo a esses segmentos, poucos foram concretizados. Um dos planos de ação que obteve resultados interessantes foi o Programa Nacional de Ecoturismo (PNE), que teve como destino-piloto a região da Amazônia Legal. Com sua ampliação, o PNE também apoiou os seguintes projetos voltados para o Ecoturismo: pólo ecoturístico do sertão central do Ceará, pólo ecoturístico do Lagamar, agenda de Ecoturismo do vale do Ribeira e capacitação técnica do Parque Nacional Serra da Capivara (Silva 2004: 60).

Quanto à promoção turística do período, a campanha principal adotou o slogan “Quando o Turismo cresce, o Brasil cresce junto”, que destacava Amazônia, Foz do Iguaçu, Pantanal, Patrimônio Histórico-Cultural, Sol e Praia, Região Nordeste, Pesca Esportiva e Rio de Janeiro como seus principais segmentos. Assim, o patrimônio cultural voltou a ser valorizado na publicidade brasileira, o que não acontecia desde a década de 1970. A partir de então passou a ser possível ver, no material publicitário, imagens de igrejas e casarões históricos, descontextualizadas e desvinculadas do estado ou da cidade em que estavam localizadas. Essas imagens apareciam no material de divulgação publicitária misturadas a 
cenas do Rio de Janeiro, de praias, do Carnaval e de mulheres. A partir de 1996 imagens do tipo passaram, em vários materiais de divulgação, a representar o Brasil como símbolo da própria cidade em que se situavam, ou ganharam destaque em material específico de Turismo Histórico (2006: 69). Já em 1997 a campanha da EMBRATUR foi norteada pela intenção de associar a imagem do país à natureza, tentando romper como o estigma do trinômio "praia, mulheres e Carnaval” - muito em função de pressões internacionais, em especial da ONU, que exigiu ações contra o Turismo sexual no Brasil.

Com a continuidade do governo Fernando Henrique Cardoso foi lançado o PNMT 2000, cujos objetivos estratégicos eram: o fortalecimento da gestão estadual e municipal do Turismo; o envolvimento das entidades privadas e a terceirização de serviços (Brusadin 2005). O PNMT - 2000 foi o primeiro programa a apresentar propostas de desenvolvimento sustentável da atividade. O desenvolvimento turístico municipal deveria ser planejado "com base na sustentabilidade econômica, social, ambiental, cultural e política” (2005). Uma das ações mais interessantes propostas pelo PNMT foi a realização de oficinas desenvolvidas para favorecer a implementação do programa. As oficinas eram pensadas a partir da seguinte sequência: sensibilização, capacitação e planejamento. Outras ações eram voltadas à elaboração de relatórios sobre as informações turísticas locais, o treinamento dos Agentes Multiplicadores, a "conscientização" da comunidade e o incentivo à criação de Conselhos, Fundos Municipais e Planos de Desenvolvimento Turístico nos municípios. A proposta dos Conselhos de Turismo era uma forma de garantir a participação das comunidades no desenvolvimento do Turismo em âmbito municipal.

O PNMT possibilitou o surgimento de outros segmentos turísticos, entre eles o Turismo Religioso, com a produção de material sobre festas religiosas, roteiros católicos e sobre as Missões Jesuíticas. Até então a religiosidade era representada por algumas igrejas e pelo candomblé, ao passo que o Turismo de Aventura era voltado à visitação dos Parques Nacionais.

Em suas campanhas publicitárias no período a EMBRATUR buscou valorizar o início de um novo século e as comemorações dos 500 anos do Descobrimento do Brasil. Os relatórios da entidade apontavam para o interesse da gestão de reforçar o nacionalismo nas campanhas de marketing turístico (Alfonso 2006: 110). Vale ressaltar a campanha "O Brasil Barroco - 500 anos do Descobrimento do País”, cujo intento era fazer com que os brasileiros e estrangeiros "redescobrissem" o Brasil. No âmbito da campanha foi realizada a distribuição de uma série de 24 filmes de curta-metragem sobre o país para escolas públicas e particulares no Brasil e cinco mil escolas da Europa e América Latina (2006: 110). A campanha destacou 
Olinda, o Pelourinho, Ouro Preto e Diamantina, que passaram a representar o Patrimônio Histórico do país, em especial por serem Patrimônios da Humanidade (2006: 114).

Até 2002, embora tenham sido mencionados como objetivos de alguns programas os benefícios sociais que o Turismo poderia trazer para a população - as melhorias na distribuição de renda, a preservação de bens patrimoniais, sustentabilidade, a participação, entre outros -, todas as administrações da EMBRATUR deram ênfase e prioridade ao aspecto economicista do Turismo. Investimentos e esforços tiveram como alvo a infraestrutura, a legislação, os incentivos fiscais, os investimentos estrangeiros, entre outros. Porém, não tiveram prioridade a capacitação e a sensibilização da população para o Turismo, a melhoria real da sua qualidade de vida, o envolvimento das comunidades de forma igualitária no processo de desenvolvimento turístico local, tampouco as pesquisas sobre as consequências positivas e negativas da atividade para as sociedades receptoras (2006: 71). Os trabalhos de sensibilização quanto ao Turismo foram direcionados para empresários e autoridades do setor, como forma de atrair investimentos.

O Turismo era visto pelo governo federal como uma ferramenta para o desenvolvimento econômico, a melhoria de distribuição de renda, o controle de migração e o fortalecimento das fronteiras, por isso os planos de ação governamentais priorizaram regiões como a Amazônia e o Nordeste. Foi apenas o PNMT que possibilitou ações mais concretas de formação de multiplicadores, com o envolvimento das comunidades. Porém, vale destacar que a maioria das ações era de propostas verticais, impostas pelos responsáveis federais e municipais de forma a privilegiar o desenvolvimento dos programas nas localidades e não reflexões mais amplas sobre a atividade turística e sobre os contextos socioeconômicos e patrimoniais locais. Quanto à preservação e valorização dos bens culturais, somente após 1975 foram iniciados debates sobre o tema. Todavia, as ações preservacionistas estiveram voltadas para o incentivo ao Turismo interno do Brasil, uma vez que se partia do raciocínio de que se o brasileiro conhecesse seu país, passaria a valorizá-lo, o que criaria uma forte identificação do povo com sua nação.

Em 2003 mudou a estrutura federal do Turismo no país. O então presidente Luiz Inácio Lula da Silva criou o Ministério do Turismo (MTUR), que passou a ser o responsável pela estruturação da atividade turística. Com a formação do MTUR a EMBRATUR passou a ser responsável apenas pelo marketing, pela divulgação e apoio à comercialização dos produtos, serviços e destinos turísticos do Brasil para o mercado internacional. Essas mudanças na gestão nacional do Turismo trouxeram grandes alterações na forma de estruturação da atividade. No âmbito desse processo o governo federal lançou, em 2003, o 
PNT, que apresentou e institucionalizou como um de seus macroprogramas o Programa de Regionalização do Turismo do Brasil.

O mencionado macroprograma objetivou estruturar, ordenar e diversificar a oferta turística no Brasil por meio de um modelo de gestão descentralizada de políticas públicas, coordenadas e integradas, com base nos princípios de "flexibilidade, articulação, mobilização, cooperação intersetorial e interinstitucional e na sinergia de decisões como estratégia orientadora dos demais macroprogramas, programas e ações do PNT” (Ministério do Turismo 2009). Suas principais metas eram: ampliar e qualificar o mercado de trabalho voltado à atividade turística, melhorar a qualidade do produto, diversificar a oferta estruturando destinos turísticos, incentivar e ampliar o Turismo nacional, favorecer maior a inserção do produto turístico no mercado internacional e aumentar o tempo de permanência e gasto médio do turista em destinos brasileiros (2009). O Macroprograma de Regionalização do Turismo apresenta os seguintes programas: Programa de Planejamento e Gestão da Regionalização, Programa de Regionalização do Turismo, Programa de Estruturação dos Segmentos Turísticos, Programa de Estruturação da Produção Associada ao Turismo e Programa de Apoio ao Desenvolvimento Regional do Turismo (PRODETUR).

O Programa de Planejamento e Gestão da Regionalização tem por fim a articulação, a sensibilização e mobilização da sociedade para a elaboração e a implementação dos planos estratégicos das regiões turísticas. Suas principais ações, segundo o site do MTUR, são: o Inventário da Oferta Turística, a estruturação dos 65 Destinos Indutores, Planejamento e a Gestão Regional do Turismo e a Gestão das Instâncias de Governança Regionais.

O Projeto Destinos Indutores do Desenvolvimento Turístico Regional tem por objetivo definir parâmetros, avaliar o estágio de desenvolvimento e elaborar planos de ação para que os 65 destinos indutores alcancem competitividade de nível internacional. Em 2008 foi realizada a primeira edição do estudo, que apresentou o estágio de competitividade turística internacional de cada destino do país. Um dos planos de ação desenvolvidos no âmbito de viabilização de destinos indutores e de interesse para esta tese foi o projeto de estruturação do Turismo em áreas priorizadas, que previa o desenvolvimento sustentável do Turismo em regiões de baixo Índice de Desenvolvimento Humano (IDH). Desenvolvido em parceria com a Agência Espanhola de Cooperação Internacional para o Desenvolvimento (AECID), o projeto era pautado pela identificação da necessidade de fomento à inserção produtiva em diferentes destinos, onde foram implantadas iniciativas de replicação de tecnologia social, com a incubação de cooperativas populares para fomentar as atividades econômicas envolvidas no Turismo, como meio para geração de renda e o desenvolvimento sustentável 
local. Um dos destinos selecionados para integrar o projeto foi a Serra da Capivara, no Piauí.

As ações do Planejamento e Gestão Regional do Turismo envolveram a roteirização da atividade turística, ou seja, o incentivo à formação de roteiros integrados entre municípios (2009) agrupados em Circuitos Turísticos, isto é, municípios próximos ou que possuam características atrativas semelhantes, organizados em consórcio. No âmbito da proposta do programa os municípios iniciaram um processo de Inventário do patrimônio natural e cultural, de modo a verificar sua potencialidade e planejar a estruturação de atrativos. O Inventário da Oferta Turística é o resultado do levantamento, da identificação e do registro de atrativos, serviços e equipamentos turísticos e da infraestrutura de apoio ao Turismo nacional.

O Programa de Estruturação de Segmentos Turísticos visou promover a ampliação e diversificação do consumo de produtos turísticos brasileiros, apoiando a consolidação de segmentos turísticos. Dentre suas principais ações está a Rede de Cooperação Técnica para a Roteirização Turística, fruto de uma parceria entre o Ministério do Turismo e o Serviço Brasileiro de Apoio a Micro e Pequenas Empresas (SEBRAE). Suas primeiras edições acarretaram a formação de alguns roteiros turísticos, a saber: "Caminhos da Revolução Acreana”, "Rota das Emoções”, "De Brasília à Chapada dos Veadeiros: uma viagem pelo coração do Brasil”, “Caminho Velho da Estrada Real: De Paraty a Ouro Preto”, "Iguassu Missiones: uma experiência de integração no Mercosul”, "Rota 174: Amazonas Roraima”, “Civilização do Açúcar”, “Travessia do Pantanal”, "Roteiro Integrado do Sudeste e Aparados da Serra”.

O Programa de Apoio ao Desenvolvimento Regional do Turismo teve por objetivo assegurar o desenvolvimento turístico sustentável e integrado, trazendo melhorias às condições de vida das comunidades, aumentando as receitas geradas pelo setor e aperfeiçoando a gestão da atividade. O PRODETUR vem possibilitando uma série de propostas regionais, dentre elas o incentivo ao Pólo das Origens, no Piauí.

Outro macroprograma de interesse desta tese é o Macroprograma de Promoção de Apoio à Comercialização, que teve como uma de suas ações o Projeto Caravana Brasil, realizado pela EMBRATUR a partir de 2003 e cuja meta era incentivar a comercialização de novos produtos turísticos brasileiros nos mercados nacional e internacional. Segundo o site do Ministério do Turismo foram realizadas mais de 100 caravanas para quase 450 destinos, com a participação de cerca de 900 profissionais formadores de opinião, operadoras de Turismo nacional e internacional, além de membros da imprensa. Um dos destinos contemplados pelo Projeto foi a Serra da Capivara. Vale destacar ainda o Plano de Ação para Estruturação e 
Promoção do Turismo nos Parques Nacionais, com o intuito de estruturar e promover o Turismo nos Parques inseridos no Sistema Nacional de Unidades de Conservação (ICMBio 2010).

O Programa de Regionalização do Turismo teve continuidade mesmo com a mudança de governo em 2011. Como resultado desse projeto, muitos municípios que antes não objetivavam o desenvolvimento do Turismo passaram a fazer parcerias e a buscar melhorias de infraestrutura e a evidenciação de atrativos para se inserir na atividade. Para que se tenha uma ideia, em 2011 - durante o sexto Salão do Turismo - Roteiros do Brasil, um dos eventos mais importantes do setor voltado para a divulgação da oferta turística brasileira - foram apresentados 279 roteiros turísticos, 94 deles estruturados por meio da filosofia do Programa de Regionalização (Ministério do Turismo 2011). O programa incentivou ainda que bens patrimoniais pouco valorizados pelo Turismo nacional passassem a ser fortalecidos como atrativos diferenciais para vários roteiros. É o caso de alguns museus e bens históricos e arqueológicos.

Embora o Programa de Regionalização tenha gerado mudanças na forma como a Arqueologia vinha tomando parte dos atrativos oficiais do Turismo nacional, os resultados do Programa não trouxeram transformações imediatas para a publicidade oficial do Brasil. Até 2010, o número de destinos de Turismo Arqueológico inseridos no Turismo Convencional brasileiro era ínfimo. Essa constatação comprova que o patrimônio arqueológico propriamente dito não havia sido alvo de interesse do governo nacional e não era reconhecido como bem cultural representativo da nação brasileira. Em 2009, segundo o site oficial da EMBRATUR, o Brasil possuía apenas sete atrativos arqueológicos. Vale ressaltar que no Salão de Turismo realizado no mesmo ano foram apresentados 3.819 destinos turísticos envolvidos em circuitos em todo o Brasil. Os sete atrativos nacionais eram os seguintes:

- Parque Nacional de Sete Cidades (PI) - Criado na década de1960 pelo decreto 50.744, é administrado pelo Instituto Brasileiro do Meio Ambiente e dos Recursos Naturais Renováveis (IBAMA). Localiza-se no norte do estado do Piauí, a cerca de 18 quilômetros do município de Piracuruca, e possui uma área de 6.221 hectares. Caracteriza-se pela ocorrência de sete grandes afloramentos rochosos ruiniformes, identificados como "As Sete Cidades de Pedra”. Na unidade encontra-se uma densa concentração de sítios arqueológicos, a maioria com pinturas e gravuras rupestres, localizados em uma área de transição de cerrado, com caatinga e floresta latifoliada e recursos hídricos. As pesquisas arqueológicas na região se desenvolveram após a criação do Parque Nacional de Sete Cidades. O Parque era considerado 
uma importante atração turística do estado. A área aberta à visitação turística possui aproximadamente de 12 quilômetros de trilhas. Segundo o material publicitário da região, cada cidade imaginária tem suas particularidades; as cidades são divididas em: Piscina dos Milagres, Arco do Triunfo, Cabeça de Dom Pedro I, Gruta do Catirina, Pedra do Camelo, Pedra da Tartaruga e Reserva Ecológica para a preservação da fauna, flora e dos monumentos ricos em inscrições rupestres. Nesta última o acesso é permitido somente com autorização do Instituto Chico Mendes de Conservação da Biodiversidade (ICMBio). Embora o site oficial do Turismo brasileiro divulgasse o atrativo, a maior parte dos materiais publicitários sobre o parque sequer mencionavam a existência dos sítios arqueológicos.

- Chapada Diamantina (BA) - Situada no centro do estado da Bahia, onde nascem quase todos os rios das bacias do Paraguaçu, do Jacuípe e do Rio de Contas. Localiza-se em um Parque de Proteção Ambiental margeado por planaltos, serras quebradas e montanhas. A vegetação é composta de espécies da caatinga semiárida e da flora serrana. O parque foi criado tendo como objetivo proteger amostras dos ecossistemas da Serra do Sincorá, controlar a visitação espontânea e possibilitar a pesquisa científica e a conservação de sítios arqueológicos, em sua maioria com pinturas e gravuras rupestres e estruturas de interesse histórico. A exploração racional e ordenada do Ecoturismo seria, segundo seus idealizadores, incentivada com o intuito de gerar uma alternativa econômica sustentável à população local. Em 2009, poucas eram as ações de divulgação dos sítios arqueológicos. Hoje, porém, o Guia Turístico da Chapada Diamantina (2011) possui um tópico especial para os sítios arqueológicos. Vale ressaltar que o texto sobre os sítios do guia apresentam informações questionáveis sobre os bens patrimoniais - caso, por exemplo, de: "muitos especialistas acreditam que essas pinturas possuem cerca de oito mil a 35 mil anos e a sua origem está ligada a rituais religiosos” (2011).

- Parque Nacional da Serra do Cipó (MG) — Localizado na Serra do Espinhaço, a 100 quilômetros da capital, Belo Horizonte. O Parque Nacional da Serra do Cipó foi criado como uma Área de Proteção Ambiental. São ao todo 100 mil hectares de cerrado, matas ciliares, capões de mata, cânions, cavernas, rios e sítios arqueológicos. A topografia acidentada favorece a formação de inúmeras cachoeiras, que atraem grande quantidade de visitantes, provenientes, principalmente, de Belo Horizonte. Um dos objetivos principais da criação do parque foi o ordenamento da visitação, visando à preservação da fauna, flora e das várias nascentes que alimentam as bacias dos rios Doce e São Francisco. A preocupação foi 
motivada pelo fato de que haviam sido identificadas diversas atividades relacionadas à visitação desordenada, tais como caminhadas e cavalgadas não-autorizadas, a visitação excessiva de alguns atrativos - principalmente rios e cachoeiras - a especulação imobiliária, práticas inadequadas - como o uso de motocicletas e jipes, provenientes do Turismo de aventura, e a extração irregular de pedras e cristais. No Parque são encontrados sítios arqueológicos, a maioria com pinturas e gravuras rupestres; os sítios incluídos nos roteiros encontram-se no Paredão do Gentio e no Paredão de Santana do Riacho.

- Chapada dos Guimarães (MT) - O Parque Nacional da Chapada dos Guimarães é uma unidade de conservação localizada nos municípios de Chapada dos Guimarães e Cuiabá. Foi formado em 1989, com uma área total de 33 mil hectares. Sua constituição objetivou a proteção dos ecossistemas de savanas e matas, cabeceiras dos vários rios que compõem as bacias do Alto Paraguai e Amazônica, bem como os sítios arqueológicos e históricos. A Chapada possui aproximadamente 46 sítios arqueológicos, em abrigos sob rochas, com pinturas e gravações rupestres e sítios líticos. O Parque possui oito roteiros turísticos oficiais, todos acessados por trilhas. Segundo os responsáveis por sua administração, a visitação está sendo reestruturada para que os atrativos sejam abertos de acordo com a capacidade de gestão e com a adequação das estruturas e do sistema de controle de cada atrativo.

- Parque Nacional da Tijuca (RJ) - Localiza-se na cidade do Rio de Janeiro, no Maciço da Tijuca, e inclui as serras dos Três Rios, da Carioca e o grupo Pedra da Gávea. A área foi criada em 1961 e compreende uma área de 3.972 hectares, sendo o menor dos parques nacionais. Com a função de proteger uma amostra de mata pluvial atlântica, as nascentes dos rios que abastecem a cidade do Rio de Janeiro e a fauna, vale ressaltar que nele se inscreve a Floresta da Tijuca, a maior floresta urbana do mundo e de importância ambiental e cultural para a cidade do Rio de Janeiro — o que favoreceu que o parque fosse elevado, em 1991, à categoria de Reserva da Biosfera. Atualmente o parque é gerido conjuntamente pelo Instituto Chico Mendes de Conservação da Biodiversidade (ICMbio) e pela Prefeitura do Rio de Janeiro. Conta ainda com o apoio da sociedade através de ONGs como a Associação de Amigos do Parque Nacional da Tijuca. A área do Parque Nacional da Tijuca passou a sofrer com a ocupação agrícola a partir de meados do século XVII, com plantações de cana-deaçúcar e café nos séculos XVIII e XIX. Entre os pontos turísticos do Parque estão trilhas, grutas e cachoeiras, a Pedra da Gávea, o Corcovado e o Pico da Tijuca. O Corcovado é um dos pontos mais visitados do Rio de Janeiro, o que favorece a visibilidade do Parque como 
importante atrativo nacional. Dentre os sítios arqueológicos para visitação destaca-se o Museu-Sítio Arqueológico Casa dos Pilões, uma das antigas unidades de produção da Real Fábrica de Pólvora. Vale salientar que o material publicitário referente ao parque pouco menciona os bens arqueológicos.

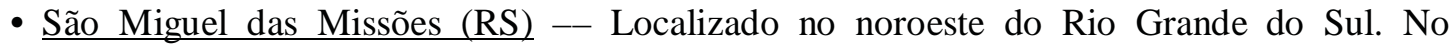
município localiza-se o Sítio Arqueológico São Miguel Arcanjo, conjunto de ruínas da antiga redução de São Miguel Arcanjo e um dos principais vestígios do período das Missões Jesuíticas dos Guaranis em todo o mundo. Foi declarado Patrimônio Mundial pela UNESCO em 1983, juntamente com as ruínas de San Ignacio Muní, Santa Ana, Nossa Senhora de Loreto e Santa María Mayor, localizadas na Argentina. O Sítio Arqueológico abarca as ruínas edificadas no século XVIII, entre 1735 e 1745. Tanto as ruínas como o Museu das Missões são visitados por turistas de todo mundo, especialmente argentinos, paraguaios, uruguaios e europeus. O sítio faz parte do roteiro internacional "Iguassu-Missiones”.

- Parque Nacional da Serra da Capivara (PI) - Principal atrativo do Turismo Arqueológico nacional, está localizado no sudeste do estado do Piauí e ocupa áreas dos municípios de São Raimundo Nonato, João Costa, Brejo do Piauí e Coronel José Dias, esta última a cidade mais próxima do Parque Nacional. O parque fica a 530 quilômetros de distância da capital do estado, Teresina. A criação do Parque Nacional Serra da Capivara teve múltiplas motivações, ligadas à preservação de um meio ambiente específico e de um importante patrimônio cultural pré-colonial. O parque está subordinado à Diretoria de Ecossistemas do IBAMA. Em torno do parque foi criada a Área de Preservação Permanente, de dez quilômetros de extensão. Em 1994 a Fundação Museu do Homem Americano (FUMDHAM) assinou um convênio de cogestão com o IBAMA. Na unidade há uma densa concentração de sítios arqueológicos, a maioria com pinturas e gravuras rupestres. Atualmente estão cadastrados mais de mil sítios, dos quais mais de 600 apresentam pinturas rupestres. Por seu valor cultural, em 1991 a UNESCO inscreveu o parque na lista do Patrimônio Cultural da Humanidade. Existem no Parque 14 roteiros turísticos, compostos por várias trilhas de acesso aos sítios arqueológicos e locais de interesse natural. Atualmente chegam a 128 os sítios preparados para a visitação, dos quais 16 oferecem serviços de acesso para pessoas com dificuldade de locomoção. Apenas nos últimos quatro anos o governo federal vem investindo de forma mais enfática na divulgação desse atrativo turístico como destino de importância nacional. 
A seleção desses atrativos não estava diretamente relacionada à Arqueologia como área de interesse nas Políticas de Turismo, mas principalmente aos projetos voltados ao desenvolvimento do Turismo de Aventura em Parques Nacionais. Cabe ressaltar que o Plano de Ação do projeto tinha como uma de suas prioridades a intensa promoção, no Brasil e no exterior, dos 25 Parques Nacionais. Para a seleção da Chapada Diamantina e do Parque Nacional de Sete Cidades contribuiu o fato de ambos estão localizados na região Nordeste do país, alvo constante do interesse dos PNT nacionais.

A análise da divulgação desses sete atrativos demonstra que apenas a Serra da Capivara e São Miguel das Missões apresentam os bens arqueológicos e culturais como o principal elemento a ser visitado. Ambos destacam-se por serem reconhecidos como Patrimônios da Humanidade, o que os valoriza enquanto atrativos turísticos. Os demais atrativos apresentam como seus principais elementos os bens naturais. $\mathrm{O}$ material de divulgação dos parques, com exceção da Serra da Capivara, raramente mencionava a existência e a possibilidade visitação aos sítios os arqueológicos. Mais interessante ainda é observar que em alguns dos atrativos divulgados oficialmente era proibida a visitação aos sítios.

Não é possível estimar a eficácia da publicidade da EMBRATUR, pois não se tem conhecimento do número de turistas que os atrativos arrolados receberam, já que na maior parte dos casos não havia um controle de entrada de visitantes. Porém, em uma breve análise dos roteiros turísticos comercializados pela CVC Turismo - atualmente a maior operadora do país -, pode-se verificar que dos sete atrativos divulgados durante anos pela EMBRATUR apenas dois estão inseridos em roteiros turísticos da empresa — a Chapada dos Guimarães e a Floresta da Tijuca. No texto de divulgação do site da CVC sobre a Chapada dos Guimarães os sítios arqueológicos não são mencionados entre os atrativos do Parque. E a Floresta da Tijuca é apresentada apenas em razão de suas belezas naturais. Vale ressaltar que no site não há menção alguma aos atrativos de Turismo Arqueológico no Brasil. Também ficou patente que as pirâmides do Egito são divulgadas como monumentos históricos e classificadas em viagens exóticas. São encontradas referências à Arqueologia apenas em roteiros internacionais, ao divulgarem Machu Picchu e alguns sítios do México.

Em 2011, as políticas de promoção do Ministério do Turismo propiciaram a divulgação de 12 destinos em que a Arqueologia se faz presente, a saber:

- Nova Olinda - Localizada na região Sul do Ceará, em zona de transição entre o sertão e a Chapada do Araripe. O município fica a 566 quilômetros de Fortaleza. Trata-se de um dos 65 
Destinos Indutores do "Projeto Destinos Indutores do Desenvolvimento Turístico Regional”, e está inserido no Roteiro "Chapada do Araripe - Terra dos Kariris - CE”. A divulgação do destino feita pelo site oficial do Ministério do Turismo enfatiza que o turista poderá conhecer "o verdadeiro parque dos dinossauros, nesta que é a maior reserva mundial de fósseis do cretáceo, quando essas criaturas incríveis passeavam pela Terra”. E segue afirmando que o passeio favorece conhecer a "Arqueologia, história, artesanato, misticismo, tudo em meio a muito verde, que garante um clima ameno no meio do sertão”. Por fim, divulga o Memorial do Homem Cariri como um museu que reúne acervo do Sítio Arqueológico Furna Pintada.

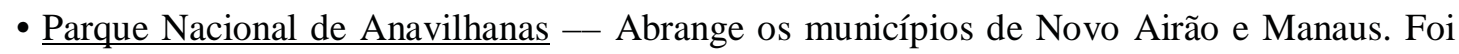
criado para preservar o arquipélago fluvial de Anavilhanas e suas diversas formações florestais, além de estimular a pesquisa científica e valorizar a conservação do bioma Amazônia. Quando de sua criação foram previstas ações voltadas para a educação ambiental e o Turismo Sustentável, de forma a favorecer as relações entre as comunidades do entorno e a Unidade. O ordenamento do Uso Público do Parque Nacional de Anavilhanas ainda encontrase em processo de elaboração, embora a visitação já aconteça mesmo sem a regulamentação da atividade turística. Um dos aspectos favoráveis para o Turismo é a proximidade de Manaus. O roteiro oficial do governo federal no qual o parque está inserido é denominado Os Parques Nacionais de Conservação do nosso Brasil. O número de atrativos culturais envolvidos no roteiro é baixo, porém a Arqueologia aparece como um "grande potencial da região". Trata-se de mais um dos parques abrangidos pelo mencionado programa de estruturação de parques nacionais.

- Itapeva - Faz divisa com os municípios de Itaí, Paranapanema, Buri, Taquarivaí, Capão Bonito, Guapiara, Ribeirão, Ribeirão Branco, Nova Campina, Itararé e Itaberá. Está localizado a 270 quilômetros da capital, São Paulo. Itapeva não está inserida em um roteiro oficial do governo federal. Entre seus principais atrativos estão os cânions Pirituba e Itanguá - hoje considerado o oitavo maior do mundo em extensão - , cachoeiras, cavernas e "oito sítios arqueológicos, dentre eles alguns com inscrições rupestres, além de importantes sítios históricos como a Fazenda Pilão d’Água, Catedral de Santana, Capela do Carmo, Estação Ramos de Azevedo e Quilombo do Jaó” (Ministério do Turismo). O texto oficial de divulgação do destino turístico ressalta ainda que o município “foi fundado em 1769, situada próximo a uma aldeia de ‘índios catequizados’, no local hoje conhecido como Vila Velha”. 
- Cuiabá - Capital do estado do Mato Grosso, situada à margem esquerda do rio Cuiabá e a poucos quilômetros da Chapada dos Guimarães. A região metropolitana abarca os municípios de Várzea Grande, Santo Antônio do Leverger e Nossa Senhora do Livramento, Acorizal e Chapada dos Guimarães, formando um aglomerado urbano com aproximadamente um milhão de habitantes. O site do MTUR divulga como principal atrativo arqueológico de Cuiabá o "Museu de Pedras Ramis Bucair, que reúne rochas, pedras preciosas e semipreciosas e centenas de peças de Arqueologia - entre as quais o fêmur de um tiranossauro com mais de 100 milhões de anos e machados de pedra da época neolítica, descobertos na região”. O município está inserido nos roteiros “Turismo Tecnológico" e "Pantanal à Amazônia - MT". Vale destacar que os sítios arqueológicos da Chapada dos Guimarães deixaram de ser divulgados como atrativo turístico. Os textos divulgados pelo site demonstram o desconhecimento quanto ao patrimônio arqueológico, que no caso de Cuiabá é confundido com bens paleontológicos.

- Paranaguá - Está localizado no litoral do estado do Paraná e faz divisa como os municípios de Antonina e Guaraqueçaba, através da baía de Paranaguá; ao sul, com Guaratuba e Matinhos; a leste, com Pontal do Paraná, e a oeste, com Morretes. Paranaguá fica a 91 quilômetros da capital do estado, Curitiba. O atrativo principal do destino é o passeio de barco pela baía de Paranaguá; o único atrativo arqueológico é o Museu de Arqueologia e Etnologia de Paranaguá, fundado em 1755. O município está inserido em dois roteiros oficiais do país: “Paraná: Um Cenário de Atrações do Atlântico ao Iguaçu - PR” e "Descobrindo o Litoral do Paraná - PR”.

- $\underline{\text { Parintins }}$ - Está localizada no estado do Amazonas, a aproximadamente 400 quilômetros por via fluvial e faz divisa com os municípios de Nhamundá, ao norte; Barreirinha, ao sul; o estado do Pará, ao leste; e Urucurituba, a oeste. Seu principal atrativo é o Festival Folclórico de Parintins, festa a céu aberto em que competem os bois Garantido e Caprichoso. A Festa do Boi de Parintins é tida como um importante patrimônio cultural da América Latina e está inserida no roteiro "Boi-Bumbá e Festivais - AM", que possui como atrativo arqueológico apenas um passeio à Serra Valéria, com vista panorâmica para um sítio arqueológico.

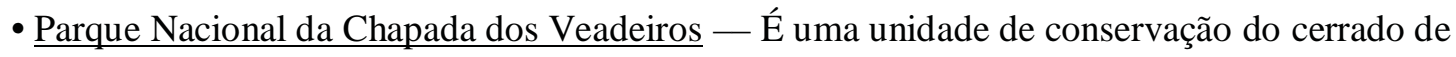
altitude localizada na Chapada dos Veadeiros, região nordeste do estado de Goiás. O parque é Patrimônio Natural Mundial da Humanidade pela UNESCO desde dezembro de 2001 e faz 
parte da Reserva da Biosfera de Goiás. O uso público só e permitido em 3\% da área do parque, o restante é reservado para fins de pesquisa e preservação. Os principais atrativos da Chapada dos Veadeiros são naturais, em especial as cachoeiras. "Enquanto o aspecto cultural pode ser percebido apenas nos sítios arqueológicos oriundos de cartas utilizadas no período de garimpo do quartzo" (Ministério do Turismo). O parque faz parte do roteiro "Os Parques Nacionais de Conservação do nosso Brasil”.

- Belo Horizonte - É a capital do estado de Minas Gerais. O município é cercado pela Serra do Curral e faz limite com: Nova Lima e Brumadinho, ao sul, Sabará e Santa Luzia, a leste; Santa Luzia e Vespasiano, ao norte; e Ribeirão das Neves, Contagem e Ibirité, a oeste. Belo Horizonte está inserida em quatro roteiros oficiais de Turismo: "Integrado Caminho Velho da Estrada Real - MG/RJ”, “Caminhos Reais - MG”, “As Serras e um Sexto Sentido - MG” e “Da Pré-História de Petter Lund às Histórias de Guimarães Rosa - MG”. Este último, embora tenha como tema principal a espeleologia, envolve o município de Lagoa Santa, importante região para a Pré-História do Brasil. As principais atrações da cidade são a Gruta da Lapinha e o Museu de Arqueologia de Lagoa Santa, que oferece, entre outras atividades, oficinas de cerâmica indígena. Os roteiros integram ainda o Museu de História Natural que, segundo o site do Ministério do Turismo, apresenta acervo arqueológico. A Linha Lund foi um dos roteiros abrangidos pelo Programa de Voluntários da Organização Mundial do Turismo (OMT), que tem por objetivo desenvolver projetos de cooperação técnica em diversos países do mundo. A inserção do roteiro no projeto da OMT foi favorecida pelo grande interesse e mobilização do estado de Minas Gerais para transformar a região das grutas em um importante atrativo turístico internacional. O intuito do apoio da missão internacional será trabalhar a gestão turística integrada, desenvolver um planejamento estratégico e criar, até 2014, a operação da Rota das Grutas de Lund, voltada para a Copa do Mundo do Brasil.

- Campo Grande - É a capital do estado de Mato Grosso do Sul e faz limite com os municípios de Jaraguari e Rochedo, ao norte; Nova Alvorada do Sul e Sidrolândia, ao sul; Ribas do Rio Pardo, ao leste; e Terenos, ao oeste. Campo Grande está inserida em três roteiros turísticos oficiais: "Pantanal - Bonito - MS", "Foz do Iguaçu-Pantanal-Bonito - MS/PR" e “Brasília/Bonito/Pantanal - Os Encantos do Brasil Central - MS/GO”. O atrativo turístico inserido nos roteiros é o Museu Dom Bosco - Museu do Índio, que apresenta coleções de Etnologia, Arqueologia, Geologia e Zoologia. Segundo o site, possui o maior acervo da cultura indígena do estado, com cerca de cinco mil peças. 
Além dos dez atrativos citados, compõem a lista oficial de atrativos nacionais São Miguel das Missões e a Serra da Capivara, já descritos anteriormente. Dos sete atrativos turísticos por muitos anos divulgados pela EMBRATUR, quatro foram desconsiderados e a Chapada dos Guimarães foi inserida no destino Cuiabá, porém não é mais divulgada como atrativo arqueológico. A mudança da representação dos atrativos arqueológicos para o Turismo nacional foi gerada a partir dos resultados do Programa de Regionalização, que formatou os seguintes roteiros - em que foram inseridos os mencionados destinos:

1. Roteiro Integrado da Civilização do Açúcar

2. Litoral Norte e Capital - SP

3. Além dos Túmulos - Os mistérios de São Paulo - SP

4. Da Pré-História de Petter Lund às Histórias de Guimarães Rosa - MG

5. Sertão do Seridó e Pipa - RN

6. Aventuras nas Serras do Seridó - RN

7. Serra da Capivara - Terra de Aventura e Pré-História - PI

8. Cariri - Um Tributo a Você - PB

9. Chapada do Araripe - Terra dos Kariris - CE

10. Roteiro Integrado Amazonas e Roraima - AM/RR

11. Pedras e Águas que Encantam - RS

12. Roteiro Integrado Iguassu - Missiones - PR/SC/RS

13. Pantanal à Amazônia - MT

14. Roteiro Patrimônios de Goiás - GO

15. Monte Roraima - RR

Embora ainda seja pequeno o número de roteiros e atrativos arqueológicos envolvidos nas ações do governo federal e divulgados pela EMBRATUR como oficiais do Brasil, pela primeira vez o governo brasileiro formatou roteiros que apresentam em seu nome a PréHistória, diferentemente dos países apresentados no segundo capítulo desta tese, nos quais a Arqueologia é o principal atrativo turístico. Por conta da relevância da Serra da Capivara e de São Miguel das Missões, que permaneceram na listagem de destinos de Turismo Arqueológico do país e que por décadas vêm recebendo o apoio e integrando as campanhas oficiais da EMBRATUR, optou-se por apresentar aqui uma breve análise sobre ambos.

\section{O TURISMO ARQUEOLÓGICO NA SERRA DA CAPIVARA}

O Parque Nacional Serra da Capivara foi criado pelo decreto $\mathrm{n}^{\circ} 83.548$ de 5 de junho de 1979, com uma área de 129 mil hectares e objetivando preservar as belezas naturais, na categoria de proteção integral (NUPAUB 2011: 164). Além do patrimônio natural foram 
apresentados outros fatores preponderantes para a formação do parque: o patrimônio cultural e o potencial para o Turismo (Oliveira Filho e Monteiro 2007: 6). Segundo Oliveira e Monteiro (2009: 231), dos parques existentes no Brasil a Serra da Capivara se distingue por possuir importância histórica, cultural e ambiental, em função dos mais de mil sítios arqueológicos catalogados, além de apresentar fauna e flora específicas do bioma caatinga e formações rochosas. O parque está inserido em região semiárida que apresenta grandes dificuldades socioeconômicas. Nesse contexto os fluxos de Turismo para os municípios abrangidos pelo parque são vistos como possibilidade de geração de emprego e renda e de valorização cultural e natural (2009: 231).

O Parque Nacional Serra da Capivara é subordinado à Diretoria de Ecossistemas do Instituto Brasileiro do Meio Ambiente e dos Recursos Naturais Renováveis (IBAMA), mas a partir de 1994 sua administração passou a ser realizada em cogestão com a FUMDHAM (2011: 164). Vale destacar que, assim como a criação de vários parques nacionais, a demarcação das terras da Serra da Capivara e sua formação não foram processos simples e democráticos. A criação do parque atingiu uma gama de populações locais que viviam nos municípios de Coronel José Dias, João Costa e Brejo do Piauí. Na área do parque se situavam a comunidade do Zambelê e outras comunidades menores, que surgiram "a partir da metade do século XIX no momento em que as terras no entorno da serra foram ocupadas para a exploração da maniçoba” (NUPAUB 2011: 165). As comunidades eram formadas por agricultores, famílias de assentados e quilombolas (Sousa in NUPAUB 2011: 165). O parque foi criado sem a participação ou consulta da comunidade local, o que causou a insatisfação da população que utilizava as áreas, que acabou se revoltando contra o patrimônio arqueológico, uma vez que a criação do parque sempre esteve vinculada à necessidade de preservar os sítios arqueológicos. A demora na demarcação das terras também acarretou sérios problemas, pois os "recursos naturais deixaram de ter reconhecimento de domínio comum e passaram a ser explorados e depredados como terra de ninguém” (Levy in NUPAUB. 2011: 166).

Foi com esse contexto que a FUMDHAM teve de lidar desde seus primórdios. De acordo com documentação da fundação, a FUMDHAM é uma "entidade científica, filantrópica, uma sociedade civil, sem fins lucrativos, declarada de utilidade pública estadual e federal e cadastrada no Conselho Nacional de Assistência Social” (FUMDHAM 2009). Dos cinco objetivos da fundação, que constam de seu estatuto, um deles está relacionado exclusivamente ao Turismo, de forma a "colaborar com o Governo do Estado e outros órgãos interessados, visando o desenvolvimento econômico da região através de uma ação destinada a atrair um Turismo diferenciado” (FUMDHAM 2009). Essa colaboração está manifesta nas 
diversas ações de desenvolvimento turístico promovidas pelo governo federal no Parque Nacional Serra da Capivara.

Ao longo das décadas a FUMDHAM desenvolveu ações comunitárias que envolvem educação, higiene e saúde pública, possibilidades de progresso socioeconômico das comunidades das zonas periféricas e desenvolvimento ecologicamente autossustentável do parque. As ações voltadas para essas temáticas foram consideradas importantes no sentido de favorecer a criação de novas associações ou consolidar as existentes, por compreenderem a importância de propostas de melhorias da qualidade de vida das populações do entorno. O Plano de Manejo do Parque Nacional foi elaborado de forma a considerar que a Serra da Capivara não é apenas uma unidade de conservação, mas sim um Parque Arqueológico. Sendo assim, as atividades de conservação do patrimônio cultural e de pesquisa foram consideradas prioritárias, ressaltando a relação entre patrimônio cultural e Ecologia (FUMDHAM 2009: 7).

Como forma de minimizar as consequências da formação do parque, inclusive com o deslocamento de moradores que habitavam a área, a fundação realizou ações para criar, nas áreas habitadas do entorno do Parque Nacional, núcleos de apoio à comunidade para atuar nos setores da saúde, educação e produção alternativa. O projeto contou com financiamento da Cooperação Técnica Internacional do Ministério das Relações Exteriores da Itália. Cobrindo o perímetro do Parque, foram construídos quatro Centros de Educação Ambiental e um Centro de Ensino Profissionalizante, que funcionaram de 1989 até 2000, quando foram fechados por falta de recursos (FUMDHAM 2009).

A FUMDHAM levou em conta a atividade produtiva, de forma a buscar a diversificação, possibilitando que as diferentes comunidades possuíssem propostas específicas e diversas. Dentre as ações realizadas destaca-se o incentivo à produção apícola, com mais de "10 mil caixas distribuídas nas comunidades, três casas de mel e um centro de produção" (Guidon, 2007: 76). De acordo com narrativas locais os moradores da região não sabiam lidar com abelhas, sentindo inclusive medo, o que fez com que o projeto não obtivesse sucesso. Também foi criada a cerâmica Serra da Capivara, construída na década de 1990, e que produz peças com representações da arte rupestre. O projeto ainda está em funcionamento: além de atender aos fluxos turísticos locais, aproximadamente $80 \%$ da produção da cerâmica é vendida para lojas de decoração de diferentes capitais do país. Segundo Ries (2003: 10), diversificar as atividades artesanais poderia criar condições para que as comunidades se complementassem no plano econômico, gerando maiores possibilidades de cooperação. 
Outro projeto desenvolvido pela FUMDHAM e ainda atuante é o Pro Arte, vencedor do concurso Embratel Instituto Ayrton Senna - Cidadão 21 Arte em 2002 e do Prêmio Itaú Cultural em 2007. O projeto tinha por objetivo a formação, a pesquisa e a criação por meio da integração artística e social com o meio ambiente (Ries 2003: 10). Vários outros projetos desenvolvidos pela Fundação foram reduzidos ou não tiveram continuidade devido à falta de investimentos e apoio financeiro. Segundo Guidon (2007: 89), o trabalho social realizado pela FUMDHAM nem sempre é reconhecido "porque não nos alinhamos à corrente assistencialista que domina no Nordeste”.

Quanto à formação de mão de obra local, os projetos envolvem a capacitação de moradores do entorno para trabalhar no parque em áreas como a segurança e a manutenção. Muitos jovens recebem formação técnica para auxiliarem nos trabalhos arqueológicos e de conservação dos sítios, bem como na limpeza, na catalogação e análise dos acervos. Também foram capacitados moradores para trabalhar na atividade turística. Segundo Guidon (2007: 87), o Turismo foi visto como "a única alternativa que permitiria um desenvolvimento mais amplo, regional, no qual preservação patrimonial e desenvolvimento da comunidade fossem concomitantes”. Essa afirmação justificou uma série de estudos e investimentos voltados para o desenvolvimento do Turismo local, de forma a organizar os fluxos de visitantes e atrair turistas para o parque. Muitos investimentos foram concentrados na infraestrutura do local, o que acarretou que o parque fosse reconhecido (em 2003) pela Declaração das Nações Unidas de Unidade de Conservação como o possuidor da melhor estrutura de Parques Nacionais das Américas e a melhor estrutura de parques arqueológicos do mundo, segundo Guidon (2007: 89). Tal infraestrutura é composta por guaritas, salas de descanso, sanitários, trilhas, estradas, passarelas, decks de observação, vários destes adaptados para a recepção de pessoas especiais. Outros investimentos voltados para o Turismo e para as pesquisas sobre a região resultaram na criação do Museu do Homem Americano e do Centro Cultural Sérgio Motta.

Quanto à infraestrutura turística e de apoio dos municípios, em sua pesquisa Oliveira e Monteiro investigaram as possibilidades de ganhos econômicos, sociais, culturais e ambientais que o Turismo praticado no parque poderia gerar para as comunidades dos municípios de Coronel José Dias e São Raimundo Nonato. A escolha dos municípios se deu porque se considerou que eram os únicos a "oferecer suporte à atividade turística, com lojas de artesanato, guias de Turismo, entrada aos mais importantes atrativos naturais e culturais do PNSC” (2009: 231-232). Os resultados da pesquisa apontam que o parque possibilitou a ampliação da prestação de serviços turísticos, principalmente de meios de hospedagem de pequeno porte, porém sem planejamento. Os autores ressaltaram que a implantação da rede 
hoteleira não pode ser apenas creditada ao Turismo, pois São Raimundo Nonato configura-se como pólo comercial regional, o que favorece a presença de comerciantes, representantes de vendas e caminhoneiros, que também utilizam os meios de hospedagem.

A região possui um grupo de condutores de turistas formados pela Fundação Museu do Homem Americano e o IBAMA e organizados em torno de uma associação (Oliveira e Monteiro 2009: 237). Vale ressaltar que muitos dos condutores já trabalham há anos no Parque, inclusive tendo participado de trabalhos arqueológicos junto às equipes de pesquisadores. Essa interação entre a pesquisa e os condutores de turistas constitui uma das mais importantes ações da FUMDHAN voltadas para a atividade turística, pois no contexto brasileiro via de regra os monitores ou condutores que recebem visitantes passam por pouca ou nenhuma formação. A pesquisa de Oliveira e Monteiro corrobora essa afirmação, pois 71\% dos visitantes avaliaram a atuação dos condutores de Turismo como "componente fundamental da oferta turística para o pleno conhecimento e entendimento do conjunto dos atrativos” do parque (2009: 243).

Os realizadores da pesquisa identificaram ainda que aproximadamente $80 \%$ dos entrevistados consideraram o Parque Nacional Serra da Capivara um local de preservação e fonte geradora de empregos e renda (2009: 240). Os pesquisadores verificaram também que a ampliação da atividade turística exigiria melhorias da infraestrutura, como "saneamento básico, limpeza urbana, comunicação, sinalização, rodovias, hotéis e restaurantes”, bem como a organização da oferta turística, a introdução de outros atrativos, a instalação de centros de apoio ao turista e a integração do poder público, setor privado e população (2009: 240).

Constatou-se que aproximadamente 95\% dos visitantes são brasileiros, dos quais metade é do estado do Piauí, configurando uma limitação do fluxo internacional e nacional. O dado demonstra que mesmo com as intensas tentativas da EMBRATUR no sentido de valorizar o parque como atrativo turístico, a publicidade governamental não conseguiu atrair um fluxo considerável de visitantes internacionais. Vale destacar que o instituto governamental tem incluído o destino nas mais diversas ações realizadas no exterior, caso de uma campanha agressiva realizada nos Estados Unidos em 2008, ano anterior ao estudo de Oliveira e Monteiro. A campanha envolveu a divulgação de diversos destinos turísticos em três cidades do mencionado país, a partir de estampas em ônibus, painéis em aeroportos e lugares públicos, outdoors e mídia.

Os autores justificam o baixo número de estrangeiros pela ausência de infraestrutura receptiva, em especial pela "inconclusão da construção do aeroporto internacional de São Raimundo Nonato e a distância do parque em relação a Teresina e Petrolina, cidades mais 
próximas que possuem voos diários para grandes centros nacionais” (2009: 241). Lage (2007) também aponta como um problema para a atividade a dificuldade de acesso, “o péssimo estado das estradas de acesso e a falta de um aeroporto nas proximidades do parque, além de outros dificultadores, têm repercutido de forma negativa no fluxo turístico, o que interfere diretamente na sustentabilidade do atrativo". A pesquisa identificou ainda que o Parque Nacional e o Museu do Homem Americano constituem-se nos únicos atrativos com condições adequadas de atender à demanda turística dos municípios em apreço. Por fim, os autores ressaltam a importância da elaboração de uma Política Municipal de Turismo voltada para o planejamento da atividade (Oliveira e Monteiro 2009: 240-241).

Outra pesquisa realizada no parque foi realizada durante uma visita técnica de agentes de viagens, fomentada pelo Ministério do Turismo. Os participantes da visita eram capacitados a identificar e avaliar os principais atrativos e produtos de diferentes destinos turísticos. As avaliações apontaram que o Turismo Arqueológico no município de São Raimundo Nonato e no Parque Nacional era um segmento potencial, o que significa que ainda não pode ser considerado um segmento real para o município, tanto por conta de problemas de infraestrutura como pela baixa recepção de visitantes. Como principal ponto forte do Parque destacou-se o patrimônio cultural: "lugar incrível, singularidade, diversidade, sítios arqueológicos” (Ministério do Turismo 2009b: 36); o Museu do Homem Americano ficou em quarto lugar, seguido pela valorização da História. A capacitação dos monitores foi ressaltada nas respostas dos avaliadores: "a qualidade e variedade de informações fornecidas pelo guia local foram de extrema importância ao sucesso do programa” (2009b: 37). Quanto ao grau de conhecimento do destino pelo mercado turístico, os avaliadores consideraram que o parque e o município de São Raimundo Nonato precisam de ações mais intensas voltadas para o reconhecimento destes destinos pelo trade turístico. Por fim, também foi analisada a inclusão e o envolvimento da comunidade no Turismo local: “a comunidade está visivelmente envolvida com a história local e o reconhecimento do valor dos atrativos do Parque” (2009b: 37).

Segundo um levantamento realizado pelo Núcleo de Apoio à Pesquisa Sobre Populações Humanas em Áreas Úmidas Brasileiras da Universidade de São Paulo (NUPAUB 2011: 166), seguem alguns depoimentos de moradores das comunidades atingidas acerca as mudanças causadas pela formação do Parque Nacional Serra da Capivara: 
"A cultura era totalmente diferente aqui, porque a gente tinha que viver do mato, da roça, ia ter que criar uns cabritos. A caça acabava sim” (Zeca, 40 anos, Sítio do Mocó).

“Antigamente a pessoa pegava a caça era prá viver e não pra vender, era pra seu consumo. Hoje é só pra comercio. A proibição gerou a valorização da caça. Depois da proibição a caça ficou muito cara, antigamente não tinha valor porque todo mundo podia caçar livremente” (Almeida e Lucas, 75 anos, Alegre).

"tudo o que tem lá no Parque, por tudo que nós sofremos, não faz mais sentido" (Severino, 80 anos, Cambraia)

Esses depoimentos são recentes, de 2011, o que demonstra que tanto os pesquisadores como os avaliadores do mercado turístico não puderam identificar, tampouco problematizar, uma série de demandas e problemas da relação entre o parque, o Turismo e as comunidades locais. Nos trabalhos publicados não foram mencionados ações de sensibilização da sociedade quanto ao Turismo, visto como o grande possibilitador de melhorias para as comunidades, porém não como gerador de debates e reflexões sobre os bens patrimoniais e as realidades locais. O Turismo no Parque Nacional Serra da Capivara já acontece, talvez em menor escala do que o esperado por administradores, responsáveis do trade turístico e demais envolvidos, porém não segue os preceitos da participação e da sustentabilidade.

Pode-se notar ainda a inexistência de tentativas de gestão compartilhada do Turismo e dos bens patrimoniais por parte dos administradores e das comunidades. Vale ressaltar que diante da maneira como as políticas públicas de Turismo vêm organizando os atrativos e destinos nacionais, as ações desenvolvidas na Serra da Capivara são exemplos de possibilidades de envolvimento da comunidade em projetos propostos por um "outro", neste caso a FUMDHAM e seus parceiros. Depois de tantos anos de projetos e ações desenvolvidos na região, a pouca apropriação e reconhecimento de parte das comunidades com relação ao Parque, ao Turismo e aos sítios arqueológicos — conforme aponta a citação a seguir — é importante ponto para a reflexão sobre a relevância do diálogo, da sensibilização crítica e do planejamento conjunto, entre os diversos segmentos interessados, em contextos nos quais os bens patrimoniais se fazem presentes. Estariam a Arqueologia e o Turismo cumprindo nesse contexto o seu papel social?

A caça continua e, faz dois anos vimos tudo ser ameaçado pela implantação de assentamentos agrários na área do entorno, nos limites do parque. A instalação de 
pessoas nestas áreas é prejudicial e uma ameaça ao patrimônio, com o aumento de queimadas. Como hoje os animais silvestres são encontrados exclusivamente dentro do parque, porque fora dele foram exterminados pela caça predatória, as infrações aumentarão... O que será dos mais de 400 sítios arqueológicos com registros rupestres, que estão situados na periferia do parque e que estão desprotegidos?

\section{SÃO MIGUEL DAS MISSÕES - ONDE ESTÃO OS INDÍGENAS?}

A região das Missões se organizou em circuitos turísticos mesmo antes do Programa de Regionalização do Turismo. O Circuito Internacional das Missões Jesuíticas foi implantado em meados da década de 1990, de forma a integrar a Argentina, o Brasil, o Paraguai e o Uruguai. O Circuito Turístico é um dos produtos de Turismo Cultural, considerados pela UNESCO como os principais roteiros históricos internacionais do mundo, “ao lado da Rota das Sedas na Ásia, da Rota Escrava no Caribe e do Mundo Maia na América Latina” (Nogueira e Burkhard 2008: 3). Seu principal atrativo são as ruínas das antigas Reduções Jesuíticas-Guarani, algumas delas Patrimônios Culturais da Humanidade, a saber: São Miguel das Missões (no Brasil), San Ignácio, Santa Ana, Santa Maria e Loreto (na Argentina); Trinidad e Jesus (no Paraguai), e Colônia de Sacramento (no Uruguai). Para Batista Neto, a chancela da UNESCO favorece o aumento do número de visitantes a qualquer sítio cultural, o que aconteceu na região missioneira independente "dos países onde as ruínas estavam localizadas e das dificuldades de acesso para a visita desse patrimônio" (Batista Neto 2009: 2).

Segundo Nogueira e Burkhard, a região das Missões é transfronteiriça onde se localiza um conjunto patrimonial relacionado aos “Trinta Povos das Missões”. Para as autoras, dentre os elementos significativos para a "a tratibilidade turística pode-se dizer que o conhecimento das diferenças culturais existentes entre os povos constitui-se numa das mais importantes motivações das viagens turísticas” (Nogueira e Burkhard 2008: 3). Assim, o Circuito Internacional das Missões Jesuíticas foi pensado, planejado e divulgado de forma a atender aos seguintes objetivos: a divulgação da história local; a valorização e localização de obras realizadas nas Missões pela comunidade jesuítico-guarani; a consolidação local como importante pólo internacional de Turismo; valorização das culturas e bens patrimoniais locais e regionais pelas futuras gerações; e possibilitar o desenvolvimento regional, "uma vez que 
seus territórios constituem-se em espaços periféricos em relação a seus respectivos centros nacionais, passando por séria crise econômica” (2008: 5).

Como forma de cumprir esses objetivos, durante o período entre 2003 e 2005 foi criado e implantado o Programa de Capacitação para Conservação, Gestão e Desenvolvimento Sustentável das Missões Jesuíticas-Guarani - Argentina, Brasil, Paraguai e Uruguai. O programa foi elaborado no âmbito de uma Oficina Técnica promovida pelo Word Monument Fund (WMF), realizada na região em 2002. Essa oficina objetivou a elaboração de diretrizes para a conservação dos bens patrimoniais das Missões e a definição de um plano de desenvolvimento turístico comum para toda a região, ressaltando seu potencial histórico, artístico, sociológico e turístico (2008: 12). A oficina possibilitou a preparação de uma proposta de cooperação internacional visando a integração das ações desenvolvidas nos diferentes países, a formação e o fortalecimento de parcerias com entidades públicas e privadas nacionais e internacionais, a capacitação de conservadores e diretrizes para a conservação e a elaboração de projetos de intervenção e gestão das áreas e seus componentes (2008: 12).

Com objetivos semelhantes aos do Circuito Internacional, em 2001 foi lançado o “Caminho das Missões”, exemplo interessante para as discussões aqui propostas. O roteiro turístico, inspirado no "Caminho de Santiago de Compostela", em sua proposta inicial previa um percurso de 170 quilômetros abrangendo seis dos antigos Sete Povos das Missões; hoje o trajeto engloba os Sete Povos, tendo 325 quilômetros de extensão (2008: 16). O caminho é feito pelas antigas estradas missioneiras que ligavam as reduções jesuíticas. Para a melhor compreensão do roteiro turístico, valem algumas explicações de como ele se inicia. O início da caminhada é marcado pela entrega de um cajado de bambu, feito pela comunidade guarani da reserva do Inhacapetum, para cada visitante. O cajado simboliza a importância do gado trazido para a região pelos primeiros jesuítas. Os participantes também recebem uma réplica em madeira da cruz missioneira, que segundo Pommer serve para "reforçar o imaginário mítico-religioso da proposta” (2009: 78). Os idealizadores do roteiro afirmam que o "outro caminhante" pode verificar a partir do caminho tudo o que ele precisa saber da região, "a epopeia, virtuosa e valorativa da qual o missioneiro é produto”. São apenas alguns dos exemplos apresentados por Pommer de como as representações do passado "tem sido utilizadas para projetar a região para o Turismo” (2009: 78).

Brum apresenta a motivação que leva os visitantes a fazer o Caminho das Missões. Para a autora, a visita é realizada para se reviver o passado missioneiro, a partir de conversas sobre a história das Missões, da visitação aos sítios arqueológicos "como atividade de 
peregrinação" e pelo contato com os costumes e as tradições da região missioneira e do sul do Brasil. Tal contato é feito entre os turistas, os moradores dos municípios e os trabalhadores do trade (Brum 2007: 62). Brum também aponta que o visitante participa das caminhadas e visitações com a intenção de conhecer a situação atual do povo guarani (2007: 62).

Pommer ressalta que a valorização das Missões como patrimônio pode ser explicada pela necessidade do governo Borgista de defender os ideais republicanos, sendo o incentivo à limpeza e ao restauro das ruínas de São Miguel estratégico para destacar o aspecto progressista da obra reducional. Segundo ela, o patrimônio das Missões foi utilizado para representar a evolução do ser guarani, o que fazia parte de um amplo projeto que visava mostrar que “o Rio Grande sempre viveu sobre a égide da evolução” (Pommer 2009: 83). Também como parte desse plano destaca-se a criação, em 1940, do primeiro museu para a região das missões, cujo intuito era mostrar a cultura da nação de forma a valorizar o espírito nacionalista "consagrando as glórias e os costumes da nação, em detrimento das culturas populares e regionais” (2009: 84). La Salvia já apontava que o museu teria um belo conjunto arquitetônico, idealizado por Lúcio Costa, mas que seria "totalmente desprovido de vivências" (La Salvia in Pommer 2009: 86).

Para analisar a imagem criada pelas autoridades da região sobre os atrativos, Brum cita Ricoeur por compreender a memória coletiva como uma "produção narrativa baseada na refiguração do passado, visando a construção de imagens que se desejam mostrar de si” (in Brum 2007: 59). Assim, o Turismo é pretexto interessante para uma reflexão acerca dos discursos e as narrativas construídos e reconstruídos sobre o passado, no presente, como forma de transformá-los em produto turístico que atenda às realidades do mercado (2007: 59).

Para que se tente compreender que mercado é esse em que os sítios das missões estão inseridos, vale ressaltar uma breve análise de público realizada no principal atrativo brasileiro da região, São Miguel das Missões. A maioria dos visitantes de São Miguel vive em regiões próximas às Missões e no estado do Rio Grande do Sul. Segundo pesquisa do IPHAN realizada na região, quase 70\% dos visitantes de São Miguel são estudantes, sendo a escola o principal público do atrativo. Vários trabalhos sobre o público das Missões têm identificado que o fluxo de visitantes estrangeiros é pequeno, mesmo com os muitos investimentos feitos pela região e pelo governo federal na divulgação do destino turístico. Os visitantes que não fazem parte do público escolar alegaram que a motivação para conhecer o local se devia à indicação de amigos e parentes, e não às campanhas de divulgação (Batista Neto 2009: 5). No caso de São Miguel das Missões nota-se ainda que, assim como para a Serra da Capivara, o 
número de visitantes idealizado pela comunidade e pelos responsáveis pelos atrativos não correspondeu ao real fluxo de visitantes à região.

A pesquisa identifica também que a infraestrutura da cidade de São Miguel das Missões é apropriada para a recepção dos atuais visitantes, porém Batista Neto ressalta que caso haja um aumento do numero de turistas a estrutura se mostrará inadequada. O que é um problema diante da ênfase em ações municipais, estaduais e federais voltadas para a publicidade do destino. Foram coletadas ainda informações sobre o Museu das Missões, que apresenta espaços limitados para as exposições e salvaguarda dos acervos. Houve o registro de críticas quanto aos meios públicos de transporte, à sinalização e ao acesso (2009: 4). As dificuldades de acesso são tidas como grandes problemas para o desenvolvimento turístico regional: "as distâncias são grandes entre os centros maiores, tanto da Argentina, como do Brasil, como do Paraguai e Uruguai e as estradas estão comprometidas pela falta de manutenção". Também são alvo de críticas os hotéis e restaurantes e a infraestrutura dos sítios. Para Nogueira e Burkharda, a implantação do circuito não satisfez às expectativas da comunidade regional (Brum 2007: 8).

A insatisfação tem gerado uma série de inovações levadas a cabo por diferentes órgãos e instituições interessadas em "agregar valor” à visitação a São Miguel e às outras ruínas. Batista Neto destaca as ações do IPHAN destinadas à catalogação das imagens missioneiras, obras de preservação e conservação, apoio às rotas e circuitos turísticos, realização de mutirões de limpeza, treinamento de guias mirins, dentre outras ${ }^{59}$. Brum evidencia as ações de preservação do patrimônio empreendidas por diferentes agentes, em especial as administrações municipais. Menciona o reconhecimento do IPHAN quanto às ações realizadas pela prefeitura de São Nicolau na tentativa de se relacionar melhor com as comunidades do entorno das ruínas (2007: 70). Para a autora, há contradições com relação à preservação do patrimônio histórico nos discursos e narrativas locais, em especial quanto ao fomento e ao desenvolvimento de atividades de Turismo por parte dos municípios (2007: 70). Brum faz uma crítica aos projetos de Educação Patrimonial desenvolvidos pelos municípios em parceria com o IPHAN, por serem voltados exclusivamente ao público escolar, não atingindo o restante da comunidade. Segundo ela, a ausência de ações direcionadas à comunidade em geral tem acarretado o descaso e a depredação do patrimônio histórico, bem como a desvalorização de outros aspectos culturais que também deveriam ser ressaltados, inclusive para o Turismo (2007: 70-71). La Salvia já havia apontado que na região as ações

${ }^{59}$ Vale ressaltar os projetos desenvolvidos pela Zanettini Arqueologia (2009, 200b) nas regiões solicitadas pela $12^{\mathrm{a}}$ Superintendência Regional / RS - IPHAN. 
preservacionistas eram voltadas para os sítios monumentais, ao passo que outros, de importância igual ou superior, não recebiam a mesma atenção (in Pommer 2009: 91).

Pommer (2009: 90) ressalta a importância dos trabalhos arqueológicos financiados pelo IPHAN e faz uma análise sobre a apropriação da Arqueologia e do patrimônio arqueológico pelos dirigentes locais. Segundo ela, foram os trabalhos arqueológicos os responsáveis por mostrar aos dirigentes dos setores políticos e culturais da região das Missões que referências do passado eram importantes elementos a serem utilizados em ações que buscassem dinamizar as economias locais, em especial o Turismo (2009: 91). A autora cita a fala de um prefeito de São Nicolau a partir de achados arqueológicos: "Pretendo elevar ainda mais o nome de São Nicolau através do Turismo. Entendo que a única maneira de atrair a atenção das pessoas dos mais distantes pontos é através da conservação deste patrimônio cultural deixado pelos jesuítas no Brasil” (2009: 90-91). E os comentários de um jornalista que, com ironia, falava da possibilidade de a "velha civilização dos índios” ganhar destaque com o título da UNESCO (2009: 132). Pommer ressalta ainda que apenas na década de 1980 foi possível evidenciar uma tendência historiográfica comprometida com os grupos identificados como os "vencidos da história”, e para falar sobre a questão indígena na região das Missões cita como exemplo o filme República Guarani ${ }^{60}$ (Pommer 2009: 205).

Em sua pesquisa sobre o público visitante, Batista Neto identificou que a impressão principal do atrativo, após a visitação, foi a de "admiração pela capacidade do indígena de realização” (2009: 11). Na saída do sítio de São Miguel das Missões os turistas pareciam “deslumbrados com a capacidade do indígena, especialmente para a época”: "ser indígena e construir uma grande igreja deve causar muita admiração, mas fazer isso no século XVIII com a ausência de recursos que hoje está à disposição do engenheiro - é de ficar numa situação de quase pasmo” (2009: 14). Os jesuítas aparecem junto com os guaranis como construtores de uma grande obra, e alguns poucos visitantes demonstraram contrariedade quanto à utilização da mão de obra indígena e da forma como foi "destruída sua cultura pelo colonizador europeu, representado nessas paragens pelo jesuíta e a Igreja Católica” (2009: 14).

É interessante a consideração do autor quanto à “destruição” da cultura indígena. Trata-se de um discurso recorrente em se tratando da região das Missões. Nesse contexto vale

\footnotetext{
${ }^{60}$ Entre 1610 e 1767, ano da expulsão de jesuítas das Américas, desenvolveu-se em uma vasta área dominada por índios guaranis e banhada pelos rios Paraná, Uruguai e Paraguai um discutido projeto sociopolítico, religioso e também arquitetônico, único na história de relacionamento conquistador-índio: uma sociedade criada por jesuítas com sucessivas gerações de guaranis que chegou a abranger 500 mil pessoas. O filme República Guarani, dirigido por Sylvio Back, é de 1982.
} 
destacar o vídeo Comunidades Mbya-Guarani unidas pela história, do primeiro contato até o intenso convívio com os brancos de hoje, dirigido por Ariel Ortega. Uma das cenas do filme mostra os guaranis sentados em esteiras vendendo artesanato, enquanto uma guia de Turismo faz um tour com um grupo de visitantes e afirma que tinha sido fácil catequizar os guaranis por serem dóceis. Enquanto o tour prossegue os indígenas ironizam, na língua guarani, a fala da guia. Na maioria dos roteiros turísticos a venda de artesanato é o único momento em que o turista entra realmente em contato com os guaranis, em uma relação marcada pela troca comercial e que não cumpre o papel que o conceito de Turismo Cultural deveria cumprir. Da forma como o Turismo vem se desenvolvendo na região das Missões, os indígenas são apenas “figurantes silenciosos, implantados no cenário histórico” (Oliveira 2009: 169) construído para atender aos visitantes.

Para os guaranis o Turismo aparece como algo importante, pois reconhecem que a atividade pode ser um fator que possibilitaria a valorização de sua cultura (Marcon 2007: 351). Quanto ao interesse dos guaranis pelo Turismo cabe destacar que lideranças guaranis da região das Missões solicitaram que fosse inserida a temática turística em um projeto que seria desenvolvido nas aldeias pelo IPHAN. O Projeto Inventário Nacional de Referências Culturais Guarani Mbya, desenvolvido entre 2009 e 2011 pelo Centro de Trabalho Indigenista (CTI), o IPHAN e a Agencia Española de Cooperación Internacional para el Desarrollo (AECID), teve como uma de suas ações a realização de uma oficina sobre visitação em terras indígenas. Do encontro resultou a publicação, em 2012, de um livro intitulado Visitação nas Aldeias Guarani: conhecendo uma aldeia indígena - Juruakuéry Oipou vy Tekoa Guarani: recebendo visitantes, escrito por lideranças guaranis do Brasil. O livro aponta para questões relacionadas à abertura de aldeias para visitação, planejamento turístico de comunidades receptivas a partir de experiências de aldeias que já vinham recebendo visitantes, e orientações básicas para os turistas, pois se considerou que a falta de informações tem sido uma das maiores dificuldades para a otimização da atividade turística nas aldeias (Lideranças Guarani 2012).

Para Marcon, considerando-se o aspecto dos acervos arquitetônico e arqueológico enfatizados pelo município e pelo Estado, pode-se concluir que a atividade turística é bemsucedida na região das Missões. Porém, o Turismo implica relacionamento humano e o conhecimento do outro, e a forma como hoje a comunidade guarani é representada nos sítios arqueológicos para a atividade turística não demonstra que esse contato esteja acontecendo (Marcon 2007: 350). 
Não se trata de uma realidade encontrada apenas na região das Missões. A imagem dos povos indígenas e a questão indígena não vêm tendo representatividade no Turismo desde sua institucionalização no Brasil. Para Bignami, em sua análise da imagem do Brasil turístico em termos de atratividade, as imagens de representação da nação brasileira estão divididas em cinco categorias, a saber: o Brasil paraíso - ideias de ambiente selvagem, Éden, Eldorado, as Amazonas, os recursos naturais e paisagísticos, as origens da descoberta conforme carta de Pero Vaz de Caminha; o lugar de sexo fácil - ideias de beleza, sensualidade, a mulher brasileira associada à praia, ao sol e ao mar; o Brasil do brasileiro - características atribuídas ao povo brasileiro como a musicalidade, a hospitalidade, a malandragem, a alegria, a democracia racial; o país do Carnaval - as manifestações divulgadas pela mídia, manifestações folclóricas, desportivas, artísticas e culturais, gastronomia, artes, cinema e literatura nacional; e lugar do exótico e do místico - religiosidade, em especial religiões de raiz africana, mistério, ritos e indígenas “pelo seu aspecto exótico” (2005: 110).

Embora Bignami tenha apontado para o exotismo dos povos indígenas nas representações de Brasil, uma breve análise das campanhas da EMBRATUR no período entre 1966 e 2002 permite notar que são quase inexistentes imagens representativas dos povos indígenas nas campanhas oficiais de Turismo. Pode-se verificar apenas a imagem de um indígena na capa do Calendário Turístico de 1978, em que o nativo foi representado junto à imagem de um Saci e de uma iara, dentre outros personagens do folclore brasileiro. Após essa campanha de 1978, somente no final da década de 1990 a imagem de uma criança indígena foi veiculada em associação ao Ecoturismo, numa campanha de divulgação do PNMT. É interessante ressaltar que no mesmo período, no final do século XX, o material divulgou uma linha do tempo iniciada em 1500 e que não faz qualquer referência aos povos indígenas que aqui habitavam no passado ou que vivem no presente. O mais curioso é que um dos destinos divulgados pelo mesmo material era a Serra da Capivara (Prancha 1).

Segundo Schmidt \& McIntosh (in Shepherd 2002: 203), um dos grandes obstáculos encontrados pelos arqueólogos para desenvolver um senso local de valorização e identificação imediata das comunidades com os objetos do passado é a ausência de um imaginário histórico que liga os diferentes povos do presente aos povos do passado. Diante dessa constatação resta refletir sobre como os povos indígenas brasileiros foram pensados e repensados nas diversas tentativas de construção de um imaginário nacional. 


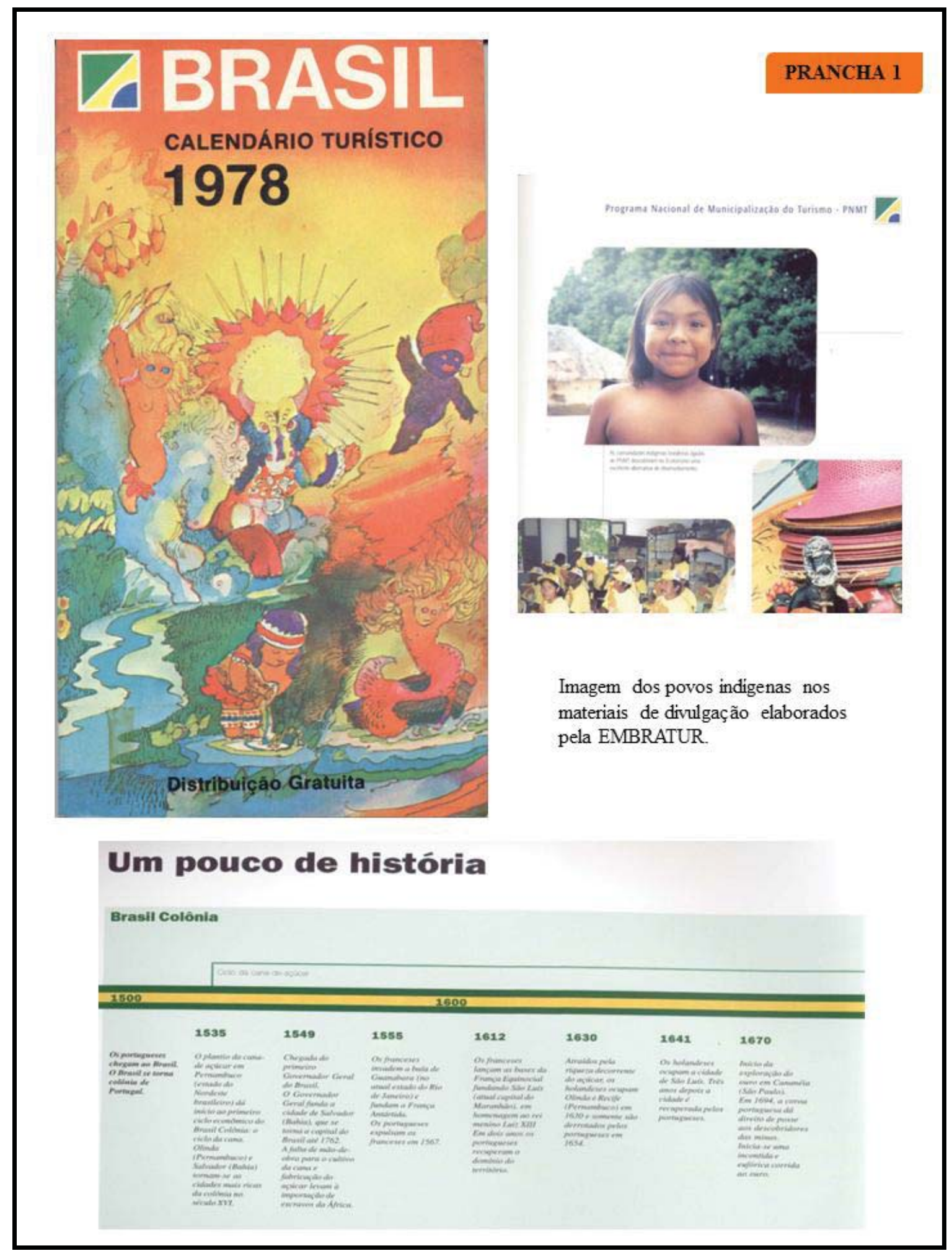


A imagem das populações indígenas foi construída pelo pensamento ocidental desde a chegada dos primeiros colonizadores ao Brasil, e vem sendo reproduzida a partir de trabalhos realizados por um "saber autorizado" que procura explicar a formação da nação brasileira em diferentes épocas, de diferentes maneiras. A legitimação do estereótipo indígena deu-se a partir desses debates, acarretando que em pleno século XXI a sociedade brasileira ainda tenha com relação a esses povos uma visão genérica, que reduz sua diversidade cultural a um conjunto estereotipado e essencializado de traços. Imagem essa partícipe das antigas representações de um país exótico, resultado de uma busca pela “orientalização” do país. Por "orientalização" compreende-se a transformação do Brasil em uma realidade ontológica distinta e distante do "Ocidente”, em um processo análogo ao ocorrido com relação ao “Oriente” e presente na tradição orientalista, tal como entende Edward Said (1990) ${ }^{61}$. Os povos indígenas foram enquadrados como parte da "natureza exuberante” de um Brasil que “se apresentou aos sábios europeus como uma espécie de reserva botânica e zoológica, muito incidentalmente povoado por seres humanos. Rebaixados para o posto de meros apêndices de reino natural (...)”62 (Descola 1988).

A formação do "outro" como um diferente, muitas vezes exótico, e a aceitação dessa diferença, fizeram com que surgisse no seio da Antropologia, em meados do XIX, o uso de dicotomias analíticas (Collier e Yanagisako 1987), tais como Natureza e Cultura, que com o tempo passaram a ser questionadas por representarem uma visão ocidental e por serem categorias fixas, que sacrificam o poder de análise sobre como esses domínios vem a ser constituídos de formas particulares, em diferentes sociedades e com consequências distintas. Viveiros de Castro, ao analisar o perspectivismo no pensamento ameríndio, verifica que as categorias dicotômicas Natureza e Cultura não possuem o mesmo estatuto de analogias ocidentais tampouco as mesmas representações, não podendo, portanto, ser utilizadas para a explicação de cosmologias não-ocidentais sem passar por uma rigorosa crítica etnográfica. A mesma censura também é feita por Strathern (1988), para quem o pensamento dos acadêmicos ocidentais já vem formado, por isso eles modelam o pensamento dos “outros” de acordo com o "pensamento ocidental”. Strathern acredita que é o uso da semântica da negação — por exemplo, o conceito de que um povo não tem sociedade ou de que não é evoluído - que acarreta uma divisão entre eu/ele, criando-se, pois, uma oposição e formando-se uma ideia de diferenças. Para a autora, as noções de "pessoa” no pensamento ocidental evocam ideias de

\footnotetext{
${ }^{61}$ O trabalho de Edward Said (1990) tem inspirado autores que se dedicaram a compreender o lugar de instituições e de intelectuais na invenção de determinadas realidades históricas, geográficas e culturais.

${ }^{62}$ se presentó a los sabios europeus como una especie de reserva botánica y zoológica, muy ccesoriamente poblado de seres humanos. Rebajados en el puesto de meros apéndices del reino natural (...)” (Descola 1988).
} 
“evolução”. A cultura e as indústrias são construídas como um rompimento com a natureza e supõem certa dominação das primeiras sobre a última.

Vale ressaltar que essa ideia evolucionista está diretamente ligada ao surgimento da Antropologia, conforme demonstrado anteriormente nesta tese, quando os pesquisadores acreditavam que deveriam recolher todos os dados possíveis, nos mínimos detalhes, dos “povos primitivos”, já que com o conato estes viriam a desaparecer, juntamente com sua cultura "rudimentar" (Evans-Pritchard 1972). Essa visão dos povos indígenas vivendo em sociedades estáticas que desaparecerão devido à aculturação — já que o contato é inevitável - ainda é muito recorrente no Brasil, mesmo com a divulgação de dados oficiais pela FUNAI (2002) mostrando um constante crescimento das populações indígenas.

A exotização do Brasil e dos povos indígenas acompanhou todo o processo intelectual em torno da discussão da formação do Brasil, do seu povo e da singularidade do que viria a denominar-se “cultura brasileira” (Alfonso 2006a: 8). Desde o século XIX o projeto nacional passou a ser objeto de disputa entre pesquisadores de diversas áreas, intelectuais, políticos, artistas etc., todos movidos pelo desejo de formar uma imagem consistente do país. Cumpre destacar que, do ponto de vista "nacional”, esse desejo remonta às décadas que antecederam e sucederam a independência política brasileira, também conhecido como Período Romântico (Alfonso 2006a: 8).

Segundo Funari e Ferreira (2006: 20), é nesse contexto do século XIX que o patrimônio e as pesquisas arqueológicas foram vinculados ao debate sobre a identidade do povo brasileiro. A Arqueologia, por intermédio do Instituto Histórico e Geográfico (IHGB), fez parte do processo nacionalista embasando a visão distorcida das populações indígenas como grupos de degenerados e fossilizados ou estanques. Os pesquisadores disseminaram a ideia de que os indígenas já haviam sido civilizados, mas com o tempo haviam se degenerado. Para Ferreira, era papel da Arqueologia conhecer o indígena, favorecendo sua dominação e civilização, "para aproveitá-lo como mão de obra e como colonizador do interior do país, para amansá-lo como sujeito econômico e de direito, para abrigá-lo sob a égide de um contrato social” (Ferreira 2003: 138). Segundo Jones (in Ferreira 2003: 145), as políticas de identidades na Arqueologia “estão embebidas em relações de poder, em práticas e táticas de legitimação social”. Funari e Ferreira citam Bhabha para afirmar que o discurso colonial é um aparato de poder, um sistema de representações que objetiva a construção de uma imagem do colonizado como degenerado visando dominá-lo (2006: 250). Ao classificar os indígenas 
brasileiros como degenerados e estáticos, a partir de sua cultura material, o IHGB enfatizou e comprovou suas diferenças culturais, afirmando sua inferioridade (2006: 25).

Ao mesmo tempo, o indianismo, uma das principais vertentes do Romantismo brasileiro, representou um esforço dos intelectuais e literatos do Brasil no sentido de afirmar uma identidade nacional, idealizando no elemento indígena as origens naturais do povo e da índole brasileira, para tanto espelhando-se no mito do "bom selvagem” de Rousseau.

A $1^{\text {a }}$ Geração do Romantismo (chamada de nacionalista ou indianista) teve como principal escritor o maranhense Gonçalves Dias (1823 - 1864). Apesar de não ter introduzido o gênero no Brasil — papel que coube a Gonçalves de Magalhães (1811 -1882) —, Dias foi o responsável pela consolidação da literatura romântica por aqui. A exaltação da natureza, a volta ao passado histórico e a idealização do índio como representante da nacionalidade brasileira são temas típicos do Romantismo presentes nas obras de Gonçalves Dias.

Já os romances do Romantismo levaram os leitores da época uma realidade idealizada, com a qual eles se identificaram (escapismo, fuga da realidade, típica característica do Romantismo). Entre eles, o romance indianista foi o que mais fez sucesso entre o grande público, por trazer consigo personagens idealizados, representados por índios. Esses "heróis" caracterizavam uma tentativa dos autores de simbolizar uma tradição do Brasil, o que nem sempre acontecia, em virtude da caracterização artificial do personagem, mais "europeizada" ainda que os indígenas de Gonçalves Dias.

José de Alencar (1829 - 1877) foi o maior autor da prosa romântica no Brasil, autor principalmente de romances indianistas e urbanos. O indianismo de José de Alencar está presente em O Guarani (1857) além de outros clássicos como Iracema (1865) e Ubirajara (1874). Alencar defendeu o estabelecimento de um "consórcio entre os nativos (que fornecem a abundante natureza) e o europeu colonizador (que, em troca, oferece a cultura, a civilização). Dessa forma, surgiu então o brasileiro. Em todo o momento, a natureza da pátria é exaltada, um cenário perfeito para um encontro simbólico entre uma índia e um europeu, por exemplo.

Como representante da vertente indianista do Romantismo ressalta-se também o compositor Carlos Gomes (1836 - 1896) com sua ópera O Guarany (1870), de renome internacional. Por outro lado, autores tão diversos como Nina Rodrigues, Sílvio Romero, João Batista Lacerda, Euclides da Cunha e Oliveira Viana, em sua maioria formados e informados pelos paradigmas raciais europeus construídos ao longo do século XIX, viam com pessimismo o país formado por uma população miscigenada. O Estado passou a criar estratégias de 
controle cultural e social diferentes para "índios” e "negros”, gerando "formas distintas de lidar com a alteridade representada por indivíduos não-brancos, incivilizados, inferiores em termos mentais e culturais que, no entanto, precisavam ser assimilados ou absorvidos pela nação brasileira” (Arruti 1997: 9), quando não exterminados.

Foi apenas na década de 1930 que se consolidou uma imagem positiva do Brasil. Um dos intelectuais que contribuiu para essa nova imagem foi Gilberto Freyre (1900 -1987), cuja obra Casa-Grande \& Senzala (1933) procurou explicar a realidade do país a partir do estudo de sua sociogênese. Para Freyre, a formação da sociedade brasileira se deu no período colonial, quando houve o lançamento das bases da "cultura brasileira”, definida pela fácil adaptação dos portugueses aos trópicos, por meio de uma estrutura familiar pautada pelo poder do patriarca, pela atração do homem português pela mulher morena (negra, índia, mulata ou cabocla) e por uma grande licenciosidade sexual, resultado do surgimento de mestiços, o que aproximou o Brasil de uma “democracia racial” (Alfonso 2006a: 11).

Embora o pensamento de Freyre seja alvo de muitas críticas, é certo que sua teoria contribuiu para a construção de uma imagem hegemônica do país, formado pelo encontro de três raças, cada qual portadora de uma “cultura” e responsável pela originalidade da "nação". Freyre mostrou um Brasil de um povo diferente e com características próprias, discutindo sua formação de forma inovadora, não pelo aspecto racial mas por meio da contribuição cultural de cada um de seus formadores (2006a: 11). Num momento em que se buscava a modernização e o desenvolvimento do país através da captação de investimentos externos, a imagem de um Brasil democrático poderia atenuar os aspectos negativos de uma nação que nunca “daria certo" por conta de seu caráter mestiço (2006a: 19).

$\mathrm{O}$ mito da democracia racial se fixou devido às questões primordiais suscitadas sobre a inferioridade dos indígenas e negros, partes formadoras da nação brasileira. Para Juaristi (2000), um mito fundacional não se forma em torno de um consenso, mas sim em torno de um debate. Chauí (2000: 9) complementa essa afirmação alegando que um mito propicia uma solução "imaginária para tensões, conflitos e contradições que não encontram outro caminho para serem resolvidos no campo da realidade”.

Assim, o Brasil se forma como resultado do contato, da miscigenação, deixando para trás o que veio antes da colonização; nessa nova imagem da nação brasileira os povos indígenas são apagados. Para Funari (2003: 92), no imaginário nacional os brasileiros podem até ter sangue indígena, mas não são mais nativos, e sim civilizados. Assim, as elites nacionais conseguiram excluir os "selvagens" do mix que compõe o povo brasileiro. Goldstein 
(in Funari 2001: 3) afirma que "o mito popular encontrado no Brasil de que este país é racialmente democrático ajuda a mascarar, normalizar e internalizar o racismo cotidiano”,63. Como "não há complexidade étnica sem fricção" (Cabral 1993: 95), os debates em torno dos "nacionalismos contemporâneos" defendem que os conflitos que envolvem "minorias nacionais” são causados devido ao fato de que as nações não conseguem lidar com a diferença. No Brasil a discriminação não se restringe aos povos indígenas, mas afeta também uma pletora de grupos étnicos, incluindo judeus e árabes, populações das áreas pobres do país, afrodescendentes e grupos étnicos de imigração recente (como coreanos). Sem falar no preconceito contra mulheres e homossexuais (Funari 2003: 92).

A Arqueologia teve participação ativa em todo o processo de construção do nacional. Seu viés colonialista "invariavelmente diminuiu as conquistas das sociedades nativas"64 (Shepherd 2002: 196). A disciplina se apresenta não como uma maneira neutra de descoberta de histórias enterradas em solo colonizado, mas como construtora ativa de passados (Shepherd 2002: 192) e de presentes. É assim que ela precisa ser compreendida.

Segundo Pinter, atualmente os arqueólogos possuem a oportunidade de sensibilizar e influenciar o trade turístico de forma a contribuir para que a atividade seja mais democrática e inclusiva, mas para tanto os arqueólogos precisam criar estratégias e metodologias de como fazê-lo. Para o autor, os arqueólogos devem sensibilizar primeiramente a si mesmos, para então dialogar com a comunidade turística no que concerne a questões críticas relacionadas à Arqueologia, ao Turismo e à relação entre as disciplinas em diferentes contextos. E também devem determinar de que maneira trabalhar como parceiros do trade turístico (2005: 11). O Heritage Tourism Task Group, parte do SAA's Public Education Committee, tem tentado avançar nesse sentido, analisando o papel da comunidade arqueológica de forma que esta consiga atuar de maneira mais eficaz, unindo diversas perspectivas para o debate em questão. Trata-se de uma tentativa real de aproximação consciente entre as áreas (2005: 11), uma vez que "os arqueólogos não estão integrados a esta indústria com uma estratégia coordenada" (2005: 11). Por isso se faz necessário que as instituições acadêmicas reflitam sobre seu papel na formação de profissionais aptos a gerir os recursos arqueológicos no contexto da atividade turística sustentável.

Um princípio-chave dos programas de Turismo dentro dos preceitos da sustentabilidade é que seu desenvolvimento traga impactos positivos às comunidades locais

\footnotetext{
63 the popular myth found in Brazil, that this country is a color-blind democracy helps to mask, normalize, e internalize everyday racism.

${ }^{64}$ frequently denigrated the achievements of native societies (Shepherd 2002: 196).
} 
(2005: 11). Também se enfatiza que qualquer projeto de Turismo deve propor o apoio e envolvimento da comunidade no que tange a gestão, planejamento e implantação da atividade turística, mas também na decisão de como o passado será mostrado, bem como na compreensão do enorme impacto econômico da indústria do Turismo. Shackel reforça que é fundamental que o planejamento turístico seja feito de forma a beneficiar a comunidade e, ao mesmo tempo, fortalecer a compreensão multicultural e a preservação (2005: 35). 


\title{
Arqueologia e Turismo:
}

\section{sustentabilidade e inclusão social}

\author{
Louise Prado Alfonso
}

Orientador:

Pedro Paulo Abreu Funari

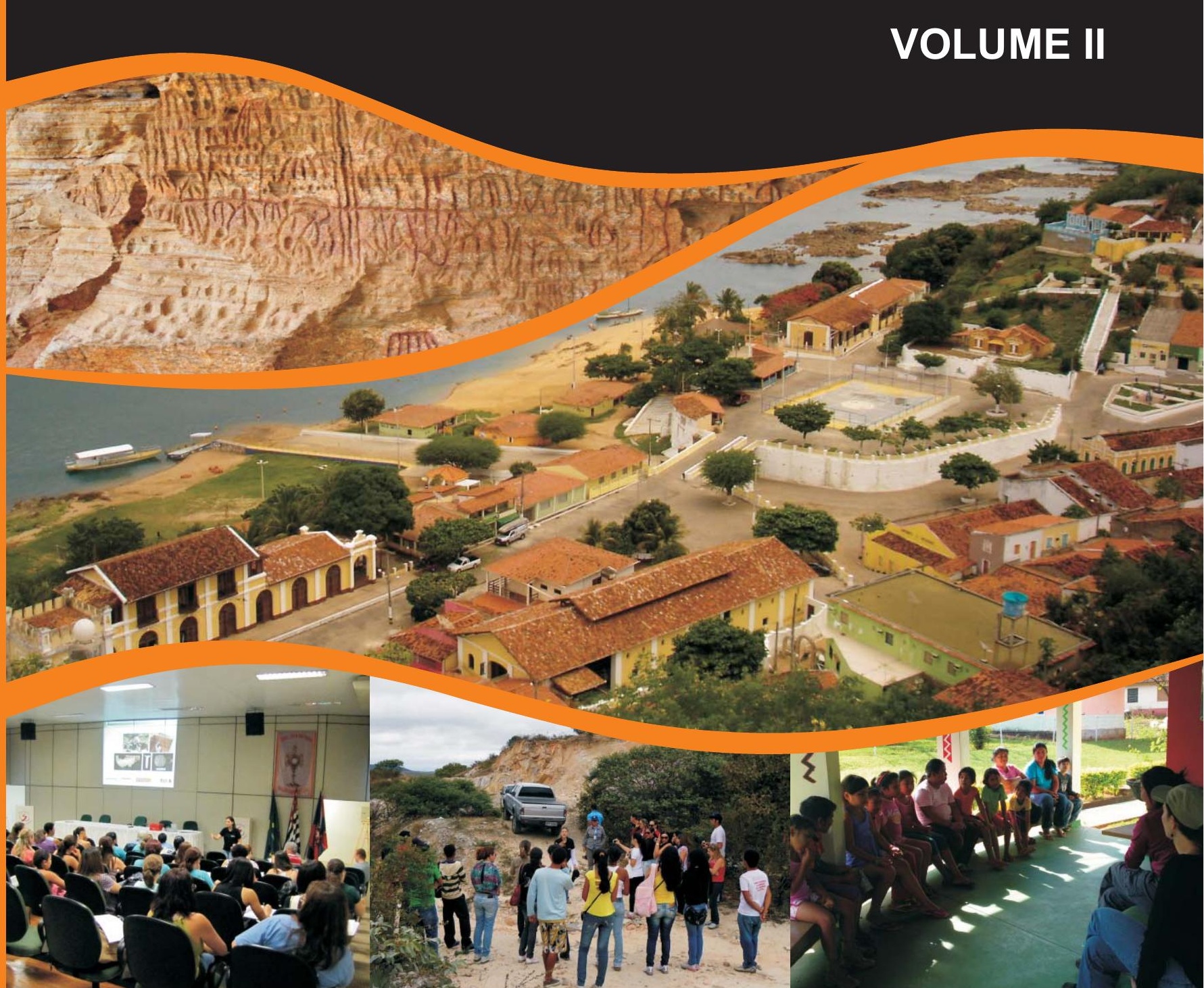




\author{
Universidade de São Paulo \\ Museu de Arqueologia e Etnologia \\ Programa de Pós-Graduação em Arqueologia
}

ARQUEOLOGIA E TURISMO: sustentabilidade e inclusão social.

Aluna: Louise Prado Alfonso

Tese de Doutorado, apresentada ao Programa de Pós-Graduação em Arqueologia, do Museu de Arqueologia e Etnologia da Universidade de São Paulo para obtenção do título de doutor em Arqueologia.

Orientador: Pedro Paulo Abreu Funari

Linha de Pesquisa: Gestão do Patrimônio Arqueológico

São Paulo

2012 


\section{SUMÁRIO}

\section{VOLUME I}

LISTA DE ABREVIATURAS E SIGLAS................................................................. 12

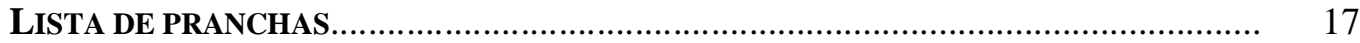

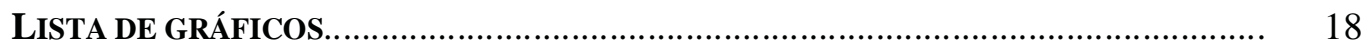

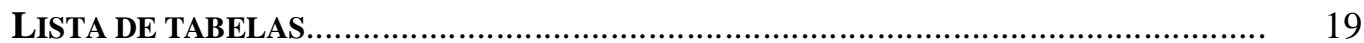

APRESENTAÇÃO DE UMA TRAJETÓRIA................................................................. 20

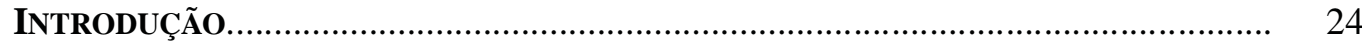

CONSIDERAÇÕES SOBRE SUSTENTABILIDADE QUE DIALOGAM COM ESTA TESE......... 26

INCLUSÃO SOCIAL E DIÁLOGOS COM A VALORIZAÇÃO DA DIVERSIDADE

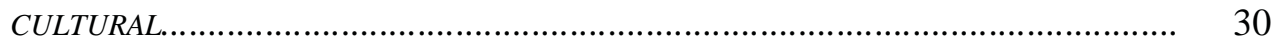

OBJETIVOS. TESTANDO UMA HIPÓTESE.......................................................... 32

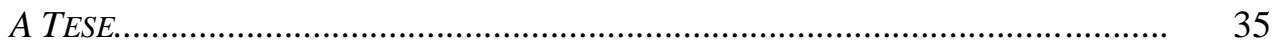

CAPÍTULO 1 - DIÁLOGOS INTERDISCIPLINARES...................................................... 38

1.2 TURISMO, PATRIMÔNIO E PLANE JAMENTO PARTICIPATIVO.................................. 52

1.3 O OLHAR ANTROPOLÓGICO DA ALTERIDADE SOBRE A DIVERSIDADE................. 62

1.4 A MUSEOLOGIA E OS BENS PATRIMONIAIS COMO HERANÇA................................ 75

1.5 BENS ARQUEOLÓGICOS E NOVAS PRÁtICAS SOCIAIS: APROXIMAÇõES INTERDISCIPLINARES

Capítulo 2 - O CONTEXTO InTERnacional: Turismo Arqueológico em DUAS REALIDADES DA AMÉRICA LATINA............................................................. 91

2.1 MÉXICO: NAÇÃO, NEOLIBERALISMO E MOBILIZAÇÕES SOCIAIS.......................... 92

POLÍTICAS PÚBLICAS E PROJETOS CULTURAIS NA HISTÓRIA DO PATRIMÔNIO ARQUEOLÓGICO MEXICANO.

MOVIMENTOS SOCIAIS E USOS CRÍTICOS DO PATRIMÔNIO ARQUEOLÓGICO NO ÂMBITO DO NEOLIBERALISMO. 
2.2 Peru: ATRATIVOS TURísticos, CONFLITOS E EXCLUSÃo.

TURISMO E APROPRIAÇÃO SIMBÓLICA DE REFERENCIAIS INDÍGENAS PARA A INDÚSTRIA CULTURAL

MOCHE, INCA E CHIMÚ: CONFLITOS SOCIAIS E DESIGUALDADE NAS POLÍTICAS DE USO DO PATRIMÔNIO ARQUEOLÓGICO PERUANO.

TURISMO CULTURAL E NOVOS DISCURSOS SOBRE A “CULTURA INDÍGENA” E O PASSADO PRÉ-HISPÂNICO.

Capítulo 3 - Arqueologia e Turismo Convencional no contexto BRASILEIRO.

POLÍTICAS PÚBLICAS NA HISTÓRIA DO TURISMO DO BRASIL

O TURISMO ARQUEOLÓGICO NA SERRA DA CAPIVARA.

SÃO MIGUEL DAS MISSÕES - ONDE ESTÃO OS INDÍGENAS?

\section{VOLUME I I}

Capítulo 4 - Estudo de Caso 1: O Turismo E A relação entre COMUNIDADE E PATRIMÔNIO NO SERTÃO ALAGOANO.

ALGUMAS REFLEXÕES SOBRE OS PROGRAMAS REALIZADOS NO SERTÃO ALAGOANO.

CAPítulo 5 - Estudo de CAso 2: o TURismo em Programas de EduCAÇão Patrimonial na Arqueologia Preventiva - um eXemplo no sudoeste BAIANO.

ETAPA 1 - DIAGNÓSTICO PRELIMINAR DO TERRITÓRIO PATRIMONIAL 205

ETAPA 2 - CONCEPÇÃO DO PROGRAMA DE EDUCAÇÃO PATRIMONIAL. 205

ETAPA 3 - PRIMEIRA ETAPA DE INTERVENÇÃO. 206

Etapas 4 e 5 - REtroalimentaÇÃo do Diagnóstico e do PROGRAMA E ESTRUTURAÇÃO DO MATERIAL DE APOIO.

ETAPA 6 - SEGUNDA ETAPA DE INTERVENÇÃO............................................... 212

AVALIAÇÃO DAS ATIVIDADES REALIZADAS. 
ETAPA 7 - ACOMPANHAMENTO DA MULTIPLICAÇÃO DO CONHECIMENTO E DO

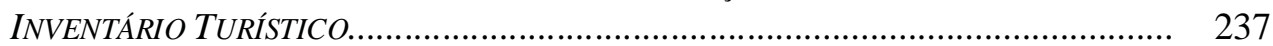

RESULTADOS DO PROCESSO DE INVENTARIADO................................................ 243

ETAPA 8 - FECHAMENTO DO PROGRAMA DE EDUCAÇÃO PATRIMONIAL................. 246

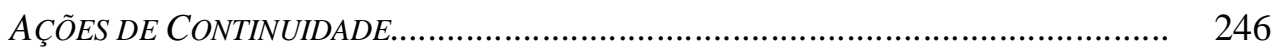

ALGUMAS REFLEXÕES SOBRE AS AÇÕES REALIZADAS NO SUDOESTE BAIANO........... 250

Capítulo 6 - Estudo de Caso 3: O Museu Histórico e Arqueológico de LINS.

AVALIAÇÃO DA EXPOSIÇÃO ARQUEOLÓGICA KIJU SAKAI..................................... 268

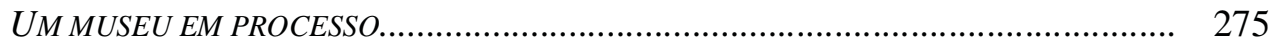

A CONCRETIZAÇÃO DOS SONHOS DE TANTOS GRUPOS......................................... 288

ALGUMAS REFLEXÕES SOBRE O PROCESSO DE FORMAÇÃO DO MHA DE LINS......... 297

AlguMAS CONTRIBUIÇõES Ao TURISMo ARQUEOLÓGICO..................................... 306

REFERÊNCIAS BIBLIOGRÁFICAS.................................................................... 312

ANEXo 1 - GLOSSÁRIO (MINISTÉRIO DO TURISMO 2007)....................................... 339

ANEXo 2 - MAPA DO CIRCUITO TURÍSTICO DO SERTÃo ALAGOANO....................... 342

ANEXo 3 - LiVRo Diálogos SOBRe o PATrimônio CUltural DE CAETITÉ, GUANAMBI E IGAPORÃ E FOLDER...................................................................... 343 


\section{LISTA DE ABREVIATURAS E SIGLAS}

ABCEL - Associação Beneficente Cultural e Esportiva de Lins

AECID - Agência Espanhola de Cooperação Internacional para o Desenvolvimento

APAE - Associação de Pais e Amigos dos Excepcionais

APRA - Aliança Popular Revolucionária Americana

Areté - Centro de Estudos Helênicos do estado de São Paulo

BNDES - Banco Nacional de Desenvolvimento Econômico e Social

CAPES - Coordenadoria de Aperfeiçoamento de Pessoal de Nível Superior

CDHU - Companhia de Desenvolvimento Habitacional e Urbano do Estado de São Paulo

CEIMAM - Centro de Estudos Indígenas Miguél Angel Menedez

CETEP - Centro Territorial de Educação Profissional do Sertão Produtivo

CHCM - Centro Histórico da Cidade do México

CICATUR - Centro Interamericano de Capacitação Turística

CICLA - Conselho de Integração Cultural Latinoamericana

CONACULTA - Conselho Nacional para a Cultura e as Artes

CONAMA - Conselho Nacional do Meio Ambiente

CONCYTEC - Conselho Nacional de Ciência e Tecnologia

CNTur - Conselho Nacional do Turismo

CTI - Centro de Trabalho Indigenista

ECA-USP - Escola de Comunicações e Artes da Universidade de São Paulo

EJA - Educação para Jovens e Adultos

EMBRATUR - Instituto Brasileiro de Turismo

ETEC - Escola Técnica Estadual

FAPESP - Fundação de Amparo à Pesquisa de São Paulo

FATEC - Faculdades de Tecnologia de São Paulo

FNA - Fondo Nacional Arqueológico

FUMDHAM - Fundação Museu do Homem Americano

FUNAI - Fundação Nacional do Índio

GESTA - Grupo de Estudos em Temáticas Ambientais

GLO - Resultados Genéricos de Aprendizado

GT - Grupo de Trabalho

IBAMA - Instituto Brasileiro do Meio Ambiente e dos Recursos Naturais Renováveis 
IBGE - Instituto Brasileiro de Geografia e Estatística

ICMBio - Instituto Chico Mendes de Conservação da Biodiversidade

ICOFOM - International Committe For Museology

ICOM - International Council of Museums

IDH - Índice de Desenvolvimento Humano

IHGB - Instituto Histórico e Geográfico Brasileiro

INAH - Instituto Nacional de Antropología e Historia

INC - Instituto Nacional de Cultura

INCRA - Instituto Nacional de Colonização e Reforma Agrária

IPHAN - Instituto do Patrimônio Histórico e Artístico Nacional

LEEH - Laboratório de Estudos Evolutivos Humanos

LFMZAAH - Lei Federal de Monumentos y Zonas Arqueológicos, Artísticos e Históricos

MAE-USP - Museu de Arqueologia e Etnologia da Universidade de São Paulo

MASB - Museu do Alto Sertão da Bahia

MAX - Museu de Arqueologia de Xingó

MHA - Museu Histórico e Arqueológico

MHOL - Movimento Homossexual de Lima

MINOM - Movimento Internacional da Nova Museologia

MITINCI - Ministério de Indústrias, Turismo, Integração e Negociações Comerciais

Internacionais

MST - Movimento Sem Terra

MTM - Museu do Templo Mayor

MTUR - Ministério do Turismo

OMT - Organização Mundial do Turismo

ONGs - Organizações não governamentais

ONU - Organização das Nações Unidas

PAC - Plano de Aceleração do Crescimento

PCNs - Parâmetros Curriculares Nacionais

PEA - Proyectos Especiales de Arqueología

PIB - Produto Interno Bruto

PIT - Posto de Atendimento ao Turista

PNE - Programa Nacional de Ecoturismo

PNMT - Programa Nacional de Municipalização do Turismo

PNSC - Parque Nacional Serra da Capivara 
PNT - Plano Nacional de Turismo

PRODETUR - Programa de Apoio ao Desenvolvimento Regional do Turismo

PROECOTUR - Programa de Desenvolvimento do Ecoturismo na AmazôniaLegal

PROMPERÚ - Comisión de Promoción del Perú para la Exportación y el Turismo

SAA - Society for American Archaeology

SAB - Sociedade de Arqueologia Brasileira

SEBRAE - Serviço Brasileiro de Apoio às Micro e Pequenas Empresas

SECTUR - Secretaria de Turismo

SEDESU - Secretaria de Desenvolvimento Sustentado

SENAI - Serviço Nacional de Aprendizagem Industrial

SEPLAN - Secretaria de Estado do Planejamento e do Orçamento

SISEM - Sistema Estadual de Museus

SPI - Sistema de Proteção ao Índio

T.I. - Terra Indígena

TRC - Turismo Rural Comunitário

UFBA - Universidade federal da Bahia

UNCED - Comissão Mundial sobre o Meio Ambiente e o Desenvolvimento

UNEB - Universidade do Estado da Bahia

UNESCO - Organização das Nações Unidas para a Educação, a Ciência e a Cultura.

UNESP - Universidade Estadual Paulista

UNICAMP - Universidade Estadual de Campinas

UNIMEP - Universidade Metodista de Piracicaba

UNISALESIANO - Centro Universitário Católico Salesiano Auxilium

UNSAAC - Universidade Nacional San Antonio Abaddel Cusco

USP - Universidade de São Paulo

WAC - World Archaeological Congress

WMF - Word Monument Fund

WTTC - Conselho Mundial de Viagens e Turismo 


\section{LISTA DE PRANCHAS}

Prancha 01. Imagem dos povos indígenas nos materiais de divulgação Elaborados pela EMBRATUR.

Prancha 02. Ações educativas realizadas em 2007, no Sertão Alagoano. 175

Prancha 03. Proposta de Roteiro Arqueológico 176

Prancha 04. Projeto Circuito Arqueológico do Sertão Alagoano. 178

Prancha 05. Oficinas realizadasno Sertão Alagoano. 181

Prancha 06. Oficina realizada na Comunidade da Cruz - Delmiro Gouveia......

Prancha 07. Oficinas do Programa de Educação Patrimonial desenvolvido no sudoeste baiano

Prancha 08. Visitas Técnicas aos Sítios Arqueológicos.

Prancha 09. Palestras do Programa de Educação Patrimonial desenvolvido no sudoeste baiano

Prancha 10. Trabalhos referentes às palestras, avaliados a partir da metodologia proposta pelo GLO.

Prancha 11. Trabalhos referentes às ações de multiplicação, avaliados a partir da metodologia proposta pelo GLO..

Prancha 12. Exposição Arqueológica Kiju Sakai. 266

Prancha 13. Trabalhos referentes à Exposição Kiju Sakai, avaliados a partir da metodologia proposta pelo GLO...

Prancha 14. Ações realizadas durante o processo de formação do Museu Histórico e Arqueológico de Lins.

Prancha 15. Alguns painéis da Exposição Externa do Museu Histórico e Arqueológico de Lins..

Prancha 16. Alguns Painéis da Exposição de Longa Duração do Museu Histórico e Arqueológico de Lins.

Prancha 17. Alguns painéis da Exposição de Curta Duração do Museu Histórico e Arqueológico de Lins. 


\section{LISTA DE GRÁFICOS}

Gráfico 01. Temáticas que aparecem nas composições das Palestras........................ 236

Gráfico 02. Formas das composições das Palestras............................................... 237

Gráfico 03. Temáticas que aparecem nas composições das ações de multiplicação..................................................................................................... 240

Gráfico 04. Formas das composições das ações de multiplicação............................ 241

Gráfico 05. Distribuição das fichas do Inventário da Oferta Turística de Caetité.... 243

Gráfico 06. Distribuição das fichas do Inventário da Oferta Turística de

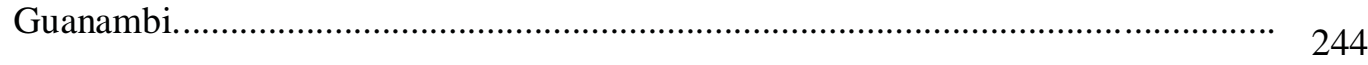

Gráfico 07. Distribuição das fichas do Inventário da Oferta Turística de Igaporã.... 245

Gráfico 08. Temáticas que aparecem nas composições sobre a exposição................ 272

Gráfico 09. Formas das composições sobre a exposição............................................ 272 


\section{LISTA DE TABELAS}

Tabela 01. Esquema das Ações Realizadas no Âmbito dos Projetos Desenvolvidos em Alagoas...................................................................................

Tabela 02. Esquema das Ações Realizadas no Âmbito do Programa de Educação Patrimonial.

Tabela 03. Esquema do Planejamento Estratégico do Turismo no Programa de Educação Patrimonial.

Tabela 04. Processo de Formação do Museu Histórico e Arqueológico de Lins. 


\section{CAPÍTUlo 4 - ESTUdo de CASO 1: O TURISMO E A RELAÇÃo ENTRE COMUNIDADE E PATRIMÔNIO NO SERTÃO ALAGOANO}

Este estudo de caso $^{1}$ visa discutir a relação entre Turismo, comunidade e patrimônio arqueológico no oeste do sertão alagoano. A área de estudo está localizada à margem esquerda do rio São Francisco, situada nos limites dos municípios de Delmiro Gouveia, Olho D’Água do Casado, Piranhas e Pão de Açúcar, onde há centenas de sítios de arte rupestre, muitos deles evidenciados durante as pesquisas relacionadas à construção e implantação da hidrelétrica de Xingó. Os sítios rupestres da região apresentam uma das maiores concentrações de grafismos (pintados e gravados) do Nordeste, com um "conjunto singular de manifestações pictóricas, com temáticas e técnicas variadas, aplicadas a diferentes tipos de abrigos e paredes rochosas”, segundo relatório da Zanettini Arqueologia (2007: 41), que desenvolveu trabalhos na área em 2007 e 2008.

A região é formada por vários cânions de pequenas a grandes dimensões; o Cânion do Talhado, também conhecido como Caniôn do Xingó, configura-se como importante atrativo turístico regional -- ali recentemente foi gravada a telenovela "Cordel Encantado” da Rede Globo. Na maioria de seus roteiros para Sergipe a CVC Turismo, maior operadora turística do país, inclui um passeio de catamarã pelo Cânion do Talhado; os mesmos roteiros incluem também o Museu de Arqueologia de Xingó - MAX localizado na região, porém já no estado de Sergipe. Vale ressaltar que Alagoas é um dos estados mais pobres do Brasil - em 2009, registrava o pior Índice de Desenvolvimento Humano (IDH) do país e um dado aterrador: aproximadamente $25 \%$ da população do estado era de analfabetos. Altos investimentos têm sido feitos pela iniciativa privada, governo estadual e alguns municípios na tentativa de formatar roteiros e melhorar a infraestrutura de forma a desenvolver o Turismo nos estados de Alagoas e Sergipe, visando gerar renda e melhorias para as comunidades. Nesse contexto, os sítios arqueológicos passam a ter importância como atrativos turísticos.

Na região do Talhado, bem como por todo o Brasil, os sítios arqueológicos vêm recebendo turistas espontâneos, sem planejamento e sem autorização do IPHAN. Segundo a Secretaria de Estado do Planejamento e do Orçamento (SEPLAN) do estado de Alagoas, qualquer visitante pode "ver ao vivo e em cores os sítios, com painéis de artes rupestres”, pois facilmente se encontra na região "um guia local, que leve os visitantes aos mais de 200 sítios

${ }^{1}$ Várias das reflexões deste capítulo foram apresentadas em eventos nacionais e internacionais, bem como publicadas no Brasil e no exterior (Alfonso 2009, 2010, 2010b, Funari, Manzato e Alfonso 2010 2010b). 
resgatados, trabalhados e conservados por arqueólogos” (SEPLAN, 2008). A preservação passa a ser uma grande preocupação dos pesquisadores da região e do IPHAN, pois o Turismo não-planejado é um item que se adiciona à lista dos possíveis geradores de impacto ao patrimônio. Desde "1950 os paredões graníticos são alvos da ação da população, que quebrava o granito para a produção e venda de paralelepípedo e brita” (SEPLAN, 2008), sendo que a extração do minério é muitas vezes a única forma de sustento da comunidade. Segundo Fischer, a instalação da Hidrelétrica de Xingó provocou o alto índice de desemprego nas áreas rurais da região, bem como a destruição dos recursos naturais, gerando aumento das migrações e desestruturação das famílias. Por outro lado, a implantação da hidrelétrica favoreceu a instalação de assentamentos de reforma agrária do Instituto Nacional de Colonização e Reforma Agrária (INCRA) nas proximidades de vários sítios arqueológicos localizados na lagoa formada no rio São Francisco.

Vale destacar que Movimento Sem-Terra (MST) é o mais importante movimento voltado à reforma agrária no Brasil. Com quase 30 anos de existência, é responsável pela implantação de mais de 900 acampamentos e 2.500 mil ocupações de latifúndios, envolvendo aproximadamente 350 mil famílias assentadas (MST, 2009). Sua atuação no estado de Alagoas teve início na década de 1980. Segundo dados do MST, em 2004 o estado possuía aproximadamente 40 assentamentos com mais de três mil famílias, além de mais de 50 acampamentos, onde viviam mais de cinco mil famílias. Vale ressaltar que uma série de conflitos pauta as relações entre assentados e acampados, comunidades dos municípios, proprietários rurais e poder público. Embora o movimento seja amplamente conhecido por sua militância acerca da posse da terra, os objetivos do MST também incluem a busca por outras garantias para as comunidades rurais, tais como o crédito para a produção rural e o acesso à saúde e à educação. Os acampamentos e assentamentos localizados na região do sertão alagoano apresentam dificuldades de inclusão e de sustentabilidade econômica, social e ambiental.

A instalação dos assentamentos na região do Talhado resultou em melhorias de infraestrutura básica para algumas comunidades rurais - por exemplo, a construção de estradas - , porém essas obras causaram também o desmatamento da vegetação - tanto para as vias de acesso como para abertura de roças —, além de queimadas, que aumentaram as possibilidades de incêndio e levaram comunidades a viver nas proximidades dos sítios arqueológicos, convivendo de maneira mais próxima com os bens patrimoniais. Com vistas à preservação do patrimônio arqueológico local, várias instâncias do poder público e pesquisadores passaram a elaborar propostas para lidar com o fluxo espontâneo de visitantes 
que alguns sítios vinham recebendo, levando em consideração a necessidade de ações de sensibilização da comunidade local. Vale destacar que em 2007 foi publicada em uma revista regional uma reportagem destacando a beleza dos sítios localizados em Olho D’Água do Casado e convidando os leitores a conhecê-los.

Nesse contexto, em 2007 a 17 ${ }^{\text {a }}$ Superintendência Regional do Estado de Alagoas do Instituto do Patrimônio Histórico e Artístico Nacional (IPHAN) contratou os serviços da Zanettini Arqueologia para realizar na região um projeto que resultasse em um estudo voltado à analise da degradação dos sítios arqueológicos. O "Programa de Diagnóstico e Ações Emergenciais em Sítios Rupestres, municípios de Olho D’Água do Casado e Delmiro Gouveia, Alagoas” teve como propósito o levantamento dos sítios arqueológicos rupestres na região do Talhado e envolveu os seguintes aspectos: a elaboração de metodologia de diagnóstico para o monitoramento contínuo do patrimônio; a identificação de fatores de degradação dos sítios e registros rupestres; a intervenção necessária para redução e/ou eliminação de elementos de degradação biológicos e físico-químicos; a criação de um prognóstico para a conservação dos sítios rupestres em curto, médio e longo prazo; a realização de ações-piloto de Educação Patrimonial e proposições para o uso público dos sítios identificados (Zanettini Arqueologia 2007).

O programa de ações emergenciais evidenciou que, naquele momento, a ação antrópica não constituía risco preponderante para o patrimônio em apreço (2007: 32), pois eram praticamente inexistentes as intervenções diretas sobre os grafismos e as pinturas. Ainda segundo o relatório, a ausência de intervenções antrópicas estava ligada a uma "percepção ou pré-noção de valor a respeito do patrimônio em tela", o que favorecia um "programa de educação continuada a respeito” (2007: 32).

No âmbito do programa, a Zanettini Arqueologia optou por desenvolver ações de Educação Patrimonial, mesmo que isso não estivesse originalmente previsto no termo de licitação proposto pelo contratante. A realização de uma ação mais efetiva de Educação Patrimonial buscou criar junto às comunidades dos mencionados municípios reflexões sobre o patrimônio arqueológico, já que os relatórios técnicos da $17^{\circ}$ SR do IPHAN indicavam que a instalação e a expansão de assentamentos rurais na região poderiam constituir "risco potencial para o patrimônio arqueológico” no futuro (2007: 32).

As ações educativas possibilitaram um sem-número de resultados positivos: a realização de reuniões com diversos segmentos da comunidade, a elaboração de material de apoio com a apresentação do programa e conceitos básicos relacionados à Arqueologia e ao patrimônio arqueológico, a criação de um encarte formado por imagens da paisagem e cultura 
do Nordeste; a confecção e instalação de Placas de Sinalização de Sítio Arqueológico e Placas de Acolhimento destinadas à sensibilização da comunidade e dos visitantes; e a produção de camisetas (2007: 33) (Prancha 2).

Os encontros tiveram como público-alvo membros do Poder Executivo dos municípios envolvidos, professores e alunos da rede de ensino público e comunidades das agrovilas do assentamento Nova Esperança II, localizadas próximas aos sítios arqueológicos em Olho D’Água do Casado. Nas agrovilas foram realizadas reuniões conjuntas com a Associação dos Produtores Rurais do Assentamento Nova Esperança II e com o grupo de jovens “Juventude e Atitude”, bem como uma visita técnica aos sítios arqueológicos.

A partir das atividades realizadas com o assentamento Nova Esperança II, ficou evidente que o fluxo de visitantes aos sítios arqueológicos criava a oportunidade para que os moradores do assentamento se interessassem pelo patrimônio arqueológico e buscassem sua preservação, apontando para possibilidades de cogestão dos sítios por parte da comunidade (2007: 32). Essas atividades deram ensejo à elaboração da proposta de Projeto "De Bem com o Passado", que objetivou a formação de um roteiro arqueológico envolvendo os sítios localizados junto às Agrovilas I, II e III do Assentamento Sem-Terra, para fins educativos e turísticos. Tal proposta foi pensada a partir da compreensão de que os recursos arqueológicos podem “constituir um fator de estímulo ao Turismo e à ampliação de renda” (2007: 112), e de que o "uso correto constitui um dos principais fatores de preservação de um bem cultural, conforme apontam os documentos internacionais dedicados à preservação” (2007: 112). O projeto previa a capacitação da mão de obra local e o apoio e fiscalização dos órgãos responsáveis pelos patrimônios culturais e naturais; o relatório ressaltou ainda a importância de ações continuadas de Educação Patrimonial (Prancha 3).

Os resultados e a proposta turística apontados pelo relatório da Zanettini Arqueologia incentivaram o IPHAN Alagoas a propor em 2008 o Projeto “Circuito Arqueológico do Sertão Alagoano: Municípios de Piranhas, Olho D’Água do Casado e Delmiro Gouveia”. O objetivo do projeto era planejar e refletir sobre a atividade turística que já vinha sendo realizada de maneira espontânea e desordenada nos sítios arqueológicos da região do Talhado. O escopo do projeto foi a elaboração de uma proposta de Circuito Arqueológico como forma de socializar os recursos arqueológicos e de possibilitar seu uso em conformidade com os preceitos da sustentabilidade. Outro objetivo foi buscar uma aproximação entre tais bens patrimoniais e os bens históricos e culturais da região, por meio de estudos sobre a Paisagem Cultural, o patrimônio arqueológico e a atividade turística nos três municípios mencionados (Zanettini Arqueologia 2008). 


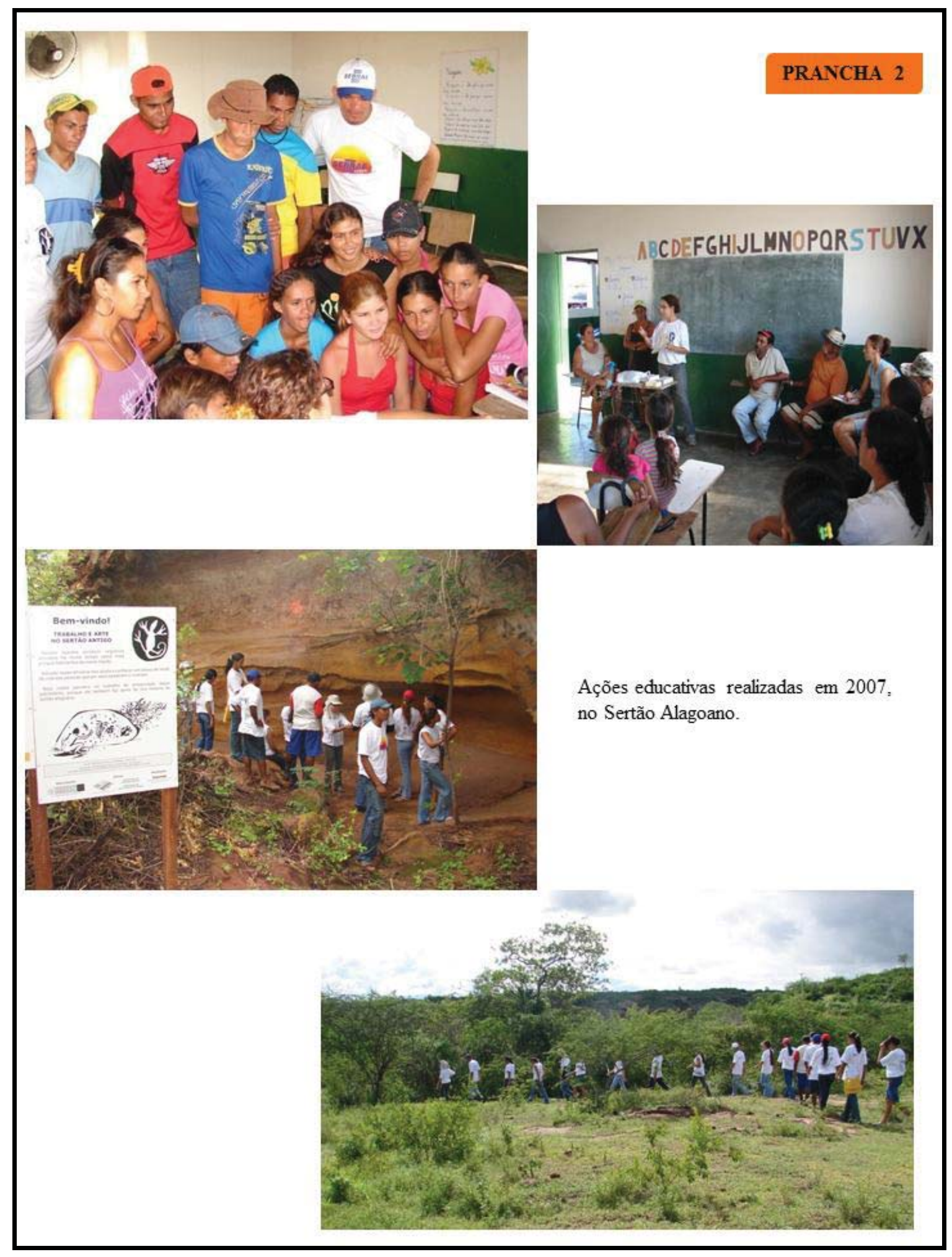




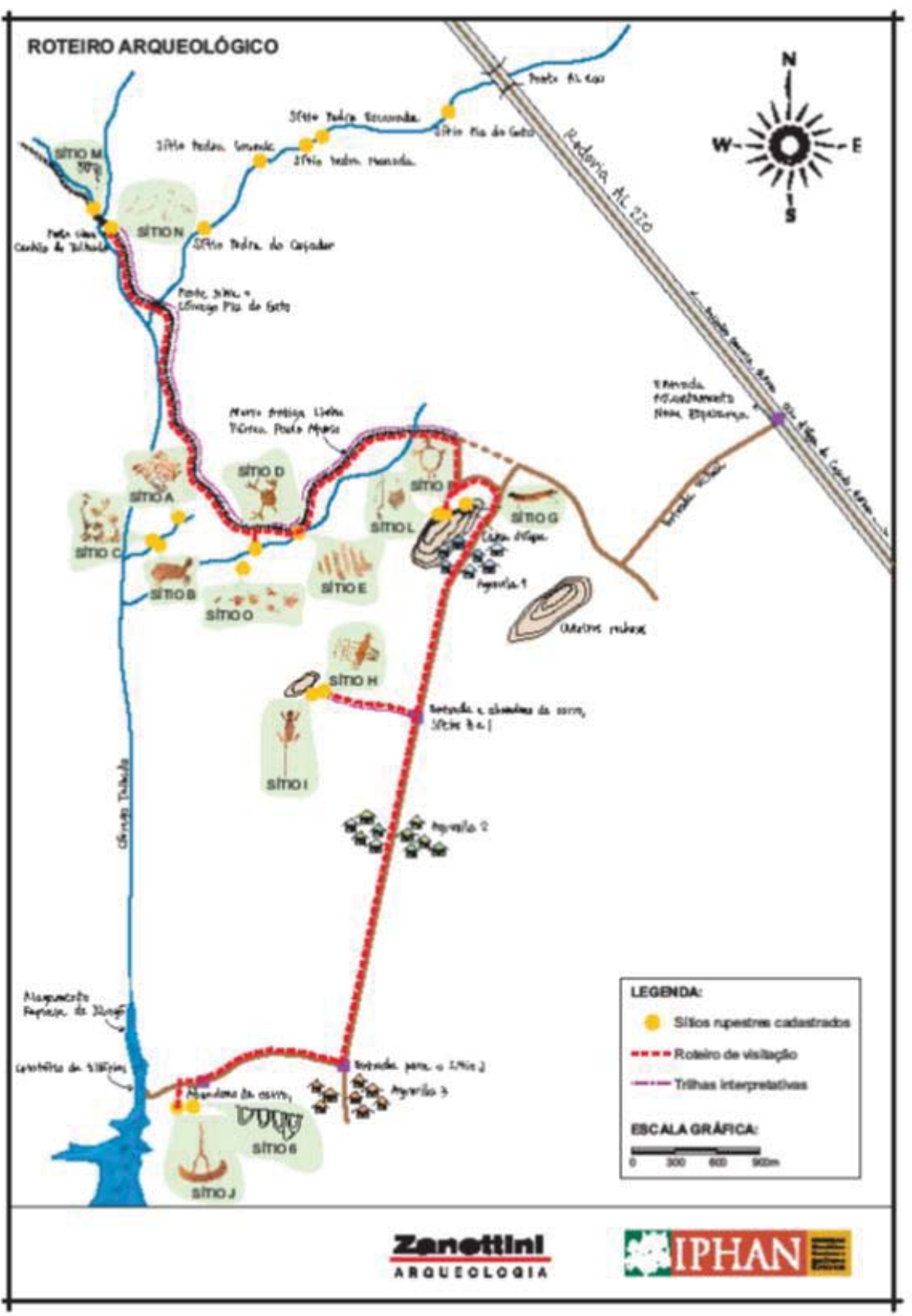


Vale ressaltar que para esse projeto o Turismo não foi compreendido como uma atividade ampla, de massa, que movimenta grandes públicos, mas que incentiva a própria comunidade regional a visitar e conhecer seus bens patrimoniais.

Dentre os pressupostos do projeto, vale destacar para esta tese o conceito de Paisagem Cultural. Segundo a UNESCO, trata-se do reconhecimento de porções singulares dos territórios, em que a relação entre a cultura e o ambiente natural confere à paisagem uma identidade única. Tal conceito abrange os sítios arqueológicos como parte dos componentes materiais e imateriais que caracterizam o patrimônio cultural brasileiro, segundo a Política Nacional de Paisagem Cultural do Brasil. Os bens arqueológicos devem ser tomados em conjunto com os sítios de valor histórico, paisagístico, artístico, paleontológico, ecológico e científico (Alfonso 2009). O conceito de Paisagem Cultural evidencia a importância do patrimônio arqueológico ao considerar elementos das paisagens anteriormente e/ou atualmente habitadas: "O enfoque do patrimônio habitado é interativo e prevê o envolvimento e participação da comunidade na gestão do patrimônio em que vive” (Zanettini Arqueologia 2008: 14).

As ações do Projeto Circuito Arqueológico do Sertão Alagoano resultaram em três documentos, a saber: Inventário da Oferta Turística, Diagnóstico da Oferta Turística dos Municípios e Programa de Uso Turístico do Patrimônio Arqueológico da Região (Prancha 4).

Segundo dados do Ministério do Turismo do Brasil (2006: 10), o Inventário da Oferta Turística, conforme descrito anteriormente, consiste de um processo de "levantamento, identificação e registro dos Atrativos Turísticos culturais e naturais, dos Serviços e Equipamentos Turísticos e da Infraestrutura de Apoio ao Turismo” de determinado município ou região. É realizado com o objetivo de formatar um instrumento que contenha informações básicas para fins de planejamento e gestão da atividade turística. Para a realização do Inventário da Oferta Turística da região de abrangência do projeto optou-se pela utilização das fichas oficiais elaboradas pelo Ministério do Turismo, seguindo a metodologia e as diretrizes propostas pelo órgão máximo do Turismo Nacional. O Instrumento de Pesquisa-Inventário Turístico divide a Oferta Turística em três componentes: A) Infraestrutura de Apoio ao Turismo, B) Serviços e Equipamentos Turísticos, e C) Atrativos Turísticos. As diretrizes nacionais evidenciam o Turismo como uma ferramenta para propostas de redução das desigualdades sociais, de geração e distribuição de renda e de geração de empregos, e apontam para a necessidade de um processo de planejamento e gestão da atividade turística de forma a favorecer o desenvolvimento municipal e regional, além da preservação dos bens patrimoniais culturais e naturais. 


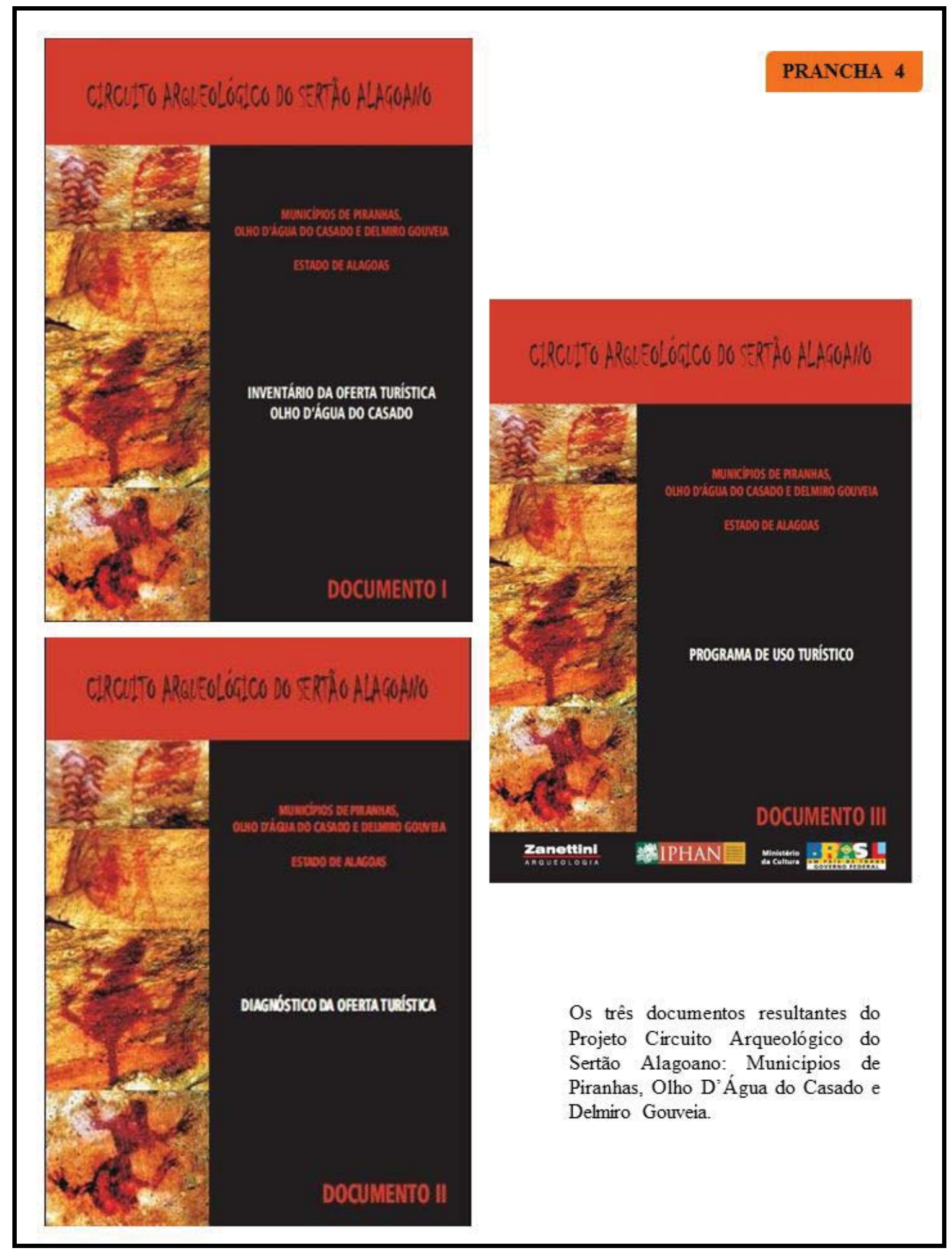


A orientação metodológica do governo federal para a realização do Inventário da Oferta Turística está embasada no conceito de território, que permite posteriores intervenções na localidade, capazes de reativar as bases econômicas e reintegrar o meio humano. Assim, a formação de parcerias e a requalificação e humanização do território para seus habitantes são os princípios objetivados pelo Ministério do Turismo (Zanettini Arqueologia 2008). Os Inventários foram realizados pelas diretorias de Turismo dos municípios, em parceria com a equipe da Zanettini Arqueologia.

O programa privilegiou a realização de um Inventário participativo. Assim, como parte do processo de Inventariado foram realizadas oficinas com a população local dos municípios de Delmiro Gouveia e Olho D’Água do Casado. Vale ressaltar que não foi possível empreender ações mais profundas no município de Piranhas devido à falta de abertura do poder público ao projeto, por questões políticas. As oficinas foram realizadas de acordo com o método $\mathrm{ZOPP}^{2}$ que propõe a reunião de grupos representativos das comunidades receptoras tendo em vista reflexões sobre o planejamento participativo e sobre os contextos locais (Prancha 4). As oficinas foram norteadas pelas seguintes temáticas:

- Oficinas sobre Construção da Imagem Turística: buscaram realizar uma reflexão sobre a imagem que se quer dos municípios e como planejá-la a curto, médio e longo prazo. Nessas oficinas foram discutidas formas de alteração e manutenção da imagem já existente não apenas dos municípios, mas também de localidades e comunidades. Também houve debates sobre a inserção de novos recursos e atrativos a essa imagem, de forma responsável e diante da percepção de que as imagens são construções. As discussões se deram principalmente a partir do material turístico - em especial folders - que os municípios já haviam elaborado e distribuído. As oficinas tiveram como público-alvo as comunidades de Delmiro Gouveia e Olho D’Água do Casado.

- oficinas sobre Identidade e Patrimônio: visaram propor a diferentes comunidades uma reflexão sobre a relação das comunidades e seus bens patrimoniais. A partir de histórias pessoais buscou-se o levantamento de bens patrimoniais naturais, culturais e arqueológicos, criando um debate sobre o patrimônio regional, sua importância e ações necessárias para sua preservação. As oficinas abrangeram os moradores das Agrovilas I, II e III, a comunidade

\footnotetext{
${ }^{2}$ No início da década de 1980 a Sociedade Alemã de Cooperação Técnica (GTZ) desenvolveu o Método ZOPP (ZielorientierteProjektplanung - Planejamento de Projeto Orientado por Objetivos). Essa iniciativa procurou minimizar problemas de centralização de decisões, a pouca objetividade e clareza dos objetivos e a fraca sustentabilidade dos projetos elaborados. Com esse novo conceito de planejamento buscou-se uma maior integração, participação e comprometimento dos diferentes atores envolvidos no processo (comunidade, gestores e técnicos), objetivos exequíveis e focados, estratégias claras e desenhadas de comum acordo entre os envolvidos (Zanettini Arqueologia 2008).
} 
quilombola Povoado Cruz, a comunidade rural do Povoado Olho D’águinha, docentes, a comunidade em geral e membros da Fundação Delmiro Gouveia, importante instituição cultural local.

- oficinas de Sensibilização quanto ao Turismo: buscaram mostrar a importância do envolvimento da comunidade em todo o processo de planejamento, implantação, gestão e avaliação da atividade turística. Dessa maneira as oficinas iniciaram um trabalho de sensibilização quanto ao Turismo, discutindo temáticas como a legislação sobre crimes ambientais, a preservação do patrimônio e dos sítios arqueológicos e buscaram desmistificar a ideia de prosperidade súbita que o Turismo passa. Foram incentivadas propostas de estruturação econômica diversificada dos municípios, ações para capacitação de mão de obra, distribuição democrática dos benefícios gerados pela atividade turística, entre outras. Essas oficinas contaram com o envolvimento de diferentes públicos: associações de taxistas, a comunidade das Agrovilas I, II e III, comerciantes, docentes, alunos e poder público.

Foram realizados, ainda, dois Cursos de Capacitação Docente com a temática “Identidade e Turismo", cujo propósito foi levar aos professores multiplicadores reflexões sobre o patrimônio regional e sobre o papel educativo do Turismo Sustentável. No decorrer dos cursos foram propostos debates sobre ações preservacionistas, o papel da atividade turística junto às escolas, a inserção de discussões sobre os bens patrimoniais nos Projetos Políticos Pedagógicos das escolas, entre outros. Os cursos foram possíveis somente graças ao apoio das secretarias municipais de Educação. Vale destacar a importância do trabalho com os docentes, pois são multiplicadores da proposta das ações educativas.

A escolha dos temas das oficinas foi feita de acordo com as diretrizes do Ministério do Turismo, que apontam para a necessidade do engajamento da comunidade em educação, hospitalidade e na compreensão da atividade turística, a necessidade de promover a integração e participação social das comunidades locais no planejamento turístico regional, de induzir a sensibilização quanto à importância da preservação dos patrimônios históricos, culturais e ambientais e de iniciar um trabalho de capacitação e utilização da mão de obra local (Zanettini Arqueologia 2008) (Prancha5). 


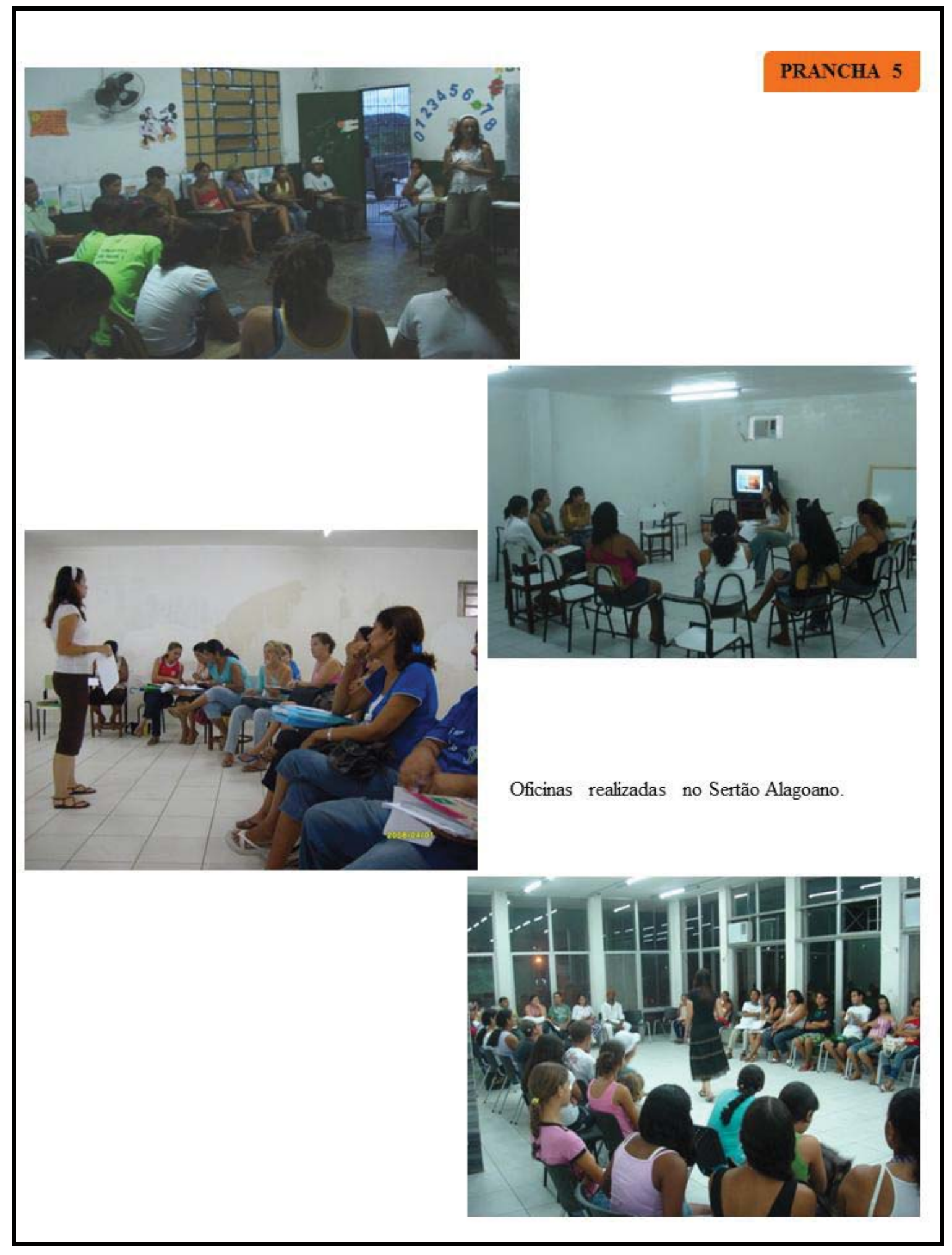


Assim, também fizeram parte do Inventário da Oferta Turística a elaboração e a realização de entrevistas com proprietários e funcionários de estabelecimentos de alimentação, de meios de hospedagem, de empresas de transporte, de associações de artesãos e de taxistas, organizações não-governamentais, entre outras, com o fim de levantar novas informações para complementar as fichas de Inventário preenchidas pelas secretarias de Turismo dos municípios envolvidos (Alfonso, 2009).

Ainda durante o procedimento de Inventário foram realizadas ações de avaliação da degradação dos sítios arqueológicos. Vários sítios que haviam sido avaliados durante o programa de ações emergenciais de 2007 foram reavaliados a partir da mesma metodologia utilizada no ano anterior. A continuidade das ações em 2008 favoreceu a avaliação da conservação dos sítios e sua sinalização um ano após o trabalho inicial. Segundo o relatório final do programa (Zanettini Arqueologia 2008), as pinturas e gravuras não sofreram intervenções de natureza antrópica, observando-se apenas intervenções decorrentes de fatores naturais (bióticos e físico-químicos), mesmo com a visitação informal aos sítios. Nesse mesmo período a equipe identificou 16 novos sítios arqueológicos, dois deles históricos.

O Inventário da Oferta Turística resultou em mais de $\mathbf{3 0 0}$ fichas preenchidas, envolveu aproximadamente 350 pessoas em sua elaboração e apresentou o levantamento de mais de uma centena de recursos turísticos, muitos deles pouco ou nada estruturados para o recebimento de visitantes, portanto ainda não reconhecidos como atrativos ${ }^{3}$. Dentre os recursos identificados pela comunidade estão rios, fontes, frutas, comidas, músicas, danças, esportes, festas populares e diferentes eventos, igrejas e santos, artesanato, casas coloniais, edificações relacionadas à antiga estrada de ferro, heróis regionais e locais, museus, sítios arqueológicos, a caatinga, entre outros (Alfonso 2009).

Após as ações do Inventário da Oferta Turística foram realizados Diagnósticos da Atividade Turística dos municípios, com o objetivo de propiciar uma análise das informações levantadas pelo Inventário. As avaliações foram pensadas a partir da proposta Oficial do Ministério do Turismo, que incentiva a elaboração de diagnósticos que levam em consideração o conceito de redes humanas e institucionais participativas e compartilhadas. A inter-relação dos participantes deve conduzir ao desenvolvimento local, dentro dos preceitos da sustentabilidade. A proposta também privilegiou o elemento local, em contraponto ao

\footnotetext{
${ }^{3}$ Entende-se por recursos turísticos o conjunto de elementos de uma localidade com potencialidade para tornarse atrativo turístico, ou seja, constituir-se na matéria-prima do Turismo. (BRAGA, 2007) Por atrativo turístico entende-se o elemento que efetivamente recebe visitantes de forma planejada e que tem estrutura para propiciar uma experiência turística (BRAGA, 2007). Dentro dessa perspectiva, alguns locais que já apresentam fluxo turístico não podem ser considerados propriamente atrativos, por não possuírem infraestrutura adequada nem planejamento da atividade.
} 
global massificado, objetivando a proposição de produtos e serviços diferenciados, de acordo com o contexto local. Foram elaborados quatro diagnósticos distintos, sob as seguintes temáticas:

- Diagnóstico da Oferta de Meios de Hospedagem: teve por objetivo identificar e analisar os meios de hospedagem de cada município. Foram identificados problemas de acesso e sinalização e a necessidade de capacitação de mão de obra. Foi possível verificar ainda que as ofertas de hospedagem dos municípios são complementares.

- Diagnóstico da Oferta de Alimentação: evidenciou, de forma quantitativa e qualitativa, as deficiências e as potencialidades dos estabelecimentos de alimentação dos municípios. O principal critério de seleção dos estabelecimentos foi a indicação dos diretores de turismo e da população local, durante as oficinas e entrevistas - bem como as sugestões citadas no material turístico das secretarias de Turismo municipais.

- Diagnóstico da Oferta de Atrativos / Recursos Naturais: objetivou identificar e avaliar os recursos e atrativos naturais dos municípios. A seleção dos atrativos e recursos naturais foi feita através da consulta a guias turísticos, trabalhos realizados por outras instituições sobre a região, material de divulgação dos municípios e informações obtidas junto à comunidade local.

- Diagnóstico da Oferta de Atrativos / Recursos Culturais e Arqueológicos: teve como finalidade identificar e avaliar os recursos e atrativos culturais e arqueológicos dos municípios. A seleção dos atrativos e recursos foi feita através da consulta ao material de divulgação dos municípios e informações obtidas junto à própria comunidade local e ao poder público.

Diante do reconhecimento da importância do envolvimento da comunidade em todo o processo de planejamento sustentável do Turismo, o programa buscou envolver a comunidade também na elaboração dos Diagnósticos. Além dos dados e informações levantados durante a pesquisa e oficinas do Inventário Turístico, foram realizadas também reuniões voltadas para formação de parcerias com lideranças dos municípios envolvidos.

Os Diagnósticos tornaram claros e manifestos alguns problemas, relacionados especialmente a: falta de mão de obra local capacitada, ausência de sinalização básica e turística, dificuldade de acesso aos recursos e atrativos e a alguns meios de hospedagem e alimentação, ausência de políticas públicas e diretrizes que regulamentassem a atividade turística, pouca comunicação entre o poder público e a iniciativa privada, e ausência de 
planejamento estratégico. Porém, as avaliações diagnósticas demonstraram também o potencial turístico da região, a partir do alto número de recursos naturais e culturais descritos, muitos inclusive já recebendo fluxos de visitantes.

A partir dos resultados do Inventário da Oferta Turística e dos Diagnósticos foi elaborado o Programa de Uso Turístico do Patrimônio Arqueológico da região, plano de ação que teve por finalidade apresentar propostas para o uso turístico sustentável dos recursos arqueológicos evidenciados na região, levando em conta o contexto local. O programa em questão propôs a formação de um Circuito Turístico do Sertão Alagoano e não um Circuito Arqueológico como havia proposto o IPHAN, pois levou em conta a importância de se pensar o patrimônio arqueológico em conjunto com os outros bens culturais. O Circuito seria formado por quatro diferentes roteiros: "Roteiro Arqueológico", "Roteiro Histórico”, "Roteiro Religioso" e "Roteiro Rural”.

O Circuito Turístico do Sertão Alagoano foi idealizado a partir das diretrizes do Ministério do Turismo (2006). Circuitos Turísticos são entendidos como municípios de uma mesma região, com afinidades que podem ser culturais, sociais e econômicas, que atuam em conjunto, unindo-se para organizar e desenvolver a atividade turística regional dentro dos preceitos da sustentabilidade e tendo em mente a consolidação de uma atividade regional. As diretrizes sugerem que o planejamento de Circuitos leve em conta a oferta diversificada de infraestrutura, serviços e preços, demanda diversificada, atrativos multitemáticos e aspectos geográficos.

O Programa de Uso Turístico propôs como elementos necessários para a formação do Circuito Turístico (Zanettini Arqueologia 2008):

- a formação de uma comissão gestora, que garantisse que a gestão ficasse a cargo de uma equipe interdisciplinar, com representantes do poder público, iniciativa privada e lideranças locais, responsáveis por propor, aprovar e administrar projetos e orçamentos. A participação da comunidade é crucial tanto para garantir que as ações sejam feitas de modo a incluir os diversos segmentos da sociedade como para garantir a sustentabilidade do processo diante as descontinuidades políticas dos municípios. Tal definição se deu após a discussão acerca dos problemas de continuidade que caracterizam diferentes projetos e planos quando o poder público é o responsável. Vale ressaltar que ao longo de 2007 um dos municípios avaliados pelo projeto trocou quatro vezes de administração municipal (Alfonso, 2009).

- a elaboração de um Plano de Desenvolvimento Estratégico, segundo as orientações do Ministério do Turismo, voltado para estruturar a atividade do Circuito dentro dos preceitos do desenvolvimento sustentável participativo. 
O Plano de Desenvolvimento Estratégico propôs as seguintes ações:

- criar estratégias voltadas para garantir o envolvimento da comunidade - tanto no processo de tomada de decisões como no desenvolvimento e gestão da atividade. A continuidade dos trabalhos deveria envolver reflexões sobre o Turismo, capacitação de mão de obra e programas de Educação Patrimonial contínuos.

- buscar a regulamentação do Turismo de forma a possibilitar políticas públicas por meio de discussões entre a comissão gestora, os órgãos municipais, estaduais e federais, a comunidade e demais interessados.

- incentivar e promover parcerias - intensificar a aproximação e interação entre diferentes setores e grupos como o poder público, as universidades, comunidades rurais, iniciativa privada, órgãos e instituições de financiamento, entre outros.

- elaborar um Plano de Marketing - ressaltou-se que o marketing não se limita à elaboração de material publicitário, mas é um plano que envolve produto, preço, distribuição e promoção, bem como mecanismos de controle, avaliação e fiscalização das atividades turísticas na região.

- formatar diferentes Roteiros - como forma de levantar e disponibilizar dados e informações sobre a região (Inventário / diagnóstico), favorecer melhorias na infraestrutura turística local e regional, potencializar o receptivo local e apresentar e propor oportunidades de negócios para investidores (Zanettini Arqueologia 2008).

Já o Roteiro Arqueológico do Sertão Alagoano seria formado tendo por base o roteiro proposto pela Zanettini Arqueologia em 2007, após avaliação e acréscimo de outros sítios arqueológicos. Para o roteiro foi proposto um Plano de Estratégico de Gestão dos Recursos Arqueológicos que envolvia as seguintes temáticas: limpeza e conservação dos sítios; sinalização e facilitadores turísticos; melhorias de acesso aos sítios; envolvimento da comunidade; formação de parcerias; sinalização turística e de equipamentos de apoio do roteiro, plano de marketing; agregadores de valor ao produto e estudos ambientais, bem como a Gestão dos Recursos Arqueológicos, por meio da musealização dos sítios arqueológicos a serem visitados e a formação de um sistema de sítios incorporados a uma instituição (museológica ou universitária) e a uma Comissão Gestora multidisciplinar e participativa. Ademais, projetos educativos contínuos, que incentivassem a pesquisa, processos de avaliação, sensibilização e capacitação dos envolvidos e preservação do patrimônio. As várias atividades realizadas pelo Projeto "Circuito Arqueológico do Sertão Alagoano. Municípios de 
Piranhas, Olho D’Água do Casado e Delmiro Gouveia” iniciaram muitas das ações propostas pelo Programa de Uso Turístico do Patrimônio Arqueológico da região, porém foi ressaltada a necessidade de continuidade do programa.

O programa apresentou propostas de operacionalização, aplicação e gestão da atividade turística e indicou a possibilidade de inserção de outros municípios no Circuito, visando ao fortalecimento regional (Zanettini Arqueologia 2008). O programa indicou a inclusão do município de Pão de Açúcar, localizado nas proximidades da região de abrangência do Circuito, inclusão justificada uma vez que o município apresenta vários recursos com potencial atrativo diferenciados dos municípios de Piranhas, Delmiro Gouveia e Olho D’Água do Casado, além de alguns complementares, como pinturas e gravuras rupestres, a presença do rio São Francisco, semelhanças históricas, entre outros.

Pensando nessa possibilidade foi realizado no município de Pão de Açúcar um Inventário prévio com o objetivo de identificação de atrativos e recursos turísticos municipais e verificação da viabilidade de parcerias locais para o Turismo. As ações foram empreendidas no âmbito do Programa de Mapeamento, Cadastro e Conservação dos Sítios de Arte Rupestre do Baixo São Francisco, Etapa 1 - Município de Pão de Açúcar, também desenvolvido pela Zanettini Arqueologia em 2008, conforme edital proposto pela Superintendência Regional do IPHAN em Alagoas.

O poder público local demonstrou interesse na inserção do município no Circuito proposto pelo programa, o que evidenciou a possibilidade de parceria visando ao desenvolvimento da atividade, fator de extrema importância quando se pensa em implantação de projetos de Turismo Sustentável. Outro facilitador foi a abertura da comunidade para a formação de parcerias - apesar de sua pouca identificação com o patrimônio local principalmente com relação aos prédios históricos, que não se apresentam em bom estado de conservação, e ao patrimônio arqueológico, praticamente desconhecido pela população.

Outros grupos que se mostraram interessados pelo programa foram as populações indígenas e quilombolas da região. O programa apontou para a necessidade da realização de atividades que possibilitassem a discussão sobre patrimônio e histórias locais com as diferentes comunidades do município, com a intenção de que a atividade turística fosse pensada de forma a representar não apenas as elites locais, por meio de seu patrimônio edificado, mas sim os diversos grupos que compõem o município. Sugeriu-se um projeto de continuidade do planejamento turístico de Pão de Açúcar, que envolvesse a elaboração de diagnósticos turísticos, a sensibilização da comunidade local, a realização de um plano gestor da atividade turística e o acompanhamento da continuidade do Inventário da Oferta Turística. 
Ressalta-se que o Inventário iniciado pelas ações da equipe da Zanettini Arqueologia passou a ser realizado espontaneamente pela Prefeitura Municipal (Zanettini Arqueologia 2008b).

Como resultado do processo desenvolvido na região foi elaborado um Mapa Circuito Turístico do Sertão Alagoano, apresentando os municípios de Delmiro Gouveia, Olho D’Água do Casado, Piranhas e Pão de Açúcar. O mapa aponta os bens patrimoniais culturais e naturais elencados pelas próprias comunidades dos municípios no Inventário da Oferta Turística e durante as oficinas, e apresenta também os calendários oficiais de eventos das quatro localidades de abrangência dos programas, fornecidos pelas Diretorias de Turismo e complementados pelos participantes das oficinas. Após o levantamento dos dados foi elaborado um material fotográfico dos bens, a partir dessas informações o artista Ricardo Valery Sanzi elaborou uma aquarela ilustrando os bens dos municípios. O mapa foi distribuído para as comunidades como retorno das ações participativas.

Assim, o esquema a seguir apresenta todo o processo - descrito anteriormente - - das ações realizadas no âmbito dos projetos solicitados pelo IPHAN de Alagoas a partir de uma demanda turística aos sítios arqueológicos:

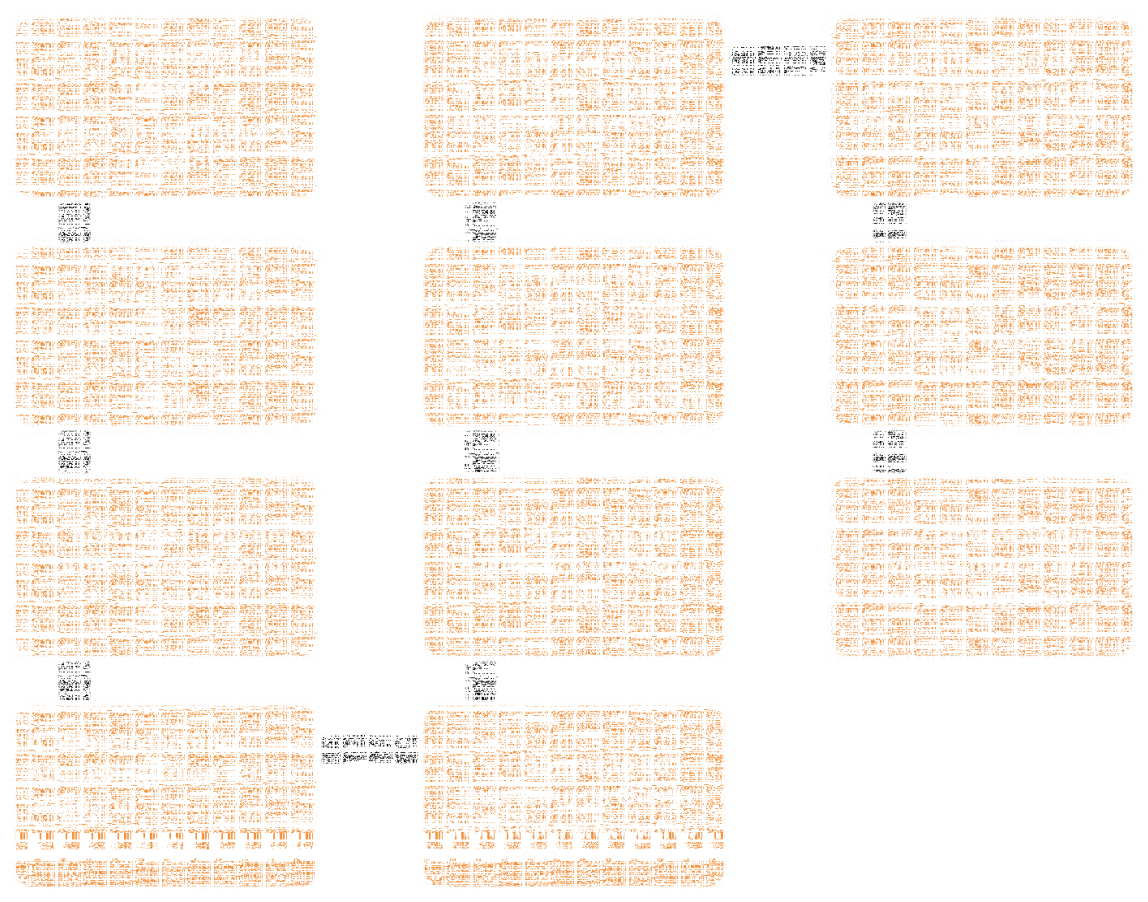

Tabela 01. Esquema das Ações Realizadas no Âmbito dos Projetos Desenvolvidos em Alagoas 
O expressivo número de recursos e atrativos identificados pelos Inventários Turísticos, o alto interesse de participantes nas mais diversas oficinas e ações realizadas no âmbito dos programas, o interesse e o apoio do poder público e a demanda turística já existente demonstraram cabalmente o potencial da região para a formação de um Circuito Turístico e de roteiros sustentáveis e participativos.

O trabalho interdisciplinar realizado na região em apreço - e alterado de acordo com o contexto local - só foi possível devido ao olhar diferenciado da equipe de Arqueologia desde o primeiro projeto desenvolvido pela Zanettini Arqueologia no local. Um olhar desconstrutivista, engajado e de responsabilidade socioambiental, que possibilitou a evidenciação das vontades e necessidades das comunidades, em especial quanto ao uso do patrimônio arqueológico como forma de sustentabilidade de algumas localidades, por meio da visitação dos sítios. Os resultados dos programas foram, pois, favorecidos pela continuidade de projetos e ações da equipe em uma mesma região. O programa realizado em 2007 possibilitou uma análise aprofundada do patrimônio arqueológico dos municípios envolvidos e uma breve compreensão do contexto de atuação, além da identificação do fluxo turístico existente. As ações realizadas em 2008, envolvendo também outros municípios do sertão alagoano, possibilitaram não uma análise comparativa, mas a ampla compreensão do contexto regional, ressaltando o Turismo como ferramenta interessante para o fortalecimento da região.

Outro fator relevante dos projetos foi a iniciativa da $17^{\text {a }}$ Superintendência Regional do IPHAN de solicitar e financiar um estudo voltado para o planejamento estratégico do Turismo dentro dos preceitos da sustentabilidade. Tal atitude demonstrou um amadurecimento das reflexões dos profissionais responsáveis pela preservação do patrimônio cultural nacional com relação ao uso sustentável e qualificado dos bens patrimoniais. Essas ações podem favorecer a concretização de um importante diálogo entre os órgãos públicos responsáveis pela preservação do patrimônio e pelo Turismo, as comunidades e demais interessados acerca da necessidade de regulamentação da atividade e de políticas públicas para o Turismo, de forma a possibilitar estratégias de preservação dos bens.

Vale ressaltar que foi possível observar algumas lacunas nas ações realizadas, entre elas o não envolvimento das comunidades indígenas da região no projeto de forma mais enfática e a impossibilidade de realização de algumas atividades em Piranhas, por questões políticas. Além disso, chamou a atenção o fato de que durante as atividades não foi formada uma comissão gestora, que fortaleceria as discussões locais sobre as possibilidades de implantação do programa e a continuidade das ações de Inventariado e de elaboração de diagnósticos por parte da comunidade, mesmo sem o apoio financeiro do IPHAN. No final do 
relatório de 2008 propôs-se a realização de um encontro de apresentação dos resultados do projeto para possíveis parceiros, como forma de incentivar a continuidade das reflexões, o que, contudo, jamais se concretizou.

\section{ALGUMAS REFLEXÕES SOBRE OS PROGRAMAS REALIZADOS NO SERTÃO ALAGOANO}

Os programas desenvolvidos no sertão alagoano são exemplos interessantes para uma reflexão acerca de uma proposta de gestão e planejamento sustentável participativo da atividade turística e do patrimônio arqueológico. As ações realizadas possibilitaram tentativas de aproximação e envolvimento da comunidade com a atividade turística e com os patrimônios culturais e naturais da região, em especial com os bens arqueológicos; ademais, favoreceram também a democratização do conhecimento arqueológico e a sensibilização local para a importância da preservação dos sítios.

A participação da comunidade em todas as ações e etapas do processo de planejamento da atividade turística foi uma preocupação da Zanettini Arqueologia no desenvolvimento dos programas e na elaboração dos planos para a formação do Circuito Turístico e do Roteiro Arqueológico. As ações visaram a "uma política de multiplicação de parcerias" para fortalecer os diversos grupos abrangidos, fazendo-os coautores e responsáveis pelo planejamento e desenvolvimento do Turismo Sustentável na região (Bastos 2007: 166).

Cardozo (2008) aponta para a necessidade de reflexões e análises de exemplos aplicados de metodologias de desenvolvimento de Turismo Sustentável participativo, pois são raros os estudos que apresentam de forma clara e crítica o processo e a metodologia de planejamento e implantação, especialmente os que levam em consideração o contexto local. A autora ressalta como itens cruciais e necessários para uma metodologia de desenvolvimento turístico participativo os seguintes aspectos: estar de acordo com a Política Estadual ou Nacional de Turismo; realizar um levantamento da oferta turística potencial e real - o levantamento é fundamental para o envolvimento da comunidade local na discussão; providenciar um estudo da demanda; possibilitar debates e reflexões sobre o programa a ser traçado como o trade turístico e com representantes de diferentes setores da comunidade local, de forma igualitária; avaliar os resultados; e propor alterações ao programa durante sua implantação e execução.

A metodologia desenvolvida pela Zanettini Arqueologia no sertão alagoano mostra-se de acordo com os itens elencados por Cardozo (2008) em seu modelo participativo e pode ser 
aplicada a diferentes contextos, pois é o diálogo com a comunidade que favorece a elaboração das pesquisas bases do planejamento participativo. As atividades e propostas procuraram ser elaboradas e realizadas de acordo com a Política Nacional de Turismo. Conforme sugere Cardozo (2008), foram devidamente realizados os levantamentos da oferta turística potencial e real envolvendo a comunidade em todo o processo de Inventário e análise, com proposta para uma participação igualitária da sociedade no plano ou programa a ser implantado. Apontou-se ainda a necessidade de formas de avaliação da atividade durante sua implantação e execução (Alfonso 2009).

A metodologia utilizada permitiu também o questionamento e a análise crítica dos instrumentos de elaboração de Inventário da Oferta Turística propostos pelo Ministério do Turismo do Brasil, que não se mostraram aplicáveis às diferentes realidades socioeconômicas, geográficas e patrimoniais. Vale ressaltar o exemplo das fichas, em que as questões aparecem em linguagem técnica, de difícil compreensão não apenas para os entrevistados, mas também para os entrevistadores. As fichas tampouco dialogam com o padrão dos estabelecimentos analisados no sertão alagoano, pois foram elaboradas para a realidade de locais em que os estabelecimentos possuem padrão turístico - como no caso das fichas de hospedagem, que perguntam se os hotéis possuem pontos de Internet, piscinas, bares, quadras poliesportivas, campos de golfe etc. Porém, o uso da metodologia oficial favoreceu a aceitação e credibilidade do Inventário realizado.

Outra questão que este estudo de caso levanta é a possibilidade de investimento em ações fundamentadas e eficazes de aproximação com a comunidade e com o Turismo e o fortalecimento de parcerias com diferentes atores - instituições públicas, por exemplo -, mesmo dentro de propostas com tempo e recursos limitados. O objetivo é demonstrar que as possibilidades levantadas a partir do estudo de caso podem auxiliar a evidenciar que "a Arqueologia pode fazer a sociedade entender que seu estilo de vida é importante para a ciência” (Funari e Robrahn-González 2005) e que a ciência, ao sair da esfera acadêmica, pode trazer benefícios à sociedade e à preservação do patrimônio.

Conforme mencionado anteriormente, não existe Arqueologia neutra. Destarte, cada vez mais os arqueólogos devem estar cientes de seu papel social, fazendo uma análise crítica de suas escolhas ao "tratar ideologias, teorias, metodologias no decorrer das pesquisas", como sugere Reis (2005: 212). É papel da Arqueologia mostrar a diversidade e as diferenças culturais, alçar categorias de verdade às narrativas alternativas, porém ciente de sua responsabilidade. O estudo pode incentivar os arqueólogos a trabalhar com outros interessados no passado, a ouvir vozes alheias e compreender que os profissionais da 
Arqueologia não são os únicos donos do patrimônio e que sua interpretação dos bens patrimoniais talvez seja apenas uma das muitas vozes sobre o passado no presente. Além disso, o estudo pode também lançar luz sobre a importância de se ressaltar a valorização igualitária do conhecimento, ou seja, que todas as pessoas possuem conhecimentos válidos e “esses saberes podem variar de acordo com a trajetória de vida de cada um dos indivíduos, mas possuem igual importância” (Holtorf in Carvalho e Funari 2009: 3). O trabalho do arqueólogo pode, então, dar uma relevante contribuição no presente, dialogando com o passado, valorizando os bens patrimoniais e criando diferentes debates sobre preservação.

Nesse sentido destacam-se como interessantes exemplos do diálogo entre a Arqueologia, a comunidade e o patrimônio arqueológico as oficinas realizadas com a comunidade do Assentamento Nova Esperança II, que possibilitaram a constatação de que existe uma ideia comum e corrente de que as pinturas rupestres foram obra de Lampião, durante o período que o cangaceiro ficava escondido nos abrigos em meio à caatinga.

O Cangaço foi um fenômeno ocorrido na região Nordeste do Brasil entre os séculos XIX e XX e ocasionado principalmente por questões fundiárias e sociais. Segundo narrativas da população da região, o primeiro bando de cangaceiros foi liderado por “Jesuíno Brilhante” por volta de 1870, e o último bando liderado pelo cangaceiro Corisco. Porém, o cangaceiro mais conhecido em todo o sertão nordestino foi mesmo Virgulino Ferreira da Silva, o Lampião (1897? - 1938).

A memória de Lampião (o "Rei do Cangaço” e “governador do sertão") e dos cangaceiros está bem viva em todo o Nordeste. Vários municípios que se querem turísticos constroem museus referentes ao cangaço e a histórias das passagens dos cangaceiros por suas terras. Não é difícil encontrar na região ex-cangaceiros ou ex-membros da volante, grupo de policiais responsáveis por perseguir os bandos armados, ou mesmo parentes de alguns cangaceiros famosos. Quem chega a uma comunidade quilombola denominada Comunidade da Cruz, localizada em Delmiro Gouveia, só precisa perguntar quem é a prima de Maria Bonita, e todos apontarão para uma senhora que está sempre disposta a contar “causos” sobre sua prima e sobre o cangaço. Não é difícil encontrar pessoas cujos pais recebiam em casa os cangaceiros, ou outros que passavam dias escondidos na caatinga depois que um bando havia invadido sua casa. O interessante é que as opiniões sobre Lampião são diversas e ambíguas: a mesma pessoa que discorre sobre a brutalidade e a maldade de Virgulino - principalmente por meio de histórias de assassinatos de crianças, por exemplo —, é capaz de definir Lampião como homem corajoso, bravo, justo, como um herói. Em diferentes lugares e situações e por 
meio de relatos de diferentes pessoas é possível ouvir a reprodução de histórias similares sobre o Rei do Cangaço, numa mistura de medo, respeito e admiração por parte da população.

Em 1938 o bando de Virgulino foi apanhado em uma emboscada e Lampião foi assassinado junto de sua mulher, Maria Bonita, e mais nove cangaceiros de seu bando. Todos foram decapitados e suas cabeças foram entregues às autoridades em Piranhas, Alagoas. As fotos das cabeças estão expostas no Museu do Cangaço, em Serra Talhad, Pernambuco, cidade natal de Virgulino. Até hoje são realizadas missas em todo o Nordeste em homenagem a Lampião, no dia de sua morte. No dia $1^{\circ}$ de setembro de 2010 foi realizado um encontro das Escolas de Igaporã, na Bahia, em homenagem ao centenário de Maria Bonita. O respeito dos sertanejos por Lampião e seu bando faz com que muitos sítios arqueológicos sejam preservados em sua homenagem.

Durante as oficinas foi possível perceber que as pinturas eram consideradas importantes por fazerem parte do imaginário do cangaço, tão valorizado pela comunidade sertaneja. Por outro lado, os povos indígenas da região pesquisada são vistos como bandidos e preguiçosos, e qualquer patrimônio a eles relacionado é tido pelos moradores como desnecessário, por não compor a identidade do sertanejo. O preconceito se dá, em especial, em relação ao povo xocó, que habita a Ilha de São Pedro, nas proximidades do município. A partir dessa constatação o trabalho educativo foi repensado. Vale ressaltar que a possibilidade de análise crítica do trabalho e de alterações no decorrer de seu desenvolvimento também evidencia que o programa desenvolvido está dentro da proposta metodológica de Cardozo (2008).

Durante a oficina foram inseridas para debate com os moradores dos assentamentos as diversas interpretações sobre os sítios e as diferentes formas de se compreender o mundo, valorizando-se ambas as interpretações como válidas em regime de verdade. O que gerou um (re)pensar sobre a diferença, a diversidade cultural do sertão e a exclusão social das minorias, ensejando uma reflexão sobre a própria realidade das agrovilas enquanto comunidades marginalizadas. As discussões possibilitaram ainda um repensar acerca dos povos indígenas e quilombolas, também marginalizados na região e excluídos não apenas socialmente, mas da imagem regional. Aparentemente as reflexões geradas pela população das agrovilas durante o trabalho educativo mostraram a valorização das pinturas e gravuras e suscitaram um "olhar com outros olhos” para os diferentes povos do passado e do presente. Pôde-se notar um maior respeito à diferença, gerado a partir de uma identificação com a realidade e o pensar dos outros povos. Parece que para aquela comunidade o mesmo sertão era mais antigo e multicultural. 
Segundo Ferreira (2003), a Arqueologia do Baixo São Francisco, região de Olho D’Água do Casado, poderia tornar-se uma chave decisiva para a compreensão do passado e a reflexão acerca de alternativas para o futuro, gerando integração, respeito e sustentabilidade regional. Para o autor, todo trabalho arqueológico é político, cabendo aos pesquisadores da região um posicionamento político. O descaso dos arqueólogos vis-à-vis as populações indígenas e ribeirinhas e o distanciamento dessas populações da comunidade em geral - em especial durante a construção da Hidrelétrica de Xingó no Baixo Rio São Francisco remetem a uma série de ponderações quanto ao lugar dos povos indígenas no imaginário e nos interesses nacionais, bem como com relação à responsabilidade da Arqueologia brasileira para com esses povos.

Também para Funari (et al. 2005) o trabalho do arqueólogo é político, e o diálogo com as comunidades é provavelmente o mais importante compromisso do pesquisador, e pode envolver muitos interesses conflitantes, já que a sociedade é formada por diferentes grupos humanos, é heterogênea e conflitiva. É fundamental para a disciplina trabalhar com as comunidades, seguindo proposição de Paulo Freire (1999) em sua Pedagogia do Oprimido, e para esses públicos distintos, conforme a tentativa apresentada no estudo de caso.

Para Hodder, o passado está incluso no presente e implicado nas atuais estratégias de poder, sendo o objetivo da disciplina a inserção do indivíduo na História e sua valorização no presente como agente social. Ainda segundo o autor, a cultura material tem seu significado construído por indivíduos e grupos e pela relação entre eles, por isso tem a feição de objeto ativo. Segundo Olivier (2005: 132), a identidade da cultura material é fluida, sua compreensão é alterada de acordo com diferentes situações. No início do século XX, Marc Bloch (1911), teórico da Escola dos Annales, afirmou que toda a História é uma história do presente, pois é impossível pensar algo fora de seu contexto, de sua época, lugar e cultura. Tudo que fazemos ou lemos está carregado de significado, portanto a objetividade ou a neutralidade são irreais.

Foucault (1987) afirmou que a sociedade possui o que ele denominou "regimes de verdade”, isto é, as verdades variam de grupo a grupo, e no tempo e espaço, segundo cada um. Não há discurso neutro, os discursos são práticas que geram significados apoiados em regras históricas para estabelecer o que pode ser dito ou não, e essa prática resulta de um complexo de relações com outras práticas discursivas e sociais. Para Foucault, todo discurso contém seleções, que geram exclusões e estabelecem o que é aceito ou rejeitado, verdadeiro ou falso. Assim, a verdade não existe como um saber absoluto, é uma invenção histórica, construída socialmente. 
Deste modo, desde o início do século $\mathrm{XX}$ a objetividade na narrativa cientifica é bastante questionada, assim como a verdade absoluta, de acordo com Ranke. Hayden White (1991) sustenta que a narrativa histórica é uma narrativa também literária, porque escolhemos aspectos do passado em detrimento de outros para "criar” um objeto a partir de preferências políticas, sociais, econômicas, ideológicas, que não são na maior parte das vezes conscientes. A interpretação arqueológica, pois, é uma construção a partir de um contexto político, social, econômico e ideológico do arqueólogo enquanto agente construtor de seu ramo específico do conhecimento.

Para Moro-Abadía (2006: 4), apenas recentemente a história da Arqueologia passou a ser analisada de forma crítica quanto ao seu discurso colonial. Segundo Shepherd (2002: 194), as arqueologias coloniais tendem a depreciar as sociedades indígenas representando-as como estáticas e buscando demonstrar sua incapacidade de desenvolvimento sem estímulo externo. Dessa forma, legitima vários projetos coloniais, que envolveram conquista, extermínios etc.

Segundo Funari, no Brasil pós-independência a sobrevivência das ideias colonialistas e as relações sociais patriarcais, entre outros fatores, acarretaram a exclusão social de povos indígenas, homossexuais, trabalhadores do Movimento Sem-Terra, crianças de rua, bem como a discriminação de afrodescendentes e outras minorias - que apesar de configurarem mais da metade da população brasileira estão notavelmente ausentes das posições de influência e poder. Ressalta-se que, segundo Mazower (2001) e Hannah Arendt (1997), o século XX é marcado pelo movimento de emergência das minorias.

Ainda no escopo dessa discussão, há outro exemplo interessante para esta Tese. Tratase da participação da comunidade do Povoado Cruz nas ações do Projeto "Circuito Arqueológico do Sertão Alagoano: Municípios de Piranhas, Olho D’Água do Casado e Delmiro Gouveia”. As lideranças do povoado não foram convidadas oficialmente para participar das atividades do projeto, pois os primeiros parceiros locais, o poder público e algumas lideranças de diferentes comunidades não mencionaram a existência do Povoado Cruz durante as reuniões de Planejamento. Porém, as oficinas foram divulgadas por toda a cidade de Delmiro Gouveia por meio das caixas de som espalhadas pelo município, o principal meio de divulgação da região. Ao tomar ciência das atividades que estavam sendo realizadas na cidade, uma liderança do mencionado povoado compareceu a uma das oficinas. Durante as apresentações iniciais, a tal liderança informou que era da comunidade do Povoado Cruz, reconhecido como quilombola pela Fundação Palmares em 2005.

A informação chocou os outros participantes da oficina, pois a maioria não sabia da existência de comunidades quilombolas no município. No decorrer da oficina a liderança 
passou a discutir com os outros participantes a questão do preconceito na região e apontou uma série de problemas de relacionamento entre a comunidade quilombola e a população de Delmiro Gouveia. Um dos exemplos apresentados pela liderança foi quanto à ausência de convites para a apresentação do grupo de dança do povoado na cidade. A julgar pelo relato da liderança quilombola, no passado a Prefeitura Municipal havia convidado o grupo para se apresentar em eventos da cidade; porém, ao contrário do que acontecia com outros grupos culturais da região, o grupo do povoado não recebera apoio para o transporte dos participantes, o que impossibilitou a participação dos moradores do povoado, localizado na zona rural do município.

A liderança também compartilhou com os participantes da oficina as dificuldades em fazer com que os jovens se interessassem pela cultura da comunidade e a manutenção do grupo de dança, uma vez que geralmente os mais jovens tinham vergonha de dizer na cidade que eram tanto quilombolas como moradores da zona rural do município. Tal questão gerou reflexões do grupo quanto ao preconceito, não apenas com relação ao Povoado Cruz e com afrobrasileiros, mas também com outros grupos, caso dos povos indígenas da região. Ao término da oficina uma professora solicitou que a comunidade organizasse uma apresentação a ser feita na escola em que ela lecionava, como forma de levar o conhecimento da comunidade para ser dividido com seus alunos. Concluída a ação, a liderança solicitou à equipe da Zanettini Arqueologia a realização de uma oficina sobre Identidade e Patrimônio no Povoado Cruz.

A oficina sobre Identidade e Patrimônio realizada no Povoado contou com a participação de mais de 40 jovens, vários deles membros do grupo de dança, e de alguns idosos, que aos poucos foram se integrando ao grupo. Durante a oficina houve debates sobre a descendência africana do grupo, sobre o reconhecimento como quilombolas pela Fundação Palmares, sobre exclusão e preconceito - a mediadora citou exemplos das comunidades indígenas da região e das comunidades dos assentamentos do MST. Vale ressaltar que as informações sobre esses grupos vieram à baila durante outras oficinas participativas do programa. Os participantes, no decorrer da oficina, apresentaram diferentes narrativas sobre os bens patrimoniais do povoado, discorreram sobre suas dificuldades e ouviram as histórias de alguns idosos que passaram a acompanhar a oficina. Vários dos idosos disseram que poucas vezes os jovens paravam para escutar suas narrativas. Discutiu-se o papel da Arqueologia e do Turismo junto à sociedade. Quando foram mostradas imagens de sítios arqueológicos, membros do grupo convidaram a equipe para conhecer o Cruzeiro que dera 
nome ao povoado, alegando que ali poderiam ser encontrados vários fragmentos de potes de barro parecidos com os apresentados nas imagens (Prancha 6).

O Cruzeiro consiste de uma cruz erguida por um casal de escravos fugidos e que representa o marco da formação do povoado. É utilizado como local de orações; entretanto, outrora havia sido um local de sepultamento, principalmente de crianças. Os participantes da oficina contaram que a escrava rezava pelas pessoas e as curava. Nas proximidades do Cruzeiro, onde segundo as narrativas do grupo ficava a antiga vila dos escravos, foram encontradas evidências de interesse arqueológico, indicando a área como dotada de potencial para intervenções futuras. No final da oficina, após a visita ao Cruzeiro, em agradecimento a comunidade organizou uma apresentação de dança, pois segundo a liderança o grupo de dança já havia recebido mais cinco convites de apresentação desde a realização da oficina na cidade.

Durante o curso de capacitação docente realizado no município de Delmiro Gouveia a mediadora apresentou as narrativas e os problemas mencionados pelo Povoado Cruz durante as ações do programa. A apresentação encetou uma série de discussões sobre o papel dos educadores no trabalho em sala de aula com a questão do preconceito. Muitos dos docentes se queixaram, alegando não possuírem informações suficientes sobre as diferentes comunidades como quilombolas, indígenas e moradores dos assentamentos, o que dificulta o trabalho educativo. Os professores elencaram o Turismo como um possibilitador desse contato entre os diferentes grupos, que "vivem tão próximos de nós, mas são desconhecidos", segundo palavras de uma das educadoras. Na visão dos professores partícipes do curso essas comunidades passaram a ser consideradas instâncias portadoras de importantes conhecimentos para eles até então desconhecidos; os educadores pareceram valorizar a aproximação entre os diferentes grupos que compõem o município de Delmiro Gouveia, como forma de buscar uma maneira de diminuir o preconceito.

O trabalho realizado no sertão alagoano pode ser inserido no modelo democrático de Holtorf (in Carvalho e Funari 2009: 2), que propõe que os saberes devem ser construídos de forma cooperativa, de modo a fornecer instrumentos para que todos os envolvidos tenham condições de elaborar questionamentos e conclusões a respeito dos diferentes temas debatidos. Os diálogos, as críticas e as reflexões propostos pelas ações realizadas no âmbito dos programas - tanto sobre a cultura material quanto sobre as diferentes narrativas buscaram criar uma relação igualitária "entre os arqueólogos e os não arqueólogos”, o que, segundo Carvalho e Funari (2009: 3), é uma das principais responsabilidades da Arqueologia. 


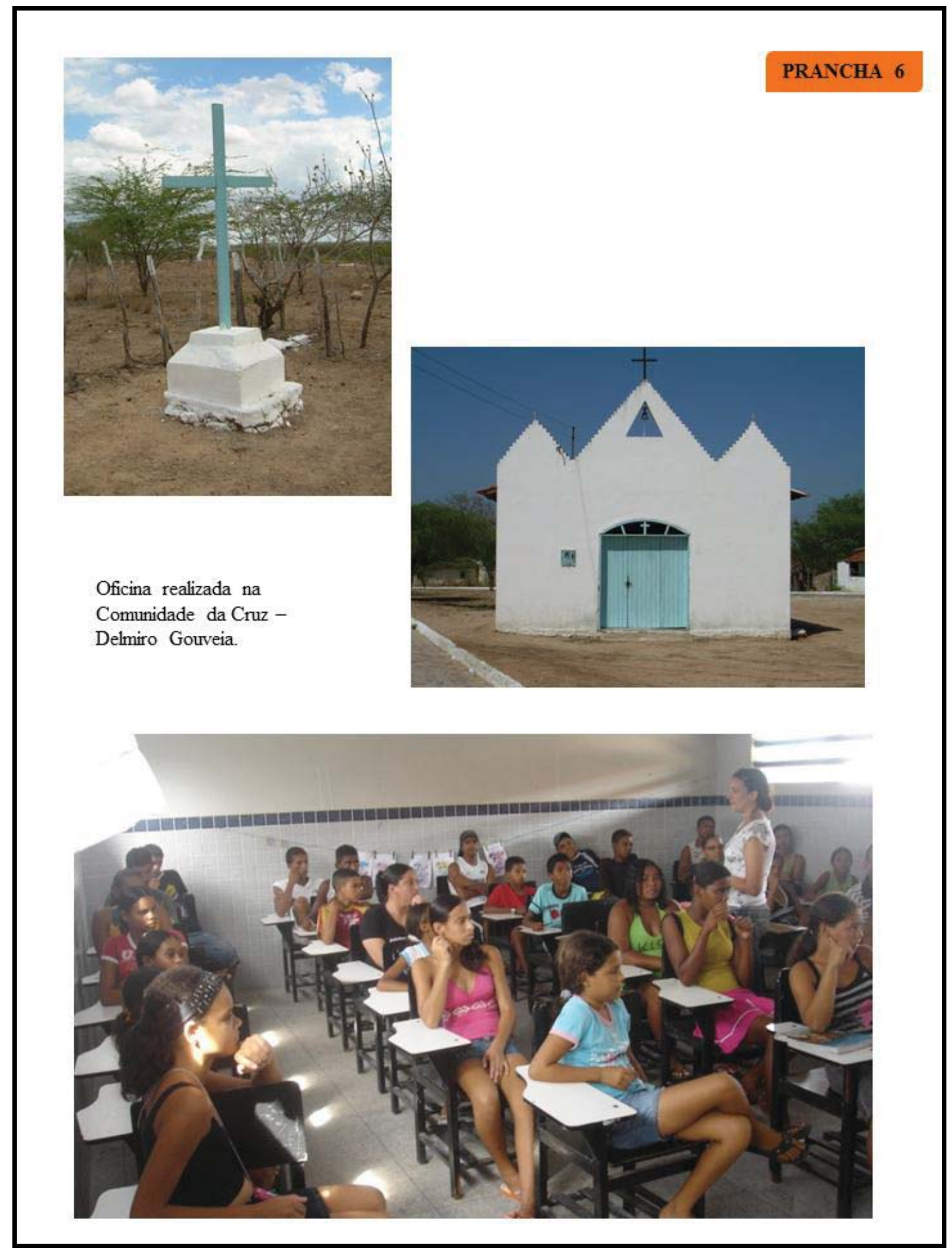


Para Bezerra, o desenvolvimento de projetos que tenham por objetivo o diálogo entre grupos diferentes favorece o "descentramento das tomadas de decisão sobre a gestão do patrimônio arqueológico e a legitimação do passado” (2011: 62). A autora ressalta a importância da compreensão das relações entre as pessoas e os bens patrimoniais no presente, sendo a Arqueologia "ao mesmo tempo, produto e vetor de reflexões acadêmicas, de ações políticas e de estratégias de gestão” (Bezerra 2011: 62). Para ela a Arqueologia tem papel importante como instrumento de ação política e social e o trabalho do arqueólogo é de caráter interventivo, "desde o momento de sua chegada ao local, onde as pesquisas de campo terão lugar, até as interpretações dos vestígios arqueológicos e a consequente construção de uma dada visão do passado” (2011: 62). Os arqueólogos devem buscar compreender as relações entre os diferentes grupos e seus bens patrimoniais, considerando as suas narrativas e a importância de cada um na gestão do patrimônio, cientes do impacto que o discurso acadêmico gera em suas visões de mundo (Pyburn e Wilk 2000, Almeida 2011, Bezerra de Almeida 2003, Funari 2004).

A Arqueologia não deve apenas reconhecer o “outro", mas incentivar a sua participação em "todo o processo investigativo, assim como no gerenciamento comunitário do patrimônio arqueológico”. Para a autora (2011: 62), a Arqueologia Pública é uma postura, uma forma de se fazer Arqueologia que valoriza as narrativas locais no planejamento, realização e alteração das pesquisas arqueológicas e ações educativas. Nesse contexto, cita Castañeda para falar da relação entre a Arqueologia e a Etnografia. Esta tese considera importante o modo de articulação entre ambas, o que o autor chama de "Arqueologia Etnográfica”, que propõe a Arqueologia como sujeito da Etnografia (2011: 30). Para o autor, trata-se da integração de métodos da Etnografia no fazer arqueológico, com o objetivo de compreender e estudar o passado e os contextos sociais do presente (Castañeda in Bezerra 2011: 30). Na atualidade, vários autores se propõem ao desafio de estudar as formas pelas quais as sociedades compreendem os vestígios do passado e refletem sobre as novas formas de relação entre os diferentes grupos e os pesquisadores.

Os projetos desenvolvidos no sertão alagoano buscaram se inserir nesses debates. A realização das oficinas no próprio Povoado Cruz e em outras comunidades rurais seguiu a proposta Castañeda (in Bezerra 2011: 66) de "instalação etnográfica”, em que as ações são realizadas em local que favoreça o diálogo de diferentes visões de mundo, possibilitando relações horizontais entre pesquisadores e comunidades. Os projetos almejaram utilizar uma metodologia de pesquisa participante como forma de compreender o "outro" em sua condição de diferente do pesquisador — ambos no papel de importantes atores na pesquisa. Os 
exemplos aqui citados procuram demonstrar a tentativa de não permitir que a compreensão sobre o passado e o presente e as necessidades e narrativas do "outro" fossem dissolvidas em dados levantados pelo próprio pesquisador a partir de sua própria compreensão de mundo, como mencionam Airoza e Bezerra (2011: 1-2). Foi um primeiro passo para o aprofundamento da reflexão acerca do desenvolvimento de ações voltadas para a lógica das comunidades e não dos arqueólogos, favorecendo a participação do "outro" no processo de forma democrática.

Nessa mesma linha de reflexão, outro exemplo interessante foi a elaboração do Mapa do Circuito Turístico do Sertão Alagoano, resultado do Inventário da Oferta Turística participativo e pensado no âmbito da proposta de mapeamento participativo, um processo de "registro de conhecimentos provenientes de um determinado grupo acerca de seu ambiente vivido em seus diferentes aspectos, construído a partir do trabalho coletivo dos atores envolvidos” (Campos e Mattos 2011: 331). Trata-se de um instrumento útil e instigante, pois propõe a inclusão dos conhecimentos dos diferentes atores locais sobre suas comunidades, trabalhando com informações que refletem a complexidade social, cultural e econômica das localidades, possibilitando ainda a inclusão de suas prioridades, normalmente não identificadas pelos pesquisadores. Deste modo, considerou-se o mapa participativo uma ferramenta metodológica eficaz, que permitiu que as comunidades dos municípios pudessem ver materializadas suas próprias percepções sobre seu ambiente vivido, em especial seus bens patrimoniais.

Assim, o estudo de caso do sertão alagoano buscou apresentar uma breve reflexão sobre a epistemologia da ciência arqueológica, aplicada a uma realidade específica, mostrando a tessitura discursiva por trás da metodologia de ação aplicada ao Projeto "Circuito Arqueológico do Sertão Alagoano: Municípios de Piranhas, Olho D’Água do Casado e Delmiro Gouveia”, em que se procurou valorizar as narrativas sobre o passado, mas também desconstruir discursos marginalizantes arraigados a imaginários e sensos comuns. O trabalho realizado em Alagoas é uma tentativa de evidenciar projetos pensados no âmbito das discussões apresentadas.

Buscou-se não apenas apresentar o Turismo como meio de geração de melhorias socioeconômicas e inclusão social, mas também como forma de inserção de diferentes populações na identidade do sertanejo, consequentemente nacional, evidenciando a pluralidade cultural brasileira, incentivando o respeito às diferenças, a preservação e a gestão do patrimônio arqueológico, lidando na prática de campo com as questões contemporâneas, nossa responsabilidade social para combater os preconceitos, as marginalizações, exclusões, 
xenofobias, de acordo com o preceito de que os seres humanos devem se respeitar na diferença, em que constroem sua identidade. Assim, a proposta apresentada pela Zanettini Arqueologia em seu relatório final evidencia o Turismo Arqueológico como ferramenta que possibilita que a prática arqueológica faça das comunidades "sujeitos de seu próprio patrimônio, partícipes de um processo de reinterpretação dos signos e símbolos”, conforme sugere Ferreira (2003: 46). 


\section{Capítulo 5 - Estudo de Caso 2: o Turismo em Programas de EduCaÇão Patrimonial na Arqueologia Preventiva - UM eXemplo no sudoeste BAIANO}

Este capítulo visa apresentar as ações realizadas no âmbito do Programa de Educação Patrimonial inserido no Programa de Prospecções e Resgate Arqueológico de Parques Eólicos implantado no sudoeste baiano, nos municípios de Caetité, Guanambi e Igaporã. Diferentemente das ações apresentadas no capítulo anterior desta tese, financiadas e solicitadas pelo órgão governamental responsável pela preservação dos bens patrimoniais, o Programa de Educação Patrimonial descrito a seguir foi desenvolvido pela Zanettini Arqueologia, na esfera de ação do Licenciamento Ambiental. ${ }^{4}$ Vale ressaltar que na maioria dos projetos de Arqueologia Preventiva os programas educativos são solicitados às empresas de Arqueologia de maneira a apenas cumprir as exigências legais. Este estudo de caso se revela interessante por apresentar outras possibilidades.

O Programa de Prospecções e Resgate Arqueológico, iniciado em 2010, é importante para a Arqueologia Preventiva efetuada em empreendimentos eólicos pois apresenta propostas metodológicas específicas, pensadas a partir de uma abordagem regional (Zanettini Arqueologia 2011: 9), que por sua vez trouxe elementos cruciais para a elaboração e o desenvolvimento do Programa de Educação Patrimonial. As pesquisas realizadas na região até o presente momento resultaram na identificação de aproximadamente 90 sítios arqueológicos, com mais de 12 mil peças coletadas, que evidenciam a diversidade da ocupação humana da região. Os estudos de Arqueologia Preventiva lançaram as bases para o incremento da Arqueologia histórica na região em pauta, favorecendo o registro de elementos da cultura material e imaterial relativas ao cotidiano das comunidades tradicionais locais (Zanettini Arqueologia 2011: 9).

O Programa de Educação Patrimonial visou socializar os resultados dos estudos arqueológicos realizados para o referido empreendimento. A proposta foi a concepção de um programa de socialização em que o patrimônio arqueológico pudesse ser abordado enquanto recurso das sociedades envolvidas, ressaltando a importância de que os bens fossem pensados a partir de sua interação com outros segmentos patrimoniais e segundo os preceitos do conceito de Paisagem Cultural. Esses recursos têm possibilitado que os agentes envolvidos

\footnotetext{
${ }^{4}$ As informações sobre o Programa de Educação Patrimonial desenvolvido pela Zanettini Arqueologia para a Renova Energia foram retiradas do Relatório Final Zanettini Arqueologia 2011b.
} 
realizem reflexões e articulações no presente, acerca do passado da região, problematizando a realidade social e visando ao desenvolvimento das sociedades em tela (Zanettini Arqueologia 2011b).

As ações foram realizadas a partir de um diagnóstico patrimonial local que favoreceu a elaboração de um programa voltado para os contextos socioculturais abrangidos pelo projeto. As ações foram pensadas de forma integrada, tendo em vista a promoção de reflexões acerca da importância do patrimônio arqueológico enquanto recurso, a partir de iniciativas associadas à educação formal e não-formal. Também foram pensadas e desenvolvidas ações de sensibilização quanto ao Turismo e ao incentivo à realização do Inventário da Oferta Turística, favorecendo o planejamento participativo do Turismo, com o intuito de organizar o fluxo espontâneo de visitantes aos municípios e aos sítios arqueológicos. O Turismo também foi pensado como uma ferramenta interessante para o desenvolvimento socioeconômico regional. Vale ressaltar que a identificação do interesse turístico regional e dos fluxos de visitantes já existentes nos municípios e sítios arqueológicos só foi possível porque os coordenadores do projeto e as equipes de campo estavam sensibilizados quanto à questão turística e seu relevante papel em projetos educativos. As atividades de Educação Patrimonial, Turismo e Divulgação Científica buscaram ressaltar a importância do patrimônio cultural na construção, negociação e afirmação das identidades e memórias locais (Zanettini Arqueologia 2011b).

O programa foi concebido de modo a estar a todo momento sensível às realidades sociais envolvidas; assim, a metodologia participativa tem sido a norteadora das ações. As metodologias participativas foram pensadas a partir de conceitos trazidos das Arqueologias Pós-Processuais, da Sociomuseologia, da Antropologia Aplicada e do Turismo Sustentável, e sempre voltadas à interdisciplinaridade, considerando o patrimônio um recurso do presente, tendo em mente o desenvolvimento e as melhorias na qualidade de vida das comunidades envolvidas; em momento algum se perdeu de vista o objetivo de procurar identificar as demandas, as narrativas e compreensões das comunidades a partir de ações e propostas provenientes dos próprios grupos participantes do projeto.

Para o Programa de Educação Patrimonial foi proposta a realização de oficinas idealizadas de acordo com o método ZOPP, já explicado anteriormente. A metodologia de oficinas participativas foi adotada como tentativa de inverter a antiga concepção de administração centralizada, em que normalmente a comunidade recebe referências do corpo técnico, que desconhece a realidade local. Com tal enfoque o trabalho buscou discutir o patrimônio cultural, arqueológico e a atividade turística, explorando a experiência de cada 
município e contextualizando-o regionalmente. As oficinas tiveram como finalidade instigar reflexões por parte de diferentes segmentos da comunidade, incentivando as próprias populações a escolherem temas e projetos de interesse voltados ao patrimônio. A proposta também incentivou que esses projetos fossem pensados de forma a serem autossustentáveis. Assim, o papel dos mediadores das oficinas não foi de propor ações aos participantes, mas incentivar que a própria população traçasse - a partir das discussões realizadas - formas de manutenção do diálogo, que fomentasse discussões de apropriação do conhecimento gerado durante as oficinas e que elaborasse propostas direcionadas às temáticas (Zanettini Arqueologia 2011b).

A escolha pela elaboração do Inventário da Oferta Turística dos municípios envolvidos se deu por se considerar que se trata de um instrumento solidificador das informações e narrativas levantadas durante as ações. O Inventário possibilita o planejamento e a gestão participativos, tanto da atividade turística como de demais ações educativas (de desenvolvimento local, relacionadas à políticas públicas, dentre outras), passíveis de elaboração a partir da gama de dados compilados pela pesquisa. Assim como no caso do sertão alagoano, o Inventário Turístico foi realizado segundo a metodologia indicada pelo Ministério do Turismo (MTUR, 2006). Optou-se por tal metodologia pois engloba as diretrizes oficiais aceitas pelo órgão máximo do Turismo Nacional, o que favorece a credibilidade dos dados levantados, em especial no caso de solicitação de recursos e embasamento para a consolidação de políticas públicas.

Segundo a Zanettini Arqueologia, a concepção do programa foi pensada de forma a levar em conta problemáticas e reflexões apontadas pelas comunidades envolvidas para que estas pudessem retroalimentar as ações em desenvolvimento: "Esse design de projeto resultou em um programa composto por etapas sucessivas e encadeadas, sendo que os resultados (outputs) da etapa anterior sempre trouxessem novas informações (inputs) à próxima etapa” (2011b: 18). Assim, o arcabouço do Programa de Educação Patrimonial obedeceu à seguinte estrutura: 


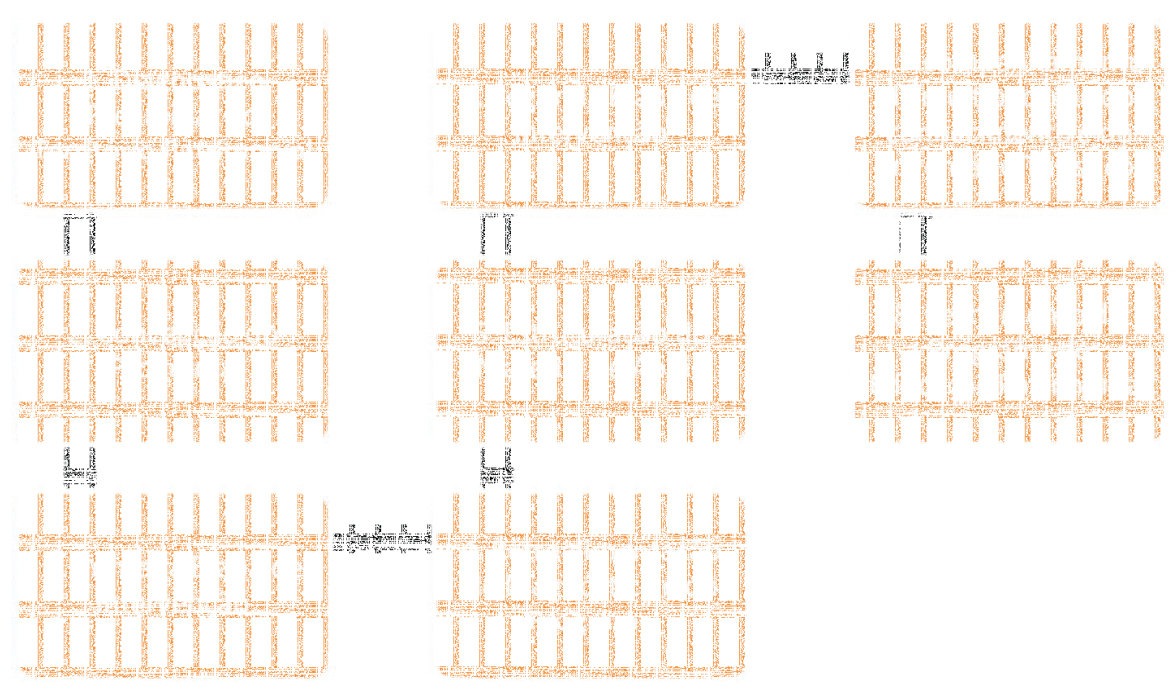

Tabela 02. Esquema das Ações Realizadas no Âmbito do Programa de Educação Patrimonial

A primeira etapa do programa foi realizada concomitantemente à primeira etapa da pesquisa arqueológica em 2010, envolvendo entrevistas e conversas com as comunidades que seriam diretamente afetadas pelo empreendimento, e possibilitou a identificação da demanda local quanto ao Turismo.

A segunda etapa envolveu reflexões e debates entre a equipe sobre as ações a serem propostas. Os resultados das discussões, acrescidos das informações coletadas na etapa anterior, possibilitaram a formulação do programa e seu envio à Superintendência Regional do IPHAN e à Secretaria do Meio Ambiente do estado da Bahia.

A terceira etapa, realizada em 2011, envolveu as primeiras experiências educativas com as comunidades dos municípios envolvidos. Nessa fase foram realizadas reuniões para a formação de parcerias locais e planejamento da segunda etapa de intervenção e palestras de sensibilização. Além disso, foi ministrado um módulo denominado "Educação Patrimonial, Arqueologia e Turismo Cultural” - por município, como parte de um curso realizado em parceria com a empresa responsável pelas ações de Educação Ambiental.

A quarta etapa buscou a retroalimentação do programa, a partir da análise das informações coletadas na terceira etapa e dos resultados das primeiras ações.

A quinta etapa foi realizada concomitantemente à etapa anterior, e envolveu a criação e a produção do material de apoio. 
A sexta etapa, ou segunda etapa intervenção, aconteceu em meados de 2011. Foi uma etapa de campo em que a equipe realizou palestras, oficinas, entrevistas e acompanhou o processo de elaboração participativa do Inventário de Oferta Turística.

A sétima etapa previu o acompanhamento das ações de multiplicação e produção de conhecimento, tanto em atividades pensadas nas oficinas de sensibilização e capacitação quanto na elaboração e sistematização do Inventário Turístico.

A oitava etapa, última prevista para o Projeto, envolveu o fechamento do Programa, a sistematização das ações e resultados e a elaboração do Relatório Final.

Todas estas etapas serão detalhadas a seguir.

\section{ETAPA 1 - DIAGNÓSTICO PRELIMINAR DO TERRITÓRIO PATRIMONIAL}

A primeira ação foi a realização do diagnóstico local. É importante destacar que na primeira etapa foi realizado um diagnóstico prévio, realimentado durante todo o período de aplicação do programa e que culminou em dados e informações que contribuíram para o Inventário da Oferta Turística dos municípios. Para a realização do diagnóstico foi definido como território patrimonial do programa a área dos três municípios de abrangência do empreendimento, a saber: Caetité, Guanambi e Igaporã. Tal território foi compreendido a partir da realidade arqueológica associada às referências patrimoniais apontadas pelas próprias comunidades envolvidas. O diagnóstico desse território na Etapa 1 incluiu um breve levantamento de algumas características sociais, culturais e econômicas, bem como possibilitou ações que permitissem o acesso às referências presentes nas memórias locais, a partir de narrativas.

\section{ETAPA 2 - CONCEPÇÃO DO PROGRAMA DE EDUCAÇÃO PATRIMONIAL}

Durante o período de concepção do programa foi realizada uma reunião de planejamento junto ao empreendedor e à empresa responsável pelas ações de Educação Ambiental. $\mathrm{O}$ encontro visou coordenar ações entre as diferentes responsáveis por trabalhos educativos na região em apreço, e possibilitou a inserção de um módulo voltado ao Patrimônio Cultural e à Arqueologia em um curso de Educação Ambiental ministrado para os 
professores do ensino municipal das cidades envolvidas. Os cursos foram realizados durante a primeira etapa de intervenção. Também ficou decidido que ambos os projetos educativos, tanto o de Educação Patrimonial como o de Educação Ambiental, fariam parte de um programa único, denominado "Território do Saber”.

Ainda durante etapa de concepção foi elaborado um primeiro material de apoio didático a ser distribuído durante a primeira etapa de intervenção. Organizado em meio digital, o material continha: textos de apoio sobre patrimônio cultural, Educação Patrimonial e Arqueologia; sequências didáticas com exemplos de possíveis atividades a serem desenvolvidas em sala de aula, inspiradas em atividades propostas no periódico Nova Escola; dois textos complementares — "Os índios antes de Cabral: Arqueologia e história indígena no Brasil”, de Eduardo Góes Neves, e "Indiana Jones deve morrer”, de Paulo Zanettini; e imagens do Programa de Prospecções e Resgate Arqueológico, com fotos dos trabalhos de campo, dos sítios arqueológicos e das peças coletadas. Além do material digital, foi organizado para uso no curso um kit de peças arqueológicas. O kit foi pensado de forma a abranger diversas facetas do patrimônio arqueológico coletado nos sítios da região: instrumentos de pedra lascada e polida, fragmentos de cerâmica de produção indígena e de produção local/regional, peças em metal e fragmentos de louças de diferentes épocas e procedências.

\section{ETAPA 3 - PRIMEIRA ETAPA DE INTERVENÇÃO}

A primeira ação da terceira etapa, ou primeira etapa de intervenção, foi a realização do módulo do curso para professores dos municípios de Caetité, Guanambi, e Igaporã. As turmas foram organizadas pelas secretarias municipais de Educação, que selecionaram grupos de aproximadamente 30 professores. Cada módulo teve a duração de quatro horas. Como forma de avaliação os educadores receberam duas fichas para preenchimento: uma denominada "Marco Zero" e aplicada no início do curso, e outra de avaliação pós-curso.

O módulo "Educação Patrimonial, Arqueologia e Turismo Cultural” teve início com a apresentação do "Programa de Educação Patrimonial: Conceitos, Métodos e sua Inserção no Ensino Formal”, seguido pelo estímulo à curiosidade dos participantes acerca da presença de arqueólogos nos municípios da região. Após as primeiras discussões foi proposta a Dinâmica 1, com o objetivo de aproximar os integrantes e também para incentivar uma discussão sobre seus antepassados, sobre identidade e sobre preconceito e discriminação. Os relatos apresentados pelos docentes durante a dinâmica possibilitaram um trabalho de reflexão sobre 
as identidades locais. A Parte Expositiva 1 tentou incentivar uma análise crítica da diversidade cultural da região, partindo de seus bens patrimoniais. A Dinâmica 2, apresentou a Ficha de Bem Cultural, proposta como material de apoio didático no DVD. A dinâmica foi feita em grupos de quatro a seis pessoas como forma de buscar uma perspectiva multivocal; incluindo a construção de "narrativas em primeira pessoa", evidenciou o potencial da metodologia de trabalho (Zanettini Arqueologia 2011b).

A Parte Expositiva 2 foi devotada a explicitar de forma mais detalhada a Arqueologia e os resultados do programa nos municípios, pois nem todas as ideias e conceitos eram de conhecimento dos participantes. A Parte Expositiva 3 ressaltou a maneira como a metodologia de pesquisa e os conhecimentos da Arqueologia poderiam ser utilizados como ferramenta educativa a ser pensada de forma a contribuir para que fossem atendidos os Parâmetros Curriculares Nacionais (PCNs). No final do módulo foram apresentados o material de apoio didático e o kit de peças arqueológicas.

Os professores demonstraram interesse pelos conteúdos ministrados e participaram das atividades propostas manifestando, durante as dinâmicas, suas frustrações, experiências e histórias pessoais. As peças arqueológicas se mostraram importantes ferramentas didáticas: "Em todos os municípios surgiram demandas pela continuidade das atividades, que foram atendidas durante a segunda etapa de intervenção” (2011b: 65).

A aplicação de dois instrumentos de avaliação, um no começo do curso e outro no final, possibilitou a análise comparativa entre os dois momentos de avaliação e entre os três municípios envolvidos no programa. Participaram do curso para professores aproximadamente 80 docentes de 17 escolas municipais. Das oito temáticas apresentadas no Marco Zero, três figuraram como aquelas sobre as quais a maior parte dos professores julgou possuir conhecimento regular ou ruim: Arqueologia, Turismo Cultural e Educação Patrimonial — o que atestou a importância de trabalhar esses temas no Programa Educativo. Quando questionados sobre seus municípios, os professores disseram orgulhar-se do clima, das riquezas naturais, da história e da cultura, das atividades econômicas e de alguns poucos bens patrimoniais. Os docentes afirmaram ainda não sentir orgulho algum da desigualdade social, da falta de oportunidades de emprego, da escassez de água, dos problemas com a saúde pública, da falta rede esgoto, das poucas opções de lazer e de cursos universitários e de capacitação profissional. Vale ressaltar que vários desses elementos foram trabalhados na segunda etapa de intervenção.

No final do curso, o segundo instrumento de avaliação indicou uma mudança considerável nas respostas dos docentes. Nos três municípios, a maioria dos professores 
afirmou ter aprimorado seus conhecimentos sobre as temáticas Arqueologia, Turismo Cultural e Educação Patrimonial. Em uma questão específica sobre o Turismo Arqueológico como ferramenta de transmissão do conhecimento sobre Arqueologia para a comunidade, os professores responderam que a atividade turística poderia divulgar a história local e seus antepassados, possibilitar a valorização dos bens patrimoniais e das identidades locais: “As respostas dos participantes dos três cursos confirmam o diagnóstico inicial realizado para a região e justificaram a escolha do Turismo como uma das temáticas de interesse da comunidade” (2011b: 63). Como forma de propiciar reflexões e aprofundar conhecimentos sobre Turismo foram planejadas para a segunda intervenção Oficinas sobre "Patrimônio e Turismo” e "Construção de Imagem Turística".

Outra mudança relevante foi a inserção do patrimônio arqueológico entre os itens de orgulho dos municípios: o importante patrimônio arqueológico da região, pois auxilia a “contar, sob novo olhar, a história do local, do povo, dos antepassados” (2011b: 64). Como problemas dos municípios foram citados: “a falta de ações de preservação dos bens arqueológicos, a discriminação racial e os preconceitos, a falta de benefícios gerados para a cidade pelo uso das riquezas naturais e culturais e a ausência de políticas públicas e planejamento voltados ao Turismo” (2011b: 65). Os resultados apontaram para elementos fundamentais para o diagnóstico da realidade sociocultural, patrimonial e turística da região, que foram apropriados na concepção da etapa seguinte do programa.

Também durante a primeira etapa de intervenção foi realizada uma palestra para cerca de 80 alunos do Centro Territorial de Educação Profissional do Sertão Produtivo (CETEP) de Caetité, que vinham trabalhando o tema Patrimônio Cultural com a professora de artes. A apresentação mostrou imagens dos trabalhos de campo e de artefatos dos sítios arqueológicos da região e suscitou reflexões sobre os antepassados de cada um, sobre patrimônio cultural, sobre preservação e identidades locais. No final da palestra foi mostrado o kit arqueológico.

Como forma de avaliação, a professora de artes do CETEP solicitou dos alunos textos sobre as temáticas trabalhadas. Os resultados foram divididos em quatro temas principais (2011b: 68): valorização do patrimônio e sua preservação: “Agora só nos resta a preservação para a conservação do nosso patrimônio"; trabalho do arqueólogo: "Os arqueólogos procuram identificar os objetos históricos de cada região"; a descoberta da existência de sítios arqueológicos no município: “Descobri que em Caetité há vários sítios arqueológicos onde se encontram objetos de diversas épocas”; e, por fim, a antiguidade dos sítios: "Na minha região há muitos pontos que comprovam a existência de pessoas há seis mil anos, mas antes não 
havia essa comprovação. Hoje é diferente, há a comprovação, há o registro confirmando tudo isso".

Também tiveram início as atividades voltadas à elaboração participativa do Inventário da Oferta Turística dos três municípios envolvidos no programa. Buscou-se estabelecer parcerias com os poderes públicos locais e Conselhos de Cultura municipais, estes últimos incumbidos da realização do Inventário. Os Conselhos de Cultura são formados por diferentes lideranças das localidades, o que possibilitou o envolvimento de grupos diversos na elaboração da pesquisa. Os parceiros receberam o material básico para o início das atividades: as fichas de Inventariado, os manuais de preenchimento e um resumo com reflexões sobre as pessoas, instituições e estabelecimentos de interesse para a participação.

O diagnóstico regional partícipe da realização do Inventário foi aprimorado durante a etapa de intervenção com informações coletadas durante os cursos, visitas aos bens patrimoniais, levantamento de pesquisas já realizadas por diferentes instituições e visitas aos equipamentos de apoio e de infraestrutura turística. O processo de Inventariado da Oferta Turística teve continuidade até o final do projeto.

Por fim, a primeira etapa de campo envolveu visitas técnicas a sítios arqueológicos e áreas de interesse histórico, visando ao planejamento de uma visita dos professores que participariam do módulo do curso e das Oficinas sobre Identidade e Patrimônio para Professores. A demanda para a visitação de sítios arqueológicos surgiu durante o curso para professores da primeira etapa de intervenção. Mais de dez sítios arqueológicos foram visitados pela equipe e hierarquizados a partir de uma metodologia proposta pelo Ministério de Turismo do Brasil. A hierarquização de atrativos turísticos brasileira segue os preceito da Organização Mundial do Turismo (OMT) e do Centro Interamericano de Capacitação Turística (CICATUR). Os itens, analisados por sítio, foram (2011b: 83-84):

- o grau de uso atual: análise do atual volume de visitação e uso e sua importância para o município.

- a representatividade: análise da singularidade ou raridade do atrativo.

- o apoio local e comunitário: avaliação do grau de interesse da comunidade local pelo atrativo por meio das narrativas locais.

- o estado de conservação da paisagem circundante: verifica o nível de conservação da paisagem que circunda o atrativo.

- a infraestrutura: análise da infraestrutura disponível nas proximidades do atrativo.

- o acesso: análise das vias de acesso existentes e condições de uso. 
Levando-se em consideração esses itens, foram selecionados dois sítios arqueológicos para visitação dos professores: o Sítio Morro do Jacaré e o Sítio Histórico Pajeú. Ambos foram preparados para receber as visitas técnicas.

\section{Sítio Arqueológico Pajeú}

O sítio histórico a céu aberto Pajeú, localizado no município de Guanambi, é caracterizado pela presença de alicerce, trechos de parede e montículo de casa de adobe colapsada, açude, além de cerâmicas de produção local/regional, faianças finas e outros vestígios dispersos em uma área de 10.170m² (Zanettini Arqueologia 2011b: 84). Segundo narrativa do proprietário e de historiadores locais, a construção remonta ao período escravista.

A classificação do sítio se deu da seguinte maneira — segundo relatório do programa (2011):

- o grau de uso atual: o sítio é visitado esporadicamente e está localizado em área de pastagem de animais nas proximidades da casa do atual proprietário.

- a representatividade: o sítio é representativo por apresentar vestígios de um dos muitos modos de vida e padrões de subsistência dos habitantes da região.

- o apoio local e comunitário: segundo o proprietário, há professores e historiadores do município que às vezes visitam o local a fim de obter mais informações sobre a casa. $\mathrm{O}$ depoimento do proprietário demonstra o interesse da comunidade pelo patrimônio em apreço.

- o estado de conservação da paisagem circundante: a paisagem circundante é caracterizada por pastagem e o açude se mantém preservado. Vale ressaltar que uma historiadora do município montou em uma das praças principais da cidade uma sala expositiva com peças retiradas do sítio.

- a infraestrutura: os equipamentos de apoio mais próximos estão no município de Guanambi.

- o acesso: as vias de acesso até o sítio estão em bom estado de conservação. O acesso se dá por meio da estrada que liga Guanambi a Caetité, e depois por uma estrada de chão. O sítio arqueológico está localizado a cerca de 200 metros de distância da estrada. 


\section{Sítio Arqueológico Morro do Jacaré}

Localizado no município de Caetité, em meio a uma pedreira ilegal, trata-se de um abrigo sob rocha que apresenta pinturas rupestres com pigmento vermelho e traços de pigmento amarelo. Por ser um local que serve de abrigo do sol, o sítio vem sendo constantemente utilizado por indivíduos que dali extraem placas de arenito, em especial na hora da alimentação dos trabalhadores. A extração ilegal e a utilização de fogueiras no interior do sítio vêm causando impactos irreversíveis.

A classificação do sítio se deu da seguinte maneira:

- o grau de uso atual: o sítio vem sendo constantemente impactado, e se faz urgente a necessidade de ações preservacionistas e de valorização do patrimônio arqueológico, em especial para a comunidade do entorno.

- a representatividade: o sítio apresenta pinturas rupestres, cuja datação recua mais de quatro mil anos no tempo.

- o apoio local e comunitário: segundo a narrativa da comunidade que habita as proximidades do sítio, os trabalhadores da pedreira reconhecem as pinturas como algo diferente e tentam preservar o local onde elas estão. Porém, o sítio arqueológico apresenta sinais de impacto devido ao seu uso como abrigo. A importância da sensibilização da comunidade quanto à preservação do sítio foi um dos fatores cruciais para a escolha deste para a visitação dos professores.

- o estado de conservação da paisagem circundante: os locais de extração ilegal de placas de arenito ficam a poucos metros do abrigo, o que descaracterizou a paisagem.

- a infraestrutura: os equipamentos de apoio mais próximos estão no município de Caetité.

- o acesso: as vias de acesso até o sítio estão em bom estado de conservação. O acesso se dá por meio da estrada que liga Caetité à Igaporã, e depois por uma estrada de chão. O sítio arqueológico está localizado a cerca de 200 metros de distância da estrada.

ETAPAS 4 E 5 - RETROALIMENTAÇÃO DO DiAGNÓSTICO E DO PROGRAMA E ESTRUTURAÇÃO DO MATERIAL DE APOIO 
Durante a etapa 4 do programa foram realizados a análise dos resultados obtidos em campo, a organização de dados e o planejamento das etapas futuras. Concomitantemente, na quinta etapa se deu a elaboração do material de apoio para as atividades da segunda etapa de intervenção. O material foi composto por um livro de apoio ao multiplicador e um folder de divulgação do projeto. Ambos encontram-se noo Anexo 3.

O livro de apoio, intitulado Diálogos sobre o patrimônio cultural de Caetité, Guanambi e Igaporã, foi pensado para os multiplicadores que participariam das oficinas e apresentou as seguintes temáticas: Educação Patrimonial, Identidade, Patrimônio, Arqueologia, e informações sobre o Programa de Educação Patrimonial e sobre os trabalhos arqueológicos realizados na região em apreço. Com relação ao Turismo o livro procurou apontar alguns conceitos e exemplos de como a atividade vem se desenvolvendo na região Nordeste do país. Optou-se por utilizar como estudo de caso um exemplo do Turismo Convencional, representado pela Serra da Capivara, e um exemplo nos preceitos do Turismo Não-Convencional e Participativo: o Circuito Turístico do Sertão Alagoano.

O folder, elaborado para atender aos participantes das palestras, apresentou os resultados dos trabalhos arqueológicos realizados na região, a metodologia de pesquisa da Arqueologia e o Programa de Educação Patrimonial.

Vale ressaltar que no decorrer das ações do programa ficou claro que a linguagem dos textos - do livro de apoio e do folder - se mostrou acessível para alguns dos grupos, caso dos professores, porém não para a maioria do público. A linguagem acadêmica dificultou a leitura dos textos. Por outro lado, o uso das imagens e ilustrações contribuiu para aguçar o interesse dos participantes pelo material. Houve o cuidado deliberado da utilização fotos de bens patrimoniais e de moradores dos municípios envolvidos no programa. Destaca-se o exemplo de uma professora que teve sua fotografia publicada no livro: "Vou levar para minha família e meus alunos verem minha foto no livro, verem como sou importante”. Outro detalhe que chamou a atenção foi a existência de páginas em branco para anotações no final do livro. O espaço foi utilizado por muitos participantes no decorrer das oficinas. Uma senhora de uma comunidade rural, aluna do curso de alfabetização de adultos, disse ter gostado das páginas, pois nelas poderia praticar a escrita. As diferentes narrativas sobre o livro e o folder propiciaram uma gama de informações que possibilitaram a avaliação do material, crucial para a elaboração de outros materiais para o programa.

ETAPA 6 - SEGUNDA ETAPA DE INTERVENÇÃO 
A segunda etapa de intervenção, ou sexta etapa do programa, envolveu a realização de oficinas, palestras, visitas técnicas e reuniões. O público das atividades foi selecionado pelas secretarias municipais de Educação, Conselhos de Cultura e lideranças comunitárias, pois de acordo com as metodologias participativas não caberia à Zanettini Arqueologia a seleção de lideranças e segmentos participantes das atividades, que tiveram as seguintes temáticas:

\section{Oficinas sobre Identidade e Patrimônio para Professores}

O conteúdo ministrado nas oficinas foi idêntico ao do módulo oferecido no curso durante a primeira etapa de campo. O material de apoio didático foi acrescido do folder e do livro. Aplicaram-se os mesmos instrumentos avaliativos explicitados anteriormente. Ao final da oficina foram propostas ações de multiplicação, voltadas para a realização de atividades relativas às temáticas trabalhadas em sala de aula, pelos professores. O envio de relatório sobre as atividades deu direito a um certificado de 30 horas para cada docente. Mais adiante serão descritos os resultados das atividades de multiplicação.

\section{Oficinas sobre Identidade e Patrimônio}

As oficinas visaram a uma reflexão da comunidade acerca dos bens patrimoniais, além de fomentarem o debate sobre temáticas semelhantes às descritas anteriormente - como a relação entre patrimônio e a construção/negociação das identidades locais —, porém adaptadas a públicos diversificados. O objetivo das dinâmicas foi incentivar as narrativas dos participantes acerca de sua relação com os bens patrimoniais dos municípios, em especial por meio de histórias pessoais. Houve profícuas discussões sobre preservação e preconceito, e foram apresentadas a Arqueologia e os trabalhos realizados na região. As oficinas abrangeram diferentes públicos: trabalhadores rurais, artesãos, funcionários públicos, grupos de jovens, lideranças das comunidades quilombolas, associações de mulheres, agentes de saúde, grupos da melhor idade, comunidade em geral, interessados na atividade turística, entre outros. Vale destacar que a avaliação das oficinas se deu de diferentes maneiras, pois muitos participantes eram analfabetos. Quando não foi possível a aplicação dos formulários de avaliação, houve discussões sobre algumas perguntas dos instrumentos avaliativos.

\section{Oficinas sobre Identidade e Turismo}


Além das discussões sobre Patrimônio Cultural, identidades, preconceitos e diversidade cultural, essas oficinas abrangeram também conceitos básicos do Turismo, e tiveram como objetivo o início de um trabalho de sensibilização quanto à atividade turística, buscando debater com a comunidade aspectos negativos do Turismo espontâneo e nãoplanejado, as possibilidades de planejamento estratégico da atividade, ações voltadas para a preservação dos bens patrimoniais, entre outros temas de relevância para a mencionada região. No final de cada oficina foram apresentados os resultados do Programa de Prospecções e Resgate Arqueológico dos Parques Eólicos, a metodologia de pesquisa da Arqueologia e o kit de peças arqueológicas. As oficinas tiveram como público profissionais dos setores de transporte, alimentação, hospedagem, poder público, representantes da comunidade, de organizações não governamentais, professores e alunos.

\section{Oficinas sobre Construcão de Imagem Turística}

O objetivo dessas oficinas foi fomentar a reflexão sobre a imagem que se quer dos municípios e como planejá-la a curto, médio e longo prazo. Foram analisadas as imagens atuais dos municípios, os bens patrimoniais culturais e arqueológicos, o aproveitamento dos fluxos de visitantes e os resultados prévios do Inventário da Oferta Turística. Estimulou-se a participação das comunidades na execução da proposta de Inventariado. O público-alvo se compôs de funcionários dos Conselhos de Cultura municipais, representantes dos diferentes setores envolvidos com a atividade turística local, poder público e lideranças comunitárias. Foram aplicados os instrumentos avaliativos em todas as oficinas.

Vale ressaltar que, diferentemente das demais propostas nas quais a Parte Expositiva 1 foi voltada para uma discussão sobre identidade, diversidade cultural e preconceito, as Oficinas sobre Construção de Imagem Turística foram iniciadas com a apresentação da Arqueologia e dos trabalhos arqueológicos realizados no âmbito do programa na região. A inversão se explica porque se mostrou necessário um esclarecimento prévio sobre a Arqueologia e as atividades das equipes de pesquisadores, com o objetivo de se criar desde o início da atividade um elo de ligação entre os bens patrimoniais arqueológicos e os demais bens culturais. Esse vínculo era importante para que fosse possível pensar o Turismo e o planejamento turístico no decorrer da oficina de forma a levar em conta os diferentes bens patrimoniais da região, incluindo os bens arqueológicos.

Para cada uma das oficinas e das palestras programadas foram elaboradas apresentações diferenciadas, de acordo com o público-alvo e os contextos municipais. No 
município de Caetité foram realizadas sete oficinas: duas sobre Identidade e Patrimônio para professores, três sobre Identidade e Patrimônio para a comunidade, uma sobre Identidade e Turismo e uma sobre Construção de Imagem Turística. No município de Igaporã foram realizadas oito oficinas: três sobre Identidade e Patrimônio para professores, três sobre Identidade e Patrimônio, uma sobre Identidade e Turismo e uma sobre Construção de Imagem Turística. Em Guanambi, foram realizadas quatro oficinas; uma sobre Identidade e Patrimônio para professores, uma sobre Identidade e Patrimônio para a comunidade, uma sobre Identidade e Turismo e uma sobre Construção de Imagem Turística (Prancha 7).

Ainda durante a segunda etapa de campo foram realizadas as visitas técnicas dos professores aos sítios arqueológicos selecionados. Os professores de cada cidade visitaram apenas um sítio arqueológico, em função do tempo reduzido e dos custos da visita técnica. Assim, a definição de qual dos dois sítios seria visitado se deu levando-se em considerando a proximidade da cidade da área dos sítios.

Os sítios arqueológicos Morro do Jacaré e Pajeú foram preparados para as visitas técnicas. A preparação envolveu melhorias nas condições de acesso em ambos os sítios, bem como de acessibilidade até o local, e foi realizada por moradores das proximidades dos sítios como forma de iniciar uma sensibilização quanto a esses bens patrimoniais (Pranchas 8).

O Sítio Arqueológico Morro do Jacaré foi visitado pelos professores de Caetité e de Igaporã. Após chegarem ao local os participantes foram reunidos defronte à pedreira em que vem sendo efetuada a extração ilegal de arenito. Inicialmente os professores foram instruídos com algumas informações sobre a visita e sobre procedimentos de segurança e tiveram um tempo para tirar fotos da área de entorno do sítio. O tempo para fotografias serviu para propiciar aos visitantes a oportunidade de prestar atenção tanto à paisagem do local como à descaracterização do cenário causada pela extração ilegal e pelos desmatamentos.

Em seguida foram propostas discussões relacionadas ao impacto das atividades extrativistas e sua importância para a sobrevivência das famílias, sobre o papel dos sítios arqueológicos no contexto presente em que estão inseridos e das ações educativas com a comunidade do entorno. Alguns professores ressaltaram que a visitação de um grupo de docentes ou alunos ao local poderia fazer com que a comunidade e os trabalhadores da pedreira olhassem com outros olhos para o sítio, constatando que pessoas de fora estão visitando o local justamente por julgarem que se trata de uma área de importância para o município. Uma professora mencionou que provavelmente os filhos das pessoas que trabalham na pedreira eram alunos de alguns deles, e refletiram sobre como trabalhar essas questões em sala de aula. 


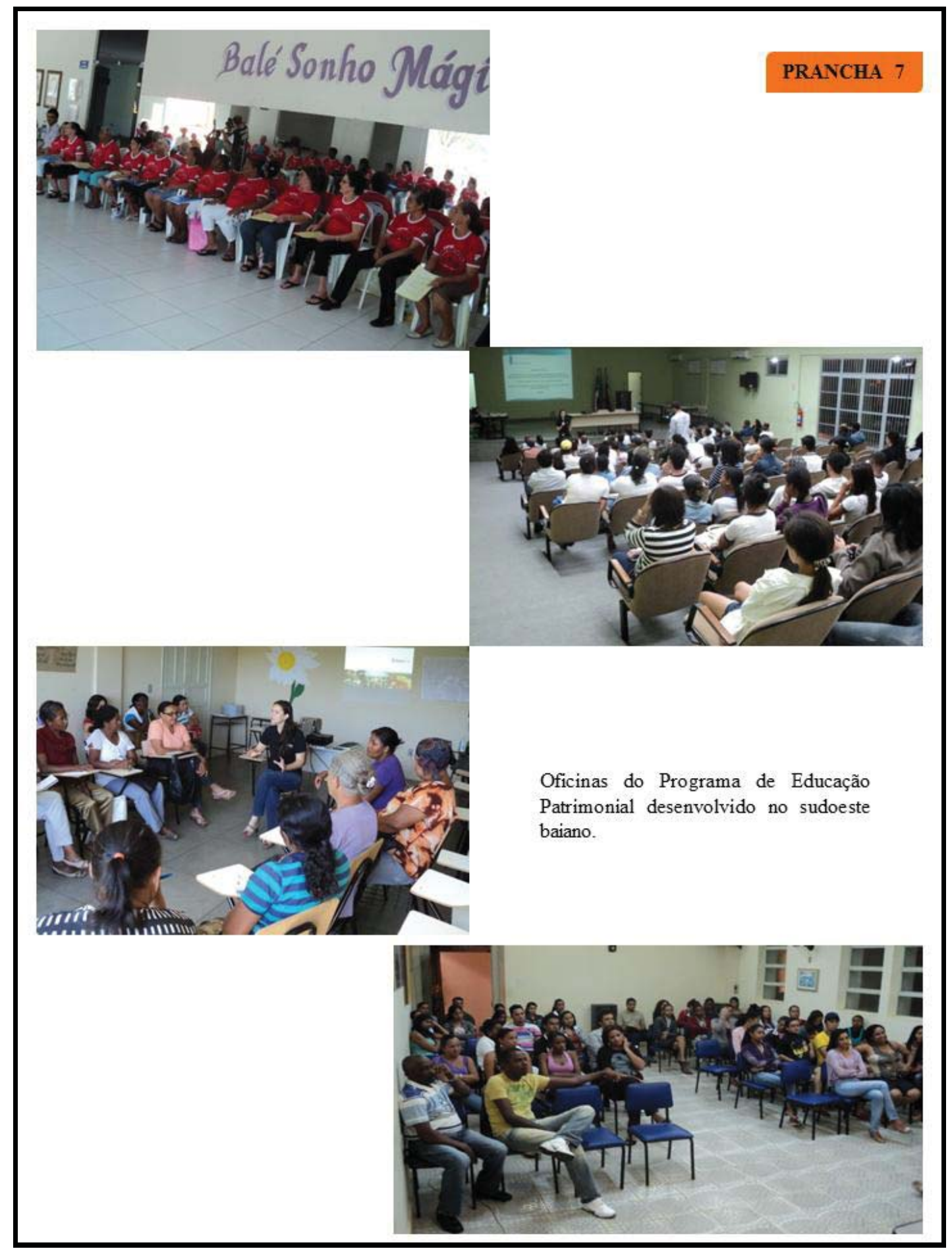




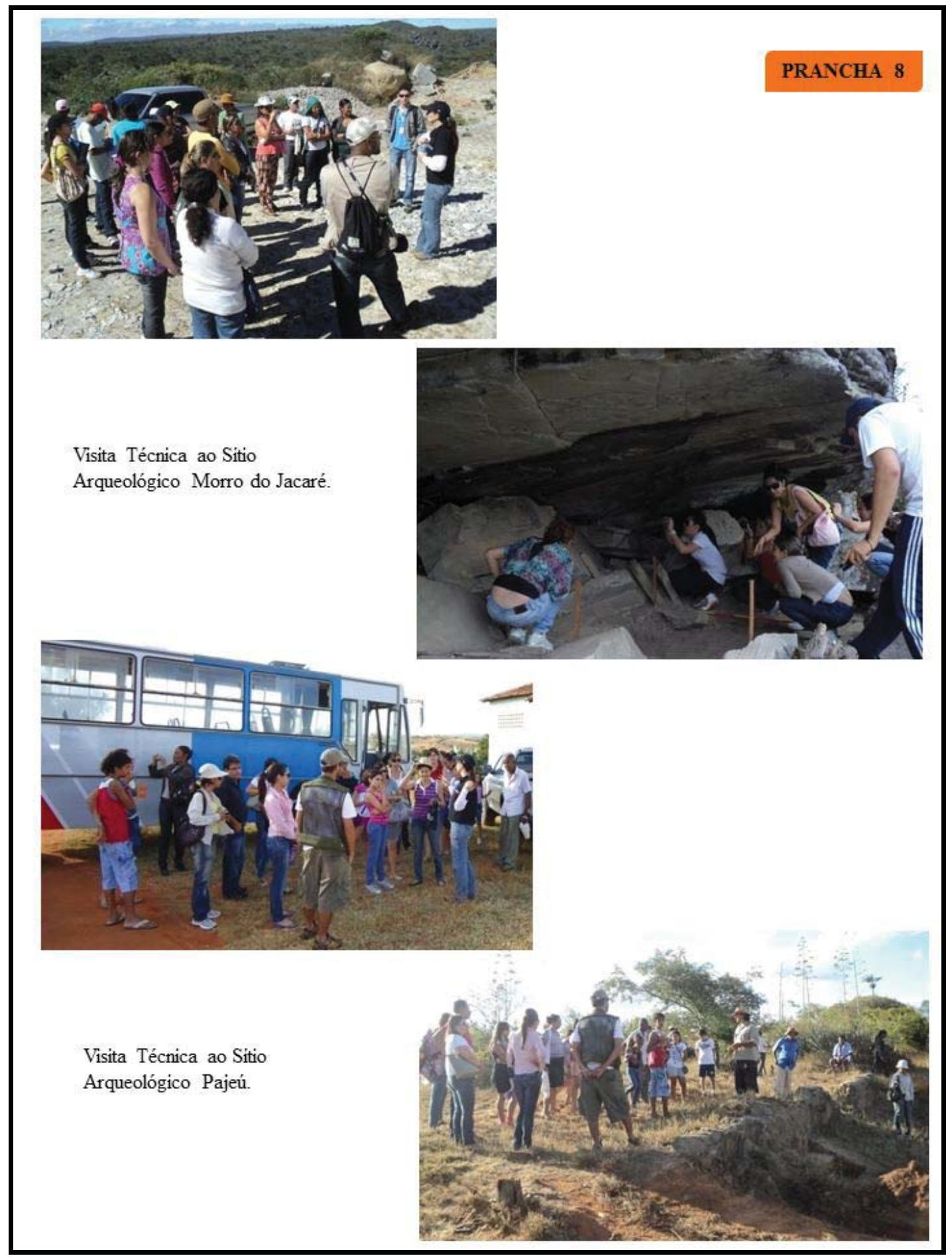


Os docentes falaram também sobre a experiência do Turismo, que não se limita a sair e visitar algum lugar, mas envolve preparativos, escolha do transporte e dos acessos, formação dos grupos, preparação dos sítios, entre outros aspectos. A discussão foi proposta pela mediadora como forma de gerar reflexões sobre o Turismo como uma atividade ampla, que não está relacionada apenas à visitação, mas requer um planejamento estratégico dentro dos preceitos da sustentabilidade. Também se discutiu a necessidade de uma sensibilização prévia à visitação.

A equipe de arqueólogos explanou sobre o Projeto de Prospecções e Resgate Arqueológico e sobre a metodologia do trabalho de campo utilizada pelas equipes da Zanettini Arqueologia. Foram realizados exercícios de leitura da paisagem, por meio dos quais se evidenciaram alterações no decorrer do tempo.

Os participantes foram divididos em grupos, pois como o abrigo é pequeno não comportaria uma única visitação. Ao visitar o abrigo cada grupo recebeu orientações quanto aos trabalhos realizados no local, sobre a forma de compreender as pinturas - por exemplo, sua disposição no suporte rochoso, formas e métodos de datação, matérias-primas utilizadas em sua confecção - e sobre aspectos relacionados à interpretação de arte rupestre.

No final os professores encetaram uma série de discussões sobre como transcorreu a visita, sobre o Programa de Educação Patrimonial e as possibilidades de sua continuidade, sobre a visitação a sítios arqueológicos, o planejamento participativo do Turismo, bem como sobre a importância de conhecer pessoalmente um sítio arqueológico para compreender seu papel educativo e valorizá-lo como bem cultural. Vários professores mencionaram que a partir daquela visita suas aulas sobre a temática seriam completamente diferentes. O que atesta a eficácia da proposta educativa de visitação de multiplicadores aos sítios arqueológicos.

A visita técnica ao Sítio Arqueológico Pajeú foi realizada com um grupo de Guanambi. Diferentemente das visitas dos outros municípios, agora o público participante não era formado apenas por professores, mas também por crianças e pessoas da comunidade em geral. Após chegada ao local os visitantes ouviram algumas informações básicas de segurança e foi discutida a diferença entre passeio e visita técnica. A explicação se fez necessária uma vez que o grupo era heterogêneo e nem todos haviam sido previamente sensibilizados, pois não haviam participado da oficina.

Em seguida foram apresentadas a proposta da visita técnica e as ações do Programa de Educação Patrimonial. Durante a breve caminhada até o Sítio Pajeú os participantes fizeram questionamentos sobre Arqueologia, a metodologia de trabalho, a importância dos sítios de interesse históricos, as diferenças da vida no local em períodos diversos, entre outros tópicos. 
Ao chegarem ao sítio os visitantes foram recebidos por vários membros da comunidade do Pajeú do Josefino, que passaram a integrar a visita técnica. Os arqueólogos apresentaram os trabalhos arqueológicos ainda em eamento no local e discorreram sobre a metodologia de trabalho aplicada ao contexto. Realizou-se uma leitura participativa, em que os arqueólogos, os participantes e os moradores locais dos alicerces leram trechos de parede e do montículo de casa de adobe colapsada. Houve comentários sobre a distância e a relação entre a casa e o açude localizado nas proximidades da propriedade, sobre a formação do bairro em que o sítio está situado e a importância do sítio para a compreensão da história da localidade. O grupo buscou comparar as informações levantadas pelas escavações às informações orais dos moradores e também às informações contidas no livro da historiadora Terezinha Santos, filha de um antigo proprietário do local, que levou algumas peças para expor na cidade. Um dos moradores mostrou para os participantes as ruínas da antiga casa de farinha. Os visitantes, a partir do conhecimento prévio que tinham dessas construções, puderam discutir a localização dos diversos elementos do tipo de unidade produtiva no espaço.

No final da visita os professores puderam caminhar pelo sítio identificando material arqueológico no solo, sob a supervisão dos pesquisadores. Também foi realizada uma rodada de discussões sobre a visita, sobre o Turismo e sobre os sítios arqueológicos como bens culturais.

O perfil dessa visita foi bem diferenciado em comparação às visitas realizadas nos outros municípios. Porém, o saldo foi positivo, pois demonstrou aos professores presentes e ao grupo de arqueólogos que a visitação deve ser alterada — em linguagem e conteúdo — de acordo com o público visitante. A participação das crianças, tanto as visitantes como as moradoras do local, foi de extrema importância para a análise da acessibilidade e para uma melhor percepção do conteúdo trabalhado. Elas se mostraram participativas, em especial no momento em que foi proposta a localização de peças no solo. Vale ressaltar que uma delas, no final da visita, afirmou: “Agora quero ser arqueóloga quando crescer”, o que atesta a eficácia do trabalho de sensibilização quanto à Arqueologia e à valorização do trabalho do arqueólogo, ambos elementos básicos do trabalho educativo em programas de Arqueologia. A participação dos moradores e a sua interação com os visitantes demonstraram o interesse com relação ao sítio arqueológico e às possibilidades de visitação. Essa participação só foi possível devido ao perfil do trabalho arqueológico que a equipe estava realizando no local, um trabalho proposto de forma horizontal, favorecendo o diálogo, valorizando o conhecimento das comunidades em suas narrativas. 
Assim, as visitas possibilitaram debates sobre a Arqueologia, a metodologia de trabalho do arqueólogo em campo, o patrimônio arqueológico, as diferentes narrativas existentes sobre o passado, sobre formas de leitura da paisagem e possibilidades de ações preservacionistas para os bens patrimoniais dos municípios. As visitas técnicas também criaram condições para análises sobre a visitação turística aos sítios e sobre a importância do Inventário Turístico para o planejamento estratégico de atrativos.

Durante a segunda etapa de campo foram realizadas ainda palestras para diferentes públicos, como forma de atender às demandas surgidas a partir das atividades realizadas na primeira etapa de intervenção. As palestras foram concebidas para grupos com número de participantes ilimitado, e pensadas de acordo com as faixas etárias que seriam abrangidas, em especial com o uso de imagens. A avaliação das palestras se deu de diferentes maneiras. Para as palestras em que a presença de analfabetos era grande foi utilizada a "metodologia da pergunta” para identificar tanto o conhecimento prévio dos participantes quanto o conhecimento adquirido. Também foi importante avaliar o grau de permanência dos participantes nas atividades. Já para o público com educação formal elaborou-se um instrumento cujos resultados serão apresentados no decorrer deste capítulo (Prancha 9).

As palestras tiveram dois eixos temáticos diferentes:

\section{$\underline{\text { Palestras sobre Identidade e Patrimônio }}$}

As palestras buscaram estimular reflexões sobre os antepassados dos participantes, a diversidade cultural no passado e no presente, o preconceito, o patrimônio cultural, a preservação, as identidades locais e sobre a morte. A partir de discussões sobre os patrimônios pessoais estimulou-se um debate sobre bens patrimoniais culturais e o patrimônio arqueológico e sua diferenciação do patrimônio paleontológico. Vale ressaltar que as pesquisas paleontológicas eram constantemente associadas às pesquisas arqueológicas, em especial devido a uma telenovela da Rede Globo cuja personagem principal era uma paleontóloga, o que fez com que as discussões de diferenciação das áreas se tornassem extremamente necessárias.

Outra temática inserida nas palestras sobre Identidade e Patrimônio foi a morte. A inclusão do tema se deveu à afirmação de um dos docentes participantes da oficina sobre Identidade e Patrimônio que não conseguia visualizar de que maneira a Arqueologia poderia contribuir com elementos que auxiliassem os professores a trabalhar com o tema da morte em sala de aula. Assim, a palestra foi alterada para atender à demanda dos docentes da região. 


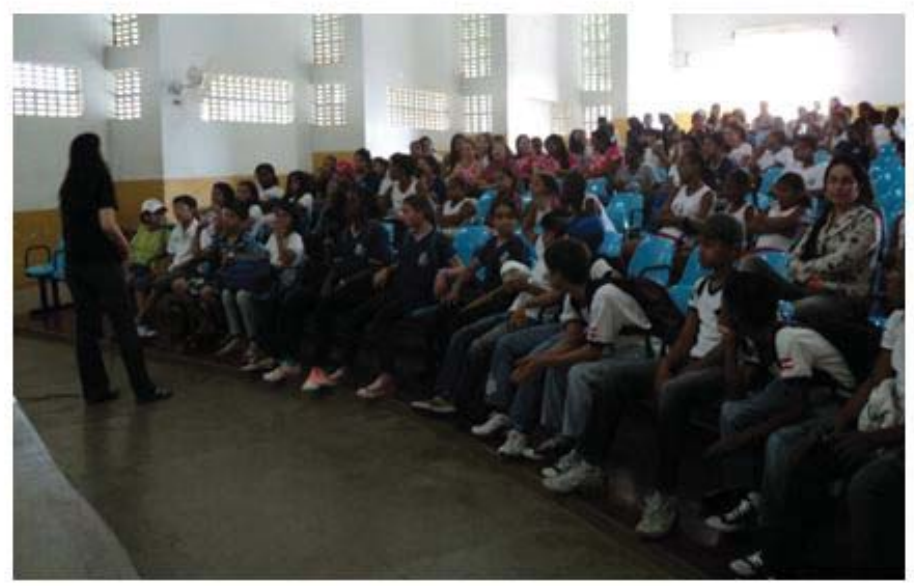

PRANCHA 9

Palestras do Programa de

Educação Patrimonial

desenvolvido no sudoeste baiano.
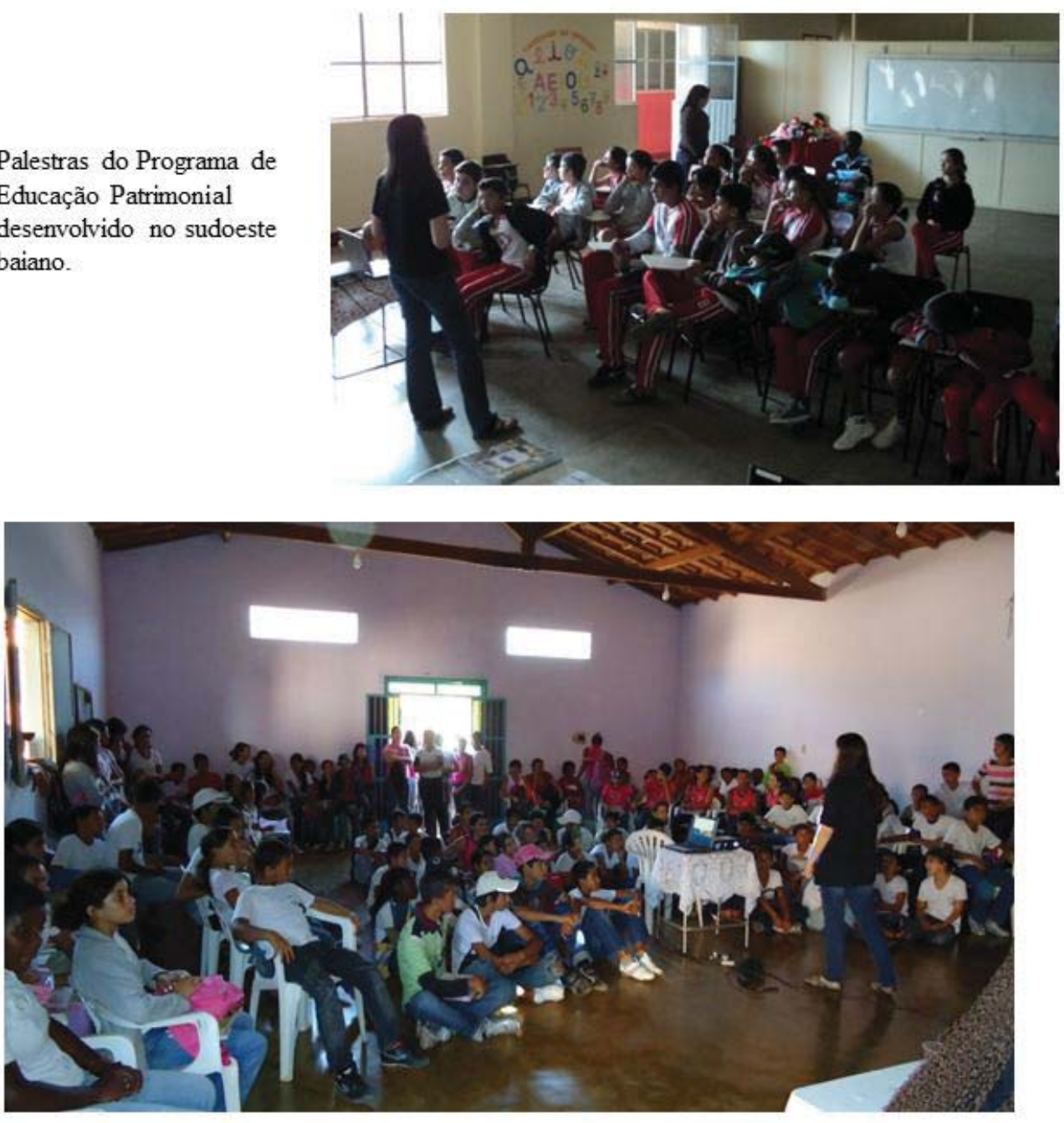
A apresentação mostrou diferentes formas de sepultamentos de diferentes povos e em épocas distintas, o que possibilitou ainda uma reflexão sobre a diversidade cultural. No final das palestras foi apresentado o kit de peças arqueológicas.

\section{Palestra sobre Identidade e Turismo}

Aqui o objetivo foi a sensibilização quanto ao uso qualificado dos patrimônios culturais locais e quanto à atividade turística. Foram discutidos aspectos negativos e positivos da atividade, alguns conceitos de planejamento turístico, possibilidades de ações de capacitação de mão de obra e preservação do patrimônio cultural e natural. Também foi uma oportunidade de apresentação da Arqueologia e dos resultados do Programa de Prospecção e Resgate na região. Essa palestra se deu no município de Guanambi, com aproximadamente uma centena de participantes. Como se tratava de um grupo heterogêneo, não foi possível a avaliação formal da atividade.

\section{AVALIAÇÃO DAS ATIVIDADES REALIZADAS ${ }^{5}$}

Levando em consideração que a avaliação constitui um importante elemento para projetos educativos, em especial aqueles que são pensados e realizados em conformidade com preceitos participativos, o Programa de Educação Patrimonial, Arqueologia e Turismo Cultural envolveu a criação de instrumentos avaliativos específicos para cada tipo de ação as diferentes oficinas, palestras, atividades aplicadas pelos docentes e trabalhos de alunos integrante do programa.

\section{Avaliação das Oficinas sobre Identidade e Patrimônio para Professores}

Os instrumentos avaliativos das Oficinas sobre Identidade e Patrimônio para professores foram elaborados contendo questões dissertativas e de múltipla escolha. Ambos os instrumentos continham questões semelhantes, porém no Pós-Curso foram acrescidas algumas perguntas mais direcionadas às temáticas de interesse do programa. As questões dos instrumentos abrangiam:

\footnotetext{
${ }^{5}$ Vale ressaltar que todas as citações descritas neste item foram retiradas do Relatório Final do programa, elaborado pela Zanettini Arqueologia (2011b).
} 
- perguntas básicas quanto ao nível de escolaridade, à área de formação acadêmica, às disciplinas lecionadas pelos professores, à escola por eles representada e à idade;

- as temáticas de interesse do programa - Localidade, Identidade e Cultura, Arqueologia, Patrimônio Cultural, Educação Patrimonial e Turismo Cultural; solicitou-se que os participantes avaliassem seus conhecimentos sobre cada tema de acordo com os conceitos Ótimo, Bom, Regular ou Ruim;

- os elementos de ordem econômica, social, histórica ou natural dos quais os participantes se orgulhavam e os que não admiravam em sua cidade;

- as expectativas dos docentes com relação às Oficinas, e se possuíam as habilidades suficientes para trabalhar em sala de aula questões relativas às temáticas discutidas;

No Pós-Curso foram acrescidas questões cujo intuito era saber:

- se a oficina para professores atendeu às expectativas e como os docentes pretendiam multiplicar o conteúdo de Arqueologia e ao patrimônio cultural;

- se o Turismo Arqueológico é uma proposta interessante para levar à comunidade o conhecimento sobre Arqueologia.

A seguir são apresentadas informações de interesse para esta tese, levantadas pelos instrumentos avaliativos.

O instrumento avaliativo Marco Zero apontou que antes das oficinas os elementos dos municípios que eram valorizados pelos participantes eram: algumas praças, festas populares, esportes, instituições culturais como a Casa de Dona Dedé, a Casa Anísio Teixeira e o arquivo público municipal de Caetité, igrejas, marcos históricos dos municípios, projetos sociais, a educação, a agricultura, os rios, a solidariedade e o acolhimento do povo, a limpeza pública, a localização, a segurança, o clima, as riquezas minerais, o comércio, entre outros. No instrumento Pós-Curso, as respostas para a mesma questão evidenciaram uma maior atenção com relação aos sítios arqueológicos e para os bens patrimoniais culturais, em especial os não relacionados às elites dos municípios. Dentre os elementos adicionados estão: o reisado, a festa de Santana, as tradições culturais, a religião, o patrimônio histórico, o patrimônio arqueológico, a Via Sacra, a manufatura de farinha, a feira livre, a origem dos nomes das cidades, os contadores de história, a fé, o Turismo, a identidade cultural, os sítios arqueológicos, entre outros. O que atesta não apenas a valorização de outros bens, mas a inserção do patrimônio arqueológico nas discussões sobre patrimônio local.

Os principais elementos negativos dos municípios citados pelos professores no Marco Zero foram: a política, a corrupção, as desigualdades econômica e social, o clima, a poluição, 
o trânsito, o desemprego, o lixo, as queimadas, o sistema de saúde, o pouco investimento na preservação ambiental e histórica, a inexistência de ações de preservação ambiental, a desorganização da feira, o esgoto, a desvalorização do patrimônio público, a desvalorização da educação, as poucas opções de lazer, as drogas, a prostituição, o desemprego, entre outros. Já no instrumento Pós-Curso pôde-se notar que grande parte dos participantes demonstrou maior preocupação com questões culturais tais como: a desvalorização e a falta de incentivo à cultura e aos aspectos históricos, a falta de investimentos e de preservação dos patrimônios culturais, o desrespeito às diferentes identidades culturais locais, a destruição dos prédios antigos, o desconhecimento e a destruição dos sítios arqueológicos, a ausência de uma política cultural, a escassez de material para trabalho em sala de aula, entre outros. Também foi possível notar uma maior apropriação dos bens culturais, demonstrada em frases como "Falta de valorização e reconhecimento do nosso patrimônio” (2011b: 170), o que não havia sido evidenciado nos instrumentos Marco Zero.

Quando questionados sobre como pretendiam multiplicar o conteúdo referente à Arqueologia, ao Patrimônio Cultural e ao Turismo, os professores responderam que isso se daria por meio de pesquisas, debates, utilização do material oferecido por parte dos mediadores, oficinas práticas em sala de aula, trabalhando com a realidade dos alunos, ações com a comunidade escolar, exposição de imagens, trabalhos de campo, exposições orais e estudo dirigido do tema. Algumas colocações dos professores: “Colocando em prática tudo o que aprendi, porque o interessante é passar informações, isto é, colocar na prática, não deixando só no papel”, "Explorando o material recebido e adequando as informações adquiridas para utilizá-las em sala de aula” e "Com meus alunos e meus filhos, pois precisamos conhecer e respeitar a nossa história”. Nota-se também o uso de termos como o pronome possessivo “nosso”, que não haviam sido utilizados no Marco Zero.

Em questão específica sobre o Turismo Arqueológico os participantes, em sua grande maioria, responderam que a atividade seria interessante para divulgação dos bens arqueológicos. Afirmaram que geraria conhecimento, apropriação, valorização e preservação. É importante destacar que alguns professores ressaltaram a importância do planejamento responsável, para que o Turismo traga mais benefícios do que problemas para a comunidade. Alguns depoimentos: "Sim, para a comunidade conhecer e valorizar seu patrimônio tirando proveito dele sem destruí-lo"; "Pois proporciona que os alunos, através do contato com os locais, desenvolvam o sentimento de necessidade de conservação e valorização dos mesmos”; "Sim, mas é necessário também prever os possíveis impactos negativos desse Turismo. Isso pode futuramente ser praticado sem controle e sem consciência, podendo trazer prejuízos”; 
"Sim, até para contribuir para a preservação da cultura isso se for bem estruturado”, "Sim, só se respeita o que conhece”, “Claro, o Turismo Arqueológico certamente oportunizará um conhecimento mais amplo do patrimônio histórico da região", "Sim, pois pode contribuir com a economia do município" e "Sim, porque através dessa atividade a comunidade 'desperta' para o valor da cultura local/patrimônio cultural”.

Houve ainda uma questão formulada com o intuito de aferir se a oficina havia atendido às expectativas dos docentes. Todos os professores responderam que sim, e justificaram suas respostas falando em especial sobre os conhecimentos que haviam adquirido durante a ação educativa. Alguns comentários interessantes: "Aprendi muito a respeito do assunto abordado", "Ampliou meus conhecimentos e fez aflorar ideias para o trabalho em sala de aula"; "Conheci um pouco mais da história e do patrimônio cultural amplo de meu município"; "Fez pensar sobre os nossos antepassados”; "Proporcionou uma percepção sobre a identidade de forma mais ampla, bem como dos bens patrimoniais do município e seu acervo arqueológico, nos dando outra visão de preservação"; e "Porque me possibilitou uma nova visão acerca de questões relativas ao Turismo cultural”. As respostas comprovam a aceitação da ação educativa e das temáticas trabalhadas, demonstrando que as oficinas alcançaram os objetivos propostos.

\section{$\underline{\text { Avaliação das Oficinas sobre Identidade e Patrimônio para a Comunidade }}$}

Os instrumentos avaliativos das Oficinas sobre Identidade e Patrimônio para a comunidade também foram elaborados contendo questões de múltipla escolha e dissertativas. As questões dos instrumentos abrangiam:

- perguntas básicas quanto ao nível de escolaridade, à área de formação acadêmica, às disciplinas lecionadas pelos professores, à escola por eles representada e à idade;

- as temáticas de interesse do programa — Localidade, Identidade e Cultura, Arqueologia, Patrimônio Cultural, Educação Patrimonial e Turismo Cultural; solicitou-se que os participantes avaliassem seus conhecimentos sobre cada tema de acordo com os conceitos Ótimo, Bom, Regular ou Ruim;

- os elementos de ordem econômica, social, histórica ou natural dos quais os participantes se orgulhavam e os que não admiravam em sua cidade;

- a existência de patrimônios culturais na cidade e se esse patrimônio representava os diversos segmentos da sociedade;

- as expectativas com relação à oficina. 
No Pós-Curso, perguntou-se:

- se a oficina atendeu às expectativas;

- quais bens patrimoniais poderiam representar a diversidade cultural da região.

- se o Turismo Arqueológico era uma proposta interessante para levar à comunidade o conhecimento sobre Arqueologia.

O instrumento avaliativo Marco Zero apontou que antes da oficina os principais elementos dos municípios dos quais os participantes se orgulhavam eram: a Casa dos Escravos, a igreja Matriz, as Festas Juninas, a prática de esportes, o reisado, a igreja Nossa Senhora do Livramento, a religião, a boa qualidade das águas, a pecuária, o comércio, a educação, o clima, o Parque da Cidade, o Acarajé, a Casa de Dona Dedé, a Pedra do Índio, as festas, o Bolsa-Família, a Praça do Feijão, as creches, áreas para esportes, a paisagem, o passeio ciclístico, a Festa da Camiseta, a música, a dança, a Leocádia, a família, o Movimento de Mulheres, a Associação do Sapé, Waldick Soriano, entre outros. O documento Pós-Curso demonstrou que alguns elementos que antes não haviam sido citados passaram a ser valorizados, caso de: Boi de Idalino, a Festa de Santana, os Cruzeiros, os diferentes tipos de casas, as comidas, o Patrimônio Material e Imaterial, "nossa história”, os sítios arqueológicos, os casarões antigos, o artesanato, o conhecimento dos mais velhos, entre outros. É interessante destacar que em uma oficina de Caetité, aproximadamente 50\% dos participantes não souberam citar no Marco Zero pontos positivos do município. No instrumento Pós-Curso todos os participantes elencaram pelo menos um aspecto positivo, o que demonstra a valorização dos bens locais.

Os principais elementos negativos citados no primeiro instrumento avaliativo foram: o alto índice de analfabetismo e do desemprego, a inexistência de um museu e um teatro, a falta de engajamento e responsabilidade social das empresas mineradoras, a Micareta, a Festa do Ralo, o aumento da violência, as drogas, evasão das pessoas para São Paulo para trabalhar no corte de cana, a poluição, o descaso das autoridades, as pessoas de fora trazendo mudanças, entre outros. No instrumento Pós-Curso pôde-se notar que grande parte dos participantes demonstrou maior preocupação com questões como: o preconceito acerca da diferença, a derrubada dos antigos casarões, a inexistência de incentivo ao Turismo Cultural, o esquecimento das técnicas de construção das casas de pau a pique, as poucas oportunidades de lazer, a falta de sensibilização da comunidade quanto ao patrimônio cultural, a falta de incentivo à produção de cachaça artesanal, a falta de diálogo entre as gerações, a pouca 
importância dada à preservação, a ausência de cuidado com os sítios arqueológicos, casas de farinha antigas, artesanatos, o carro de boi, a colher de pau, os benzedeiros, as ladainhas em latim, entre outros.

Quando solicitado que os participantes citassem bens patrimoniais que poderiam representar a diversidade cultural da região, foram mencionados: os reisados, a alvorada, peças de cerâmica, casas de pau a pique, casas de tijolo, casas de pedra, a Casa dos Escravos, as pinturas rupestres, os objetos utilizados pelos antepassados, o engenho de carne feito de madeira, a casa de farinha ("onde eu nasci, porque lá faz um alimento que o povo baiano gosta, a farinha”), as brincadeiras de criança, a comida, entre outras.

Quanto ao Turismo Arqueológico, a grande maioria dos participantes considerou que a atividade turística é uma proposta interessante para levar até a comunidade o conhecimento sobre Arqueologia, divulgando os bens patrimoniais, gerando o reconhecimento, a valorização e a preservação. Alguns depoimentos: "Hoje pudemos ter a oportunidade de saber o quanto algo que julgávamos sem importância pode ser tão precioso"; "Sim, porque é uma forma de conhecer e reconhecer os nossos recursos arqueológicos além do compartilhamento dos conhecimentos”; “Sim, porque só aprendemos a valorizar uma coisa quando alguém diz que é bom ou bonito"; "Precisamos mudar nosso conceito com relação ao Turismo"; "Sim, afinal a Arqueologia pode ajudar a desenvolver a região que tem esta necessidade”; e "Porque ajuda a conhecer o passado e a entender o presente”.

No que se tange a saber se a oficina havia atendido às expectativas, todos responderam que sim. Alguns comentários: "Nos levou a analisar e refletir sobre nossa própria identidade e reconhecer a história da nossa vida”; "Porque aprendi o que é Turismo Arqueológico”; "Porque fez com que eu me informasse sobre os recursos arqueológicos, além de saber que na nossa região havia vida desde seis mil anos atrás"; "Pois abriu o meu olhar para novas experiências em sociedade, através dos conhecimentos adquiridos"; e "Fez com que me interessasse a pesquisar a respeito dos meus antepassados”. A oficina se mostrou eficaz, pois conseguiu transmitir as informações básicas propostas para os participantes, tornando-os multiplicadores.

\section{$\underline{\text { Avaliação das Oficinas sobre Identidade e Turismo }}$}

As questões dos instrumentos avaliativos preparados para as Oficinas sobre Identidade e Turismo abrangiam: 
- perguntas básicas quanto ao nível de escolaridade, à área de formação acadêmica, às disciplinas lecionadas pelos professores, à escola por eles representada e à idade;

- as temáticas de interesse do programa - Localidade, Identidade e Cultura, Arqueologia, Patrimônio Cultural, Educação Patrimonial e Turismo Cultural; solicitou-se que os participantes avaliassem seus conhecimentos sobre cada tema de acordo com os conceitos Ótimo, Bom, Regular ou Ruim;

- os elementos de ordem econômica, social, histórica ou natural dos quais os participantes se orgulhavam e os que não admiravam em sua cidade;

- a existência de patrimônios culturais na cidade e se esse patrimônio representava os diversos segmentos da sociedade;

- as expectativas com relação à oficina;

- a percepção do participante sobre o potencial turístico do município.

No Pós-Curso, perguntou-se:

- se a oficina atendeu às expectativas;

- quais bens patrimoniais poderiam representar a diversidade cultural da região;

- se o Turismo Arqueológico era uma proposta interessante para levar o conhecimento sobre Arqueologia para a comunidade;

- se o município estava estruturado para receber visitantes.

Os motivos de orgulho apontados pelos participantes foram: a criatividade do povo, as manifestações culturais, as antigas gincanas, a Cachoeira do Brejo, a Casa de Pedra, as Festas Juninas, as igrejas, as praças, o Lago da Gameleira, as Comunidades quilombolas, a natureza, o Espaço Cultural, a feira livre, as Vias-Sacras, as comidas, a hospitalidade, o clima agradável, o solo fértil, a educação, a Casa de Anísio Teixeira, os morros, entre outros. No instrumento Pós-Curso, as respostas para a mesma questão evidenciaram a valorização de outros elementos que não apenas os apontados no Marco Zero, tais como: a cultura popular, as festas, o artesanato, o reisado, as narrativas da localidade, o cemitério da volta da estrada, as pinturas rupestres e sítios arqueológicos, a riqueza de vestígios do passado, o povo, entre outros.

Os pontos negativos elencados foram: o desemprego, questões políticas, ações municipais sem continuidade, o clima, falta de opções de lazer, drogas, má distribuição de renda, o descaso com a cultura, o não desenvolvimento turístico, o desconhecimento dos antepassados ou fundadores, as desigualdades, o preconceito, o aumento do alcoolismo, o 
mercado de trabalho restrito, o custo de vida elevado, as empresas que exploram o meio ambiente. Já no instrumento Pós-Curso pôde-se notar que grande parte dos participantes demonstrou maior preocupação com a desvalorização da cultura regional, a falta de informação sobre os bens patrimoniais, o desconhecimento por parte da comunidade e governantes, a falta de um museu e o desemprego, a ignorância da população que não sabe preservar, a não valorização da pluralidade, o descaso com a cultura, a falta de respeito com os pontos turísticos, a não valorização da identidade, a demolição de casarões, o preconceito, entre outros. Vale notar que grande parte das respostas girou em torno da preocupação com bens patrimoniais, o que demonstrou que a oficina sensibilizou os participantes quanto à importância da preservação.

Quando questionados sobre os bens patrimoniais e sua representação da diversidade cultural da região, os participantes mencionaram: as festas juninas e religiosas, as comunidades quilombolas, a arte rupestre, as rezas, as casas antigas, as barragens, os festejos, a culinária, os reisados, a Casa de Pedra ("porque mostra de certa forma como os escravos viviam”), as casas simples, os sítios arqueológicos, o terno de reis, a dança, a música, o artesanato ("porque demonstra o modo de vida da comunidade"), as narrativas da oralidade local, o patrimônio imaterial (“que parece possuir um alto potencial turístico”), entre outros.

Quanto ao potencial turístico do município, a questão do Marco Zero obteve respostas positivas e negativas, conforme atestam alguns depoimentos: "Sim, devido às riquezas culturais ainda por serem descobertas"; "Não, porque em nossa cidade não tem muitas opções turísticas”; "De verdade, não”; “Não, porque o nosso município não possui muitos pontos turísticos"; "Sim, tanto no espaço urbano quanto rural”; "Sim, pois há muitas casas antigas, paisagens naturais que chamam atenção”; "Sim, porque em determinada época do ano já recebe certo número de visitantes”; e "Não, pois faltam mais investimentos em estadia para acolher turistas”. Vale ressaltar que os participantes que responderam "não" alegaram a ausência de infraestrutura para a recepção de visitantes. Já no Pós-Curso a maioria dos participantes respondeu que a seu ver os municípios possuíam potencial turístico, como atestam as seguintes falas: "Sim, possui diversos patrimônios que são poucos conhecidos"; "Sim, o povo tem sede de se transformar e buscar novidades para o nosso município"; "Sim, basta ter investimento e conscientização"; "Sim, pois nele há diversos pontos que podem ser explorados por aqueles que buscam algo novo, que têm motivação para conhecer”; “Sim, porque há localidades que podem ser revistas com outro olhar”; "Não, no momento não, mas pode ser que a partir deste projeto isso aconteça”; "Sim, porém faltam consciência e desenvolvimento de projetos voltados para a área"; e "Sim, porque o curso 
deixou claro que Turismo não é só viajar para conhecer determinado lugar”. Os participantes que responderam negativamente alegaram ausência de infraestrutura e incentivos.

Quando questionados se o Turismo Arqueológico seria uma proposta interessante para levar à comunidade o conhecimento sobre Arqueologia, em sua maioria os participantes responderam que sim: "Sim, pois através do Turismo Arqueológico as pessoas passam a ter uma nova visão sobre a Arqueologia"; "Sim, pois assim as pessoas valorizam um patrimônio que durante muito tempo permaneceu desconhecido"; "Sim, pois com isso traz informações e conhecimentos sobre nossa cultura desde os tempos passados até nossos dias atuais"; "Sim, porque através dessa realidade poderá se difundir o conhecimento arqueológico e otimizar o seu uso em prol da comunidade"; "Sim, leva o turista a ver aquilo que normalmente não enxerga no dia a dia normal”; "Talvez seja a contrapartida para não haver o desaparecimento de sítios tão relevantes para a região"; e "Sim, porque a troca de experiências vai levar conhecimentos não só sobre a Arqueologia, mais sobre a história dos antepassados que viveram por lá”. A mudança de olhar dos participantes com relação ao Turismo demonstrou que a oficina atingiu seu objetivo, em especial quanto ao Turismo entendido não como deslocamento, mas como uma nova maneira de olhar para seu cotidiano.

No Pós-Curso, quando questionados se a oficina havia atendido às expectativas, $100 \%$ dos participantes responderam que sim. Seguem algumas observações sobre as Oficinas sobre Identidade e Turismo: "Porque eu abri os meus olhos para a parte cultural do nosso município, assim nos leva a valorizar a preservar nossos patrimônios”; “Alargou à minha capacidade de participação consciente"; "Pois serviu como um despertador para a realidade, na qual nos mostrou que não é preciso depender da valorização dos outros para nos interessarmos por nossos tesouros”; “Gostei muito e me fez repensar em como não conheço nada sobre mim mesma”; "Sim, por ter despertado o senso crítico dessa realidade importante”; "Um começo para realizar novas leituras e para envolvimento com a questão”; "Porque várias coisas que tem em nossa cidade eu não conhecia”. As citações demonstram que as temáticas abordadas eram de interesse dos participantes.

Os instrumentos de avaliação evidenciaram de que os participantes passaram a compreender o Turismo como uma possibilidade interessante, que favoreceria o incentivo ao conhecimento, à valorização, à apropriação e à preservação do patrimônio cultural pela comunidade. A atividade turística não foi vista apenas como possibilidade de geração de renda, mas de valorização da diversidade. Deste modo considera-se que as Oficinas sobre Identidade e Turismo atingiram plenamente seus objetivos. 


\section{$\underline{\text { Avaliação das Oficinas sobre Construcão de Imagem Turística }}$}

Finalmente, os instrumentos avaliativos das Oficinas sobre Construção de Imagem Turística abrangeram:

- perguntas básicas quanto ao nível de escolaridade, à área de formação acadêmica, às disciplinas lecionadas pelos professores, à escola por eles representada e à idade;

- as temáticas de interesse do programa - Localidade, Identidade e Cultura, Arqueologia, Patrimônio Cultural, Educação Patrimonial e Turismo Cultural; solicitou-se que os participantes avaliassem seus conhecimentos sobre cada tema de acordo com os conceitos Ótimo, Bom, Regular ou Ruim;

- os elementos de ordem econômica, social, histórica ou natural dos quais os participantes se orgulhavam e os que não admiravam em sua cidade;

- a existência de patrimônios culturais na cidade e se esse patrimônio representava os diversos segmentos da sociedade;

- as expectativas com relação à oficina;

- a percepção do participante sobre o potencial turístico do município.

No Pós-Curso, perguntou-se:

- se a oficina atendeu às expectativas;

- quais bens patrimoniais poderiam representar a diversidade cultural da região;

- se o Turismo Arqueológico era uma proposta interessante para levar até a comunidade o conhecimento sobre Arqueologia;

- se o município estava estruturado para receber visitantes;

- se o município apresentava potencial turístico.

No Pós-Curso, perguntou-se:

- se a oficina atendeu às expectativas;

- sobre o papel de cada um no desenvolvimento turístico municipal.

Os resultados dos instrumentos avaliativos para a questão relacionada aos principais elementos do município dos quais os participantes se orgulhavam foram um pouco diferentes nas Oficinas sobre Imagem Turística. Isso se deu porque muitos participantes já haviam tomado parte de outras oficinas do projeto, o que acarretou um alto número de conceitos trabalhados, bens patrimoniais e arqueológicos citados no Marco Zero, tais como: 
diversidade cultural, o artesanato, a identidade, entre outros. No Pós-Curso, menção interessante foi feita ao Cine Anísio Teixeira, aos Pontos de Cultura, aos "nossos" sítios arqueológicos, à Cadeia velha, ao Quebra-Panela em casamentos, entre outros.

Os pontos negativos elencados pelos participantes no instrumento Marco Zero foram: a inexistência de lugares e possibilidades de lazer, a falta de empregos, a má distribuição de renda, a desvalorização do patrimônio, a violência, a qualidade dos serviços médicos, a política, a ignorância do poder público sobre o potencial do município, a preservação do Túmulo de Leocádia, a Barragem de Ceraíma, a falta de projetos sociais, o abandono do patrimônio cultural, a especulação imobiliária, a pouca valorização das culturas religiosas, a inexistência de uma Secretaria Municipal de Cultura e de políticas culturais, entre outros. Já no Pós-Curso foram adicionados: a inexistência de articulação para o desenvolvimento do Turismo, a não preservação do patrimônio, a ausência de políticas públicas de Turismo, a falta de cuidado com os atrativos turísticos, entre outros.

Indagados sobre os bens patrimoniais que poderiam representar a diversidade cultural da região os participantes mencionaram: a Casa de Pedra ("porque é um patrimônio antigo do município e tem uma história muito interessante”), a igreja, os casarões históricos, as praças, os sítios arqueológicos, os festejos juninos, artesanato, o conhecimento histórico oral, as comunidades quilombolas, a comida típica, as memórias das pessoas mais velhas, os engenhos, a dança, a reza e as casas antigas. Cabe destacar que os sítios arqueológicos passaram a ser citados como bens patrimoniais do município.

Sobre o potencial turístico dos municípios, no Marco Zero os participantes responderam tanto positivamente como negativamente, conforme segue: “Acredito que o nosso potencial turístico seja razoável, pois não apresenta nada de tão extraordinário, mas como também existem locais bonitos a se visitar"; "Sim, temos casas históricas, costumes”; "Sim, porque embora seja no interior ela possui certos atrativos, o município tem lá os seus encantos”; "Sim, porque existem alguns atrativos que já recebem, talvez de forma desordenada, um certo número de visitantes"; e "Sim, porque existem recursos tantos naturais como patrimoniais para a exploração do Turismo, a diversidade cultural, ambiental como a dança, a música, as rochas, entre outros”. No Pós-Curso, todos os participantes responderam de forma positiva, por diversos fatores: "Depois do que foi exposto, a nossa cidade apresenta todas as possibilidades necessárias para se tornar um lugar turístico”; “A partir deste momento acredito que nosso município tem esse potencial”; "Valorizar a cultura e estimular o Turismo"; e "Pois possui uma variedade muito grande de lugares, nos quais explorados e com algum investimento pode oferecer potencial turístico”. As respostas citadas evidenciam a 
sensibilização quanto à diversidade cultural dos municípios, bem como quanto à importância do planejamento para a recepção de visitantes.

Acerca da existência de uma estrutura para receber visitantes, a maioria dos participantes respondeu que não: "Porque não possuímos nenhum tipo de agência turística, logo não existem pessoas preparadas para tal situação"; "Porque nossa cidade tem um grau de dificuldade muito grande em relação ao que está relacionado ao Turismo, pois a única parte que importa é o financeiro"; "Não, pois há muito no que se investir em várias áreas, em hotelarias, mais restaurantes para que se possam atender bem os visitantes”; “Ainda falta infraestrutura suficiente para receber os turistas"; e "Falta mão de obra capacitada para essa atividade; além disso, é necessário que a população envolvida tenha noção de preservação”.

Quando indagados se o Turismo Arqueológico era uma proposta interessante para levar à comunidade o conhecimento sobre Arqueologia, todos os participantes responderam que sim: “Através dele seria mais fácil a comunidade valorizar sua própria história”; "Leva as pessoas a conhecer e valorizar o passado do nosso município”; "Através destes estudos aguçase na comunidade o sentimento de pertencimento e identidade"; e "Através dele poderemos entender a nossa pluralidade cultural". As respostas demonstram que as discussões possibilitadas pelas oficinas sensibilizaram os participantes quanto ao Turismo como ferramenta de valorização do patrimônio local, bem como da pluralidade cultural da região. Todos os participantes responderam que o investimento no Turismo Arqueológico seria viável, por considerarem o segmento turístico uma proposta interessante para a transmissão do conhecimento sobre Arqueologia para a comunidade.

No final das oficinas os participantes discorreram sobre seu papel no desenvolvimento turístico municipal: "Sou professora e por isso tenho um papel importante por contribuir para formação cultural de pessoas”; “Colaborarei por trabalhar na área cultural, com música e artesanato"; "Ajuda no levantamento do que possa ser significativo"; "Sou membro de uma ONG, membro do Conselho Municipal do Meio Ambiente e colaborei na elaboração do Plano Diretor do município"; "Papel de multiplicador de informação, visto que a deficiência de estrutura do município é imensa”; “Como membro do Conselho da Cultura, juntamente com a comunidade estamos fazendo o Inventário e a partir dele buscaremos políticas públicas de preservação destes atrativos”; "Estar engajada em vários projetos podendo ajudar a organizar o Turismo que já existe”; “Na conscientização, na orientação e visitação”; e "Participação ativa em grupos, encontros ficando bem informado sobre o que ocorre na região". Os depoimentos demonstram que a oficina cumpriu seu papel na formação de agentes de cultura 
ativos, e que os participantes se apropriaram da ideia do planejamento participativo do Turismo.

No Pós-Curso, todos os participantes ressaltaram que a oficina atendeu às expectativas, pois: "Contribuiu para esclarecer despertar o interesse pela cultura e patrimônio histórico, ao passo que nos traz um novo olhar sobre nossa região"; "Me incentivou a me comprometer mais com a cultura do meu município"; e "Apresentou-me uma visão rica e diferenciada das possibilidades turísticas da cidade”. Os depoimentos demonstram que a temática trabalhada propiciou o debate e a reflexão objetivados pelo programa, atestando assim a eficácia dos encontros.

As avaliações demonstraram que os participantes passaram a reconhecer novos elementos como bens patrimoniais, inclusive os bens arqueológicos. Além disso, evidenciaram reflexões sobre as possibilidades do uso qualificado desses bens, por meio do Turismo. Os participantes mostraram-se sensibilizados quanto à necessidade do planejamento turístico participativo, em especial para lidar com os fluxos de turistas já existentes, com a ausência de infraestrutura e a falta de incentivo e de políticas públicas. Todas as oficinas foram elaboradas com o objetivo de formar "agentes da memória” que contribuíssem para a transformação dos bens arqueológicos em patrimônio cultural e em recurso turístico, dentro dos preceitos da sustentabilidade e a partir de noções de herança e pertencimento. Os depoimentos demonstraram que os participantes reconheceram seu papel como agentes ativos, pois a forma como as oficinas foram desenvolvidas favoreceu que a comunidade atuasse como partícipe do processo de construção do conhecimento, e não mera receptora de informações ou espectadora do programa educativo (2011b: 110).

Foram realizadas também avaliações das palestras sobre Identidade e Patrimônio ministradas para o ensino formal. Os professores solicitaram que os alunos elaborassem desenhos e textos em sala de aula sobre as temáticas apresentadas. Essa análise só foi possível porque vários professores disponibilizaram os trabalhos dos alunos. A avaliação feita em mais de 200 trabalhos foi de suma importância para a verificação dos conteúdos e informações apreendidos pelos alunos.

Diante da lacuna bibliográfica no que tange à análise de trabalhos discentes em projetos de Educação Patrimonial, conforme ressaltou Wichers (2011: 295), as avaliações foram realizadas seguindo a metodologia do Conselho de Museus, Arquivos e Bibliotecas da Grã-Bretanha. Essa metodologia já havia sido utilizada pela Zanettini Arqueologia (2009; 2011c) em projetos desenvolvidos em São Miguel das Missões e no interior do estado de São 
Paulo - este último sido analisado por Wichers em sua tese de doutorado "Patrimônio Arqueológico Paulista: proposições e provocações museológicas” (2012).

O uso da metodologia inglesa no Programa de Educação Patrimonial desenvolvido no sudoeste baiano configurou uma interessante forma de verificar sua aplicabilidade a outros contextos brasileiros e também na análise de matérias produzidos a partir de palestras. O método, denominado Learning Impact Research Project, tem como uma de suas premissas a de que os Resultados Genéricos de Aprendizado são sustentados por uma definição ampla de aprendizagem, que identifica os benefícios que as interações com instituições culturais trazem para os visitantes. São cinco os Resultados Genéricos de Aprendizado (GLOs), segundo a leitura de Almeida (2006):

- Conhecimento e Compreensão: Aprender fatos ou informações sobre uma temática específica acerca de si mesmo, sobre a família, a comunidade e o mundo; Aprofundar o conhecimento; Aprender como instituições culturais funcionam; Dar informações específicas — nomear coisas, pessoas ou lugares; Estabelecer ligações e relações entre coisas; Usar conhecimento prévio de maneiras novas;

- Habilidades: Saber como fazer algo; Habilidades fundamentais (domínio dos números, alfabetização, aprender a aprender); Habilidades intelectuais (ler, pensar criticamente e analiticamente, fazer julgamentos); Habilidades de gerenciamento de informação (localizar e usar informação, avaliar informação); Habilidades sociais (encontrar pessoas, partilhar, trabalhar em grupo); Habilidades emocionais (reconhecer os sentimentos de outros, lidar com sentimentos intensos, canalizar energia para resultados produtivos); Habilidades de comunicação (escrever, falar, ouvir); Habilidades físicas (correr, dançar, manipular, fazer);

- Atitudes e Valores: Sentimentos e percepções; Opiniões sobre nós mesmos, desenvolvimento de autoestima; Opiniões e atitudes em relação a outras pessoas; Atitudes em relação a uma organização (museu, empresa etc.); Atitudes positivas/ negativas em relação a uma experiência; Razões para ações e pontos de vista; Empatia, capacidade de tolerância (ou falta delas);

- Prazer, Inspiração, Criatividade: Se divertir, ser surpreendido; Pensamentos, ações ou coisas novas; Exploração, experimentação e fazer;

- Ação, Comportamento, Progresso: O que as pessoas fizeram - O que as pessoas fazem - O que as pessoas pretendem fazer (intenção de agir); Uma mudança no modo em que as pessoas conduzem suas vidas, incluindo contextos de trabalho, estudo, família e 
comunidade; Mudança de comportamento; Planejamento: como dará continuidade ao processo.

Diante da impossibilidade de se avaliar todos os mais de 220 trabalhos no que concerne à identificação dos cinco resultados de aprendizado, foi realizada uma classificação geral quanto às referências patrimoniais mencionadas ou rejeitadas. A partir dessa classificação foram selecionados aproximadamente $20 \%$ dos trabalhos para a análise baseada nos GLOs. As temáticas mais citadas nos trabalhos foram: Povos Indígenas, Patrimônio, Arqueologia, Memória, Identidade e Morte. Dos 41 trabalhos analisados de maneira mais aprofundada, pôde-se notar que houve uma predominância das seguintes temáticas: Patrimônio, Arqueologia e Povos Indígenas:

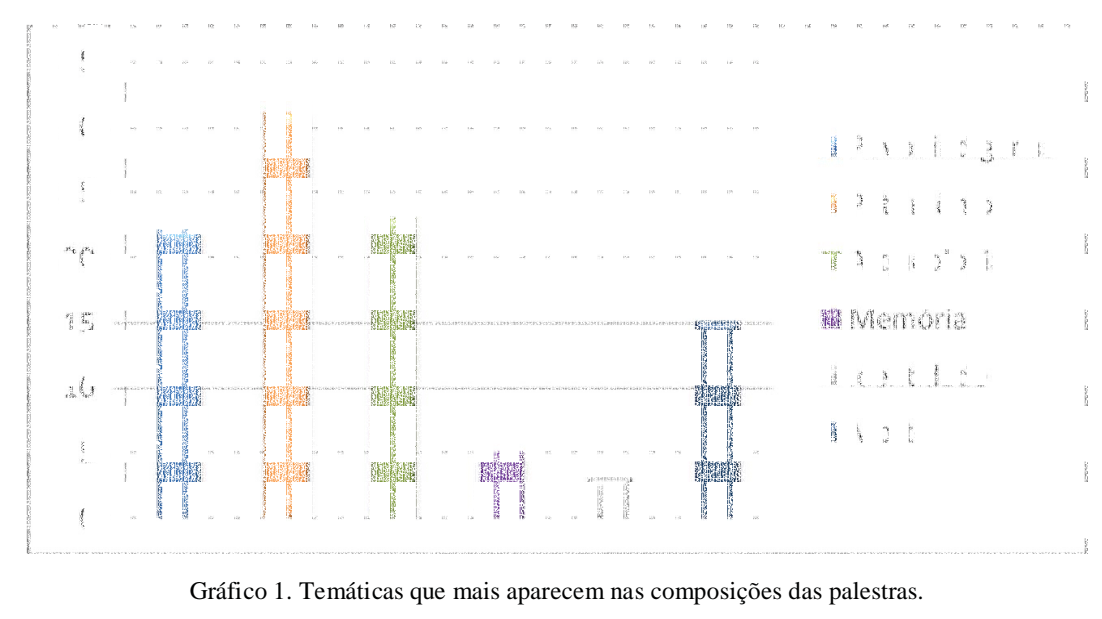

Quanto à forma do trabalho, predominaram as atividades que envolveram tanto a linguagem visual como a escrita, conforme demonstrado no gráfico a seguir: 


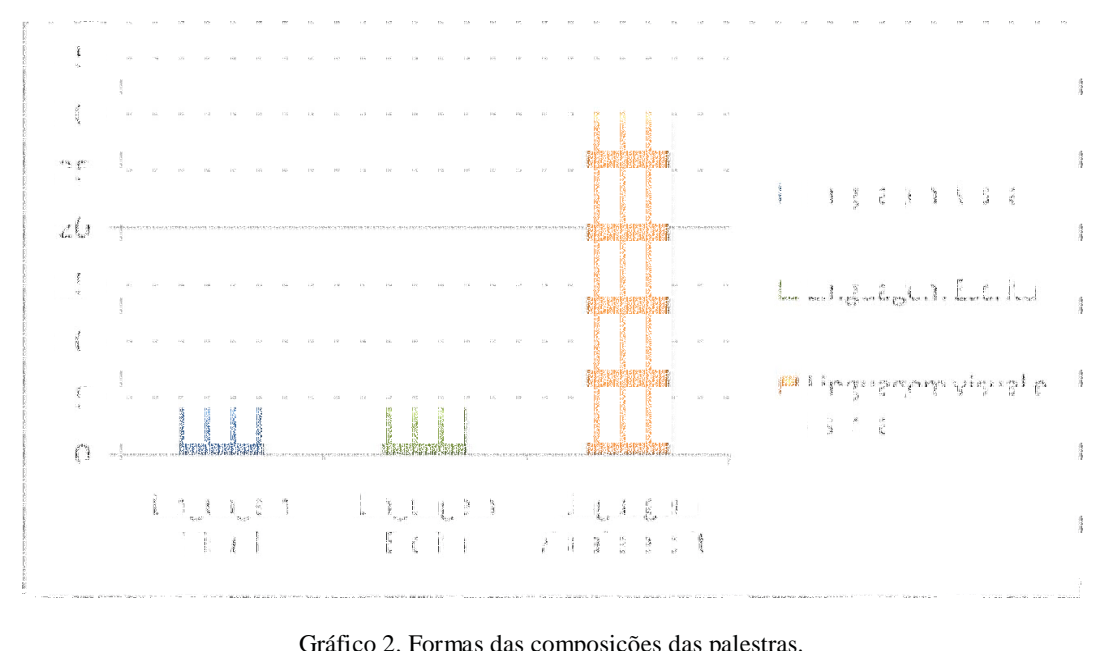

Gráfico 2. Formas das composições das palestras.

As avaliações mais aprofundadas realizadas nos trabalhos selecionados comprovaram que as palestras foram eficazes em tratar as temáticas de interesse do Programa de Educação Patrimonial, já que os alunos demonstraram em seus textos e desenhos terem criado suas próprias reflexões acerca dos temas. Alguns exemplos de trabalhos avaliados a partir da metodologia proposta pelos Resultados Genéricos de Aprendizado podem ser visualizados na Prancha 10.

ETAPA 7 - ACOMPANHAMENTO DA MULTIPLICAÇÃO DO CONHECIMENTO E DO INVENTÁRIO TURÍSTICO

A Etapa 7 do Programa de Educação Patrimonial envolveu o acompanhamento das ações de multiplicação realizadas pelos professores e alunos em sala de aula, bem como a realização do Inventário da Oferta Turística nos três municípios de abrangência do programa. Quanto ao acompanhamento da multiplicação, os mediadores do Projeto atenderam às solicitações dos docentes quanto a materiais de apoio como textos, fotos e partes das apresentações elaboradas para as oficinas, bem como sugestões para aplicação de algumas atividades e conteúdos. Mais de uma dezena de professores e aproximadamente 150 alunos participaram da atividade e enviaram para a Zanettini Arqueologia o resultado do trabalho realizado em sala de aula sobre as temáticas. 


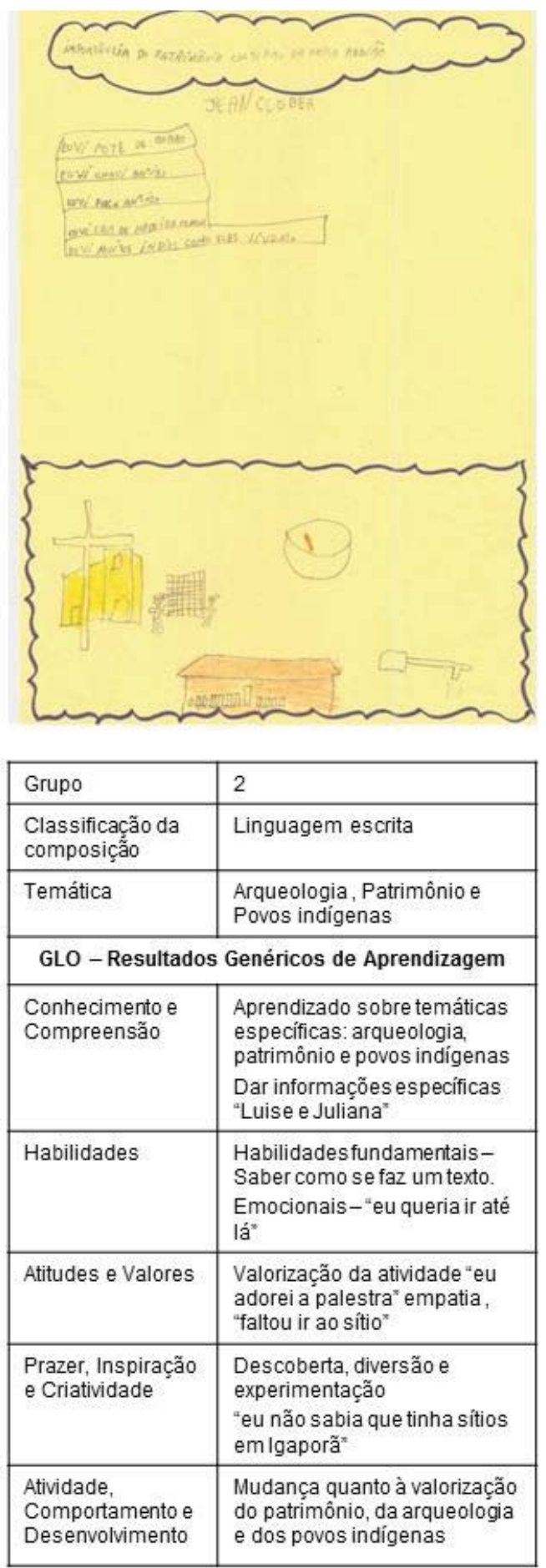

\begin{tabular}{|l|l|}
\hline Grupo & 1 \\
\hline $\begin{array}{l}\text { Classificação da } \\
\text { composiçâo }\end{array}$ & Linguagem visuale escrita \\
\hline Temática & Povos indigenas e Patrimônio \\
\hline \multicolumn{2}{|c|}{ GLO - Resultados Genéricos de Aprendizagem } \\
\hline $\begin{array}{l}\text { Conhecimento e } \\
\text { Compreensão }\end{array}$ & $\begin{array}{l}\text { Aprendizado sobre temáticas } \\
\text { especificas. "eu vi muitos indios e como } \\
\text { eles vivem" }\end{array}$ \\
\hline Habilidades & $\begin{array}{l}\text { Habilidades fundamentais - Saber como } \\
\text { se faz um texto. }\end{array}$ \\
\hline $\begin{array}{l}\text { Atitudes e Valores } \\
\text { Empatia com os povos indigenas }\end{array}$ \\
\hline $\begin{array}{l}\text { Prazer, Inspiração e } \\
\text { Criatividade }\end{array}$ & Diversão e experimentação \\
\hline $\begin{array}{l}\text { Atividade, } \\
\text { Comportamento e }\end{array}$ & $\begin{array}{l}\text { Mudança quanto à valorização da } \\
\text { patrimônio e povos indigenas }\end{array}$ \\
\hline
\end{tabular}

Trabalhos referentes às palestras, avaliados a partir da metodologia proposta pelo GLO.

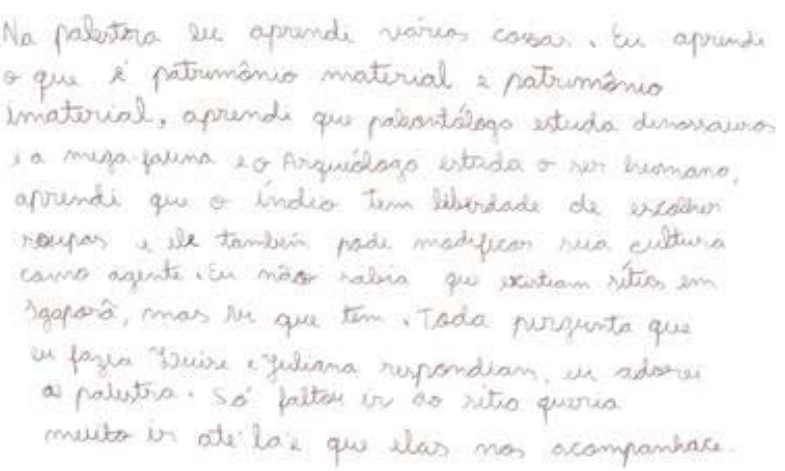


Vale ressaltar que a realização das atividades não foi obrigatória. Seguem alguns resultados:

Grupo de Trabalho 1 - segundo relatório das docentes, por meio de oficinas foram trabalhadas as temáticas Arqueologia, Patrimônio Cultural material e imaterial do município e Identidade. As oficinas foram desenvolvidas em duas etapas: a primeira consistiu de uma apresentação sobre a Arqueologia e a profissão do arqueólogo; a segunda teve a forma de uma roda de discussão sobre Patrimônio e bens patrimoniais municipais, pessoais e das comunidades onde vivem. Também foram propostas atividades relacionadas à confecção de desenhos a partir de tintas naturais, o que propiciou discussões sobre arte rupestre.

Grupo de Trabalho 2 - a primeira atividade envolveu uma reflexão sobre o conceito de Educação Patrimonial e Patrimônio Cultural. Segundo o relatório, os alunos concluíram que “a Cultura é Patrimônio, mas que vai mudando ao longo do tempo". Em seguida foi realizada uma pesquisa com familiares sobre alguns bens históricos do município, além de uma visita aos bens pesquisados. Também foi aplicada a ficha de análise do objeto, com uma explicação do passo a passo do trabalho dos arqueólogos.

Grupo de Trabalho 3 - as atividades tiveram como temas geradores a Educação Patrimonial e a Arqueologia, desenvolvidas de forma interdisciplinar. Houve leitura e discussão de textos e foi ministrada uma aula expositiva sobre Patrimônio, Cultura e Arqueologia. Os alunos produziram desenhos e textos sobre as temáticas.

Grupo de Trabalho 4 - inicialmente foi apresentado o vídeo sobre Educação Patrimonial (parte do material de apoio didático) e realizou-se uma discussão sobre "as origens de cada um”. Foi proposta uma atividade em grupo, em que os alunos deveriam pesquisar a procedência dos primeiros habitantes do bairro onde moravam, selecionar objetos antigos de seus antepassados e organizar as fotos da família. Os alunos apresentaram os trabalhos para toda a escola, em um grande evento de culminância.

Grupo de Trabalho $\mathbf{5}$ - as primeiras atividades foram voltadas para o tema Patrimônio material e imaterial. A partir de uma discussão sobre os antepassados dos alunos foram trabalhadas as temáticas Arqueologia e Identidade. Reflexões foram propostas a partir 
de imagens de diferentes bens patrimoniais do município e conversas com familiares, que resultaram em textos e exercícios de oralidade.

Grupo de Trabalho 6 - trabalhou a preservação dos bens patrimoniais do município e a Arqueologia. O tema do projeto desenvolvido foi "Eu, arqueólogo da minha origem, conhecer o passado é sinônimo de preservar no presente”. Houve leitura de textos, pesquisas sobre a origem do nome dos alunos e seus antepassados, aplicação da ficha de bens culturais e discussão sobre a conservação dos bens. Os alunos confeccionaram objetos da cultura local e aplicaram a ficha "Análise de objetos”. Por fim, todos os trabalhos foram apresentados para os demais alunos da escola.

A avaliação dos trabalhos dos discentes nas ações de multiplicação também foi realizada segundo o método apresentado pelo projeto do Conselho de Museus, Arquivos e Bibliotecas da Grã-Bretanha, o Learning Impact Research Project. Também não foi possível a avaliação de todos os trabalhos quanto à identificação dos cinco Resultados de Processos de Aprendizagem. A fim de conhecer o universo de análise realizou-se uma avaliação prévia sobre as referências patrimoniais mencionadas ou rejeitadas, o que favoreceu a seleção de 24 trabalhos para a análise mais detalhada baseada nos GLOs.

No universo analisado predominaram os trabalhos que apresentaram como temáticas principais a Memória, o Patrimônio e a Identidade.

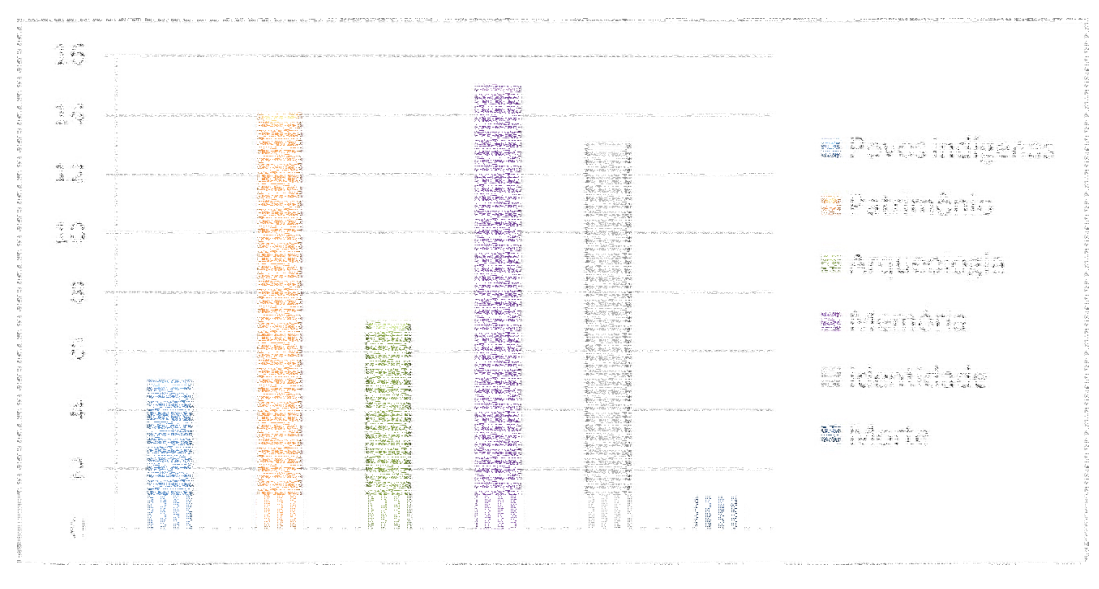

Gráfico 3. Temáticas que mais aparecem nas composições das ações de multiplicação. 
Diferentemente das palestras, nas ações de multiplicação notou-se a predominância das atividades que envolveram a linguagem escrita, conforme demonstrado no gráfico a seguir.

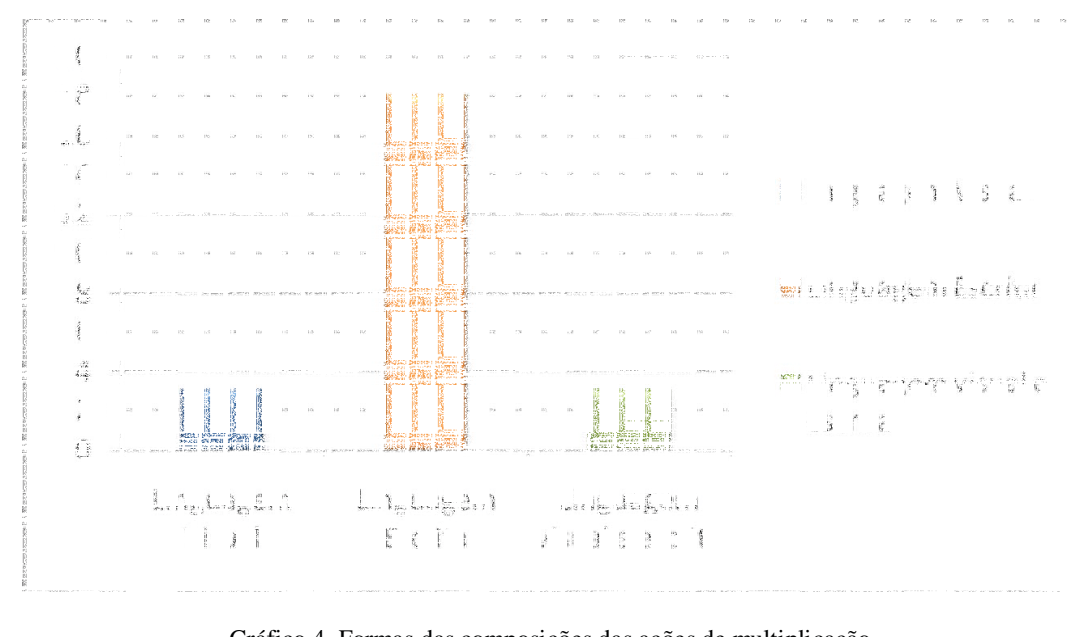

Gráfico 4. Formas das composições das ações de multiplicação.

A avaliação de alguns dos trabalhos, segundo a metodologia proposta pelos Resultados Genéricos de Aprendizado, é demonstrada na Pranchas 11.

Ainda na Etapa 7 foi realizado o acompanhamento das ações do Inventário da Oferta Turística. Sobre o Inventário é importante fazer alguns esclarecimentos. A proposta não objetivava que os parceiros completassem todo o Inventário nos poucos meses de desenvolvimento do programa, mas sim que os Conselhos de Cultura e a comunidade testassem a aplicação da metodologia proposta, refletissem sobre o processo a ponto de adaptá-lo às realidades dos municípios envolvidos e debatessem as possibilidades de uso qualificado dos dados elencados. Tratava-se de um exercício de reflexão, para que após o encerramento do programa a própria comunidade tivesse condição de continuar, realimentar e fazer uso do Inventário Turístico. Foi durante o período de acompanhamento que os parceiros responsáveis pela pesquisa puderam debater sobre o processo, organizar entrevistas e conversas com diferentes grupos, selecionar os estabelecimentos que seriam inventariados, adaptar as fichas para as realidades locais e sanar as dúvidas quanto à aplicação da metodologia (Zanettini Arqueologia 2011b: 193). 


\begin{tabular}{|l|l|}
\hline Grupo & 1 \\
\hline $\begin{array}{l}\text { Classificação da } \\
\text { composiçấo }\end{array}$ & Linguagem visual \\
\hline Temática & $\begin{array}{l}\text { Arqueologia, Patrimônio e povos } \\
\text { indigenas }\end{array}$ \\
\hline \multicolumn{1}{|c|}{ GLO - Resultados Genéricos de Aprendizagem } \\
\hline $\begin{array}{l}\text { Conhecimento e } \\
\text { Compreensão }\end{array}$ & $\begin{array}{l}\text { Aprendizado sobre temáticas } \\
\text { especificas. "arte rupestre }\end{array}$ \\
\hline Habilidades & $\begin{array}{l}\text { Habilidades fundamentais - } \\
\text { Saber como se faz desenho e } \\
\text { tinturas naturais. }\end{array}$ \\
\hline Atitudes e Valores & Empatia com a temática \\
\hline $\begin{array}{l}\text { Prazer, Inspiração e } \\
\text { Criatividade }\end{array}$ & Diversão e experimentação \\
\hline $\begin{array}{l}\text { Atividade, } \\
\text { Comportamento e } \\
\text { Desenvolvimento }\end{array}$ & $\begin{array}{l}\text { Mudança quanto à forma de } \\
\text { Compreender o patrimônio. }\end{array}$ \\
\hline
\end{tabular}

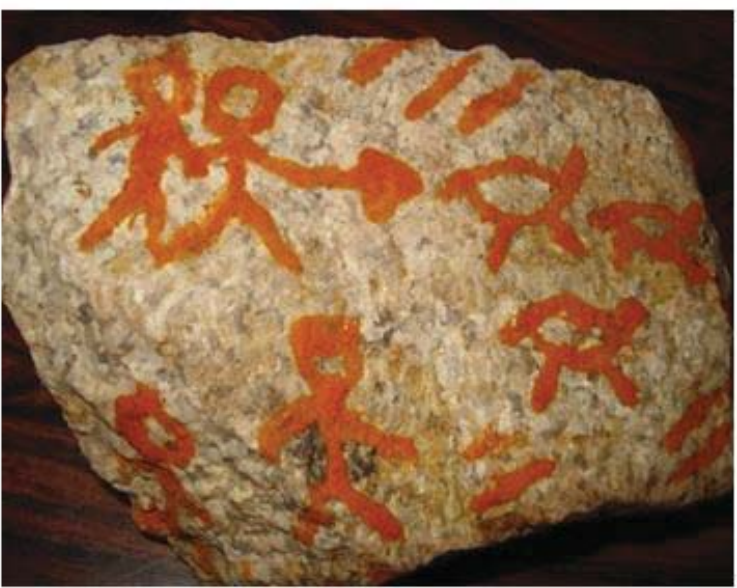

Trabalhos referentes às ações de multiplicação, avaliados a partir da metodologia proposta pelo GLO.

\begin{tabular}{|c|c|}
\hline Grupo & 5 \\
\hline $\begin{array}{l}\text { Classificação da } \\
\text { composiçẵo }\end{array}$ & Linguagem escrita \\
\hline Temática & Memória e Identidade \\
\hline \multicolumn{2}{|c|}{ GLO - Resultados Genéricos de Aprendizagem } \\
\hline $\begin{array}{l}\text { Conhecimento e } \\
\text { Compreensão }\end{array}$ & $\begin{array}{l}\text { Aprendizado sobre temáticas } \\
\text { específicas. Sobre si mesmo, } \\
\text { sobre a familia e comunidade. } \\
\text { "minha familia é de negros } \\
\text { misturados com brancos" }\end{array}$ \\
\hline Habilidades & $\begin{array}{l}\text { Habilidades fundamentais e de } \\
\text { comunicação-Saber como se faz } \\
\text { um texto. Habilidades sociais - } \\
\text { troca de informações coma } \\
\text { familia }\end{array}$ \\
\hline Atitudes e Valores & Percepções sobre nós mesmos \\
\hline $\begin{array}{l}\text { - Prazer, } \\
\text { Inspiraçãoe } \\
\text { Criatividade }\end{array}$ & Diversão e aprender coisas novas \\
\hline $\begin{array}{l}\text { Atividade, } \\
\text { Comportamento e } \\
\text { Desenvolvimento }\end{array}$ & $\begin{array}{l}\text { Mudança quanto à compreensão } \\
\text { de sua identidade e valorização } \\
\text { da memória }\end{array}$ \\
\hline
\end{tabular}


RESULTADOS DO PROCESSO DE INVENTARIADO

\section{Caetité}

No município de Caetité a Gerência de Cultura, vinculada à Secretaria Municipal de Educação, ficou responsável pela realização do Inventário da Oferta Turística, já que o Conselho de Cultura encontrava-se em processo de formação. Os responsáveis iniciaram o trabalho com uma pesquisa dos estabelecimentos, associações, atrativos e parceiros que deveriam ser envolvidos no processo. Foram relacionados mais de 2050 estabelecimentos comerciais. O trabalho foi iniciado pelas escolas, uma vez que esses dados já eram de posse da Secretaria e precisavam apenas ser formatados de acordo com a metodologia do MTUR. Quanto aos estabelecimentos comerciais, foram selecionados como universo de estudo para a primeira etapa de Inventariado aqueles localizados na área urbana do município.

As grandes dificuldades enfrentadas pela equipe de Caetité foram a impossibilidade de parceria com professores e alunos da Universidade do Estado da Bahia (UNEB) — que na ocasião estava em greve - e as trocas político-administrativas ocorridas na Diretoria de Cultura durante o período do programa. Outra dificuldade esteve relacionada à resistência dos proprietários em passar informações sobre seus estabelecimentos a funcionários da prefeitura. Muitos dos estabelecimentos não possuem alvará de funcionamento, o que justifica a dificuldade de conseguir informações confiáveis. Até o final do Programa de Educação Patrimonial foram preenchidas aproximadamente 80 fichas de Inventariado, distribuídas entre os três componentes de organização da Oferta Turística, conforme gráfico a seguir:

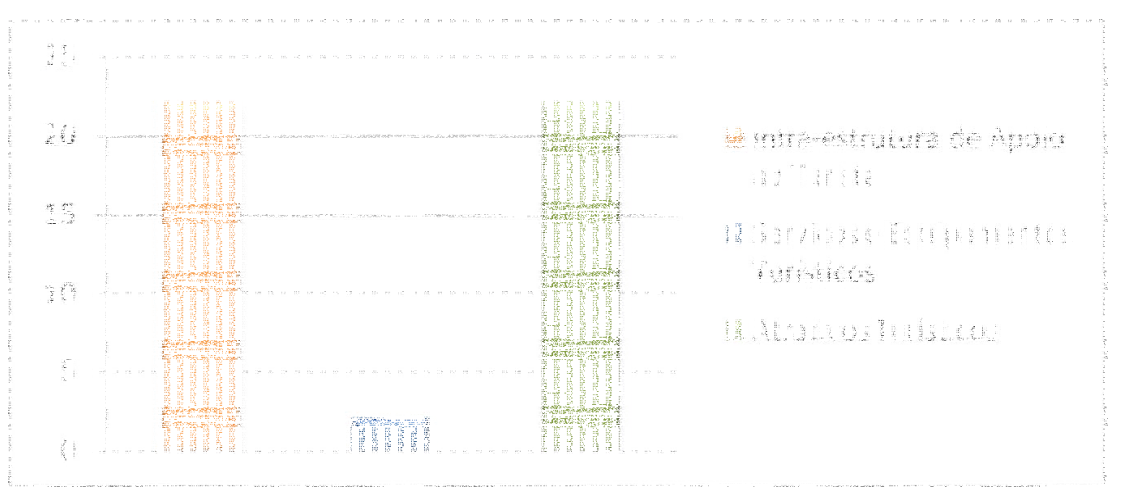

Gráfico 5. Distribuição das fichas do Inventário da Oferta Turística de Caetité. 
Como continuidade do processo de Inventariado foi sugerida a formação de parcerias que possibilitem que a pesquisa alcance um número maior de estabelecimentos. Foi proposto que sejam abrangidos na próxima etapa apenas estabelecimentos que possuam alvará de funcionamento, como forma de garantir a veracidade das informações.

\section{Guanambi}

No município de Guanambi, a Secretaria de Esporte, Turismo e Lazer ficou responsável pela realização do Inventário da Oferta Turística de forma participativa. A pesquisa inicial visou selecionar os estabelecimentos que seriam analisados na primeira etapa. Foram distribuídas fichas para vários estabelecimentos da área urbana do município, envolvendo diversos setores, com o objetivo de conseguir uma amostra dos diferentes tipos de formulários propostos pela metodologia adotada. Até o final do período de aplicação do programa foram preenchidas 32 fichas de Inventariado, divididas conforme se segue:

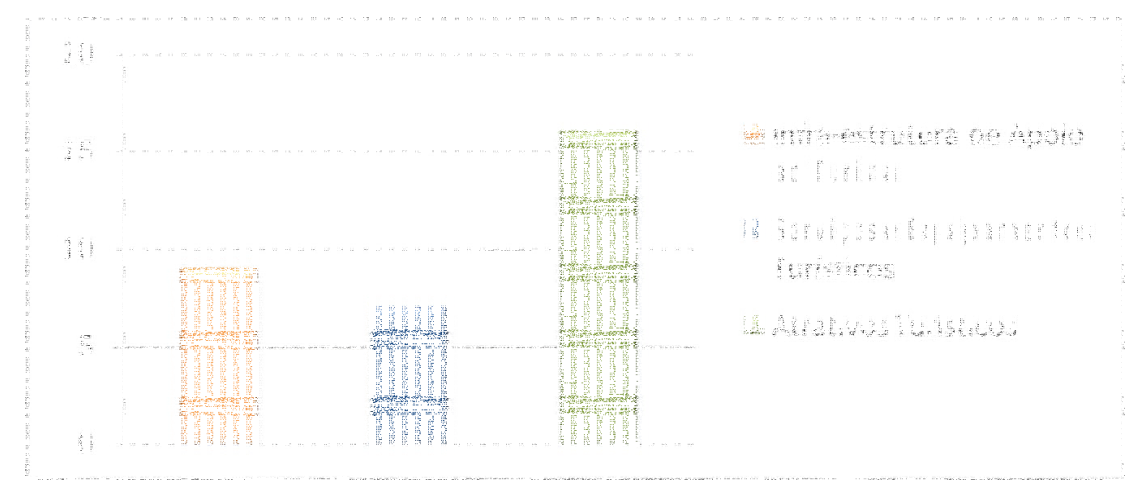

Gráfico 6. Distribuição das fichas do Inventário da Oferta Turística de Guanambi.

Foi proposta como continuidade das ações, a ampliação da amostra inicial dos três componentes analisados. A elaboração de um Inventário Turístico no município vem sendo discutida há alguns anos, inclusive em reuniões com diferentes autoridades, porém com poucos resultados positivos por questões políticas. Questões estas, que também influenciaram a formação de parcerias para a realização de um Inventário de forma participativa no âmbito do Programa. Estes elementos dificultadores, foram apontados como desafios para a continuidade do processo de realização do Inventário da Oferta Turística em Guanambi. 


\section{Igaporã}

No município de Igaporã o Conselho de Cultura Municipal e demais parceiros do projeto participaram ativamente de todo o processo de pesquisa. Os responsáveis optaram por abranger durante a pesquisa os três componentes, como forma de testar a metodologia. Porém, as pesquisas foram aprofundadas nos componentes A e B. Como o Conselho de Cultura já possui um mapeamento cultural do Município, com mais de 1500 fichas preenchidas, procurou-se complementar tal levantamento por meio de entrevistas com lideranças de diferentes comunidades. Foram também realizadas entrevistas com proprietários de diferentes estabelecimentos da área urbana de Igaporã. Até o final do programa foram preenchidas 107 fichas de Inventariado, distribuídas conforme se segue:

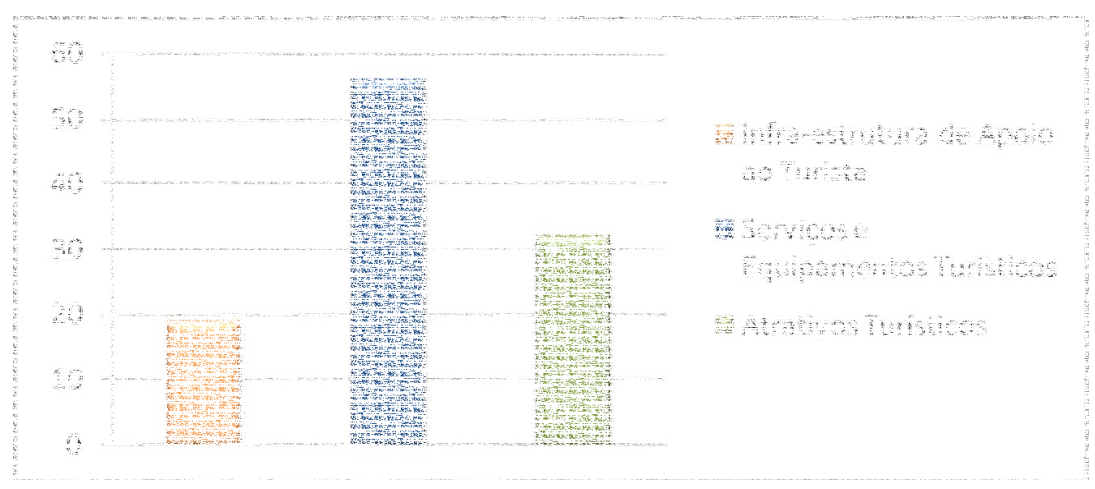

Gráfico 7. Distribuição das fichas do Inventário da Oferta Turística de Igaporã.

Em Igaporã, o Inventário da Oferta Turística foi realizado por mais de 60 pessoas. Muitos dos pesquisadores participaram das oficinas realizadas no município. A formação de parcerias com diferentes lideranças se mostrou eficaz, tanto por ampliar a possibilidade de ações devido ao maior número de pesquisadores quanto por efetivar o envolvimento de diferentes setores e grupos da comunidade do município na pesquisa, o que favoreceu um processo participativo.

As informações descritas demonstraram que o objetivo do processo de Inventariado, definido no Programa em apreço, foi atingido. Nos três municípios houve reflexões sobre a metodologia e suas diferentes formas de aplicação, foram identificadas as dificuldades de seleção do universo de pesquisa, os problemas enfrentados na realização de parcerias como forma de garantir que a pesquisa fosse participativa, entre outros. Os debates gerados pelo 
processo - entre poder público, conselhos de cultura, lideranças comunitárias, comerciantes e mediadores do projeto - favoreceram o levantamento de dados e narrativas que possibilitaram um maior conhecimento do contexto de abrangência do projeto. O breve diagnóstico da Oferta Turística já evidenciou a potencialidade da pesquisa e levou os responsáveis a refletirem sobre as diferentes possibilidades de utilização das informações, de maneira a contribuir para melhorias socioeconômicas da comunidade. Os resultados da pesquisa, somados às questões debatidas nas oficinas, trazem elementos importantes para se pensar políticas públicas não apenas de Turismo, mas de educação, saúde, entre outras, bem como favorecer um planejamento estratégico para o uso qualificado dos bens patrimoniais dentro dos preceitos da sustentabilidade.

\section{ETAPA 8 - FECHAMENTO DO PROGRAMA DE EDUCAÇÃO PATRIMONIAL}

A etapa 8 envolveu o término das avaliações das atividades e a elaboração do relatório final Programa de Educação Patrimonial do Programa de Prospecções e Resgate Arqueológico dos Parques Eólicos do sudoeste baiano.

O programa atingiu mais de 2.000 pessoas diretamente envolvidas nas atividades realizadas: oficinas, cursos, palestras, entrevistas, pesquisas, entre outras. De acordo com o mencionado relatório, procurou-se evidenciar "os resultados qualitativos desses processos: socialização do conhecimento científico, construção e afirmação das identidades locais com base nas referências patrimoniais elencadas, estímulo à prática cidadã, para mencionar apenas alguns” (Zanettini Arqueologia 2011b: 203). O programa teve como premissa básica a perspectiva dialógica, "postura julgada adequada e eficaz, metabolizando a interação entre agentes externos e a sociedade local em prol do aprimoramento do debate e, consequentemente, do uso qualificado dos amplos recursos culturais que a região oferece” (2011b: 203). Os resultados apresentados demonstraram a necessidade de novos inputs como forma de atender às recentes demandas das comunidades.

\section{AÇÕES DE CONTINUIDADE}

Em todas as oficinas realizadas no âmbito do Programa de Educação Patrimonial, durante a explanação sobre a Arqueologia e sobre a metodologia de pesquisa dos arqueólogos foram debatidas com a comunidade questões relacionadas aos acervos gerados pelas 
pesquisas. Também houve reflexões sobre a dificuldade de se conseguir instituições qualificadas para a salvaguarda dos acervos, e foram propostas análises das instituições culturais da região. Em todas as atividades mencionou-se que o acervo formado seguiria para o litoral do estado, pois a instituição de guarda mais próxima está localizada em Ilhéus e tem anuência do IPHAN para a emissão de endossos de apoio. Desde as primeiras atividades, em especial no módulo "Educação Patrimonial, Arqueologia e Turismo Cultural” do Curso ministrado em Caetité, a saída do acervo da região criou intensas discussões sobre o que deveria ser feito para a manutenção do acervo em um dos municípios de abrangência do programa. A partir da primeira discussão no mencionado curso, um grupo de lideranças locais — representantes de diferentes setores da sociedade civil, de instituições públicas de ensino e de cultura - passou a se reunir para discutir propostas para a manutenção do acervo em Caetité. Os membros do grupo passaram a participar ativamente das oficinas, levantando a questão sobre o acervo e convidando algumas lideranças para tomar parte das discussões.

O resultado dessa mobilização propiciou, ainda em junho de 2011, a formação oficial de um Grupo de Trabalho (GT) que naquele momento teve por objetivo debater propostas para o acervo e também formar parcerias e favorecer discussões sobre instituições culturais junto aos grandes empreendimentos instalados no sudoeste baiano. O empreendedor dos parques eólicos contatou a Zanettini Arqueologia para participar do GT, visando à qualificação técnica das discussões e a formatação de um projeto que representasse os anseios da comunidade quanto à guarda do acervo arqueológico. A partir da identificação das demandas desse grupo foi encaminhada uma proposta de elaboração de um Plano Museológico, o qual tem sido desenvolvido no âmbito dos investimentos socioambientais e de sustentabilidade da empresa. Esse planejamento na região é crucial devido à inexistência de instituições no sudoeste baiano voltadas a atender às demandas da Arqueologia em conformidade com o licenciamento ambiental. Todas as ações do GT têm sido colaborativas, desde a formatação do projeto, a escolha do nome da instituição — o Museu do Alto Sertão da Bahia (MASB) —, de seu território de atuação e das tipologias de museu que seriam integradas, de forma a constituir uma instituição apropriada para os anseios de diversos segmentos da comunidade da região. Embora o movimento de formação do GT tenha acontecido em Caetité, representantes de Guanambi e Igaporã também se uniram ao projeto.

Os atores sociais têm destacado o desejo de um museu que tivesse papel social em seu território, que fosse pensado segundo diretrizes do conceito de Museu de Território e Ecomuseu, que aproxima a instituição ao Turismo desenvolvido dentro dos preceitos da sustentabilidade. Além disso, a instituição tem sido pensada como um espaço de preservação 
e pesquisa, com enfoque em Arqueologia, História e Antropologia. O empreendedor do programa, a Zanettini Arqueologia, a UNEB e o poder público municipal — representado pela secretaria de Educação e pela Diretoria de Cultura - e o poder público estadual tornaram-se parceiros do GT para a concretização do projeto.

O envolvimento do Turismo no Projeto de elaboração do Plano Museológico e sua aproximação com a ideia do museu se deu desde as Oficinas sobre Identidade e Turismo e sobre Construção da Imagem Turística, que foram palco para a realização de várias discussões que propiciaram a formação do GT. Desde o primeiro encontro do Grupo de Trabalho com a doutora em Museologia Camila Moraes Wichers, responsável da Zanettini Arqueologia pela elaboração do Plano Museológico colaborativo, os participantes apresentaram questões relacionadas ao papel do Turismo junto à instituição museológica em planejamento.

As dinâmicas desenvolvidas no decorrer dos encontros e voltadas para reflexões sobre como deveria ser o Museu do Alto Sertão da Bahia geralmente apresentaram o Turismo como elemento de interesse do projeto. Dentro de uma das dinâmicas voltadas para as utilidades de um museu na região, os participantes definiram que seria interessante que o museu possibilitasse o mapeamento dos "espaços turísticos do território e garantisse o acesso a eles”. Além disso, o Turismo deveria ser fomentado e utilizado como forma de atrair olhares para o patrimônio local. Foi para atender a essas demandas da comunidade representada no GT que a continuidade da realização do Inventário da Oferta Turística foi inserida como uma das linhas de atuação do Plano Museológicos do MASB. A elaboração do Inventário foi tida como crucial para o projeto, pois o levantamento possibilitará uma maior compreensão do Território Patrimonial do Museu, favorecendo que sua atuação seja inclusiva e conectada com as demandas e realidades locais.

A parceria do GT com o empreendedor possibilitou a inserção do Projeto de elaboração colaborativa do Plano Museológico do Museu do Alto Sertão da Bahia no Programa de Sustentabilidade da Empresa, denominado Programa Catavento, que agrupa projetos de desenvolvimento socioambiental e sustentabilidade na região em apreço e é subdividido em quatro áreas de atuação, segundo o site da empresa: Socioeconômica, Meio ambiente, Cultural e Patrimonial e Desenvolvimento Organizacional ${ }^{6}$. O museu foi inserido na área Cultural e Patrimonial. O empreendedor solicitou um financiamento ao BNDES como forma de obter recursos para implantar o Programa Catavento. O financiamento foi aprovado em março de 2012.

\footnotetext{
${ }^{6}$ As informações sobre o Programa Catavento foram retiradas do site da Renova Energia.
} 
Com a aprovação do Programa de Sustentabilidade foram iniciadas as atividades de elaboração colaborativa do Plano Museológico, que envolveram os encontros mensais do GT, e foram planejadas as ações de continuidade do processo de Inventariado. Em junho de 2012 ocorreram as primeiras reuniões com os responsáveis pela primeira etapa do Inventário Turístico. Todas as parcerias firmadas durante o Programa de Educação Patrimonial foram retomadas e houve contatos com outros possíveis parceiros. Ficaram acertadas reuniões para agosto de 2012, a fim de alinhar ações de continuidade e capacitação de parceiros locais responsáveis pelas pesquisas e pelo levantamento de dados para elaboração do Inventário da Oferta Turística.

Sendo assim, até o momento o processo de planejamento estratégico do Turismo no âmbito do Programa de Educação Patrimonial e sua continuidade foram realizados de acordo com as etapas demonstradas abaixo:

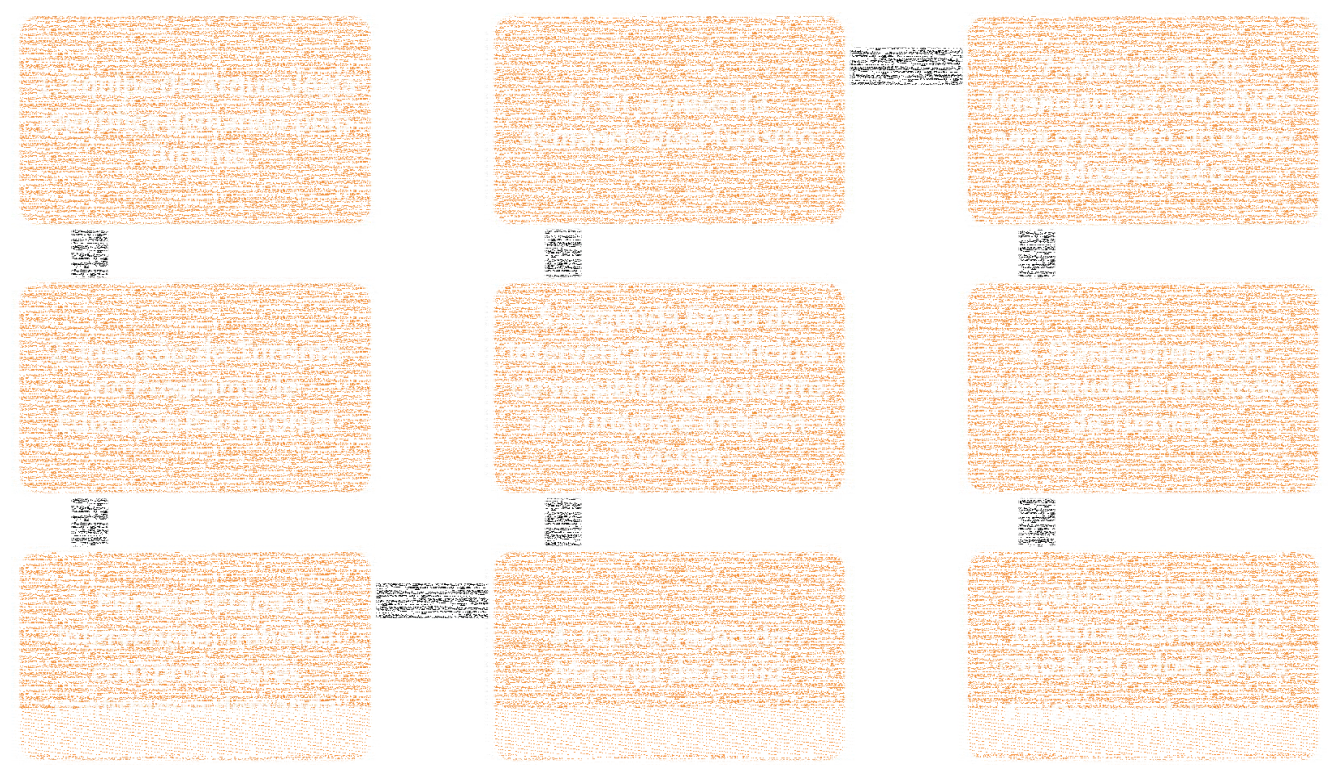

Tabela 03. Esquema do Planejamento Estratégico do Turismo no Programa de Educação Patrimonial

Outra ação que a ser realizada no âmbito do Projeto do Plano Museológico é a elaboração de um projeto voltado para o planejamento estratégico do Turismo do sítio arqueológico Moita dos Porcos, também chamado de Toca do Tapuio. O sítio consiste de um abrigo sob rocha cujas paredes apresentam gravuras rupestres. Esse sítio já foi submetido a estudos por duas equipes de Arqueologia: a primeira coordenada pelo Prof. Dr. Carlos Echevarne (MAE/UFBA), e a segunda sob a coordenação da Profa. Dra. Maria Beltrão 
(Museu Nacional/UFRJ). O recurso turístico é um bem patrimonial arqueológico que vem recebendo fluxo espontâneo de visitantes. A proposta é que seja elaborado um documento que aponte ações necessárias para estruturação do sítio em atrativo turístico, como forma de garantir o uso qualificado do bem patrimonial, favorecendo sua preservação. Vale ressaltar que o relatório final da Zanettini Arqueologia (2011: 58) aponta para marcas de impacto decorrentes de ações antrópicas no sítio.

A inserção das ações referentes ao sítio arqueológico no Plano Museológico se deu porque o projeto visa à descentralização das ações do MASB, sendo o sítio arqueológico um parceiro do museu desde o momento em que proprietário entrou em contato com membros do GT solicitando ajuda para estruturar o atrativo. Não se pode esquecer que, por ser um Museu de Território, o MASB visará fomentar outros locais de uso qualificado do patrimônio no território de intervenção do museu, dialogando com o conceito de Paisagem Cultural, tão caro às propostas delineadas nesta tese. Para atender à demanda local foi realizada uma primeira reunião com o proprietário do local onde o sítio está localizado. Durante a reunião foi possível identificar a demanda do proprietário com relação à visitação, e será elaborado um primeiro cronograma de pesquisa e planejamento local turístico durante o segundo semestre de 2012.

Vale ressaltar a importância da atuação dos arqueólogos que realizaram trabalhos no sítio Moita dos Porcos anteriormente à ação da Zanettini Arqueologia. Destaca-se que a inserção de sítios de arte rupestre da Bahia na atividade turística já vinha sido pensada por Echevarne desde a década de 1990, quando escreveu um dos poucos artigos sobre Turismo Arqueológico - "Proposta para o aproveitamento turístico de áreas arqueológicas da Bahia, Brasil” — até hoje publicados na revista Turismo em Análise. O trabalho das equipes possibilitou a valorização do bem patrimonial, de forma a criar junto aos proprietários uma demanda por sua preservação e pela organização da visitação, o que acarretou o cercamento do sítio e ações de controle de visitantes.

\section{ALGUMAS REFLEXÕES SOBRE AS AÇÕES REALIZADAS NO SUDOESTE BAIANO}

O Programa de Educação Patrimonial que é alvo de estudo deste capítulo procurou demonstrar que ações educativas podem aproximar a sociedade de seus diversos bens patrimoniais. Ao longo do programa não se almejou disseminar conhecimentos detalhados sobre os bens arqueológicos ou outros bens da região, mas possibilitar diálogos e reflexões entre a sociedade e seus diferentes patrimônios. Para a elaboração e a realização do programa procurou-se entender a sociedade como uma entidade heterogênea, pois segundo 
Lins de Barros (1997: 91) a heterogeneidade é uma das categorias básicas das sociedades contemporâneas. A partir da compreensão de que fronteiras são criadas coletivamente e classificam, hierarquizam, aproximam e separam grupos e categorias sociais, o programa foi pensado de forma a buscar entender, por meio da observação e da conversa, princípios básicos da Etnografia, a maneira como essas comunidades se organizam no seu cotidiano e como construíram e constroem suas representações. A relação entre indivíduos e bens patrimoniais se dá de forma dinâmica, pois as relações se alteram a partir da realidade social, que é, cada vez mais, plural. É no âmbito dessa realidade que são construídos os significados.

Neste contexto, as narrativas apresentam força por seu caráter social e são determinadas pelo lugar em que os "narradores se encontram, caracterizado pela interseção dos vários universos socioculturais a que estão referidos” (1997: 91-92). A partir dessa perspectiva e sob a inspiração da concepção social e coletiva de Halbwachs (1968), as ações foram organizadas de forma a levantar diferentes narrativas. A ênfase na formação de grupos para discussão e não de entrevistas individuais foi pautada pela crença de que o grupo social é importante para a memória de cada indivíduo. Ainda para Halbwachs, o sujeito é participante na experiência da memória do grupo. Segundo Lins de Barros, as oficinas e palestras permitiram que interpretações e reflexões sobre o contexto local e a relação entre sociedade e patrimônio fossem realizadas no momento das atividades, "ocasião em que a memória individual atualiza as representações coletivas sem ocultar as colorações que cada indivíduo dá à sua história de acordo com trajetórias de vida particulares” (Daniel Bertaux in Lins de Barros 1997: 93). Nas atividades debateram-se as diversidades e particularidades e, ao mesmo tempo, os aspectos homogeneizadores da cultura (1997: 93). As ações possibilitaram identificar que existem diferentes memórias coletivas e discordâncias entre diversas versões de acontecimentos passados e presentes, que se consolidam em memórias submersas e dominantes muitas vezes influenciadas por relações de poder. Os bens patrimoniais são como pistas para a identificação dessas memórias, pois concentram um conjunto de significados fundamentais para as lembranças.

Para Lins de Barros existe uma intenção na preservação de determinados bens com o objetivo do não esquecimento. Os bens trazem em si diferentes possibilidades de narrativas, elementos diferentes para o relato do passado, "não só objetos, mas os lugares oferecem pistas para as recordações” (1997: 102). Nessa perspectiva o contexto local se faz importante, pois os bens apenas ocupam a função de "desencadeadores de lembranças” quando as pessoas thes dão sentido a partir de suas vivências. Segundo Pollak (1989), a história construída a partir de 
narrativas de diversas vivências é diferente da história oficial, portanto a memória coletiva possibilita que a história seja contada a partir de várias versões sobre o passado.

A partir dessa compreensão de patrimônio, memória e história, o programa buscou apresentar por meio das próprias narrativas locais um passado e um presente plurais, valorizando os diferentes segmentos daquelas sociedades. Assim, foram convidados para participar das atividades crianças, idosos, professores e grupos de organizações comunitárias - trabalhadores rurais, comunidades quilombolas, associações de mulheres, entre outros. Grupos que muitas vezes têm suas culturas reconhecidas e reduzidas a imagem de algo frágil, por conta de uma atitude política e bem definida "que exotiza, exorciza e infantiliza as culturas dos grupos ditos populares, rurais e tradicionais” (De Certeau in Cunha 2008: 161). Tentando romper com essa crença, durante as ações buscou-se não trabalhar com os grupos apenas separadamente, mas sim realizar atividades que propiciassem sua interação com outros grupos, em posição de igualdade. Para ilustrar essa tentativa é interessante apresentar o exemplo de uma Oficina sobre Identidade e Patrimônio para professores, realizada no município de Caetité durante a segunda etapa de intervenção.

Participaram professores de História e Geografia da rede municipal e trabalhadores rurais proprietários de áreas onde estão localizados sítios arqueológicos estudados no âmbito do Programa. A oficina teve uma proposta diferenciada, pois buscou favorecer discussões que evidenciassem diferentes perspectivas sobre a Arqueologia e os bens patrimoniais. A chegada dos trabalhadores rurais para a oficina estimulou, a princípio, a curiosidade dos docentes. A ação educativa apresentou a mesma organização das outras oficinas para professores. Assim, durante as discussões sobre identidade e sobre preconceito os proprietários deram seus depoimentos quanto à discriminação sofrida pelos trabalhadores rurais na cidade de Caetité. Um dos participantes, o Sr. Sebastião, que dá o nome a um dos sítios arqueológicos da região, falou sobre como o preconceito vem acompanhando gerações. E citou o exemplo de sua mãe, que enviuvou quando estava grávida de três meses do sexto filho. Durante toda a narrativa o Sr. Sebastião buscou enfatizar "a garra” da mãe na lida com a roça para criar seus filhos. Foi o trabalho rural que possibilitou sua sobrevivência. O senhor comentou ainda que pela pesquisa arqueológica a história de sua mãe será contada e escrita, pois o sítio que leva seu nome é a casa onde sua mãe viveu. A narrativa do Sr. Sebastião demonstra a importância que a Arqueologia passou a ter para essas pessoas, pois terão sua história de luta contada e valorizada.

No decorrer da oficina os trabalhadores falaram sobre o conhecimento e o uso de ervas medicinais, sobre os benzedeiros e benzedeiras das comunidades, sobre as rezadeiras, as 
carpideiras, as festas religiosas, as festas juninas, os cemitérios de pedras, o reisado, as rezadeiras das almas, entre outros. Esses diferentes bens citados geraram discussões diversas com os professores, que também passaram a contar suas histórias pessoais. Naquele momento, todos os participantes tinham algo de importante para acrescentar ao debate, tanto os professores como os trabalhadores da roça.

As explanações sobre o trabalho realizado pelas equipes de Arqueologia na região não foram feitas pela mediadora, e sim pelos proprietários rurais que acompanharam o resgate dos sítios arqueológicos. A fala do arqueólogo foi apenas uma, em meio às várias vozes que realizaram o debate sobre a Arqueologia. Os proprietários contaram histórias da convivência com as equipes da Arqueologia, falaram sobre a metodologia de resgate dos sítios, sobre como eram formadas as equipes, entre outras coisas. Vale destacar que a apresentação da oficina mostrou que no projeto predominaram sítios arqueológicos históricos dos séculos XIX e XX, diretamente relacionados às histórias das comunidades rurais que ocupam a região. No encerramento, foram mostradas fotos dos trabalhos arqueológicos realizados nas propriedades dos participantes - alguns deles, inclusive, se emocionaram. Os professores ressaltaram a importância da participação dos proprietários, não apenas para sua autoestima, mas também pelo conhecimento que haviam transmitido aos docentes. O kit de peças arqueológicas possibilitou que de forma descontraída os participantes interagissem ainda mais. O Sr. Sebastião relatou no final da oficina que havia ido para a atividade "meio desconfiado, pensando que seria de uma forma, mas chegando lá era totalmente diferente do que eu imaginava”, e que, se dependesse dele, toda a vizinhança ficaria sabendo do que aconteceu durante a oficina (Zanettini Arqueologia 2011b: 45). Em outros encontros realizados no decorrer das ações do programa, os proprietários presentes ressaltam que guardaram com cuidado o livro e o certificado que receberam durante a oficina.

Desde a primeira oficina, temas como preconceito, discriminação e exclusão suscitaram importantes reflexões que valem ser mencionadas nesta tese. No módulo ministrado para professores em Caetité, a primeira dinâmica gerou grande discussão entre os participantes. Trata-se de uma dinâmica que propicia que cada um fale sobre seus antepassados, e normalmente evidencia que os participantes não sabem discorrer sobre o passado de suas próprias famílias. Porém, em Caetité a atividade ganhou contornos diferenciados, uma vez que vários professores expuseram o orgulho por serem descendentes das famílias da elite da região - alguns chegaram a citar nomes de importantes personagens de Portugal como seus antepassados. Enquanto as professoras se gabavam de sua ascendência podia-se notar o incômodo dos outros participantes da ação educativa, que, porém, de início 
não se manifestaram. As críticas vieram à tona somente após uma das docentes afirmar que possuía “praticamente sangue azul”. Vários participantes afirmaram que as famílias tradicionais da região sempre se posicionavam de forma a excluir e desvalorizar os outros segmentos da comunidade da história local. Essa afirmação foi constante durante as oficinas realizadas pelo programa.

Em outra oficina, uma professora relatou que havia desenvolvido um trabalho acadêmico sobre a história de Guanambi e que a documentação usada como fonte possibilitou a desconstrução da história oficial do município. A professora continuou o relato informando que, após a apresentação oficial dos primeiros resultados de seu trabalho na universidade, sofreu ameaças, foi obrigada a interromper o trabalho e proibida de fazer qualquer tipo de publicação a respeito das descobertas.

Na oficina que teve como público-alvo as lideranças do Movimento das Mulheres, uma das participantes expôs que havia iniciado uma pesquisa via a Pastoral da Igreja Católica para verificar as raízes genealógicas das famílias locais. Segundo ela, as pesquisas evidenciaram que o local onde atualmente fica a região de Félix Pereira foi no passado uma aldeia indígena, que acabou exterminada pela família Pimentel. Hoje os descendentes dessa família residem na Comunidade Invernada, próxima à Moita dos Porcos. A participante informou que a pesquisa precisou ser interrompida, pois vários paroquianos se descobriram descendentes tanto da citada família como do povo indígena que foi exterminado, o que causou grande ressentimento e constrangimento para o grupo. Outros participantes deram depoimentos sobre preconceitos sofridos por eles mesmos e seus familiares. Uma professora contou a história de sua avó, que era uma parteira respeitada, mas mesmo assim sofria discriminação por ser mãe solteira. Também se discutiu a discriminação de moradores de outros estados do Brasil com relação à Bahia. Uma das participantes relatou que sua sobrinha, que reside em São Paulo, se recusa a aceitar e a dizer que sua família é baiana, pois tem vergonha.

Os ciganos também foram citados como objeto de discriminação na região, invariavelmente vistos como saqueadores, violentos e invasores. Vários participantes disseram que os ciganos são usados para chantagear ou pressionar as pessoas: "É só colocar nas mãos de ciganos que eles resolvem”. Em várias atividades foi mencionada a cidade de Ibotirama, localizada às margens do rio São Francisco e onde há um bairro só de ciganos: “As pessoas têm medo de passar lá perto”. Os depoimentos colhidos durante as oficinas favoreceram debates quanto às relações entre ciganos e não-ciganos nos municípios. Embora muita gente negasse a existência dessas relações, as discussões possibilitaram que os grupos 
evidenciassem que elas de fato existem, e que os ciganos também contribuíram e contribuem para a cultura local. Também figuraram como grupos discriminados as famílias circenses e a desconfiança da comunidade com relação à passagem dos romeiros pelas cidades da região. Um professor concluiu a discussão dizendo que a discriminação contra esses grupos "é um preconceito social”. Tal afirmação gerou um amplo debate sobre a pluralidade cultural e social da nação brasileira. Alguns docentes ressaltaram que não há uma cultura melhor que a outra. E citaram Paulo Freire para afirmar que "Não existe saber mais ou saber menos, há saberes diferentes”.

Muito se discutiu durante as oficinas sobre o preconceito contra os afrobrasileiros. É interessante destacar que, na maioria das oficinas, a princípio os participantes negros sentiamse extremamente incomodados com as discussões propostas, porém no decorrer das atividades ficavam mais à vontade para participar dos debates e apresentar seus depoimentos acerca das diferentes formas de discriminação no país. Vários professores apontaram suas dificuldades em lidar com atitudes preconceituosas entre os alunos, muitas vezes por falta de conhecimento ou de ferramentas que os ajudassem a tratar dessas temáticas em sala de aula. Para Gomes, a "escola não é um campo neutro onde, após entrarmos, os conflitos sociais e raciais permanecem do lado de fora” (1996: 69), mas sim um espaço sociocultural onde convivem os conflitos e as contradições, o racismo, a discriminação, o preconceito, não apenas com os negros, mas também de gênero, com os indígenas e com diversos outros grupos.

Durante as ações educativas procurou-se mostrar um Brasil que foi "historicamente ávido por branqueamento" e que reproduziu discursos "marcados por visões eurocêntricas na formulação de uma pretensa cultura nacional, discriminando culturas negras ou de negros” (Cunha 2008: 158) e de outros grupos. Os debates incentivados durante as oficinas e palestras buscaram desconstruir a visão homogeneizada do continente africano e a localização dos negros apenas no passado. Houve a intenção de trazer para o presente questões como a escravidão. Procurou-se mostrar a Arqueologia como uma ferramenta de auxilio aos professores no tratamento dessas questões.

Nas avaliações, os participantes ressaltaram a importância do fato de que a oficina propôs discussões claras sobre temas que, muitas vezes, ainda são tabus na sociedade moderna. Nas avaliações também foram criticadas a maneira como a temática da "história afro” é tratada nas escolas e a resistência dos professores em mudar a didática e a postura em relação ao preconceito racial no Brasil. Para Gomes (1996: 69), embora o número de professores sensibilizados para tais questões tenha aumentado, a grande maioria dos 
educadores ainda discute a escola de maneira reducionista, pois não leva em consideração que outras relações dentro da instituição também interferem no processo de escolarização.

"Falar em relações raciais e de gênero, discutir as lutas da comunidade negra e dar visibilidade aos sujeitos sociais não implica em um trabalho a ser realizado esporadicamente. Implica em uma nova postura profissional, numa nova visão das relações que perpassam cotidiano escolar e a carreira docente, e ainda, no respeito e no reconhecimento da diversidade étnicocultural” (Gomes 1996: 81).

As oficinas visaram auxiliar na formação deste novo educador, um agente de mudança dentro da escola e da sala de aula, um profissional que respeita e valoriza a sociedade plural em que vive.

Outra reflexão proposta, em especial na oficina com as lideranças das comunidades quilombolas, foi com relação a “o que é ser quilombola?” As lideranças comentaram que muitas vezes suas lutas por reconhecimento são confundidas com uma reivindicação apenas por terra. Essa reflexão propiciou um debate sobre os traços culturais das comunidades quilombolas, sobre a desvalorização da cultura por parte da juventude e a possibilidades de valorização a partir da Educação Patrimonial. Alguns participantes discorreram sobre as dificuldades diante da resistência de alguns indivíduos, em especial os jovens, de se aceitarem e se reconhecerem como negros ou provenientes das áreas rurais dos municípios. Várias lideranças solicitaram que a equipe da Zanettini Arqueologia realizasse palestras e oficinas com os mais jovens das comunidades. Uma liderança quilombola de Caetité afirmou ainda que a presença negra na história da cidade é negligenciada pela história oficial, e fez uma crítica à Casa de Anísio Teixeira, importante instituição cultural do município, que recentemente passou por obras de restauro. Segundo o participante, diversos cômodos foram restaurados, mas não a antiga senzala. O fato causou muita indignação nas comunidades quilombolas, e os participantes aproveitaram o espaço de discussão para refletir sobre a representação das comunidades nas instituições culturais do município.

A análise de instituições culturais da região foi uma temática tratada em várias oficinas. Em geral os participantes debateram sobre a razão pela qual as pessoas não têm o hábito de visitar museus e sobre a falta de identificação das pessoas com os objetos expostos. A maioria das instituições culturais da região conta a história de membros da elite dos municípios. Muito se discutiu sobre a necessidade de valorização dos "saberes que as pessoas possuem”. Em uma oficina realizada em Guanambi, após uma dessas discussões sobre os 
saberes populares um aluno da Educação para Jovens e Adultos (EJA) — o Sr. Mário, de 86 anos - se manifestou mostrando seu orgulho por saber construir uma casa de pau a pique e fazer artesanato em madeira, como colheres de pau, vassouras, entre outros. Tal afirmação gerou intenso diálogo entre os participantes, que passaram a questioná-lo sobre seus diversos saberes. O interesse dos jovens durante a oficina fez surgir uma discussão sobre a falta de diálogo entre os jovens e os mais velhos. Foi enriquecedora a contribuição de alguns alunos do EJA, principalmente do próprio Sr. Mário, que afirmou que aquela oficina era a primeira vez em que alguns alunos mais jovens da turma conversavam com ele.

Também durante as discussões sobre a valorização dos saberes populares tratou-se da confecção de casas de enxumento ou pau a pique, que passaram a ter mais importância depois que as imagens das escavações realizadas na região mostraram o interesse dos arqueólogos por essas construções. Em uma oficina realizada em Igaporã, alguns participantes afirmaram saber construir as casas de barro e que ainda moravam em casas de enxumento. A afirmação causou um intenso debate, pois também participava da oficina um representante da Secretaria Municipal de Saúde. O representante do poder público discorreu sobre as campanhas realizadas no município com o objetivo de desestimular que as pessoas construíssem esse tipo de casa, pois Igaporã é um município com elevado índice de pessoas portadoras da doença de Chagas, diretamente relacionada a esse tipo de habitação. Após reflexões o grupo concluiu que o importante seria estimular nas escolas o ensino das técnicas de construção dessas casas. Uma participante citou o exemplo de uma professora do colégio particular do município, que convida senhores das comunidades rurais de Igaporã para construírem com os alunos maquetes de casas de pau a pique, explicando o método de confecção das habitações.

Além das casas de pau a pique, outros bens foram debatidos durante os encontros. $\mathrm{O}$ mais relevante foi verificar que a maioria dos participantes procurou pensar em formas de contribuir para a preservação dos diferentes bens. O depoimento de uma professora demonstra como os participantes passaram a se tornar agentes ativos voltados para a preservação dos bens patrimoniais. Durante uma discussão sobre o enfraquecimento de uma das festas tradicionais do município, a docente afirmou estar chocada porque havia acabado de perceber que também era culpada pelo desaparecimento da festa, já que, como não frequentava mais as festas tradicionais, seus filhos não haviam aprendido a valorizá-las.

Assim como as casas de enxumento, os objetos e as narrativas trabalhados pelos arqueólogos passam a ser valorizados e a cumprir um novo papel para as comunidades. Vale ressaltar o caso de dona Maria, que vive nas proximidades de um dos sítios arqueológicos estudados: após os trabalhos da equipe ela coleta e guarda peças arqueológicas, por saber que 
são importantes, já que foram feitas pelos indígenas que moravam naquele local antes dela. O arqueólogo, assim, reintroduz objetos e narrativas em uma sociedade. Os vestígios arqueológicos, os bens patrimoniais e diferentes narrativas possuem grande potencial de conscientização cultural (Funari 2003: 35), pois a partir do momento em que são "reintegrados num contexto cultural em funcionamento", tornam-se novamente mediadores. Os objetos e as narrativas reintegrados pelo arqueólogo "passam a possuir novas funções e a exercer mediações no interior das relações sociais em que foram inseridos” (2003: 34). É interessante pensar, neste contexto, na apropriação do acervo coletado. A sociedade se mobilizou de forma a pensar e criar estratégias para a permanência das peças na região mesmo que grande parte do acervo conte a história de grupos indígenas e de comunidades rurais e quilombolas, tão discriminadas, conforme ficou patente durante as oficinas. Segundo Funari, esses artefatos podem adquirir funções ideológicas, incentivando a crítica às ideias dominantes e favorecendo a reflexão social e a ação social concreta (2003: 34). Assim, o material arqueológico possibilita leituras diversas: "É a maneira de abordar as evidências materiais que as faz falar” (2003: 44). Isso também se aplica ao arqueólogo.

Para esta tese, vale ressaltar que foi o olhar do arqueólogo em campo - atento aos sítios arqueológicos e ao contexto em que eles estão inseridos no presente -- que favoreceu a elaboração de um Programa de Educação Patrimonial voltado para os interesses da comunidade. Foi desde o início o olhar do arqueólogo que possibilitou a identificação dos fluxos espontâneos de visitantes aos sítios e o interesse pelo Turismo Arqueológico na região. Tal evidenciação demonstrou a sensibilização das equipes quanto ao papel do Turismo Sustentável em projetos educativos e seu envolvimento na elaboração dos projetos de Educação Patrimonial. A valorização dos sítios históricos pelas equipes de Arqueologia também possibilitou que o Programa Educativo atingisse de forma mais intensa a comunidade, pois grande parte dos grupos trabalhados durante as ações se reconhece no acervo histórico coletado.

Conforme discutido anteriormente, o papel do Turismo no Programa de Educação Patrimonial foi pensado dentro dos preceitos da sustentabilidade, cuja premissa é a participação. Desde seu planejamento até sua implantação buscou-se seguir os passos recomendados à real e efetiva participação da comunidade e das equipes de Arqueologia. Um projeto participativo, segundo Rabinovici (2010: 3), requer o diálogo desde seu planejamento, e suas intenções e objetivos também devem ser definidos de forma democrática. O autor critica "projetos iniciais que já determinam aonde querem chegar, o que alcançar, com qual prazo, estratégias e parcerias, antes de dialogar com as comunidades-alvo". 
Ciente de que a participação precisa ser amadurecida por todos os atores sociais envolvidos (2010: 3), o Programa de Educação Patrimonial foi desenvolvido de forma a ser retroalimentado, ou seja, a etapa seguinte está diretamente pautada pelos resultados da etapa anterior. Os públicos das palestras e oficinas e as temáticas a serem aprofundadas foram sendo formados e amadurecidos no decorrer da realização das ações. Como exemplo, vale citar a continuidade das ações com vistas à elaboração do Plano Museológico de uma instituição cultural, o que não havia sido proposto no projeto inicial. Verificou-se que a metodologia de realimentação só tem eficácia se cada atividade desenvolvida for imediatamente avaliada. Assim, a avaliação se mostrou essencial para o programa. Vale ressaltar que embora haja importantes exemplos no país a avaliação ainda é extremamente negligenciada em Projetos de Educação Patrimonial, em especial da Arqueologia Preventiva (Wichers 2012). Para o programa em questão, a avaliação objetivou produzir informações de qualidade para a tomada de decisões (Zanettini Arqueologia 2011b), inspirando mudanças nas etapas seguintes, apresentando eixos de reflexão que contribuíram para o amadurecimento das diferentes ações (2011b).

A iniciativa da comunidade quanto à criação do museu e quanto ao envolvimento do Turismo na proposta demonstra que o programa possibilitou a mobilização da sociedade, que por conta própria se reuniu, discutiu e identificou suas demandas. O papel atuante da comunidade, favorecido pelas ações educativas, diferencia o programa em pauta dos projetos de Turismo desenvolvidos por ONGs e analisados por Rabinovici (2010: 10-11), que propiciaram durante sua implantação o "desmantelamento de iniciativas locais, com a dependência e acomodação comunitária” (2010; 11). Segundo o autor (2010; 11), os projetos de Turismo Sustentável devem incentivar debates e a problematização das ações realizadas no local - por exemplo, as pesquisas arqueológicas e o Inventário da Oferta Turística -, objetivando transformar as comunidades em sujeitos atuantes e inseridos na construção de parcerias sociais e políticas voltadas para a preservação dos bens patrimoniais. Além disso, os projetos devem ter em mente o fortalecimento de identidades locais, o acesso aos bens culturais e econômicos e a inclusão social. Para Rabinovici, essas seriam as metas capazes de criar possibilidades emancipatórias para as comunidades. O que demonstra que o programa aqui discutido compartilha das mesmas premissas do autor.

Visando ao envolvimento da comunidade como agente, as Oficinas sobre Construção de Imagem Turística, propostas pelo programa, possibilitaram a reflexão sobre a sociedade, os costumes, as mudanças, os impactos causados pelos grandes empreendimentos, entre outros temas, buscando demonstrar para os participantes seu poder de modificar sua realidade e seu 
entorno. Vale destacar o exemplo da oficina de Caetité, em que os participantes analisaram a imagem do município e constataram as dificuldades de construção de uma imagem positiva para a cidade, já que nos últimos anos tem sido amplamente divulgada uma imagem negativa, associada aos problemas causados pela extração de urânio. Uma participante relatou que quando pesquisou o nome do município no mecanismo de buscas Google as primeiras reportagens que aparecem diziam respeito a um caso recentemente ocorrido de um caminhão que supostamente trazia lixo radioativo para o município. Os participantes refletiram sobre como seria possível construir uma imagem turística positiva do município se a veracidade das informações é a premissa básica. Concluíram que seria crucial uma mudança em diferentes aspectos do município, para que a imagem turística ganhasse contornos positivos e espelhasse os reais aspectos da localidade. Os participantes ressaltaram ainda a importância da construção coletiva da imagem, com o envolvimento dos diversos segmentos que compõem a comunidade, de modo a incluir vários grupos atualmente excluídos da imagem que se tem da cidade.

Outro debate interessante proposto durante as ações foi quanto ao conceito de Turismo. Vale destacar que ainda prevalece no Brasil uma visão muito limitada da atividade, relacionada a pressupostos do Turismo de Massa e que envolve, por exemplo, preparar os lugares para que propiciem conforto para os visitantes. Essa compreensão minimalista do Turismo muitas vezes ainda pode causar a má compreensão de projetos desenvolvidos dentro dos preceitos do Turismo Não-Convencional, pois o resultado esperado - por exemplo, pelos financiadores do projeto - muitas vezes não é o objetivo das ações. Muitos financiadores esperam que, após o desenvolvimento das ações do planejamento estratégico participativo, muitos atrativos estejam estruturados e que vários ônibus de visitantes cheguem para conhecer a cidade. Tal compreensão faz com que projetos sejam abandonados pela "interrupção do financiamento de patrocinadores preocupados somente com a dimensão econômica” (Rabinovici 2010: 12). As ações do Turismo Sustentável devem se analisadas de forma a levar em conta a amplitude da atividade turística e seu papel educacional e irradiador de iniciativas. Assim, para tentar mudar essa imagem estreita da atividade turística, durante as ações procurou-se apresentar Turismo a partir da motivação, ou seja, o sair de casa para conhecer algo novo ou olhar sob uma nova perspectiva algo que já conhece. Em uma oficina de Guanambi, vários participantes alegaram nunca terem sido turistas, pois nunca haviam deixado o município em que residiam. Após a exposição do conceito, um dos presentes comentou: "Então hoje eu sou turista, pois é a primeira vez que venho à Câmara Municipal de Guanambi!”. Deste modo, o conceito de Turismo trabalhado pelo programa visou enfatizar 
não o preparo de atrativos para recepção de visitantes, mas sim preparar as pessoas para serem turistas responsáveis, que saibam compreender e respeitar a diferença e favorecer a preservação.

Por fim, as ações procuraram mobilizar a sociedade para que, de forma consciente, tenha condições de propor e exigir dos grandes empreendedores projetos que garantam a sustentabilidade socioambiental da região em apreço. Dentro dessa perspectiva, foi possível observar mudanças em alguns segmentos da sociedade com relação à aceitação de projetos de cunho assistencialista, projetos que não atendem às reais demandas locais ou que foram pensados apenas para atender a exigências legais. Vale citar como exemplo a constatação de uma das secretárias de Educação parceiras do programa, que rejeitou um projeto de Educação Patrimonial que propunha a realização de apenas uma palestra, em uma única escola do município. A secretária alegou que hoje ela sabe que é possível exigir mais que uma mera palestra. 


\section{CApítulo 6 - Estudo de Caso 3: O MuSeu Histórico e Arqueológico de LINS}

Neste capítulo apresenta-se o processo de formação do Museu Histórico e Arqueológico de Lins.

O município de Lins localiza-se no noroeste do estado de São Paulo, a aproximadamente 500 quilômetros da capital, São Paulo. Em 2009, a população da cidade era estimada pelo IBGE em 73 mil habitantes. De economia eminentemente industrial, Lins é um dos maiores pólos exportadores do estado, em especial de carne bovina e derivados. Destacase também a produção de açúcar e álcool. Com o fortalecimento do município como pólo exportador houve um aumento considerável do fluxo de negociantes e viajantes para Lins, o que favoreceu a expansão de seu parque hoteleiro. Por conta da demanda por meios de hospedagem, bem como em função das águas termais que são por si só um interessante atrativo, a rede de hotéis Quality construiu na cidade um de seus resorts, o que propiciou o aumento do número de visitantes para Lins. Vale ressaltar que, assim como outras redes de resorts, a Quality tem por filosofia criar estratégias e atividades para que o hóspede não deixe as dependências do hotel durante toda sua estada. Essa postura impossibilita o contato entre o visitante e a comunidade local e, em muitos casos, a existência do resort gera pouco gera benefícios para os moradores.

Em 2007, o governo municipal de Lins, por meio da Secretaria de Desenvolvimento Sustentado (SEDESU), passou a considerar a possibilidade de o município se desenvolver turisticamente. O interesse se deu por incentivo do Programa de Regionalização do Turismo do governo federal. A SEDESU passou a desenvolver uma série de iniciativas visando elaborar um Projeto Municipal de Turismo, no âmbito dos preceitos da sustentabilidade. Inicialmente a Secretaria realizou uma análise de inventários turísticos elaborados pelo Curso de Turismo da Universidade Metodista de Piracicaba (UNIMEP). Os resultados dos inventários nortearam a organização do setor, com a elaboração de estratégias de aproveitamento de dados, estabelecimentos e infraestrutura já existentes no município. Como forma de aproveitar os dados disponíveis sobre os diferentes eventos que aconteciam em Lins, atualizou-se o calendário de eventos do município, que passou a ser divulgado por meio de uma publicação. O calendário de eventos possibilitou a viabilização de incentivos e planos de apoio a vários eventos do município, em especial à Festa de Nossa Senhora de Fátima. 
Ainda em 2007 foi publicado o primeiro Guia Gastronômico de Lins, com um rol de nomes, endereços, telefones e horários de funcionamento de estabelecimentos como restaurantes, lanchonetes, churrascarias, sorveterias, entre outros. Também foi editado um folheto denominado Destinos Rodoviários, dando a conhecer as linhas rodoviárias que atendiam à cidade. Outra importante iniciativa foi a estruturação e inauguração da Casa do Artesão, com o intuito de incentivar o artesanato local, oferecendo cursos de capacitação e a venda dos produtos artesanais. Essas iniciativas possibilitaram uma breve sensibilização da comunidade quanto a alguns bens patrimoniais do município e seu potencial turístico.

Com base na metodologia do Programa de Regionalização do Turismo, a SEDESU formatou dois roteiros turísticos em Lins. O primeiro foi intitulado Lins, diversidade cultural - nossos templos religiosos, e possibilitou a estruturação e visitação de diferentes templos religiosos do município - algumas igrejas católicas, a igreja ortodoxa, um templo budista, entre outros - , valorizando sua importância cultural, histórica e arquitetônica. Vale ressaltar que para a formatação do roteiro foi realizada uma série de reuniões com os responsáveis pelos templos e igrejas, a fim de verificar possibilidades de apoio aos bens patrimoniais e sensibilizá-los quanto ao Turismo.

A formatação do segundo roteiro - Roteiro Rural do Campestre - objetivou o planejamento e a estruturação de atrativos na área rural do município, de modo a aproveitar estabelecimentos de alimentação já existentes e incentivar novas iniciativas. Neste caso destacam-se um restaurante japonês e uma sorveteria. A sorveteria, depois de um ano de participação no roteiro turístico, já tinha seu quadro de funcionários triplicado e suas instalações haviam sido ampliadas.

Foi elaborado e implantado no município um programa de sinalização turística, desenvolvido segundo as diretrizes nacionais apontadas no Guia Brasileiro de Sinalização Turística. O programa serviu de modelo para diferentes cidades paulistas. A Prefeitura Municipal de Lins também divulgou o município em um dos maiores eventos de Turismo brasileiro, o "Salão São Paulo de Turismo”. As ações apresentadas, todas elas voltadas para o desenvolvimento turístico municipal, geraram material de divulgação, porém somente depois que cada atrativo tinha sido estruturado e seus responsáveis haviam sido sensibilizados quanto à atividade e à recepção de visitantes. Como forma de planejamento das atividades para o ano de 2008, foram realizados estudos sobre diferentes segmentos turísticos que pudessem ser desenvolvidos em Lins com vistas à diversificação da oferta turística. Esses estudos evidenciaram a Arqueologia como uma área de interesse do município, o que fez com a 
SEDESU iniciasse um debate com alguns arqueólogos sobre as possibilidades de implantação de Turismo Arqueológico em Lins.

Em 2008 foram atualizados o Guia Gastronômico e o calendário de eventos de Lins, e ganharam corpo ações voltadas para a ampliação do Roteiro Rural, a partir da formação de novas parcerias com proprietários rurais. No mesmo ano foi planejado e elaborado um projeto de comemoração dos 100 anos da imigração japonesa no Brasil. Vale salientar que Lins - e, de maneira geral, o noroeste de São Paulo — recebeu os primeiros contingentes de imigrantes japoneses vindos para o Brasil. O projeto envolveu a construção de um portal japonês e a estruturação de uma rua com decoração japonesa no centro do município. Também foi inserida no projeto uma exposição proposta pelos pesquisadores Robson Rodrigues, Louise Alfonso, Márcia Lika Hattori e eré Strauss com o propósito de iniciar um debate sobre a Arqueologia em Lins, por se considerar que o patrimônio arqueológico era um interessante recurso turístico municipal.

A exposição — denominada “Exposição Arqueológica da Coleção Kiju Sakai” — teve por objetivo apresentar à comunidade o acervo coletado pelo imigrante japonês e arqueólogo amador Kiju Sakai. Durante a primeira metade do século XX, o pesquisador desenvolveu importantes escavações arqueológicas na região dos municípios de Lins e Promissão, no interior do estado de São Paulo e Ribeira do Iguape, litoral paulista. Sakai também organizou, antes da Segunda Guerra Mundial, uma sociedade de pesquisa integrada por imigrantes japoneses, o Instituto Paulista de Arqueologia. O acervo arqueológico foi formado a partir de diversas etapas de campo empreendidas e coordenadas pelo pesquisador e sua equipe, e era composto por material lítico lascado e polido, recipientes e fragmentos cerâmicos com procedências diversas, remanescentes esqueletais humanos, fauna, peças em metal e documentação das atividades de campo - por exemplo, o diário de Kiju Sakai e aquarelas de sua autoria (Fundação Araporã 2008).

A inserção da exposição arqueológica nas comemorações do centenário da imigração japonesa visou ressaltar as contribuições dos imigrantes japoneses na construção do conhecimento científico brasileiro, propiciando um diálogo entre o público e os pesquisadores, democratizando informações históricas, antropológicas e arqueológicas. Tal diálogo foi propiciado por meio de recursos educativos, didáticos e museológicos. A realização do evento foi possível graças a uma parceria entre a Prefeitura Municipal de Lins, o Centro de Estudos Indígenas Miguél Angel Menedez (CEIMAM) da Universidade Estadual Paulista (UNESP), a Fundação Araporã e pesquisadores ligados ao Laboratório de Estudos 
Evolutivos Humanos (LEEH) do Instituto de Biociências da Universidade de São Paulo (IB USP) - responsável pela guarda da coleção - e a comissão organizadora da comemoração do centenário.

A exposição foi montada com os seguintes módulos:

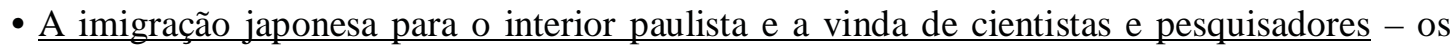
painéis discorreram sobre os aspectos que motivaram a imigração japonesa para o Brasil, bem como sobre o contexto que os recém-chegados encontraram aqui e as dificuldades vivenciadas pelos imigrantes;

- A história de vida de Kiju Sakai - o arqueólogo e suas pesquisas - os painéis contaram a história de Kiju Sakai e mostraram sua contribuição para o desenvolvimento da Arqueologia brasileira, que "não se deu somente no âmbito de seus estudos, mas também através do seu comprometimento político e social com os grupos indígenas que tem sua história impressa nesses objetos” (Fundação Araporã 2008).

- A pesquisa arqueológica - os painéis expuseram informações sobre as seguintes temáticas: os kaingang, montículos kaingang, instrumentos líticos e cerâmica tupi, o povo do sambaqui e sepultamentos em sambaquis. Neste módulo buscou-se mostrar a diversidade das populações indígenas que viveram e vivem no Brasil;

- A Etno-história do oeste paulista, com enfoque para a região de Lins - a questão indígena na região de Lins, a formação de reservas multiétnicas pelo Sistema de Proteção ao Índio (SPI), enfatizando a reserva formada entre Lins e Promissão e a situação atual dos povos indígenas no noroeste paulista.

A exposição ocorreu durante o mês de junho de 2008, na Casa de Cultura Nicolau Zarvos, e teve como mediadores alunos do então existente curso de História do Centro Universitário Católico Salesiano Auxilium (UNISALESIANO). Juntamente com a montagem e concomitante à exposição foi implementado o Programa Educativo da Exposição Kiju Sakai, projeto que propôs "um diálogo direto entre a exposição, aqueles que a conceberam e o público visitante, considerando este público enquanto sujeitos históricos ativos com significações de olhar distintos” (Hattori e Alfonso 2008: 1) (Prancha 12). 


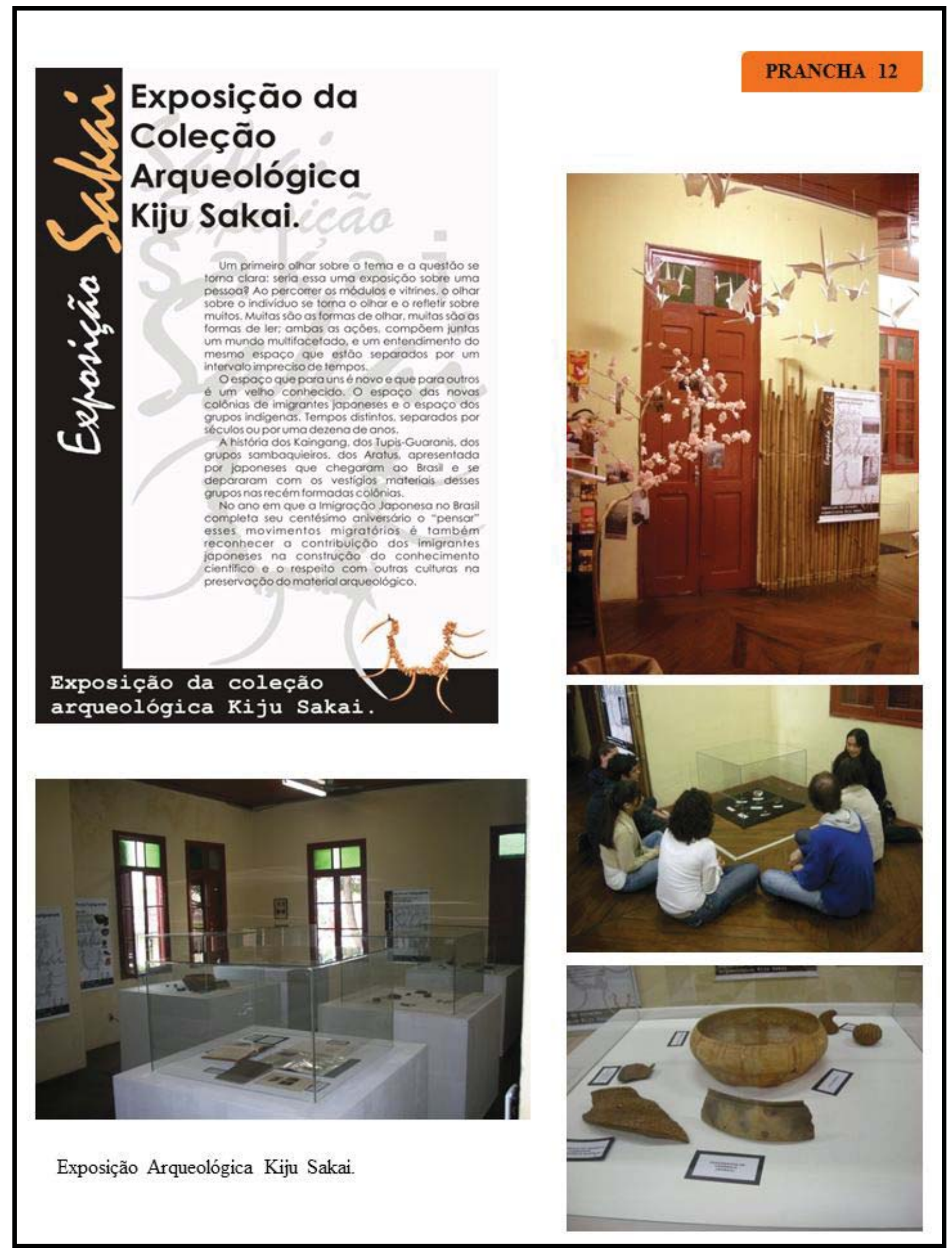


O projeto envolveu as seguintes atividades:

- Oficina com a comunidade japonesa - visando a um debate com a comunidade japonesa sobre o trabalho de Kiju Sakai e as escavações no noroeste paulista, sobre Arqueologia e sobre a Exposição propriamente dita. A oficina procurou trabalhar a valorização e a contribuição da imigração japonesa para a região a partir da apresentação denominada $O$ japonês em cada um de nós. Também objetivou o envolvimento da comunidade na elaboração do módulo sobre a imigração, por meio do levantamento de histórias de vida e de acervo fotográfico (Alfonso e Hattori 2012).

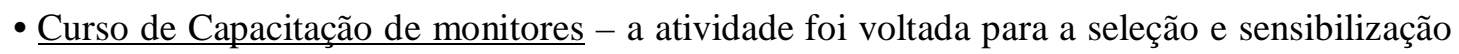
de alunos do curso de História do UNISALESIANO para atuarem como mediadores entre o público e a exposição. O curso contou com a leitura e discussão de textos, módulos aplicados pelos curadores sobre o acervo e etnohistória regional, discussões sobre Museologia e sobre educação em museus. Os monitores participaram ainda da montagem da exposição e da capacitação para professores.

- Seminário com os pesquisadores curadores de diversas especialidades - realizado nas dependências da UNISALESIANO, para alunos da universidade. O debate foi desenvolvido pelos curadores da exposição: Robson Rodrigues, Louise Prado Alfonso, eré Strauss, Márcia Lika Hattori e Pedro Damin. As apresentações tiveram as seguintes temáticas: Etnohistória kaingang, Arqueologia, Museus e Museologia, Bioarqueologia, Curadoria do acervo Kijo Sakai e Educação em Museus.

- Curso de Capacitação de professores - envolveu professores da rede municipal de ensino. A atividade procurou apresentar aos docentes a proposta de curadoria da Exposição Kiju Sakai, além de ensejar um debate sobre temas como Arqueologia, imigração, o conceito de patrimônio material e imaterial, museus e identidade. Visou ainda suscitar reflexões acerca do acervo e do conteúdo da exposição como ferramentas didáticas para o trabalho com diferentes conteúdos em sala de aula. O curso também teve o intuito de sensibilizar os docentes com relação à importância da discussão prévia de algumas temáticas em sala de aula antes da visita, como forma de preparar os alunos para a exposição. Além disso, discutiram-se possíveis atividades a serem realizadas após a visitação. 
No espaço de um mês a exposição teve público de aproximadamente dois mil visitantes, em sua maioria alunos de escolas estaduais e municipais de Lins e região e público espontâneo de diversas de partes dos estados de São Paulo e Rio de Janeiro. O alto número de visitantes se deve à divulgação feita pela mídia e também por boletins de divulgação acadêmica como a Agência de notícias da Fundação de Amparo à Pesquisa de São Paulo (FAPESP).

\section{AVALIAÇÃO DA EXPOSIÇÃO ARQUEOLÓGICA KIJU SAKAI}

A Exposição Kiju Sakai envolveu a criação de instrumentos avaliativos diferenciados, que foram respondidos por docentes e pelos mediadores da exposição. Como forma de determinar a qualidade da apreensão das temáticas por parte dos alunos foi realizada também a avaliação de trabalhos realizados pelos discentes em sala de aula. Por fim foram analisadas as considerações dos visitantes espontâneos, registradas no Livro de Impressões.

\section{Avaliação dos mediadores}

O instrumento avaliativo da Exposição Kiju Sakai para mediadores foi elaborado contendo questões dissertativas. A avaliação buscou analisar a mediação e interação com o público escolar. Entre as questões do instrumento havia perguntas básicas quanto ao grupo visitante: ano escolar, nome da escola, nome do professor, disciplinas lecionadas pelo docente e número de alunos. Além disso, as outras questões objetivavam ter uma ideia sobre aspectos como: a capacitação do docente (se o professor havia participado do Curso de Capacitação), $\underline{\mathbf{~}}$ preparo para a visitação (o mediador descreveu as atividades desenvolvidas antes dos alunos adentrarem a exposição), a visitação (espaço para o mediador explicar como foi realizada a mediação); o pós-visita (as discussões realizadas com os alunos após a visita, ainda na Casa de Cultura).

Inicialmente os mediadores procuravam aguçar a curiosidade dos alunos acerca da exposição e das temáticas por ela abrangidas. A partir dos nomes dos alunos, os mediadores questionavam sobre os antepassados dos discentes e também procuravam incentivar uma breve reflexão sobre a diversidade dos povos indígenas ontem e hoje. Foi possível notar que muitos alunos e professores não tinham conhecimento da Arqueologia, disciplina que confundiam com a Paleontologia. 
No início da visitação os mediadores solicitavam aos alunos que visitassem todos os módulos da exposição - uma forma de diminuir a ansiedade dos discentes —, para então darem início a reflexões e debates com os visitantes. Os mediadores e os alunos sentavam-se no chão, ao redor de uma vitrine preparada especialmente para ser trabalhada com o público escolar. Os visitantes eram indagados acerca de suas impressões quanto aos diversos módulos da exposição; assim que apresentavam suas considerações, os mediadores estimulavam reflexões sobre a imigração, sobre as mudanças verificadas no decorrer do tempo quanto a aspectos como alimentação, modos de vida, diferentes formas de sepultamento, a Arqueologia, a profissão de arqueólogo e museus. Após as discussões os mediadores faziam novamente o circuito da exposição com os discentes. No final das visitas os mediadores buscavam fazer com que os alunos pensassem o seu presente a partir dos objetos do passado apresentados nos diferentes módulos da exposição.

Era evidente que em sua maioria dos professores que haviam feito o Curso de Capacitação levaram seus alunos para conhecer a exposição. Esses docentes sensibilizaram suas turmas antes da visita, o que, segundo os mediadores, favoreceu tremendamente o trabalho com os grupos - em comparação com os grupos coordenados por docentes que não haviam feito o curso. Os monitores também avaliaram a vitrine feita especialmente para o trabalho com os alunos; segundo eles, a vitrine teve papel eficaz, pois as peças motivaram os alunos a discutir os temas de interesse da exposição. Os mediadores avaliaram que era importante que os alunos realizassem sozinhos a primeira visitação, pois bastava aos mediadores acompanhar os alunos para identificar questões de interesse da turma e comentários que auxiliaram posteriores debates. Os mediadores verificaram ainda que as vitrines ficaram muito altas para os alunos do Ensino Infantil e Fundamental 1 e 2. Por fim houve perceptíveis mudanças nas falas e percepções dos alunos e dos professores quanto às temáticas trabalhadas.

\section{Avaliação dos professores}

O instrumento avaliativo da Exposição Kiju Sakai para professores foi elaborado contendo questões dissertativas que buscaram identificar as impressões dos professores quanto à exposição e à mediação. O questionário do instrumento era composto de:

- perguntas básicas quanto ao grupo visitante: ano escolar, nome da escola, nome do professor, disciplinas lecionadas pelo docente e número de alunos;

- questões sobre as expectativas dos docentes em relação à exposição; 
- questões sobre o preparo para visitação: solicitou-se uma breve explicação das atividades desenvolvidas com os alunos em sala de aula antes da exposição;

- questões sobre como se deu a visitação e a monitoria;

- questões sobre o pós-visita: que atividades foram desenvolvidas em sala de aula, quais os seus objetivos e quais os resultados;

- questões sobre o aprendizado do aluno, sobre o papel educativo da exposição e sobre sua validade para os alunos.

As docentes afirmaram ter ficado ansiosas e apreensivas quanto ao comportamento que os alunos teriam durante a exposição. Algumas professoras estavm preocupadas, pois a seu ver os alunos não seriam capazes de se interessar pelas temáticas, em especial pela Arqueologia, já que segundo elas se tratava de uma área muito distante da realidade dos alunos. As professoras também relataram o temor de que os alunos não se comportassem bem, porque jamais haviam visitado um museu ou uma exposição com vitrines, dada a inexistência de instituições culturais na região. Algumas considerações dos professores: “Achei que eles iriam achar sem-graça, sem sentido, mas logo de cara se mostraram muito curiosos"; "Me despertou o interesse para ver como seria apresentado o tema e me surpreendeu, foi muito além das expectativas"; e "Ficamos curiosas e ansiosas, também era a nossa primeira oportunidade de visitar um museu arqueológico”.

Quanto ao preparo prévio dos alunos para a visita, os professores que não haviam participado do Curso de Capacitação responderam que não tinham preparado seus alunos para a visitação. Os docentes que participaram do curso utilizaram diferentes metodologias: entrevistas com os mais velhos, pesquisas sobre os antepassados de cada um, sobre elementos do cotidiano no passado e no presente, sobre os povos indígenas e sobre a profissão de arqueólogo. Com relação à visitação, todos os professores responderam positivamente, afirmando que a visita atendeu às suas expectativas, pois despertou o interesse dos alunos. Os docentes elaboraram questões durante a visita e depois, em sala de aula. Algumas considerações dos professores: "Eles tinham muitas perguntas a fazer"; "Ao chegar na classe percebi o interesse em comentar o que haviam visto"; e "Se comportaram bem e se mostraram interessado pela origem dos objetos expostos”. Todos os docentes avaliaram positivamente a monitoria: "Pareciam saber muito sobre o que falavam" e "Tiraram as dúvidas dos alunos com paciência”.

Após a visitação, diferentes atividades foram desenvolvidas pelos professores em sala de aula, envolvendo pesquisas na Internet, estudos sobre Arqueologia, o trabalho do 
arqueólogo e sobre os povos indígenas, bem como produção de textos e ilustrações, registros individuais e coletivos, visitas à exposição com familiares - para que agora o próprio aluno fizesse a mediação --, oficinas de cerâmica e de confecção de colares feitos com sementes para que fosse trabalhado o tema das culturas indígenas. Na opinião das professoras a exposição cumpriu seu papel educativo, pois: "Despertou no visitante a curiosidade de conhecer e se informar de assuntos que ele pensa estarem longe de sua realidade"; "Eu não esperava tanto, os alunos chegaram ainda com mais perguntas em sala de aula. É aquele velho ditado: quanto mais se sabe, mais se quer saber, e na educação é isso que interessa”; e "Teve ensino aprendizagem, os alunos conseguiram fazer um paralelo entre o passado e o presente”.

Para os professores a visita foi válida, pois despertou o interesse dos alunos pelas temáticas. Grande parte dos docentes ressaltou a importância da exposição por não haver na região outras instituições culturais que possibilitassem experiências semelhantes: "Foi válida, pois oportunizou que alunos e professores visitassem uma exposição arqueológica e vivenciassem uma ida ao museu, coisa difícil em nosso cotidiano"; "É necessário este tipo de informação em cidade tão carente em estruturas deste porte”. Os docentes finalizaram avaliando elementos da exposição, como o conteúdo e as temáticas, que segundo eles foram apresentados com clareza e profundidade, em módulos organizados de forma a facilitar a apreensão do conteúdo. Mencionaram a dedicação dos curadores na montagem de uma boa estrutura no município. Algumas considerações: "O trabalho de pesquisa foi riquíssimo, a exposição teve uma sequência lógica” e "os temas estavam interligados, demonstrando que tinham conhecimento sobre o assunto abordado”.

\section{Avaliação dos alunos}

A avaliação dos trabalhos dos discentes nas ações de multiplicação em sala de aula sobre as discussões propostas pela exposição também foi realizada segundo o método do Conselho de Museus, Arquivos e Bibliotecas da Grã-Bretanha, Learning Impact Research Project. A fim de conhecer o universo de análise realizou-se uma avaliação prévia sobre as referências patrimoniais mencionadas ou rejeitadas, o que permitiu a seleção de 10 trabalhos para a análise mais detalhada baseada nos Resultados Genéricos de Aprendizado (GLOs).

No universo analisado predominaram os trabalhos que apresentaram as seguintes temáticas principais; elementos expográficos, imigração e morte: 


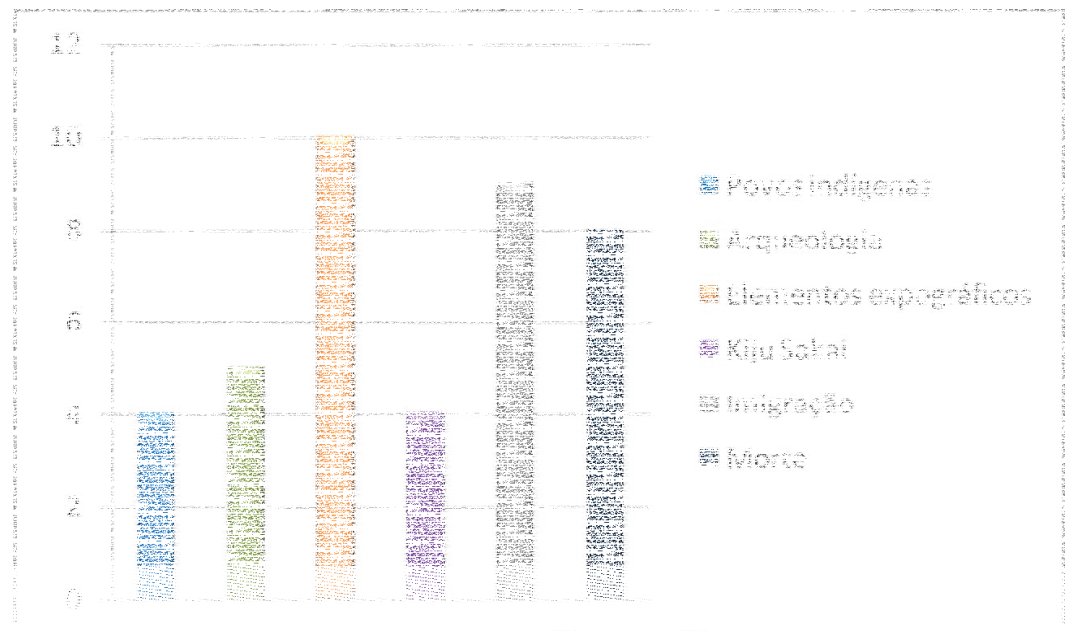

Gráfico 8. Temáticas que mais aparecem nas composições sobre a exposição.

Quanto à forma do trabalho, predominaram as atividades que envolveram a linguagem escrita, conforme demonstrado no gráfico a seguir:

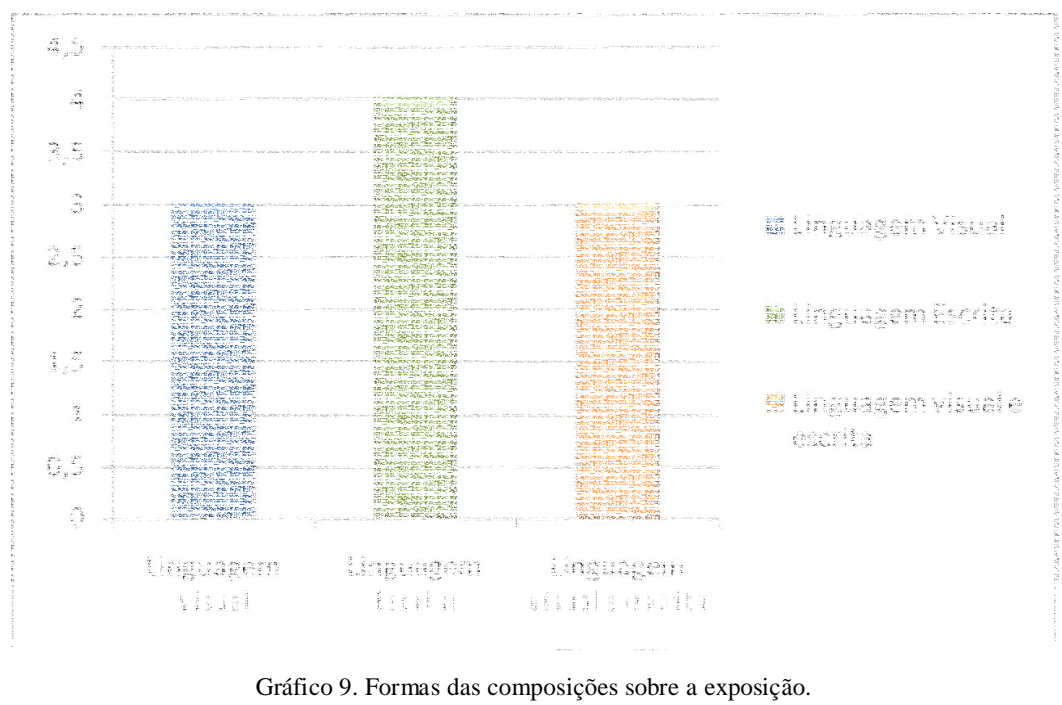

As avaliações mais aprofundadas, realizadas nos trabalhos, demonstraram que a Exposição Arqueológica Kiju Sakai cumpriu seu papel educativo, pois possibilitou debates e reflexões quanto às temáticas apresentadas, já que nos textos e desenhos produzidos pelos alunos estavam presentes elementos resultantes dessas reflexões. Uma vez que a experiência museal era uma novidade para os discentes, optou-se por inserir a temática "Elementos expográficos”, que figurou com destaque nas produções — por exemplo, a mediação, as 
vitrines, o livro de visitantes, os tsurus ${ }^{7}$ e a cerejeira com as fotos das famílias japonesas. Vale destacar que as fotos que compunham o módulo da imigração foram cedidas pelos participantes da oficina realizada com a comunidade japonesa. Alguns exemplos de trabalhos avaliados a partir da metodologia proposta pelos Resultados Genéricos de Aprendizado podem ser visualizados na Pranchas 13.

\section{Avaliação do público espontâneo}

A avaliação foi realizada a partir das observações dos visitantes registradas no Livro de Impressões. As temáticas mais citadas pelos visitantes foram: História, origem, cultura, identidade, povos indígenas, preservação, diversidade, Arqueologia, imigração e Kiju Sakai. Uma afirmação interessante foi citada por vários visitantes diz respeito à importância de se conhecer o passado para se pensar o futuro da região. Chama a atenção que muitas pessoas tenham usado os termos "nossa” cultura, "nosso” passado, o que demonstra uma apropriação dos bens patrimoniais e das narrativas apresentados pela exposição. Outra temática mencionada no Livro de Impressões foi quanto à mediação. A grande maioria dos visitantes que assinou o livro elogiou os mediadores por sua qualificação, paciência, atenção e conhecimento. Vale citar algumas considerações: "Os monitores foram ótimos, usaram uma linguagem simples, a qual entendermos com facilidade" e "O monitor demonstrou ter conhecimento sobre os objetos”. Por fim, outros elementos abordados referem-se à ausência de instituições culturais em Lins e região e à importância da realização de ações semelhantes: "Muito boa a iniciativa, são exposições desse tipo que vão colaborar com a formação cultural de Lins"; "Nossa cidade precisa de mais exposições desse tipo"; "Parabéns por esta exposição, e que outras venham para que nós possamos cultivar o gosto por conhecer outras culturas"; "Espero que haja mais exposições arqueológicas aqui em Lins”; "Lins precisa muito desse incentivo à cultura”; e "Lins precisa de mais exposições”.

As avaliações demonstraram a importância da exposição como motivadora de debates sobre diferentes temas, mas também por possibilitar uma experiência museal para a comunidade.

\footnotetext{
${ }^{7}$ No módulo referente à imigração japonesa foram feitos tsurus de origami; os tsurus são pássaros de dobradura em papel, símbolos de paz, prosperidade e longevidade. Uma antiga lenda diz que se deve dobrar esses pássaros e ofertá-los às pessoas a quem desejamos saúde, felicidade e boa sorte.
} 


\begin{tabular}{|l|l|}
\hline Grupo & 1 \\
\hline $\begin{array}{l}\text { Classificação da } \\
\text { composição }\end{array}$ & Linguagem visual \\
\hline Temática & $\begin{array}{l}\text { Arqueologia, Elementos } \\
\text { Expográficos, Imigração e Kiju } \\
\text { Sakai }\end{array}$ \\
\hline GLO - Resultados Genéricos de Aprendizagem \\
\hline $\begin{array}{l}\text { Conhecimentoe } \\
\text { Compreensão }\end{array}$ & $\begin{array}{l}\text { Aprendizado sobre temáticas } \\
\text { especificas. }\end{array}$ \\
\hline Habilidades & $\begin{array}{l}\text { Habilidadesfundamentais- } \\
\text { Saber como se faz desenho. }\end{array}$ \\
\hline Atitudes e Valores & Empatia com a temática \\
\hline $\begin{array}{l}\text { Prazer, Inspiração } \\
\text { e Criatividade }\end{array}$ & Diversãoe experimentação \\
\hline $\begin{array}{l}\text { Atividade, } \\
\text { Comportamento e } \\
\text { Desenvolvimento }\end{array}$ & $\begin{array}{l}\text { Mudança quanto à forma de } \\
\text { Compreender o patrimônio e }\end{array}$ \\
\hline
\end{tabular}

Trabalhos referentes à Exposição Kiju Sakai, avaliados a partir da metodologia proposta pelo GLO.

Whina. Mathena cassionzo Ode Jeans

Z Dús saimea da Dassa escila para tisitar una

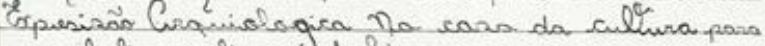
ver obyitos antiges de lims e regiã.

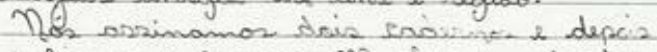

entranges a firomes Mutros impulgadrs por ter pisto antros abretas difiennis.s.

1 Hermano esplicay para nós aue não ustraparse a baisca branca serque timba

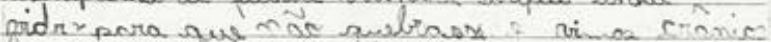
lancas, moidas y dentes de tularár, celar de denies de Macacorde sorco en bermano fiz. plrgunios solve o que vimos e deposs explican soure todos os ofritos aus istairo exposto.

\begin{tabular}{|l|l|}
\hline Grupo & 2 \\
\hline $\begin{array}{l}\text { Classificação da } \\
\text { composição }\end{array}$ & Linguagem escrita \\
\hline Temática & $\begin{array}{l}\text { Arqueologia e Elementos } \\
\text { Expográficos }\end{array}$ \\
\hline GLO - Resultados Genéricos de Aprendizagem \\
\hline $\begin{array}{l}\text { Conhecimento e } \\
\text { Compreensão }\end{array}$ & $\begin{array}{l}\text { Aprendizado sobre temáticas } \\
\text { especíicas. Sobre exposições } \\
\text { e bens arqueológicos }\end{array}$ \\
\hline Habilidades & $\begin{array}{l}\text { Habilidades fundamentais e } \\
\text { de comunicação-Saber como } \\
\text { se faz um texto. Habilidades } \\
\text { sociais-troca de informações } \\
\text { coma comunidade }\end{array}$ \\
\hline Atitudes e Valores & $\begin{array}{l}\text { Empatia evalorização dos } \\
\text { bens patrimoniais. }\end{array}$ \\
\hline $\begin{array}{l}\text { Prazer, Inspiração } \\
\text { e Criatividade }\end{array}$ & $\begin{array}{l}\text { Diversãoe aprender coisas } \\
\text { novas }\end{array}$ \\
\hline $\begin{array}{l}\text { Atividade, } \\
\text { Comportamento e } \\
\text { Desenvolvimento }\end{array}$ & $\begin{array}{l}\text { Mudança quanto à } \\
\text { compreensãa da arqueologia e } \\
\text { das exposições }\end{array}$ \\
\hline
\end{tabular}


Esses resultados alvissareiros favoreceram um diálogo com a Prefeitura Municipal de Lins referente à realização de outras ações com a temática arqueológica na cidade. Vale ressaltar que desde a primeira reunião entre os pesquisadores e a SEDESU o objetivo dos gestores municipais era a realização de prospecções na área do município. O interesse do poder público pelas pesquisas se dava pelo desejo de identificação de sítios arqueológicos com potencialidade turística. O intuito dos pesquisadores era estudar o vale dos rios Dourado e Peixe, a fim de abranger o conhecimento arqueológico da área em apreço, já que se trata de área ainda pouco estudada pela Arqueologia brasileira. A partir dos resultados da Exposição Arqueológica Kiju Sakai tiveram início reflexões sobre a implantação de um museu em Lins, como forma de possibilitar que o acervo gerado pelo trabalho arqueológico ficasse no município. Também foram iniciadas negociações sobre a possibilidade de manter sob a guarda dessa nova instituição o acervo Kiju Sakai.

\section{UM MUSEU EM PROCESSO}

A partir da Exposição foram traçadas algumas estratégias para o desenvolvimento do Turismo Arqueológico no município, dentre elas a parceria com pesquisadores de diferentes áreas para atuarem como consultores da SEDESU, por meio de um convênio entre a Prefeitura Municipal de Lins e a Fundação Araporã. No segundo semestre de 2008 e no primeiro semestre de 2009 foram realizadas reuniões de planejamento do projeto de formação da instituição museológica, de forma que o museu fosse pensado como espaço para a salvaguarda dos acervos, a preservação do patrimônio arqueológico futuramente gerado pelas pesquisas de campo e a democratização da Arqueologia.

O local escolhido pela Prefeitura Municipal para abrigar o museu foi a antiga estação ferroviária do município. Vale ressaltar que a utilização de antigas estações ferroviárias para sediar instituições culturais tem sido uma prática constante no país, a exemplo das estações de Piranhas, Olho D’Água do Casado e Delmiro Golveia em Alagoas, Campinas, Jaguariúna e Itapeva no estado de São Paulo, dentre muitas outras.

Ao longo de 2009 se materializaram ações voltadas para a solicitação de financiamentos para a reforma do prédio, então ocupado pela Polícia Militar. Também foram realizados acordos visando à desocupação do prédio e à formação de parcerias com a iniciativa privada e os poderes públicos estadual e federal. Além disso, passaram a ser desenvolvidas atividades voltadas à sensibilização da comunidade com relação à importância do museu, em especial por meio da mídia local. Os funcionários da SEDESU tomaram parte 
de diferentes debates sobre questões relacionadas a museus e à preservação do patrimônio cultural, como o Encontro Regional de Preservação de Ferrovias.

Ainda em 2009, o já mencionado resort trocou de bandeira e passou a fazer parte da Rede Blue Tree. A alteração da administração do estabelecimento foi de extrema importância, pois a política da Rede Blue Tree, ao contrário da Rede Quality, incentiva que os hóspedes conheçam a região onde o hotel está localizado, o que possibilita um diálogo entre os visitantes e a população local. Em conjunto, o resort e a SEDESU planejaram ações voltadas à atração de turistas, dentre elas a divulgação massiva das águas termais. Essa aproximação criou condições para que em 2009 a cidade de Lins fosse considerada o décimo melhor destino turístico para a melhor idade do país. Os atrativos do município tiveram ampla divulgação em grandes eventos e Lins foi reconhecida como exemplo de desenvolvimento do Turismo regional. Outra iniciativa foi a criação do Posto de Atendimento ao Turista (PIT), disponibilizando pessoas para fornecer informações aos visitantes informações sobre a cidade. Também foi organizada uma "Feira dos Sabores de Lins", que incentivou a venda de produtos artesanais, tornando-se um interessante atrativo turístico.

Em 2010 as obras do novo prédio da Polícia Militar foram finalizadas, o que possibilitou a desocupação do prédio do museu e o início de sua reforma. Vale ressaltar que o espaço contava com três construções: o prédio da antiga estação — que irá abrigar as exposições —, o antigo barracão — que abrigava a oficina mecânica da ferrovia — e a portaria. A obra teve início pelo barracão, local em que ficará localizada a reserva técnica. Também fez parte do projeto a rua Ceará, a antiga colônia da estação ou rua dos Trabalhadores da Estrada de Ferro, que fica nas proximidades do museu e onde ainda residem parentes de ex-ferroviários. Uma vez que as fachadas de várias casas se encontram alteradas, o projeto previa a possibilidade de incentivo fiscal para os moradores que mantivessem as fachadas originais. No mesmo ano, Lins passou a ser o terceiro destino nacional para a melhor idade. O município foi considerado um dos principais destinos da Semana Nacional da Vitalidade, e o resort passou a configurar um importante produto comercializado pela CVC Turismo.

Ainda em 2010 o poder público demonstrou interesse em realizar uma exposição na área externa do museu e afirmou que isso já poderia ser pensado e executado concomitantemente às obras dos prédios. A equipe multidisciplinar de pesquisadores consultores do projeto discutiu com a SEDESU os conceitos da exposição e identificou alguns grupos que já poderiam ser envolvidos pelas ações do museu. Vale ressaltar que foram realizadas várias reuniões e discussões para que se chegasse a um formato de museu e de 
ações educativas que atendessem às expectativas do poder público, bem como aos anseios dos pesquisadores, já que muitas vezes havia discrepâncias.

Dentre as diversas discussões destacam-se as realizadas em torno do nome da instituição, pois mesmo após debates sobre tipologias de museus o poder público acabou por denominá-lo Museu Histórico e Arqueológico de Lins, apesar de compreender e apoiar que a instituição fosse pensada a partir de pressupostos de diferentes tipologias. Outro exemplo se dá quanto à reforma do prédio principal da estação ferroviária. O objetivo dos representantes do poder público era que com a reforma da estação o prédio voltasse a ter as características de sua construção original. Porém, os pesquisadores consideraram importante que ao menos um lado da fachada do prédio mantivesse as características da ocupação da Polícia Militar, pois a história da ocupação do local também é importante para o município. Após a apresentação da justificativa dos pesquisadores a SEDESU aceitou a proposta. Essas discussões foram de suma importância por propiciarem reflexões sobre trabalhos colaborativos e possibilidades de se pensar projetos dentro dos preceitos do Turismo sustentável, da Sociomuseologia e das Arqueologias Pós-Processuais, em parceria com o poder público. Os pesquisadores consultores e a SEDESU passaram a planejar as ações de parceria como forma de construir um museu participativo que representasse diferentes segmentos da comunidade linense, a partir da afirmação de Varine-Bohan (2009: 29), que ressalta a importância da participação ativa e criativa das comunidades locais, sem a qual haveria meramente "uma mera execução de programas tecnocráticos”.

\section{Ações realizadas com a comunidade da Terra Indígena Icatu}

A Exposição Kiju Sakai propiciou discussões sobre as populações indígenas que habitam a região no presente e a importância de que esses grupos estejam representados no museu. Também foi levado em consideração o fato de o museu estaria localizado na antiga estação ferroviária de Lins, o que possui um valor simbólico importante, pois a construção da estrada de ferro ampliou os conflitos entre indígenas e não-indígenas na região, enfrentamentos que acarretaram o massacre dos povos kaingang que lá habitavam. A região de Lins foi fundamental para o governo da época na tentativa de minimizar os conflitos por meio de um discurso de "pacificação", que realmente buscava a retirada dos indígenas das áreas de interesse para a construção da ferrovia e por questões principalmente econômicas. Nesse contexto, o primeiro aldeamento do SPI foi realizado entre Lins e Promissão, no Ribeirão dos Patos. O aldeamento foi desfeito porque os fazendeiros da região tinham 
interesse em utilizar a área para produção agrícola, o que resultou a transferência das populações para duas terras indígenas: T. I. Icatu, hoje localizada no município de Braúna, e T. I. Vanuíre, localizada no município de Arco-Íris (Rodrigues 2007: 58). Segundo o relatório de trabalho da Fundação Araporã, o envolvimento da comunidade indígena com o museu, apropriando da instituição a fim de expor elementos da cultura e da história indígena, simbolicamente daria voz a essas comunidades que durante muito tempo tiveram sua história contada “por outros” em uma perspectiva etnocêntrica (Fundação Araporã 2011). O relatório cita ainda Bruno ao destacar a importância e o compromisso que as instituições hoje possuem de valorizar "enfoques patrimoniais que têm sido pouco abordados, ou mesmo desprezados" pelos museus, em especial, aqueles "vinculados aos nossos traumas, fracassos e dependência isto é, o desvelamento de uma estratigrafia do abandono ou das trincheiras de preconceitos construídas ao longo do tempo” (Fundação Araporã 2011: 13).

Assim, os pesquisadores entraram em contato com as lideranças kaingang e terena da T.I. Icatu para discutir se gostariam de se representar na área externa do museu e como seria essa representação. Os pesquisadores levaram as lideranças e alguns professores da escola indígena para conhecer o espaço e acompanhar as obras do museu. Houve reuniões e foram realizados estudos de exemplos de outras iniciativas de museus brasileiros quanto à autorrepresentação de populações indígenas. As lideranças optaram pela construção de uma casa, que possibilitaria a inserção do grupo no processo histórico da cidade de Lins através da instituição museológica. A construção da casa foi pensada a partir de ações realizadas em outros contextos - como no Museu do Índio no Rio de Janeiro e um projeto realizado pelo laboratório da Faculdade de Arquitetura e Urbanismo da Universidade de São Paulo (FAU USP), que envolveu a comunidade indígena guarani do Pico do Jaraguá. Tal comunidade foi ouvida ao longo de todo o processo de planejamento e desenvolvimento do projeto, que envolvia a valorização da arquitetura guarani. Segundo algumas lideranças guaranis, a comunidade não esperava ser ouvida, uma vez que esta não é uma prática comum em propostas desenvolvidas em parceria com o não-indígena, em especial com o poder público (Fundação Araporã 2011: 24).

Assim que ficou decidido que seria construída a casa em Lins, foram iniciadas discussões sobre o projeto arquitetônico. Por solicitação das lideranças de Icatu, o arqueólogo Robson Rodrigues apresentou algumas imagens de modelos de casas relacionadas aos antigos habitantes da região, segundo fontes arqueológicas. Foram selecionadas também imagens das primeiras casas construídas na T. I. e das casas atuais, fruto de uma parceria entre a Fundação Nacional do Índio (FUNAI), a Companhia de Desenvolvimento Habitacional e Urbano do 
Estado de São Paulo (CDHU) e a Prefeitura Municipal de Braúna. Após reuniões as lideranças optaram por utilizar como modelo uma casa circular representada no artesanato da T. I. Vanuíre, construída em 2011 pelas lideranças de Icatu, com o auxílio de alguns de moradores da aldeia Ekeroá da T. I. Araribá.

Simultaneamente à construção da casa foi realizada uma entrevista com as lideranças de Icatu responsáveis pela obra: o Sr. Ranufo, então representante da FUNAI, e Sr. Candido, pajé terena. Ambos falaram sobre o processo de autorrepresentação no museu e ressaltaram a importância da instituição para auxiliar na busca por soluções para as dificuldades que as populações indígenas têm encontrado tanto na "manutenção das culturas nos tempos de hoje” como também em questões relacionadas à demarcação de terras indígenas. Ambos ressaltaram que a área da T. I. Icatu possui o mesmo tamanho desde sua formação em 1916. Tal narrativa se mostrou interessante para a compreensão das expectativas da população indígena quanto ao museu.

Ainda como forma de aproximar essas populações do MHA de Lins abriu-se a possibilidade de venda do artesanato produzido em Icatu na Casa do Artesão e foram realizadas ações de parceria com a Escola indígena Índia Maria Rosa da comunidade Icatu. As ações junto à escola indígena tiveram início em fevereiro de 2011. A primeira reunião foi realizada durante o planejamento pedagógico da escola junto aos docentes e à coordenação. As pesquisadoras expuseram a proposta do museu e a intenção de ações de aproximação com a escola, e informaram que a ideia era contribuir para os projetos que a escola já vinha desenvolvendo e não apresentar uma proposta inteiramente nova. A princípio os professores demonstraram surpresa, e justificaram seu estranhamento alegando que normalmente os pesquisadores já chegavam à escola com projetos prontos para que eles apenas os desenvolvessem. As pesquisadoras explicaram que somente os professores saberiam dizer de que maneira o museu seria capaz de contribuir para as ações da escola e que projetos eles tinham interesse em desenvolver. Os professores apresentaram um projeto que seria desenvolvido pelos docentes durante o ano voltado para o "levantamento da memória sobre as culturas indígenas kaingang e terena” (Fundação Araporã 2011b). Os docentes enfatizaram que para compreender como o museu poderia contribuir com o projeto, precisariam entender o conceito de museu.

A partir dessa primeira reunião foram enviados diferentes textos para os docentes sobre museus, Museologia, a questão indígena em museus brasileiros e sobre Educação Patrimonial. As reuniões com o corpo docente ocorreram mensalmente ao longo de 2011. Os docentes se interessaram pela metodologia da Educação Patrimonial e passaram a utilizá-la 
em sala de aula para auxiliar no levantamento de memória que estavam realizando. Como ferramenta didática para contribuir com as atividades da escola, as pesquisadoras intermediaram o empréstimo de kits educativos desenvolvidos pelo Museu de Arqueologia e Etnologia da Universidade de São Paulo (MAE/USP), bem como um kit de réplicas de objetos arqueológicos do interior paulista cedido pela Zanettini Arqueologia. Os professores demonstraram também o interesse pelas pesquisas arqueológicas da região. Para atender a essa demanda convidou-se o dr. Robson Rodrigues, para apresentar ao grupo sua tese de doutorado. As ações de 2011 culminaram na realização de um sítio simulado com os alunos e professores da escola indígena. Vale ressaltar que foi o único contato das pesquisadoras com os alunos, pois a proposta era a de que o trabalho fosse realizado com os multiplicadores. Os professores e alunos participaram intensamente da atividade de escavação. No decorrer de 2011 também foram realizadas duas apresentações do grupo de canto e dança de Icatu no município de Lins, como forma de valorização das culturas indígenas kaingang e terena.

\section{Ações realizadas com a comunidade da Rua Ceará}

A rua Ceará fica localizada próxima à antiga estação ferroviária; conforme mencionado anteriormente, os moradores possuem uma memória ligada ao funcionamento da estação. Nessa rua estão localizadas as antigas casas dos funcionários e do chefe da estação, o posto de saúde e de alimentação da ferrovia. Considerou-se extremamente importante que os moradores estivessem envolvidos nas atividades relacionadas à instalação do museu, pois se trata da comunidade de entorno da instituição, diretamente relacionada à história da ferrovia. Vale ressaltar que em contextos ferroviários os principais atores são os trabalhadores que deram e dão vida ao espaço ao estabelecer sua singularidade, fazendo com que tais contextos se constituam em lugares e territórios específicos (Pérez 2009/10: 58-59).

Foram propostas atividades voltadas para a discussão da implantação do museu, o levantamento de memórias individuais e coletivas sobre a história do edifício, dos trabalhadores da ferrovia e dos moradores da rua Ceará.

Os trabalhos foram desenvolvidos em duas ações: uma associada a entrevistas e conversas informais com os moradores, e outra que consistiu de uma oficina centrada na apresentação e discussão do Museu Histórico e Arqueológico e da ferrovia.

Primeiramente as pesquisadoras visitaram todas as casas da antiga colônia, dialogando com os moradores sobre a estação, sobre as diversas ocupações dos prédios da antiga estação, sobre a rua Ceará e sobre as diferentes histórias de vida. Os moradores se 
interessaram pela proposta, mostraram fotos e objetos relacionados ao ofício de seus antepassados que trabalharam na Ferrovia Noroeste. A segunda ação contou com moradores de diferentes gerações e com diferentes perfis: senhoras esposas de ex-ferroviários, muitos já falecidos; filhos de ferroviários, que vivem desde a infância na rua Ceará; jovens netos de ferroviários e crianças netas ou bisnetas de empregados da ferrovia. Também participou da atividade um ex-ferroviário. A participação de um público diverso possibilitou que as narrativas sobre a rua Ceará apresentassem diferentes ângulos, desde o ponto de vista das donas de casa sobre "a criação de seus filhos, sobre as dificuldades do oficio de ferroviário, até sobre as brincadeiras de rua no passado e no presente, sobre as mudanças ocorridas na rua no decorrer do tempo, sobre a relação de vizinhança estabelecida pelos moradores” (Fundação Araporã 2011b) bem como outras informações apresentadas por meio de relatos de vidas dos participantes. No final da oficina, vários participantes se comprometeram a divulgar a proposta da instituição, participar das discussões e elaboração das exposições e contribuir para a implantação do museu.

Também foram entrevistados dois ex-funcionários da Ferrovia Noroeste do Brasil na antiga estação, o Sr. Sebastião de Oliveira Vallim, antigo trabalhador administrativo e chefe de estação, e o Sr. Eli da Silva, ex-maquinista. Essas entrevistas foram realizadas nas dependências do museu. Vale ressaltar que primeiramente optou-se por conversas individuais e depois uma discussão entre os pesquisadores e os dois ex-funcionários. Os entrevistados apresentaram as dependências do prédio, explicaram as repartições, apontaram as alterações feitas nos prédios pelos ocupantes posteriores à desativação da estação ferroviária, discorreram sobre as linhas, sobre a Noroeste e sobre outros ofícios e trabalhadores da ferrovia. Também relataram diversas histórias sobre os conflitos com os povos indígenas, personagens da época, relações de trabalho, entre outras informações (Fundação Araporã 2011b).

Ações voltadas para a compreensão dos usos dos prédios

Foram realizadas entrevistas com o intuito de compreender as outras ocupações dos prédios onde foram instaladas as diferentes dependências do museu. A primeira foi realizada com o soldado Reginaldo de Souza Brito, representante da Polícia Militar, que fez relatos quanto à história da PM no município, à ocupação dos edifícios por diferentes segmentos da polícia, às reformas realizadas nos prédios para melhor atender às necessidades da corporação. O policial também narrou histórias sobre profissionais e personagens que 
trabalharam no local. A PM disponibilizou fotos antigas de eventos e reformas realizadas nos prédios, reportagens da imprensa local sobre a polícia militar, cópias de legislações e termos legais e um histórico oficial da PM em Lins (Fundação Araporã 2011b). Também foram realizadas entrevistas com o cabo João Gandolfi, representante da Polícia Militar indicado pelo soldado Souza, e com o Sr. Francisco, hoje chefe da Guarda Municipal instalada provisoriamente no prédio da portaria do museu. Foram coletadas narrativas individuais e depois foi realizado um diálogo entre os pesquisadores e ambos os entrevistados. As narrativas apresentaram dados sobre as ocupações do edifício, as reformas realizadas pelos próprios policiais, histórias relacionadas à cavalaria, ao corpo de bombeiros e demais corporações que ocuparam os prédios. Ainda durante o encontro os entrevistados ressaltaram a importância do uso da área para implantação de um museu (Fundação Araporã 2011b).

\section{$\underline{\text { Ações com a comunidade japonesa }}$}

Desde a realização da Exposição Arqueológica Kiju Sakai a comunidade japonesa tem sido parceira do Museu Histórico e Arqueológico de Lins. Entre as ações esteve o apoio da equipe de pesquisadores ao lançamento oficial do livro A história da imigração japonesa em Lins, de autoria de Maria Kazue Mori. O livro foi resultado de um concurso de monografias desenvolvido pela Prefeitura Municipal de Lins durante as comemorações dos 100 anos da imigração japonesa. Também foram desenvolvidas reuniões com a diretoria da Associação Beneficente Cultural e Esportiva de Lins (ABCEL) e com membros da comunidade visando ao levantamento de narrativas e de acervo fotográfico das famílias. Foi a partir desse acervo que se pensou a construção de uma casa do trabalhador rural para compor a exposição externa. A casa foi construída por um funcionário da Prefeitura Municipal, filho de trabalhadores rurais.

Desde as primeiras reuniões a diretoria da ABCEL manifestou o interesse de doar ao MHA de Lins o acervo do museu da associação. Os diferentes encontros foram de extrema importância, pois a doação do acervo não era consenso. Os senhores mais idosos que participaram da formação do museu não eram a favor da doação. Por outro lado, a diretoria e os associados apresentaram as dificuldades de manutenção do acervo, fosse por conta de sua preservação, pela necessidade de uso da sala atualmente ocupada pelo museu ou pela ausência de pessoas para atendimento ao público visitante (Alfonso e Hattori 2012). Apesar das divergências, o acervo foi doado oficialmente para o MHA de Lins. 
Demais ações no decorrer de 2011

As ações do MHA de Lins foram apresentadas também em diferentes eventos científicos, como o Encontro de Arqueologia, Patrimônio e Turismo em Rio Claro e a Semana de Patrimônio de Araraquara. Houve reuniões para a formação de parcerias com diferentes instituições e órgãos governamentais - destacam-se a reunião com a professora Marília Xavier Cury, docente do MAE/USP e representante do Museu Índia Vanuíre de Tupã, e com o Sistema Estadual de Museus (SISEM) de São Paulo.

Outra importante parceria foi realizada com a Zanettini Arqueologia, que por força da obrigatoriedade da legislação ambiental foi contratada pela Gás Brasiliano para realizar ação educativa no município de Lins. Visando não apenas empreender uma ação pontual, descontextualizada das discussões sobre patrimônio promovidas pelas instituições locais, a Zanettini Arqueologia propôs uma parceria com o MHA de Lins, e as ações de Educação Patrimonial tiveram por objetivo que as discussões propostas pelos pesquisadores do museu sobre patrimônio, identidade, povos indígenas e Museologia pudessem abranger novo públicos. No âmbito desse projeto foram realizadas oficinas sobre Identidade e Patrimônio e uma reunião com o Conselho Negro de Lins. Imagens das ações realizadas no processo de formação do MHA de Lins são apreaentadas na Prancha 14.

As oficinas sobre Identidade e Patrimônio envolveram os seguintes públicos: alunos da Escola Técnica Estadual (ETEC) Paula Souza, alunos das Faculdades de Tecnologia de São Paulo (FATEC) de Lins, alunos do Serviço Nacional de Aprendizagem Industrial (SENAI) e alunos de Pedagogia do UNISALESIANO. O propósito das oficinas era formar multiplicadores sobre o patrimônio regional, a Arqueologia, a questão da identidade e o MHA de Lins. O conteúdo programado para as oficinas foi composto por uma parte expositiva, com a apresentação de conceitos e proposição de debates e reflexões e por dinâmicas. As ações visaram a uma reflexão quanto aos bens patrimoniais de Lins e região, bem como a divulgação do conhecimento produzido por pesquisas arqueológicas desenvolvidas no estado de São Paulo (Zanettini Arqueologia 2011d). Apresentaram linhas de reflexão semelhantes às oficinas descritas anteriormente, pois também enfocaram a relação entre patrimônio e construção / negociação das identidades locais. Por meio de histórias e narrativas pessoais foi possível suscitar debates sobre os bens patrimoniais da região, ações possíveis para sua preservação e sobre o processo de implantação do Museu Histórico e Arqueológico de Lins. No final das oficinas foi mostrado o kit de réplicas de peças arqueológicas do estado de São Paulo. 


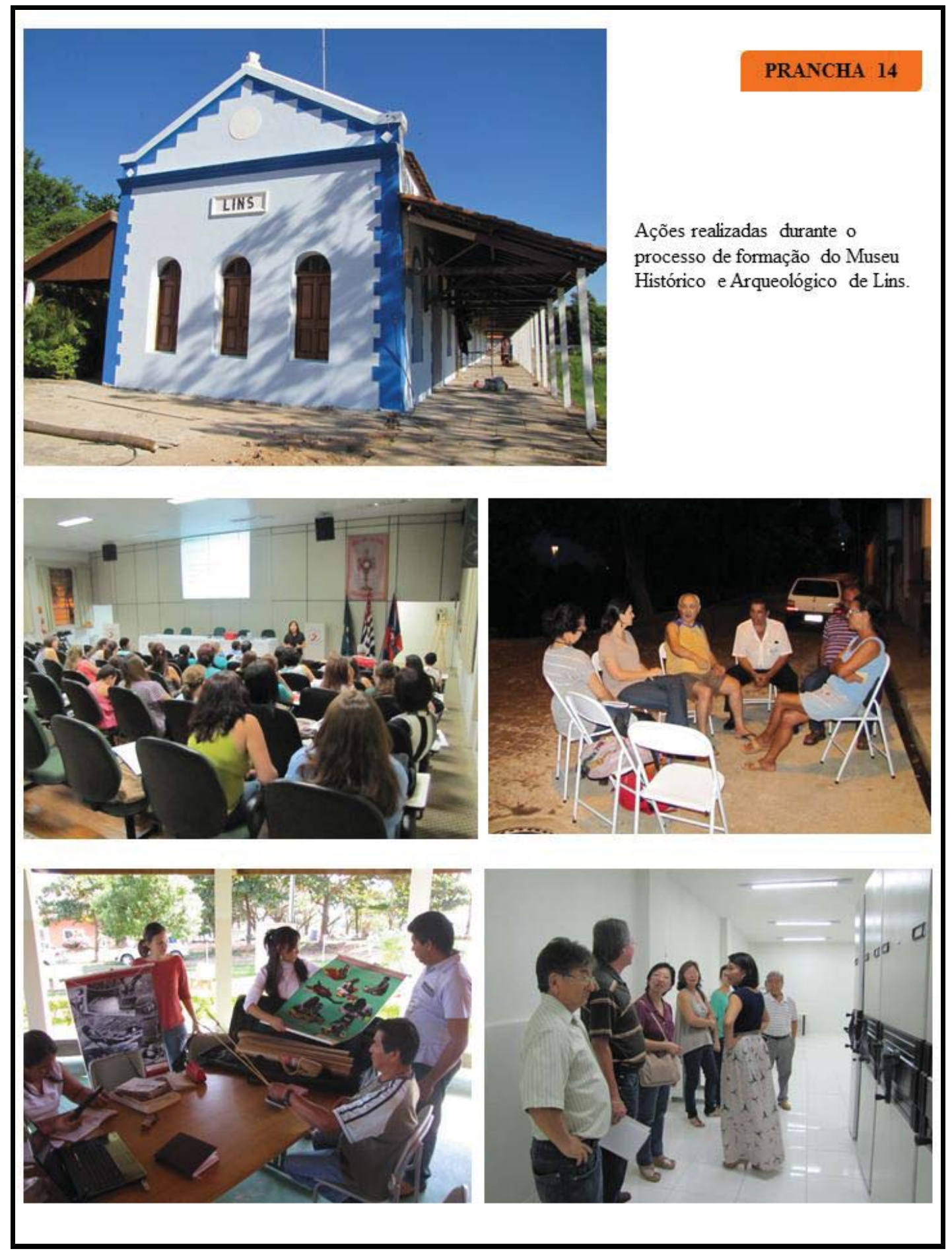


O kit foi pensado de forma a abranger diversas facetas do patrimônio arqueológico e se compunha de: peças líticas - instrumentos de pedra lascada e polida — e peças cerâmicas vasilhas e fragmentos com diferentes tipos de decoração.

A avaliação das oficinas foi realizada por meio do mapeamento de reflexões dos participantes a partir das temáticas trabalhadas. Durante a primeira dinâmica, ao falar de seus antepassados vários participantes afirmaram ser descendentes de indígenas, porém somente depois que uma das mediadoras se identificou como tal. Essa dinâmica possibilitou reflexões sobre o tabu que existe no país sobre a questão indígena e a ocupação do território hoje entendido como Brasil. Em uma das oficinas, um dos estudantes afirmou que "os indígenas matavam muita gente” (Zanettini Arqueologia 2011d). A partir dessa afirmação foi possível trabalhar a questão do preconceito e a importância de um olhar crítico para a história oficial da região.

Quanto à profissão de arqueólogo houve grande curiosidade, em especial dos alunos do ensino médio, que se mostraram surpresos ao saber que não existia graduação em Arqueologia no estado de São Paulo. Outros temas de interesses foram a Arqueologia Subaquática, os equipamentos utilizados nas pesquisas de campo, novas tecnologias aplicadas na Arqueologia no Brasil e no mundo, a contratação de trabalhadores para auxiliar nas pesquisas arqueológicas, sobre o dia a dia do arqueólogo e sobre datação. Também houve questionamentos sobre a maneira como o licenciamento ambiental vem sendo desenvolvido em todo o mundo e as diferenças e semelhanças com os processos de licenciamento no Brasil.

Os bens patrimoniais mais citados durante as oficinas foram: a rotunda, as estações ferroviárias, a igreja dos gregos, o templo budista de Cafelândia, a Praça da Bandeira, a praça Coronel Joaquim Pizza, as ruas de paralelepípedos, a linha do trem, a Igreja Matriz de Lins, a música do caminhão de gás, o $37^{\circ}$ Batalhão de Infantaria Leve, o vendedor de biju, a trilha do Barbosinha, o Bar do Bira, o monumento aos soldados da Revolução de 1932, a praça dos japoneses, a Expolins, a quermesse de Guaiçara e a cápsula do tempo feita pela população de Guaiçara. Vários participantes afirmaram que alguns bens só são valorizados quando não existem mais. A maioria dos participantes pareceu ter se apropriado dos bens patrimoniais de Lins e região. Além do patrimônio regional refletiu-se sobre a preservação dos vestígios arqueológicos. O Museu Ferroviário e o Museu Afro de Bauru foram citados como as instituições culturais mais próximas de Lins. Também foi discutida a doação do acervo da colônia japonesa de Lins. Os participantes também fizeram questionamentos sobre políticas de doação e descarte de objetos. A grande maioria dos participantes considerou que o Museu Histórico e Arqueológico de Lins pode contribuir para a divulgação e a apropriação do 
patrimônio arqueológico pelas comunidades dos municípios da região. Discorreram também sobre a percepção de que a instituição propiciará debates sobre cultura, patrimônio e sobre a história de Lins junto à comunidade. Ressaltaram a importância dos museus como locais de pesquisa e apoio para projetos de diferentes disciplinas. Os participantes se mostraram muito interessados pelo kit de réplicas.

Ainda em parceria com a Zanettini Arqueologia foi realizado um encontro com o Conselho Negro de Lins, que funciona no município desde 1992 e é composto por filiados e conselheiros engajados em questões relacionadas aos negros da região. A então presidente Maria Aparecida Saldanha apresentou algumas das ações desenvolvidas pelo conselho e o interesse em participar das ações do Museu Histórico e Arqueológico de Lins.

A partir dessas ações realizadas em 2011 foi elaborada a exposição externa do museu. As temáticas da exposição foram selecionadas a partir dos resultados das discussões com os diferentes grupos participantes. A exposição é composta por cinco painéis: o primeiro apresenta a proposta da exposição externa; o segundo, a Ferrovia Noroeste, com enfoque em trabalho e conflito; o terceiro se ocupa das diferentes ocupações do prédio; o quarto mostra a casa de um trabalhador rural, com enfoque na arquitetura popular; e o quinto é sobre a casa indígena e sua história no passado e no presente (Prancha 15).

A partir de 2012 ganhou fôlego o projeto de elaboração do Plano Museológico da instituição, idealizado pela doutora em Museologia Camila Azevedo de Moraes Wichers, e cujo desenvolvimento está sendo realizado a partir de uma parceria entre a SEDESU, a Fundação Araporã e a Zanettini Arqueologia, empresa parceira envolvida, sobretudo, por meio da consultoria da museóloga. O projeto visa à construção do Plano Museológico de forma colaborativa. Segundo Wichers, tal construção deve ser compreendida como um processo de capacitação dos envolvidos, pois o planejamento museológico não se limita apenas a "uma técnica com o objetivo de melhorar a ação dos museus. É, sobretudo, crescimento humano. É um processo educativo de ação e reflexão, que deve ser alcançado com a participação, tanto na fase de estruturação como de reestruturação da instituição" (Santos in Fundação Araporã 2012). O plano é uma ferramenta de planejamento estratégico que possibilita que o museu desempenhe sua função social, dentro de uma proposta museológica que compreende que, para que sua prática educativa seja libertadora, são necessárias "metas, ações e formas de sustentabilidade institucional” (Santos in Fundação Araporã 2012). N Nesse contexto a Museologia possui 'vocação' para estabelecer pontes entre diferentes campos do conhecimento, no âmbito de uma abordagem interdisciplinar que envolva a Arqueologia, a História, a Antropologia, o Turismo e a Pedagogia (2012). 


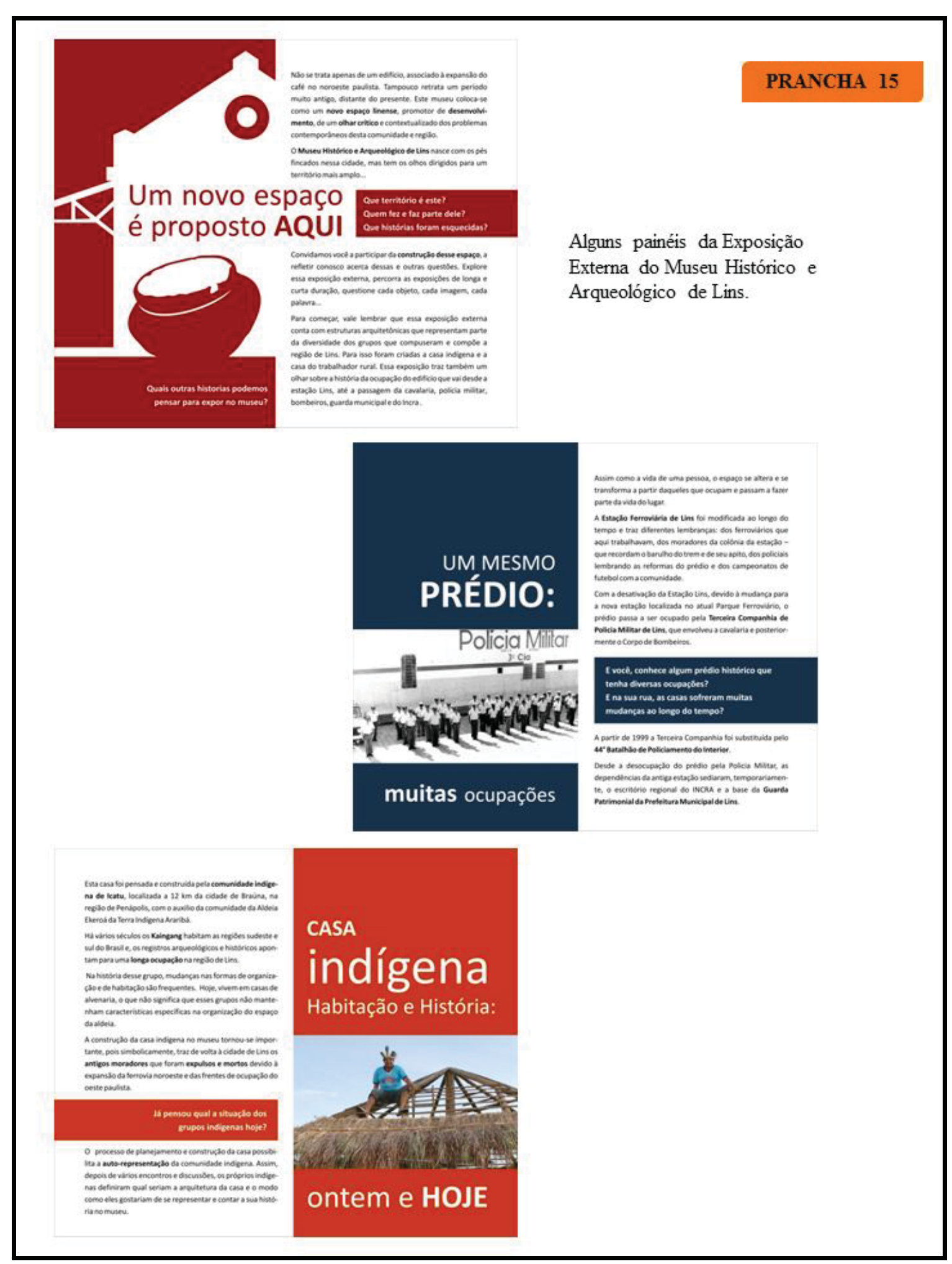


O Plano Museológico foi pensado de forma a abranger oito programas, a saber: 1 . Programa Institucional; 2. Programa Arquitetônico; 3. Programa de Salvaguarda Museológica; 4. Programa de Comunicação Museológica; 5. Programa Expográfico; 6. Programa de Segurança; 7. Programa de Recursos Humanos, e 8. Programa Econômico. Essas temáticas vêm sendo discutidas durante Oficinas de Construção Museológica, realizadas com diferentes segmentos sociais e voltadas para a elaboração participativa do conteúdo de cada um dos itens (2012). As Oficinas de Construção Museológicas envolvem dois grupos de docentes da Diretoria Regional de Ensino de Lins, um grupo de docentes do Instituto Americano de Lins e um Grupo de Trabalho formado por lideranças de diferentes segmentos da comunidade. Dentre as diferentes discussões realizadas nas oficinas visando à elaboração do Plano Museológico é importante destacar que uma das temáticas mencionadas como de interesse para o museu é o Turismo.

Durante o primeiro semestre de 2012 os mencionados grupos iniciaram as discussões com vistas à construção do Programa Institucional - refletindo sobre Missão, Valores, Conceitos Geradores e Design Institucional do Museu -, do Programa de Comunicação Museológica - segundo Wichers, a metodologia que tem sido empregada nas atividades educativas realizadas ao longo dos últimos anos possibilitou "resultados inéditos para o interior paulista” (Fundação Araporã 2012) — e do Programa Expográfico, que definiu as temáticas, forma e conteúdo da exposição de longa-duração (interna e externa), bem como das temáticas a serem abordadas pelas exposições de curta duração. Os outros programas do Plano Museológico serão debatidos no decorrer do segundo semestre de 2012.

A construção e a avaliação das exposições, cuja inauguração está prevista para agosto de 2012, são tidas como "estratégia metodológica para a consolidação do museu, uma vez que se pretende construir um espaço de diálogo entre os diversos segmentos sociais de Lins e região, por meio da construção de narrativas em primeira pessoa e da curadoria participativa dos objetos” que farão parte das exposições inaugurais (Fundação Araporã 2012).

\section{A CONCRETIZAÇÃO DOS SONHOS DE TANTOS GRUPOS}

A construção da primeira exposição de longa duração do Museu Histórico e Arqueológico de Lins se deu a partir de reflexões geradas durante as Oficinas de Construção Museológica e encontros com os grupos parceiros do museu. Em um primeiro momento 
foram realizadas reuniões com as lideranças de diferentes segmentos, com o intuito de apresentar o projeto e a proposta do museu e estender o convite para a ampla participação nas oficinas. Nesse contexto, houve encontros com a Associação Comercial de Lins, a Diretoria Regional de Ensino de Lins, o Sindicato Rural de Lins, Usinas de Lins e região e representantes do Instituto Maturi, dentre outros parceiros.

Após o contato inicial foi realizada a primeira Oficina de Construção Museológica com cada grupo; além das discussões do plano museológico foram identificadas temáticas a serem apresentadas na primeira exposição. Durante a segunda oficina com os grupos foram realizadas reflexões e discussões sobre as temáticas. Os resultados dessas discussões estão apresentados em cada painel da Exposição Museu, território da vida, palco da diversidade, desenvolvida a partir de uma expografía de perguntas em que "o passado e o presente são confrontados a todo instante" (Wichers 2012: 326) e de uma expografía temática em que os módulos são divididos em temas (2012: 326) que possibilitam uma reflexão sobre o cotidiano de cada um (Prancha 16). A saber:

Um novo museu para os novos tempos - apresenta a proposta do Museu Histórico e Arqueológico de Lins e as atividades realizadas desde 2008;

Território: caminhos e lugares — apresenta o território de atuação do museu;

De que é formado o museu - trata das duas coleções do MHA de Lins: a coleção Kiju Sakai e a coleção da ABCEL;

Antropologia, Arqueologia e História, estas ilustres desconhecidas - explica as três disciplinas de pesquisa do MHA;

Você tem fome de quê? — mostra os aspectos do cotidiano relacionados à alimentação;

Terra e Trabalho — busca reflexões sobre o trabalho no campo;

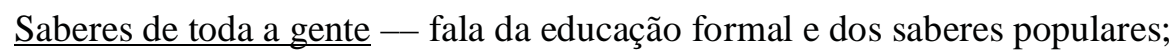

Muitos trabalhos, diversas formas de fazer — apresenta diferentes saberes;

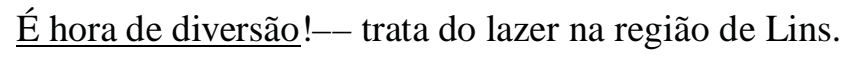




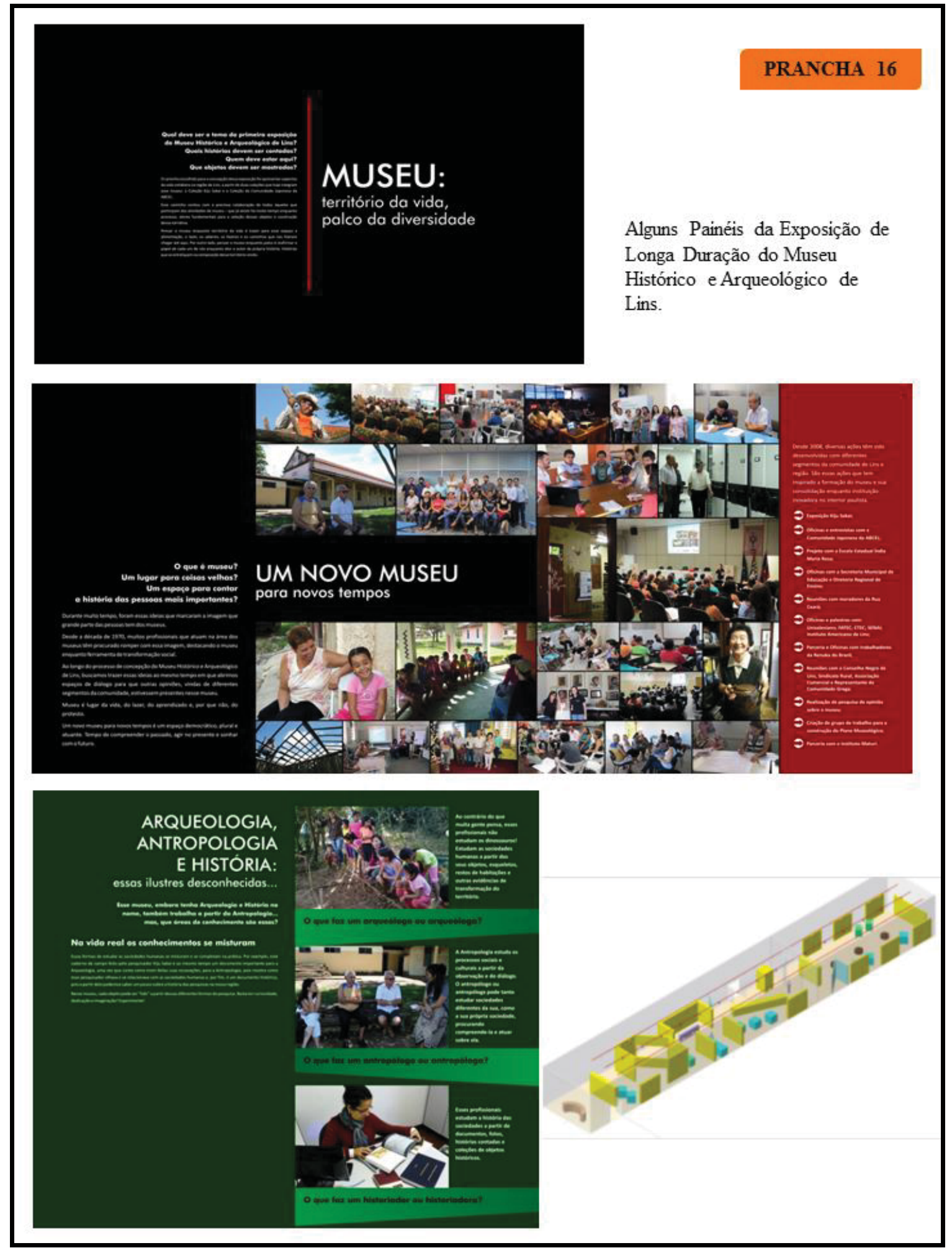


A exposição apresenta ainda uma linha do tempo, vídeos, legenda, vitrines, painéis interativos, além dos painéis de conteúdo.

A exposição de curta duração foi denominada Nós por nós mesmos e apresenta narrativas em primeira pessoa, feitas por cinco grupos parceiros do museu, e mais desenhos realizados por alunos de várias escolas de Lins e região, dentre elas a Associação de Pais e Amigos dos Excepcionais (APAE). Cada módulo da exposição foi concebido por um grupo, em diferentes encontros. Vale a pena apresentar uma breve descrição das ações por grupo trabalhado:

\section{Ações com moradores da rua Ceará}

As ações com moradores da rua Ceará envolveram uma visita técnica das lideranças às obras do museu. Durante a visita foi realizada uma primeira discussão sobre as temáticas da exposição de longa duração e sobre o módulo da rua Ceará na exposição de curta duração, bem como foram identificadas as expectativas dos moradores da rua Ceará quanto às exposições do MHA de Lins. Durante a segunda oficina os moradores apresentaram narrativas sobre o trabalho na ferrovia e suas lembranças da época em que ela ainda estava operante. Os moradores falaram da importância do apito do trem e da possibilidade de o museu apresentar sons nas exposições. Durante o encontro foi elaborado o texto a ser apresentado no módulo específico do grupo. Foram ainda selecionadas imagens e os objetos que o grupo irá expor.

\section{Ações com a comunidade japonesa de Lins}

As ações com a comunidade japonesa foram desenvolvidas com uma comissão da ABCEL de apoio ao museu. Vale ressaltar que outros membros da comunidade nipo-brasileira participam do GT de discussão do Plano Museológico. Foi realizada uma visita técnica ao museu da ABCEL e às obras do MHA de Lins. As visitas propiciaram o levantamento de narrativas, tanto sobre o acervo como sobre diferentes vivências dos participantes, algumas relacionadas à ferrovia. A comissão da comunidade japonesa pôde conhecer os prédios e verificar os equipamentos que serão utilizados para a salvaguarda dos acervos. Em outro encontro foram discutidas as temáticas formadoras da exposição de longa duração e as expectativas dos participantes quanto às exposições; além da elaboração do texto do módulo 
representativo da comunidade japonesa, também foram discutidas as imagens e objetos que farão parte do módulo.

\section{Ações com a Escola Indígena de Icatu}

Foram realizados dois encontros com os docentes da Escola Indígena Índia Maria Rosa na T. I. Icatu. O primeiro encontro foi planejado para atingir dois objetivos: agendar uma oficina com a comunidade indígena como parte do plano Museológico e dar continuidade às ações educativas com a escola referentes à montagem das exposições do MHA de Lins. Nesse encontro foram apresentadas as temáticas da exposição de longa duração, debatidas a partir de dois olhares: do povo terena e do povo kaingang. O segundo encontro foi voltado para a elaboração do texto do painel que representará a escola indígena. Também foram selecionadas fotos e os objetos que ficarão expostos. Os professores demonstraram muito interesse pelas atividades, em especial a intenção de que seja montado um museu em Icatu, projeto antigo da aldeia. Vale ressaltar que o MHA de Lins está apoiando a proposta a partir de discussões, da formação dos docentes e da consultoria museológica.

\section{Ações com a comunidade grega de Lins}

Os encontros objetivaram, em primeiro lugar, uma aproximação com os descendentes gregos, grupo que ainda não havia participado de outras ações educativas do MHA de Lins. É importante ressaltar a resistência inicial da liderança grega em participar do projeto, por ser opositora política da atual gestão. Depois de apresentadas a proposta do museu e as ações desenvolvidas até o momento na região, a liderança "disse ter sido convencida de que se tratava de um projeto sério” (Fundação Araporã 2012). Foram levantadas diferentes narrativas sobre a comunidade grega em Lins, sobre a igreja grega localizada no município e sobre a falta de ações da parte da diocese responsável no sentido da preservação da igreja. A partir do primeiro contato foi realizada uma parceria com o Areté Centro de Estudos Helênicos do estado de São Paulo, que passou a participar intensamente das reflexões. Foram discutidos os temas da exposição de longa duração e elaborou-se o texto do módulo grego da exposição de curta duração. Também foi realizada a seleção de imagens e objetos que farão parte do módulo.

\section{$\underline{\text { Ações com cortadores de cana }}$}


Após a firmação da parceria com usinas da região foram realizadas duas oficinas com 40 trabalhadores rurais, durante as quais foi possível discutir temas como patrimônio, museus, preservação, Arqueologia, identidade e a questão indígena, bem como a representação dos trabalhadores rurais no MHA de Lins. Com eles foram discutidas as temáticas da exposição de longa duração e levantadas diferentes narrativas que formaram o texto da exposição de curta duração. Identificados os objetos que os trabalhadores gostariam que estivessem no módulo, definiu-se que quanto às imagens a proposta era que os próprios trabalhadores registrassem o seu cotidiano para mostrarem no museu.

\section{Oficinas com a Diretoria Regional de Ensino e com o Instituto Americano de Lins}

As oficinas para professores realizadas no âmbito da elaboração do Plano Museológico possibilitaram a formação de um módulo da exposição de curta duração voltado para as escolas de Lins. Foi proposta a realização em sala de aula de uma atividade que objetivava a identificação dos elementos que os alunos consideravam bens patrimoniais da região, e que deveriam estar representados no MHA. As ações resultaram em desenhos de aproximadamente 500 alunos, de diferentes escolas de Lins, bem como da APAE.

Pesquisa com fichas distribuídas para a comunidade

Em meio às ações de elaboração das exposições foi realizada uma campanha que visava abranger outros segmentos da comunidade que ainda não eram parceiros oficiais do museu. Foram distribuídas mais de 10 mil fichas indagando sobre três elementos que não poderiam faltar no Museu Histórico e Arqueológico de Lins. Os cinco temas mais citados foram: artefatos arqueológicos, a estação de trem e a ferrovia, a história de Lins, fotografias atuais e antigas e a história do Clube Atlético Linense. Cabe um destaque: o item mais mencionado foi a Arqueologia, o que demonstra que as ações educativas e de sensibilização se mostraram eficazes no município de Lins. Os módulos da exposição serão apresentados conforme se segue (Prancha 17):

Painel de Abertura- Nós por nós mesmos: apresenta a proposta da exposição;

Índio cuidando de índio. Quem sabe a realidade do índio é o índio: mostra a luta pela educação diferenciada e sobre a escola indígena; 


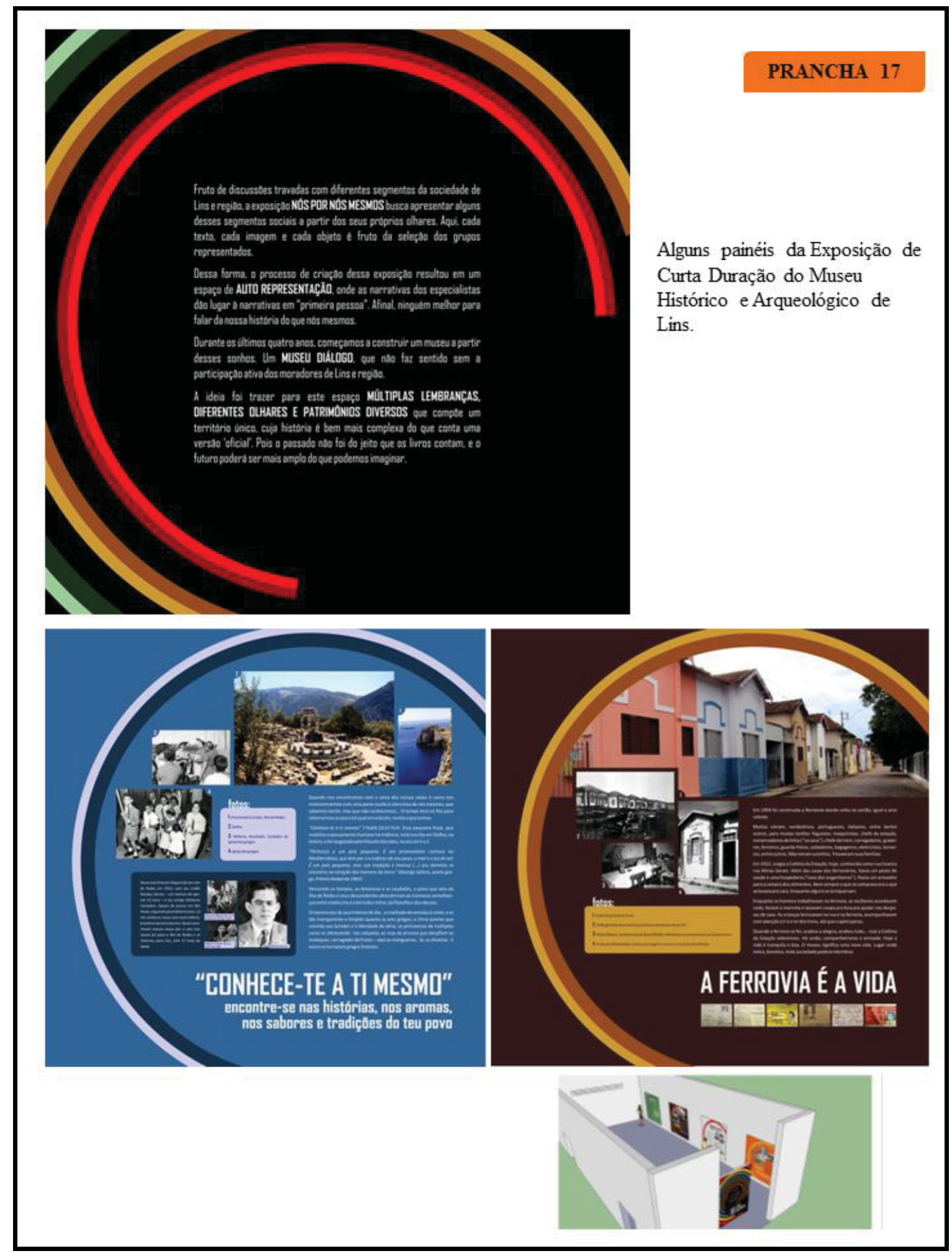


O imigrante samurai: o espírito guerreiro dos japoneses na região de Lins: apresenta a luta da comunidade japonesa no passado e no presente;

A ferrovia é a vida: a ferrovia e a vida na rua Ceará;

Conhece-te a ti mesmo: encontre-se nas histórias, nos aromas, nos saberes e tradições de teu povo: a comunidade grega em Lins;

Trabalho é honra, é caráter: apresenta o trabalho no corte da cana e suas mudanças no decorrer do tempo;

Mural das Escolas - apresenta os desenhos e painéis de grafite produzidos pelos alunos da região sobre os bens patrimoniais da região.

A exposição apresenta ainda legendas, vitrines, painéis interativos, além dos painéis de conteúdo.

\section{$\underline{\text { Outras ações }}$}

Ainda no primeiro semestre de 2012 foi finalizada a curadoria do acervo Kiju Sakai. A Fundação Araporã disponibilizou dois estagiários qualificados que ficaram responsáveis por auxiliar os técnicos e estagiários do LEEH na finalização da curadoria do acervo. As ações do Museu de Lins foram inscritas e apresentadas em diversos eventos científico, dentre eles: o VII Seminário Memória, Cidade e Educação das Sensibilidades; o VI Congresso de Teoria Arqueológica da América do Sul e III Seminário Museus, Identidades e Patrimônio Cultural.

Assim, o processo de formação do Museu Histórico e Arqueológico de Lins foi iniciado a partir de uma demanda do poder público em formatar atrativos para o desenvolvimento do Turismo Arqueológico no município. A primeira ação realizada na região foi a Exposição Arqueológica Kiju Sakai, que permitiu a identificação da necessidade de uma instituição cultural na região em apreço. O Museu de Lins, desde então, passou a existir por meio de um processo que envolveu ações educativas com diferentes segmentos da comunidade da cidade e região. Concomitantemente, foram realizadas obras de adequação dos prédios para sediar o museu. Como forma de planejar as ações para os primeiros cinco anos da instituição, atendendo a uma imposição legal, encontra-se em elaboração o projeto do 
Plano Museológico colaborativo. Essas ações educativas possibilitaram o levantamento de narrativas diversas, que favoreceram a elaboração das primeiras exposições do Museu.

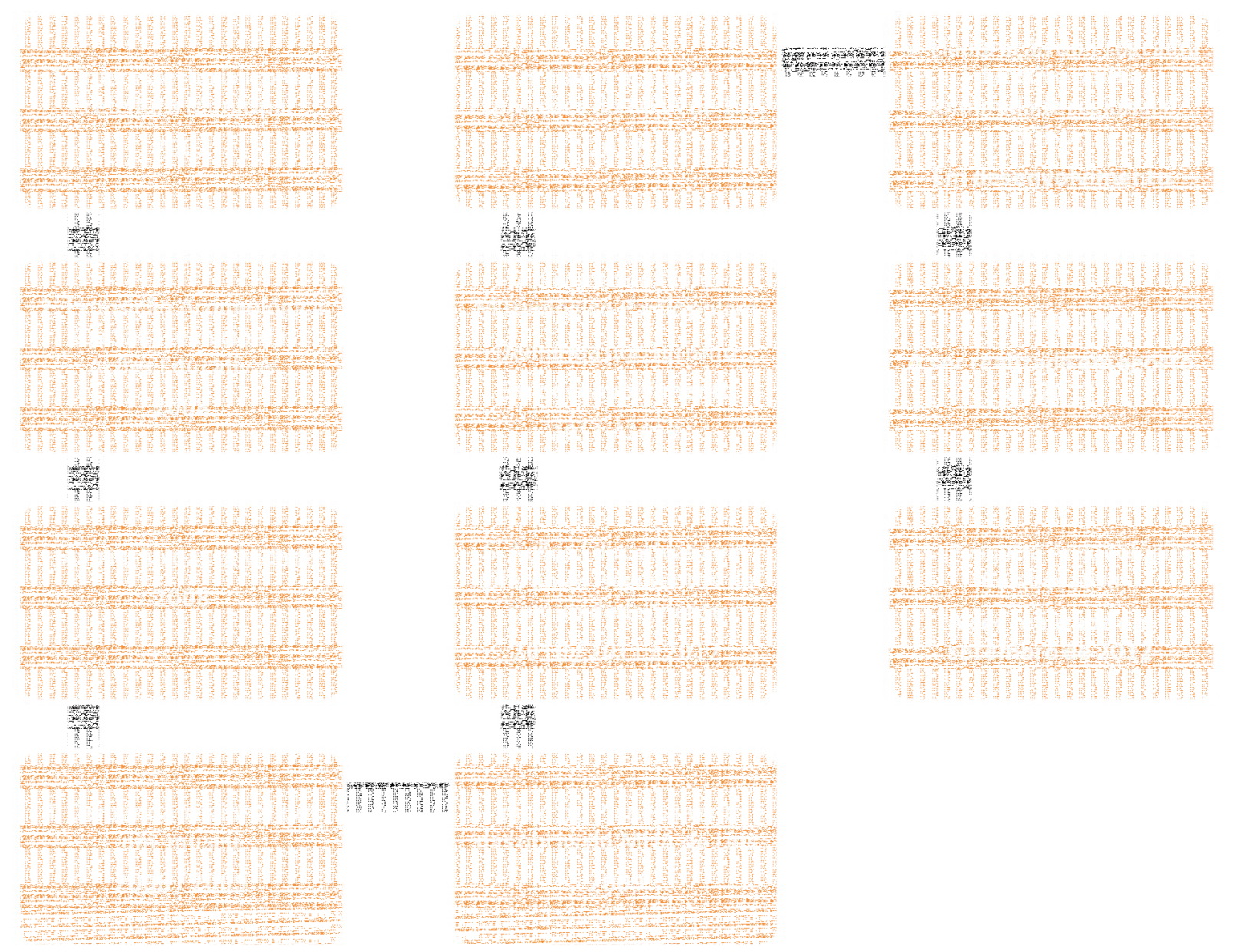

Tabela 4 - Processo de Formação do Museu Histórico e Arqueológico de Lins.

A reforma dos prédios está praticamente finalizada. A reserva técnica já está equipada para receber os acervos. A inauguração do museu acontecerá na primeira semana de agosto de 2012. Para tanto, ainda encontra-se em processo de elaboração o Programa Educativo do museu para a recepção da comunidade local e de turistas. Vale ressaltar que o Programa Educativo terá como base as ações educativas já realizadas na região. Além da continuidade da elaboração do Plano estão previstas ainda para o segundo semestre de 2012 as primeiras pesquisas arqueológicas realizadas no âmbito do MHA de Lins.

O projeto arqueológico visa favorecer formas de participação de diferentes grupos na pesquisa arqueológica. Partindo da Arqueologia comunitária, um dos maiores desafios é “criar estratégias para facilitar o envolvimento das pessoas locais na investigação e interpretação do passado" (Hattori e Alfonso 2012). Esse tem sido um desafio para as diferentes ações do processo de formação do MHA de Lins, que envolveram ações educativas, a elaboração das exposições e do Plano Museológico e o projeto de pesquisa arqueológica, 
todos tendo em vista a aproximação de diferentes segmentos da comunidade, levando-se em consideração reflexões da Arqueologia comunitária.

A Arqueologia comunitária busca o envolvimento da comunidade nas "pesquisas arqueológicas e nas políticas de representação do patrimônio cultural” (Marshall in Hattori e Alfonso 2012). Vale ressaltar que a prática colaborativa ainda vem sendo entendida como uma consulta às comunidades, não envolvendo a real interação, discussão e tomada de decisões entre os diferentes grupos. Deste modo, a dimensão pública da Arqueologia deve levar em conta o intenso diálogo sobre a pesquisa científica e seu papel no presente da comunidade (Hattori e Alfonso 2012). Pretende-se quebrar a herança colonialista ainda presente na Arqueologia paulista, propondo o envolvimento e a representação de populações que sempre foram excluídas da participação na sociedade e nas formas de se autorrepresentarem em instituições culturais, caso dos povos indígenas da região e dos trabalhadores do corte de cana. Nota-se na Arqueologia brasileira que muitas vezes a relação dos arqueólogos com a comunidade se dá apenas no final dos trabalhos, em ações de Educação Patrimonial, invariavelmente pontuais e pouco abrangentes. Neste estudo de caso compreende-se que a relação com a comunidade e a gestão do patrimônio arqueológico é parte integrante da Arqueologia (Hattori e Alfonso 2012) e deve ser levada em conta durante todo o processo da pesquisa.

Ainda como ações de continuidade, vale citar: a manutenção dos grupos após a elaboração do Plano Museológico; a formação de um Conselho de Amigos do Museu para participar da gestão da instituição; a continuidade das pesquisas arqueológicas envolvendo diferentes grupos; o cumprimento das diretrizes apontadas pelo Plano Museológico; e a manutenção do MHA de Lins com as mudanças políticas. Todo o processo de formação do Museu só foi possível graças ao interesse no desenvolvimento do Turismo Arqueológico, bem como pela preocupação dos gestores públicos para com a comunidade e a qualidade do projeto, o que os levou a contratarem profissionais especialistas para implantarem as diferentes ações.

\section{ALGUMAS REFLEXÕES SOBRE O PROCESSO DE FORMAÇÃO DO MHA DE LINS}

No Brasil os museus nunca se configuraram como atrativos turísticos importantes, mesmo com o exemplo de contextos internacionais em que as instituições culturais, como os museus, têm se consagrado como grandes atrativos "por suas características, sua edificação, 
funções, coleções etc.” (Pizzari in ICOM 1995: 73). Segundo o International Council of Museums (ICOM), os museus estão constantemente lidando com a "necessidade de gerar novos produtos e se firmarem como atrativos turísticos” (ICOM 1995: 13), pois o Turismo é uma atividade rentável, geradora de recursos que podem ser aplicados na manutenção das instituições, inclusive favorecendo sua sobrevivência. Além das questões financeiras, a atividade turística permite o acesso de um maior fluxo de visitantes às instituições culturais, levando aos museus públicos múltiplos. Segundo Bruno (1997), nas últimas décadas as instituições têm apresentado um "esforço metodológico, na busca de novos caminhos que possam aproximar mais rapidamente a sociedade dos museus”, sendo o Turismo uma dessas possibilidades. Para o ICOM, a ética do Turismo Sustentável prevê que o visitante participe de um contexto social desconhecido, conheça a vida e os saberes da comunidade receptora. É a partir dessa percepção que novas propostas museológicas favorecem uma aproximação cultural com pessoas de outros lugares, mediante a observação direta e pela interação (Carmona 2011: 115).

Em muitos lugares essa aproximação com o Turismo tem criado condições para que gestores públicos se interessem pelos bens patrimoniais e pelos museus apenas como uma atração turística, planejada para os turistas, o que origina muitas vezes verdadeiros "museusshow”, caso dos museus da costa norte peruana, aqui apresentados anteriormente. Trata-se de museus excludentes, tanto fisicamente, pelo alto valor que cobram, como em suas propostas expositivas. Para Varine-Bohan (2008: 17), esses museus são projetos políticos, que dificilmente apresentam planos e programas voltados para o desenvolvimento de três dimensões: a cultural, a social e a econômica. Nesses casos o museu é reconhecido pelos poderes públicos como uma "manifestação e reivindicação identitária ou da inclusão do cultural no desenvolvimento, que é seguidamente considerado apenas econômico” (2008: 17).

Conforme já citado anteriormente nesta tese, os museus, bem como as exposições, surgiram como veículos de "afirmação de discursos para a dominação", sendo produtores e difusores de ideias por meio dos seus textos, objetos e imagens, selecionados segundo os interesses de "grupos detentores do poder de afirmação e manutenção de referenciais patrimoniais oficiais” (Cunha 2008:164). Nesse sentido são importantes exemplos que tenham por objetivo "novas perspectivas de seleção, preservação e exibição dos traços culturais desprezados, trazendo à cena outras narrativas e atores sociais, até então relegados a segundo plano” (2008:164).

Bruno afirma que há um esforço no sentido de transformação dos conteúdos e formas de atuação dos museus, em especial no que se refere ao objetivo de cumprir seu papel 
social (Bruno 1997), tendência gerada a partir do movimento mundial da Nova Museologia, em que os museus comunitários, ecomuseus e museus de território passam a ser planejados de forma a se fortalecerem como agentes de desenvolvimento local. Também é relevante que as instituições sejam pensadas a partir de novas tipologias institucionais e que inovem na forma de gestão, bem como de concepção e planejamento das exposições, "abrindo brechas para a introdução de conteúdos antes impensáveis como possíveis de preservação e exposição” (Cunha 2008:164). Para Cunha, as instituições devem ser pensadas a partir de posturas e olhares críticos, possibilitadores de transformações nas práticas profissionais museológicas, gerando a reelaboração de discursos, de forma a eliminar "posturas hegemônicas e monopolizadoras produzidas pelas elites e classes dominantes” (2008:171). O resultado deve ser a transformação dos museus em atores na promoção de mudanças político-culturais voltadas para a cidadania, a igualdade de direitos e o respeito à diversidade (2008:171).

O estudo de caso do Museu Histórico e Arqueológico de Lins é interessante por contrariar a tendência economicista do interesse do poder público pelo Turismo. Embora o Turismo tenha incentivando o poder público a construir o museu, a instituição museológica foi pensada de forma a possibilitar o reconhecimento do patrimônio cultural como "recurso do território", como "instrumento central na valorização deste patrimônio" (2008: 18) e das identidades locais. O poder público entende seu papel de operar a instituição, fornecer recursos e propiciar o conhecimento qualificado de especialistas para seu planejamento, implantação e funcionamento, porém incentiva a gestão compartilhada e a participação da comunidade nos mais diversos setores do museu (Tamanini 1998: 211/12). Nesse sentido vale ressaltar a relevância desse exemplo, se considerada a fala do Prof. Dr. Paulo Knauss em evento realizado na UNICAMP ${ }^{8}$, ocasião em que o docente afirmou que é de extrema importância a implantação de museus de grupos específicos, os museus comunitários, em especial de segmentos da sociedade excluídos. Contudo, o mais importante é que a história desses grupos seja incluída nas narrativas dos museus públicos, “oficiais”. Para o professor, o acervo desses grupos precisa compor os acervos oficiais para garantir sua preservação e para fazer da memória comunitária uma memória da sociedade, não apenas daquela comunidade. Caso contrário a memória dos diferentes grupos sempre será uma memória paralela.

A proposta do MHA de Lins apresenta os bens culturais como importantes ferramentas para a educação escolar e para a educação popular, para a reflexão sobre a imagem e a

\footnotetext{
${ }^{8}$ Fala apresentada no VII Seminário Nacional do Centro de Memória da UNICAMP.
} 
identidade do território, para o encorajamento da criatividade individual, dos lazeres coletivos, favorecendo o acolhimento de visitantes provenientes de diversos segmentos da sociedade, bem como o reforço e a inserção de diversos grupos na história e na identidade do território (2008: 18). Neste sentido, são inseridas ações do museu voltadas para a autorrepresentação de grupos diversos nas exposições, caso dos imigrantes gregos e japoneses, dos cortadores de cana e dos povos indígenas - estes últimos anteriormente vistos apenas como parte de um passado longínquo - bem como a representação dos bens patrimoniais realizada por mais de 500 alunos das escolas da região em pauta.

O processo de formação do Museu de Lins tem caráter único, pois segundo VarineBohan (2008:15) cada unidade local é original, porque se adapta aos diferentes parceiros e contextos. Todavia, embora ainda principiante a iniciativa tem servido de exemplo no estado de São Paulo, devido à carência de métodos e técnicas capazes de orientar as novas perspectivas práticas, que seguem as tendências conceituais de um "universo museal que está em mutação constante nas últimas décadas” (Bruno 1997: 28). Vale destacar o desafio que tem sido integrar um Museu de tutela municipal, o que já determina certo perfil institucional, à participação dos vários segmentos da sociedade. Os limites impostos pelo enquadramento do museu têm sido vencidos na medida do possível, conforme vão se apresentando diferentes questões, tanto do poder público quanto da sociedade. Situação esta que tem se intensificado em ano eleitoral. Para Bruno, são importantes os processos museológicos que objetivam a "experimentação metodológica, pois a Museologia viável para o Brasil depende das citadas experimentações e respectivas análises” (1997: 32). A autora valoriza ainda as pesquisas acadêmicas que apresentam estudos sobre essas novas tendências e experiências, em especial que envolvam reflexões sobre o diálogo das instituições com diversos setores da sociedade, pois “o espaço museal não está apenas circunscrito a quatro paredes preenchidas por objetos e nem o processo de musealização se restringe à exposição de coleções para uma elite” (Bruno 1997:8).

As sociedades são diversas; assim, o público dos museus não é mais constituído de artistas e letrados, mas por públicos múltiplos, muito em função da contribuição do Turismo de Massa (Varine-Bohan 2008: 11). Embora incentivada pelo Turismo, a proposta do MHA de Lins não foi pensada de forma a representar o município para o "outro", visando mostrar aos visitantes a magnitude de suas lideranças, da sua indústria e dos seus costumes, mas sim que a instituição fosse um "espelho onde a comunidade vê a si própria”, faz reflexões sobre sua imagem e procura uma explicação para o território do qual faz parte (Varine-Bohan inTamanini 1998: 211/12). Essa proposta só se torna possível a partir das ações participativas. 
Vale ressaltar que a participação não é consensual, mas sim conflituosa e, muitas vezes, desigual, o que trouxe uma série de desafios para o MHA de Lins, inclusive pela tentativa de censura, por parte de empresários locais, à autorrepresentação crítica de alguns grupos nas exposições. A participação pode favorecer a identificação de interesses e valores que reflitam a diversidade das comunidades, pode incentivar a valorização da complexidade do campo patrimonial e a menor verticalidade dos projetos (2009/2010: 284). As ações que envolvem segmentos diversos da sociedade podem propiciar o planejamento e a execução de projetos mais sustentáveis, em especial quando considerados os bens patrimoniais (Urtizberea 2009/2010: 285).

Para Moutinho, a interdisciplinaridade, em particular na área das ciências humanas, deve ser uma prática constante nos museus que estão a serviço da sociedade, de forma a estimular que a comunidade se faça agente de ação e transformação, incentivando a consciência crítica e buscando melhorias para a sociedade (in Tamanini 1998: 212/13). A agência da comunidade requer o reconhecimento e a visualização da realidade cultural e da complexidade social e patrimonial da região. Para tanto, é crucial a aproximação com a Antropologia, já que esta objetiva a compreensão do "outro" e de aspectos de seu cotidiano (Salamon 2006: 145). A participação de antropólogos favorece estratégias que visem à relação próxima com as comunidades envolvidas, a compreensão das estruturas de poder no interior destas comunidades, bem como o entendimento dos processos culturais que envolvem os bens patrimoniais, em especial quando a aproximação se apresenta em contextos de exclusão, como é o caso das comunidades tradicionais, dos povos indígenas e de populações rurais.

As "memórias excluídas" combinam elementos de um corpo social perdido, por terem sido separadas do conjunto do qual faziam parte. Insinuam uma alteridade cultural que se mantém excluída. Essas práticas constituem autênticos "deslocamentos de costumes que não se beneficiam de uma linguagem própria que as simbolize ou congregue” (De Certeau in Salamon 2006: 148). Assim, estrangeiros, imigrantes, diferentes, marginalizados e minorias são “a 'outra' humanidade que mora em nossa herança epistemológica”. Essa alteridade abriga conflituosas relações de convivência em diferentes lugares. Por isso, é primordial a aceitação de um conjunto de costumes e tradições como história por fazer e inventar. (De Certeau in Salamon 2006: 148)

A representação de grupos culturais tradicionais ou excluídos em museus pode incentivar discussões e favorecer alterações nas práticas institucionais, buscando "garantir a manutenção e justificativa da existência de suas memórias” (Cunha 2008:158). Porém, Cunha evidencia a "resistência dos museus no redirecionamento de suas práticas e abordagens" 
verificando uma defasagem nos "discursos afirmativos que explicitem valores de grupos historicamente colocados à margem na sociedade e nos seus mecanismos de representação simbólica” (2008:158). Os processos de exclusão social remetem à formulação da nação brasileira e de sua identidade nacional, conforme já discutido anteriormente, quando se "utilizou a cultura como ferramenta operacional”, para fundamentar a ideia de depuração do “cenário”, de organização e classificação “das referências nativas, portuguesas, africanas, com a idealização das narrativas e a mitificação de algumas participações e presenças heróicas das três raças ao longo da história” (Cunha 2008:159). Nesse processo ficaram marcados papéis de destaque e de subordinação, com indivíduos que vencem e outros que são vencidos, grupos que constroem e outros que "atrapalham”, “decorrendo um discurso maniqueísta e manipulado em torno de histórias nacionais” (2008:159). A diversidade e a pluralidade passam a significar "riscos para imagens idealizadas e construídas, ameaçando poderes e lugares instituídos (2008:159). Isso se fez presente durante a realização das exposições. O MHA de Lins empenhou-se em mostrar que em pensamento, palavras, ações e omissões cada grupo excluído participa da construção de sua história e da história de onde estão inseridos (Carneiro da Cunha 2002:7).

Em suas diversas ações a equipe do museu buscou compreender a complexidade da constituição e reconstituição das identidades e histórias locais, que implicam a "diversidade e pluralidade, bem como na contradição, e mesmo oposição de referências, contextos, indivíduos e seus interesses” (Cunha 2008:159). Vale ressaltar as várias discussões voltadas para a reflexão acerca das formas de participação indígena no museu, considerando que estará sediado na antiga estação da Ferrovia Noroeste, grande causadora de conflitos e mortes para as populações indígenas que habitavam a região. Procurou-se compreender a ferrovia como um feito social - com efeitos espaciais - , que envolveu e envolve "tanto aspectos econômicos como sociais, políticos, jurídicos, ideológicos, imaginários e simbólicos” (Pérez 2009/10: 58). No que tange às pesquisas arqueológicas colaborativas, embora os professores indígenas apresentem grande interesse de participação, há resistência dos fazendeiros em permitir sua entrada nas propriedades, por questões relacionadas aos conflitos e demarcação de terras indígenas.

Durante todo o processo de formação do museu ficou evidente a coexistência de narrativas contraditórias. Se por um lado as famílias dos ex-ferroviários criticam a ferrovia pelas condições de trabalho desfavoráveis, por outro a exaltam por fazer parte de sua própria história. A mesma ferrovia suscitou interessantes discussões na T. I. Icatu, pois quando foi debatida a temática Caminhos os terena apontaram a importância da estrada de ferro, já que 
suas famílias foram trazidas de trem do Mato Grosso do Sul para a T.I. Em seguida, um kaingang comentou: "O que foi bom para vocês foi péssimo para nós”, referindo-se aos conflitos e mortes acarretados pela construção da ferrovia. Para os kaingang os Caminhos eram as trilhas nas matas, hoje substituídas pela cana-de- açúcar. Nos canaviais, "Caminhos” são os carreadores e as estradas, conforme evidenciado pelos cortadores de cana. Para os pesquisadores as ações participativas tem sido o "Caminho" para ligar o Museu ao "território, à comunidade, ao patrimônio e em geral à vida cotidiana (Varine-Bohan 2008: 19).

A constituição do Museu de Lins tem se pautado pela construção de um lugar de encontro, de trabalho comum, de trocas (Varine-Bohan 2008: 19), para que não fique apenas a serviço do capital cultural da comunidade, mas favoreça o capital social, a partir da valorização das coleções, técnicas de expressão, narrativas, seus saberes e fazeres e suas redes de relações, de forma a contribuir com o presente da sociedade. Cabe aqui ressaltar a importância do planejamento estratégico do museu estar sendo realizado de forma participativa. O Plano Museológico, que define as ações e os interesses da instituição, não deve ser realizado apenas pelo poder público, gestor do Museu. Sua elaboração colaborativa possibilita uma instituição voltada para os interesses da sociedade favorecendo ações que possam realmente intervir no contexto sóciocultural do território em apreço. A elaboração do Plano Museológico pela comunidade tem trazido um caráter inovador ao projeto do MHA de Lins, bem como ao desenvolvido no sudoeste baiano.

O trabalho educativo voltado para a construção das exposições também favoreceu exercícios de trocas simbólicas, de negociações entre os diversos grupos participantes e seus interesses coletivos e específicos (Cunha 2008:158). Vale mencionar a disputa dos grupos por representação durante a elaboração das exposições, o que tem gerado narrativas que possibilitam a percepção de uma compreensão do museu a partir de seu próprio grupo, tais como: “O museu da imigração japonesa” o "Museu Indígena de Lins”, “O museu da Ferrovia” (Alfonso e Hattori 2012). O trabalho colaborativo também identificou nas narrativas o uso do termo "nosso": "Não vejo a hora que inaugure o nosso museu” "Temos que estar presentes na nossa festa” (Alfonso e Hattori 2012).

Em contextos plurais, embora haja novos agrupamentos culturais também se conservam os "traços referenciais antigos e longínquos, em ambientes onde a tradição e a inovação dialogam, possibilitando rupturas, acréscimos e exclusões” (Cunha 2008:159). É nesse contexto que a Museologia encontra o desafio de articular objetos e sentidos que por vezes se apresentam “desterritoralizados, deslocados e reinterpretados” (2008:163), em especial em museus que apresentam objetos do passado pré-colonial. Neste sentido, vale 
ressaltar a fala de um memorialista de Lins, que afirmou não compreender o porquê de o museu envolver a Arqueologia se esta é uma disciplina distante da comunidade, pois “o passado indígena da região não está na memória das pessoas, não faz sentido para elas”. O interessante é que foi o interesse pela Arqueologia que possibilitou a identificação do anseio por um museu e favoreceu sua implantação. Cumpre destacar que a pesquisa realizada por meio de fichas preenchidas pela comunidade também identificou a grande demanda de participação da Arqueologia na instituição.

Demandas que consideraram que a Arqueologia pode contribuir para uma maior compreensão da história da região, pode trazer novos elementos que possibilitem reflexões sobre o território, pode contar histórias - de pessoas desconhecidas, do passado longínquo ou do passado recente - a partir de objetos. Essas demandas ficaram evidentes nas avaliações dos visitantes da Exposição Kiju Sakai, em que se mencionou que a exposição arqueológica possibilitou aos moradores conhecer mais sobre suas próprias histórias, sobre seu passado, a partir de um ângulo diferente. E também na fala dos grupos participantes, que constaram a importância de seus objetos para uma maior compreensão de seu próprio cotidiano. Durante o processo de seleção dos objetos cada grupo quis contar detalhadamente para os pesquisadores a história de cada objeto, o que demonstrou que as comunidades não apenas olharam para os objetos, mas olharam-se no em seu patrimônio (Camacho in Tamanini 1998: 211/12).

A aproximação com a Arqueologia deve ser pensada de forma a favorecer que indicadores da memória do passado pré-colonial, ou mais recentes, sejam integrados à dinâmica da sociedade (Bruno 1997: 128). Segundo Bruno, a Arqueologia possibilita a evidenciação de peculiaridades das sociedades, de um passado muitas vezes esquecido, e "faz aflorar indicadores da memória”, mas a disciplina tem ainda encontrado dificuldades em se comunicar com as sociedades do presente (1999: 128). A Museologia pode contribuir para a efetivação dessa comunicação, porém tendo como base a produção de conhecimento das áreas que estudam os diferentes indicadores da memória (1999: 130), como é o caso da Arqueologia, da História e da Antropologia, disciplinas de interesse do MHA de Lins.

Além da narrativa dos pesquisadores, os representantes das comunidades também devem ter voz ativa e falar em primeira pessoa. É o caso dos povos indígenas, que por muito tempo foram representados nos museus a partir apenas do olhar dos especialistas; atualmente existem experiências que ensejam a participação desses grupos na elaboração e desenvolvimento de projetos educativos, na realização de curadoria, restauro e demais procedimentos técnicos, bem como na organização de narrativas museográficas (Chagas 
2007:190) - é o caso das comunidades kaingang e terena da T. I. Icatu em Lins, onde os grupos se autorrepresentaram na construção da casa, na escolha das temáticas trabalhadas em seu módulo, na elaboração dos textos e na seleção das fotos e objetos. Assim, buscou-se fazer um museu COM a comunidade e não PARA a comunidade (Rússio 1990:9).

Deste modo, o MHA de Lins foi formado a partir das demandas de grupos que compõem as comunidades da região, demandas que vão desde o interesse turístico até o interesse por novos elementos que contenham fatos desconhecidos sobre o passado regional. A instituição tem permitido tecer considerações sobre a possibilidade de os museus regionais cumprirem papel descolonizador, voltado para auxiliar na produção de narrativas alternativas às oficiais, incluindo grupos marginalizados na história e no imaginário das sociedades que vivem no território em apreço. A Arqueologia tem papel fundamental neste contexto, pois pode trazer à tona a cultura material de diversos desses grupos, estudando-os em seus cotidianos e particularidades, ajudando a tecer os fios da história daqueles que não produzem, ou pouco produzem, documentos escritos.

Portanto, a Arqueologia possibilita outras narrativas, pelo fato de ter acesso a diferentes fontes que não necessariamente as orais ou escritas, como a Antropologia e a História, também disciplinas fundamentais para o museu. A participação ativa dos diferentes grupos que hoje compõem o museu demonstra sua necessidade e vontade de mudar suas próprias realidades; ao expor e divulgar as histórias, narrativas e objetos desses grupos, o museu atua como possibilitador de mudanças, de forma que os diferentes grupos também façam parte da história e das narrativas oficiais. Cabe finalizar este capítulo com uma citação dos cortadores de cana sobre sua participação no museu: "Somos discriminados, não apenas quando passamos de ônibus, mas ainda pelo uniforme. O museu pode mostrar o valor do nosso trabalho e mudar a visão que os outros têm da nossa profissão” (Fundação Araporã 2012). 


\section{Algumas CONTRIBUições Ao Turismo ArQueológico}

O Turismo pode contribuir para a gestão do patrimônio cultural no Brasil? Fiz-me essa pergunta em uma viagem de volta do Peru - após um período de experiência com os atrativos e destinos turísticos na costa norte peruana -, país em que os referenciais arqueológicos são difundidos e conhecidos por grande parte da população. Por que, afinal, no Brasil, as pessoas pouco falam de Arqueologia? Por que não é compreendida como patrimônio, como acontece em alguns outros países latino-americanos? Crente de que o Turismo, em uma vertente específica, o Turismo Sustentável, por meio da metodologia que configura o planejamento estratégico participativo, pode contribuir para a democratização do conhecimento arqueológico e acirrar, ou mesmo dar início, a diálogos entre a Arqueologia e a comunidade, ingressei no Museu de Arqueologia e Etnologia da Universidade de São Paulo após passagem pela Antropologia e pelo Turismo.

A opção por inserir-me na Arqueologia - em uma das instituições nacionais mais tradicionais, berço da difusão da chamada Nova Arqueologia no país - e não no Turismo adveio da possível contribuição que o Turismo poderia dar no sentido de aumentar as possibilidades de uso de novas ferramentas que permitiriam maior acesso à comunidade, assim como da materialização das inovações pela Educação Patrimonial para a continuidade do esforço dos profissionais envolvidos. Ao consultar a bibliografia especializada sobre trabalhos de Turismo realizados por arqueólogos percebi que a Arqueologia, na grande maioria das vezes, pouco conhece de Turismo, em geral reduzindo a atividade turística à estruturação de acessos e à visitação a sítios arqueológicos; o Turismo, obviamente, é mais, é planejamento, é compreensão de contexto, é lidar com pessoas em suas diferenças.

Num primeiro momento, muitos colegas do MAE consideraram que uma pesquisa desse escopo - investigar a fundo as imbricações entre Turismo e Arqueologia - sequer se enquadrava devidamente na disciplina da "Arqueologia”, compreendida muitas vezes, de forma limitada e restritiva, enquanto "o campo”, “a escavação”, a "largar os materiais em um museu” e a raras análises confinadas a pesquisas acadêmicas. O que me levou a outras indagações; por que a Arqueologia é ainda tão reticente a pensar a própria epistemologia da ciência? Quem pode pensar a história da Arqueologia se não também os próprios arqueólogos? A crítica à sua práxis deve vir sempre de fora?

Movida por esse interesse, busquei levantar discussões tendo como mote as preocupações com reflexões epistemológicas da ciência arqueológica, a fim de desvendar a 
tessitura discursiva por trás de algumas metodologias de ação relacionadas ao Turismo e à Educação Patrimonial. Ficou claro que, se por um lado é possível valorizar narrativas sobre o passado, desconstruindo discursos marginalizantes arraigados a imaginários e sensos comuns, por outro pode-se acabar acirrando o distanciamento dos arqueólogos com as comunidades - o que de fato é perceptível em alguns trabalhos - , caso as metodologias e disciplinas não sejam utilizadas de modo crítico.

Destarte, são imprescindíveis as posturas descolonizantes da Arqueologia, como as que busquei mostrar ao longo desta tese, partindo de pressupostos da valorização de narrativas alternativas aos discursos oficiais e de visões mais críticas dos usos do passado, o que Said (1990) muito bem chamou de tratativas contradiscursivas em relação a imaginários coletivos. O uso do Turismo Sustentável, assim como de algumas correntes da Arqueologia PósProcessual, permitiu direcionar olhares e manifestar preocupações em torno do envolvimento de comunidades locais no fulcro dos processos de planejamento e nos modos como seu próprio passado é apresentado, e representado, pelo mundo a sua volta.

Para além de reflexões teóricas, as experiências de estudo alvo desta tese colocaramme diante de questões e imbróglios bastante práticos, surgidos no exercício da profissão em sua forma mais crua: no dia a dia e no trato direto com as comunidades. Dotada de referenciais que nem sempre são facilmente aplicáveis, perguntei-me muitas vezes: "E agora?” Nenhum livro, manual ou bibliografia preparou-me o suficiente, e nunca dará conta das surpresas do cotidiano de um profissional que lida com o patrimônio cultural em suas relações com as pessoas e seus territórios. A partir das experiências dos estudos de caso, pude ressignificar e estruturar, para mim mesma, o que seria uma metodologia de planejamento estratégico participativo para o Turismo Arqueológico, aplicado a programas de Arqueologia.

De forma bastante sintética, esta metodologia seria constituída:

a) pela realização de um Inventário de Oferta Turística realizado pela própria comunidade local, que permite o levantamento de dados a partir de fichas oficiais do governo federal, que abarcam não apenas informações relacionadas ao patrimônio cultural, mas englobando contextos como escolas, saúde, serviços de infraestrutura, transporte, entre outros elementos que possibilitam o acesso a narrativas sobre o patrimônio e sobre características socioeconômicas da região;

b) oficinas de Turismo e imagem turística, que possibilitam tecer críticas à construção do imaginário local para o Turismo, uma vez que a imagem que se quer mostrar deve, necessariamente, basear-se na realidade local ou promover debates sobre o território ou município, levantando reflexões acerca das instituições culturais e a quem elas representam, 
inclusão e exclusão social, Arqueologia, identidade e sobre o próprio Turismo, a partir das narrativas de diferentes segmentos das comunidades;

c) e, por fim, de um diagnóstico turístico, que parte da compreensão e da análise dos dados levantados tanto no Inventário quanto nas oficinas.

A visitação a sítios e o uso de kits arqueológicos também se mostraram importantes, pois ensejaram a criação de laços e vínculos entre os bens patrimoniais arqueológicos e as comunidades, diferentes daqueles estabelecidos apenas com tradicionais fotografias em apresentações de PowerPoint. Com isso foi possível notar que o uso dessa metodologia propiciou a efetivação de ações que acarretaram o fortalecimento do contato direto das comunidades com seus bens patrimoniais, arqueológicos no caso.

Vale ressaltar que para a efetivação das ações que apresentei como estudos de caso, as fichas de Inventário Turístico elaboradas pelo governo federal são uma ferramenta bastante interessante, uma vez que têm maior representatividade perante os órgãos oficiais. Contudo, se por um lado as fichas permitem uma maior aproximação e um maior diálogo entre órgãos oficiais de Turismo, nossa experiência demonstrou que não alcançam a realidade dos estabelecimentos pesquisados, tornando-se dificultadoras. É preciso propor a elaboração de novas fichas, mais compreensíveis, de Inventários.

O diálogo entre o Turismo Sustentável e projetos de Arqueologia traz à tona debates sobre quais são, afinal, as formas de Turismo e de gestão dos bens patrimoniais mais interessantes para cada comunidade, em relação a seu próprio patrimônio cultural, rompendo com algumas estruturas hierárquicas, demasiadamente rígidas, que caracterizam, muitas vezes, as posturas dos pesquisadores. Como pontuam Carman e Keitumetse (2005), o Turismo Sustentável propõe o fortalecimento das comunidades enquanto agentes culturais. Tem forte potencial para promover melhorias socioeconômicas e a inclusão social de alguns grupos, possibilitando reflexões sobre sua própria cultura e situação social, valorizando identidades no âmbito da pluralidade cultural brasileira, da preservação do patrimônio e de sua gestão. A questão está, como tentei apontar, no difícil diálogo com a Arqueologia, em geral tão avessa às críticas a seu próprio fazer.

Ao lado da Educação Patrimonial, as oficinas, os diagnósticos e Inventários participativos favorecem a valorização de novas narrativas, compreendendo não apenas os territórios patrimoniais, mas também dialogando com as teorias de alteridade e com as visões do outro, dentro da lógica etnográfica, bem como as relações entre comunidade e bens patrimoniais. Metodologias como as dos Inventários participativos e seus usos na Arqueologia, em conjunto com a Educação Patrimonial, permitem reconhecer os principais 
elementos para a identificação de possibilidades de gerenciamento e gestão do patrimônio. Os estudos de caso apresentados nesta tese exemplificam o fato.

Mesmo em contextos diferentes de inserção do Turismo, por meio do IPHAN, de empresas privadas e do poder publico municipal, fica patente que projetos de Arqueologia associados ao Turismo Sustentável podem ser levados a cabo com êxito e contribuir para a gestão do patrimônio. Em Lins, a vontade de se desenvolver turisticamente fez com que a Prefeitura Municipal se interessasse por um museu e financiasse uma pesquisa de Arqueologia, incentivando, assim, o próprio Turismo Arqueológico. Em Caetité, a iniciativa privada, por meio do cumprimento da legislação referente aos estudos de impacto ambiental, contratou um programa de Educação Patrimonial no qual foi inserido o Turismo. A utilização de Inventários Turísticos levantou dados que, somados às informações das oficinas e da Educação, serviram de base para convencer e incentivar o empreendedor a dar continuidade ao projeto, com a possibilidade de criação de um museu, no escopo de ações de sustentabilidade e responsabilidade social da empresa. Esse projeto de museu, vale lembrar, conta atualmente com financiamento do BNDES. Em Alagoas, por meio de suas diretrizes sustentáveis o Turismo permitiu ao IPHAN delinear de maneira mais efetiva suas políticas de preservação, em especial no controle do fluxo de visitantes que diversos sítios rupestres já recebiam.

Logo, um Turismo de caráter participativo e sustentável pode auxiliar na elaboração de políticas públicas, no refinamento de suas estratégias, e gerar reflexões para além das passarelas sobre sítios arqueológicos. Incentivando a criação de museus e minimizando problemas de acervo, sanando também a falta de instituições que fornecem endossos aos programas de Arqueologia, o Turismo pode reforçar políticas reais de salvaguarda do patrimônio cultural brasileiro. A vontade de construir atrativos turísticos em projetos arqueológicos gerou, assim, possibilidades de preservação e consolidação de vias de comunicação continuada com as comunidades, seja pelos museus, seja pelo favorecimento do interesse local pelos acervos. As instituições museais, neste contexto, são de suma importância. Os museus gerados a partir dessa metodologia devem ser pensados de forma a refletir o processo participativo que os tornou possível, por meio da elaboração do Plano Museológico colaborativo. Deste modo, além do Planejamento Estratégico do Turismo, esta tese vem demonstrar a importância dos Planos Museológicos das instituições também serem pensados de forma participativa, pois estes são o Planejamento Estratégico dos Museus. Eles devem favorecer as mesmas propostas de agência da comunidade, gerando melhorias. Por isso, é impossível que essas instituições sejam pensadas longe das diretrizes da 
Sociomuseologia, afinal é necessário que as populações se reconheçam nessas instituições. Sabe-se, por outro lado, que instituições que promovem salvaguarda e comunicação continuada são pouco exploradas pelos projetos de Arqueologia, especialmente devido ao contexto.

Os estudos de caso apontados aqui demonstram que a utilização do Turismo, a partir do planejamento estratégico participativo, possibilita, ademais, a aproximação dos bens arqueológicos a outros bens patrimoniais, alçando diferentes linguagens de valoração a um mesmo patamar. Separados dos demais bens patrimoniais, afastados da compreensão da comunidade, normalmente exilados, como diria Bruno (1997), o potencial dos sítios arqueológicos apenas como atrativo turístico está aquém da valorização de narrativas alternativas levantadas nos diferentes estudos de caso. Para muitos, desenvolver o Turismo é estruturar os sítios para receber visitantes, assim como programas de Educação Patrimonial resumem-se a distribuir lápis de cor. O Turismo possibilitou, assim, a materialização de alguns elementos com os quais lidamos na Educação Patrimonial, em especial em torno do uso qualificado do passado no presente. Ressalto que a forma de aplicação dos programas de Educação Patrimonial na prática, na realidade, nem sempre é clara para a comunidade, o que se agrava em contextos de projetos de curta duração como aqueles realizados no âmbito preventivo, o que poucas vezes favorece a continuidade das discussões propostas.

Essa metodologia permite uma maior aproximação da Arqueologia com a comunidade, obrigando a própria Arqueologia a repensar sua metodologia e sua forma de atuação no presente. Sua união com o Turismo pode consolidar, por um lado, os impactos positivos (porque, sim, eles existem) do Turismo nas comunidades, e, por outro, fazer com que a Arqueologia atue como mais uma das ferramentas disponíveis para a melhoria na qualidade de vida e inclusão social das comunidades com as quais trabalha.

É claro que resultados positivos a partir do planejamento estratégico só são possíveis com um olhar interdisciplinar ou uma equipe interdisciplinar. Pesquisas com vieses não pósprocessuais levantam dados insuficientes para que se promovam ações como estas. Há que se reconhecer que a perspectiva da Arqueologia Pós-Processual, considerando questões éticas e a importância da sustentabilidade e da inclusão social, fortalece ferramentas para que a própria comunidade torne-se, ela mesma, agente de mudança em seus cotidianos; a não utilização das diretrizes do Turismo Sustentável não permite alcançar resultados como os apresentados nos estudos de caso desta tese, assim como as problemáticas seriam outras caso não fossem adotadas reflexões da Sociomuseologia e da Antropologia Aplicada. 
Isso é possível apenas partindo-se da própria lógica do outro, compreendendo-o dentro de seu contexto e de suas relações com os bens arqueológicos, e auxiliando na estruturação de críticas tanto aos bens como às realidades socioeconômicas. Nos contextos em que trabalhei, esta postura resultou tanto nas apropriações do patrimônio pelas comunidades — vide o caso dos alagoanos, que passaram a cuidar deles - quanto na geração de instituições que garantirão salvaguarda, como evidenciado nos casos linense e baiano.

Esta pesquisa defendeu que o potencial do Turismo está em discutir identidades, patrimônio, museus, mesmo que o Turismo em si não ocorra, mesmo que a instituição museológica não se torne, efetivamente, um atrativo turístico. Pois por si só a reflexão engendrada para sua criação e o caminho percorrido para a estruturação da proposta de gestão dos bens patrimoniais de determinada localidade já alteram e transformam alguns aspectos socioeconômicos e culturais daquele local, uma vez que fazem das comunidades agentes de transformações. Em última instância, não importa de que maneira exatamente o Turismo se insere nos projetos, dado que é capaz de favorecer reflexões, a democratização do conhecimento e possibilidades de salvaguarda e políticas públicas, contribuindo para que as comunidades sejam ativas em seus contextos, mais do que atrair visitantes. Para que isso ocorra, é necessário que o Turismo associe-se a problemáticas mais pós-processuais.

A metodologia do planejamento estratégico pretende incentivar uma prática arqueológica mais ética, inclusive propondo que desde o inicio das atividades as equipes sejam norteadas por formas de ação mais inclusivas, seja inserindo diretamente membros da comunidade no processo, seja levando em conta suas narrativas e outros olhares sobre o patrimônio e sobre a Arqueologia. Afinal, o discurso do arqueólogo é apenas mais um dos regimes de verdade, como pontua Foucault (1977), não sendo nem o único, nem o último, tampouco o mais objetivo, e sequer o menos neutro dos olhares.

Nesta tese, a necessidade de aproximação de disciplinas como a Arqueologia, o Turismo, a Antropologia e a Museologia girou em torno da hipótese de que os bens arqueológicos podem estruturar e fortalecer novas práticas sociais. Vale lembrar que o patrimônio arqueológico é composto muito mais do que por uma série de fragmentos de peças do passado. Coleções, artefatos, sítios e narrativas caracterizam o patrimônio arqueológico em toda sua dinamicidade e fluidez. Para a análise levada a cabo nesta tese considerei teorias específicas de cada disciplina, conforme busquei demonstrar nos capítulos apresentados. Assim, são os debates entre elas que possibilitaram outros vieses para a atuação do Turismo na Arqueologia, reafirmando os bens patrimoniais como geradores de novas práticas. 


\section{REFERÊNCIAS BIBLIOGRÁFICAS}

Agencia Peruana de Noticias. 2011. Perú: llegada de turistas internacionales creció 16\% en primer trimestre del 2011.General Management Leadership Program. Dom, 27/03/2011 14:10. Disponível em:

http://www.americaeconomia.com/negocios-industrias/peru-llegada-de-turistasinternacionales-crecio-16-en-primer-trimestre-del-2011. Acesso em: 02 nov. 2011.

Aidar, G. 2002. Museus e inclusão social In: Ciências \& Letras. Faculdade Porto-Alegrense de Educação, Ciências e Letras. Porto Alegre, n. 31.

Airoza, M; Bezerra, M. 2011. O lugar do passado: A construção da ideia e Museu pelos moradores da Vila de Joanes, Ilha do Marajó, Brasil. II Simpósio de Ciências Sociais, subalteidades, trânsitos e cenários. Novembro, Universidade Federal de Goiás.

Albert, B.; Ramos, A. (orgs). 2002. Pacificando o branco: cosmologias do contato no NorteAmazônico. São Paulo: Editora UNESP: Imprensa Oficial do Estado.

Alcayaga, M. 2006. Tradición y modernización: los espejismos en las políticas patrimoniales de México y Chile. Cuicuilco Revista de la Escuela Nacional de Antropología e Historia. Nueva Época, v.13, n.38, Septiembre-Diciembre.

Alfonso, L. 2006a. EMBRATUR: Formadora de Imagens da nação brasileira. $138 \mathrm{f}$. Dissertação (Mestrado em Antropologia Social) - Unicamp, Campinas.

Alfonso, L. 2006b. A Humanização do turismo: uma experiência de voluntariado. Lins: Rotary Club de Lins.

Alfonso, L. 2009. O Patrimônio Arqueológico e sua vinculação a Circuitos Turísticos NãoConvencionais no Brasil. Revista Digital História e História. Disponível em:

http://www.historiaehistoria.com.br/. Acesso em: 04 Nov. 2009.

Alfonso, L. 2010. Desenvolvimento Sustentável Participativo de Turismo Arqueológico no Brasil - formação de circuitos e roteiros não convencionais. Informe científico técnico de la Secretaría de Ciencia y Tecnología de la Universidad Nacional de la Patagonia Austral .Río Gallegos. Argentina. Disponível em:

http://168.226.35.7/secyt/ict/files/ICT-UNPA-20-2010.pdf. Acesso em: 10 Maio 2012.

Alfonso, L. 2010b. El patrimonioarqueologico y suvinculación a circuitos turisticos no convencionales en Brasil. Mirada Antropológica. Benemérita Universidad Autónoma de Puebla. México.

Alfonso, L. Hattori, M. 2012. Território e Apropriação no Noroeste Paulista: Educação e Implantação do Museu Histórico e Arqueológico de Lins. Texto apresentado no I Encontro Paulista Questões Indígenas e Museus e III Seminário Museus, Identidades e Patrimônio Cultural. Tupã. 
Almeida, A. M. 2006. Texto apresentado no $1^{\circ}$ Encontro das Ações Educativas em Museus da cidade de São Paulo. Mesa 2: Avaliação de Ações Educativas em Museus - 14/08/2006. Disponível em:

http://www.forumpermanente.org/.event_pres/encontros/dim-educ/doc/mesa2/a-mortaraapres. Acesso em:13 maio 2011.

Almeida F. N. 1997. Transdisciplinaridade e saúde coletiva. Rio de Janeiro. Ciência \& Saúde Coletiva2 (1/2) 1-16

Almeida, M. B. 2003. O público e o patrimônio arqueológico: reflexões para a arqueologia pública no Brasil. Revista Habitus - Instituto Goiano de Pré-História e Antropologia/Universidade Católica de Goiás, v. 1, n. 2, p. 275-296, jul./dez.

Aranha, M. S. 2000. Inclusão social e municipalização. Em E. Manzini (Org), Educação especial: temas atuais. Marília: UNESP-MaríliaPublicações, p.1-9.

Ardren, T. 2004. Where are the Maya in ancient Maya archaeological tourism? Advertising and the appropriation of culture in Y. Rowan \& U. Baram (ed). Marketing heritage: Archaeology and the consumption of the past. Walnut Creek, Altamira Press, p.103-113.

Arendt, H. 1997. A Condição Humana. Rio de Janeiro. Revista Forense Universitária, 8a edição.

Arizpe, L. 2006. Los debates internacionales en torno al patrimonio cultural inmaterial. Acercamiento, problemáticas y perspectivas. Cuicuilco Revista de la Escuela Nacional de Antropología e Historia. Nueva Época, v.13, n. 38, Septiembre-Diciembre.

Arruti, J. 1997. A emergência dos remanescentes: notas para o diálogo entre indígenas e quilombolas. Mana, Rio de Janeiro, v. 3, n. 2, p. 7-38.

Assis, W. 2011. In-visibilizar populações e legitimar iniquidades: a apropriação do discurso do desenvolvimento sustentável na publicidade do setor elétrico. In: Zhouri, Andréa (Org.). As tensões do lugar: hidroelétricas, sujeitos e licenciamento ambiental. Belo Horizonte: editora UFMG, p. 219-238.

Baba, M.; Hill, C. 1997.Introduction.Em the Global Practice of Antrophology.Williamsburg, Vi.: Studie n third world societies, p.1-24.

Barbosa, J.; Teixeira, R. 2001.Avaliação do Produto turístico em Sergipe: Formulação de Estratégias para o setor. Revista Turismo em Análise. CRP/ECA/USP: São Paulo: Aleph, v.12, n.1, p.86-105.

Baroni, M. 1992. Ambiguidades e deficiências do conceito de desenvolvimento sustentável. Revista de Administração de Empresas, São Paulo, v. 32, n. 2, p.14-24.

Barretto, M. 1995. Manual de Iniciação ao estudo do Turismo. Campinas, SP: Papirus. (Coleção Turismo)

Barretto, M. 1996. Produção Bibliográfica em Turismo no Brasil. Revista Turismo em Análise. CRP/ECA/USP: São Paulo: Aleph, v.7, n.2, p. 93-102. 
Barretto, M. 2000. Turismo e legado cultural: as possibilidades do planejamento. Campinas: Papirus.

Barretto, M. 2002. Planejamento e organização em turismo. $7^{\text {a }}$ Ed. Campinas: Papirus.

Bastos, R. 2007a. O papel da Arqueologia na inclusão social. Revista do Patrimônio Histórico e Artístico nacional - Patrimônio Arqueológico: o desafio da preservação. v. 33, p. 289-303

Bastos, R. 2007b. Arqueologia Pública. In Bastos, R.L. et al. A Arqueologia na ótica patrimonial IPHAN, contrato e sociedade. Erechim: Habilis, p. 31-39

Bastos, R. 2007. A Arqueologia Pública. Mori, Souza, Bastos, Gallo (orgs). Patrimônio: Atualizando o debate. São Paulo: 9ª SR/IPHAN, p. 157-167.

Batista Neto, J. 2009. Recepção Estética e turismo nas Ruínas Jesuíticas de São Miguel Arcanjo - RS. Laboratório de Estudos em Psicologia da Arte (LAPA) da Universidade de São Paulo. São Paulo. Disponível em:

http://www.ip.usp.br/laboratorios/lapa/versaoportugues/2c86a.Pdf/. Acesso em: 20 fev. 2010

Beni, M. 2006. Análise Estrutural do Turismo. São Paulo: Senac 11 ed.

Beni, M. 2006b. Política e planejamento de turismo no Brasil. São Paulo: Aleph.

Bezerra, M. 2003. O Público e o Patrimônio Arqueológico: reflexões para a Arqueologia Pública no Brasil. Habitus, v. 1, n. 2. p. 275-295.

Bezerra, M. 2011. As moedas dos índios: um estudo de caso sobre os significados do patrimônio arqueológico para os moradores da Vila de Joanes, ilha de Marajó, Brasil. Boletim Museu Paraense Emílio Goeldi. Ciencias Humanas, Belém, v. 6, n. 1, p. 57-70, jan.- abr.

Bhabha, H. 1994. The Location of Culture. London: Routledge.

Bignami, R. 2005. A imagem do Brasil no turismo. 2a Edição. São Paulo: Ed. Aleph.

Bloch, M. 1911. Blanche de Castille ET lês serfs du Chapitre de Paris, em Mémoires de La Societé de l'Histoire de Paris et de I'Ile-de-France, XXXVIII, p. 224-72.

Blok, A. 1976.The Mafia of a Sicilian Village 1860-1960: A Study of Violent PeasantEntrepeneurs, Harper Torchbook.

Braga, D. C. 2007. Planejamento turístico: teoria e prática. Rio de Janeiro: Elsevier. p. 71-91.

Britt, K.M.; Chen, C. 2005. The (re)birth of a nation. Urban archaeology, ethics, and the heritage tourism industry, SAA Archaeological Record, 5, 3: p. 26-28.

Brum, C.2007. Turismo, Arqueologia e Literatura: Análise Antropológica da Construção da Memória Coletiva em São Nicolau. RS Revista Brasileira de Pesquisa em Turismo, v. 1, n.1, p. 54-83, Set. 
Brum, C. 2007. Turismo, Arqueologia e Literatura: Análise Antropológica da Construção da Memória Coletiva em São Nicolau, Rio Grande do Sul. Revista Brasileira de pesquisa em Turismo. Disponível em:

http://www.rbtur.org.br/arquivos/journals/1/articles/5/submission/review/5-10-1-RV.pdf/. Acesso em: 22 fev. 2010

Bruno, M. 1997. Funções do museu em debate: preservação. Cadernos de sociomuseologia. Vol. 10, n10. Disponível em:

http://revistas.ulusofona.pt/index.php/cadernosociomuseologia/article/view/298

Acesso em: Junho 2012.

Bruno, M. C. O. 2002. Entre a Museologia e a Museografia: propostas, problemas e tensões. Comunicação em Mesa redonda Exposições e narrativas em museus de Historia. Museu Histórico Nacional, RJ.

Bruno, M. C. O. 2005. Arqueologia e Antropofagia: a musealização de Sítios Arqueológicos. In: Chagas, M. (Org.). Museus: antropofagia da memória e do patrimônio. Revista do Patrimônio Histórico e Artístico Nacional, n. 31. São Paulo: IPHAN, p. 235 - 247.

Bruno, M.C.O.; Fonseca, A.; Neves, K.R.F. 2008. Mudança Social e Desenvolvimento no Pensamento da Museóloga Waldisa Rússio Camargo Guarnieri: textos e contextos. IN: Museus como Agentes de Mudança Social e Desenvolvimento: São Cristóvão, Museu de Arqueologia de Xingo.

Brusadin, L. 2005. Avaliação do programa nacional de municipalização do turismo: diferentes visões. Universidade Anhembi Morumbi. Diponível em:

http://www2.anhembi.br/publique/media/leandro. Acesso em: Nov. 2011.

Cabral, J. ; Lourenço, N. 1993. Em Terras de Tufões: Dinâmicas da Etnicidade Macaense. Macau: Instituto Cultural de Macau.

Caldarelli, S. 2007. Pesquisa Arqueológica em projetos de infraestrutura: a opção pela preservação. Revista do Patrimônio Histórico e Artístico nacional - Patrimônio Arqueológico: o desafio da preservação. n. 33, p. 153-173.

Camargo, H. 2001. Turismo e patrimônio Cultural no Brasil: Impasses para a construção de uma "metodologia nacional" para o inventário de atrativos culturais. Resumo do Seminário I jornada de Turismo, Meio Ambiente e Patrimônio Cultural. São Paulo; Editora Aleph, p.6574.

Campos, L. G.; Mattos, C. P.2011. Práticas de etnoconhecimento na gestão participativa do turismo sustentável na Amazônia: Quilombo de Tapanagem (Oriximiná/PA, Brasil).Revista Brasileira de Pesquisa em Turismo. V.5, n.3, p. 325-337, dez.

Cardozo, P. 2008. Planejamento Turístico Participativo: para além dos discursos uma proposta para execução. Disponível em: http://www.partes.com.br/turismo. Acesso em: 20 jul. 2008. 
Carman, R.J.; Keitumetse, S. 2005.Talking about heritage and tourism: ideas from the conference 'Making the Means Transparent: research methodologies on heritage studies'. SA Archaeological Record: special issue 'Archaeology and Heritage Tourism', v.5, n. 3, p. 39-41.

Carmona A. 2011. Los Museos Comunitarios Participativos. Una aproximación a la nueva museología. Disponível em:

http://www.comunicaciones.usmp.edu.pe/cultura/imagenes/pdf/25_5.pdf. Acesso em: 03 dez. 2011.

Carneiro da Cunha, M. 2002. Apresentação. Pacificando o branco: cosmologias do contato no Norte-Amazônico. Bruce Albert e Alcida Rita Ramos (orgs) São Paulo: Editora UNESP: Imprensa Oficial do Estado.

Carneiro, C. G.2009. Ações educacionais no contexto da arqueologia preventiva: uma proposta para a Amazônia. Tese de Doutorado apresentada na Faculdade de Filosofia, Letras e Ciências Humanas da Universidade de São Paulo. São Paulo.

Carrasco, C.: Aguero, C.; Ayala, P.; Uribe, M.; Cases, B. 2003. Research in Quillagua: Difusion of Archaeological Knowledge and Protection of Cultural Heritage.ChileanjournalChungará. v.35, n.2, p. 321-326.

Carvalho, A; Funari, P. 2009. As possibilidades da Arqueologia Pública. História e História. Atualizado em 24 de março de 2009.

Carvalho, H.; Nolasco, M. 2007. Potencial de antigas trilhas garimpeiras em Igatu, Parque Nacional da Chapada Diamantina- BA. Global Tourism. v.3, n.2, Disponível em: http://www.geoturismobrasil.com/artigos/>. Acesso em: 22 fev. 2010

Casanova, C. V. B. 2006. Huacas del Sol y la Luna: experiencia de turismo vivencial. In: InfotravepPeru.com. Disponível em:

http://www.infotravelperu.com/espanol/article/> Acesso em: 15 fev. 2010.

Cassiano, C. M. 2000. Cinema educativo: a imagem rural na memória nacional moderna. Revista de Comunicação da Fav, FAV, Valinhos, v. III, p. 98-112.

Castañeda, Q. E.; Matthews, C. N. (Eds.). 2008. Ethnographic Archaeologies: reflections on stakeholders and Archaeological practices. Plymouth: Altamira Press.

Castaño, D. 2011. Incidencia de la diplomacia cultural en el posicionamiento del Perú a nível regional y su aplicabilidad como herramienta de política exterior en el caso Colombiano periodo 2001-2010. Universidad Colegio Mayor de nuestra Señora del Rosario. Falcultad de Relaciones Internacionales. Bogota. Disponível em :

http://mutis.urosario.edu.co/bitstream/10336/2901/3/1030550524-2012.pdf. Acesso em: 25 fev. 2012.

Castro, F. 2012. Desenvolvimento sustentável requer transformação também na ciência. Entrevista com Lidia Brito. Divulgando a cultura científica. Agencia de notícias da fundação de amparo à pesquisa de São Paulo. Disponível em:

http://www.agencia.fapesp.br/15723. Acesso em: 13/06/2012 
Chagas, M. 1994. Novos Rumos da Museologia. Cadernos de Sociomuseologia, n.2. Lisboa: Edições Universitárias Lusófonas.

Chagas, M. 2007. Casas e portas da memória e do patrimônio. Em Questão, Porto Alegre, v. 13, n. 2, p. 207-224, jul/dez.

Chagas, M. 2007. Museu do Índio: Uma Instituição Singulare um Problema Universal. Antropologia e patrimônio cultural: diálogos e Desafios contemporâneos / organizadores Manuel Ferreira Lima Filho, Jane Felipe Beltrão, CorneliaEckert. - Blumenau: Nova Letra. 368p.

Chagas, M.2009. O Campo de Atuação da Museologia. Cadernos de Sociomuseologia Centro de Estudos de Sociomuseologia, América do Norte, 2, Maio. Disponível em:

$<$ http://revistas.ulusofona.pt/index.php/cadernosociomuseologia/article/view/533/436>. Acess o em: 14 fev. 2012.

Chauí, M. 2000. Mito fundador e sociedade autoritária. São Paulo: Fundação Perseu Abramo. (Coleção Históriado Povo Brasileiro).

Clifford, J. 1988. The Predicament of Culture: Twentieth-Century Ethnography, Literature, and Art. Cambridge: Harvard University Press.

Clifford, J.; Marcus, G. 1986. Writing Culture: the poetics and politics of ethnography, Berkeley, University of California Press.

Collier, J. F.; Yanagisako, S.J. (Ed.). 1987. Gender and Kinship: Essays toward a unified analysis. Stanford: Stanford University Press.

Conselho de Museus, Arquivos e Bibliotecas da Grã-Bretanha. 2011. Learning Impact Research Project. http://www.inspiringlearningforall.gov.uk/.Acesso em:13 maio 2011.

Cooper, C. et al. 2001. Turismo: princípios e práticas. 2a Ed.. Porto Alegre: Bookman.

Costa, G. 1999. Turismo e Epidemiologia no Peru. Revista Turismo em Análise. CRP/ECA/USP: São Paulo: Aleph, v.10, n. 2, p. 64-77.

Cuicuilco Revista de la Escuela Nacional de Antropología e Historia. 2006. El patrimonio cultural en La era de La globalización. Acercamiento, problemáticas y perspectivas. Nueva Época, v 13, n 38, Septiembre-Diciembre.

Cunha, M. 2008. Museus, Exposições e Identidades: os desafios do tratamento museológico do patrimônio afro-brasileiro. In: Bruno, C. O; Fonseca, A. M. da; Neves, K.R.F. (Org.) Museus como Agentes de Mudança Social e Desenvolvimento. São Cristóvão: Museu de Arqueologia de Xingó.

Cury, M. 2009. Museologia, novas tendências. In Museu e Museologia: Interfaces e Perspectivas/Museu de Astronomia e Ciências Afins - Organização de: Marcus Granato, Claudia Penha dos Santos e Maria Lucia de N. M. Loureiro . Rio de Janeiro: MAST. 25-42. 
Da Matta, R. 1987. Dez anos depois: em torno da originalidade de Gilberto Freyre. Artigo que retoma idéias anteriormente publicadas no Boletim Informativo e Bibliográfico de Ciências Sociais, BIB, Rio de Janeiro, n. 24, p. 17-37.

Da Silva, M. 2004. Cidades Turísticas: identidades e cenários de lazer. São Paulo: Aleph. (Série Turismo)

D’Andrade, W. 2011 a . Turismo deve crescer 20\% este ano, prevê entidade. Agência Estado qua, 28 de dez de 2011. Disponível em:

http://br.noticias.yahoo.com/turismo-deve-crescer-20-ano-prev\%c3\%aa-entidade-

200100245.html.Acesso em: 26 jan. 2012

D’Andrade, W. 2011b. Meta é turismo chegar a 6\% do PIB até final da década. Agência Estado - qua, 28 de dez de 2011. Disponível em:

http://br.noticias.yahoo.com/meta-\%c3\%a9-turismo-chegar-6-pib-final-d\%c3\%a9cada-

195700109.html. Acesso em: 26 jan. 2012.

Dantona, A. 2005. Turismo em Parques Nacionais. In Funari P. P. e Pinsky J (orgs). Turismo e Patrimônio Cultural. São Paulo: Contexto, $4^{\mathrm{a} e d}$. (Coleção turismo Contexto)

Das, V. 1997. Critical Events: An Anthropological Perspective on Contemporary India. Oxford University Press.

De Oliveira, R. C. 1988. Sobre o Pensamento Antropológico. Rio de Janeiro, Tempo Brasileiro, MCT/ CNPq. P 201

De Varine, H. 1973. El Ecomuseo, Los Museos en el Mundo. Barcelona, Salvat Editores.

De Varine, H. 2003. Tomorrow `s Community Museums. Disponível em:

http://assembly.coe.int/Museum/ForumEuroMusee/Conferences/tomorrow.htmPonenecia presentada el 15 October 1993, enelSenate Hall oftheUniversityof Utrecht

Descola, P. 1988.La Selva Culta: Simbolismo y praxis en la ecología de los Achuar. IFEA.

Díaz, R.; Hernández, L. 2009/10. El patrimonio arqueológico en los espacios urbanos de Mérida, Yucatán, y sus implicaciones sociales. Revista Del Cuerpo Académico de Antropología la Facultad de Filosofía y Letras de La Buap - Nueva Época, números 8-9.

Diretoria de Negócios do Turismo - DINETUR 2007. Relatório das Atividades Desenvolvidas em 2007. Secretaria de Desenvolvimento Sustentado e Diretoria de Negócios de Turismo da Prefeitura Municipal de Lins, p. 0-11.

Diretoria de Negócios do Turismo - DINETUR 2008. Relatório das Atividades Desenvolvidas em 2008. Secretaria de Desenvolvimento Sustentado e Diretoria de Negócios de Turismo da Prefeitura Municipal de Lins, p. 0-11.

Diretoria de Negócios do Turismo - DINETUR. 2008. Relatório das Atividades Desenvolvidas em 2009. Secretaria de Desenvolvimento Sustentado e Diretoria de Negócios de Turismo da Prefeitura Municipal de Lins, p. 0-15. 
Dupas, G. 2000. Economia e Exclusão Social: Pobreza, Emprego, Estado e o Futuro do Capitalismo. São Paulo: Paz e Terra.

Dutra, J. 2004. Turismo como alternativa de desenvolvimento do semi-árido Experiências de Gestão Pública e Cidadania - Ciclo de premiação 2004 / Organizadores: Marco Antônio Carvalho Teixeira, Melissa G. de Godoy e Carla Coelho. São Paulo: Programa Gestão Pública e Cidadania, 228p. Disponível em:

http://www.eaesp.fgvsp.br/subportais/ceapg/Acervo\%20Virtual/Cadernos.. Acessoem: 05 março 2010.

Eddy, E.; William P., Eds. 1987.Applied Anthropology in America.New York: Columbia University Press.

Espanha. 2006. Criterios para La elaboración Del Plan Museológico. Espanha: Ministério da Cultura.

Etchevarne, C. 1996. Proposta para o aproveitamento turístico de áreas arqueológicas da Bahia - BR. Revista Turismo em Análise. CRP/ECA/USP: São Paulo: Aleph, v. 7, n. 2, p.7784.

Evans- Pritchard, E. 1972. Antropologia Social. Lisboa: Língua Portuguesa.

Ferreira, L. 2003. Transposição de Identidades: O Patrimônio Arqueológico do Baixo São Francisco. In: Funari, P.P. Et al. eds. Cultura Material Histórica e Patrimônio. Campinas, IFCH/UNICAMP.

Ferreira, L. 2009. Arqueologia da Escravidão e Arqueologia Pública: Algumas Interfaces. Palestra de Abertura da I Semana Acadêmica de Arqueologia da FURG. 15 de junho.

Ferreira, L; Bezerra, M. 2011.O lugar da exposição: Reflexões sobre a gestão comunitária do patrimônio arqueológico na Amazônia - Um estudo de caso da Vila de Joanes, Ilha do Marajó - Pará. XI Congresso Luso Afro Brasileiro de ciências Sociais Diversidades e (dês) igualdades. Salvador Universidade Federal da Bahia.

Figueiredo, F. S. P. 2005. OIM-IPORÃ-MA ORE-REKÓ. Trabalho final de graduação: registro e projeto gráfico. Experiência de estudantes universitários e os Guarani. Faculdade de Arquitetura e Urbanismo da USP.

Forte, M. 2011. Beyond Public Anthropology: Approaching Zero Keynote. Video to the $8^{\text {th }}$ Annual Public Anthropology Conference, "(Re)Defining Power: Paradigms of Praxis," American University, Washington, DC, p. 14-16, October.

Foucault, M. 1977. O nascimento da clínica: uma arqueologia do olhar médico. Rio de Janeiro: Forense.

Foucault, M. 1987. As palavras e as coisas: uma arqueologia das ciências humanas. S.T. Muchail, Trad. São Paulo: Martins Fontes. 
Francisco, C. 1995. O uso de sistemas geográficos de informação (SGI) na elaboração de planos diretores de Unidades de Conservação - uma aplicação no Parque Nacional da Tijuca - RJ. Dissertação apresentada à Escola Politécnica da Universidade de São Paulo. São Paulo.

Freire, P. 1999. Educação como prática da liberdade. 29a Ed. Rio de Janeiro (RJ): Paz e Terra.

Freire, P. 2001. Educação e Mudança. 25ª Ed. Rio de Janeiro: Paz e Terra. Coleção Educação e Comunicação, v.1.

Fumdham. 2009. Documento sobre a Fundação Museu do Homem Americano.

Fumdham. Parque Nacional Serra da Capivara. Disponível em:

http://www.fumdham.org.br/parque.asp />. Acesso em: 20 fev. 2010.

FUNAI. 2002. Fundação nacional do Índio. Disponível em: http://funai.gov.br. Acesso em: Março 2012.

Funari.P. 2001. Public archaeology from a Latin American perspective. Public Archaeology. AAA. v.1, n. 4, p. 239-243.

Funari, P. 2002. Class Interests and struggle in Brazilian Aechaeology. International Journal of Historical Achaeology. v.6, n.3: p. 209-216.

Funari, P. 2003. Arqueologia. São Paulo: Contexto.

Funari, P. 2003. Conflict and interpretation of Palmares, a Brazilian runaway polity.HistoricalArchaeology, v. 37, n. 3: p. 81-92.

Funari. P.2003b. Desaparecimento e emergência dos grupos subordinados na Arqueologia brasileira. Horizontes Antropológicos, v.8, n.18: p. 131-154.

Funari, P. 2004. Public Archaeology in Brazil. In: Merriman, N. (Ed.). Public Archaeology. London: Routlegde, p. 202-210.

Funari, P. 2009. Historical Archaeology and Global Justice. Historical Archaeology. v. 43, n.4, p.120-121.

Funari, P.; Ferreira, L. 2006. A Social History of Brazilian Archaeology: A Case Study. Bulletin of the History of Archaeology, v.16, n.2, p. 18-27.

Funari, P.; Manzato, F.; Alfonso, L. 2009. Tourism and archaeology in Brazil: postmodern epistemology in two case studies. Texto apresentado na Conferencia Anual do Theoretical Archaeology Group- TAG

Funari, P.; Manzato, F.; Alfonso, L. 2010. Turismo e Arqueologia no Brasil: a epistemologia pós - moderna em dois estudos de caso in Pelegrini, S \&Pinheiro, A \&Nagabe, F (org) Turismo e Patrimônio em tempos de globalização. FECILCAM. 
Funari, P.; Manzato, F.; Alfonso, L. 2010b. Tourism and archaeology in Brazil, an epistemological approach in Díaz-Andreu, M \& Villalobos, C. (org) The Ethics of Heritage Tourism, Archaeology and Identity. No prelo

Funari, P.; Oliveira, N.; Tamanini, E. 2005. Arqueologia para o público leigo no Brasil: três experiências. In: Funari, P.P. et al. eds. Identidades, discurso e poder: estudos da arqueologia contemporânea. São Paulo: Annablume.

Funari, P.; Pinsky, J. 2005. Turismo e Patrimônio Cultural. (orgs). São Paulo: Contexto, $4^{\mathrm{a} e d .}$ (Coleção turismo Contexto)

Funari, P.; Robrahn-González, E. 2005. Ethics, CapitalismandPublicArchaeology in Brazil. In: Funari, P.P. \&Robrahn-González, E.M. (Org.). Archaeology and capitalism: from Ethics to Politics.

Funari P.; Zarankin, A. 2003.Social Archaeology of Housing from a Latin American Perspective: a case. Journalof Social Archaeology, v.3, n. 1, p. 3-26.

Fundação Araporã. 2008. Relatório Final da Exposição Arqueológica Kiju Sakai. Entregue para a Secretaria de Desenvolvimento Sustentado da Prefeitura Municipal de Lins.

Fundação Araporã. 2011b. Relatório das ações educativas. Entregue para a Secretaria de Desenvolvimento Sustentado da Prefeitura Municipal de Lins.

Fundação Araporã. 2012. Projeto Plano Museológico. Entregue à Secretaria de Desenvolvimento Sustentado da Prefeitura Municipal de Lins.

Galán, B. 2011. Nuevas y viejas narrativas turísticas sobre la cultura indígena en los Andes. Turismo y patrimonio, entramados narrativos / Llorenço Prats y Agustín Santana (Coords.)/El Sauzal (Tenerife. España): Aca y Pasos, RTPC / 2011. 305p.

Gamboggi, A.; Melville, G. 2007. Museo comunitario como tecnología social en América Latina. Revista Digital Nueva Museología. Disponívelem:

http://www.nuevamuseologia.com.ar. Acesso em: 20 nov. 2010.

Geertz, C. 1973. A interpretação das Culturas. Zahar. Rio de Janeiro.

Geertz, C. 2001. A Mitologia de um Antropólogo. Entrevista de Victor Aiello Tsu com Clifford Geertz, originalmente publicado na Folha de São Paulo de 18 de fevereiro de 2001

Getz, D. 1991. Festivals, Special Events and Tourism. Van Nostrand Reinhold, New York.

Gnecco, C. 2008. Manifiesto moralista por umaarqueologia reaccionaria. IN:

Acuto, Félix A. \&Zarankin, Andrés (Eds). (2008). Sed non satiata II: acercamientos sociales en la arqueología latinoamericana. $1^{a}$ ed., p.93-102. Córdoba: Encuentro Grupo Editor.

Goeldner, C; Ritchie, B; McIntosh, R. 2002. Turismo - Princípios, Práticas e Filosofias, São Paulo, $8^{\text {a }}$ Edição, Bookman. 
Gomes, N. L. 1996. Educação: raça e gênero: relações imersas na alteridade. Cadernos Pagu (UNICAMP), Campinas, p. 67-82

González, A. 2003.Arqueology applied to the development of atacameño Communities. Chilea njournal Chungará. v.35, n,2, p. 287-293

Guardani, F; Aruca, J.; Araújo, M. 1996. Comportamento do Consumidor e a Escolha das Destinações turísticas. Turismo em Análise. CRP/ECA/USP: São Paulo: Aleph, v.7, n.2.

Guevara, A. 2003. Archaeology and Indigenous Communities of Northern Chile.Chilean journal Chungará, v.35, n.2, p.337-346.

Guerrero, G. 2011. Las dos caras del turismo. El turismo como conservador y destructor del patrimonio turístico. Revista de la Red de Expertos Iberoamericanos en Turismo Número 8. 1er Semestre de 2011, p. 10-14.

Guia Turístico da Chapada Diamantina. 2011. Pinturas Rupestres. Disponível em: http://www.guiachapadadiamantina.com.br. Acesso em: Janeiro 2012.

Guia, W. 2003. Diretrizes Políticas. Turismo: geração de riqueza e igualdade de oportunidades. In: Ministério do Turismo. Roteiros do Brasil: Programa de Regionalização do Turismo. Disponível em:

http://www.turismo.gov.br/ regionalizacao/. Acesso em: 20 fev. 2007.

Guidon, N. 2007. Parque Nacional Serra da Capivara: Modelo de preservação do patrimônio arqueológico ameaçado. Revista do Patrimônio Histórico e Artístico nacional - Patrimônio Arqueológico: o desafio da preservação, v.33, p. 75-94.

Halbwachs, M. 1968. Mémoire collective et mémoire historique. La mémoire collective. Paris: Presses Universitaires de France, Cap. 2.

Hartog, F. 1999. O espelho de Heródoto. Belo Horizonte: Ed. UFMG.

Hattori, M. 2011. Entre a capela, a ferrovia e comunidades: arqueologia, conflitos e educação no sertão pernambucano - uma proposta para o sítio arqueológico Fazendinha. Projeto de Mestrado apresentado ao programa de pós Graduação do Museu de Arqueologia e Etnologia USP - Pesquisa em andamento.

Hattori, M. Alfonso, L. 2008. Projeto Educativo Da Exposição Kiju Sakai. Entregue à Secretaria de Desenvolvimento Sustentado da Prefeitura Municipal de Lins.

Hattori, M. Alfonso, L. 2012. Memória e território no processo de formação do Museu Histórico e Arqueológico de Lins. Texto apresentado no VII Seminário Memória, Cidade e Educação das Sensibilidades. Unicamp.

Holmquist, J.; Burga, U. 2007. Proyecto Museográfico Museo de Sitio Huacas de Moche. UNT. Trujillo.

Huacas de moche. 2012. Missión del museo. Disponível em: 
http://www.huacasdemoche.pe/index.php?menuid=2\&submenuid=7\&articuloid=19\&subartic uloid=. Acesso em: 27 abril 2012.

IBAMA. Unidade: Parque Nacional de Sete Cidades. Disponível em: http://www.ibama.gov.br/siucweb/mostraUc.php?seqUc=20/. Acesso em: 20 fev. 2010

IBAMA. Unidade: Parque Nacional da Chapada Diamantina. Disponível em: http://www.ibama.gov.br/siucweb/mostraUc.php?seqUc=15/. Acesso em: 20 fev. 2010

IBAMA. Unidade: Parque Nacional Serra da Cipó. Disponível em:

http://www.ibama.gov.br/siucweb/mostraUc.php?seqUc=3/. Acesso em: 20 fev. 2010

IBAMA. Unidade: Parque Nacional da Chapada dos Guimarães. Disponível em: http://www.ibama.gov.br/siucweb/mostraUc.php?seqUc=79/. Acesso em: 20 fev. 2010

IBAMA. Unidade: Parque Nacional da Tijuca. Disponível em:

http://www.ibama.gov.br/siucweb/mostraUc.php?seqUc=7/. Acesso em: 20 fev. 2010

IBAMA. Plano de Manejo dos Parques Nacionais. Disponível em:

http://www.ibama.gov.br/siucweb/listaUcCategoria.php?abrev=PARNA/. Acesso em: 20 fev. 2010.

ICMBio. 2010. Programa de Turismo nos Parques. Revista Final. Disponível em: http://www.icmbio.gov.br/portal/images/stories/o-que-fazemos/revistafinal.pdf. Acesso em: Maio 2012.

ICOM (International council of Museum / UNESCO). 1995. ActadelEncuentro Internacional 'PatrimonioMuseos y Turismo'. Memoria. Barquisimento - Venezuela 21/26 de Abri.

INC. 2009. Plan Maestro para la conservación y manejo del Complejo Arqueológico Chan Chan. Trujillo.

Irving, M. de A. 2002. Turismo: O Desafio da Sustentabilidade. São Paulo: FUTURA.

Jafari, J. 1981. Towards a Framework of Tourism Education: Problems and Prospects. Annals of TourismResearch, n.8, p.13-34.

Jafari, J. 1994. La cientifizacion del turismo. Estudios y perspectivas en Turismo, v.3, n.1, p.7-35.

Jaramillo, G. 2009/10. Patrimonio Inmaterial: Herencia, memoria e identidad. Revista Del Cuerpo Académico de Antropología la Facultad de Filosofía y Letras de La Buap - Nueva Época, n. 8-9.

Jones, S. 2005. Categorias históricas e práxis da Identidade: a interpretação da etnicidade na arqueologia histórica. In: Funari, P. et al. Eds. Identidades, discurso e poder: estudos da arqueologia contemporânea. São Paulo: Annablume.

Joyce, R. A. 2005. Solid Histories for Fragile Nations: Archaeology as Cultural Patrimony in Meskell \& Pels (ed) Embedding ethics, Oxford. New York, Berg, p. 253-273. 
Juarist, J. 2000. El Bosque imaginario. Madri: Espasa.

Jupiassu, H. 1976. Interdisciplinaridade e Patologia do Saber. Rio de Janeiro: Imago.

Kohl, P. L. 2004.Making the Past Profitable in an Age of Globalization and National Ownership: Contradictions and Considerations in Rowan \&Baram (ed) Marketing heritage: Archaeology and the consumption of the past.Walnut Creek, Altamira Press, p. 295-301.

Kotler, P.; Armstrong, G. 2003. Princípios de Marketing. São Paulo: Prentice Hall.

Krippendorf, J. 1985. Sociologia do Turismo. Rio de Janeiro, Civilização Brasileira.

La Industria.PE. 2009. Lluvias dañaron el complejo arqueológico de Chan Chan. 13 de janeiro de 2009. Ano VII n 2338, Trujillo.

La Industria.PE. 2011. Chan Chan permaneció sin desmonte solo tres semanas. Disponível em: http://laindustria.pe/trujillo/local/chan-chan-permanecio-sin-desmonte-solo-tres-semanas. Acessoem: 15 jan. 2012.

La Industria.PE. 2012. Charla a pobladores busca evitar arrojo de basura en Chan Chan. Disponível em: http://laindustria.pe/trujillo/distrital/charla-pobladores-busca-evitar-arrojo-debasura-en-chan-chan. Acesso em:15 maio 2012

La Industria. PE. 2012b. Continúan arrojando desmonte um Chan Chan. Disponível em: http://laindustria.pe/trujillo/local/continuan-arrojando-desmonte-en-chan-chan. Acesso em: 15 maio 2012

La Industria. PE. 2012c. Proponen endurecer multas para quienesarrojen desmonte cerca a Chan Chan. Disponível em: http://laindustria.pe/trujillo/local/proponen-endurecer-multaspara-quienes-arrojen-desmonte-cerca-chan-chan. Acesso em: 15 maio 2012

La Ruta Moche. 2012. Disponível em: http://www.larutamoche.pe/en/. Acesso em: 05 maio 2012.

Lage, M. 2007. A conservação dos sítios de arte rupestre. Revista do Patrimônio Histórico e Artístico Nacional, Rio de Janeiro; IPHAN, n. 34, p.95-108.

LebrunAspillaga, A. 2007. El turismo cultural en el Perú, su sostenibilidad y los museos.Consensus. [online]. Ene./dic., v.12 n.1 [citado 19 Mayo 2012], p.167-178. Disponível em:

$<$ http://revistas.concytec.gob.pe/scielo.php?script=sci_arttext\&pid=S1680-

38172007000100015\&lng=es\&nrm=iso>. ISSN 1680-3817. Acesso em: 19 maio 2012.

Leite Moreira, D. 1983. O caráter nacional brasileiro (4a ed.). São Paulo, Brasil: Pioneira.

Lideranças Guarani. 2012. Visitação nas Aldeias Guarani: conhecendo uma aldeia indígena Juruakuéry Oipouvy Tekoa Guarani: recebendo visitantes. Testa, A. Castilla, E. Alfonso, L. Tupã, M. Ladeira, M. (orgs). São Paulo: Centro de Trabalho Indigenista, 2011. 
Lima, G. 2002. Educação e sustentabilidade: Possibilidade e falácias de um discurso. I Encontro Associação Nacional de Pós Graduação e pesquisa em ambiente e sociedade. 6 a 9 de Novembro de 2002. Indaiatuba - SP. Disponível em:

http://www.anppas.org.br/encontro_anual/encontro1/gt/sociedade_do_conhecimento/Gustavo \%20F.\%20Costa\%20Lima.pdf. Acesso em: 16 nov. 2010.

Lima, T. 1988. O Patrimônio arqueológico, ideologia e poder, Revista de Arqueologia. 5: 1928.

Lins de Barros, M.1997. O passado no presente: aos 70 falando do Rio de Janeiro, Cadernos de Antropologia e Imagem, n.4, p. 91-119.

Little, B. 2009. What Can Archaeology Do for Justice, Peace, Community, and the Earth? Historical Archaeology v.43, n.4, p. 115-119.

Little, B.; Macnamon, F. 2005. Archaeology and tourism in and around America's national parks, SAA Archaeological Record, v.5, n.3, p.12-14.

Lohmann, G.; Panosso, A. 2008. Teoria do turismo: conceitos, modelos e sistemas. Serie Turismo, São Paulo: Aleph.

Malinowski, B. 1984. Argonautas do Pacífico ocidental: um relato do empreendimento e da aventura dos nativos nos arquipélagos da Nova Guiné melanésia. São Paulo: Abril Cultural.

Mantecón, A. 2005. Usos y desusos del patrimonio cultural: retos para la inclusión social en la ciudad de México. Anais do Museu Paulista. São Paulo. v. 13 n.2, p. 235-256.

Manzato, F.; Funari, P.P. A. 2010. Museus e turismo: diversidade e participação social, Revista Museu. Disponível em: < http://www.revistamuseu.com.br>. Acesso em: 10 mar. 2010

Marcon, E. 2007. O turismo como agente de desenvolvimento social e a comunidade Guarani nas "Ruínas Jesuíticas de São Miguel das missões". Pasos. Revista de turismo e Patrimônio cultural, v. 5, n 3, p. 343-352

Martínez Alier, J. 2007. O ecologismo dos pobres: conflitos ambientais e linguagem de valoração. Trad.Maurício Waldman. São Paulo: Contexto.

Mason, P. 2003. Tourism impacts, planning and management. Jordan Hill, Oxford: Butterworth-Heinemann.

Mazower, M. 2001. Projetos para a Idade do Ouro. In Continente Sombrio: A Europa no século XX. SP, Cia da Letras, p. 185-212.

Mazzucchelli, N. 2010. Revista Entre dois mundos. Página 22 - Fevereiro. FGV.

McGuire, R. 2004. Contested Pasts: Archaeology and Native Americans.In: Meskel, L. et al. eds. A companion to social archaeology. Oxford: Blackwell Publishing. 
McKercher, B.; Du Cros, H. 2002. Cultural Tourism. The Partnership between tourism and cultural heritage management. Binghamton, Du Cros.

Megiani. A. 2001. Turismo e Patrimônio Intangível: uma primeira reflexão sobre a apropriação da cultura efêmera. Resumo do Seminário I jornada de Turismo, Meio Ambiente e Patrimônio Cultural. São Paulo; editora Aleph, p.80-85.

Melendez, A. Paradigma de una nueva era del turismo y su relación con el ambiente y con las oportunidades de empleo Turístico. Revista Turismo em Análise. CRP/ECA/USP: São Paulo: Aleph, 7, 1: 71-78.

Meneses, U. T. B. 1995. Do teatro da memória ao laboratório da História : a exposição museológica e o conhecimento histórico. Debate (continuação). Anais do Museu Paulista História e Cultura Material, São Paulo, n. 3, p. 103-126.

Meneses, U. T. B. 2007. Para que serve um museu (entrevista). Revista de História (Rio de Janeiro), v. 2 n 19, p. 46-51.

Meneses, U. T. B. 2007. Premissas para a Formulação de Políticas Públicas em Arqueologia. Revista do Patrimônio Histórico e Artístico Nacional, Rio de Janeiro; IPHAN, n. 33, p.37-55.

Mensch, P. 1994. O objeto de estudo da Museologia. Pretextos Museológicos 1, Rio de Janeiro: UNI-RIO/UGF.

Merleau-Ponty, M. 1980. De Mauss a Claude Lévi-Strauss. In: Textos selecionados (Os pensadores). São Paulo: Abril cultural.

Merriman, N. 2005. Heritage interpretation: tourism cake, not icing, SAA Archaeological Record, v.5, n.3, p.36-38.

Meskell, L. 2000. The practice and politics of Archaeology in Egypt .Annals of the New York Academy of sciences, v. 925, p. 146-169.

Meskell, L. 2005. Sites of violence: terrorism, tourism, and heritage in the archaeological present in, L. Meskell and P. Pels, edsEmbedding Ethics. Oxford, Berg, p. 123-145.

Meskell, L. 2007. Heritage Ethics for a Present Imperfect.Archaeologies: Journal of the World Archaeological Congress. v. 3, n.3, p.441-445.

Ministério do Turismo. 2005. Roteirização Turística - Módulo Operacional 7. Brasília.

Ministério do Turismo. 2006. Inventário da Oferta Turística - Instrumento de pesquisa Formulários / Ministério do Turismo, Secretaria Nacional de Políticas de Turismo, Departamento de Estruturação, Articulação e Ordenamento Turístico. Brasília.

Ministério do Turismo. 2006. Roteiros Turísticos. Roteiros do Brasil: Programa de Regionalização do Turismo. Disponível em:

http://www.turismo.gov.br/regionalizacao/. Acesso em: 20 nov. 2009. 
Ministério do Turismo. 2007. Turismo e Sustentabilidade. Portal Brasileiro do Turismo. Disponível em: http://www.turismo.gov.br. Acesso em: 10 nov. 2009

Ministério do Turismo. 2007. Roteiros Turísticos. In: Módulo Operacional 2: Mobilização. Disponível em: http://www.turismo.gov.br/regionalizacao/mobilização. Acesso em: 20maio. 2008.

Ministério do Turismo. 2007. Roteiros Turísticos. In: Módulo Operacional 8: Promoção e apoio à Comercialização. Disponível em:

http://www.turismo.gov.br/regionalizacao/mobilização. Acesso em: 20maio. 2008.

Ministério do Turismo. 2008. Cultura. In: Portal Brasileiro do Turismo. 2006. Disponível em: http://www.turismo.gov.br. Acesso em: 20 fev. 2008.

Ministério do Turismo. 2009b. Caravana Brasil. Caderno de Avaliação - Serra da Capivara Piauí. Disponível em:

http://www.turismo.gov.br/export/sites/default/turismo/caravana_brasil_nacional/

Viagens_2009/download/Caderno_Avaliacao_final_PI.pdf. Acesso em: Maio 2011.

Ministério do Turismo. 2010. Roteiro pelos sítios arqueológicos de Minas Gerais será palco de programa da OMT- Voluntários de várias regiões do mundo desenvolverão projetos de cooperação técnica no Brasil. Disponível em: http://www.turismo.gov.br/turismo/noticias/todas_noticias/20100423-4.html. Acesso em: Março 2011.

Ministério do Turismo. 2010. Aprendendo com o México - Projeto Excelência em Turismo do Mtur levará empresários brasileiros à Riviera Maya para observar a integração de diferentes segmentos turísticos. Disponível em:

http://www.turismo.gov.br/turismo/noticias/todas_noticias/20101125-4.html.

Acesso em:Março 2011

Ministério do Turismo. 2011. Turismo em cavernas ganha chancela da OMT no Brasil Missão Pioneira do Programa Voluntários OMT no país estrutura circuito mineiro de grutas turísticas. Disponível em:

http://www.turismo.gov.br/turismo/noticias/todas_noticias/20110716-12.html Acesso em: Março 2012.

Ministério do Turismo. 2011. Relatório de Atividades do sexto salão de turismo - Roteiros do Brasil.Disponível em:

http://www.salao.turismo.gov.br/salao/sobre_evento/edicoes_anteriores/detalhes_edicao/edica o_6.html.Acessoem:Maio 2012.

Mirada Antropológica 2009/10. Revista Del Cuerpo Académico de Antropología la Facultad de Filosofía y Letras de La Buap - Nueva Época, n. 8-9.

Molina, S. 2003. O Pós- Turismo. São Paulo: ALEPH.

Moraes, M. 2000. Memórias de um sertão desencantado (modernização agrícola, narrativas $e$ atores sociais nos cerrados do sudoeste piauiense). 481 p. Tese de Doutorado em Ciências Sociais apresentada na Universidade Estadual de Campinas, Campinas. 
Morais, J. 2002. A arqueologia e o turismo. In: Funari, P. P., Plinsky, Jaime (Orgs.). Turismo e Patrimônio Cultural. São Paulo: Contexto, $2^{\text {a }}$ Ed.: 97-103. (Coleção Turismo Contexto)

Moreira, F. J. 1999. O processo de criação de um museu local.

Moreira, I. 2006. A inclusão social e a popularização da ciência e tecnologia no Brasil. Inclusão Social, 1 (2), 11-16

Morin, E. 2001. A Cabeça Bem Feita: repensar a reforma — reformar o pensamento. 3.ed. Rio de Janeiro: Bertrand Brasil.

Moro-Abadía, O. 2006.The History of Archaeology as a 'Colonial Discourse.Bulletin of the History of Archaeology, v.16, n.2, p. 4- 17.

Morse, M. A. 1994. Seeking an Ethical Balance in Archaeological Practice in Ecuador.Journal of Anthropological Research, v.50, n.2, p. 169-182.

Mortensen, L. 2007. Working Borders: Contextualizing Copán Archaeology. Archaeologies: Journal of the World Archaeological Congress v.3, n.2, p. 132-152.

Moutinho, M. 2007. Definiçãoevolutiva de Sociomuseologia. XIII Atelier Internacional do MINOM, Setembro. Lisboa: Lisboa Setúbal.

Moutinho, M. 2008. Os Museus como instituições prestadoras de serviços. Revista Lusófona de Humanidades e Tecnologias, n.12, p. $1-1$.

MST. 2004. Setor de Produção do MST avança na formação de trabalhadores rurais em Alagoas. 19 de agosto de 2004. Disponível em: <http://www.mst.org.br/node/1698>. Acesso em: 15 jan. 2010

MST. 2007.Sem Terra continuam em marcha por justiça social em Alagoas. 28 de março de 2007. Disponível em: http://www.mst.org.br/node/3872 . Acesso em: 15 jan. 2010

MST. 2009. 25 anos de lutas e conquistas. Edição Especial 25 anos do Jornal Sem Terra. 289, Jan/Fev 2009. Disponível em: http://www.mst.org.br/jornal/289/estados. Acessoem: 14 jan. 2010

Muchotrigo, M. 2006. Identidad y Política Cultural en el Perú. Liberabit. Lima (Perú) 12: 4148.

Musteata, S. 2009. Let's Do Our Job Better and Then There Will Be No Reasons To Talk About the Relevancy of Archaeology, Historical Archaeology, v.43, n.4, p.122-124

Navajas, O. 2008. Una nueva museología, ponencia presentada en la Conferencia organizada por la ENAM, el Comité Argentino del ICOM y el CICOP Argentina celebraba el 11 de noviembre del 2008. Manzana de lãs Luces. Disponível em: http://www.icomargentina.org.ar/articulos.php. Acesso em: 20 Fev. 2011. 
Nogueira, C.; Burkhard, D. 2008. Políticas Públicas de Turismo para o desenvolvimento Local/ Regional as Missões Jesuítico-Guarani. Revista Eletrônica de Turismo Cultural. Volume 02 - No. $022^{\circ}$. Semestre de 2008, p. 1-16

Nowatzki, C. 2004. (Org.). O Sítio Arqueológico de São Miguel das Missões. Uma análise sob o ponto de vista da Geologia. All Print Editora. São Paulo, p. 43-58.

NUPAUB. 2011. Povos e comunidades tradicionais em área de proteção. Levantamento do núcleo de apoio à pesquisa sobre populações humanas em áreas úmidas brasileiras da Universidade de São Paulo. Disponível em:

http://www.usp.br/nupaub/levantamentoconf.pdf. Acesso em: Abril 2012.

Oliveira, P. 2009. O Passado Encravado no Presente: turismo histórico e passado-espetáculo nas Missões Jesuíticas do Rio Grande do Sul. Tempo e Argumento, Revista do Programa de Pós Graduação em História. Florianópolis, v. 1, n. 1, p. 155 - 17 1, jan./jun.

Oliveira Filho, R.; Monteiro, M. 2007. Valoração Econômica da Pratica do Ecoturismo no Semi-árido: o caso do Parque Nacional Serra da Capivara - Piauí. VII Encontro da Sociedade Brasileira de Economia Ecológica. Fortaleza, 28 a 30 de novembro.

Oliveira Filho, R; Monteiro, M. 2009. Ecoturismo no Parque Nacional Serra da Capivara: trata-se de uma prática sustentável? Revista Turismo em Análise. v.20, n.2, p. 230-250.

Olivier, L. 2005. A arqueologia do $3^{\circ}$ Reich e a França: notas para servir ao estudo da "banalidade do mal" em arqueologia. Identidades, discurso e poder: estudos da arqueologia contemporânea. In: Funari, P.P. et al. eds. Identidades, discurso e poder: estudos da arqueologia contemporânea. São Paulo: Annablume.

OMT. 2002. Contribuciones de la organización mundial del turismo a la cumbre mundial sobre el desarrollo sostenible.Johannesburgo.

Orser, C. 2005. O desafio da raça para a arqueologia histórica americana. Identidades, discurso e poder: estudos da arqueologia contemporânea. In: Funari, P.P. ê al. ês. Identidades, discurso e poder: estudos da arqueologia contemporânea. São Paulo: Annablume

Ortega, A.; Beñites, G.; Morinico, J. Comunidades Mbya-Guarani unidas pela história, do primeiro contato até o intenso convívio com os brancos de hoje. [Vídeo]. Produção vídeo nas aldeias e IPHAN, edição Ernesto I de Carvalho. 2008.

Pardi, M. L. 2007. A preservação do patrimônio arqueológico e o turismo. Revista do Patrimônio Histórico e Artístico Nacional, Rio de Janeiro; IPHAN, n. 34, p.305-337.

Passerino, L; Momtardo, S. P. 2007. Inclusão social via acessibilidade digital: proposta de inclusão digital para Pessoas com Necessidades Especiais. In Colóqui Internacional sobre a Escola Latino Americana de Comunicação, 11. Anais... Pelotas, RS, de 7 a 9 de maio.

Peirano, M. 1997. Onde Está a Antropologia? Mana. Rio de Janeiro, v. 3, n. 2, p. 67-102. 
Peirano, M. 1999. Antropologia no Brasil (alteridade contextualizada). In: SERGIO, Miceli (org.), O que ler na ciência social brasileira (1970-1995). São Paulo: Editora Sumaré/Anpocs, p. $225-263$

Pellegrini Filho, A. 1990. Problemática do Patrimônio Cultural / Natural no Brasil. Revista Turismo em Análise. CRP/ECA/USP: São Paulo: Aleph, v.1, n.1.

Pellegrini Filho, A. 1992. Interferências Humanas em bens da Natureza e da Cultura.Revista Turismo em Análise. CRP/ECA/USP: São Paulo: Aleph, v.3, n.1.

Pelegrini, S. 2005. A Propósito da fruição e de algumas perspectivas analíticas acerca do patrimônio cultural. Diálogos, DHI/PPH/UEM, v. 9, n. 1, p. 49-58, 2005

Peralta, A. 2006. La democracia cultural y los movimientos patrimonialistas en México.CuicuilcoRevista de la Escuela Nacional de Antropología e Historia. Nueva Época, v.13, n. 38, Septiembre-Diciembre.

Pereira, R. 2009. Empreendedorismo e parcerias: caminhos para o desenvolvimento sustentável à luz da agenda 21 no Cariri Paraibano. Revista Global Tourism, v.5 n.1 Maio/2009, p. 41-49. Disponivel em: www.periodicodeturismo.com.br. Acessoem: 25 mar. 2011.

Pérez, J. 2009/10. Presentación - El patrimonio cultural de la industria mexicana. Mirada Antropológica - Revista Del Cuerpo Académico de Antropología la Facultad de Filosofía y Letras de La Buap - Nueva Época, n. 8-9, p.3-6.

Pérez, J. 2009/10. Espacio social y lugares del ámbito ferroviario mexicano .Revista Del Cuerpo Académico de Antropología la Facultad de Filosofía y Letras de La Buap - Nueva Época, n. 8-9, p.58-75.

Piedras, E. 2006. Industrias y patrimonio cultural en el desarrollo económico de México. Cuicuilco Revista de la Escuela Nacional de Antropología e Historia. Nueva Época, v.13, n. 38, Septiembre-Diciembre, p. 29-46

Pikirayi, I. 2009. What Can Archaeology Do for Society in Southern Africa? Historical Archaeology, v.43, n.4, p.125-127.

Pina Cabral, J. 2003. Identidade, Socialidade e Inserção Social. Versão preliminar para publicação.

Pinter, T.L. 2005. Heritagetourismandarchaeology: criticalissues, SAA ArchaeologicalRecord, v.5, n.3, p. 9-11.

Piza, D. 1992. Experiências percussoras de Turismo ecológico no Brasil- Um depoimento Pessoal. Revista Turismo em Análise. CRP/ECA/USP: São Paulo: Aleph, v.3, n.1.

Pizarro, C. I. 2007. Exposições temporárias e itinerantes. Rio de Janeiro. Artigo Cientifico apresentado na $\mathrm{X}$ reunião de popularização da ciência e tecnologia da América Latina e Caribe, São Jose - Costa Rica. 
Poblete, D. 2003. A Proposal for Approaching the Archaeological Heritage of the Belém Community (Region of Tarapacá, Chile).ChileanjournalChungará. v.35, n. 2, p. 327-335.

Pollak, M. 1989. Mémória, esquecimento, silêncio. Estudos Históricos, Rio de Janeiro, v. 2, n. 3, p. 3-15.

Pommer, R. 2008. Missioneirismo: a produção de uma identidade regional. Tese de doutorado apresentada no curso de História da Universidade do Vale do rio dos Sinos. São Leopoldo.

Pommer, R. 2009. Missioneirismo: história da produção de uma identidade regional. Porto Alegre: Martins Livreiro.

Porto, M.; Almeida, G. 2002. Significados e limites das estratégias de integração disciplinar: uma reflexão sobre as contribuições da saúde do trabalhador. Ciência\& Saúde Coletiva, v.7, n.2, p. $335-347$.

Prentice, R. 2005. Heritage: a key sector in the "new" tourism, Heritage, Museum, and Galleries, G. Corsane, ed., London, Routledge, p. 243-255.

Pyburn, K.; Wilk, R. 2000.Responsible archaeology is applied archaeology.In M. Lynott and A. Wylie, eds., Ethics in American Archaeology.Washington: S.A.A, p. 71-76.

Rabahy, W. 2003. Turismo e desenvolvimento: estudos econômicos e estatísticos no planejamento. Barueri, SP: Manole.

Rabinow, P. 1999. Representações são fatos sociais: modernidade e pós - modernidade na antropologia. In: Antropologia da razão. Rio de Janeiro, Relume Dumará, p. 71-108

Rabinovici, A. 2010. Organizações Não Governamentais e a Sustentabilidade do Turismo. V Encontro Nacional da Anppas. Florianópolis, p. 1-20.

Rahtz, P. 1989. Convite à Arqueologia. Rio de Janeiro: Imago.

Regules, M. P. 2006. et al. Ética, meio ambiente e cidadania para o turismo. São Paulo: Núcleo de Turismo da USP/AVT.

Reis, J. 2005. Das condições de possibilidade da teoria em arqueologia: do implícito e do explícito na arqueologia brasileira. In: Funari, P.P. et al. eds. Identidades, discurso e poder: estudos da arqueologia contemporânea. São Paulo: Annablume.

Rejowski, M. 1998. Realidades versus Necessidades da Pesquisa turística no Brasil. Revista Turismo em Análise. CRP/ECA/USP: São Paulo: Aleph, v.9, n.1.

Rejowski, M.; Aldrigui, M. 2007. Periódicos Científicos em turismo no Brasil. Dos boletins técnico-informativos às revistas científicas eletrônicas. Turismo em Análise. CRP/ECA/USP: São Paulo: Aleph, v.18, n.2.

Renova Energia. 2012. Programa Catavento. Disponível em: http://www.renovaenergia.com.br/pt-br/comunidades/catavento/Paginas/default.aspx 
Acesso em: 05 junho 2012.

Revista Turismo em Análise. 1990 - 2007. São Paulo. CRP/ECA/USP: Aleph. 1ª-18b.

Reyes, S. 2006. El Instituto Nacional de Antropología e Historia: Antecedentes trayectorias y cambios a partir de la creación del Conalcuta. Cuicuilco Revista de la Escuela Nacional de Antropología e Historia. Nueva Época, v.13, n. 38, Septiembre-Diciembre, p. 47-72.

Reyes, S. 2009/10. Patrimonio Cultural: modalidades, problemática actual y experiencias relevantes en Iberoamérica. Mirada Antropológica - Revista Del Cuerpo Académico de Antropología la Facultad de Filosofía y Letras de La Buap - Nueva Época, n. 8-9, p. 144149.

Reyes, S. 2009/10. Historia y memoria de una comunidad mexicana responsable del patrimonio cultural. Mirada Antropológica - Revista Del Cuerpo Académico de Antropología la Facultad de Filosofía y Letras de La Buap - Nueva Época, n. 8-9, p. 288-310.

Ribeiro, M. 2006. Exclusão e Educação Social: Conceitos em Superfície e Fundo. Educ. Soc., Campinas, vol. 27, n. 94, p. 155-178, jan./abr. Disponível em:

http://www.cedes.unicamp.br.Acessoem: 15 abril 2011.

Richards, G. 2007.Cultural Tourism.Global and local perspectives.Binghamton, Haworth.

Ries, G. 2003. Arqueologia: Um Potencial para o ecoturismo no Brasil: Serra da Capivara, um exemplo a ser seguido. Monografia defendida no Curso de Pós-Graduação em Ecoturismo do Serviço Nacional de Aprendizagem Comercial-SENAC. São Paulo.

Riviére, G. H. 1985. Definición evolutiva del ecomuseo. Museum, 148: 182.

Rylko-Bauer, B.; Singer, M.; Van Willigen, J. 2006. "Reclaiming Applied Anthropology: Its Past, Present, and Future,” American Anthropologist, v. 108, n. 1, p. 178-190.

Rodrigues, R. 2007. Os caçadores-ceramistas do sertão paulista: um estudo etnoarqueológico da ocupação Kaingang no vale do rio Feio/Aguapeí. Tese de Doutorado, USP.

Rodrigues, R. 2009. Um passado de novidades: O papel da exposição temporária em atrair visitantes para o Museu de Arte de São Paulo (MASP). Trabalho de conclusão de curso apresentado à Pontifícia Universidade Católica de São Paulo.

Rodríguez,M.; Alfaro, L.2003. Archaeology, Cultural Heritage and Native Populations: Reflections from the Atacama Desert. Chilean journal Chungará, v.35, n.2, p. 295-304.

Rowan, Y.; Baram, U. 2004. Archaeology after nationalism: globalization and the consumption of the past, in Marketing Heritage. Archaeology and the consumption of the past. Walnut Creek, Altamira, p. 3-22.

Ruschmann, D. 1992. Turismo Sustentado para preservação do Patrimônio Ambiental. Revista Turismo em Análise. CRP/ECA/USP: São Paulo: Aleph, v. 3, n.1. 
Ruschmann, D. 1997. Turismo e planejamento sustentável - a proteção do meio ambiente. Campinas, SP: Papirus.

Rússio, W. 1984. Texto III. IN: Arantes, Antônio Augusto. (org). Produzindo o passado. Estratégias de construção do patrimônio cultural. São Paulo: Brasiliense, p.59-78.

Rússio, W. 1990. Conceito de cultura e sua inter-relação com o patrimônio cultural e a preservação. Cadernos Museológicos, nº 3. Rio de Janeiro: IBPC.

Said, E. 1990. O orientalismo: o Oriente como invenção do Ocidente. São Paulo: Companhia das Letras.

Salamon, R. 2006. Usos de la memoria: prácticas culturales y patrimonios mudos. Cuicuilco Revista de la Escuela Nacional de Antropología e Historia. Nueva Época, v.13, n. 38, Septiembre-Diciembre.

Salazar, N. B. 2006. Antropología del turismo en países en desarrollo: análisis crítico de las culturas, poderes e identidades generados por el turismo. Tabula Rasa, p. 99-128.

Santos, J. 2007. Arqueoturismo no Semi-árido Sergipano: o desafio da conservação de um patrimônio milenar. Caderno Virtual de Turismo. v. 7, n. 2, p. 35-46. Disponível em: http://www.ivt.coppe.ufrj.br/caderno/ojs/ .Acesso em: 18 fev. 2010

Santos, M.; Barbosa, J. 2001. Percepção do turismo no cotidiano dos Dirigentes: Caso Xingó. Turismo em Análise. CRP/ECA/USP: São Paulo, v.12, n.1.

Santos, M. C. 2008. Museu e Educação: conceitos e métodos. Encontros museológicos reflexões sobre a museologia, a educação e o museu.

Scatamacchia, M. 2005. Turismo e Arqueologia. São Paulo: Aleph, (Coleção ABC do Turismo).

Schaan, D. 2007. Múltiplas vozes, memórias e histórias: por uma gestão compartilhada do patrimônio arqueológico da Amazônia. Revista do Patrimônio Histórico e Artístico Nacional, v. 33, p. 109-135.

Schmitz, P. 1988. O Patrimônio Arqueológico Brasileiro. Revista de Arqueologia. V.5, p. 1118.

Schwarcz, L. 1995. Complexo de Zé Carioca- notas sobre uma identidade mestiça e malandra. In: Revista Brasileira de Ciências Sociais, n.29- ano 10, p. 49-63.

Schwartz, S. 2005. Blacks and Indians: Common Cause and Confrontation in Colonial Brazil. In: Restall, M. ed. Beyond Black and Red: African-Native Relations in Colonial Latin America. Albuquerque: University of New Mexico Press.

Seabra, G. 2003. O turismoSertanejocomoalternativaeconômicapara o semi-árido. PasosRevista de turismo y patrimônio cultural, v.1, n.2, p. 137-143. 
Secretaria de Estado do Turismo. Relatório de Atividades da SETUR 1999/2002. Belo Horizonte, 2002.

Secretaría de Turismo del MEXICO. 2006. In: Portal Oficial de la Secretaria de Turismo. Turismo Cultural y salud. Disponível em: <http://www.sectur.gob.mx/ turismo>. Acesso em: 23 fev. 2010.

Sectur. Informes de Ejecución del Plan Nacional de Desarrollo Turistico. Disponível em: < http://www.sectur.gob.mx/. Acesso em: 08 jun. 2008.

SEPLAN. 2008. Arqueologia reacende passado do Velho Chico. Secretaria do Estado do Planejamento e Orçamento. 21 de julho de 2008. Disponível em:

http://www.planejamento.al.gov.br/sala-de-imprensa/noticias/julho-2008/arqueologia-

reacende-passado-do-velho-chico.Acessoem: 14 jan. 2010

Shackel, P. 2005. Local identity, national memory, and heritage tourism, SAA Archaeological Record, v.5, n.3, p. 33-35.

Shepherd, Nick. 2002. The Politics of Archaeology in África. Annu.Rev.Anthropol, n. 31, p.189-209.

Sillitoe, P. 2007. Anthropologists only need apply: challenges of applied anthropology Journal of the Royal Anthropological Institute ,v. 13, Issue 1, March, p. 147-165.

Silva, M. 2004.Cidades Turísticas: Identidades e Cenários de Lazer. São Paulo: Aleph, (Série Turismo).

Silva Sousa, L. 2006. Turismo e desenvolvimento local sustentável na Paraíba. Edición electrónica. Disponível em: <www.eumed.net/libros/2006b/lss/.> Acesso em: 15 fev. 2010

Silveira, F; Bezerra, M. 2007. Educação Patrimonial: Perspectivas e Dilemas. Antropologia e patrimônio cultural: diálogos e Desafios contemporâneos / organizadores Manuel Ferreira Lima Filho, Jane Felipe Beltrão, Cornelia Eckert. - Blumenau: Nova Letra. 368p.

Silverman, H. 2002. Touring Ancient Times: The Present and Presented Past in Contemporary Peru.American Anthropologist, V.104, N. 3, Set. p. 881- 902.

Sociedade de Arqueologia Brasileira - SAB. 2005. .XIII Congresso da Sociedade de Arqueologia Brasileira. Anais do XIII Congresso da SAB. Campo Grande - MS.

Sociedade de Arqueologia Brasileira - SAB. 2007. XIV. Congresso da Sociedade de Arqueologia Brasileira. Anais do XIV Congresso da SAB. Florianópolis - SC.

Sposati, A. 1999. Exclusão social abaixo da linha do Equador. In: Verás, M. P. B. (ed.) Por uma sociologia da exclusão social: o debate com Serge Paugam. São Paulo, Educ.

Sposati, A. 2006. A fluidez da inclusão/exclusão social. Ciência e Cultura, v. 58, n. 4, São Paulo, Out/Dec. 
Stigliano, B. 2000. Turismo de Aventura: Off-road como prática. Turismo em Análise. CRP/ECA/USP: São Paulo: Aleph, v.11, n.1.

Strathern, M. 1988. The Gender of the Gift: Problems with Women and Problems with Society in Melanesia. Berkeley: University of California Press.

Takasago, M.;Mollo, L. 2008. A Economia do Turismo e a Redução da Pobreza e da Desigualdade no Brasil: o papel do Estado. Turismo em Análise, v.19, n.2, agosto, p. 307-329

Tamanini, E. 1998. Museu, Arqueologia e o público: um olhar necessário. In:

Funari, Pedro Paulo A. (org.). Cultura material e arqueologia histórica. Campinas (SP): UNICAMP, Instituto de Filosofia e Ciências Humanas, p. 179- 220.

Thomaz, R.2005. Estratégias para o desenvolvimento do turismo Cultural na Galícia. Disponível em: http://www.naya.org.ar/turismo/congreso2005. Acesso em: 08 jun. 2008.

Tojal, A. 2007. Políticas Públicas Culturais de Inclusão de Públicos Especiais em Museus. São Paulo: USP, Tese de doutorado.

Toledo, G. ; Quelopana, E. ; Pollero, A. Gestión del Turismo como Integrador de la Iniciativa Internacional y regional en el actual proceso selectivo de la Globalización. Estudio de caso Sierra de la Capivara - Brasil. Turismo em Análise. CRP/ECA/USP: São Paulo: Aleph, v.17, n.1, p. $64-84$

Toro, J. ; Werneck, N. 2004. Mobilização social: um modelo de construir a democracia e a participação. Belo Horizonte: Autêntica.

Tulik, O. 1990. Turismo e Repercussões no Espaço Geográfico. Revista Turismo em Análise. CRP/ECA/USP: São Paulo: Aleph, v.1, n.2, p. $63-77$

Tulik, O. 1992. Turismo e Meio Ambiente - Identificação e Possibilidades da Oferta Alternativa .Revista Turismo em Análise. CRP/ECA/USP: São Paulo: Aleph, v.3, n.1.

Turismo e Negócios. 2008. Expedição mapeia turismo sustentável no baixo São Francisco. Disponível em: http://www.revistaturismoenegocios.com. Acesso em: 03 jun. 2008.

Ugarte, J. ; Pacheco, L. 2001. Integrating Biodiversity into the tourism sector: Peru country Case Study. Asociación Especializada para el Desarrollo sostenible AEDES. Arequipa, Peru. Disponível em:

http://www.unep.org/bpsp/Tourism/Case\%20Studies\%20(pdf)/PERU\%20(Tourism).pdfAcess o em: 10 jan. 2012.

UNWTO - United Nations World Tourism Organization.2011a. International Tourism: First results of 2011 confirm consolidation of growth. Madrid. Disponível em: http://media.unwto.org/en/press-release/2011-05-11/international-tourism-first-results-2011confirm-consolidation-growth.Acessoem: 03 Fev. 2012.

UNWTO - United Nations World Tourism Organization.2011b.Tourism vital for achieving global development objectives - tourism ministers and UN.Madrid.Disponível em: 
http://media.unwto.org/en/press-release/2011-10-11/tourism-vital-achieving-globaldevelopment-objectives-tourism-ministers-and. Acessoem: 03 Fev. 2012.

UNWTO - United Nations World Tourism Organization.2012. Tourism can stimulate trade and development, agrees UN conference. Madrid. Disponível em: http://media.unwto.org/en/press-release/2012-04-24/tourism-can-stimulate-trade-anddevelopment-agrees-un-conference. Acessoem: 03 Mai. 2012.

Urtizberea, I. 2009/2010. Patrimonio cultural, administración y sociedad: ¿̇imbolizan los bienes culturales la identidad cultural de la población local? Revista Del Cuerpo Académico de Antropología la Facultad de Filosofía y Letras de La Buap - Nueva Época, números 8-9.

Varine-Bohan, H. 1995. O tempo social. Rio de Janeiro: Eça Editora.

Varine-Bohan, H. 2008. Museus e Desenvolvimento Local: um balanço crítico. IN: Museus como Agentes de Mudança Social e Desenvolvimento: São Cristóvão, Museu de Arqueologia de Xingó.

Varine-Bohan. H. 2009. Museus e Ordenamento do Território: Algumas experiências e uma tentativa de problematização. Museal, Faro, $4^{\text {a }}$ ed. p. 50-59.

Vasconcellos, C. M. 2006. Turismo e Museus. São Paulo: Aleph. Informações sobre o MASP. Disponível em: http://masp.uol.com.br. Acessoem: 03 Fev. 2010.

Vasconcellos, C. M. 2008. La formación de educadores de museos en Brasil: la experiencia del Museo de Arqueología y Etnología de la Universidad de São Paulo (Mae-Usp). Museos, Educación y Juventud. Memorias del Encuentro Regional de América Latina y el Caribe sobre Educación y Acción Cultural en el Museo CECA-ICOM. Bogotá, Colombia. Disponível em:

http://www.dibam.cl/dinamicas/DocAdjunto_1417.pdf\#page=59. Acesso em: 15 Fev. 2010.

Veloso, T; Cavalcante, J. 2007. O turismo em sítios arqueológicos: algumas modalidades de apresentação do patrimônio arqueológico. Revista de Arqueologia, n. 20, p. 155-168.

Vich, V. 2007. La nación en venta: bricheros, turismo y mercado en El Perú contemporáneo. La ruta andina, Turismo y desarrollo sostenible en Perú y Bolivia. Ypeij, A. Zoomers, J (eds.). Quito: AbyaYala, CEDLA, IEP, CBC.

Vidal, L. 2008. O museu dos povos indígenas do Oiapoque - kuahi. Gestão do Patrimônio Cultural pelos Povos Indígenas do Oiapoque, Amapá. Revista do Museu de Arqueologia e Etnologia, São Paulo, suplemento 7.

Vincent, J. 1974. The Structuring of Etnicity, Human Organization, v. 33, n. 4.

Wall, G. 2000.Planning. In: Jafari, J. Encyclopedia of tourism, Londres, Routledge, p. 439440.

White, H. 1991. A questão narrativa da teoria contemporânea da história. In: RH -Revista de História: dossiê história-narrativa. Campinas: Unicamp. 
Wichers, C. 2010. Museus e Antropofagia do Patrimônio Arqueológico: (Des) caminhos da prática brasileira. Tese de Doutorado Lusofona.

Wichers, C. 2012. Patrimônio Arqueológico Paulista: proposições e provocações museológicas. Tese de Doutorado em Arqueologia apresentada Museu de Arqueologia e Etnologia da Universidade de São Paulo.

Wilde, G. 2011. La problemática de La identidad em El cruce de perspectivas entre La antropologia e Historia. Disponível em: http://www.naya.org.ar/articulos/identi12.htmAcesso em: 26 fev. 2012.

Willigen, John. 1993. Applied Anthropology: An Introduction. Westport, CT: Bergin \& Garvey.

Ypeij, A. 2007. La cultura y la lucha por la inclusión social: un análisis de los planes de desarrollo turístico de la región andina. La ruta andina, Turismo y desarrollo sostenible en Perú y Bolivia. Ypeij, A. Zoomers, J (eds.).Quito: AbyaYala, CEDLA, IEP, CBC.

Yrais, A. 2009/10. Aportes del primer censo del patrimonio cultural Venezolano a las investigaciones sobre el patrimonio cultural en el país. Mirada Antropologica - Revista Del Cuerpo Académico de Antropología la Facultad de Filosofía y Letras de La Buap - Nueva Época, n 8-9, p. 252-263.

Zamignan, G; Sampaio, C. 2010. Turismo de base comunitária como perspectiva para a preservação da biodiversidade e de modos de vidas de comunidades tradicionais: a experiência da micro-bacia do rio Sagrado, Morretes(PR). V Encontro Nacional da Anppas. Florianópolis, p.1-16.

Zanettini Arqueologia. 2007. Programa de Diagnóstico e Ações Emergenciais em Sítios Rupestres, municípios de Olho D’Água do Casado e Delmiro Gouveia, Alagoas. Relatório Final apresentado à $17^{\mathrm{a}}$ Superintendência Regional do IPHAN.(Portaria 14de 25; 01/07).

Zanettini Arqueologia. 2008. Circuito Arqueológico do Sertão Alagoano. Municípios de Delmiro Gouveia, Olho D’Água do Casado e Piranhas. Relatório apresentado à $17^{\mathrm{a}}$ Superintendência Regional do IPHAN.

Zanettini Arqueologia. 2008b. Programa de Mapeamento, Cadastro e Conservação dos Sítios de Arte Rupestre do Baixo São Francisco, Etapa 1 - Município de Pão de Açucar. Relatório Final apresentado à $17^{\text {a }}$ Superintendência Regional do IPHAN.

Zanettini Arqueologia. 2009. Programa de Prospecções Arqueológicas- Parque Fonte Missioneira, Município de São Miguel das Missões, Rio Grande do Sul.

Zanettini Arqueologia. 2009b. Organização da Reserva Técnica do Laboratório de Arqueologia de São Miguel das Missões, Rio Grande do Sul. Relatório Final, São Paulo.

Zanettini Arqueologia. 2011. Programa de Prospecções e Resgate Arqueológico Parque Eólico Renova Energia Municípios de Caetité, Igaporã e Guanambi- Estado da Bahia. Relatório Final. 
Zanettini Arqueologia. 2011b. Programa de Educação Patrimonial do Programa de Prospecções e Resgate Arqueológico dos Parques Eólicos da Renova Energia. Relatório Final.

Zanettini Arqueologia. 2011c. Programa Guarani de Gestão dos Recursos Arqueológicos. Programa de Educação Patrimonial e Inclusão Social. Municípios de Olímpia, Barretos, Tanabi, Colina e Pedranópolis. Relatório Final (Ações 2008- 2010).

Zanettini Arqueologia. 2011d. Programa de Educação Patrimonialdo Programa de Prospecções e Resgate Arqueológico do Gasoduto Guaiçara - Lins rede secundária. Relatório Final.São Paulo.

Zanettini, P. 2005. Projetar o futuro para a arqueologia brasileira: desafio de todos.

Revista de Arqueología Americana, N. 27, p. 71-84.

Zanirato, S. 2010. Experiências de prevenção de riscos ao patrimônio cultural da humanidade.Ambient. soc. Vol.13 no.1 Campinas. Jan./June.

Disponível em: http://dx.doi.org/10.1590/S1414-753X2010000100010. Acesso em: 12 Fev. 2012. 


\section{ANEXo 1 - GLOSSÁRIO (MINISTÉRIO DO TURISMO 2007)}

Atrativos turísticos - locais, objetos, equipamentos, pessoas, fenômenos, eventos ou manifestações capazes de motivar o deslocamento de pessoas para conhecê-los. Os atrativos turísticos podem ser naturais; culturais; atividades econômicas; eventos programados e realizações técnicas, científicas e artísticas.

Capacidade de carga ou de suporte - o nível ótimo (máximo aceitável) de uso que uma área pode receber com alto nível de satisfação para os usuários (turistas, visitantes) e mínimos efeitos negativos sobre os recursos.

Comissão Gestora ou Instância de Governança Regional - organização representativa dos poderes público e privado, da sociedade e dos municípios componentes das regiões turísticas, com o papel de coordenar, acompanhar e gerir o processo de regionalização do turismo na região turística. Pode ser um Conselho, um Fórum, uma Associação, um Comitê etc.

Demanda turística - quantidade de bens e serviços consumidos em um dado período, em determinado local, e por um determinado número de turistas.

Destino turístico - local, cidade, região ou país para onde se movimentam os fluxos turísticos.

Equipamentos e serviços turísticos - conjunto de serviços, edificações e instalações indispensáveis ao desenvolvimento da atividade turística e que existem em função desta. Compreendem os serviços e os equipamentos de hospedagem, alimentação, agenciamento, transporte, eventos, lazer etc.

Fluxo turístico - todo e qualquer deslocamento de um conjunto de turistas que se movimenta de uma direção a outra, unidirecionalmente, num contexto espaço-temporal delimitado, com um ponto comum de emissão e um ou vários pontos de recepção.

Infra-estrutura de apoio ao turismo - é todo o conjunto formado por obras e instalações de estrutura física e de serviços, indispensáveis ao desenvolvimento do turismo e existentes em função dele. 
Marketing - conjunto de técnicas utilizadas para a comercialização e distribuição de um produto entre diferentes consumidores.

Oferta turística - conjunto de atrativos turísticos, serviços e equipamentos e toda infra-estrutura de apoio ao turismo de um determinado destino turístico, utilizados em atividades designadas turísticas.

Produto turístico - é o conjunto de atrativos, equipamentos e serviços turísticos, acrescidos de facilidades, ofertado de forma organizada por um determinado preço. Rotas, roteiros e destinos podem se constituir em produtos turísticos, por exemplo.

Região turística - é o espaço geográfico que apresenta características e potencialidades similares e complementares, capazes de serem articuladas e que definem um território, delimitado para fins de planejamento e gestão. Assim, a integração de municípios de um ou mais estados, ou de um ou mais países, pode constituir uma região turística.

Roteiro turístico - itinerário caracterizado por um ou mais elementos que lhe conferem identidade, definido e estruturado para fins de planejamento,gestão, promoção e comercialização turística.

Segmentos turísticos - a segmentação é entendida como uma forma de organizar o turismo para fins de planejamento, gestão e mercado. Os diferentes segmentos são estabelecidos a partir dos elementos de identidade da oferta de serviços e atrativos turísticos e da variação da demanda por esses elementos.

Serviços e equipamentos turísticos - conjunto de serviços, edificações e instalações indispensáveis ao desenvolvimento da atividade turística e que existem em função desta. Compreendem os serviços e os equipamentos de hospedagem, alimentação, agenciamento, transporte, para eventos, de lazer etc.

Trade turístico - conjunto de agentes, operadores, hoteleiros e prestadores de serviços turísticos, que incluem restaurantes, bares, redes de transporte etc. 
Valor turístico - é o conjunto da produção humana material e imaterial, individual e coletiva, fruto de relações sociais historicamente estabelecidas por uma comunidade em sua localidade, as quais são capazes de gerar um sistema organizado que agregue um composto de bens e serviços - como informação, transporte, hospedagem, alimentação, entretenimento, eventos -, fatores climáticos e geográficos, e os elementos das infra-estruturas geral e específica. Esse conjunto tem por unidade a força de atração que mobiliza o deslocamento e a permanência nessa localidade de pessoas residentes em espaços sociais distintos, chancelando seu valor e estabelecendo uma nova relação social: a hospitalidade. 


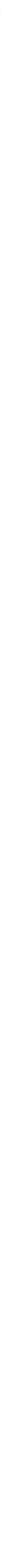



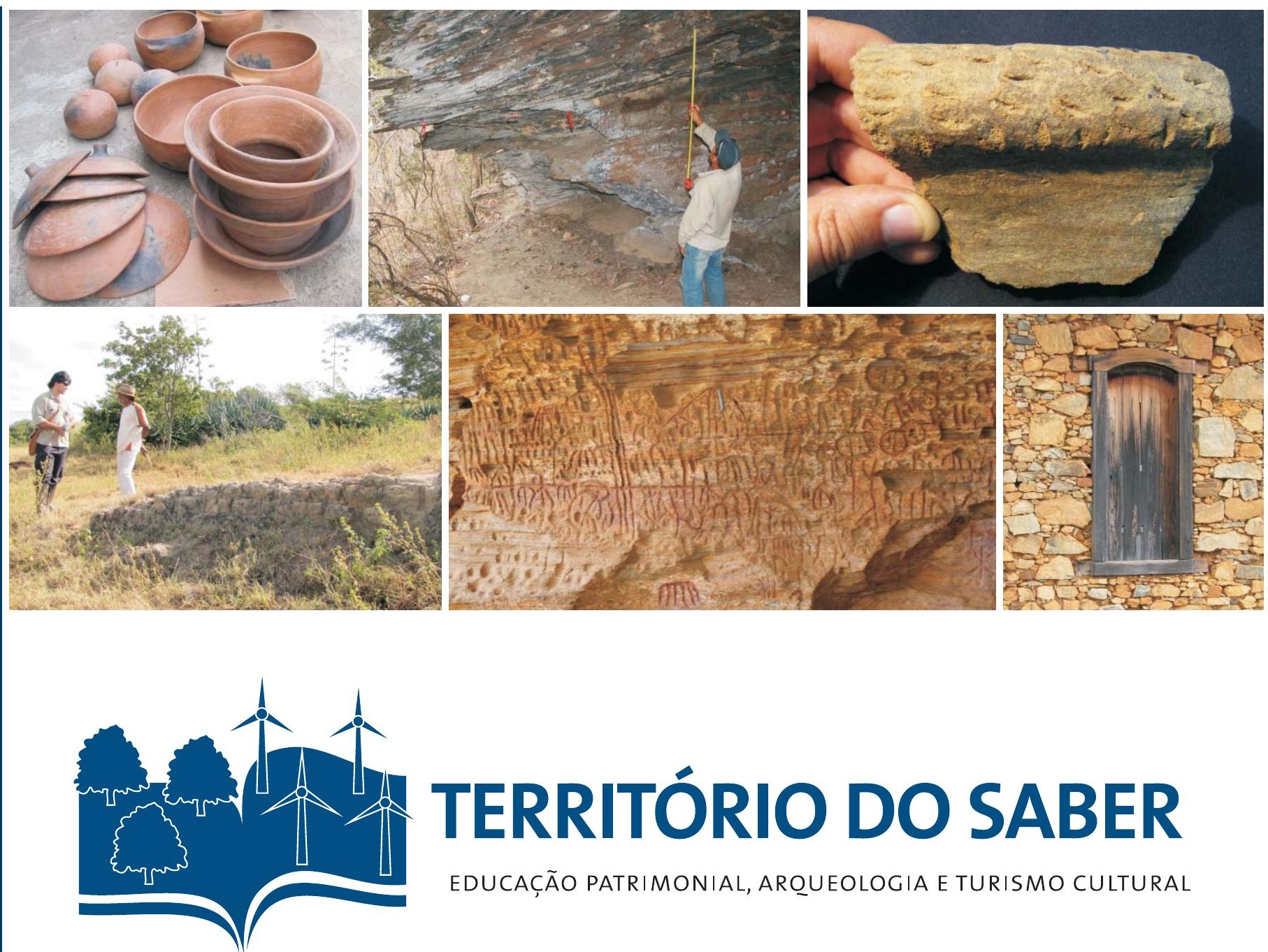

\section{TERRITÓRIO DO SABER}

EDUCAÇÃO PATRIMONIAL, ARQUUEOLOGIA E TURISMO CULTURAL

Diálogos sobre o patrimônio cultural de Caetité, Guanambi e Igaporã.
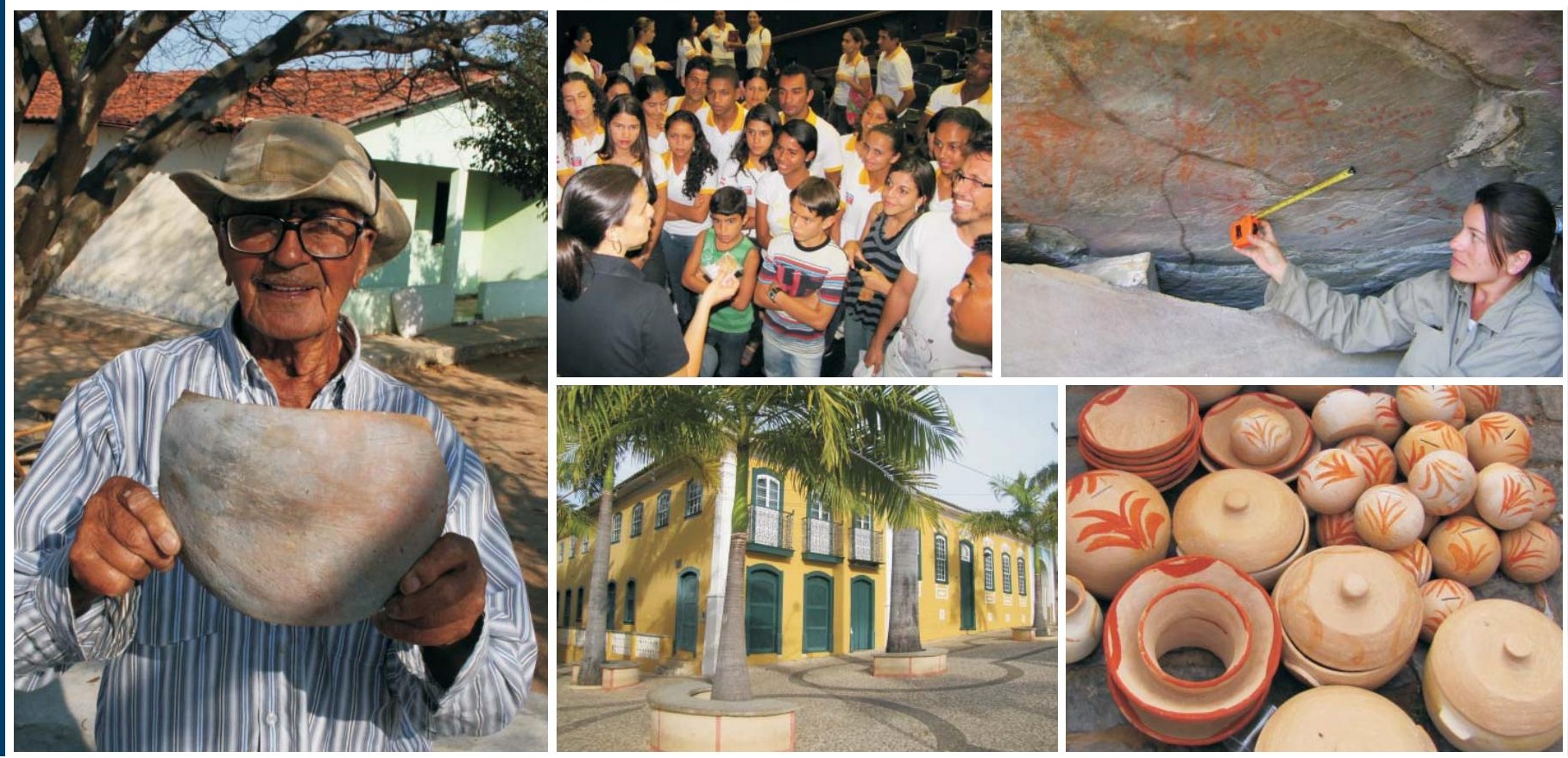


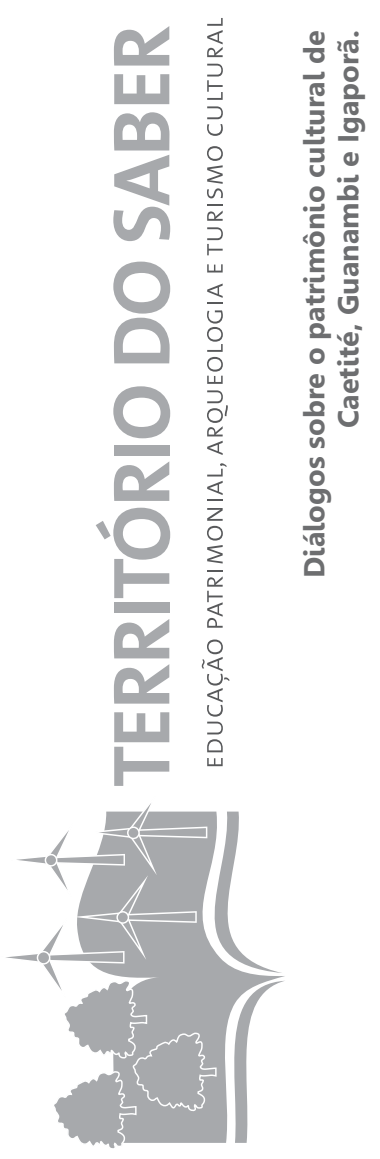



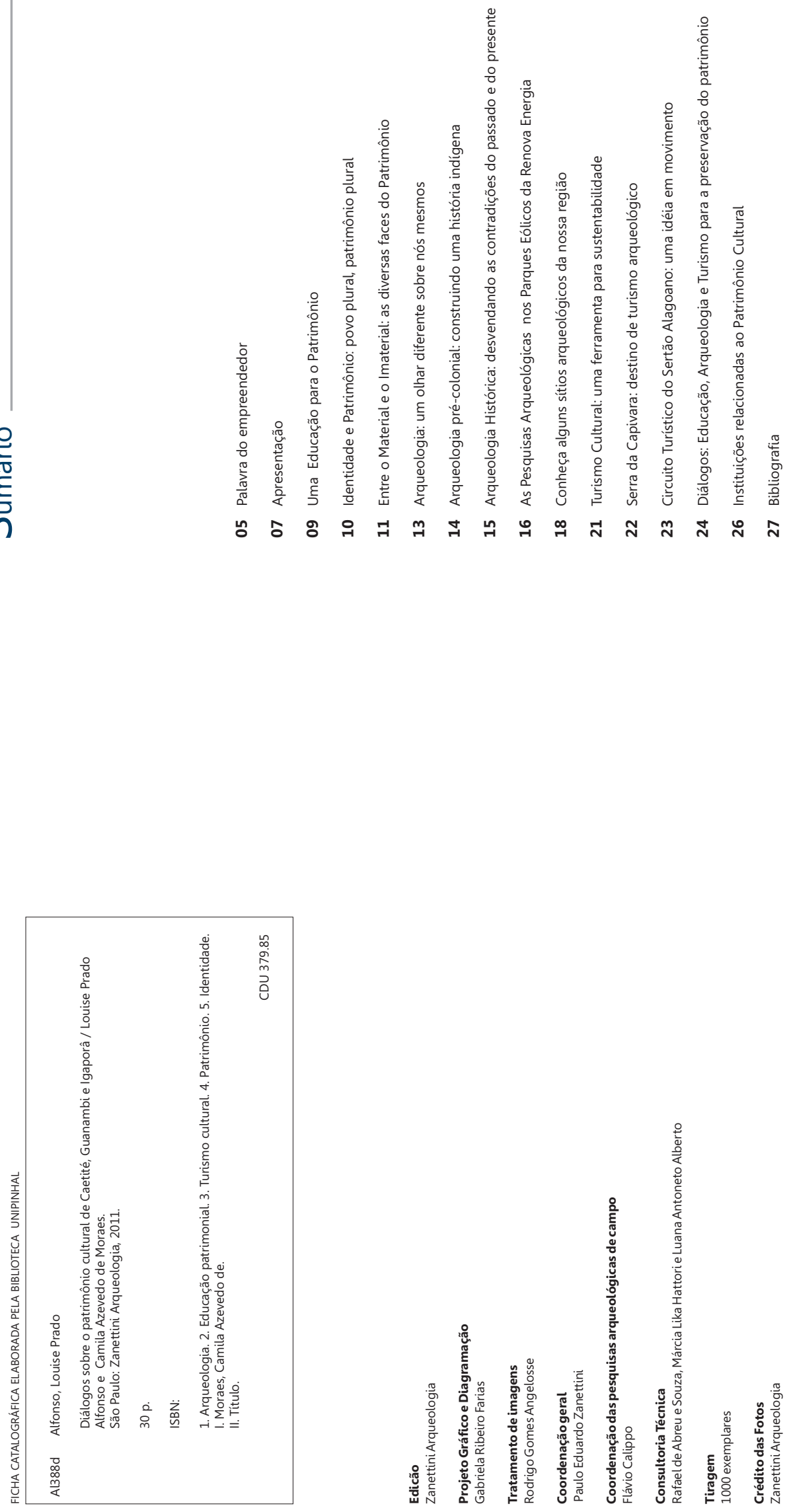

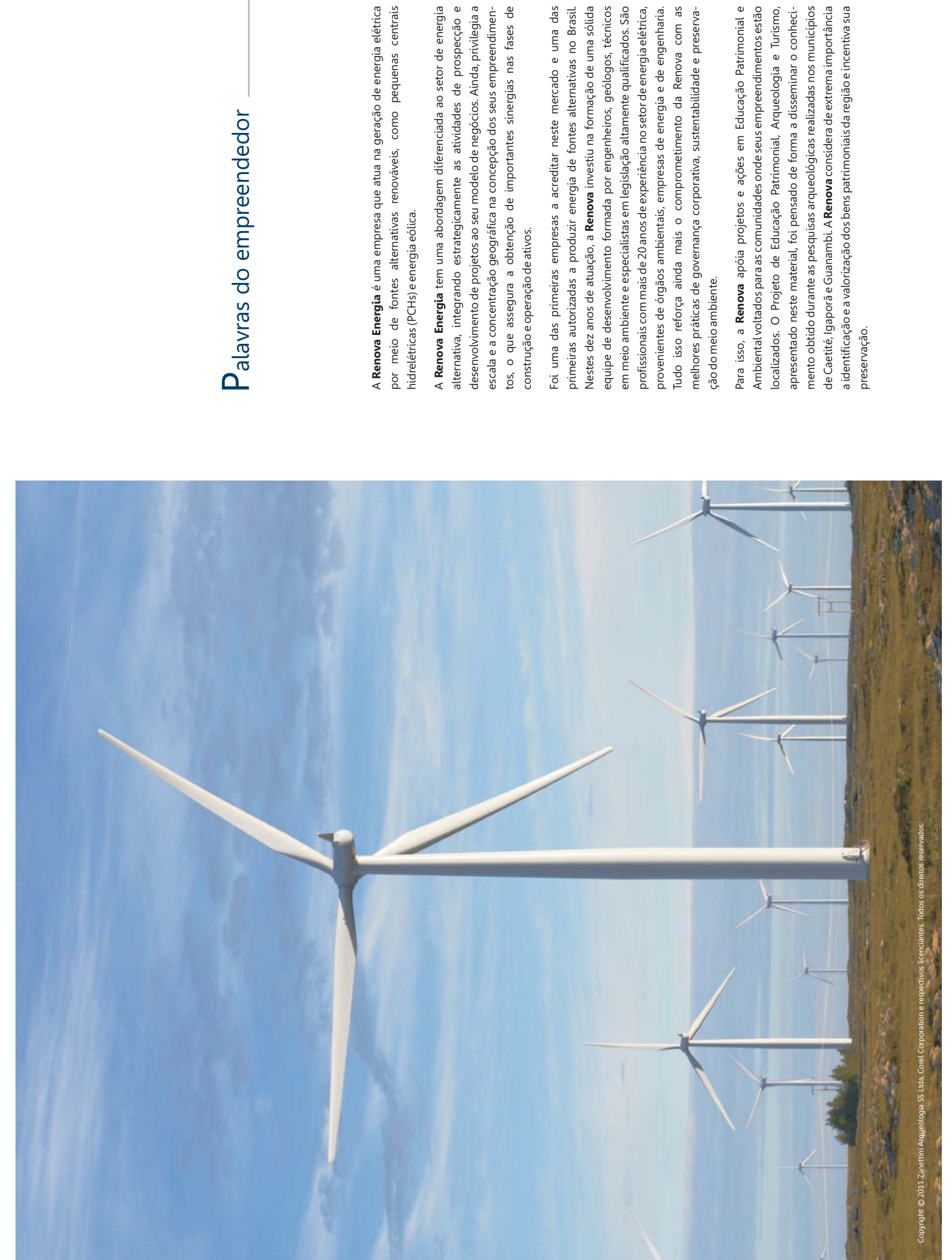
을

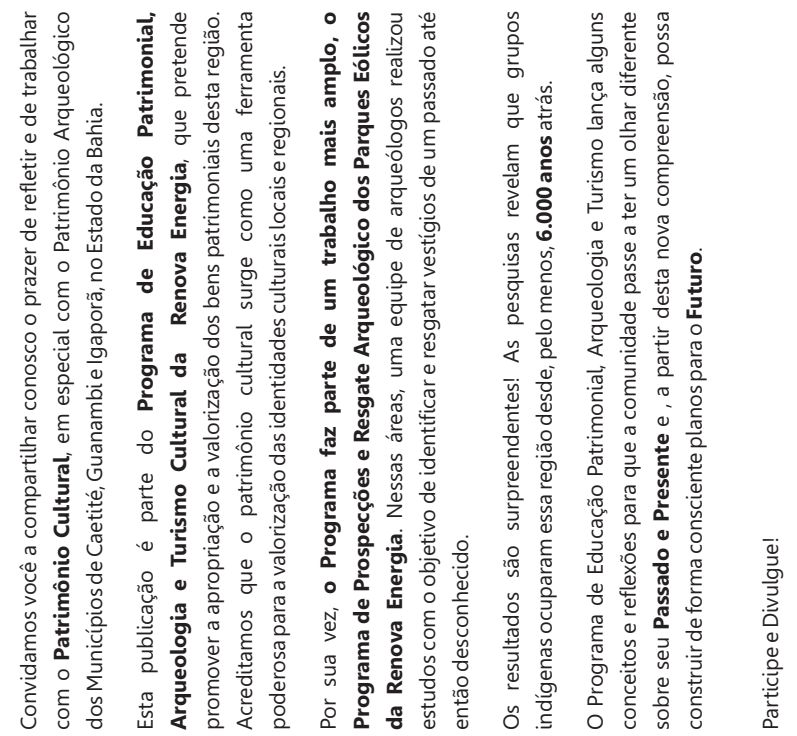
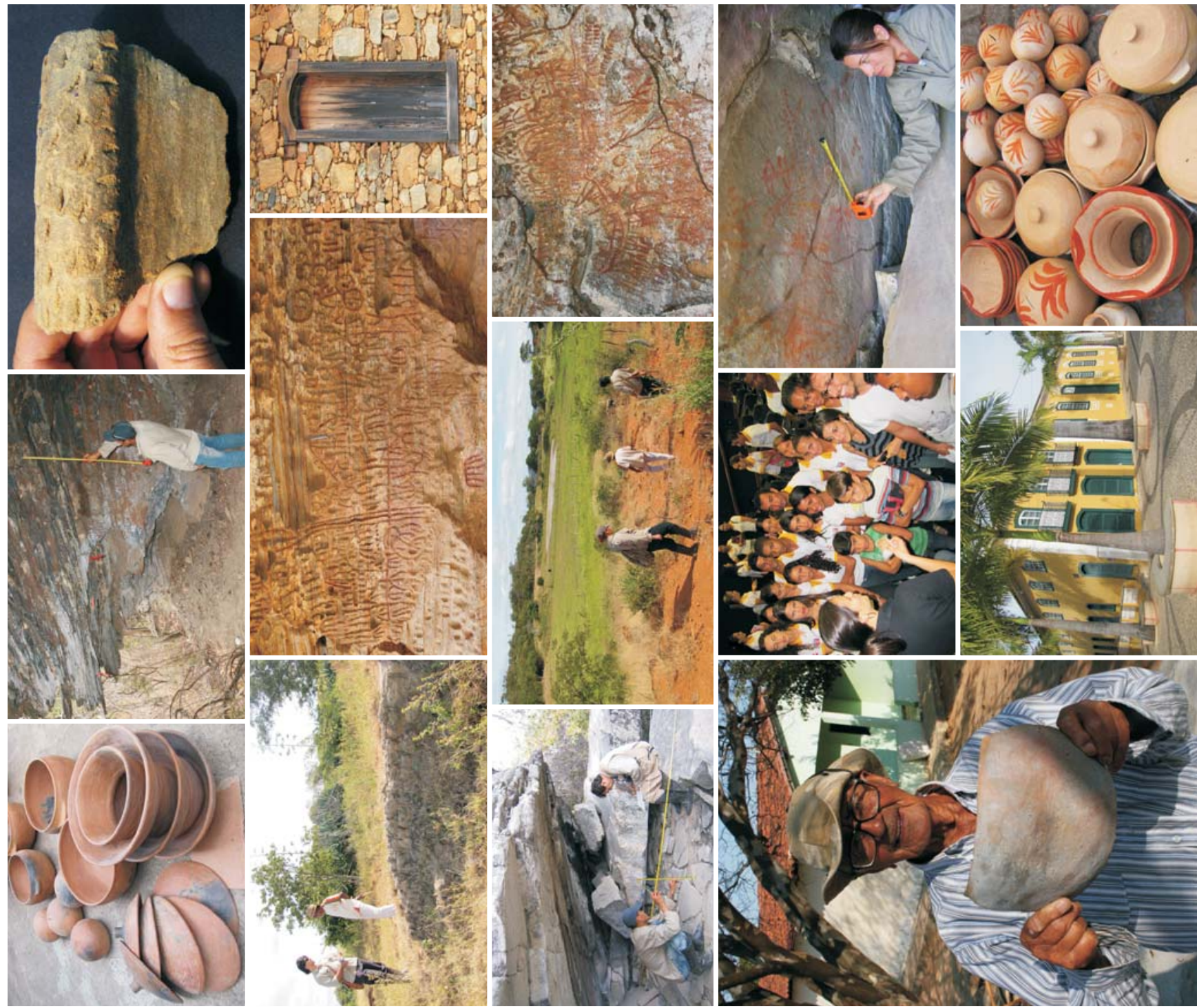

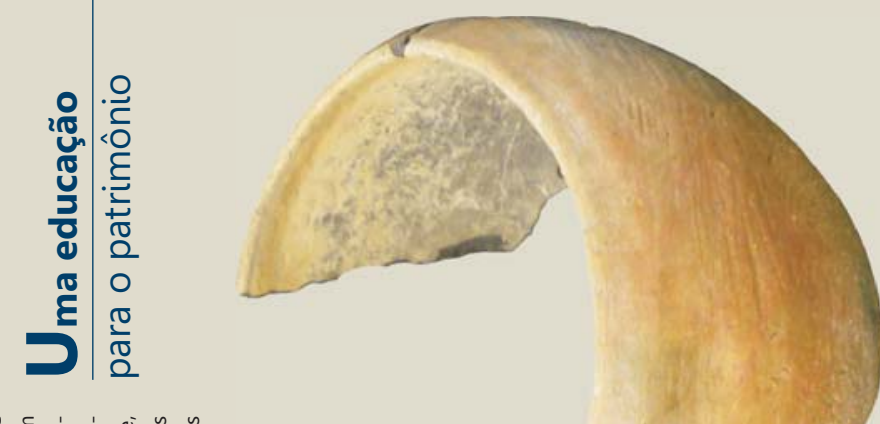

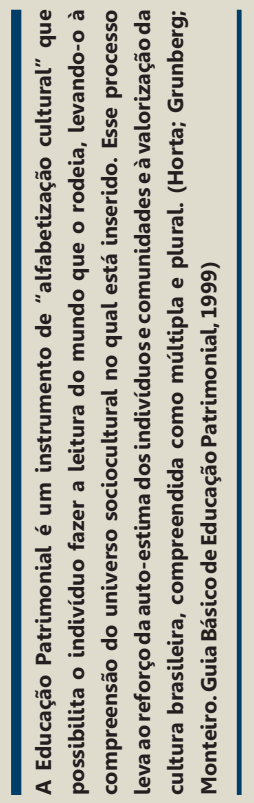

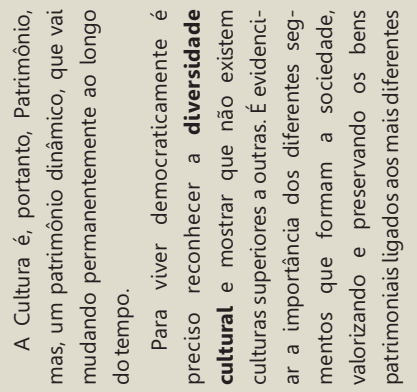

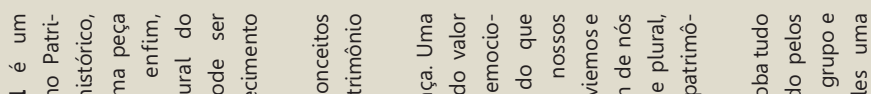

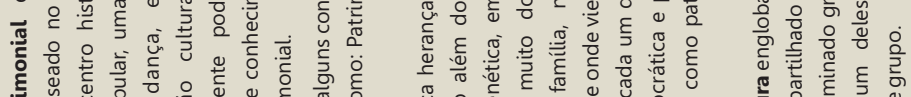

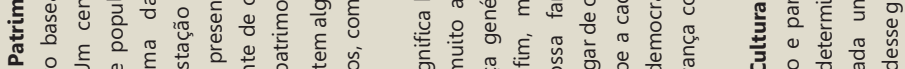

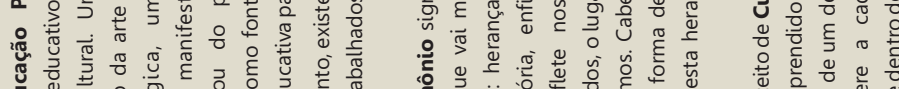

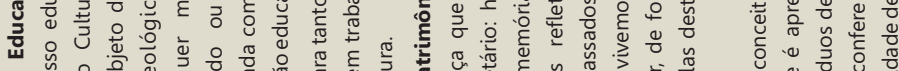

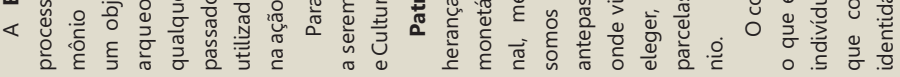

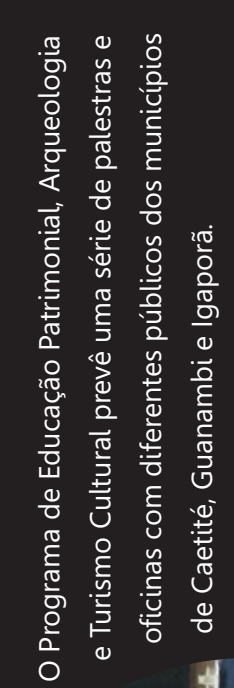

45
-132
4

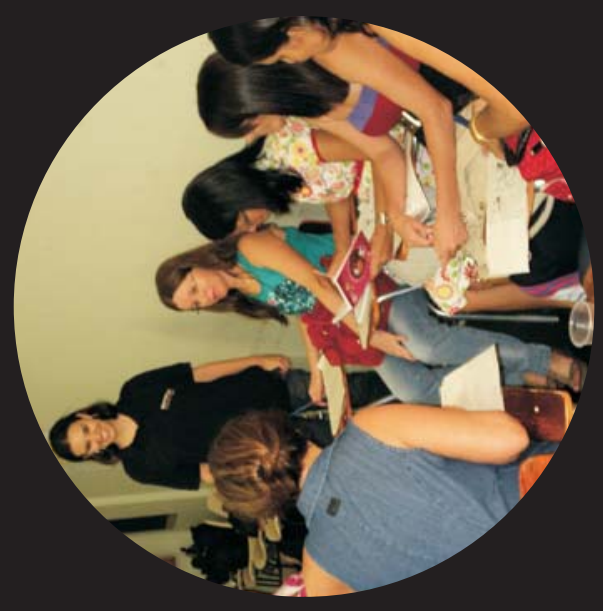

突

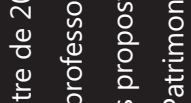

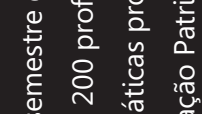

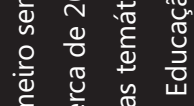

焉离

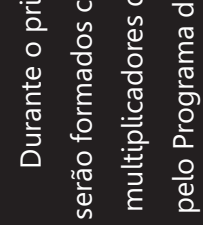

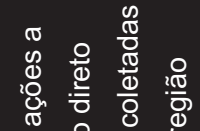
过 क्ष

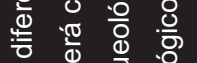

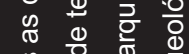

为

ف달

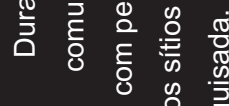

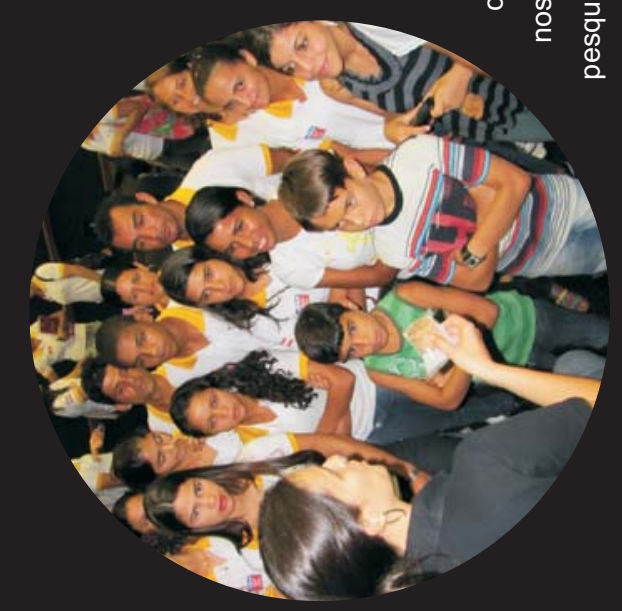



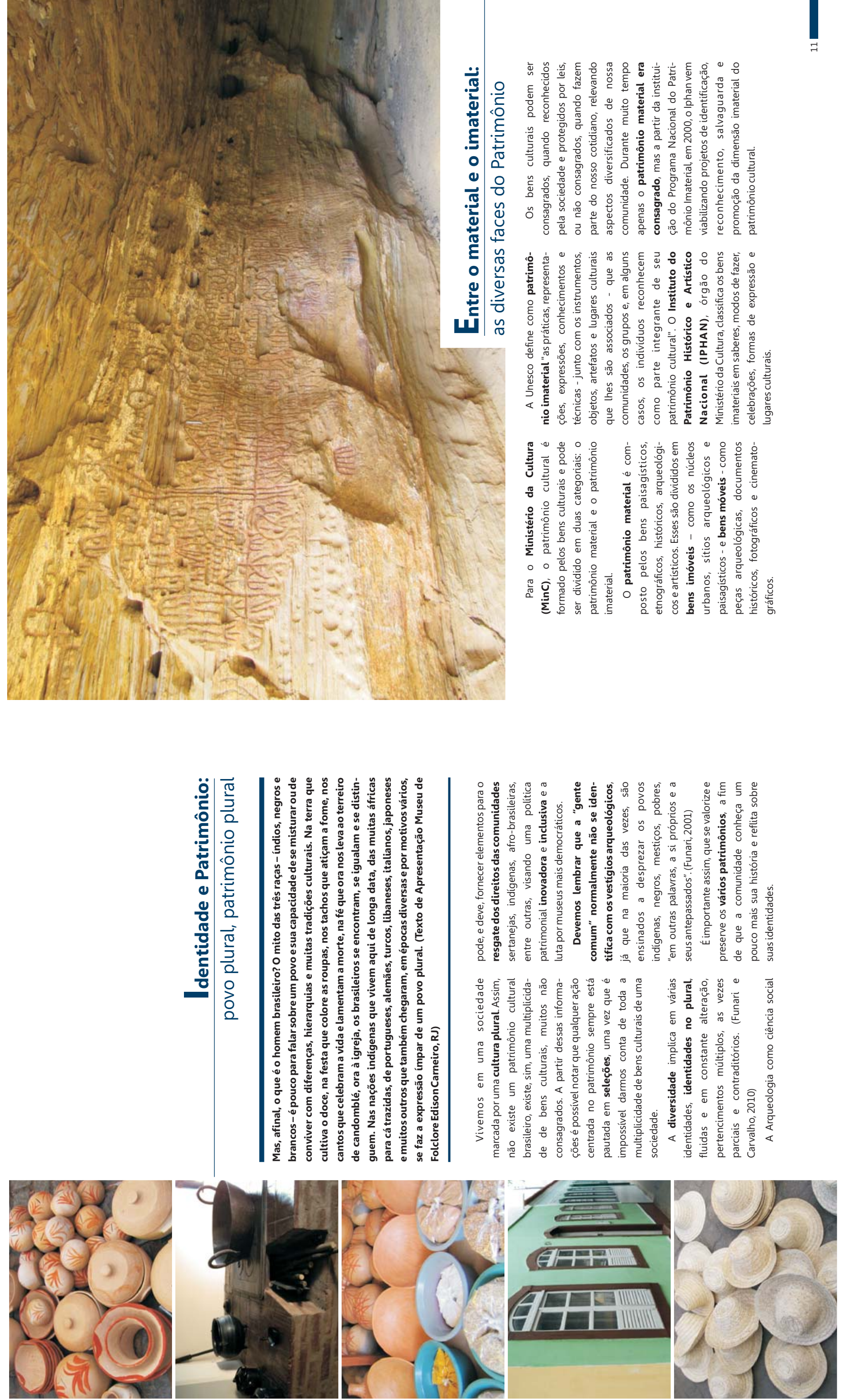
wis.

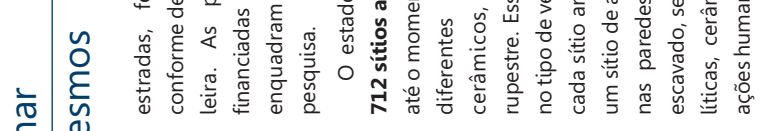

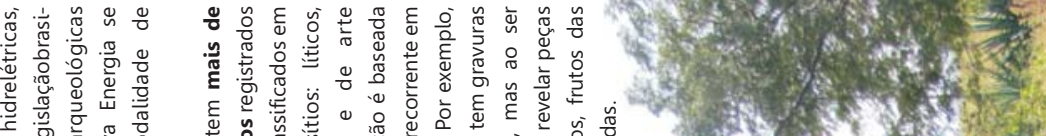

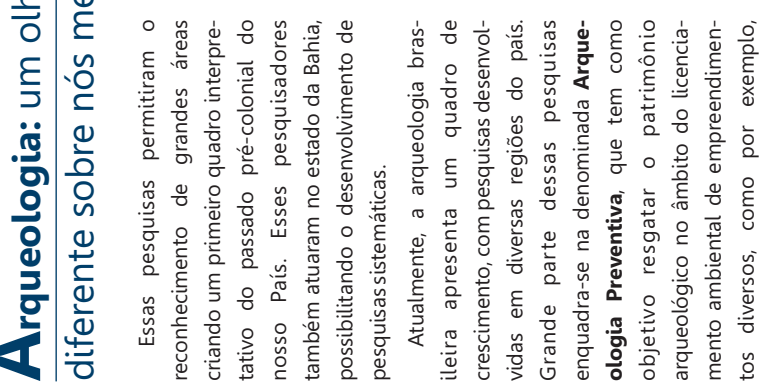

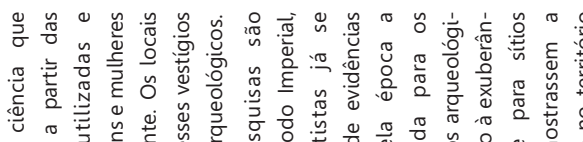

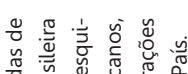

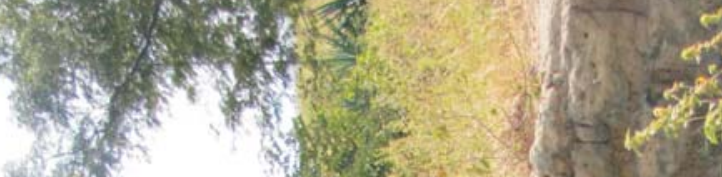

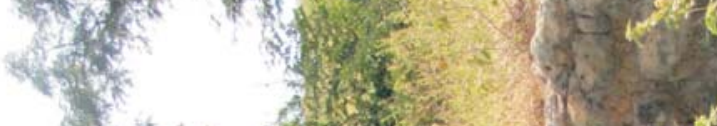

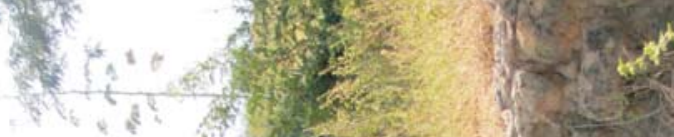

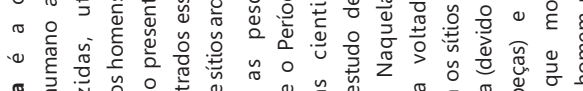

$\begin{array}{llll} & \\ 0\end{array}$

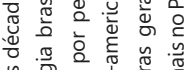

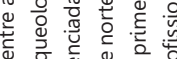

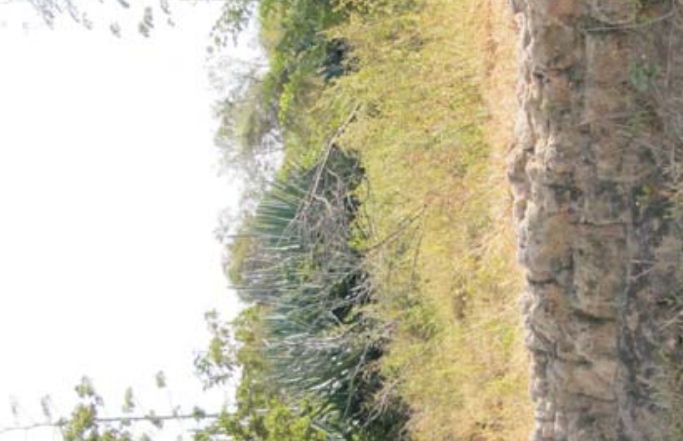

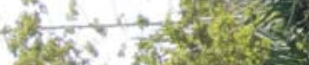

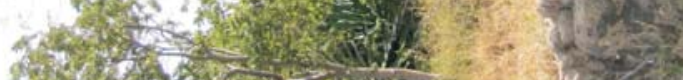

now

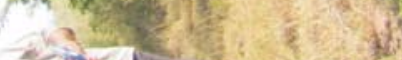

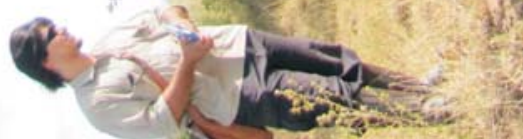

(1)

.

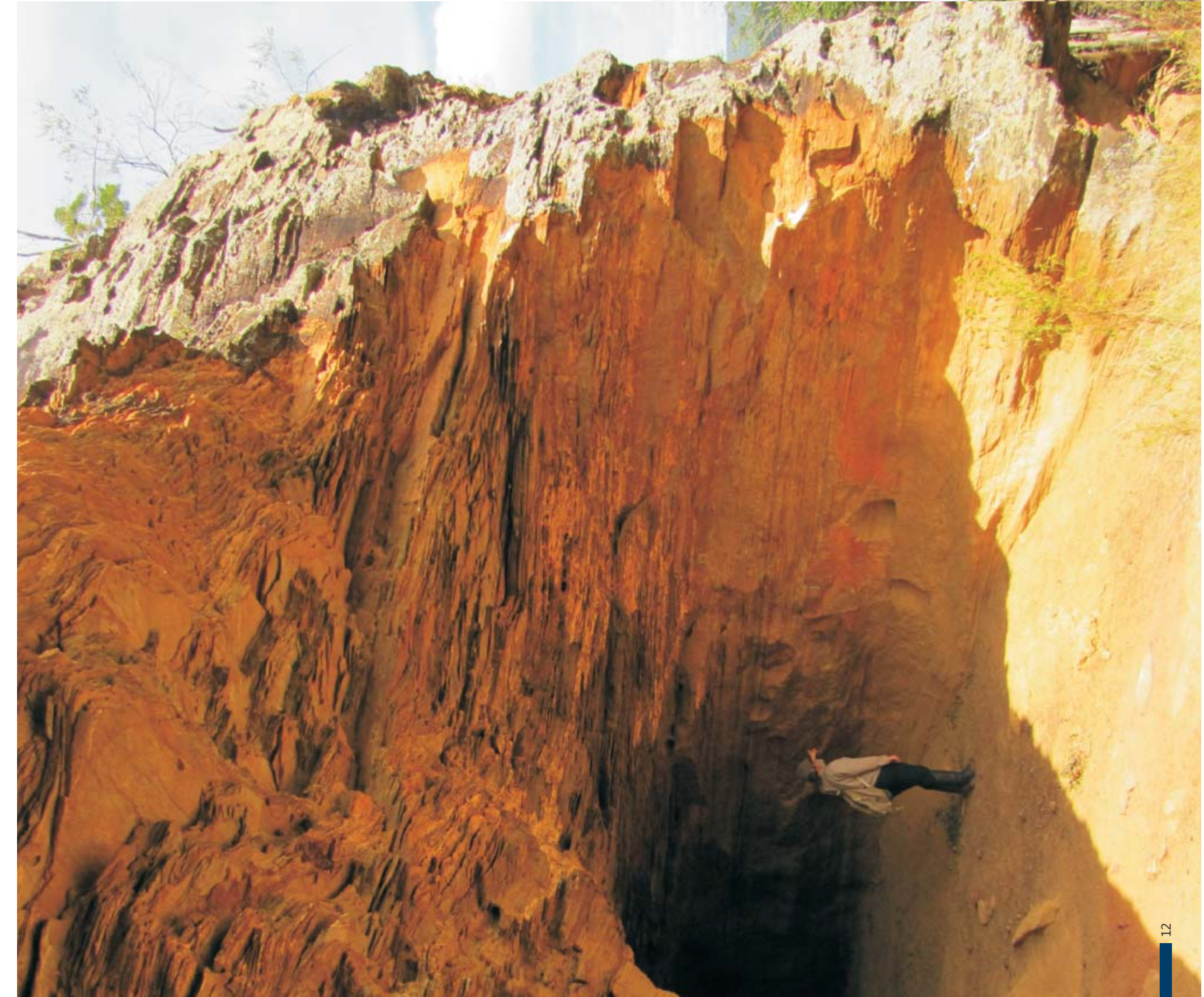



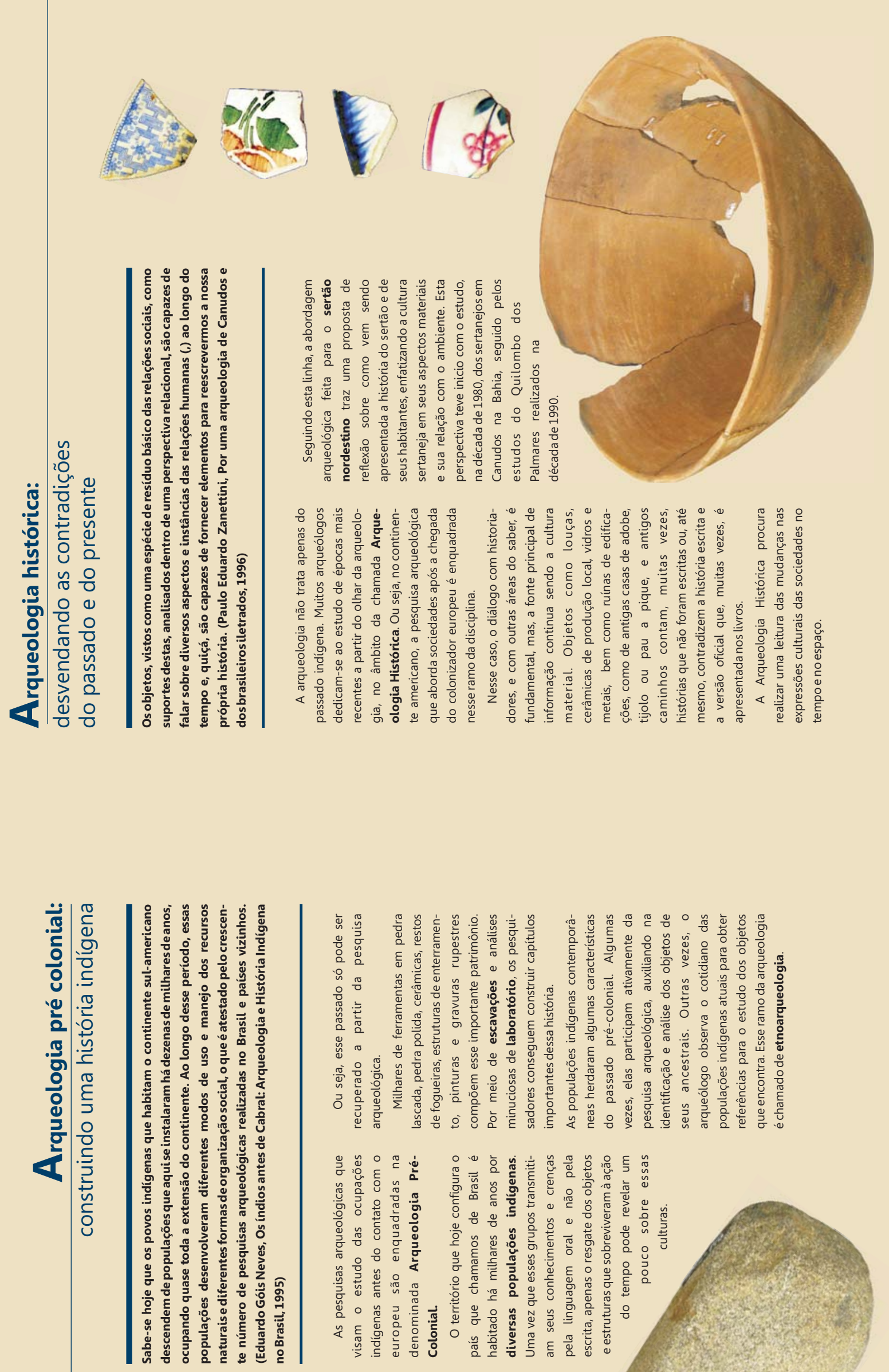

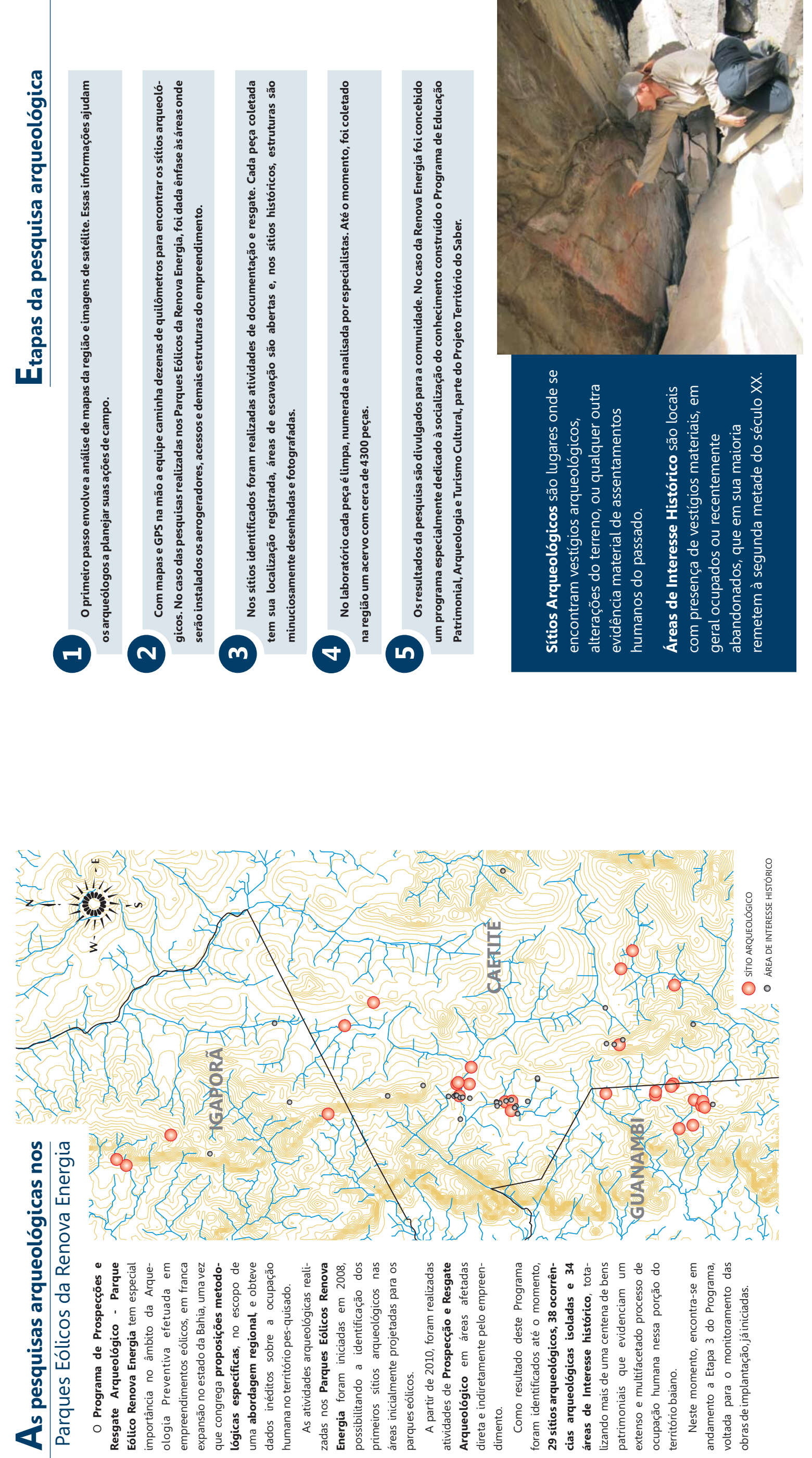


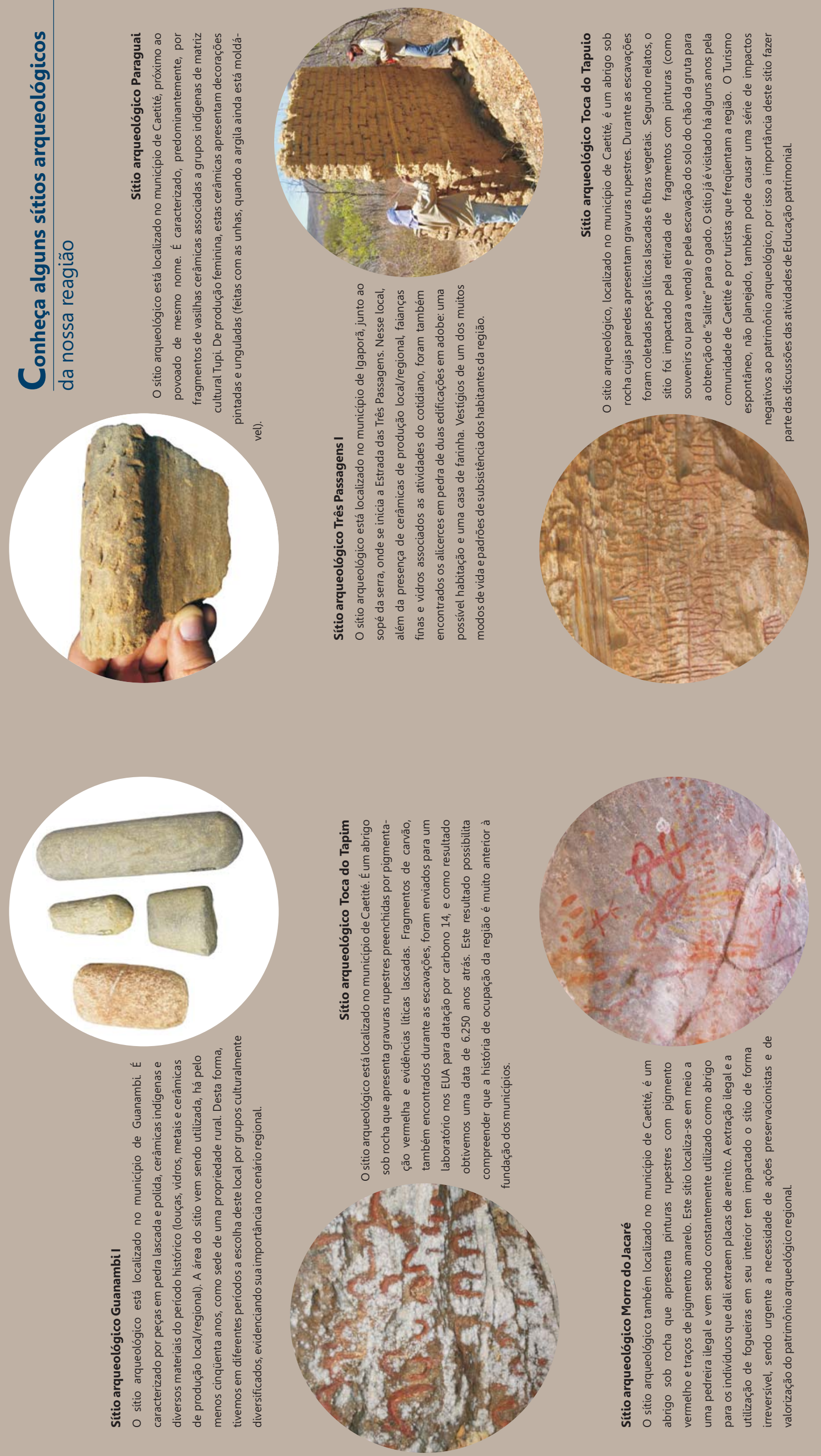




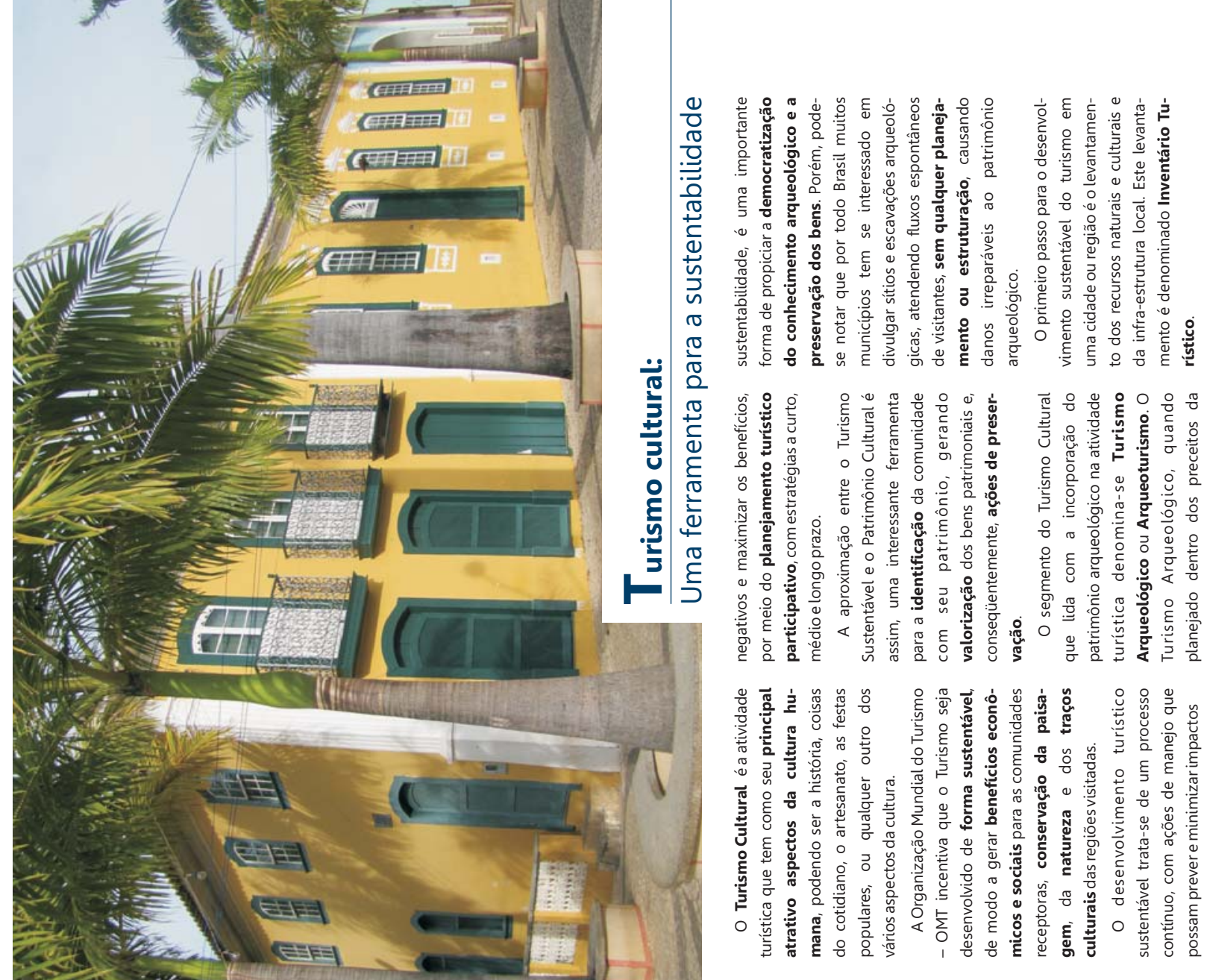



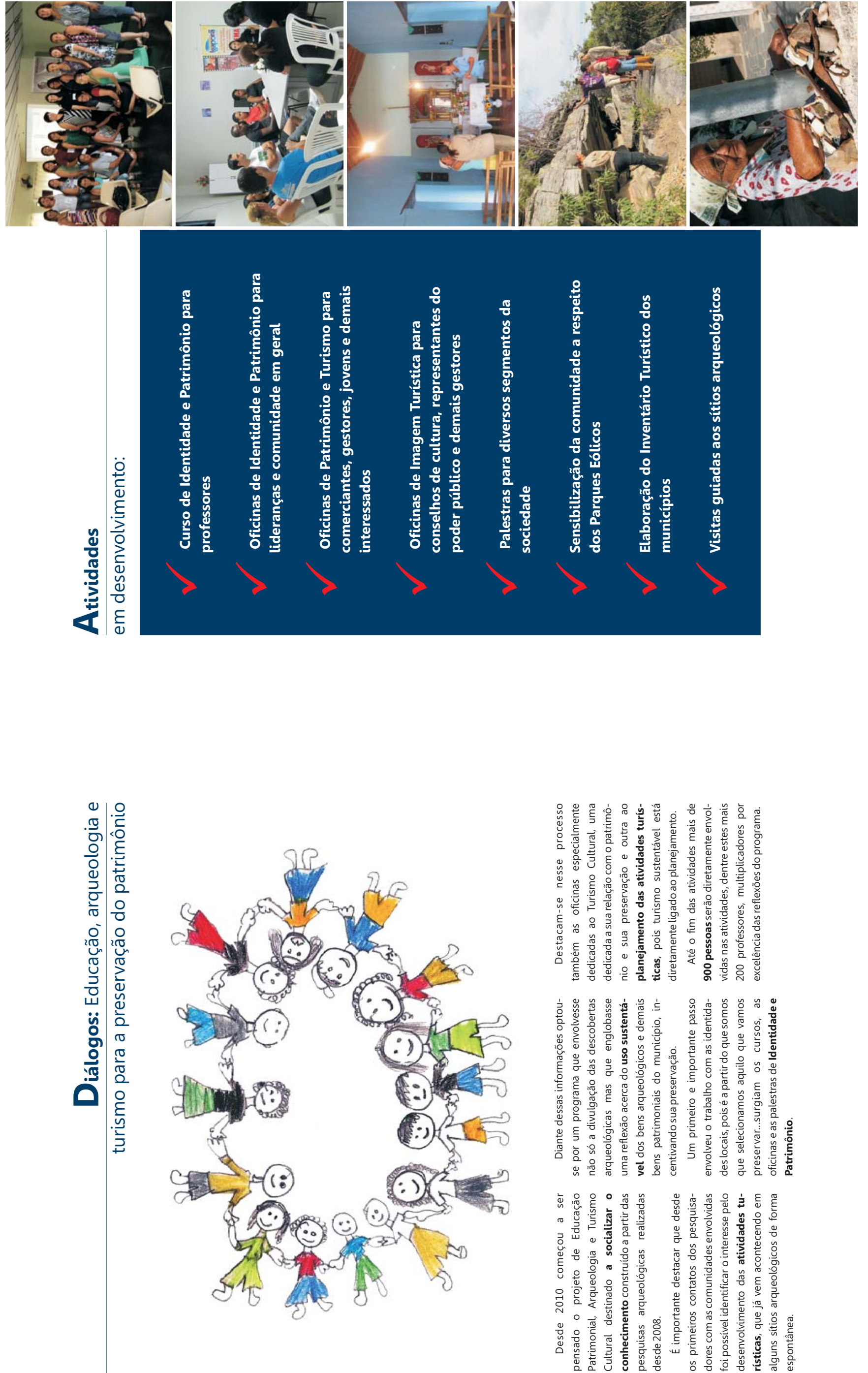

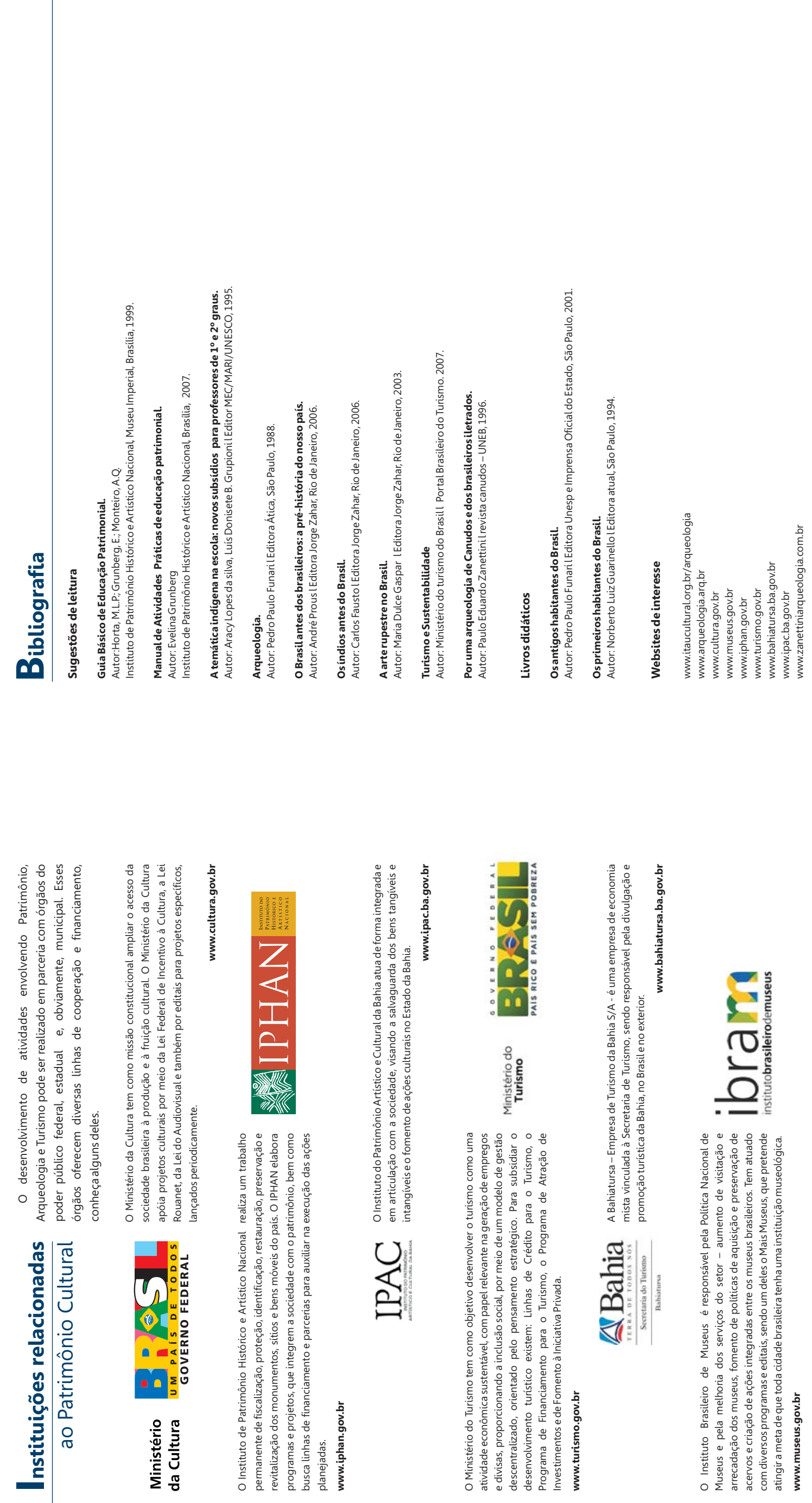

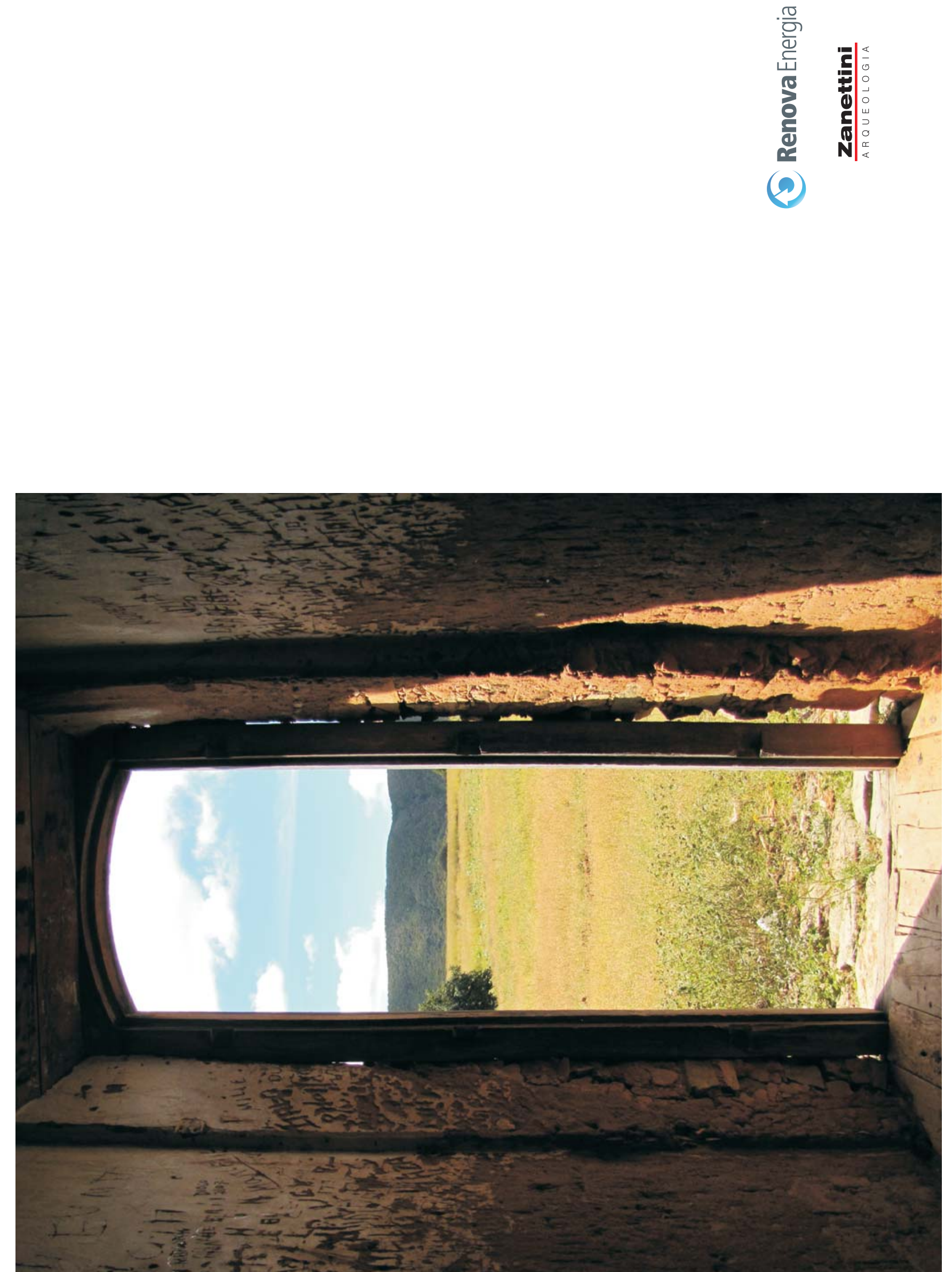


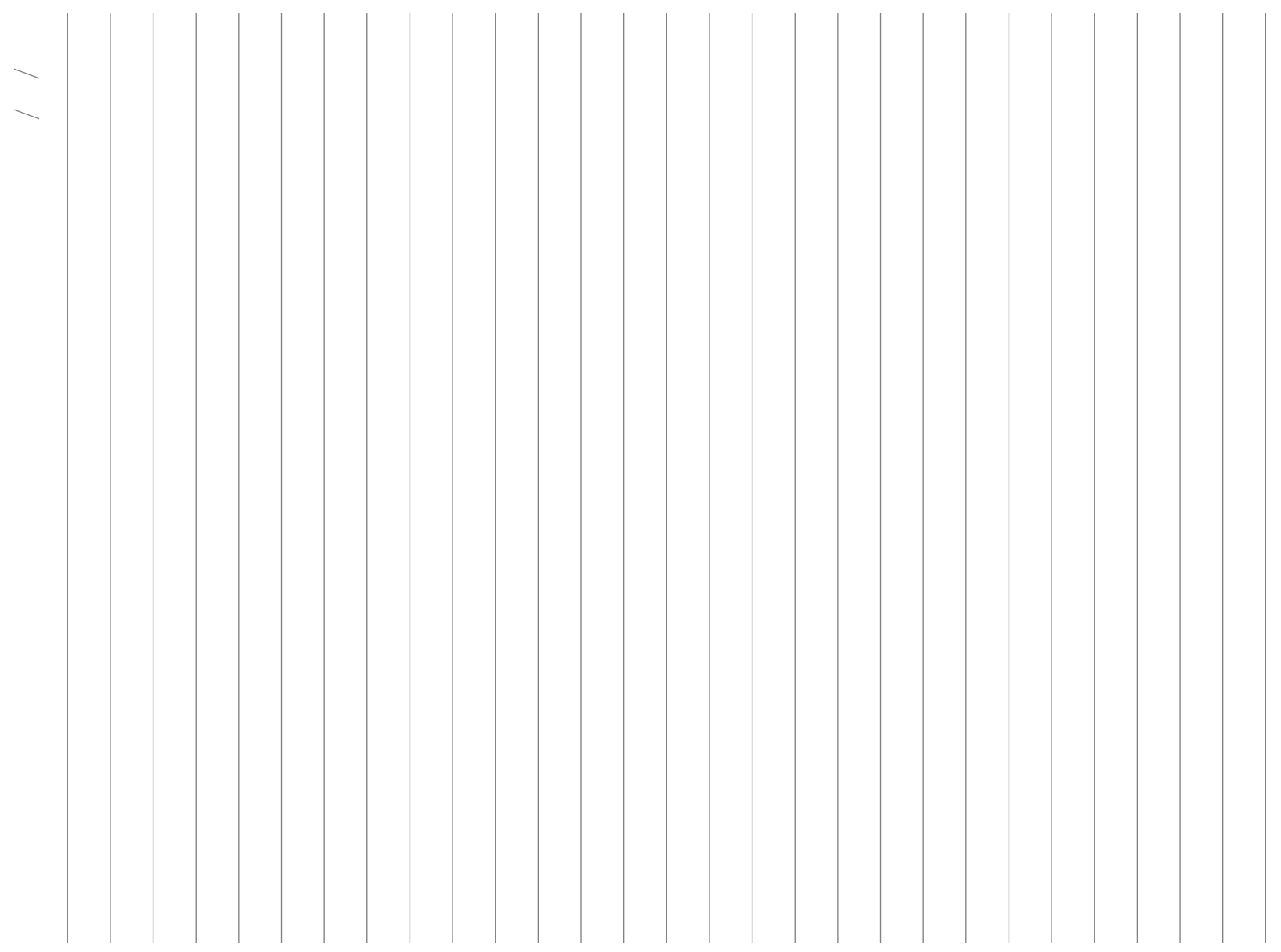



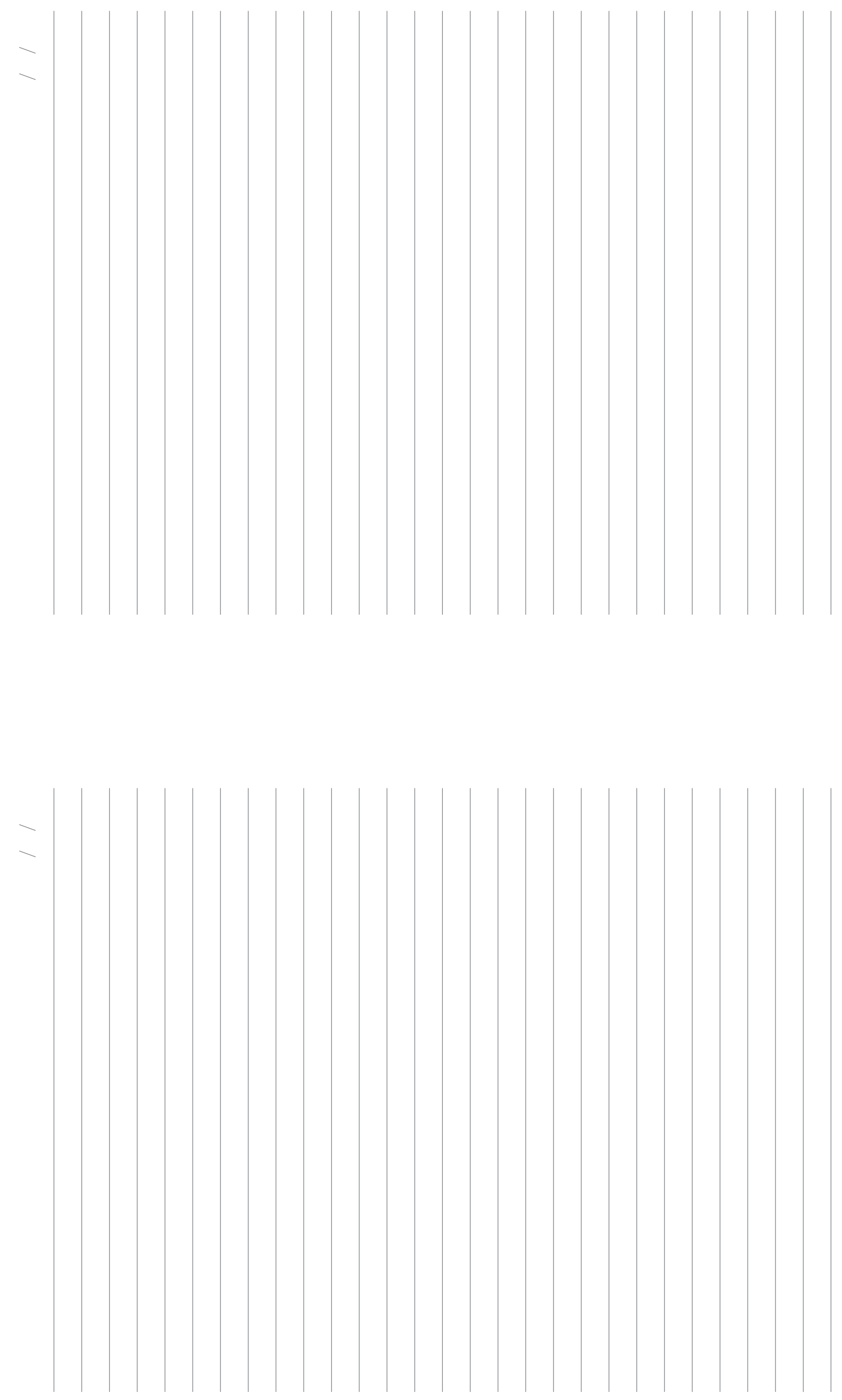

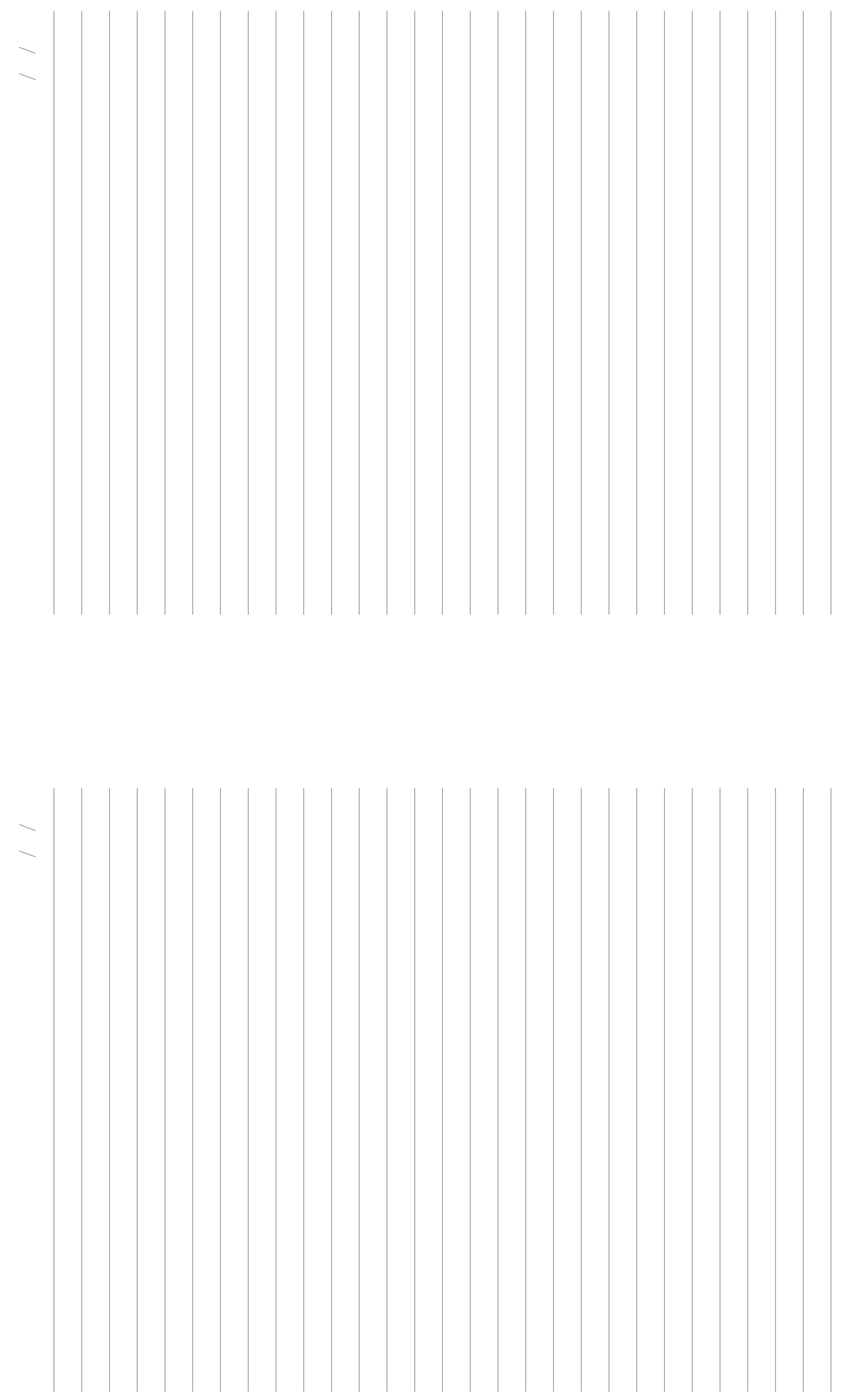


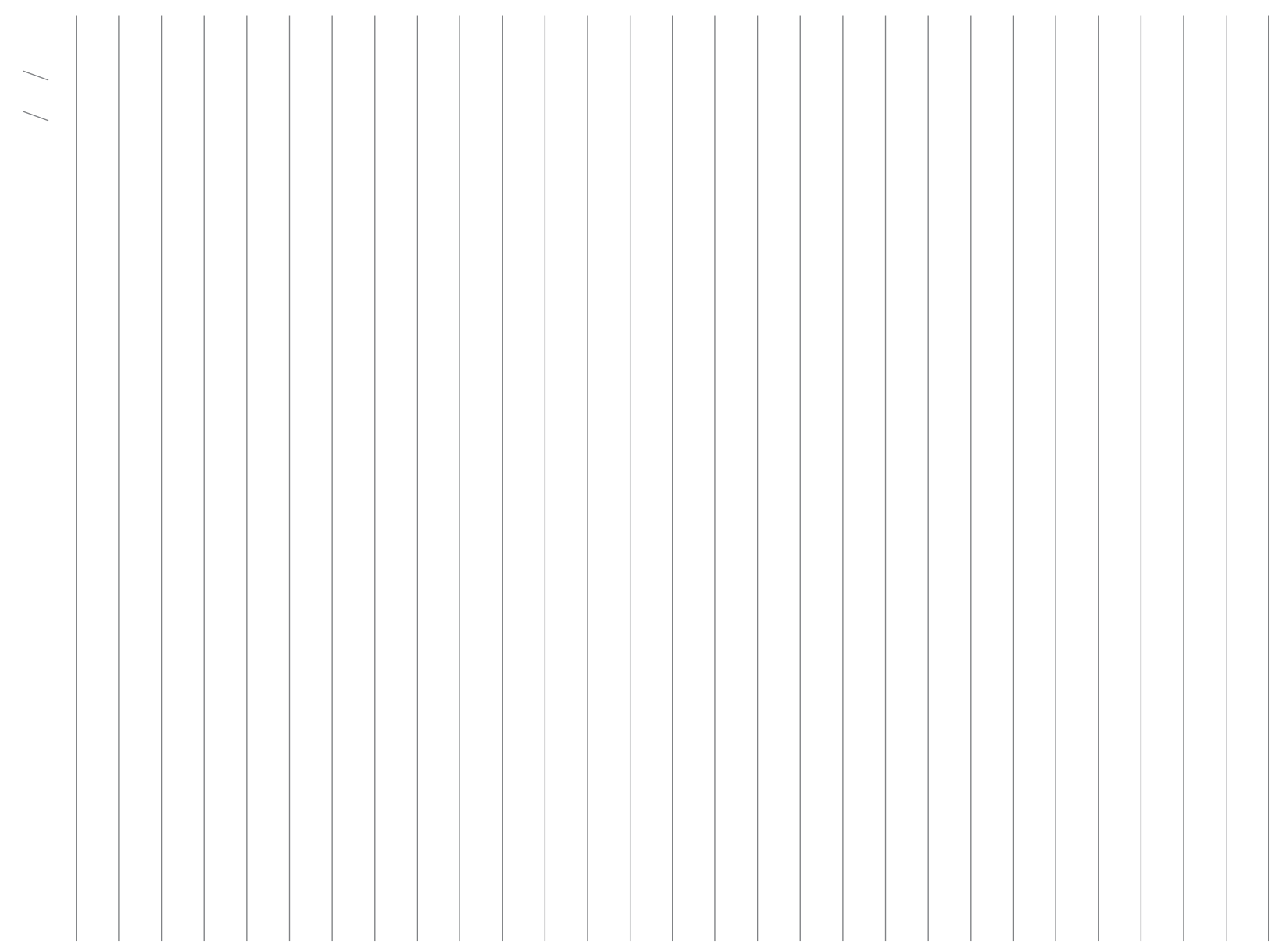




\section{Zanettini}

ARQUEOLOGIA

Renova Energia 

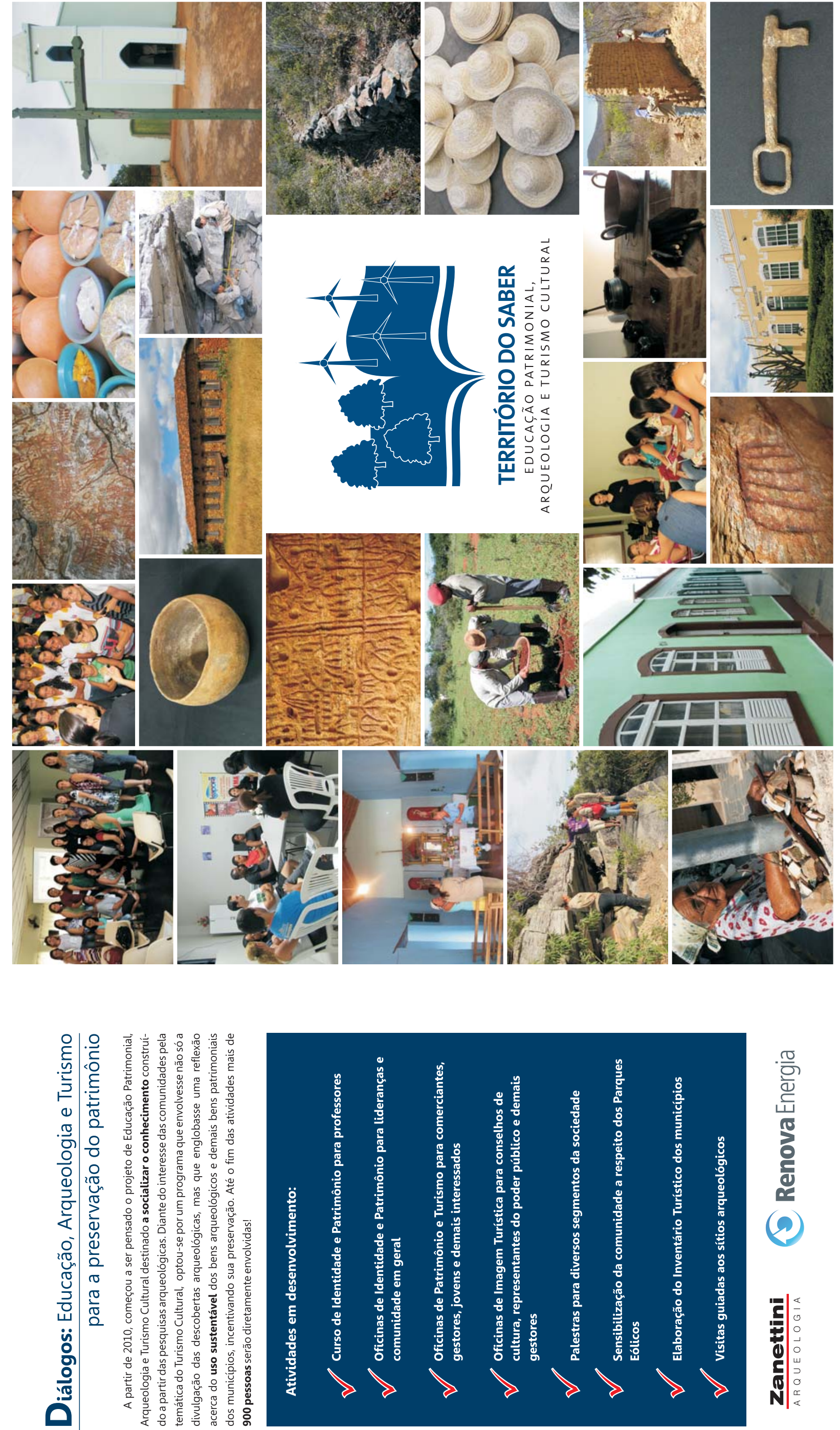

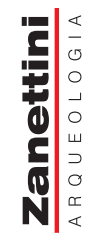



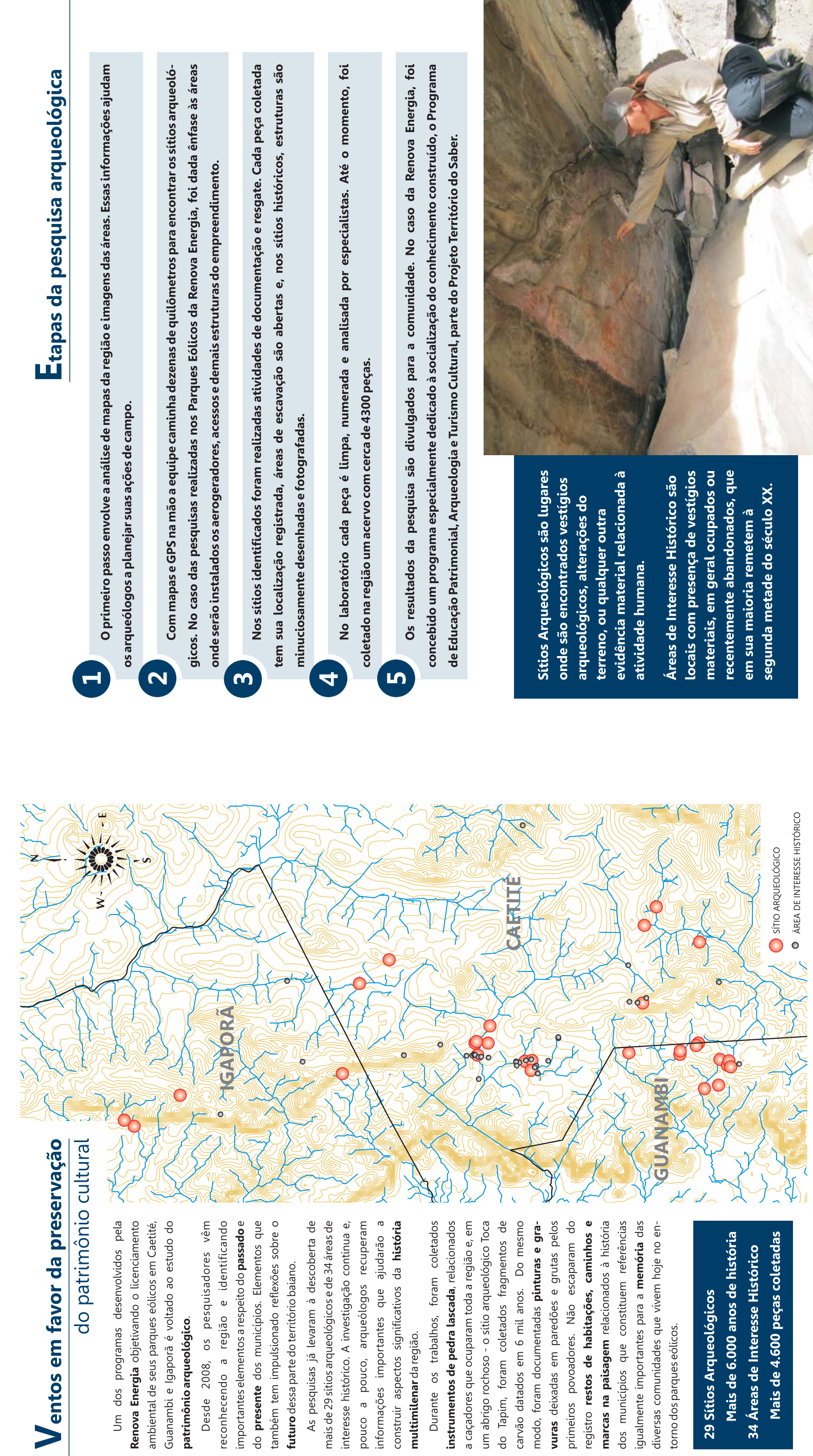